\title{
Strict liability and the aims of Tort Law
}

Citation for published version (APA):

On, A. D. (2020). Strict liability and the aims of Tort Law: a doctrinal, comparative, and normative study of strict liability regimes. [Doctoral Thesis, Maastricht University]. Maastricht University. https://doi.org/10.26481/dis.20201201do

Document status and date:

Published: 01/01/2020

DOI:

10.26481/dis.20201201do

Document Version:

Publisher's PDF, also known as Version of record

\section{Please check the document version of this publication:}

- A submitted manuscript is the version of the article upon submission and before peer-review. There can be important differences between the submitted version and the official published version of record.

People interested in the research are advised to contact the author for the final version of the publication, or visit the DOI to the publisher's website.

- The final author version and the galley proof are versions of the publication after peer review.

- The final published version features the final layout of the paper including the volume, issue and page numbers.

Link to publication

\footnotetext{
General rights rights.

- You may freely distribute the URL identifying the publication in the public portal. please follow below link for the End User Agreement:

www.umlib.nl/taverne-license

Take down policy

If you believe that this document breaches copyright please contact us at:

repository@maastrichtuniversity.nl

providing details and we will investigate your claim.
}

Copyright and moral rights for the publications made accessible in the public portal are retained by the authors and/or other copyright owners and it is a condition of accessing publications that users recognise and abide by the legal requirements associated with these

- Users may download and print one copy of any publication from the public portal for the purpose of private study or research.

- You may not further distribute the material or use it for any profit-making activity or commercial gain

If the publication is distributed under the terms of Article $25 \mathrm{fa}$ of the Dutch Copyright Act, indicated by the "Taverne" license above, 


\section{Strict Liability and the Aims of Tort Law}

\section{A Doctrinal, Comparative, and Normative Study of Strict Liability Regimes}

Alexandru Daniel On 
Copyright@2020 Alexandru-Daniel On

All rights reserved 


\title{
Strict Liability and the Aims of Tort Law:
}

\section{A Doctrinal, Comparative, and Normative Study of Strict Liability Regimes}

\author{
DISSERTATION \\ To obtain the degree of Doctor \\ at Maastricht University, \\ on the authority of the Rector Magnificus, \\ Prof. dr. Rianne M. Letschert \\ in accordance with the decision of the Board of Deans, \\ to be defended in public \\ on Tuesday 1 December 2020, at 16:00 hours
}

by

Alexandru Daniel On 


\section{Supervisor:}

Prof. dr. J.M. Smits

\section{Co-Supervisor:}

Prof. dr. O. Moréteau, Louisiana State University

\section{Assessment Committee:}

Prof. dr. G. van Dijck (Chair)

Prof. dr. C.C. van Dam

Prof. dr. I. Giesen, Utrecht University

Prof. J.R. Gordley JD, Tulane University 
"For what education in the virtues teaches me is that my good as a man is one and the same as the good of those others with whom I am bound up in human community." (Alasdair MacIntyre) 


\section{Table of Contents}

PROLEGOMENON:

COMPARATIVE LAW AND THE FOUNDATIONS OF STRICT LIABILITY

CHAPTER I

INTRODUCTION

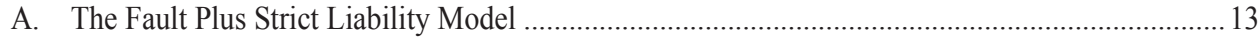

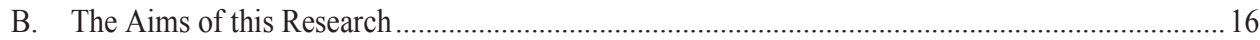

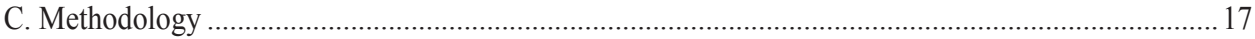

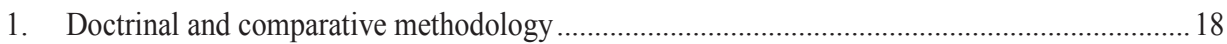

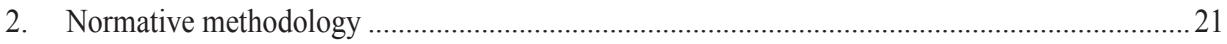

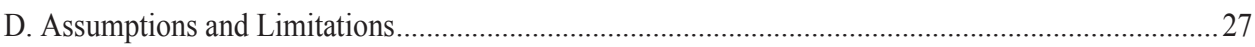

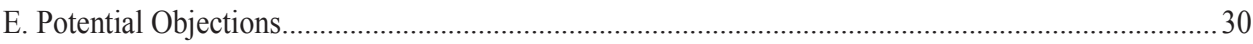

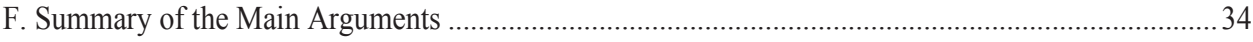

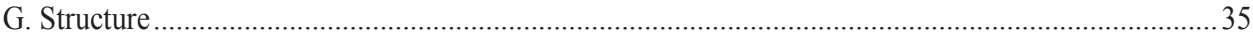

CHAPTER II

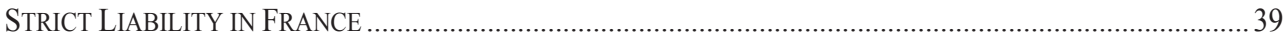

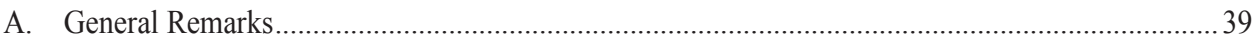

B. The Enactment of the French Civil Code - Context and Ideology ................................................ 42

C. The Creative Re-interpretation of the Code's Articles by the Judiciary............................................. 45

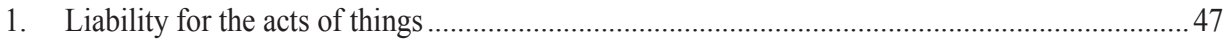

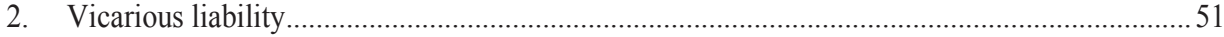

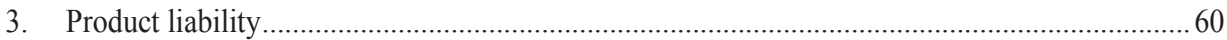

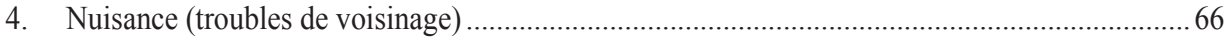

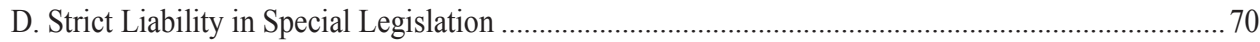

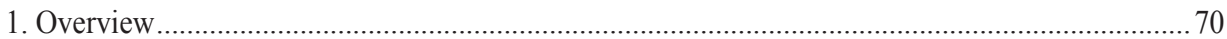

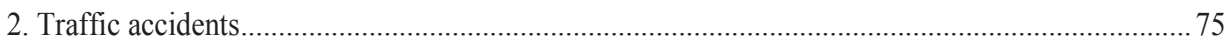

CHAPTER III

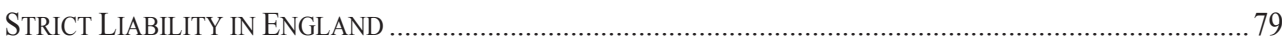

A. The Common Law Tradition and the Growth of Trespass and Negligence..................................... 79

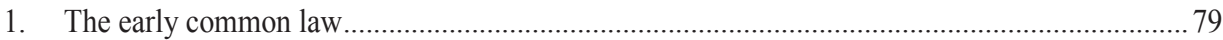

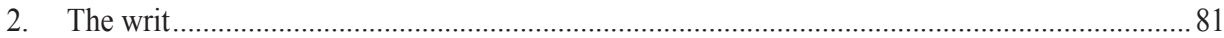

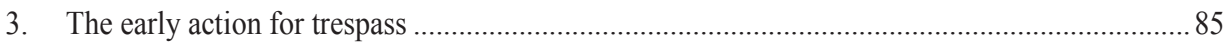




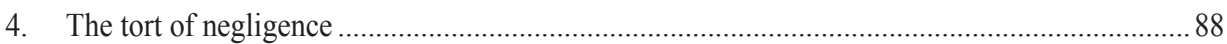

B. Strict Liability Torts in Modern English Law .................................................................................... 96

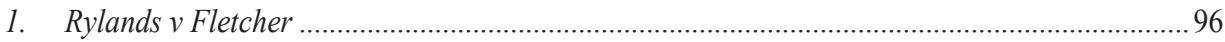

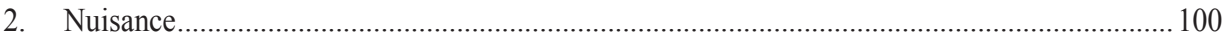

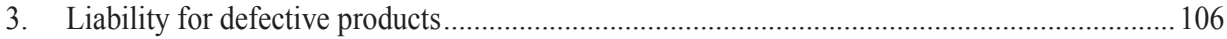

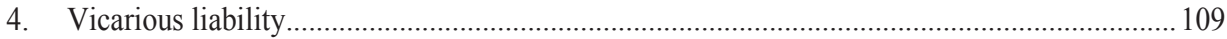

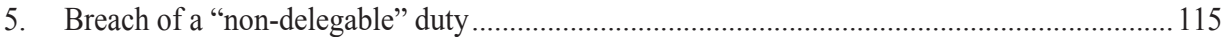

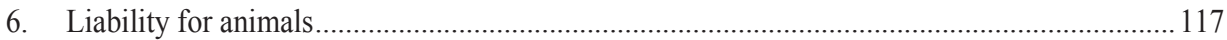

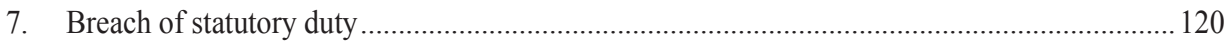

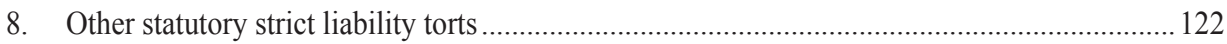

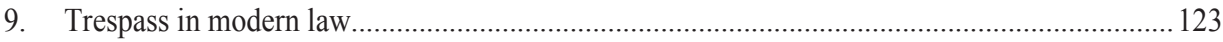

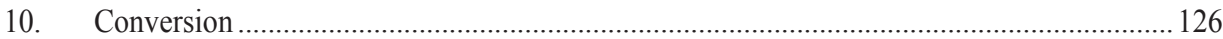

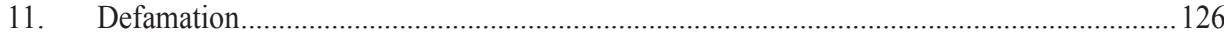

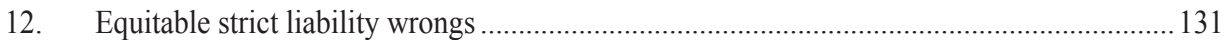

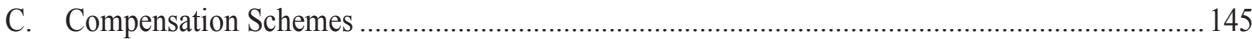

\section{CHAPTER IV}

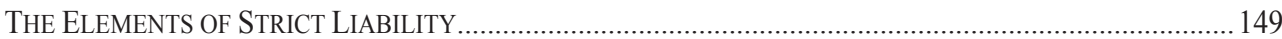

A. Problems Raised by the Standard Definition of Strict Liability................................................... 149

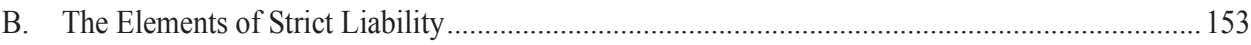

C. De facto Strict Liability, or "Fault Liability with a Reversed Burden of Proof" ........................... 161

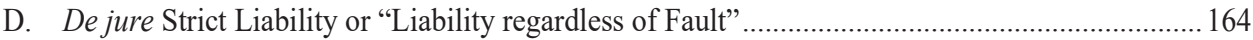

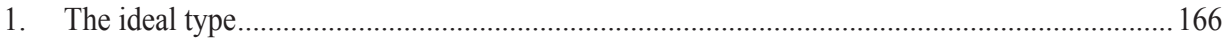

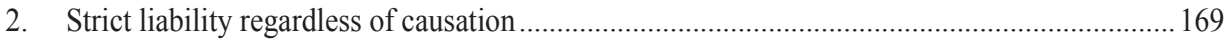

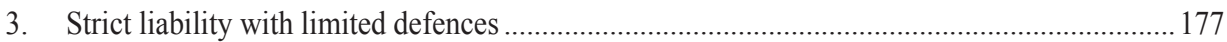

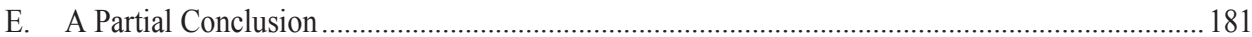

\section{CHAPTER V}

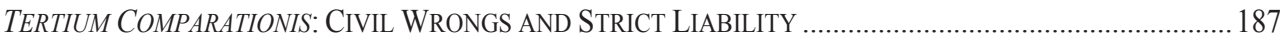
A. Introduction: The Comparative Method
B. In Search of a Different Point of Outlook 189
C. Functionalism and Aristotelian Finalism 193
D. Our tertium comparations: Defining and Correcting Civil Wrongs 194
E. Civil Wrongs 196

1. The history of the idea of 'civil wrongs' 


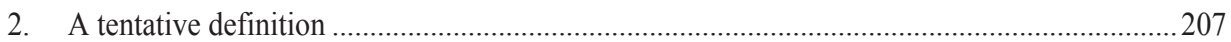

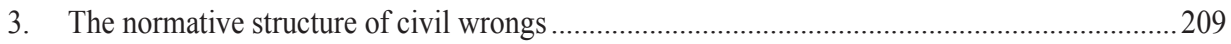

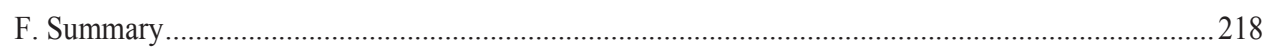

\section{CHAPTER VI}

STRICT LIABILITY AND ITS FUNCTIONAL EQUIVALENTS …......................................................................221

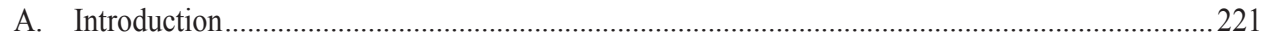

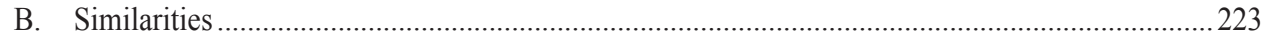

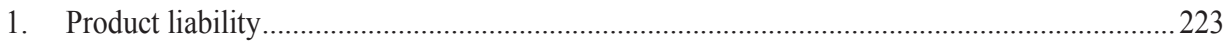

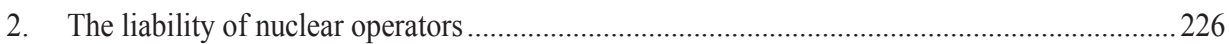

3. The liability of employers for the civil wrongs committed by their employees ........................227

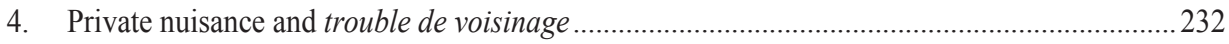

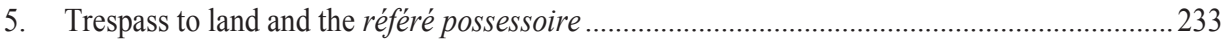

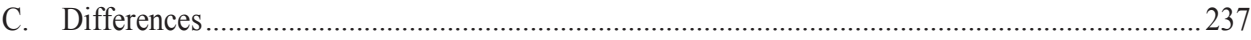

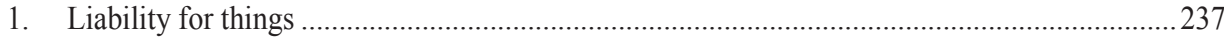

2. Liability for another (when the other is not an employee) .......................................................24

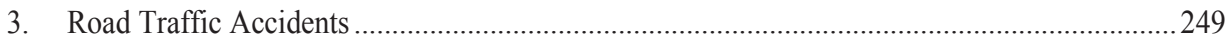

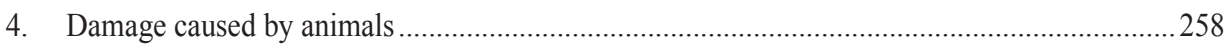

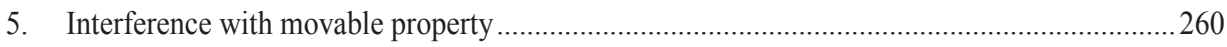

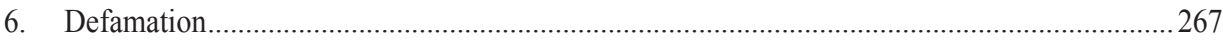

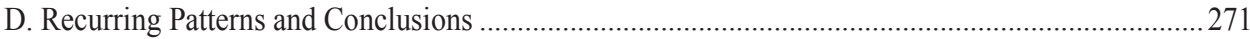

CHAPTER VII

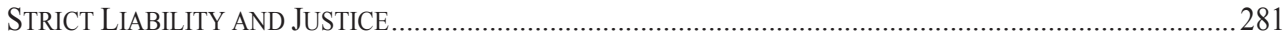

A. The Two Problems with Strict Liability in Normative Tort Law Theory ......................................281

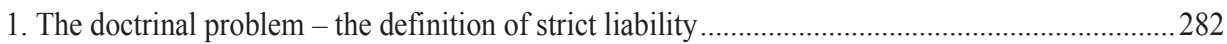

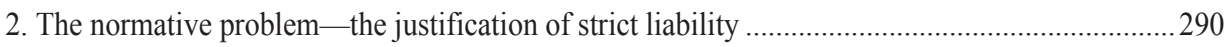

B. An Introduction to the Aristotelian Tradition of Moral Inquiry....................................................297

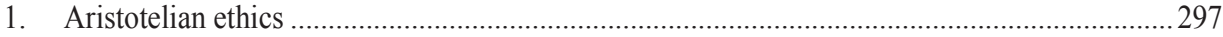

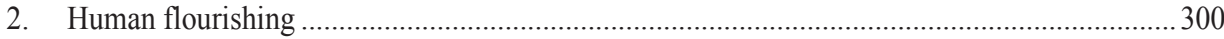

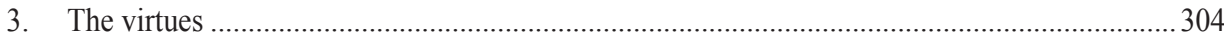

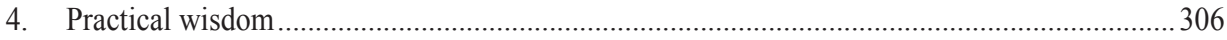

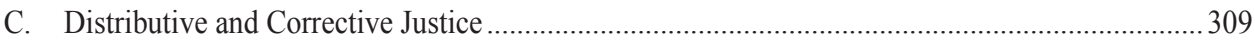

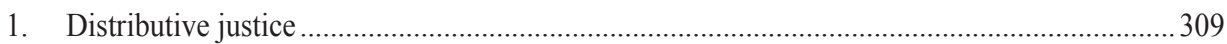

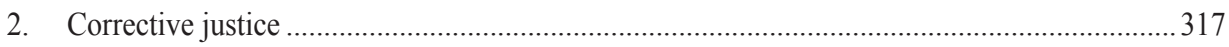


D. Corrective Justice, Distributive Justice, and the Aims of Tort Law 325

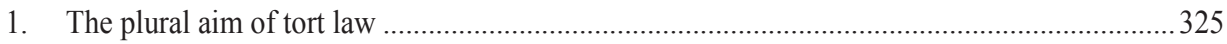

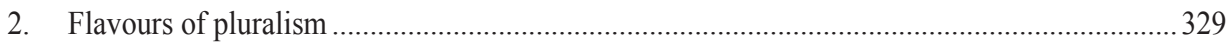

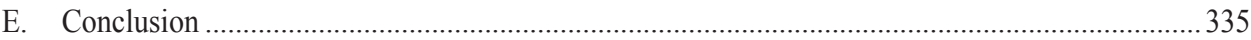

CHAPTER VIII

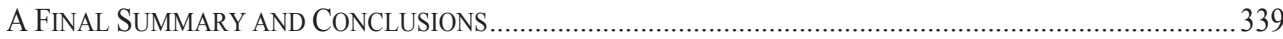

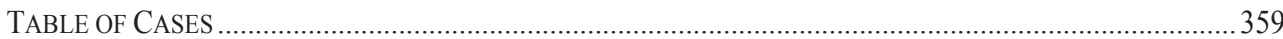

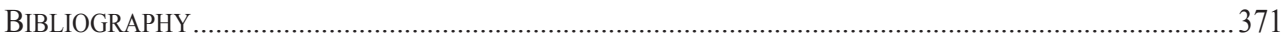

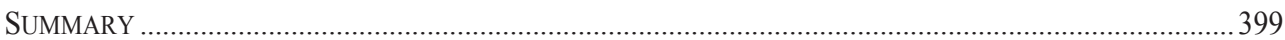

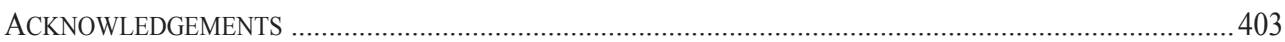

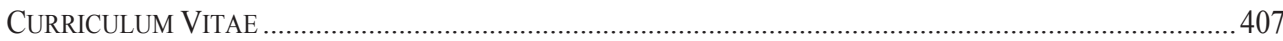

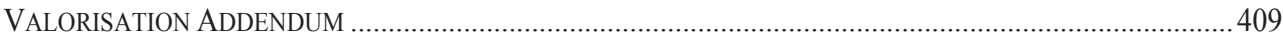




\section{PROLEGOMENON:}

COMPARATIVE LAW AND THE Foundations OF StRICT Liability

Strict liability rules have a firm foothold in the law of torts. Almost all, if not all legal systems have strict liability rules in place. ${ }^{1}$ Not all legal systems, however, resort to the same rules of strict liability. There is a great deal of diversity between legal systems with regard to the distribution of strict liability rules relative to fault-based rules, the scope of strict liability rules, and how these are perceived by various legal actors. Strict liability is ubiquitous, but problematic. ${ }^{2}$ In Europe, the diversity of approaches to strict liability is downright perplexing. Not only do the rules differ significantly between the various European jurisdictions, but so do the reasons advanced for their creation. Sometimes, even within the same jurisdiction, the justifications for some rules of strict liability differ substantially from others. ${ }^{3}$ It is hard to find a common core, a set of provisions which can truly be said to be common to all European legal systems when discussing strict liability, and it seems even harder to find the right direction that the law should take in this regard (should European legal systems embrace and expand strict liability rules, or should the pendulum swing the other way, towards a revival of fault-based rules?).

For legal scholarship, this divergence of practices and justifications opens the space for a fascinating debate about the concept of strict liability, the function of strict liability rules within the law of torts, and the factual instances which ought to be regulated by strict liability rules.

\footnotetext{
${ }^{1}$ Cees van Dam, European ToRT Law 298 ( $2^{\text {nd }}$ ed., Oxford University Press 2013): "All legal systems provide strict liability rules in addition to the basic fault liability rule."; CHRISTIAN VON BAR, 1 THE COMMON EUROPEAN LAW OF TORTS 10 (Oxford University Press 1998): "Strict liability is [...] a feature common to all European countries"; John G. Fleming, AN INTRODUCTION to the LAW OF TORTS 153 (Clarendon Press 1985): "Most, if not all, systems of law, committed though they may be to the general philosophy of fault, are prepared to countenance strict liability in some exceptional situations."

${ }^{2}$ See Gregory C. Keating, Strict Liability Wrongs, in Philosophical Foundations of THE LaW OF ToRTs 292, 294 (John Oberdiek ed., Oxford University Press 2014) (making the stronger statement that strict liability is an "embarrassment" to most contemporary moral theories of tort law)

${ }^{3}$ France is a very good example. Some strict liability rules have been created by courts or enacted by the legislature on the basis of the "risk theory", as developed by Saleilles and Josserand at the end of the $19^{\text {th }}$ century, while others are justified by more modern theories based on notions of control, or on Boris Starck's "théorie de la garantie." PhiLIPPE LE TOURNEAU ET AL., DroIt DE LA RESPONSABILITÉ ET DES CONTRATS. RÉGIMES D'INDEMNISATION 45, 50 $51, \mathrm{n}^{\mathrm{0}} 51,72,73$ (10 $0^{\text {th }}$ ed., Dalloz 2014).
} 
An interesting example that highlights just how difficult it is to articulate answers to such questions comes from the provisions and commentaries to the Principles of European Tort Law. ${ }^{4}$ Soon after the publication of two important, large scale, and collaborative comparative law studies on strict liability regimes, ${ }^{5}$ the European Group on Tort Law ${ }^{6}$ published the PETL, which contains provisions on strict liability in Chapter 5, articles 5:101 and 5:102. ${ }^{7}$

The Group hesitated at first, and considered avoiding the topic of strict liability entirely because of a conceptual issue: the term 'strict liability' is used in a very narrow sense (at least sometimes) ${ }^{8}$ and "there is [in Europe] no clear-cut concept of strict liability, not even within a single jurisdiction." However, in the end, the Group found that there is a "clear core meaning" $" 10$ on the basis of which provisions on strict liability may be elaborated.

Therefore, in the drafting phase, two solutions were proposed. The first solution was to introduce a general rule, with a "fairly broad clause which would be flexible enough to cover a wide variety of risks while still allowing for adjustments depending on the weight of the risk." 11 The alternative was to regulate "certain extreme risks" 12 as an exceptional rule, and as a general rule leave it up to

\footnotetext{
${ }^{4}$ Referred to in this study as PETL.

${ }^{5}$ UNIFICATION OF TORT LAW: STRICT LiaBILITY (B.A. Koch \& H. Koziol eds., Kluwer Law International 2002) (the contributions to this book belong to members of the European Group on Tort Law, and this work was done in preparation for the drafting of the PETL); THE BOUNDARIES OF STRICT LIABILITY IN EUROPEAN TORT LAW (Franz Werro \& Vernon Valentine Palmer eds., Bruylant/Staempfli/Carolina Academic Press 2004) (This second book is part of the Common Core of European Private Law project, also known as the "Trento Project").

${ }^{6}$ Formerly known as the "Tilburg Group."

${ }^{7}$ Art. 5:101. Abnormally dangerous activities:
}

(1) A person who carries on an abnormally dangerous activity is strictly liable for damage characteristic to the risk presented by the activity and resulting from it.

(2) An activity is abnormally dangerous if

a) it creates a foreseeable and highly significant risk of damage even when all due care is exercised in its management and

b) it is not a matter of common usage.

(3) A risk of damage may be significant having regard to the seriousness or the likelihood of the damage.

(4) This Article does not apply to an activity which is specifically subjected to strict liability by any other provision of these Principles or any other national law or international convention.

Art. 5:102. Other strict liabilities:

(1) National laws can provide for further categories of strict liability for dangerous activities even if the activity is not abnormally dangerous.

(2) Unless national law provides otherwise, additional categories of strict liability can be found by analogy to other sources of comparable risk of damage.

${ }^{8}$ European Group on Tort LaW, PRinciples of European Tort LaW. TEXT AND COMmentary 101 (Springer 2005).

${ }^{9} \mathrm{Id}$.

${ }^{10} I d$.

${ }^{11} \mathrm{Id}$. at 102.

${ }^{12}$ Id. 
national legislatures to decide what risks ought to be covered by strict liability. ${ }^{13}$ In the end, the proponents of the second option prevailed.

The European Group on Tort Law never explicitly stated in the comments to the PETL what "the core meaning" of strict liability is, and the justification it provided for the rule adopted is questionable. The Group seems to believe that in the drafting of article 5:101 it did not venture too far, ${ }^{14}$ as the provisions should be read as providing merely a "minimum residual standard". ${ }^{15}$ Article 5:101 establishes a narrow rule, which in the eyes of its drafters reflects a common European core of strict liability shared by all European jurisdictions.

However, this "minimum harmonization" rule from article 5:101 is, at least in its formulation, relatively foreign to the European nomos. ${ }^{16}$ The provision is inspired by and follows, to a significant extent, the wording of the 2004 draft of the Restatement (Third) of Torts: Liability for Physical Harm (Basic Principles) from the United States. ${ }^{17}$ In addition, its content does not reflect at all a common European standard. ${ }^{18}$ Looked at from the perspective of Continental legal systems, it covers significantly less than strict liability usually covers on the Continent. ${ }^{19}$ France, for instance, has very broad strict liability provisions for things and for persons, and does not organize its strict liability provisions at all around the notion of "ultra-hazardous activities." In general, Continental civil law systems employ strict liability for a large number of activities which cannot

\footnotetext{
${ }^{13} \mathrm{Id}$.

${ }^{14} I d$. at 17.

${ }^{15} \mathrm{Id}$. at 110 .

${ }^{16}$ See also Erdem Büyüksagis \& Willem H. van Boom, Strict Liability in Contemporary European Codification: Torn Between Objects, Activities, and Their Risks, 44 GEORGETOWn JouRnal of INTERNATIONAL LAW 609, 627-28 (2013): "Such a formulation raises many questions, particularly regarding the definition of a highly significant and foreseeable risk and the scope of activities of common usage. In the United States, these questions can be clarified to some extent by established case law. In Europe, however, there is no common law tradition on which civil courts can fall back. Therefore, there is no guiding principle common to all member states."

${ }^{17}$ EUROPEAN GROUP ON TORT LAW, supra note 8, at 103.

${ }^{18}$ According to the commentary to the Principles, " $[\ldots]$ the (admittedly narrow) solution found in this Chapter $[\ldots]$ tries to encompass the lowest common denominator as a minimum standard [...] while at the same time acknowledging existing regimes that already go beyond (though not necessarily in the same way or extent)." Id. at 109.

${ }^{19}$ That is not to say that there are no legal systems that have similarly general rules, dealing with abnormally dangerous activities. See, e.g., art. 2050 of the Italian Civil Code ("Chiunque cagiona danno ad altri nello svolgimento di una attività pericolosa, per sua natura o per la natura dei mezzi adoperati, è tenuto al risarcimento, se non prova di avere adottato tutte le misure idonee a evitare il danno."), or art. 493 para. 2 of the Portuguese Civil Code ("Quem causar danos a outrem no exercício de uma actividade, perigosa por sua própria natureza ou pela natureza dos meios utilizados, é obrigado a repará-los, excepto se mostrar que empregou todas as providências exigidas pelas circunstâncias com o fim de os prevenir."). See also 628
} 


\section{Prolegomenon:}

be categorized as "ultra-hazardous" without running the risk of stripping the term of all meaning. ${ }^{20}$ Nevertheless, from the perspective of Continental legal systems, the minimum harmonization rule of article 5:101 of the PETL is not a serious obstacle since articles 5:101 and 5:102 both explicitly provide that under national law other forms of strict liability may be adopted. However, from the perspective of English law, one can seriously doubt whether a general clause on liability for ultrahazardous activities reflects a minimum standard that also corresponds to positive English law. In fact, Rylands $v$ Fletcher, ${ }^{21}$ the case which lies at the foundation of the American strict liability rule for ultra-hazardous activities, ${ }^{22}$ was interpreted narrowly in England, and no principle, broad or narrow, exists under positive English law that an operator is strictly liable for the damages caused by ultra-hazardous or dangerous activities. ${ }^{23}$ That does not mean, of course, that there is no strict liability for certain specific types of hazardous activities under English law, like, for instance, the liability of the operator of a nuclear power plant. ${ }^{24}$ The point is simply that for a large number of activities that can be seen as ultra-hazardous, the relevant torts will be either the tort of negligence or nuisance, and not a general strict liability principle. Also, outside of the area of dangerous activities, there are numerous other rules of strict liability in English law that apply to activities which can be said to be rather mundane, and by no means ultra-hazardous. ${ }^{25}$

The purpose of this short critique is not just to draw attention to the fact that the rule from article 5:101 of the PETL is not a reflection of a common European core. In fact, taking into account the

\footnotetext{
${ }^{20}$ German law is also a good example, even though general rules of strict liability are not favoured in Germany. German law knows only specific strict liability provisions, almost all of which can be found in special legislation, and doctrinal "suggestions focusing on the introduction of a comprehensive clause regulating all cases of strict liability have so far not been influential." Jörg Fedtke \& Ulrich Magnus, Germany, in UnIFICATION OF TORT LAW: StRICT Liability 147, 154 (B.A. Koch \& H. Koziol eds., Kluwer Law International 2002). The narrower, more specific, rules of German law also provide for strict liability in many more cases, and cover substantially more ground than what is covered by article 5:101 of the PETL. Specific examples of non-ultra-hazardous activities which nevertheless are governed by strict liability rules include the regimes enshrined in the Prussian Railway Act 1838 and the Imperial Law of Liability 1871 ( $\$ 25$ Gesetz über die Einsenbahnunternehmungen; $§ 1 \mathrm{HPflG}$ ), the Road Traffic Act 1909 ( $\$ 7$ StVG), the Air Traffic Act 1936 ( $\$ 33$ LuftVG), the Act on Pharmaceutical Products [ $\S 84$ et seq. Arzneimittelgesetz (AMG)], the Act on Genetic Engineering 1993 [§§32 et seq. Gentechnikgesetz (GenTG)], or the liability of keepers of luxury animals (§833-834 BGB).

${ }^{21}$ (1868) LR 3 HL 330.

22 W. Page Keeton et Al., Prosser and Keeton on Torts 545 et seq. $\left(5^{\text {th }}\right.$ ed., West 1984); Simon Deakin ET AL., MARKESINIS AND DEAKIN's ToRT LAW 544 ( $5^{\text {th }}$ ed., Oxford University Press 2003); Garry T. Schwartz, Rylands $v$ Fletcher, Negligence and Strict Liability, in THE LAW OF OBLIGATIONS, ESSAYS IN CELEBRATION OF JoHN Fleming 209, 211 (Peter Cane \& Jane Stapleton eds., Oxford University Press 1998).

${ }^{23}$ W. V. Horton Rogers, England in UnificATION OF TORT LAW: STRICT LiabiLITY 101, 109, 114 (B.A. Koch \& H. Koziol eds., Kluwer Law International 2002).

${ }^{24}$ Nuclear Installations Act 1965, c. 57.

${ }^{25}$ Like, for instance, stepping on someone's land, committing a private nuisance, or being the employer of a person who commits a tort. For the full list of strict liability regimes identified in English law, see infra Chapter III.
} 
extreme diversity of positive rules of strict liability in Europe, article 5:101 represents a relatively decent effort to formulate such a minimum standard. Based on positive law alone, it would have been extremely hard for any group of European academics to formulate a strict liability rule that truly reflects a common European core. That being said, regulating strict liability on the basis of a minimum residual standard and justifying the provision exclusively on the idea of "a common core" was not in line with the declared overall purposes of the project. The drafters of the PETL accepted from the outset that, considering the vast differences between European national legal systems, the provisions of the PETL was not designed as restatements of the law. ${ }^{26}$ The PETL should contain principles which are able to guide decision-makers in Europe not because they represent the least common denominator, but because good reasons have been put forward in their support. In other parts of the PETL the drafters were daring, making normative choices and justifying them accordingly. As a consequence, the comparative observations and the arguments made in other chapters of the PETL and in the comments attached to those provisions can indeed be of much assistance to any regulatory body, be it European or national. The same cannot, unfortunately, be said of Chapter 5 on strict liability, which stands out as an oddity within the PETL. Nowhere else in the PETL are issues deferred to national law, and nowhere else did the drafters shy away from a discussion on what is just. The formulation of a minimum standard, of course, shows that the drafters did not want to leave this area of the law outside of their purview. It is indeed laudable that the tricky issue of strict liability was at least tackled, however awkwardly. Nevertheless, in a soft-law instrument such as the PETL, the justification of strict liability rules ought to come from something other than the least common denominator. ${ }^{27}$

Examples of bold moves made by the drafters of the PETL include, to give but a few examples, articles $3: 103,3: 104,3: 105,4: 102,7: 101,10: 301$ para 1 , and 10:401. ${ }^{28}$ The rule from article $10: 401^{29}$ is particularly interesting, and it provides us with a contrasting approach. Even within the

\footnotetext{
${ }^{26}$ EUROPEAN GROUP ON TORT LAW, supra note 8, at 30.

${ }^{27}$ Following the publication of the PETL in 2005, the European Group on Tort Law reconvened in 2009 and set out a new agenda which includes addressing topics such as public authority liability, the inter-relationship between contractual and non-contractual liability, prescription of actions (limitation periods), and the burden of proof. Reopening the debate on strict liability might also be a good idea.

${ }^{28}$ The drafters themselves admit that these provisions "break new ground." Id. at 17.

${ }^{29}$ Reduction of damages:

In an exceptional case, if in light of the financial situation of the parties full compensation would be an oppressive burden to the defendant, damages may be reduced. In deciding whether to do so, the basis of liability (Article 1:101), the scope of protection of the interest (Article 2:102) and the magnitude of the damage have to be taken into account in particular.
} 
Group there was adamant dissent with regard to this provision, because the PETL deviated from a principle which is considered almost sacrosanct in some jurisdictions - the principle of full compensation..$^{30}$ In short, article 10:401 creates an exception to the principle of full compensation, by allowing a judge discretion in determining the amount of damages to be paid by the defendanttortfeasor, when full compensation would be "oppressive" for him. The rule seems to be justified on the basis of either distributive justice or equity, as the comments on this article highlight in a very transparent manner that circumstances such as the financial situation of the parties, the magnitude of the damage, any possible insurance coverage, or the operation of insolvency law may be taken into account. ${ }^{31}$

One of the central arguments this study advances is that, just like article 10:401 of the PETL, any discussion about the desirable rules of strict liability is ultimately a discussion about justice. Until now, comparative law scholars have been, for the most part, creating awareness about the diversity of strict liability regimes in the various jurisdictions studied. The comparative exercise has been focused on building a repository of national reports, more or less detailed, which identify the main rules and avenues of development of strict liability regimes, and these national reports have been used as "raw data" for unification or harmonization projects, like the PETL. In light of the diversity of strict liability regimes in Western jurisdictions, the comparative law exercise which was started by the various national reports published in the Unification of Tort Law project, ${ }^{32}$ and The Boundaries of Strict Liability in European Tort Law project, ${ }^{33}$ can and should be taken a step further, into more normative ground. This study intends to take a first step in that direction.

\footnotetext{
${ }^{30}$ EUROPEAN GROUP ON TORT LAW, supra note 8, at 180.

${ }^{31} \mathrm{Id}$. at 179.

${ }^{32}$ Supra note 5.

${ }^{33} I d$.
} 


\section{CHAPTER I}

INTRODUCTION

\section{A. The Fault Plus Strict Liability Model}

Theoretical models and their justifications are important in legal science and have a different impact than in the natural sciences. In law or morality, how we explain and justify rules, how we understand their nature and foundations, or even how we taxonomize them, influence how such rules operate in the world. By contrast, in natural sciences, like physics or biology, the search for the nature of things does not change how the laws of nature operate. We are not the makers of the laws of nature. Therefore, what we believe a law of nature is, individually or collectively, does not impact how nature works. "Nature cannot be fooled." It will continue to operate in the same manner irrespective of our understanding of its laws. The laws of nature do not depend on our will, mental representations, perceptions, opinions, or feelings. By contrast, our views on the world, human nature and human interaction, our perceptions of essential values, and the models we construct for "a good life" all influence how we design moral and legal norms. John Stuart Mill expressed this thought very clearly by making the following analogy:

The truths which are ultimately accepted as the first principles of a science, are really the last results of metaphysical analysis, practised on the elementary notions with which the science is conversant; and their relation to the science is not that of foundations to an edifice, but of roots to a tree, which may perform their office equally well though they be never dug down to and exposed to light. But though in science the particular truths precede the general theory, the contrary might be expected to be the case with a practical art, such as morals or legislation. ${ }^{2}$

\footnotetext{
${ }^{1}$ Richard P. Feynman, Appendix F: Personal Observations on the Reliability of the Shuttle, PCSSCA, vol. II, at F5, also available online at https://science.ksc.nasa.gov/shuttle/missions/51-1/docs/rogers-commission/Appendix-F.txt;

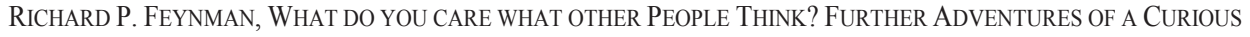
CHARACTER 237 (Penguin Books 2007).

2 John Stuart Mill, Utilitarianism. And the 1868 Speech on Capital Punishment 2 ( $2^{\text {nd }}$ ed., George Sher ed., Hackett Publishing Company, Inc. 2001). Unfortunately, Mill jumps from this idea directly to his consequentialist theory of action. He continues this paragraph with the following sentence: "All action is for the sake of some end, and rules of action, it seems natural to suppose, must take their whole character and colour from
} 
As a consequence, theoretical models and the phenomena they describe in legal science are codependent. There is a dialogue and a cross-influence between theory and practice because the practice operates on the basis of theoretical and conceptual frameworks which in turn are adapted, nuanced, or modified based on the experience of the practice they try to make sense of. In the law then, changes in theoretical models are influenced by and in turn influence for the future the practice of law-making and the resolution of disputes.

The law, therefore, is a dynamic social practice, in the sense that it is susceptible to change when presented with novel facts or theories. The position and role of tort law within modern legal systems, as well as the open-textured and flexible nature of its norms, make this area of the law uniquely susceptible to constant re-evaluation. Permanently bombarded with new facts, new cases, new theories, new philosophies, and new empirical and scientific data, the law of torts constantly changes its physiognomy. There is no widespread agreement, however, about the direction the law of torts ought to take when faced with new facts. That is one of the reasons why William Prosser saw the law of torts as a "battleground of social theory". ${ }^{3}$ In the same vein, the tort law historian G. Edward White once wrote that a central feature of tort law is "its tendency to serve as a testing ground for currently dominant intellectual theories". ${ }^{4}$

It would not be an exaggeration to say that perhaps the most important and far reaching change in the theoretical models of the law of torts is the shift from the 'fault-only model' of Pollock, ${ }^{5}$

\footnotetext{
the end to which they are subservient." Id. While it follows that the norms that we design to regulate action must themselves have an end (a purpose) this idea does not imply that the content of the norm must rest on the ends of particular actions. The purpose of a norm might be to promote actions that are good in themselves, regardless of their consequences (as argued by deontological theorists).

${ }^{3}$ William L. Prosser, Prosser on TorTS 15 (West 1941); William L. Prosser, Book Review [FoWLER VINCENT HARPER, A TREATISE ON THE LAW OF TORTS (The Bobbs-Merrill Company 1933)], 19 MinN. L. REV. 257, 257 (1935) ("battlefield of social theory"); See also Cristopher J. Robinette, The Prosser Notebook: Classroom as Biography and Intellectual History, 2010 U. ILL. L. REV. 577, 587 (2010).

${ }^{4}$ G. EdWARd White, TORT Law in America. An InTELlectual History 231 (Oxford Univ. Press 2003).

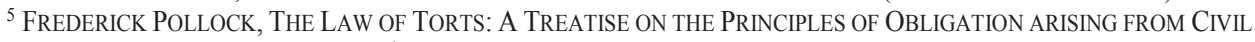
WRONGS IN THE COMMON LAW ( $3^{\text {rd }}$ ed., Stevens and Sons Ltd. 1892).
} 
Holmes, ${ }^{6}$ Domat, ${ }^{7}$ and of the drafters of the French Civil Code, ${ }^{8}$ to the 'fault plus strict liability' model most doctrinal authors accept today. ${ }^{9}$

From a historical standpoint, fault liability ${ }^{10}$ has been losing some ground as the dominant form of liability in Western legal systems. However, it remains to this day the default form of liability the core and centre of our tort law systems. Strict liability (in its modern form), by contrast, grew at the periphery of tort law and it exists today in pockets of specific and exceptional rules which have been gradually expanding in number and scope.

In the law of torts, the constant expansion of strict liability has had a significant impact on the practice of tort law: on how disputes are resolved, as well as on how rights and freedoms, and conversely duties and obligations, are defined and distributed. Dispensing with the requirement of proving fault, or removing fault issues entirely from the legal analysis of certain fact patterns, leads to a more favourable situation for victims, and because the fate of "doers" and "sufferers" is inextricably linked in the law of torts, ${ }^{11}$ the increased security and enlargement of the sphere of

\footnotetext{
${ }^{6}$ Oliver Wendell Holmes, The Common LaW (Dover Publications 1881 / Little, Brown and Company repr, 1923).

${ }^{7}$ JeAN DOMAT, 1 LeS LOIS CIVILES DANS LEUR ORDRE NATUREL; LE DROIT PUBLIC ET LEGUM DELECTUS 205-212 (Aîné Nyon 1777).

${ }^{8}$ P. A. Fenet, 13 ReCueil Complet des travaux PRÉParatoires du Code Civil 474 et seq. (Otto Zeller 1968).

${ }^{9}$ See Gerald J. Postema, Introduction. Search for an Explanatory Theory of Torts, in PHILOSOPHY AND THE LAW OF TORTS 1, 2 (Gerald J. Postema ed., Cambridge University Press 2001); Gregory C. Keating, A Social Contract Conception of the Tort Law of Accidents, in PhiLOSOPHY AND THE LAW OF TORTS 22, 30 (Gerald J. Postema ed., Cambridge University Press 2001): "The law of accidents is now, and long has been, divided between two basic principles of liability: negligence and strict liability"; Jules Coleman, Tort Law and Tort Theory. Preliminary Reflections on Method, in Philosophy AND The LAW OF TORTS 183, 185 (Gerald J. Postema ed., Cambridge University Press 2001): "The core of tort law is composed of structural and substantive elements. The substantive core is represented by its basic liability rules: fault and strict liability"; W. PAgE KeETON ET AL., PROSSER AND KEETON ON TORTS 31-32 ( $5^{\text {th }}$ ed., West 1984): "The fundamental basis of tort liability may first be divided into three parts - not because that number is traditional, but because every case in which such liability has been imposed has rested upon one of three, and only three, grounds for imposing it. These are: 1. Intent of the defendant to interfere with the plaintiff's interests. 2. Negligence. 3. Strict liability, 'without fault,' where the defendant is held liable in the absence of both intent to interfere with the plaintiff's interests and negligence."; RAYMOND YOUNGS, English, French \& German Comparative LaW 337 ( $2^{\text {nd }}$ ed., Routledge Cavendish 2007): "Liability [...] can be based on fault; or not based on fault, ie strict liability."; W. EDWIN PEEL \& JAMES GOUDKAMP, WINFIELD AND JOLOWICZ ON TORT 27 ( $19^{\text {th }}$ ed., Thomson Reuters 2014): "Despite the continuing dominance of fault liability, the English law of tort contains limited principles of strict liability with regard to personal injuries."; PHILIPPE LE TOURNEAU ET AL., DROIT DE LA RESPONSABILITÉ ET DES CONTRATS. RÉGIMES D'INDEMNISATION 7 (no 8$)\left(10^{\text {th }}\right.$ ed., Dalloz 2014) (distinguishing between liability based on "faute" and "les responsabilités objectives").

${ }^{10}$ In this study, by "fault liability" we mean those rules which attach reparative sanctions (usually the payment of damages) to behaviour which breaches a general duty of care. The normative benchmark against which the conduct of the defendant is measured in fault cases (in order to determine whether there is a breach) is a fictitious "reasonable person" who takes adequate precautions against harm in the given circumstances.

${ }^{11}$ ERnest J. WeinRIB, The IDEA OF PRIVATE LAW xiv (Oxford University Press 2012): "Liability consists in a finding that the parties are situated correlatively to each other as doer and sufferer of the same injustice."
} 
rights that comes with a shift toward strict liability automatically leads to a corresponding enlargement of the sphere of duties and obligations persons have in society.

Nevertheless, the fault plus strict liability theoretical model still has many unanswered questions. What is the basis of liability when fault is removed? Causation alone? The type of risk involved? The "dangerousness" of an activity? Or is the element of fault replaced by elements that do not have much in common? We can also look deeper into the elements of liability and ask: what are the underlying norms that inform our ascriptions of responsibility in strict liability cases? Can these norms be unified, generalized, or categorized, and how can they be best justified? Are the justifications of strict liability compatible with the justifications of fault liability? Can the overall fault plus strict liability model itself be justified? ${ }^{12}$

\section{B. The Aims of this Research}

This study aims to contribute to the larger debate on the foundations of tort strict liability rules, and thus also inform the exercise of developing national and trans-national rules of strict liability. ${ }^{13}$ It will do so by: first, clarifying and defining the concept of strict liability; second, examining the normative structures presupposed by strict liability rules; and third, providing a normative model of strict liability which will be integrated into a more general theory of responsibility and justice.

Legal scholars have been carrying out debates regarding when and to what extent strict liability rules ought to be enacted within the bounds of national law or within a defined legal tradition. ${ }^{14}$ This research was born out of a belief that there is a gap in legal scholarship that can only be filled

\footnotetext{
${ }^{12}$ While there is a great deal of scholarly work on the justifications of strict liability and the justifications of fault liability independently of each other, there seems to be no convincing account yet for the composite model we see in tort law practice. See Peter M. Gerhart, Tort Law and Social Morality 177 (Cambridge University Press 2010): "We have no theory or justification that would sustain our present mixed system of responsibility."

${ }^{13}$ So far, general strict liability principles have been addressed outside of national law only in the context of soft-law instruments. The PETL are one example, but one can also look at the Draft Common Frame of Reference (DCFR) project, prepared and drafted by the Study Group on a European Civil Code and the Research Group on EC Private Law (Acquis Group). The DCFR contains general strict liability norms in Book VI, Chapter III, Section 2 (Accountability without intention or negligence). See The Study Group on a European Civil Code and the Research Group on EC Private Law (Acquis Group), Principles, Definitions and Model Rules of European Private Law Draft Common Frame of Reference (DCFR), available online at http:/ec.europa.eu/justice/contract/files/europeanprivate-law en.pdf and http://ec.europa.eu/justice/policies/civil/docs/dcfr_outline edition_en.pdf (outline edition). ${ }^{14}$ Most of the time, authors from common law countries, like England or the United States, when writing on the topic of strict liability, generally give examples from foreign law as well, but usually only from other common law jurisdictions.
} 
by taking this debate outside of national law, and into the realms of comparative law and legal theory.

All the component parts of this study are ultimately built around an argument that a cogent understanding of strict liability in modern law should have a teleological foundation, and the telos (purpose) of strict liability rules should be the just reparation of interpersonal wrongs (corrective justice) and a just allocation of responsibility in society (distributive justice).

From an academic standpoint, it is the author's hope that this study will add something to our understanding of strict liability, by addressing the foundations of strict liability from a novel perspective, combining comparative research with a normative inquiry into the goals of tort law as a practice. From a more practical perspective, exposing the normative underpinnings of strict liability regimes and contrasting them with the normative foundations of fault liability regimes (the comparative aspect of the research) will hopefully clarify what is at stake when one regime is preferred over the other. Moreover, the normative argument and the framework it is based on may aid decision-makers in determining when and why stricter forms of liability should be resorted to. In the pursuit of these overarching goals, this study also aims to:

(1) identify the rules and the comparative domains of strict liability in the positive laws of France and England;

(2) define and classify the strict liability regimes previously identified;

(3) expose the normative content and inner structure of strict liability rules, by comparison to fault-based rules; and

(4) demonstrate that, within a framework where strict liability norms are justified on the basis of the aims of tort law as a practice, strict liability norms ultimately aim towards both corrective and distributive justice.

C. Methodology

To achieve these goals, three different methods of inquiry are used: The first method is doctrinal, consisting of a description of strict liability regimes from the perspective internal to the French and English legal systems; the second is comparative, looking at the commonalities of strict liability regimes in France and England, and their normative differences; and the third method is prescriptive (normative), consisting of providing an account of justice which, it will be argued, is 
already presupposed by most of the existing strict liability norms and may in turn justify their existence alongside fault-based tort law norms.

\section{Doctrinal and comparative methodology}

The objectives of the doctrinal and comparative parts of this research are to define the concept of strict liability and identify the domain of strict liability in the tort laws of France and England. This process of cataloguing, or mapping, strict liability regimes will be the groundwork for the formulation of generalizations about the existing normative structures of strict liability. In other words, the doctrinal narrative of the law of torts in France and England will be made with the purpose of identifying when, and for what kind of problems, strict liability rules are used in practice.

This exercise has many elements in common with Aristotle's method of political inquiry. The Philosopher first collected constitutions of various political structures in order to discover what form of constitution could be treated as a paradigm (ideal type), and in relation to which all other constitutions may be classified. ${ }^{15}$ In a similar vein, this study collects strict liability rules in order to determine an ideal type, and then categorizes all other forms of strict liability based on the deviations they present from the ideal form. This will allow us to formally conceptualize strict liability norms by explaining them in their relation to each other and to other (fault-based) liability rules.

Because the manifestations of strict liability are multiple and varied, Aristotle's inductive method (epagōge ), described above, proves very useful for conceptualizing this multifarious area of the law. The result will be that, from the perspective of comparative law, liability rules can be explained as ordered clusters which can be ranked on a spectrum. ${ }^{16}$ The rules of strict liability all cluster around an ideal type (where the prima facie case involves a showing of a non-behavioural wrong, causation, and damage; and a limited number of defences, including the victim's own fault). Most strict liability rules, it will be shown, are instantiations of the ideal type. There are,

\footnotetext{
15 See Alasdair Macintyre, Whose Justice? Which Rationality?, at 91 (University of Notre Dame Press 1988, repr. 2014).

${ }^{16}$ See Franz Werro, Vernon Valentine Palmer \& Anne-Catherine Hahn, Strict liability in European Tort Law: An Introduction, in THE BOUNDARIES OF STRICT LIABILITY IN EUROPEAN TORT LAW 3, 7 (Franz Werro \& Vernon Valentine Palmer eds., Bruylant/Staempfli/Carolina Academic Press 2004); Bernhard A. Koch \& Helmut Koziol, Comparative Conclusions, in UnifiCATIOn of TORT LAw: STRict Liability 395, 432-33 (B.A. Koch \& H. Koziol eds., Kluwer Law International 2002); Rogers, supra note 23, at 101; EUROPEAN GROUP ON TORT LAW, supra note 8, at 101; Vernon Valentine Palmer, Trois Principes de la Responsabilité sans faute, 39(4) R.I.D.C. 825, 827 (1987).
} 
however, also some strict liability rules that do not follow the ideal type but may, nevertheless, be explained by their relation to it ("absolute" forms of liability presuppose more limited defences, whereas fault-liability with a reversed burden of proof allows an additional defence - the defendant may escape liability by proving that he/she was not at fault).

A sufficiently large sample of rules of strict liability must be available in order to make the generalizations desired. That is why England and France have been selected. In Europe, they lie at opposite ends in terms of how fault and strict liability regimes are balanced. In other words, France and England represent two opposite poles within a spectrum of European diversity: in France, strict liability regimes have a broad scope, they occupy a significant part of the domain of tort law, and legal actors generally see the historical development of the law toward stricter forms of liability as a positive development; in England, however, strict liability regimes are narrow in scope, being out-shadowed by the tort of negligence, and the attitude of legal actors is one of distrust, the movement toward stricter rules of liability being regarded with suspicion. One author summarized the contrasting attitudes of the French and the English systems toward strict liability in a delightful and illuminating exaggeration: "[I]n France strict liability is seen as the basis of civilization, whereas in England it is considered a threat to (English) mankind". ${ }^{17}$ Working with two jurisdictions that are so different in their approach to strict liability allows for a better grasp of what is common and essential for strict liability regimes, and what the outcomes are when different rules are used. Most European jurisdictions fall somewhere in the middle of this spectrum which has France and England at opposite ends. ${ }^{18}$ Germany, for instance, seems to employ strict liability less than France, but more than England. ${ }^{19}$

Because France and England differ so much in their approach to strict liability, a problem-oriented version of comparative law functionalism ${ }^{20}$ will be used to supplement the conceptual phase of the

\footnotetext{
${ }^{17}$ Cees van Dam, Who is Afraid of Diversity? Cultural Diversity, European Co-operation, and European Tort Law, 20 KING's LAW JOURNAL 281, 288 (2009), also available online at http://www.ceesvandam.info/default.asp?fileid=460.

${ }^{18}$ For a good summary overview of the different approaches to strict liability in Europe see Werro, Palmer \& Hahn, supra note 16, at 26-32. See also the various national reports from UNIFICATION OF TORT LAW: STRICT LIABILITY

(B.A. Koch \& H. Koziol eds., Kluwer Law International 2002).

${ }^{19}$ See CeEs VAn Dam, EUROPEAn TORT Law 89-91 (2nd ed., Oxford University Press 2013).

${ }^{20}$ See especially Ralf Michaels, The Functional Method of Comparative Law, in THE OXFORD HANDBOOK OF COMPARATIVE LAW 339 (Mathias Reimann \& Reinhard Zimmermann eds., Oxford University Press 2006); Olivier Moréteau, Premiers pas dans la comparaison des droits, in JURILINGUISTIQUE: ENTRE LANGUES ET DROITS 419 (Jean-Claude Gémar \& Nicholas Kasirer eds., Thémis 2005); James Gordley, The Functional Method, in METHODS
} 
research. Ordering strict liability regimes into clusters and building a taxonomy allows us only to identify and order strict liability regimes in their various expressions, and conceptualize an ideal type of strict liability. It is, of course, also possible to compare the various fault and strict liability regimes with each other from the perspective of the values underlying the spectrum itself: freedom and security. From such a perspective, it is immediately apparent that strict liability regimes place more value on security, whereas fault liability regimes place more value on freedom. Very important comparative law work has been conducted already from the perspective of this balancing function, and it is not our intention to add much more to this body of comparative law literature. ${ }^{21}$ Instead, our comparative law exercise focuses on the normative function of tort liability. The aim is to identify normative similarities and differences between strict liability and fault-based liability rules. The main underlying assumption of this comparison is that tort law, first and foremost, does indeed have a normative function in the sense that it informs legal subjects of their duties toward others, as well as of what they are entitled to expect from others in return. Also, the type of functionalism the comparison is based on presumes that human beings generally experience and try to resolve similar (legal) problems, but may respond with different solutions. ${ }^{22}$

The starting point of the comparative analysis will be in the domain of strict liability rules, i.e. the types of problems which trigger the application of strict liability rules. Because French rules on strict liability are more numerous and more general, often the starting point will be the domain of a French strict liability rule. ${ }^{23}$ There are, however, also a small number of strict liability torts from England which do not have an obvious parallel in France, and for which functional equivalents

OF COMPARATIVE LAW 107 (Pier Giuseppe Monateri ed., Edward Elgar 2012). On functionalism and comparative law in a less restrictive sense and some of the critiques to functional comparative law, see also Konrad Zweigert, Des solutions identiques par des voies différentes (Quelques observations en matière de droit comparé), 18 REVUE INTERNATIONALE DE DROIT COMPARÉ [R.I.D.C.] 5 (1966); Béatrice Jaluzot, Méthodologie du droit comparé. Bilan et perspective, 57 R.I.D.C. 29, 39-41 (2005); John C. Reitz, How to Do Comparative Law, 46 Am. J. ComP. L. 617, 622-23 (1998); Günter Frankenberg, Critical Comparisons: Re-thinking Comparative Law, 26 HARV. INT'L. L. J. 411, 428-29, 434-40 (1985); Mathias Reimann, The Progress and Failure of Comparative Law in the Second Half of the Twentieth Century, 50 Aм. J. ComP. L. 671, 679 (2002).

${ }^{21}$ For a modern conceptualization of tort law as a practice concerned with the balancing of interests between injurers and victims see CEES van Dam, EuRopean Tort LAw (2 $2^{\text {nd }}$ ed., Oxford University Press 2013); The Comparative Conclusions of the European Group on Tort Law seem to reflect the same balancing function of tort law. See Bernhard A. Koch \& Helmut Koziol, Comparative Conclusions, in UnifiCation OF Tort LaW: STRICT LiABILITY 395 (B.A. Koch \& H. Koziol eds., Kluwer Law International 2002).

${ }^{22}$ Under Ralf Michaels' seven concepts of functionalism, the method used in this study fits well in the category of "finalism." See Ralf Michaels, supra note 20, at 345-47.

${ }^{23}$ We will demonstrate that even in cases where we have identified a strict liability rule in England that does not have, at first sight, a corresponding strict liability rule in France, the rules which are applicable are just as strict, if not stricter, than their English equivalent. 
will need to be identified. Irrespective of the starting point, this study will try to identify equivalent mechanisms serving the same or a similar normative purpose, i.e. mechanisms which cover, at least partially, the same or a similar domain as the strict liability rule in question.

Presuming the existence of a normative function opens up the space for comparing the normative content of tort law rules. Focusing on strict liability norms in particular, we will try to more specifically identify and contrast their normative content with that of fault-based rules covering a similar domain (where that is the case). Although we will also briefly discuss the types of problems where France and England have responded with the same strict liability regime or the same mix between strict liability and fault, the analysis focuses more on the types of circumstances in which one legal system employs strict liability and the other fault-based liability, because in such circumstances the normative similarities and differences reveal themselves more clearly.

To ensure that the generalizations made in this study stand on ground that is as solid as possible, the functional comparisons between France and England will be supplemented with the conclusions of the large-scale comparative law study on strict liability already conducted under the direction of the European Group on Tort Law in preparation for the PETL ${ }^{24}$ and the comparative law project based on the factual method of the Common Core of European Private Law $_{\text {project. }}{ }^{25}$

The comparative method thus employed allows us to identify common threads in the arguments supporting strict liability in the two jurisdictions selected for comparison. ${ }^{26}$ Two normative insights emerge from this exercise: (1) the inter-personal "wrong" triggering liability in cases of strict liability, unlike fault liability, is not described in terms of the defendant's behaviour; and (2) strict liability norms do not address the parties as individuals simpliciter (as is characteristically the case in fault liability), but as members of more narrowly defined communities.

\section{Normative methodology}

As already mentioned, pockets of strict liability regimes in the law of torts have multiplied, expanded in scope, and gained almost universal acceptance over the course of time from the

\footnotetext{
${ }^{24}$ Unification of Tort Law: Strict Liability (B.A. Koch \& H. Koziol eds., Kluwer Law International 2002).

25 The Boundaries of StRict LiabiLITY IN EuROPEAN TORT LAW (Franz Werro \& Vernon Valentine Palmer eds., Bruylant/Staempfli/Carolina Academic Press 2004).

26 Jan M. Smits, Redefining Normative Legal Science: Towards an Argumentative Discipline in METHODS OF Human Rights ReSEARCH 45, 52 (F. Coomans, F. Grünfeld, M. Kamminga, eds., Intersentia 2009); a working paper version is also available online at SSRN: https://ssrn.com/abstract=1411716Smits.
} 
participants in the practice (legislatures, lawyers, judges, academics, and private parties). There would be something very odd and suspicious in this evolution if it turned out that strict liability regimes did not fit well with the overall goals of tort law.

The intuition here is that strict liability rules survived and even flourished in the law over the centuries because they are just or, at the very least, because the participants in the practice of tort law regard them as such. ${ }^{27}$ If one is to take the concerns and arguments advanced by legal actors in the practice of tort law seriously, a better understanding of the differences between fault and strict liability regimes also brings accounts of justice into account which make no room for any type of responsibility for non-behavioural wrongs and do not address the community (or nonindividualistic) aspects of strict liability. The fact that all strict liability regimes share the two features we identified by comparing them to fault-based liability challenges, on their own terms, some of the most powerful and persuasive accounts of tort law produced thus far on the basis of the Aristotelian notions of corrective and/or distributive justice.

That is where the third method of inquiry comes in, which in essence is aimed not at explaining the concept of strict liability, but at providing a conception ${ }^{28}$ of strict liability within the practice of tort law. The main argument we advance is that the attributive norms underlying strict liability rules reflect and instantiate more general principles of both corrective and distributive justice. In other words, the doctrinal and comparative conclusions of this research will be integrated into a larger normative framework, which sets strict liability rules upon "the two fundamental concepts of justice on which all law (including therefore tort law and strict liability norms) ultimately rests":.29 distributive and commutative (corrective) justice. ${ }^{30}$

The formulation of the foundations of strict liability proposed in this study takes the form of an argument belonging to practical reasoning, which is presented from the ground up - from existing rules and practices toward first principles. The starting point of the account is therefore from within

\footnotetext{
${ }^{27}$ This sentence should not be read in the sense that each and every strict liability rule in particular is justified; the point is simply that there must be something that is common to strict liability rules, understood in a generic sense, which is just or is perceived as just by participants in tort law practice.

${ }^{28}$ For the concept - conception distinction see JOHN RAWLS, A THEORY OF JustiCE 5 (Harvard University Press 1971).

${ }^{29}$ JAmes Gordley, Foundations of Private LaW: Property, ToRt, CONTRACt, UnJust EnRICHMENT 8 (Oxford University Press 2006).

${ }^{30}$ The bridge between the exposition of what the law is in regard to strict liability and the normative criteria of justice is made in Chapter VII where we argue that the best telos (aim) for the law of torts is justice, understood in terms of both corrective and distributive justice.
} 
the system-based analysis of legal doctrine and the movement is upward, toward higher principles and values, with a particular emphasis on the demands of justice. This study therefore can be characterized as an exercise in "reflective ascent" 31 because it moves from within the confines and limits of the representations we have of the practice of strict liability in France and England, toward the more general perspectives offered by arguments regarding the overall goals of tort law in general. Under Neil MacCormick's "four quadrants of jurisprudence", 32 this is a study that moves from the quadrant of doctrinal law toward the quadrant of fundamental values and principles.

The account offered will be weakly coherentist, ${ }^{33}$ and resembles Rawls's method of reflective equilibrium. ${ }^{34}$ Its arguments are the product of "working from both ends", 35 a process of reasoning back and forth between beliefs shaped by the doctrinal analysis of strict liability (which has been attempting to organize and classify the cases that apply strict liability rules in the real world) and the formulation of general principles abstracted from day-to-day practice.

Moving from doctrinal law toward fundamental values and principles does not mean, however, that the foundations this study presents arguments for must necessarily, or perfectly, reflect the practice they justify. Any number of beliefs that form this account are revisable from both ends. Thus, if a better argument were brought forward to counter its assumptions, or if other expressions of strict liability or new developments in the world of legal practice were to give rise to new beliefs and force a revision of its assumptions, ${ }^{36}$ this account should be, in turn, either revised or abandoned. This work ought to be read as a contribution to a dialectical exercise, which will hopefully prove engaging for actors who shape tort law as a practice and as a science.

\footnotetext{
${ }^{31}$ On the distinction between "reflective ascent" and "reflective descent" see JAMES O. URMSON, ARISTOTLE's EThics 17 (Blackwell 1988); William LuCY, Philosophy OF Private LAW 11 (Oxford University Press 2007). ${ }^{32}$ D. Neil MacCormick, Four Quadrants of Jurisprudence, in PRESCRIPTIVE FORMALITY AND NormatIVE RATIONALity In MODERn LEGAL SYSTEMS. FeStSChrift FOR ROBERT S. SUMMERS 53 (Werner Krawietz et al. eds., Dunker \& Humbolt 2004).

${ }^{33}$ On coherentism in general see Peter Murphy, Coherentism in Epistemology, in THE INTERNET ENCYCLOPEDIA OF PHILOSOPHY, available online at http://www.iep.utm.edu/coherent/\#SH1b; On coherentism as a method for legal studies see Jaap Hage, Anything Goes: An Apology for Parallel Distributed Legal Science, 36 InFormaL LOGIC 271 (2016).

${ }^{34}$ RAWLS, supra note 28, at 46-53; John Rawls, Outline of a Procedure for Ethics, 60 PHILOSOPHICAL REVIEW $177-$ 197 (1951). See also Norman DANIELS, JustiCE AND JusTIFICATION: REFLECTIVE EQUILIBRIUM IN THEORY AND PRACTICE 21-46 (Cambridge University Press 1996); Norman Daniels, Reflective Equilibrium, in THE STANFORD ENCYCLOPEDIA OF PHILOSOPHY (Edward N. Zalta ed., 2016) available online at https://plato.stanford.edu/archives/win2016/entries/reflective-equilibrium/.

${ }^{35}$ Will Kymlicka, Contemporary Political Philosophy 67 (2 $2^{\text {nd }}$ ed., Oxford University Press 2002).

${ }^{36}$ It is therefore a "weak" form of coherence that I take as a standard. See Hage, supra note 33, at 277-78.
} 
On this note, it is also important to clarify that the normative argument we advance does not consist of a demonstration based solely on deductive logic. ${ }^{37}$ Some theoretical endeavours of explaining and justifying tort law rely on deductive logic alone, and conceptualize the day-to-day practice of tort law as a means to attaining a specified external aim. Under such an understanding, conclusions about the law getting things right, or being justified, characteristically take the form of how well tort law practice performs in achieving one or more defined pre-set goals. In approaching the area of tort law, authors employing this method first seek to determine what justice requires, and then only examine positive tort law institutions in order to determine whether they conform with the pre-set outcomes required by justice. ${ }^{38}$ This type of work was characterized by Jules Coleman as "top-down" legal theory. ${ }^{39}$ Efficiency theories of tort law characteristically employ such reasoning, the external goals of welfare maximization or cost reduction having the role of pre-defined external goals to which tort law generally conforms or must conform. ${ }^{40}$ Also, quite exceptionally, some proponents of a corrective justice understanding of tort law also theorize in this manner, grounding tort law practice in an external (moral) account of responsibility. ${ }^{41}$

\footnotetext{
${ }^{37}$ Joseph William Singer, Normative Methods for Lawyers, 56 UCLA L. REV. 899, 924 (2008-2009):

"Both our procedures for answering normative questions and the reasons we give to justify the rules we enforce are likely to involve controversial premises and a reasoning process that is far from a mechanical one. We need a form of normative argument that recognizes the complexity and plurality of our values and that allows for forms of moral reasoning and justification that are based on argument, persuasion, and rhetoric - not just logic." Id. at 929-30: "Perhaps reason can coexist with controversy and manage disagreement without abolishing it. Perhaps normative argument is not an enclosed deductive, self-evident system, but a form of practical reason or a means of living in the world, rather than a theoretical construct."

See also ERIC MacGilvRAY, ReConstructing Public ReAson 155 (Harvard University Press 2004):

"[J]ustification of a given end depends not on our ability to identify indubitable first principles that support it but rather on our ability to persuade others to act upon one set of uncertain beliefs rather than another."

38 Jules Coleman, Tort Law and Tort Theory. Preliminary Reflections on Method, in PhILOSOPHY AND The LAw OF TORTS 183, 184 (Gerald J. Postema ed., Cambridge University Press 2001).

39 Jules Coleman, Risks AND Wrongs 8 (Cambridge University Press 1992).

${ }^{40}$ For instance, Richard Posner's account of tort law sees the practice of tort law as welfare maximizing in just such a way: welfare maximization is the external end and tort law norms can be reconceptualized in light of such an aim and are justified only insofar as they advance it. Richard A. Posner, Utilitarianism, Economics and Legal Theory, 8 J. LEGAL STUD. 103, 104-05 (1979): "Normative economics holds that a policy, law, etc., is to be judged by its effect in promoting 'welfare'." Similarly, for Guido Calabresi, the goal of tort law is the reduction of accident costs, and tort law rules are efficient or inefficient only insofar as they lead to a reduction of accident costs. However, Calabresi also recognizes a place for justice in his theory, and even seems to subordinate accident cost reduction to the requirements of justice. See Guido CALABRESI, The Costs of ACCIDENTS: A LEGAL AND ECONOMIC ANALYsiS 24 ( $2^{\text {nd }}$ ed., Yale University Press 1970).

${ }^{41}$ Although Stephen Perry's account of corrective justice is non-consequentialist, he also seems to ground tort practice on his avoidability-based conception of outcome-responsibility. See Stephen R. Perry, Responsibility for Outcomes, Risk, and the Law of Torts, in PhiLOSOPHY AND THE LAW OF TORTS 72, 73 (Gerald J. Postema ed., Cambridge University Press 2001): "Outcome-responsibility thus conceived does not ordinarily give rise by itself to a moral obligation to compensate, although by normatively linking an agent to a harmful outcome it serves as the basis for such an obligation" (emphasis added).
} 
Tort theory, however, can also be built from a perspective internal to the practice. In such internal accounts, the practices which are constitutive of tort law norms aim towards more general principles of justice not as means to an already understood end, ${ }^{42}$ but as instantiations of those general principles in various concrete circumstances. The instantiations themselves determine, at least partly, how justice (as an end) should be understood. ${ }^{43}$ As a theoretical exercise it is therefore an exercise in the law's "self-understanding". ${ }^{44}$ Internal accounts pay more attention to the efforts of the various participants in the practice (the legal actors themselves) to reason in conformity with the requirements of justice and to construct or maintain a coherent practice. ${ }^{45}$ Explanatory models are built on the language, the structures, and the arguments of the actors who shape the practice, and justifications of tort law focus on its overall coherence. Tort practice, coherently reconstructed, is then able to determine its own ends, which ends in turn are reflected in concrete norms creating duties and entitlements, and legal decisions solving actual disputes. Principles of justice therefore play a different role in such normative theories. The law will get things right "when its particular determinations express and make known"46 the principles of justice which constitute its aims. What is just is not a priori known and then applied in individual cases: instead, principles of justice are formulated in vague terms, and represent higher-order generalizations which reflect and are built from reflection on individual cases. In the Aristotelian tradition of legal theory, in particular,

\footnotetext{
${ }^{42}$ Martin Stone, The Significance of Doing and Suffering, in PHILOSOPHY AND THE LAW OF TORTS 131, 164 (Gerald J. Postema ed., Cambridge University Press 2001).

${ }^{43} I d$.

${ }^{44} I d$.

${ }^{45}$ External accounts often bypass the reasons, arguments and the language used by participants in the practice, and attempt to rationally reconstruct the practice on the assumption that participants in the practice have been unconsciously pursuing certain goals. Richard Posner's account of economics and the law is a very good example and, in a sense, paradigmatic, because the participants to the practice of law usually do not employ economic language and do not consciously follow models of welfare maximization. See Richard A. Posner, The Economic Approach to Law, 53 TEX. L. REV. 757, 763 (1975): “A second important finding emerging form the recent law and economics research is that the legal system itself - it's doctrines, procedures, and institutions - has been strongly influenced by a concern (more often implicit than explicit) with promoting economic efficiency. The rules assigning property rights and determining liability, the procedures for resolving legal disputes, the constraints imposed on law enforcers, methods of computing damages and determining the availability of injunctive relief-these and other important elements of the legal system can best be understood as attempts, though rarely acknowledged as such, to promote an efficient allocation of resources." (emphasis added).

${ }^{46}$ Stone, supra note 42 . at 167.
} 
the law's aims are identified with principles of corrective and distributive justice, which play an ordering and interpretive role, ${ }^{47}$ instead of grounding the practice in some external aim. ${ }^{48}$

The account that follows belongs to the latter, "bottom-up" tradition of tort theory, in which many authors, including Ernst Weinrib, Jules Coleman, Martin Stone, and James Gordley, have already made significant contributions in different ways. ${ }^{49}$ It begins from within the practice of tort law as a dynamic socio-historical reality which evolved to its current form in a relatively spontaneous manner, through a long process of trial and error, involving multiple actors trying to reconcile multiple values. ${ }^{50}$ Practical reasoning, how people actually live in their communities, and the shape of their social practices play a particularly important role in this tradition of inquiry. We would not have any conception of justice as an end without actual people seeking or imparting justice, ordering their lives and organizing their communities in such ways so as to create social facts ${ }^{51}$ organized around principles of justice. I believe it is not unreasonable to assume that the actors involved in shaping tort law as a practice see, and have seen for a long time, justice as an essential goal of their activity. ${ }^{52}$ If this assumption is correct, it would be unwise to ignore the specification of justice in actual disputes and the progressive articulation of higher-level principles of justice by those who shape the practice of tort law themselves (judges, legislators, legal academics, and the parties themselves, with their counsel). That is why the proliferation of strict liability in the laws of both France and England needs to be taken seriously. Theories of tort law which do not account for what is common in all the cases which involve strict liability norms suspiciously ignore the

\footnotetext{
${ }^{47}$ Gerald J. Postema, Introduction. In search for an Explanatory Theory of Torts, in PHILOSOPHY AND THE LAW OF TORTS 1, 5 (Gerald J. Postema ed., Cambridge University Press 2001).

${ }^{48}$ See Coleman, supra note 38, at 192: "Tort law is a transparent realization of principle, not an instrument in the pursuit of an external and hidden goal."

${ }^{49}$ Many more authors have contributed to this tradition of inquiry, and I have tried to give credit and mention the work of all those authors whose work I was able to get familiar with thus far. However, I have dedicated more space to responding and moving forward the arguments of these four authors, mainly because they very clearly articulate a position I can contrast with my own, while building upon a similar methodology.

${ }^{50}$ Jan Smits argued, in a more abstract way and in a different context, that national and European private law, and perhaps even legal systems in their entirety, have evolved and should evolve in such a spontaneous manner. Jan M. Smits, European Private Law: A Plea for a Spontaneous Legal Order, in EUROPEAN INTEGRATION AND LAW 55, 75 78, 86-87, 98 (Deirdre M. Curtin, Jan M. Smits et al. eds., Intersentia 2006).

${ }^{51}$ For a detailed account of "social facts" and their ontology see John R. SEARLE, The COnSTRUCtion OF Social Reality (The Free Press 1995); John R. Searle, Making the Social World (Oxford University Press 2010).

${ }^{52}$ Sometimes judges make it explicit that they aim at developing tort law coherently with justice as an aim. See, e.g., Fairchild v Glenhaven Funeral Services Ltd \& Others [2002] 3 All ER 305, para. 32 (per Lord Bingham of Cornhill): "The law must be developed coherently, in accordance with principle, so as to serve, even-handedly, the ends of justice."
} 
intuitions of many generations of jurists which have been shaping this large and, (it will be shown) ever-expanding body of rules.

\section{Assumptions and Limitations}

Two sets of boundary conditions limit the scope of this research. On the one hand, at the doctrinal and comparative level, only two legal systems are investigated: France and England. Within each jurisdiction, a further limitation has to do with the subject-matter discussed: this study focuses only on the law of torts, and within the law of torts, specifically on strict tort liability regimes. There are strict liability rules in other areas of the law as well (notably criminal law and contract law) and even in some non-legal normative systems (to give a few mundane examples from sport games, the offside rule in football or the rules dictating how chess pieces may be moved in a chess game are also strict, in the sense that in both cases considerations of fault do not come into play).

There are also a number of limitations within the deeper levels of the argument, that is, a set of boundary conditions of the normative framework in which the argument is set. These limitations consist of a number of beliefs and assumptions which will be taken for granted and will not be further justified.

First, it is assumed that achieving corrective and distributive justice are indeed worthwhile goals for the law, and that reasons which value justice are good reasons for the law. This is not a selfevident truth. ${ }^{53}$ It would take another book to engage in a debate about the link between law and justice in a way that is not superficial. It is not uncommon though for ethical and legal theory to have such a starting point. ${ }^{54}$ John Rawls, for instance, begins his Theory of Justice with the same assumption, masterfully phrased: "Justice is the first virtue of social institutions, as truth is of systems of thought". 55

Second, although not fully spelled out in this study, a more general account of the good life is implicit in its tenets. As already mentioned, this research builds on an Aristotelian account of

\footnotetext{
${ }^{53}$ For some philosophers, for instance, the standard for justice is whatever a sovereign declares it to be. See, e.g., Thomas HobBes, LeViathan 163-64, 207 (Oxford University Press, repr. 1929).

${ }^{54}$ See Postema, supra note 9, at 8: "there is wide agreement among legal philosophers that justice is the relevant moral concept around which the theory should be constructed" (referring to moral theories of tort practice).

${ }^{55}$ RAWLS, supra note 28 , at 3.
} 
justice, ${ }^{56}$ with its two forms: corrective and distributive justice, ${ }^{57}$ and thus also shares a good number of the assumptions inherent to the Aristotelian tradition of moral inquiry. ${ }^{58}$ All writers belonging to this tradition, for instance, share the belief that "there is a distinctively human life to which all one's capacities and abilities contribute". ${ }^{59}$ The moral life thus conceived can be attained only by the perfection of the virtues - a set of abilities which can be educated, and the exercise of which is seen as necessary and central to such a life. ${ }^{60}$ But the argument of this study does not go that deeply into the foundations of the Aristotelian tradition. A great deal of attention will be paid to the virtue of justice, and the relationship between corrective and distributive justice, but not so much to the relationship between justice and the Aristotelian conception of the good (or flourishing) life.

The account that follows can safely be characterized as a mixed and pluralist account of tort law and strict liability because its key argument is that tort law as a whole, and strict liability in particular, are best understood in terms of both corrective and distributive justice. What corrective and distributive justice require of tort law and how exactly the two notions relate to each other and to the norms of tort law are discussed in detail in Chapter VII. However, the discussion of distributive justice will be in a sense incomplete, being focused almost exclusively on the distribution of responsibilities (burdens) in society, and much less on the distribution of powers (goods ${ }^{61}$ ). For the most part, the distribution of powers will be taken as already given, as it happens to be distributed nowadays in the two legal systems we discuss.

What is meant by "distribution of power" is how various entitlements are distributed by the norms defining what persons have power over in a given society, as well as how and by whom those

\footnotetext{
${ }^{56}$ Permeating the discussion on the coherence of strict liability practices with the goals of tort law and the goals of responsibility practices is an underlying Aristotelian conception of justice oriented towards eudaimonia, or human flourishing. Therefore, because the telos of all persons under Aristotle's account is human flourishing or eudaimonia, the same goal must also be pursued by legal systems and legal institutions.

Eudaimonia is very often translated as "happiness" (See Aristotle, Nicomachean Ethics I.4, in THE BASIC WORKS OF ARISTOTLE 935, 937 (Richard McKeon ed., The Modern Library 2001), but the translation "human flourishing" is preferable. See Gregory Alexander, Ownership and Obligations: The Human Flourishing Theory of Property, 43 HONG Kong LAW JOURNAL 451, 453 (2013), also available online at http://scholarship.law.cornell.edu/cgi/viewcontent.cgi?article $=2200 \&$ context $=$ facpub

${ }_{57}$ Aristotle, Nicomachean Ethics, supra note 56, V.2-6, at 1004-14.

${ }^{58}$ For a very good account of Aristotelian rationality and ethics see MACINTYRE, supra note 15, at 88-209.

59 James Gordley, Foundations of Private LaW: Property, Tort, CONTRACT, UnJust EnRichment 7 (Oxford University Press 2006).

${ }^{60}$ See Alasdair MacInTyre, After VirTue 174 ( $3^{\text {rd }}$ ed., Bloomsbury 2007, repr. 2011).

${ }^{61}$ Aristotle discusses distributive justice only in light of how goods ought to be distributed in a just society. See Aristotle, Nicomachean Ethics, supra note 56, V.2, at 1005-06.
} 
powers may be acquired. The existing distribution of power is taken as a given not because it is assumed to be just, but because of the limitations of our subject-matter: the norms of tort law do not comprehensively define or distribute powers. It is generally the province of other areas of the law to deal with broader questions of the distribution of power: property law, family law, constitutional law, human rights law, and others. In the field of private law, property law dominates the discussion of distribution of powers because the norms of property law define the powers we have over things, corporeal and incorporeal, and how such powers may be validly acquired. But other areas of private law, such as family law, may also define some ways of acquiring power, not over things, but over others: for instance, by norms defining parental authority and prescribing the conditions for acquiring it. A great number of norms dealing with the distribution of power can also be found within various fields of public law, especially in constitutional and human rights law. These areas of the law seem to be concerned preponderantly with protecting and recognizing powers which we have over ourselves and our actions. The term "freedoms" is most often used to express these powers. Our modern liberal democracies define and prescribe broad powers of action which receive legal protection: for instance, the norms protecting freedom of speech, freedom of movement, freedom of establishment, and others. In fact, at the constitutional level, the broadest possible form of individual autonomy is taken as a default in modern liberal legal systems.

The norms of responsibility define what a person ought to do in a specific set of circumstances. They are superimposed, on top of a background contoured by a broad principle of autonomy and a numerus clausus of property rights (which a legal system will define and protect). This background of default autonomy and special rules of responsibility is sometimes expressed in principles like: "everything that is not forbidden is permitted". ${ }^{62}$ By corroborating the norms defining and attributing powers with the norms of responsibility, one can then determine what a person may do in a given set of circumstances. This link between norms defining powers and norms of responsibility can be exemplified, for instance, in the law of negligence. The principle of fault in the law of negligence makes a person responsible for behaviour which is unreasonable, under an objective standard, and which causes damage to another person. This principle entails a large number of norms of responsibility dictating what persons ought to do or ought not to do in

\footnotetext{
${ }^{62}$ For instance, this broad principle is considered a first-order constitutional principle of English law. See, e.g., (Sir) John Laws, The rule of reason - an international heritage, in JUDICIAL REVIEW IN INTERNATIONAL PERSPECTIVE: LiBER AMicorum in Honour OF LoRd Slynn OF HAdLEy 247, 256 (Mads Andenas \& Duncan Fairgrieve eds., Kluwer Law International 2000).
} 
certain sets of circumstances. But what is also entailed in the principle of fault is that, as a general rule, a person is always free to act reasonably. Moreover, a person may even act unreasonably as long as another person does not suffer damage. Similarly, in the law of property, a general set of norms of absolute power over things, expressed in the principles and attributes of ownership, are curtailed by a set of norms of responsibility limiting what a person may do with his/her property (the principles pertaining to the law of negligence, the law of nuisance, legal servitudes, abuse of rights, etc.).

The link between norms of distribution of power and norms of responsibility may also take a relational form of interdependence. For this reason, the distribution of power can only be taken as a given "for the most part." All tort law norms are relational. They encapsulate duties which have correlative entitlements, and remedial obligations which imply the existence of correlative rights. In fact, any tort law relationship can be explained from "the power side" of the relationship, as well as from the "duty side." For instance, the norm allowing a person to claim exclusive ownership or exclusive possession over a piece of land would be a norm that creates or recognizes a power. However, this is the kind of power that requires the existence of a set of responsibility norms of exclusion, and such powers of exclusion sometimes translate into prohibitions imposed on others to enter the land over which the first person has exclusive power. In other words, a tort such as trespass to land is simultaneously expressive of a permissive norm which allows a person to engage in a large number of activities on his/her land with the exclusion of everybody else and a responsibility norm telling all others that they ought not trespass on that land.

To conclude, a complete and satisfactory argument regarding the right distribution of power in the law is most certainly not advanced, but a reference to power distributions in our account is unavoidable. Although the just distribution of responsibilities is the focal point of our account, the obvious links and interdependencies with norms distributing power will make it necessary to discuss, at least in passing, some related legal rules from outside of the law of torts.

\section{E. Potential Objections}

Three potential objections can be raised against an internal, bottom-up, and Aristotelian approach to theorizing about tort law. First, it could be argued that justifying a practice like tort law on the basis of its own internal coherence is a weak justification: what if tort law as whole, i.e. the practice itself, is unjustified? Second, one may contend that there is not enough distance 
between corrective and distributive justice, on the one hand, and the practice they justify (tort law), if the practice itself is constitutive of corrective and distributive justice. In other words, this justification of tort law, the argument goes, is tautological. And finally, it may also be argued that the progression of the argument from doctrinal descriptions of the law toward first principles is fallacious because such an argument, by necessity, draws ought conclusions from is premises.

Starting with the first argument - that justifying strict liability norms solely on the basis of tort law's internal coherence does not provide a complete justification ${ }^{63}$ - the concern here is that the practice of tort law as a whole may be unjustified. What if there are other social practices or other ways of constructing a practice like tort law in a way that will be better suited for achieving the same aims? Or, to take the argument to a more radical position, what if the law of torts is dysfunctional (is unable to achieve its ends with the means constitutive of the practice, like, for instance, the practice of rain-dancing) or is based on pure superstition (like, for instance, the practice of witchcraft)? In both cases, tort law practice should be abandoned as a whole, either because a better alternative is available or because it is simply an irrational practice.

It should be pointed out from the outset that the argument is perfectly valid. Of course, justifying liability norms on the basis of the aims of tort law allows for the possibility to argue that tort law, as a whole, is not a justified practice. An account which assumes that the practice of tort law itself is justified fails to show how the practice of tort law and the principles of justice it aims to reflect fit into a more general theory regarding the good (or flourishing) life.

However, the objection has no impact on the value of any type of "middle-level theory" 64 of the law. There is nothing wrong with a division of labour between theories attempting to coherently interpret (or construct) a practice, and grand theories constructing wider political and moral frameworks in which the practice may, or may not, have a place. In this study, as has already been pointed out, the relationship between corrective and distributive justice and the good life are taken for granted. ${ }^{65}$ It can be conceded that the present account speaks primarily to those who already believe that tort law is a justified practice. However, the research and the conclusions of this study

\footnotetext{
${ }^{63}$ See Stone, supra note 42, at 169-70 (raising this point and defending his own conception of tort law as corrective justice against it).

${ }_{64}^{64}$ JULES L. Coleman, Risks AND Wrongs 8 (Oxford University Press 1992, repr. 2003): “In middle-level theory, the theorist immerses herself in the practice itself and asks if it can usefully be organized in ways that reflect a commitment to one or more plausible principles."

${ }^{65}$ Supra sub-section D.
} 
may also prove useful to sceptics, although perhaps only to radical tort reformists, and not to any sceptic who believes that tort law is an entirely dysfunctional or superstitious practice (in any event, to this author's knowledge, no legal scholar has claimed that tort law is an irrational practice). While this study lacks the resources to convincingly answer radical tort law reformists ${ }^{66}$ without moving the argument to a higher level, it may nevertheless, in a more indirect way, still prove useful to those who contemplate radical tort law reforms. Internal accounts have the potential to improve our understanding not only of selective instantiations of tort law practice but also of its aims (expressed as higher-order principles). A novel or better understanding of the structure and goals of tort law will highlight what is of value in it, and implicitly show what would be lost should any radical reform actually replace parts or the whole of tort law.

The second objection is that there is not enough conceptual distance between justice, on the one hand, and the practice of tort law, on the other, if the various instantiations of the practice are constitutive of the very notions of justice that explain or justify it. ${ }^{67}$ Two distinct arguments can be brought against this objection. The first is that the practice of tort law is only partly constitutive of corrective and distributive justice, and therefore the requirements of corrective and distributive justice are built from the law as a whole and beyond, and not only from tort law practice. The two principles of justice are therefore not identical, descriptively or normatively, with the practice of

\footnotetext{
${ }^{66}$ For examples of arguments proposing such radical reforms see, e.g., PATRICK S. ATIYAH, THE DAMAGES LotTERY (Hart Publishing 1997); Patrick S. Atiyah, Personal Injury in the Twenty-First Century: Thinking the Unthinkable, in Wrongs AND Remedies In the TweNTY-First Century 1 (Peter Birks ed., Clarendon Press 1996); PAtrick S. ATIYAH, ACCIDENTS, COMPENSATION AND THE LAW (Weidenfeld and Nicholson 1970) (arguing that the English tort system ought to be replaced by a first party insurance scheme); L. Mourgeon, Pour la suppression de la responsabilité civile en cas d'accident et son remplacement par l'assurance de dommage, JCP 1981.I.3050 (making the same argument for a first party insurance scheme, but for the French legal system). See also Steven Sugarman, Doing away with tort law, 73 CAL. L. REV. 555 (1985). Radical tort law reform projects have generally been ignored national legislatures. De lege lata, the only good example of a wide-ranging and radical reform of tort law comes from New Zeeland. In New Zeeland, tort law was abolished and replaced in 1974 by a comprehensive accident compensation scheme which operates on a no-fault basis, providing compensation for injuries resulting from any type of accident, even if the accident is a consequence of the victim's own fault (with the exception of intentionally self-inflicted injuries and suicide). For more information on New Zeeland's compensation scheme see GEOFFREY W.

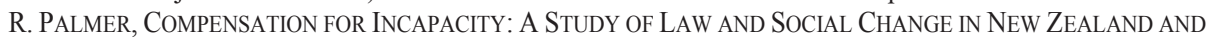
Australia (Oxford University Press 1979); TerenCe G. Ison, ACCident Compensation: A Commentary on the New Zealand Scheme (Croom Helm 1980); Lewis N. Klar, New Zealand's Accident Compensation Scheme: A Tort Lawyer's Perspective, 33 U. TORONTO L.J. 80 (1983); Geoffrey W. R. Palmer, New Zealand's Accident Compensation Scheme: 20 Years on, 44 U. TORONTO L.J. 223 (1994); IAN CAMPBELL, COMPENSATION FOR Personal InJury In New Zealand: Its Rise AND Fall (Auckland University Press 1995), and Stephen Todd, Privatization of Accident Compensation: Policy and Politics in New Zealand, 39 WASHBURN L.J. 404 (2000); Ken Oliphant, Landmarks of No-Fault in the Common law, in SHiFTS IN COMPENSATION BETweEn PRIVATE AND PubliC SYSTEMS 43, 68-75 (Springer 2007).

${ }^{67}$ Again, Martin Stone's argument in defence of corrective justice has been key to my own understanding of this problem. See Stone, supra note 42, at 165-68.
} 
tort law. The second argument is that the objection is premised on a specific, consequentialist, understanding of the law's instrumentality, and presupposes that there is an acceptable distance between the law and its ends only when its ends are specifiable independently of the practice as a state of affairs which the practice should bring about. ${ }^{68}$ However, legal practice can also be rationalized in non-instrumental ways, and even instrumental accounts need not necessarily follow a consequentialist logic. Particular legal norms can be understood as instantiations of general (and perhaps even vague) principles of justice, instead of more or less efficacious means of bringing about certain consequences. There is much to be gained in studying a philosopher who does not share the consequentialist instrumentalism this objection takes for granted. Understanding justice in teleological, but not consequentialist, terms is a defining characteristic of the Aristotelian tradition of moral and legal theorizing. ${ }^{69}$ Aristotle's own formulations of corrective and distributive justice are so vague ${ }^{70}$ that they can only be understood as rationally reconstructed principles. Principles like "giving each person his due" (a shorthand formulation of distributive justice) or "injurers owe reparation to their victims for wrongfully caused injury" (corrective justice) ought to be understood as general and vague reconstructions of what it means to act justly. Particular instantiations of justice, taken together, aim at expressing and revealing the content of these principles ${ }^{71}$ in their application to real-life situations, but the decisions made in each individual instantiation are also, in turn, guided by such general principles of justice. And the same cane be said, by the way, for other normative concepts and principles used in the law. The law of torts is fraught with general and vague concepts such as "civil wrong", "reasonable person", "defectiveness of a product", or "proximate causation" which are able to guide judges in their decision-making, but only come to be truly known in their substance through their application in a large number of real-life situations.

The third potential objection is that the progression of the argument from doctrinal descriptions of the law toward first principles is fallacious, because such an argument draws ought conclusions from is premises. This argument, however, is unsound. When a legal study operates in the area between doctrinal law and fundamental values and principles, the "is/ought" divide never comes

\footnotetext{
${ }^{68}$ Stone, supra note 42 , at 166.

${ }^{69}$ See Alasdair Macintyre, Whose Justice? Which Rationality 113 (University of Notre Dame Press 1988, repr. 2014).

${ }^{70}$ Aristotle, Nicomachean Ethics 69-76 (1130a - 1134a) (2 $2^{\text {nd }}$ ed., Terence Irwin trans., Hackett Publ. Co. 1999) (referred to in this study as NE, followed by the Bekker number).

${ }^{71}$ Stone, supra note 42, at 167.
} 
into play. Operating within the bounds of doctrinal law and fundamental values and principles opens the door only to competing "oughts". The fact that this study has a starting point in legal doctrine and the end-point in fundamental principles of justice does not mean that any of its ought conclusions are derived from is premises. Although doctrinal scholars take an internal perspective on the law and adopt a mode of thinking which is shared with legal practice, ${ }^{72}$ one should not fall into the trap of believing that legal doctrine pronounces what the law "is", or that doctrinal scholars are "describing the law" as an empirical phenomenon. Doctrinal scholars engage in what has been called "rational reconstruction" in legal philosophy. ${ }^{73}$ Pre-theoretical legal phenomena are only a "chaotic flux of activity and process" "74 which are reconstructed by doctrinal scholars from fragments, and those fragments are then re-interpreted as parts of a "coherent and well-ordered whole". ${ }^{75}$ Doctrinal law thus ends up being not a description of how legal actors and decisionmakers actually behave, but an "ideal order" which decision-makers sometimes conform to, and sometimes do not. ${ }^{76}$ Therefore, the theoretical endeavour to reconstruct legal phenomena in a system-like manner cannot escape its own normativity, ${ }^{77}$ the norms belonging to the system being selected according to normative criteria and organized in a system-like manner and generalized according to principles which are also normative.

F. Summary of the Main Arguments

Two over-arching research statements summarize the arguments which are made in the following chapters:

(1) The first is that the concept of strict liability is best understood as a continuum of forms

\footnotetext{
72 Jan Smits, What is Legal Doctrine? On the Aims and Methods of Legal-Dogmatic Research, in RETHINKING LEGAL Scholarship: A Transatlantic Dialogue 207, 210-11 (Cambridge University Press 2017).

${ }^{73}$ Zenon Bańkowski, D. Neil MacCormick, Robert Summers, Jerzy Wroblewski, On Method and Methodology, in InTERPRETING STATUTES: A COMPARATIVE STUdy 9, 10, 18-24 (Dartmouth 1991); D. Neil MacCormick, Reconstruction after Deconstruction: A Response to CLS, 10 OXF. J. LEG. STUD. 539, 541-42, 556-58 (1990); See also Jack Balkin, Understanding Legal Understanding: The Legal Subject and the Problem of Legal Coherence, 103 YALE L. J. 105 (1993); M. P. Golding, Kelsen and the concept of 'Legal System', 47 ARCHIV FÜR RECHTS- UND SOZIALPHILOSOPHIE 355 (1961).

${ }_{74}^{74}$ MacCormick, supra note 32, at 57.

${ }^{75} \mathrm{Id}$.

${ }^{76} \mathrm{Id}$.

${ }^{77}$ Doctrinal scholars do aim at a descriptive account of the normative material they work with, and purport to be faithful to the legal material they draw upon. However, describing legal rules as a system is an act of reconstruction with a normative component. No matter how detached a doctrinal scholar might want to be from the normative realm of principles and values, due to the fact that the primary material he is working with is always "somewhat episodic and gappy, the way in which it is shaped and filled out in the descriptive account will necessarily draw on, and reveal, background normative assumptions." Bańkowski et al., supra note 73, at 22.
} 
of liability which depart from the classical idea of conditioning the obligation to compensation on the existence and proof of a behavioural wrong. ${ }^{78}$ The conditions of liability in cases of strict(er) forms of tort liability, at careful analysis, reveal normative structures where the wrong, if any is to be found, is not behavioural. Also, the kind of relationships that shape strict liability rules transcend the binomial format of obligorobligee (or plaintiff-defendant), being based on a nexus of obligations which link members of a group to each other or the members of two or more groups which may have colliding interests, which the law must balance.

(2) The second argument is that, due to the position occupied by tort law in modern legal systems, the aim of tort law is to achieve both corrective and distributive justice. The gist of the normative argument is that the law of torts is aimed at repairing wrongs (corrective justice), but that by defining wrongs it also looks to provide just distribution of (legal) responsibilities in society.

\section{G. Structure}

The structure of this study follows relatively closely the methodological steps described so far.

Chapters II and III present the law of strict liability, first in France (Chapter II) and then in England (Chapter III) from a doctrinal and historical perspective, with the aim of identifying the domain of strict liability rules. The rules of strict liability are presented in a historical-doctrinal narrative because tort law rules often come about from diverse sources and evolve in time. Their scope expands or contracts depending on the interaction between various sequences of legislative enactments and court decisions, and sometimes even through interactions with academic writing. Understanding what the law is now in regard to strict liability implies understanding the origin of the existing rules, their interplay within their own legal system, and the ideas that led to their ever-

\footnotetext{
${ }^{78}$ The idea of placing strict liability forms on a spectrum is not new in comparative law studies. See, e.g., Franz Werro, Vernon Valentine Palmer \& Anne-Catherine Hahn, Strict liability in European Tort Law: An Introduction, in The Boundaries of Strict Liability in European Tort LaW 3, 7 (Franz Werro \& Vernon Valentine Palmer eds., Bruylant/Staempfli/Carolina Academic Press 2004); Bernhard A. Koch \& Helmut Koziol, Comparative Conclusions, in UnificATION OF TORT LAW: STRICT LiABILITY 395, 432-33 (B.A. Koch \& H. Koziol eds., Kluwer Law International 2002); Rogers, supra note 23, at 101; EUROPEAN GROUP ON TORT LAW, supra note 8, at 101; Vernon Valentine Palmer, Trois Principes de la Responsabilité sans faute, 39(4) R.I.D.C. 825, 827 (1987).
} 
expanding ambit. The perspective of these two chapters is internal, in the sense that strict liability will be analysed and explained in the manner that a French or English jurist sees it.

This historical and doctrinal presentation is by no means exhaustive. Only the main lines in the development of strict liability are drawn, with a particular emphasis on significant shifts of paradigm triggered by the most important statutes and landmark cases. An exhaustive jurisprudential and statutory analysis would go well beyond the purposes of this research project. The reader is invited to look at the main lines of development and at the legal and historical proof of three main ideas: first, that the law of torts in general, and the ambit of strict liability within it, has been expanding continuously; second, that the doctrinal conceptualization of both fault-based liability and strict liability is strikingly similar in France and England; and third, that despite common concepts, the law of strict liability in practice operates very differently in these two legal systems, particularly in terms of scope. ${ }^{79}$

Chapter IV examines the concept of strict liability. The perspective of this chapter is taxonomical and comparative, the goal being to conceptualize strict liability from a perspective which still relies on the common conceptual apparatus of tort law as it has developed in France and England. Three essential commonalities between the tort law systems of France and England have allowed for such a conceptualization: (i) the general principles underlying fault liability rules in France and England are sufficiently similar: under fault liability, in both jurisdictions, a person is liable for conduct which falls below an objective standard (reasonable person or bonus pater familias); (ii) both French and English scholars define strict liability as liability irrespective of fault; and finally, and most importantly, (iii) in both France and England, arguments about liability are encoded into similar, and many times identical, prima facie elements and defences. Based on the different arrangements of prima facie elements and defences, we have been able to construct a taxonomy of strict liability rules, which also ranks strict liability rules based on their "strictness" (the stricter

\footnotetext{
${ }^{79}$ The scope of tort law differs, to some extent at least, when comparing France and England. For instance, state liability is seen as part of administrative law in France, while in England it is part of tort law. Also, at the periphery of tort law, where tort law intersects with social security law or contract law, there might be some very subtle differences between France and England. That is why, in order to facilitate comparisons in future chapters, certain aspects that are not seen as tort law matters within a legal system have been mentioned in passing, such as certain liability rules that belong to administrative law or contract law in France, or compensation schemes for England.
} 
rules being the more victim-friendly, while the less strict seem to come close or closer to the balance reached by fault-liability rules).

Chapter V presents the comparative law framework of this research in greater detail. The goal of this chapter is to identify a suitable tertium comparationis. We look for a point of outlook that goes beyond the internal perspective of the French and the English legal systems, but is nevertheless internal to the practice of tort liability, equitable wrongs, and responsabilité civile délictuelle. The framework for our comparisons must be familiar and recognizable for both the French and the English jurist, yet not bound to either of the two legal systems. To this end, the thesis we articulate in this chapter is that the social practices we associate with tort law, equitable wrongs, and responsabilité civile délictuelle share a common telos: the definition and correction of civil wrongs.

Chapter VI contains explicit comparisons between France and England in the areas of product liability, nuclear accidents, vicarious liability, nuisance (trouble de voisinage), trespass to land, damage caused by the acts of things, road traffic accidents, damage caused by animals, interference with movable property, and defamation. The goal of this chapter is to identify the main normative commonalities and differences between French and English law in situations where at least one of the two jurisdictions adopts a strict liability rule.

Chapter VII aims to integrate the concept of strict liability into an overarching normative framework. As mentioned earlier, this part of the research intends to develop a complex argument about the right purpose (telos) of strict liability norms. It is first argued that strict tort liability norms aim to achieve the same purpose as all tort law norms, and that the ultimate purpose of tort law norms is achieving justice in its two forms: corrective and distributive. It is then further argued that corrective justice and distributive justice are linked in the law of torts by the concept of wrongfulness, which opens up a space for arguments regarding the right distribution of duties and entitlements to penetrate the binomial structure of corrective justice.

Chapter VIII consists of a summary of our findings and concluding remarks. 
Chapter II 


\section{CHAPTER II}

\section{STRICT LIABILITY IN FRANCE}

\section{A. General Remarks}

France is a civil law jurisdiction. In a way, it is the archetypal civil law jurisdiction, in the sense that it ticks most of the boxes we usually associate with the civil law tradition. ${ }^{1}$ In France, legislation is seen as the most important source of law. ${ }^{2}$ Traditionally, the role of courts has been simply to interpret the law, and many judges see their role restricted to just that, even in cases regarding tort liability, where the creative role of jurisprudence is manifest. ${ }^{3}$ Under this view, courts do not make law.

Legal doctrine has also been traditionally seen as something other than a source of law, in the sense that doctrinal opinions are only persuasive and not mandatory. ${ }^{4}$ The role of scholars is to explain what the law is and present it in doctrinal form. Scholars are seen as "guardians of the temple", 5 not its builders.

Today, most French lawyers would nuance such statements because the courts have had an increasing role in shaping the law and the influence of legal scholars on the development of certain areas of the law is hard to refute. ${ }^{6}$ That being said, legislation is still the starting point within the

\footnotetext{
${ }^{1}$ Besides the primacy of legislation and the codified system of laws, emphasized in the text above, other "civilian" characteristics of the French legal system that are worth mentioning are: (a) the main method of reasoning, which is deductive, from general principles to particular cases; (b) the inquisitorial model of civil procedure; (c) judges are trained as "career judges", and not chosen from among experienced lawyers or voted into office; and (d) the very limited number of jury trials (restricted to serious criminal law matters in France). See H. PATRICK GLENN, LEGAL TRADITIONS OF THE WORLD 145 ( $4^{\text {th }}$ ed., Oxford University Press 2010). The taxonomy used by comparative law scholars sometimes refers to legal families, and not to traditions. See RENÉ DAVID, LES GRANDS SYSTÈMES DE DROIT CONTEMPORAIN 20-21, 29 et seq. (Dalloz 1966); (who placed France in the Romanistic-German family); KONRAD Zweigert \& HeIn KötZ, InTRODUction to COMPaRative LaW 74-131 ( $3^{\text {rd }}$ ed., Tony Weir trans., Oxford University Press repr. 2011 repr.) (for whom France is the main representative of the Romanistic legal family). ${ }^{2}$ PhilipPe MalinVAud, InTROdUCtion À L'ÉTUde DU DROIT 50 ( $12^{\text {th }}$ ed., LexisNexis/Litec 2008); See also http://www.legifrance.gouv.fr/Aide/A-propos-de-l-ordre-juridique-francais.

${ }^{3}$ See DAVID, supra note 1, at 123.

${ }^{4}$ JaQues Ghestin et Al., TRaité De Droit Civil. InTRoduction GÉNÉRAle 529 (4 $4^{\text {th }}$ ed., L.G.D.J. 1994) (The authors of this book do consider doctrine as a source of law lato sensu due to its indirect influence on the formation of legal rules); See also PhiLIPPE Jestaz \& Christophe Jamin, LA DOCTRINe (Dalloz 2014).

${ }^{5}$ Olivier Moréteau, Les professeurs de droits ne seraient-ils que les gardiens du temple?, available online at http://jurexpat.blog.lemonde.fr/2014/09/12/les-professeurs-de-droits-ne-seraient-ils-que-les-gardiens-du-temple/; OLIVIER MORÉTEAU, LE JURISTE FRANÇAIS ENTRE ETHNOCENTRISME ET MONDIALISATION 15-16 (Dalloz 2014). ${ }^{6}$ See the very open approach from PHILIPPE JeSTAZ, LeS SOURCES DU DROIT (Dalloz 2005).
} 
French legal nomos. In the French legal tradition, the preferred manner of presenting legislation is through codes, and France currently has around 75 such codes in force. ${ }^{7}$

The centrepiece of the French codification is the Code Civil, adopted in 1804, which contains the default rules of French private law (le droit civil or le droit commun). The French Civil Code follows Gaius's tripartite division of the law between persons, things, and actions (obligations), to which a short preliminary title was added. It is a code that attempts, systematically and comprehensively, to lay down the rights and obligations of persons, natural and legal, from their birth or creation, to their death or termination, and even beyond. It is the sedes materiae for the law of persons, the law of property, the law of contractual and non-contractual obligations, and the law of succession.

The default rules for the law of torts are to be found in the Civil Code. According to the logic of the Civil Code, these default provisions are part of the law of non-contractual liability. ${ }^{8}$ Noncontractual liability can result from two types of circumstances: (1) from quasi-contracts, when the act that triggers liability is licit (i.e. unjustified enrichment, payment of a debt not owed, and management of the affairs of another); and (2) from delicts (intentional wrongs) and quasi-delicts (negligent wrongs), when the act that triggers liability is illicit. ${ }^{9}$ In the Code Napoléon, as it stood in 1804, the whole law of torts was regulated through five civil code articles: 1382 to 1386 . All five articles are still in force, and the language of these articles has not been modified significantly since the entry into force of the code. ${ }^{10}$ However, due to the recent reform of the law of obligations, the numbering of the above-mentioned articles has changed. ${ }^{11}$ The most noteworthy modification

\footnotetext{
${ }^{7}$ See http://www.legifrance.gouv.fr/initRechCodeArticle.do.

${ }^{8}$ See FRENCH Civil CODE art. 1370.

${ }^{9}$ Muriel Fabre-Magnan, 2 Droit des obligations. Responsabilité Civile et Quasi-Contrats 2 (3rd ed., PUF 2007).

${ }^{10}$ See, however, the modifications made to art. 1384 through: Loi du 7 Novembre 1922 complétant l'article 1384 du code civil, published in extenso in the JOURNAL OFFICIEL DES ÉTABLISSEMENTS FranÇAIS DE L'OCÉANIE, 1

February 1927 , p. 80, available online at

http://lexpol.cloud.pf/document.php?document=307621\&deb=80\&fin=80\&titre=TG9pIGR1IDA3LzExLzE5MjI=; Loi du 5 Avril 1937 modifiant les règles de la preuve en ce qui concèrne la responsabilité civile des instituteurs et l'art. 1384 (paragraphe 5, dernier al.) du code civil relatif à la substitution de la responsabilité de l'État à celle des membres de l'enseignement public, JORF du 6 avril 1937, p. 3923; Loi du 4 Juin 1970 relative à l'autorité parentale, JORF du 5 juin 1970, p. 5227 ; Loi no 2002-305, 4 March 2002, relative à l'autorité parentale, JORF, 5 March 2002, p. 4161.

${ }^{11}$ The recent reform of the law of obligations led to this change in the numbering of the articles without affecting their language. See Ordonnance n 2016-131 du 10 février 2016 portant réforme du droit des contrats, du régime général et de la preuve des obligations, JORF n ${ }^{\circ} 35$ du 11 février 2016, texte $n^{\circ} 26$. An English translation can be found at www.textes.justice.gouv.fr/dossiers-thematiques-10083/loi-du-170215-sur-la-simplificationdu-droit12766/traduction-de-lordonnance-du-10-fevrier-2016-en-langue-anglaise-28998.html.
} 
made to this section of the Civil Code pre-dates the 2016 reform of the law of obligations, the most important substantive change having been the addition of articles 1386-1 to 1386-18 [now 1245 to $1245-17]^{12}$ which implemented the 1985 Product Liability Directive. ${ }^{13}$

It is important to mention that articles 1382 to 1386 [now 1240 to 1244] were initially designed to create a default system of liability based on fault alone. ${ }^{14}$ Article 1382 [now 1240] speaks of liability that results from intentional acts, and article 1383 [now 1241] extends the provision of 1382 [1240] to negligent behaviour. The following three articles, 1383-1386 [now 1242-1244], were initially seen as particular instances where the fault principle would also apply. ${ }^{15}$

Departing from this monistic system, first and foremost through the work of judges, who, in turn, were often inspired by academic work, the law of torts in France gradually changed its structure. Articles 1383-1386 [1242-1244] were reinterpreted, and the situations covered in these three articles now form instances of stricter, non-fault-based forms of liability. Because this evolution was exclusively jurisprudential, French tort law scholars have an easier time admitting the role of

\footnotetext{
${ }^{12}$ The implementation, and therefore modification of the Code, was done through Loi n ${ }^{\circ}$ 98-389, 19 mai 1998, relarding liability for defective products (relative à la responsabilité du fait des produits défectueux), JORF, 21 May 1998, p. 7744.

${ }^{13}$ Council Directive 85/374/EEC of 25 July 1985 on the approximation of the laws, regulations and administrative provisions of the Member States concerning liability for defective products, OFFICIAL JOURNAL L210, 07.08.1985, at 29-33.

${ }^{14}$ Bertrand-de-Greuille, Communication officielle au Tribunat, and Tarrible, Discours devant le corps legislatif, in

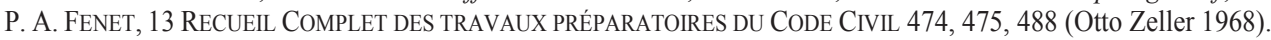
Credit is due to the French scholar Domat, whose writings were the main influence in shaping the Code-based system of tortious liability. In his Des lois civiles dans leur ordre naturel, Domat managed to rearrange the law as he found it in his century and to build a coherent system based on fundamental principles. JEAN DOMAT, 1 LES LOIS CIVILES DANS LEUR ORDRE NATUREL; LE DROIT PUBLIC ET LEGUM DELECTUS 205-212 (Aîné Nyon 1777); For a translation in English of Domat's treatise see JEAN DOMAT, 1 THE CIVIL LAW IN ITS NATURAL ORDER (Cuther S. Cushing trans., Little, Brown \& Co. 1853). The work of Domat is the mature expression of a process where the law of torts gradually took shape from a mixture of Roman law and Christian morality. GENEVIĖVE VINEY, INTRODUCTION À LA RESPONSABILITÉ 14 ( $3^{\text {rd }}$ ed., L.G.D.J. 2008). He was the first French author to enunciate the general principle of fault-based liability, but not the first European scholar to do so, being preceded in this by Grotius, who in turn was inspired by other earlier works from authors of the Spanish Salamanca school. VINEY, supra, at 16, n.42.

${ }^{15}$ VINEY, supra note 14 , at 23-24. One could argue maybe that there was one exception: the liability of employers for their employees. From the communication to the Tribunat delivered by Bertrand-de-Greuille, one can conclude that the liability of employers for their employees was designed to be stricter than the liability of parents for their minor children and of teachers and artisans for their students and apprentices. Bertrand-de-Greuille, Communication officielle au Tribunat, in P. A. FENET, supra note 14, at 476. However, the explanation provided by Bertrand-deGreuille puts a lot of emphasis on the fact that this type of liability is triggered by the employer's choice of employee, which seems to suggest that fault was the basis for liability even in this case. Id. A source that backs this interpretation of the original intent of the drafters of the Civil Code is Tarrible's discourse before the legislature, where he clearly and explicitly stated that the principle of fault is also the basis for the liability of employers for their employees. Tarrible, Discours devant le corps legislatif, in P. A. FENET, supra note 14, at 488.
} 
judges in the creation of law. Most of what is today the law of torts in France is judge made. ${ }^{16}$ That is not to say that the legislature played no role in shaping the landscape of the law. During the $20^{\text {th }}$ century, a long line of legislative enactments significantly contributed to adding new strict liability regimes. Thus, through the joint effort of judges and the legislature, the French law of torts evolved into a system where the background is still occupied by the fault principle, but on top of which a myriad of strict liability regimes arose and expanded. As we will later see, strict liability rules nowadays apply to so many situations that they somewhat overshadow the general principle of fault-based liability.

In order to see how the law reached this point, in the following, we highlight below a series of events that shaped the existing framework of the law of torts in France, starting with the enactment of the Civil Code (B), its subsequent reinterpretation (C), and the development of liability regimes outside the Code (D).

\section{B. The Enactment of the French Civil Code - Context and Ideology}

The history of the law of torts in France does not, of course, begin with 1804 and the promulgation of the Civil Code. The French law of torts is deeply rooted in Roman law, canon law, and the "barbaric" laws of the various medieval French territories. ${ }^{17}$ While it is true that the Code was intended as a break with the past, and repealed all prior laws the moment it entered into force ${ }^{18}$ the system laid down in the Civil Code was the result of a long evolutionary process which led to the separation of civil liability from criminal liability and to the unification of all causes of action in tort under one overarching principle: all liability is premised on fault. ${ }^{19} 1804$ is, however, also the starting point of a process of fragmentation of the law of torts that continues to this day, and the triggering events of this process best explain how existing strict liability regimes came into being in France. That is why, for the purposes of this study, the enactment of the Code Napoléon is an appropriate starting point.

As mentioned before, at the time of its enactment, the five articles of the Civil Code which dealt with liability for delicts were grounded in the notion of fault. The drafters of the Code had a

\footnotetext{
${ }^{16}$ See FABRE-MAGNAN, supra note 9, at 6.

${ }^{17}$ For an overview see VINEY, supra note 14, at 7-19.

${ }^{18}$ Loi du 30 Ventôse, an XII, Art. 7: “À compter du jour où ces lois sont exécutoires, les lois romaines, les ordonnances, les coutumes générales ou locales, les statuts, les règlements, cessent d'avoir force de loi générale ou particulière dans les matières qui sont l'objet desdites lois composant le présent code."

${ }^{19}$ VINEY, supra note 14, at 19.
} 
particular conception of fault in mind when the Code was adopted. The concept of fault was seen at that time as subjective and moral. Fault was subjective because the defect in behaviour that would trigger liability under the Code had to be proven to be the consequence of an improper state of mind: intent to do harm or negligence as to the results of one's actions. ${ }^{20}$ It was moral in the sense that the action, resulting from the actor's intent or negligence, was seen as a violation of moral imperatives. ${ }^{21}$ As a consequence, originally, under the Civil Code, the normative function of the law of torts was considered primary, and its compensatory function was only secondary. ${ }^{22}$ Thus, the action had to be morally imputable to the actor that committed it. ${ }^{23}$

The moralism of the principles of liability enshrined in 1804 in the Civil Code is particularly striking. This was a code written in the aftermath of the French Revolution and it bears the mark of a particular type of ideology and of the ambitions of the time. The various customs that formed the law of the Ancien Régime were to be replaced by a unified law (the Code). Inspired by the rationalism of the Enlightenment and shaped by the important influence of the school of natural law, the principles formulated in the Code were meant to express fundamental and immutable principles of justice, applicable to every man, in any society, at any given time. When examining the exposé des motifs presented by Treilhard, this becomes readily apparent, as he presented the texts on delictual liability as embodiments of "necessary" and "eternal" truths. ${ }^{24}$ One might think that these universal truths were the expression of a secular morality that the Enlightenment project

\footnotetext{
${ }^{20}$ Some authors define fault as "subjective" when it is determined in concreto, i.e. the standard used takes into consideration the personal characteristics of the author (theoretically, under such a standard a person could avoid liability for negligence for instance if he/she can prove a repeated pattern of similar clumsiness). See, e.g., Eric Descheemaeker, La dualité des torts en droit français. Délits, quasi-délits et la notion de faute, RTD Civ. 435, 446 (2010). In France, the dichotomy "subjective-objective" is more often used in reference to the internal structure of fault, not to its standard. More on point, fault is considered subjective by French jurists when the act is imputable to its author and objective when it is not. See GENEVIÈVE VINEY ET AL., TRAITÉ DE DROIT CIVIL. LES CONDITIONS DE LA RESPONSABILITÉ $689-690$ (4 ${ }^{\text {th }}$ ed., L.G.D.J. 2013) [the debate regarding the objective or subjective character of fault was triggered by the introduction of art. 489-2 (now 414-3, after being renumbered in 2007): "he who has caused harm to another while under the control of a mental disturbance is nevertheless obligated to provide reparation"(trans. Legifrance, available online at http://www.legifrance.gouv.fr/Traductions/en-English/Legifrancetranslations (last accessed on 5 May 2015))].

${ }^{21}$ See the reference to the tortfeasor's "conscience" in Treilhard's presentation of arts. 1382-1386, quoted in VINEY, supra note 14, at 23.

${ }^{22}$ VINEY, supra note 14 , at 76.

${ }^{23}$ The concept of imputation has the potential to reunite the moral and the subjective (psychological) elements of fault under one concept. See GÉrard CoRnu, VocabUlaire JuRIDIQUE 526, vo. Imputabilité (10 ${ }^{\text {th }}$ ed., PUF 2014); See also PAUL RicoeUR, Le JUSTE 43-51 (Esprit 1995).

${ }^{24}$ Treilhard, Présentation au corps législatif, et exposé des motifs, in P. A. FenET, supra note 14, at 464-468. See also, VINEY, supra note 14, at 21; See also OliviER DeSCAMPS, LES ORIGINES DE LA RESPONSABILITÉ POUR FAUTE PERSONNELLE DANS LE CODE CIVIL DE 1804 at 463 (L.G.D.J. 2005).
} 
was trying to construct: a morality based on the assumption that moral principles can be derived from certain psychological characteristics common to all persons. ${ }^{25}$ On that note, many have assumed that these immutable principles are also reflective of the individualism of the Enlightenment project. ${ }^{26}$ However, in spite of the claims to secularism that are characteristic of the French Revolution, the conception of fault that made its way into the Civil Code was never intended to be separated from Christian morality. Therefore, the concept of fault captured by the Civil Code was an expression of philosophical ideas that were "neither modern nor individualistic". ${ }^{27}$ Domat, whose text was the main source of inspiration for the five articles on tort liability, was clearly relying on a Christian conception of fault in his unifying theory. ${ }^{28}$ Moreover, although the Civil Code was mainly based on the secular ideas of the Enlightenment, references to Christian morality are also to be found in the preparatory works of the Civil Code. The following paragraph from Treilhard's exposé des motifs is illuminating in this regard:

\begin{abstract}
Binding arrangements of this type are grounded on those major principles of morality so profoundly engraved in the hearts of all men, that we ought to do unto others what we want others to do unto us in the same circumstances, and that we are bound to repair the wrongs and damages that we have caused. ${ }^{29}$
\end{abstract}

\footnotetext{
${ }^{25}$ For Immanuel Kant, for instance, the faculty of reason is what governs human behaviour. Thus, moral principles and intuitions are the result of the use of man's faulty of reason, and moral norms can be revealed by reason: the test of universalizability revealing moral norms as categorical imperatives. See IMMANUEL KANT, GROUNDWORK OF THE Metaphysics of MoRALs (Mary Gregor \& Jens Timmermann eds. and trans., Cambridge University Press 2012). The contrary approach is taken by the philosopher David Hume, for whom moral principles and intuitions are the result of man's desires, and not his reason. For Hume, moral judgment is not the prerogative of the acting agent, but of others, who cast their moral judgement, of approval or disapproval, upon the action of the agent. See DAVID Hume, A Treatise on Human NAture 297-311 (CreateSpace Independent Publishing Platform 2012). Both take for granted the ideas that either reason, or desire, are fundamentally the same in each person.

${ }^{26}$ See JeAn- Louis HalPerin, L'IMPOSSIBLE CODE CIVIL 51 (PUF 1992) ; RENÉ SAVATIER, LeS MÉTAMORPHOSES ÉCONOMIQUES ET SOCIALES DU DROIT CIVIL D'AUJOURD'HUI 6 ( $2^{\text {nd }}$ ed., Dalloz 1959).

${ }^{27}$ James Gordley, Myths of the French Civil Code, 42 AM. J. CoMP. L. 459, 479 (1994).

${ }^{28}$ According to Domat, it is the will of God himself (divine order) that gives rise to non-contractual liability. JEAN DOMAT, 1 LES LOIS CIVILES DANS LEUR ORDRE NATUREL; LE DROIT PUBLIC ET LEGUM DELECTUS 147 (Savoye 1756), available online at http://gallica.bnf.fr/ark:/12148/bpt6k117556w.r=Domat\%2C+Jean.langEN;

${ }^{29}$ Author's translation. The original text reads: "Les engagements de cette espèce sont fondés sur ces grands principes de morale si profondément gravés dans le cœur de tous les hommes, qu'il faut faire aux autres ce que nous désirerions qu'ils fissent pour nous dans les mêmes circonstances, et que nous sommes tenus de réparer les torts et les dommages que nous avons pu causer."

Treilhard, Présentation au corps législatif, et exposé des motifs, in P. A. FENET, supra note 14, at 465. See also VINEY, supra note 14, at 21.
} 
Other documents, such as the report written by Bertrand de Greuille for the Tribunat also demonstrate the central role moral principles played in shaping the articles on civil liability, ${ }^{30}$ and references to morality have been numerous in the discourses of the speakers who presented the Civil Code to the national assemblies. The speech delivered by Tarrible to the legislature stands out, as it seems to equate the legal responsibility envisaged by the code with moral responsibility:

In regard to damage caused... [t] his project deals exhaustively with the means to ensure the reparation of damage; and among these means, it puts in place a moral responsibility that is added to the vigilance of men charged with the sacred tasks of authority and that will prevent other disturbances .... ${ }^{31}$

To sum up, fault as a legal concept was, at the very least, inspired by fault in its moral sense, and this underlying idea of moral fault had profound Christian influences. Also, while it is most certainly an exaggeration to equate legal fault with moral fault at the time of the enactment of the Civil Code, Treilhard's exposé des motifs and Tarrible's speech to the legislature do not leave any room for liability based on anything other than fault. French doctrine is unanimous in reading the preparatory works of the Civil Code in the sense that fault was required also in cases covered by articles 1384-1386 [now 1242-1244]: liability of parents for their minor children, liability of educators for the students that are under their guard, of employers and artisans for their employees and apprentices, of owners for the damages caused by animals or the damage caused by dilapidated buildings $^{32}$ (buildings in a state of serious disrepair - la ruine des bâtiments). ${ }^{33}$

C. The Creative Re-interpretation of the Code's Articles by the Judiciary

The ambition of unity and perpetuity of fault-based liability under the provisions of the Civil Code was illusory. Formally the text of articles 1382-1386 [now 1240-1244] remained the same, but in substance, by the end of the $19^{\text {th }}$ century, most of them had been re-interpreted and

\footnotetext{
${ }^{30} \mathrm{Id}$.

${ }^{31}$ Authors translation. Tarrible, Discours devant le corps legislatif, supra note 14, at 491: "S'agit-il enfin de dommages causes ? Ce projet épuise tous les moyens d'en assurer la réparation ; et dans le nombre de ces moyens, il place une responsabilité morale qui doit redoubler la vigilance des hommes chargés du dépôt sacré de l'autorité et qui préviendra ainsi plus des désordres [...]."

32 The translation "dilapidated buildings" for "la ruine des bâtiments" is taken from Franz Werro et al., Strict Liability in European Tort Law: An Introduction, in THE BOUNDARIES OF STRICT LIABILITY IN EUROPEAN TORT LAW 3, 29 (Franz Werro \& Vernon Valentine Palmer eds., Staempfli Publishers, Carolina Academic Press \& Bruylant 2004).

${ }^{33}$ VINEY, supra note 14, at 23-24, quoting Treilhard and Tarrible with very explicit statements to this effect. See also PhILIPPE BRUn, RESPONSABILITÉ CIVILE EXTRACONTRACTUELLE 92-93 (2 ${ }^{\text {nd }}$ ed., LexisNexis - Litec 2009); DESCAMPS, supra note 24, at 464.
} 
their scope expanded through case law, and the work of re-interpretation continued throughout the $20^{\text {th }}$ century.

In practical terms, courts gradually expanded the definition of fault in the $19^{\text {th }}$ century, and thus the scope of fault-based liability, ${ }^{34}$ but eventually fault-based liability lost its moral and subjective dimension and its exclusivity. Today, the concept of fault is undoubtedly measured under an objective standard: one is at fault if his or her behaviour falls below the standard of a reasonable person. Arguably, even under the moral, Christian, view on fault that inspired articles 1382-1383 [now 1240-1241] of the Civil Code, fault was never a fully subjective notion, as its standard had always been the same objective one: that of a bonus pater familias. ${ }^{35}$ Still, the shift from subjective to objective in the area of fault had to do with the personal circumstances of the tortfeasor that are taken into account before applying the bonus pater familias standard, i.e. blindness, minority, insanity, etc. After a reform of the Civil Code in 1968 that declared adults without capacity liable for the damage they cause ${ }^{36}$ and a Court of Cassation decision from 1984 in which the court held that the capacity of a minor to understand the consequences of his or her act is not a requirement for fault, ${ }^{37}$ the vast majority of French scholars have been arguing that the element of fault has generally become purely objective. ${ }^{38}$

In addition to broadening fault-based liability, French tort law has also seen a permanent creation and expansion of the Code's strict liability regimes, and the following sections follow this evolution in more detail. Today it would not be an exaggeration to say that the domain of strict liability overshadows that of fault. Following the general lines of this development within the Civil Code, the following sections discuss the historical evolution of: (1) liability for the acts of things; (2) vicarious liability; (3) liability for defective products; and (4) the law of nuisance.

\footnotetext{
${ }^{34}$ RAYMOND SALEILlES, LES ACCIDENTS DE TRAVAIL ET LA RESPONSABILITÉ CIVILE. ESSAI D’UNE THÉORIE OBJECTIVE DE LA RESPONSABILITÉ DÉLICTUELLE 9-10 (Arthur Rousseau ed., Librairie nouvelle de droit et de jurisprudence 1897).

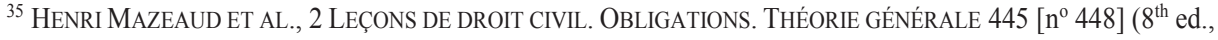
Montchrestien 1991).

${ }^{36}$ Loi n ${ }^{\circ} 68-5$ du 3 janvier 1968 portant réforme du droit des incapables majeurs, JORF du 4 janvier 1968, p. 114.

${ }^{37}$ Cass. Ass. Plén., 9 May 1984, Bull. ass. plén., no 4; D.1984.525, concl. J. Cabannes, note François Chabas ; JCP 1984.II.20255, obs. N. Dejean de la Bâtie ; JCP 1984.II.20291, Rapport Fedou; RTD. civ. 508 (1984), obs. J. Huet. ${ }^{38}$ Geneviève Viney, La faute de la victime d'un accident corporel : le présent et l'avenir, JCP 1984.I.3155; Henri Mazeaud, La faute objective et la responsabilité sans faute, D.1985.13 (Chron.).
} 


\section{Liability for the acts of things}

With regard to liability for the acts of things, the first instance of jurisprudential recognition of a strict liability regime came in 1862, when the reunited chambers of the Court of Cassation, on the basis of a law from 21 April 1810, ${ }^{39}$ ruled that the concessionary (concessionaire) of a mine is liable for damages caused to the surface, even when there was no negligence on his part. ${ }^{40}$ But this was a minor development, outside of the Civil Code. Within the Code, a few decisions opened the way for strict liability in cases of liability for the acts of animals, ${ }^{41}$ and liability for buildings in a state of ruin. ${ }^{42}$

Then came one of the most important developments in the French law of strict liability - the Teffaine case, decided in $1896 .^{43}$ In this case, the Court of Cassation creatively interpreted the first paragraph of art. 1384 [now 1242], which reads: "We are responsible not only for the damage caused by our own act, but also for that which is caused by the acts of persons for whom we are responsible, or by the things that are in our custody (emphasis added)" ${ }^{44}$ Initially, this paragraph was meant to be just an introductory text for the other paragraphs of the same article, and for articles 1385 and 1386 [now 1243 and 1244]. ${ }^{45}$ Hence, it had no normative value of its own. ${ }^{46}$ The Court of Cassation in the Teffaine case went against the original meaning of this text, thus developing a new general principle of liability for the acts of things, derogating from the general

\footnotetext{
${ }^{39}$ Nowadays, similar provisions can be found in art. 74 (1) of the French Mining Code.

${ }^{40}$ Cass, ch. Réun., 23 July 1862, D.1862.1.257.

${ }^{41}$ Cass. Req., 23 December 1879, S.1880.463 (creating a rebuttable presumption of fault); Cass., 27 October 1885, DP 1886.1.207; S.1886.1.33 (in this case the Court of Cassation ruled that the presumption of fault could be rebutted only by proof of a fortuitous event or the fault of the victim, which de facto makes the regime of liability for the acts of animals a strict liability regime).

${ }^{42}$ VINEY ET AL., supra note 20, at 874, no. 719. For a while, before 1896, when the Teffaine case was being decided, there was even a tendency to expand liability based on article 1386 to things that did not fit into the category of buildings. Id.

${ }^{43}$ Cass. Civ., 16 June 1896, D.1898.1.433, concl. Sarrut, note Saleilles; S.1897.1.17, note A. Esmein.

${ }^{44}$ The translation used is that provided by Legifrance, available online at http://www.legifrance.gouv.fr/Traductions/en-English/Legifrance-translations (Last accessed on 5 May 2015). In French, the text reads:"On est responsable non seulement du dommage que l'on cause par son propre fait, mais encore de celui qui est causé par le fait des personnes dont on doit répondre, ou des choses que l'on a sous sa garde." ${ }^{45}$ See Tarrible, Discours devant le corps legislatif, in P. A. FenET, supra note 14, at 488-89. MARCEL Planiol, 2

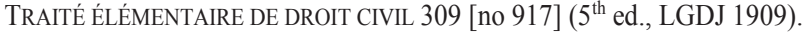

${ }^{46}$ Before this decision, at no point in French history had there been any pronunciation of a general rule regarding liability for all types of things, derogating from fault-based liability. The only special regimes recognized by the Code referred to liability for animals and the ruin of buildings, which had a long history, having been recognized even under Roman Law (as the action de pauperie and cautio damni infecti, the first applicable to damages caused by animals and slaves, and the second to damages caused by the ruin of a building). GENEVIÈVE VINEY ET AL., TRAITÉ DE DROIT CIVIL. LES CONDITIONS DE LA RESPONSABILITÉ 777 (4 ${ }^{\text {th }}$ ed., L.G.D.J. 2013).
} 
fault-based liability principle recognized by articles 1382-1383 [now 1240-1241]. ${ }^{47}$ The Court found that proof of a "manufacturing defect" (vice de construction) was sufficient to establish the liability of the owner of the thing in question (a boiler tug that exploded). ${ }^{48}$ It further stated implicitly that only force majeure or a fortuitous event would exclude the owner's liability in such case. $^{49}$

Just one year later, however, the Court of Cassation partially rejected what it had established in Teffaine. ${ }^{50}$ Whilst maintaining the general principle of liability for things grounded on article 1384 paragraph 1 [now 1242 paragraph 1], the Court decided that this article establishes only a rebuttable presumption of fault. ${ }^{51}$

In the context of this jurisprudential hesitation, the legislature decided to intervene to solve the problem of work accidents, and in 1898, a special law was adopted, designed to create a compensation system for work accidents. ${ }^{52}$ Needless to say, the new compensation system was not based on fault, ${ }^{53}$ but it also derogated from the general principle of full compensation, many provisions establishing a lump sum type of compensation, ${ }^{54}$ or caps on the amount of damages. ${ }^{55}$ This law was amended a few times ${ }^{56}$ and later incorporated in the Code of Social Security (Code de la sécurité sociale). ${ }^{57}$

As to the general rule, subsequent jurisprudence made it harder and harder for this presumption of negligence to be overturned, thus making liability for things de facto strict by the end of the 1920 's. ${ }^{58}$ In this context, in order to avoid a significant increase in insurance premiums for home

${ }^{47}$ Cass. Civ., 16 June 1896, supra note 43.

${ }^{48} I d$.

${ }^{49} \mathrm{Id}$.

${ }^{50}$ Cass. Req., 30 March 1897, S. 1987.1.71.

${ }^{51}$ Id. Other later decisions followed the same line of reasoning. E.g. Cass. Civ., 31 July 1905, S.1909.1.143; Cass.

Req., 29 April 1913, D.1913.1.427, rapport Jaffard.

${ }^{52}$ Loi du 9 Avril 1898 sur les responsabilités des accidents dont les ouvriers sont victimes dans leur travail, BULLETIN DE L'INSPECTION DU TRAVAIL, $\mathrm{n}^{\circ}$ 2, 1898, also available online at http://travailemploi.gouv.fr/IMG/pdf/Loi du 9 avril 1898.pdf.

${ }^{53}$ Art. 1 of Loi du 9 Avril 1898, supra note 52.

${ }^{54}$ E.g. art. 3 of Loi du 9 Avril 1898, supra note 52.

${ }^{55}$ E.g. art. 4 of Loi du 9 Avril 1898, supra note 52.

${ }^{56}$ For the various subsequent legislation that modified the law of April $9^{\text {th }}, 1898$, see http://www.legifrance.gouv.fr/affichTexte.do?cidTexte=JORFTEXT000000692875\&categorieLien=cid (last visited July 13, 2015).

${ }^{57}$ By way of Loi no 46-2426, 30 Octobre 1946 sur la prévention et la réparation des accidents du travail et des maladies professionnelles, JO 31 Octobre 1946, p. 9273.

${ }^{58}$ CLOTHILDE GRARE, RECHERCHES SUR LA COHÉRENCE DE LA RESPONSABILITÉ DÉLICTUELLE. L'INFLUENCE DES FONDEMENTS DE LA RESPONSABILITÉ SUR LA RÉPARATION 41 (Dalloz 2006). 
insurance, ${ }^{59}$ and as a response to a Court of Cassation decision from 1920, in which the Court ruled that neighbours may sue the owner of a building that caught fire on the basis of article 1384 [now 1242] of the Civil Code, ${ }^{60}$ two new paragraphs were added to article 1384 [now 1242] of the Civil Code, making liability for fire dependent upon proof of fault. ${ }^{61}$

A landmark decision followed on 13 February 1930, when the Court of Cassation ruled in the Jand'heur case. ${ }^{62}$ This was a traffic accident case, in which a minor child was hit by a truck owned by the defendant. ${ }^{63}$ The Court of Cassation brought two major changes to its previous jurisprudence: first, in interpreting article 1384 paragraph 1 [now 1242 paragraph 1], the Court referred in this case to a "presumption of liability", ${ }^{64}$ not a "presumption of fault", and the only way to rebut this presumption of liability was through proof of force majeure or of a fortuitous event; second, the Court of Cassation no longer required proof of any inherent defect of the thing and explicitly stated that the law makes no distinction between objects that move due to acts of a human being and objects that are moving without human intervention. ${ }^{65}$

Although at least one commentator still saw liability for the acts of things as being premised on a presumption of fault, ${ }^{66}$ the decision in Jand'heur was seen by many scholars, ${ }^{67}$ and most importantly by the courts, ${ }^{68}$ as creating a pure (de jure) strict liability regime, ${ }^{69}$ where fault was simply not an element. The result was a reduction in scope of fault-based liability, and a substantial enlargement of the scope of article 1384 (1) [1242 (1)], because every time an object was involved in an accident, liability was to be found under the general principle of liability for things, even if the object or thing was but an instrument in an action performed by the actor. ${ }^{70}$

\footnotetext{
${ }^{59}$ BRUN, supra note 33 , at $222, \mathrm{n}^{\circ} 348$.

${ }^{60}$ Cass. Civ., 16 December 1920, DP 1920.1.169, note R. Savatier.

${ }^{61}$ Loi du 7 Novembre 1922 complétant l'article 1384 du code civil, supra note 10.

${ }^{62}$ Cass. Ch. Réun, 13 February 1930, DP 1930.1.57, note Georges Ripert, rapport Le Marc'hadour, conclusions P. Matter; S.1930.1.121, note Paul Esmein.

${ }^{63} \mathrm{Id}$.

${ }^{64} I d$.

65 “[L]a loi, pour l'application de la présomption qu'elle édicte, ne distingue pas suivant que la chose qui a causé le dommage était ou non actionnée par la main de l'homme." Id.

${ }^{66}$ Henry Capitant, La responsabilité du fait des choses inanimées d'après l'arrêt des Chambres réunies du 13 février 1930, DH.1930.29 (Chron.).

${ }^{67}$ See Louis Josserand, note DH.1930.25-29.

${ }^{68}$ E.g. Cass. Civ., 13 February 1957, Bull. civ. 1957.II.59; Cass. Civ., 14 November 1958, JCP 1959.II.10394, note

R. Rodière; Cass. Civ. 2e, 14 October 1970, JCP 1971.II.16912, note N. Dejean de la Bâtie.

${ }^{69}$ See infra Chapter IV Part C.

${ }^{70}$ See the various cases cited in VINEY ET AL., CONDITIONS..., at 815, $\mathrm{n}^{\circ}$ 659, n. 196 (the examples include situations where the victim was injured by the use of a fork, a rifle, a bicycle, or a supermarket trolley, etc.).
} 
The principle of liability for the acts of things was extended further by the Desmares decision, ${ }^{71}$ in which the Court of Cassation decided that the presumption of liability from article 1384 (1) [1242 (1)] could not even be rebutted by proving the fault of the victim. This decision, however, must be read in its context. Several proposals were made, beginning with the middle of the 1960's, for a special law regarding the compensation of victims of traffic accidents. ${ }^{72}$ This decision was a way for the Court of Cassation to force the hand of the legislature to reform the law regarding compensation of victims of traffic accidents through a special law, ${ }^{73}$ and in 1985 the legislature finally adopted the well-known Law Badinter. ${ }^{74}$

The result of moving traffic accidents outside of the scope of article 1384 (1) [1242 (1)] has been a contraction of the scope of the general principle of liability for the acts of things. From Jand'heur to Desmares, liability for the acts of things became not only strict, but went well beyond that. Jand'heur opened the way for liability every time a thing was actively involved in the production of an accident, irrespective of whether it was moving or inert, ${ }^{75}$ or whether it was just a tool for an act of man. ${ }^{76}$ Two major reversals of previous jurisprudence have brought the law of liability for things to its present physiognomy. First, the Court of Cassation reversed Desmares and decided that the fault of victims can be used as a defence to limit or exclude liability. ${ }^{77}$ Also, the Court of Cassation, after vacillating on this matter, ${ }^{78}$ decided to restrict the ambit of article 1384 (1) [now 1242 (1)] even more, by requiring that an inert thing causing damage must be abnormal, or at least be left in an abnormal position or space. ${ }^{79}$ Thus, the general principle of liability for things, based on article 1242 (1) [formerly 1384 (1)] of the Civil Code, is today a sort of quasi-strict liability

\footnotetext{
${ }^{71}$ Cass. Civ. 2e, 21 July 1982, D. 1982. 449, concl. Charbonnier, note Larroumet ; JCP 1982. II. 19861, note Chabas; Defrénois 1982. 1689, obs. Aubert ; RTD civ. 1982. 607, note G. Durry. See also Geneviève Viney, L'indemnisation des victimes de dommages causés par le fait d'un chose après l'arrêt de la Cour de Cassation ( $2^{e}$ ch. civ.) du 21 juillet 1982, D.1982.201 (Chron.); Yvonne Lambert-Faivre, Aspects juridiques, moraux et économiques de l'indemnisation des victimes fautives, D.1982.207 (Chron.).

${ }^{72}$ ANDRÉ TUNC, LA SÉCURITÉ ROUTIĖRE. ESQUISSE D'UNE LOI SUR LES ACCIDENTS DE LA CIRCULATION (Dalloz 1966) ; ANDRÉ TUNC ET AL., POUR UNE LOI SUR LES ACCIDENTS DE LA CIRCULATION (Economica 1981).

${ }^{73}$ Jean-Luc Aubert, L'arrêt Desmares : une provocation ... a quelles réformes ?, D.1983.1 (Chron.).

${ }^{74}$ Loi no $^{\circ} 85-677,5$ July 1985 tendant à l'amélioration de la situation des victimes d'accidents de la circulation et à l'acceleration des procédures d'indemnisation, JO 6 July 1985, p. 7584.

${ }^{75}$ Cass. Civ., 19 February 1941, D.C.1941.85, note J. Flour; For the evolution of the jurisprudence in regard to the active role of inert things see VINEY ET AL., CONDITIONS..., supra note 20, at 817-30, nº 662-74.

${ }^{76}$ Supra note 70.

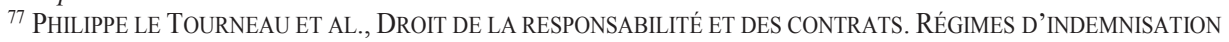
2005, no 7925 (10th ed., Dalloz 2014).

${ }^{78}$ For details see VINEY ET AL., CONDITIONS..., supra note 20, at 825-29, nº 674.

${ }^{79}$ See especially Cass. Civ. 2e, 2 April 1997, no 95-19.986, Bull. civ. II, no 110; Gaz. Pal. 1997 Pan. 283; See also the cases cited in VINEY ET AL., CONDITIONS..., supra note 20, at 829, nº 674, n.258-59.
} 
regime. ${ }^{80}$ Liability is clearly strict when the thing is motion, but fault-like considerations seem to creep in when the thing is stationary.

\section{Vicarious liability}

Under the Civil Code, as written in 1804, liability for others was special and situational. A person was considered liable for the acts of others only in the limited set of cases provided for in article 1384 [1242]: parents for their minor children [initially art. 1384 (2), then renumbered art. 1384 (4), and today 1242 (4)]; employers for their employees [initially art. 1384 (3), then renumbered art. 1384 (5), and today 1242 (5)]; teachers and educators for the children under their supervision [initially art. 1384 (4), then renumbered art. 1384 (6), and today 1242 (6)]; and artisans for the apprentices they instruct [again, initially art. 1384 (4), then renumbered art. 1384 (6), and today $1242(6)]$.

All of these articles have had a very interesting evolution on their own, and today only the liability of teachers and educators can be seen as fault-based. All the other forms of vicarious liability are now strict, but on different grounds, and to a different extent. One might say that some are "stricter" than others. The general impression one gets from the evolution of the various cases of vicarious liability is that the law has evolved in many directions, in a stratified manner, and because of this, the law of vicarious liability is today much more complex than how it was initially designed. Things are further complicated by a recent development that introduced the notion of a general principle of vicarious liability, similar to the general principle of liability for things, discussed above.

In the following, for the purpose or arranging these various regimes in a way that showcases how they evolved, the liability of employers for their employees is discussed first (a), followed by the liability of parents for their minor children (b), the liability of artisans for their apprentices (c), and, summarily, the liability of teachers and educators for the children placed under their supervision (d). Finally, we discuss the general principle of vicarious liability developed in the famous Blieck case (e).

${ }^{80}$ LE TOURNEAU ET AL., supra note 77 , at 1974, $\mathrm{n}^{\circ} 7694$. 


\section{a. Liability of employers for their employees}

Although we began this historical account with the evolution of liability for the acts of things, arguably, the first case that changed the foundations of liability under the Civil Code was a vicarious liability case. In 1813, the Court of Cassation had already created the first strict liability regime by re-interpreting what was then article 1384 (3) [now $1242(5)],{ }^{81}$ dealing with the liability of employers for their employees. ${ }^{82}$ The Court of Cassation once again used very carefully-worded language, but ruled in a clear manner that proof of fault would not exonerate the employer of its liability for the acts of his employee. ${ }^{83}$ The same ruling was confirmed time and time again, also over the course of the $20^{\text {th }}$ century. ${ }^{84}$ The evolution of this form of liability has been marked not only by its strict character, but also by a permanent trend of loosening its conditions, and thus expanding its domain. The most important changes that led to such an expansion had to do with how the relationship between employer and employees (le lien de préposition) has been defined in the jurisprudence. Up until the 1950's, the type of relationship between employer and employee that triggered liability under article 1384 (5) [now 1242 (5)] implied both a "choice" by the employer (of the employee) and the "subordination" of the employee to the employer. ${ }^{85}$ The first of these conditions has since then been essentially eliminated, and the condition of subordination has been relaxed to the point where the simple power to issue orders by the employer is considered sufficient, even if the employer does not in fact exercise that power. ${ }^{86}$ The terms employer (commettant) and employee (préposé) should be read in a broad manner. Thus, for instance, the criminal chamber of the Court of Cassation (ruling on a civil liability matter in a criminal case) found that an independent craftsman can be a préposé when performing work under the control and supervision of the customer service division of a company. ${ }^{87}$ Also, in some circumstances, a mandatary can be considered a préposé, but again only if the principal has the power to oversee

\footnotetext{
${ }^{81}$ Cass. Civ., 25 November 1813, JP, tome 15, p. 671. See also Descheemaeker, supra note 20, at 444, n.52; LAURENT KACZMAREK, LA RESPONSABILITÉ POUR FAIT NORMAL. ÉTUDE CRITIQUE SUR SON ORIGINALITÉ EN MATIÈRE EXTRACONTRACTUELLE 231 (Publibook 2012).

${ }^{82}$ The author of this study prefers to use the terms "employer" and "employee" to translate commettant and préposé, as opposed to "master" and "servant".

${ }^{83}$ Cass. Civ., 25 November 1813, JP, tome 15, p. 671.

${ }^{84}$ To give just a few examples, see Cass. Req., 6 August 1907, S.1908.1.128; Cass Req., 21 October 1942, DA 1943.21; CA Poitiers, 30 November 1955, JCP 1956.II.9125, note M. de Juglart.

${ }^{85}$ VINEY ET AL., CONDITIONS..., supra note 20, at 1044, no 792.

${ }^{86} \mathrm{Id}$.

${ }^{87}$ See Cass. Crim., 22 March 1988, no. 87-82802, Bull. Crim. no 142, available online at http://www.juricaf.org/arret/FRANCE-COURDECASSATION-19880322-8782802.
} 
the activity of the mandatary. ${ }^{88}$ The same applies to the obligor in a service contract. ${ }^{89}$ It is also possible to have an employer-employee relationship in the sense of article 1242 (5) [formerly 1384 (5)] when there is no contract between the parties, the subordination being de facto. ${ }^{90}$ That being said, in the great majority of cases where liability is found on the basis of article 1242 (5), the relationship between the commettant and the préposé stems from the existence of a labour contract. $^{91}$

On a different note, another very important change that requires some comment came in the year 2000, when the plenary assembly of the Court of Cassation, in the Costedoat case, changed the rules regarding the liability of an employee..$^{92} \mathrm{Up}$ until that time, employers were liable for their employees in the sense that when an employee was at fault during the performance of his or her functions, the employer and the employee were both liable, in solido, on different grounds: the employer based on article 1384 (5) [now article 1242 (5)], and employees based on article 13821383 [now 1240-1241]. The decision in Costedoat immunized the employee from the consequences of liability. ${ }^{93}$ Therefore, as the law stands today, while the victim still has to prove wrongdoing on the part of the employee, ${ }^{94}$ the victim's claim can only be satisfied by the employer.

b. Liability of parents for the acts of their minor children

The liability of parents for their minor children, based on article 1242 (4) of the Civil Code, has had an interesting and eventful evolution. Unlike other texts dealing with civil liability, the text of article 1242 (4) has been changed by the legislature on several occasions, and judicial interpretation has evolved in a rather non-linear fashion.

What was initially article 1384 (2) under the Code Civil of 1804 had the following wording: "The father, and the mother after her husband's death, is liable for the damage caused by minor children

\footnotetext{
${ }^{88}$ See, e.g., Cass. Civ., 4 November 1945, JCP 1946.II.3110, note J.R.; VINEY ET AL., CONDITIONS..., supra note 20, at 1052 , no $795-1$.

${ }^{89} I d$. at 1053 , no $795-2$.

${ }^{90} \mathrm{Id}$. at 1054 , no $795-3$.

${ }^{91} I d$. at 1046-51, no 792, 793.

${ }^{92}$ Cass. Ass. Plén., 25 February 2000, nº 97-20.152, Bull. ass. plén., nº 2; D.2000.673, note Brun; JCP 2000.II.10295, concl. Kessous, note Billiau; Gaz. Pal. 2000.2.1462, note Rinaldi.

${ }^{93}$ The language used by the court is unequivocal: "The employer that acts within the limits of the task assigned to him by the employer shall not be liable toward third parties." ([N]'engage pas sa responsabilité à l'égard des tiers le préposé qui agit sans excéder les limites de la mission qui lui a été impartie par son commettant).

${ }^{94}$ See the case Olympique de Marseille: Cass. Civ. 2e 8 April 2004, nº 03-11.653, Bull. civ. II, n 194 ; RTD civ. 2004.217, obs. Patrice Jourdain; D.2004.2601, note Serinet; JCP 2004.II.10131, note Imbert.
} 
who live with them." 95 This form of liability was a corollary to the power exercised over the family by the father, ${ }^{96}$ who at that time was seen as its head. In the exposé des motifs, Treilhard described this form of liability as a guarantee for the reparation of damages caused by children, and that this form of liability had the purpose of stimulating parents to better educate their children and to make the most use of their authority within the family home. ${ }^{97}$

Liability was based on a rebuttable presumption of fault, a fact made obvious by the language of article 1384 (5) [which later became 1384 (7), and today is 1242 (7)], which states in rather clear terms that when the father or mother could not have prevented the act that caused the damage, they will not be held liable. ${ }^{98}$

The exact nature of the fault that was presumed was left to be determined by the courts through interpretation. Initially what was attributable to a parent was simply a fault in supervision. ${ }^{99}$ Later, in addition to covering wrongful supervision of the child, the presumption of fault was extended to cover faults in the education of the minor child, ${ }^{100}$ thus making it much more difficult for a parent to rebut the presumption.

The initial conditions for liability of parents were slowly changed by both the legislature and the judiciary, and the general trend can be said to have been one of expansion of liability. There were, surely, some jurisprudential hesitations, evidenced by two cases decided in 1960 and 1961, when the Court of Cassation attempted to erase the presumption of fault and transform the liability of parents into a fault-based regime, where proof of fault was required. ${ }^{101}$ However, this was a

\footnotetext{
95 "Le père, et la mère après le décès du mari, sont responsables du dommage causé par leur infants mineurs habitant avec eux." The original version of the Code Civil, as it stood in 1804 can be accessed online at http://gallica.bnf.fr/ark:/12148/bpt6k1061517/f339.image (last accessed on 19 July 2020).

${ }^{96}$ VINEY ET AL., CONDITIONS..., supra note 20, at 1183, at 870.

${ }^{97}$ Treilhard, Présentation au corps législatif, et exposé des motifs, supra note 24, at 475.

${ }^{98}$ The original version of the text read: "La responsabilité ci-dessous a lieu, à moins que les père et mère . . ne prouvent qu'ils n'ont pu empêcher le fait qui donne lieu à cette responsabilité."

${ }^{99}$ See Planiol, supra note 45, at 305, no 909.

${ }^{100}$ Cass. Civ., 12 October 1955, D.1956.301, note R. Rodière; Cass. Crim., 5 October 1977, D.1978.246 (IR); Cass. Crim., 18 June 1980, D.1981.322 (IR), obs. Christian Larroumet; Cass. Civ. 1re, 16 January 1982, JCP 1982.IV.107; Cass. Civ. 2e, 4 March 1987, Bull. civ. II, nº 63, p. 35; Cass. Civ. 2e, 3 March 1988, Bull. civ. II, nº 58; Cass. Civ. 2e, 16 March 1994, JCP 1994.IV.1326.

${ }^{101}$ Cass. Civ. 2e, 2 November 1960, D. 1961.770; Bull. civ. II, p. 427; JCP 1962.II.12499, note Paul Esmein; RTD civ. 1962, p. 103, obs. A. Tunc; Cass. Civ., 8 June 1961, Bull. civ. II, p. 433.
} 
negligible development, as soon thereafter, the Court of Cassation returned to its position in previous jurisprudence. $^{102}$

An important legislative reform that had a tremendous impact on the liability of parents for their minor children was the law of 4 June $1970,{ }^{103}$ which abrogated the concept of "paternal power" ("puissance paternelle"), and replaced it with "parental authority" ("l'autorité parentale"). This profound change in family law placed the husband and the wife, or the father and the mother, on equal footing within the family. The direct effect of this change was an expansion of the liability of parents for their minor children. The mother and father became, as a result of this law, solidarily liable for their minor children, whereas before, the mother's liability was only subsidiary. ${ }^{104}$

The law of 4 June 1970 made another simultaneous change in article 1384 (4) [now 1242 (4)]: a parent was to be found liable under this article only if he or she had custody of the minor child (droit de garde). Subsequently, the law of 22 July 1987 removed the concept of droit de garde from almost every article of the Civil Code, but the drafters of that law forgot to also change article 1384 (4), thus giving rise to some uncertainty in the jurisprudence, which was finally settled by the law of 4 March 2002, a law which replaced the term "droit de garde" with "autorité parentale". ${ }^{105}$ The effect of this change was again an expansion of liability, as the concept of parental authority is much broader than that of custody.

The most significant change in this area of the law, however, came in $1997,{ }^{106}$ when the Court of Cassation ruled in the well-known Bertrand case. ${ }^{107}$ In this case, the Court of Cassation abandoned the idea of a simple presumption of fault and declared the parents strictly liable ("responsable de

${ }^{102}$ Cass. Civ. 2e, 13 June 1968, Bull. civ. II, no 176, p. 124; Cass. Crim., 14 March 1973, Bull. Crim., nº 131, p. 313; Cass. Civ. 2e, 7 July 1976, JCP 1976.IV.296; Cass. Crim., 5 October 1977, D.1978.246 (IR); Cass. Civ. 2e, 4 June 1980, JCP 1981.II.19599, note Feddal.

${ }^{103}$ Loi n ${ }^{\circ} 70-459$ du 4 juin 1970 relative à l'autorité parentale, JORF du 5 juin 1970, p. 5227.

104 VINEY ET AL., CONDITIONS..., supra note 20, at 1184, $\mathrm{n}^{\circ} 870$.

${ }^{105} \mathrm{Id}$.

${ }^{106}$ Prior to 1997, there was another attempt to shift the liability of parents toward a strict liability regime in the Fullenwarth decision: Cass. Ass. Plén., 9 May 1984, Bull. ass. plén., no 4; D.1984.525, concl. J. Cabannes, note François Chabas; JCP 1984.II.20255, obs. N. Dejean de la Bâtie ; JCP 1984.II.20291, Rapport Fedou ; RTD civ. 508 (1984), obs. J. Huet. However, the Court of Cassation quickly reverted to its former jurisprudence, based on a presumption of fault. See Cass. Civ. 2e, 4 March 1987, Bull. Civ. II, no 63, p. 35; VineY ET AL., CondiTiOnS..., supra note 20 , at $1186, \mathrm{n}^{\circ} 870$.

${ }^{107}$ Cass. Civ. 2e, 19 February 1997, Bull. Civ. II, no 56; D.1997.265, note Patrice Jourdain; JCP.1997.II.22848, concl. R. Kessous, note Geneviève Viney; Gaz. Pal., 3 October 1997, note François Chabas (arrêt Bertrand); Christophe Radé, Le renouveau de la responsabilité du fait d'autrui, D.1997.279 (Chron.). See also the critical note by Hervé Lécuyer : Une responsabilité déresponsabilisante, 3 DROIT DE LA FAMILLE (1997), Repères 3. 
plein droit"). ${ }^{108}$ To this effect, the Court explicitly stated that the only defences available to the parents are force majeure and the fault of the victim. ${ }^{109}$ This was a major step in the law of vicarious liability as a whole, as it represented the most recent step in the process of removing fault as a basis for liability for others (the only remaining exception being the liability of teachers and educators ${ }^{110}$ ) and, through this, also reinforced the general principle of vicarious liability created by the Court of Cassation six years prior in the Blieck case. ${ }^{111}$

Finally, one other important evolution concerned the requirement for parents to live with the child that caused the damage. This is a requirement that existed in the Code from 1804, and has not been removed by any of the subsequent amendments. However, the courts have relaxed this condition considerably, even before the 1997 Bertrand case. ${ }^{112}$ After 1997, this condition seemed to have become obsolete, since the liability of parents was no longer dependent on a fault in supervision or education. Still, the law of 4 March 2002 did not eliminate this condition from article 1384 (4) [now 1242 (4)]. This led to further intervention in the jurisprudence, courts now interpreting this condition in an abstract and rather fictional sense, the mere abstract possibility of cohabitation between parent and child being considered sufficient. ${ }^{113}$

\section{c. Liability of artisans for the acts of the apprentices they mentor}

The liability of artisans is considered today to be a relic of the past, without much practical importance. ${ }^{114}$ This form of liability was initially linked with the liability of teachers and educators, and regulated through the same text. However, in 1937, a special regime was created for the liability of teachers and educators, and since then, this form of liability was assimilated by courts to the liability of parents for their minor children. ${ }^{115}$ The reason for this had to do with how the master-apprentice relationship was traditionally organized in France: the apprentice would often live with the artisan and have a position akin to a family member. ${ }^{116}$ Thus, liability of artisans

\footnotetext{
${ }^{108}$ Cass. Civ. 2e, 19 February 1997, Bull. civ. II, no 56; D.1997.265, note Patrice Jourdain; JCP.1997.II.22848, concl. R. Kessous, note Geneviève Viney; Gaz. Pal., 3 October 1997, note François Chabas (arrêt Bertrand). ${ }^{109} \mathrm{Id}$.

${ }^{110}$ See infra Subpart d of this section.

${ }^{111}$ See infra Subpart e of this section.

112 See VinEY ET AL., CONDITIONS..., supra note 20, at 1192-93, nº 876.

${ }^{113} I d$., at $1196, \mathrm{n}^{\circ} 876$.

${ }^{114}$ BRUN, supra note 33 , at $301, \mathrm{n}^{\circ} 467$.

${ }^{115}$ VineY ET AL., CONDITIONS..., supra note 20, at 1222, $\mathrm{n}^{\circ} 893$.

${ }^{116}$ See Jean Carbonnier, 4 Droit Civil. Les Obligations 432, nº 238 (22 $2^{\text {nd }}$ ed., PUF 2000).
} 
traditionally rested on a presumption of fault, limited only to a duty of supervision. ${ }^{117}$ To this author's knowledge, no new cases regarding the liability of artisans have been decided by the Court of Cassation after the Bertrand case changed the liability regime of parents in 1997, but many authors anticipate that due to this, the liability of artisans is likely to also become strict, following the regime either of employers for their employees, ${ }^{118}$ or of parents for their minor children. ${ }^{119}$ Perhaps more likely, this form of liability will disappear entirely from the Code before the courts have their say, as both the Catala project to reform the law of obligations, ${ }^{120}$ the Terre proposal to reform the law of torts, ${ }^{121}$ and the most recent avant-projet on the reform of civil liability ${ }^{122}$ do not contain any article on this subject-matter.

d. The liability of educators and teachers for the acts of children that are under their supervision

The liability of educators and teachers (instituteurs), ${ }^{123}$ while initially based on a presumption of fault, ${ }^{124}$ did not evolve toward a strict liability regime. To the contrary, ${ }^{125}$ a law was passed in 1937 adding an $8^{\text {th }}$ paragraph to article 1384 of the Civil Code ${ }^{126}$ [now 1242 (8)]

\footnotetext{
${ }^{117}$ VineY ET AL., CONDITIONS..., supra note 20, at 1223, $\mathrm{n}^{0} 893$.

${ }^{118}$ LE TOURNEAU ET AL., supra note 77, at 1940, $\mathrm{n}^{0} 7472$.

${ }^{119}$ Id., at 1223-24, no 893; See also BRUN, supra note 33, at 301-302, no 467 [presenting three alternatives: (1) artisans will be assimilated to parents; (2) they will be assimilated to employers; or (3) their liability will follow the general regime of article 1384 (1)]; But see FABRE-MAGNAN, supra note 9, at 389 (who presents the liability of artisans as still based on a presumption of fault).

${ }^{120}$ See Rapport à Monsieur Pascal Clément Garde des Sceaux, Ministre de la Justice, Avant-projet de réforme du droit des obligations (Articles 1101 à 1136 du Code civil) et du droit de la prescription (Articles 2234 à 2281 du Code civil) at 157 (22 September 2005) available online at http://www.justice.gouv.fr/art pix/RAPPORTCATALASEPTEMBRE2005.pdf [Referred to in this study as the Catala Project]

${ }^{121}$ See Proposition de textes. Chapitre des délits in POUR UNE RÉFORME DU DROIT DE LA RESPONSABILITÉ CIVILE (François Terré coord., ed. Dalloz, 2011), also available online at

http://www.textes.justice.gouv.fr/art_pix/1_proposition_texte responsabilite civile_20111018.pdf [Referred to in this study as the Terré Project].

${ }^{122}$ Ministère de la Justice - Direction des Affaires Civiles et du Sceau, Avant-projet de loi portant réforme de la responsabilité civile (29 April 2016), available online at http://www.textes.justice.gouv.fr/art_pix/avpjlresponsabilite-civile.pdf.

${ }^{123}$ The French term "instituteur" has a broad definition in the law of torts. An instituteur is "any person that provides some form of education, in art or sciences, onerously or gratuitously, in a school, or in private." LE TOURNEAU ET AL., supra note 77, at 1965, nº 7599.

${ }^{124}$ Tarrible, Discours devant le corps legislatif, supra note 14, at 488-89; PLANIOL, supra note 45, at 306, $\mathrm{n}^{\circ} 910$.

${ }^{125}$ Because the liability of educators and teachers is fault-based, this section will not go into more detail as to its historical evolution.

${ }^{126}$ Loi du 5 avril 1937 modifiant les règles de la preuve en ce qui concerne la responsabilité civile des instituteurs et l'art. 1384 (paragraphe 5, dernier al.) du code civil relatif à la substitution de la responsabilité de l'État a celle des membres de l'enseignement public, JORF, 6 April 1937, p. 3923. This law did not only make the liability of
} 
that reads: "As to teachers, the fault, imprudence, or negligence invoked against them as having caused the damaging act will have to be proven by the plaintiff at the trial in accordance with the general law" (emphasis added). ${ }^{127}$

\section{e. The development of a general principle of vicarious liability}

As opposed to liability for the acts of things, a general rule of liability for the acts of others was not created until very late in the $20^{\text {th }}$ century, ${ }^{128}$ and the other cases of vicarious liability explicitly regulated by the Code were, until quite recently, considered to be based on a presumption of fault. ${ }^{129}$

The landmark case that created a general regime of vicarious liability was decided in 1991 by the Court of Cassation, and is known as the Consorts Blieck case. ${ }^{130}$ In this case, an association that was managing a centre created for the purpose of helping certain categories of persons through work was found liable for the act of one of the boarders, because the association accepted to "permanently organize, direct and control" the life of that person. ${ }^{131}$ The direct author of the damage was a person suffering from a mental handicap, who was given a series of tasks related to clearing a forest. Due to a personal grudge, this person voluntarily started a fire at his workplace, destroying in the process several hectares of forest. ${ }^{132}$ The textual support was to be found again in article 1384 (1) [now 1242 (1)]: "We are responsible not only for the damage caused by our

educators and teachers fault-based, it also created a mechanism whereby the State would be substituted to educators and teachers when they are found liable, thus immunizing them in a way, because the obligation to provide compensation rests exclusively with the State when this substitution is made (Article 2 of the same law). For teachers working in public institutions these solutions were already in place, by way of a law from 20 July 1899 . See PLANIOL, supra note 45 , at $306, \mathrm{n}^{\circ} 910$.

${ }^{127}$ Trans. Legifrance, available online at http://www.legifrance.gouv.fr/Traductions/en-English/Legifrancetranslations (last accessed on 5 May 2015).

${ }_{128}$ See infra, the presentation of the Blieck case.

${ }^{129}$ See the discussion infra regarding liability of parents for their minor children.

${ }^{130}$ Cass., Ass. Plén., 29 March 1991, no 89-15.231, Bull. ass. plén., no 1; D.1991.324, note Larroumet; Somm. 324, obs. Aubert; JCP 1991.II.21673, concl. Dontenwille, note Ghestin; Gaz. Pal. 1992.2.513, obs. Chabas; RTD civ. 1991.312, note J. Hauser; RTD civ. 1991.541, note Patrice Jourdain; Geneviève Viney, Vers un élargissement de la catégorie des "personnes dont on doit répondre": la porte entrouverte sur une nouvelle interprétation de l'article 1384, alinéa 1er, du code civil, D.1991.157 (Chron.); JCP 1991.II.21673, concl. Dontenwille, note Ghestin; Gaz. Pal. 1992.2.513, obs. Chabas; RTD civ. 1991.312, note J. Hauser; RTD civ. 1991.541, note Patrice Jourdain; Pierre Bon, La responsabilité du fait des personnes dont on a la garde : sur un rapprochement des jurisprudences administrative et judiciaire, RFDA 1991.991.

${ }^{131}$ Cass., Ass. Plén., 29 March 1991, no 89-15.231, Bull. ass. plén., no 1; D.1991.324, note Larroumet; Somm. 324, obs. Aubert; JCP 1991.II.21673, concl. Dontenwille, note Ghestin; Gaz. Pal. 1992.2.513, obs. Chabas; RTD civ. 1991.312, note J. Hauser; RTD civ. 1991.541, note Patrice Jourdain.

${ }^{132}$ Id. VINEY ET AL., CONDITIONS..., supra note 20, at 997, $n^{0} 789-8$. 
own act, but also for that which is caused by the acts of persons for whom we are responsible, or by the things that are in our custody (emphasis added)." ${ }^{133}$ After this decision, every time an entity took the charge of organizing, directing and controlling, in a permanent manner, the activity of someone else, liability could be found based on this general principle of vicarious liability. ${ }^{134}$

The context in which the Blieck decision was rendered was rather unusual because at that time the liability of parents for their minor children was still based on a presumption of fault, ${ }^{135}$ and the Court of Cassation had previously refused to extend article 1384 (4) [now 1242 (4)] to situations where the supervision of children was given to a non-parent that had the power to permanently control the child's life and education. ${ }^{136}$ However, what made the decision in Blieck a very logical step in the jurisprudence was the parallel evolution of liability for others before administrative courts. Because the French court system is divided into a civil order and an administrative order, ${ }^{137}$ cases that involve vulnerable persons placed under the supervision of a state institution, like a public hospital or a public institution charged with educating minor offenders, are decided by judges belonging to the administrative order. Also, state institutions fall under a different liability regime that is dictated by the norms of administrative law, not the Civil Code. Under such norms, by default, state institutions are liable only if proof of fault is provided by the victims of torts caused by the persons placed under their supervision. ${ }^{138}$ That being said, since 1956, through a series of decisions of the Conseil d'État, in cases where liberal methods of treatment and re-

\footnotetext{
${ }^{133}$ Trans. Legifrance, available online at http://www.legifrance.gouv.fr/Traductions/en-English/Legifrancetranslations (last accessed on 5 May 2015).

${ }^{134}$ Subsequent cases applied it to cases were minors were educated in a centre for assisted education, to cases involving the support of persons with a handicap, to cases where minors were placed in a foster family, etc. See the extensive jurisprudential presentation made in LE TOURNEAU ET AL., supra note 77, at 1916-17; The principle was extended also to situations where the direct author of the damage was not a vulnerable person, mentally or physically. Thus, the principle was affirmed for sports associations or clubs for the damage caused by the athletes who were their members, for associations of scouts for the scouts who are members, or associations of fans of a club for the damage caused by the fans. Id. at 1917-18.

${ }^{135}$ See supra Subpart b of this section.

${ }^{136}$ See Cass. Crim., 11 June 1970, Gaz. Pal. 1970 1970, p. 2, 146; Cass. Civ. 2e, 9 November 1971, D.1972.75 (Jurisp.); RTD civ. 1972. 400, obs. G. Durry; Cass. Crim., 9 March 1972, D.1972.342; Cass. Civ. 2e, 29 April 1976, JCP 1978.II.18793, note N. Dejean de la Bâtie.

${ }^{137}$ For details on the French court system, particularly its dual system, with a separate order for administrative cases, see Cristian Dadomo \& Susan FarRan, The French Legal System 46-111 ( $2^{\text {nd }}$ ed., Sweet \& Maxwell 1996); CATHERINe Elliot et AL., French Legal System 115-127 (2d ed., Pearson Education Limited 2006); Walter J. Cairns \& Robert MacKeon, Introduction to French LaW 27-45 (Cavendish Publishing 1995).

${ }^{138}$ VINEY ET AL., CONDITIONS..., supra note 20, at 991, n 789-4.
} 
education were used by state institutions, their liability was made strict, on the basis of the notion of "social risk". 139

Therefore, the decision in Blieck, although somewhat of a surprise within private law, aligned itself with the developments in the jurisprudence of the Conseil d'Etat, and brought more coherence in the law as a whole, since the difference in treatment between state and private institutions charged with the same type of duties seemed hard to explain and justify.

\section{Product liability}

As mentioned before, the only major change to the Civil Code's chapter on delicts and quasi-delicts was the introduction of articles 1386-1 to 1386-18 [now 1245 to 1245-17] by way of a law adopted on 19 May $1998 .^{140}$

These 18 articles deal with compensation of damage caused by defective products, and they find their origin in the 1985 European Directive on Product Liability. ${ }^{141}$ The EU member states had the obligation to implement this directive by July 1988, but it took ten years and a condemnation from the European Court of Justice ${ }^{142}$ for France to finally adopt a law implementing the directive.

The main reasons for the long delay were the following: (i) the opposition against implementation and the intense lobbying by associations and pressure groups of producers and consumers, ${ }^{143}$ (ii) the lack of political will to implement the directive throughout the mandates of the various governments holding power at that time; ${ }^{144}$ and (iii) the feeling that French law already offered, through its solutions, an adequate balance between consumer protection and the interests of producers. ${ }^{145}$

Indeed, until 1998, French courts had been very creative in their re-interpretation of the law, so as to provide consumers with a good number of remedies in cases where injury was caused by

\footnotetext{
${ }^{139}$ Id. at 991-92, n ${ }^{\circ} 789-4$.

${ }^{140}$ Loi no 98-389 du 19 mai 1998 relative à la responsabilité du fait des produits défectueux, JORF n 117 du 21 mai 1998 , p. 7744.

${ }^{141}$ Council Directive 85/374/EEC of 25 July 1985 on the approximation of the laws, regulations and administrative provisions of the Member States concerning liability for defective products, Official Journal L 210, 07/08/1985, p. 29-33 Referred to in this study as the Product Liability Directive].

${ }^{142}$ ECJ, 13 January 1993, C-293/91, Commission v. France, ECR I-0001; D.1993.566, note Jean-Louis Clergerie.

${ }^{143}$ LE TOURNEAU ET AL., supra note 77, at 2117, n 8345; FABRE-MAGNAN, supra note 9, at 323.

${ }^{144}$ LE TOURNEAU ET AL., supra note 77 , at $2117, \mathrm{n}^{\circ} 8345$.

${ }^{145}$ Id.
} 
defective products. Under contract law, many contracts, including sales contracts, ${ }^{146}$ had been interpreted so as to create an implied obligation of security (obligation de sécurité). ${ }^{147}$ This implied obligation of security gave its creditor the right to claim compensation when damage was caused by the defective performance of the debtor. It must be said that liability based on an obligation de sécurité is always strict because most of these obligations are seen as "obligations of result" (obligations de résultat), ${ }^{148}$ where proof of fault is not required. ${ }^{149}$ Moreover, due to its compensatory function, this form of contractual liability was in many ways similar to the regime of product liability introduced by the directive. French courts even found a way around privity of contract (effet relatif $d u$ contrat), the obligation of security being considered transferred by the effect of each successive sale, thus passing to the final user or buyer. ${ }^{150}$

On top of that, the French law of delict in place before the implementation of the directive also provided a high level of protection. Tort victims had the possibility to rely either on articles 13821383 [now 1240-1241] and base their claim on fault, or on article 1384 (1) [now 1242 (1)] (liability for things). Fault-based liability became particularly attractive in cases of damage caused by defective products because the requirement of fault was relaxed. In one decision from 1972, the Court of Cassation went as far as to say that proof of delivery of a defective product was sufficient in order to establish fault under articles 1382-1383 [1240-1241]. ${ }^{151}$

That being said, the adoption of the directive was never ignored. In the period between 1985 and 1998, the Court of Cassation began interpreting the existing national law in light of the directive, in anticipation of the directive's future implementation. ${ }^{152}$ However, this work of interpretation

\footnotetext{
${ }^{146}$ It is worth mentioning that obligations of security can be found in many other contexts such as transport, or construction contracts. In cases of personal injury that finds its cause in the wrongful performance of a service contract or the delivery of a thing that cannot be defined as a defective product (see art. 1383-3 of the French Civil Code), victims can still rely on contractual liability and the "obligation of security". Therefore, obligations of security are still the basis of numerous contractual strict liability claims, even after the implementation of the Product Liability Directive.

${ }^{147}$ See, e.g., Cass. Civ. 1re, 20 March 1989, D.1989.581, note Philippe Malaurie (“... a professional seller is bound to deliver a product without any defects that could endanger persons or property").

${ }^{148}$ Duncan Fairgrieve, L'exception française? The French law of product liability, in ProdUCT LIABILITY IN Comparative Perspective 88 (Duncan Fairgrieve ed., Cambridge University Press 2005).

${ }^{149}$ By opposition to "obligations of means" (obligation de moyens). See FrANÇOIS TERRÉ ET AL., DrOIT CIVIL. LES OBLIGATIONS 624-26, no 578-80 (11 $1^{\text {th }}$ ed., Dalloz 2013).

${ }^{150}$ See, e.g., Cass. Civ. 1re, 9 March 1983, Bull. civ. I nº 92; JCP 1984.II.20295.

${ }^{151}$ Cass. Civ. 1re, 18 July 1972, Bull. civ. 1 n $^{\circ} 189$.

${ }^{152}$ For details and examples see BRUN, supra note 33 , at 480-81, $\mathrm{n}^{0} 725$.
} 
was not always straightforward. The Court of Cassation seemed to only be cherry-picking from the directive, guided by an overall victim-friendly philosophy. ${ }^{153}$

When France finally adopted the above-mentioned law of 19 May 1998, the consumer-friendly proclivity of French law clearly influenced the manner in which the Product Liability Directive was implemented, and France found itself before the European Court of Justice on two new occasions, this time for the wrongful implementation of the directive. The generic problem was the fact that France initially treated the Product Liability Directive as a measure of minimum harmonization. ${ }^{154}$ The leitmotif of the first decision, from 2002, of the European Court of Justice was precisely the clarification of the nature of the Product Liability Directive, and the Court made it very clear that this was a maximum (total) harmonization instrument. ${ }^{155}$ In more practical terms, three concrete problems were identified in the French law of implementation: (i) according to the directive, in order to claim damage to property based on the law of product liability, the victim had to suffer damage of at least EUR $500,{ }^{156}$ whereas the law of implementation removed this minimum threshold; ${ }^{157}$ (ii) according to the directive, suppliers are subsidiarily liable only when the producer of the product is unknown, ${ }^{158}$ whereas French law made suppliers liable in all cases, even when the producer was known; ${ }^{159}$ and lastly (iii) the French law of implementation added a condition that the producer had to fulfil its obligation to monitor the product in order to rely on the exemptions from liability provided in articles 7(d) (compliance with mandatory regulations defence) and 7(e) (development risk defence) of the directive. ${ }^{160}$ In 2004, the French legislature adopted a law modifying the Civil Code, with the view of complying with the decision of the Court of Justice from 2002. ${ }^{161}$ However, in the eyes of the European Commission, this effort fell short when it came to how article 1386-7 [now 1245-6], dealing with the liability of suppliers, was

\footnotetext{
${ }^{153} I d$.

${ }^{154}$ On the distinction between minimum and maximum harmonization see Bruno de Witte et al., Chapter 5. Legal Instruments, Decision-Making and EU Finances, in THE LAW OF THE EUROPEAN UNION AND THE EUROPEAN COMmunities 273, 317-318 (P.J.G. Kapteyn et al. eds., Kluwer Law International 2008).

${ }^{155}$ ECJ, 25 April 2002, C-52/00, Commission v France; D. 2002.1670, obs. C. Rondey; D.2002.2462. note C. Larroumet; D. 2002.2935, obs. J-P. Pizzio; RTD civ. 2002.523, obs. Patrice Jourdain; RTD civ. 2002.868, obs. J. Raynard; See also Nicolas Jonquet et al, Les victimes de produits de santé épargnées par la CJCE, D.2003.1299 (Chron.).

${ }^{156}$ Art. 9(b) of the Product Liability Directive.

${ }^{157}$ ECJ, 25 April 2002, supra note 155, para. 26-35.

${ }^{158}$ Art. 3(3) of the Product Liability Directive.

${ }^{159}$ ECJ, 25 April 2002, supra note 155, para. 36-41.

${ }^{160} \mathrm{Id}$. at para. $42-48$.

${ }^{161}$ Art. 29 of Loi n 2004-1343 du 9 décembre 2004 de simplification du droit, JORF n 0287 du 10 décembre 2004, p. 20857.
} 
modified, and a new infringement procedure was introduced. The Court of Justice agreed with the Commission, ${ }^{162}$ and condemned France anew. Following this second decision, a new version of article 1386-7 [now 1245-6] was adopted by the French legislature ${ }^{163}$ to match more precisely the wording of article 3(3) of the Product Liability Directive.

It is important to note that the 2002 decision of the European Court of Justice had an impact that went beyond the three problems of implementation dealt with in that judgment. The same day, the Court of Justice also issued a preliminary ruling, after receiving a reference from a Spanish court, ${ }^{164}$ and the language used by the Court was identical, in its relevant parts, to the decision in Commission v. France. ${ }^{165}$ The more fundamental problem discussed in both decisions, regarding the nature of the Product Liability Directive as a harmonization tool, was to define the place of the newly created articles 1386-1 to 1386-18 [now 1245 to 1245-17] in the general scheme of French liability law. The Court of Justice insisted on the fact that Article 13 of the Directive did not allow the Member States "the possibility of maintaining a general system of product liability different from that provided for in the directive", ${ }^{166}$ and the Product Liability Directive is a maximum harmonization directive. ${ }^{167}$ This meant that for cases falling within the scope of the directive, national legislatures do not have the option of offering a higher level of protection than that provided for by the directive.

This is not all that surprising since the declared goal of the directive was never a higher level of consumer protection. The preamble of the directive declares that its purpose is to harmonize the laws regarding product liability in order to eliminate "existing divergences that may distort competition and affect the movement of goods within the common market"168 and provide a similar level of protection to consumers throughout the European Union. ${ }^{169}$ Legislation regarding

\footnotetext{
${ }^{162}$ ECJ, 14 March 2006, C-177/04, Commission v. France, RTD civ. 2006.265, obs. Pauline Rémy-Corlay; RTD civ. 2006.335, obs. Patrice Jourdain; JCP G 2006.I.166, no 13, obs. Philippe Stoffel-Munck.

${ }^{163}$ Loi n ${ }^{\circ} 2006-406$ du 5 avril 2006 relative à la garantie de conformité du bien au contrat due par le vendeur au consommateur et à la responsabilité du fait des produits défectueux, JORF n`82 du 6 avril 2006, p. 5198.

${ }^{164}$ ECJ, 25 April 2002, C-183/00, María Victoria Gonzalez Sanchez v. Medicina Asturiana; D.2002.1670, note C. Rondey, D.2002.2462, note C. Larroumet; D.2002.2937, obs. J.-P. Pizzio; D.2003.463, obs. D. Mazeaud; RTD civ. 2002.523, obs. Patrice Jourdain; Jean Calais-Auloi, Menace européenne sur la jurisprudence française concernant l'obligation de sécurité du vendeur professionnel (CJCE, 25 avril 2002), D.2002.2458 (Chron.).

${ }^{165}$ Id. para. 30 and 31. Compare with para. 21 and 22 of ECJ, 25 April 2002, supra note 155.

${ }^{166}$ ECJ, 25 April 2002, supra note 155, para. 21 ; ECJ, para. 30.

${ }^{167}$ ECJ, 25 April 2002, supra note 155, para. 15-20; ECJ, , para. 23-29.

${ }_{168}$ Preamble to the Product Liability Directive.

${ }^{169} I d$.
} 
product liability must find a compromise between the interests of industry and the interests of consumers, and the European Court of Justice basically limited the possibility of national legislatures reaching a different balance of interests than that offered by the directive.

That being said, the European Court of Justice did construe maximum harmonization for the damage caused by defective products in a flexible manner. The decisions of the European Court of Justice limit national legislatures only in regard to "general" parallel systems of product liability. The Court allowed a partial parallelism of remedies as long as the competing remedies have a different foundation. ${ }^{170}$ Fault-based liability and the warranty for hidden defects have been explicitly mentioned as possible alternative grounds. ${ }^{171}$

For France, the decisions of the European Court of Justice meant that its provisions regarding liability for defective products were to be construed as lex specialis in relation to liability for things and the pre-existing contractual liability based on a general obligation of security. In more practical terms, when a case falls within the ambit of articles 1245 to $1245-17$ [formerly 1386-1 to 138618], consumers are not allowed to base their action on the general principle of liability for things, or on the obligation of security of the seller, even if the conditions for actions based on these principles are met. However, they would be able to choose whether to base their action on fault liability (articles 1240-1241), warranty for hidden defects (article 1641), or on the articles regarding product liability (1245 to $1245-17)$ if, of course, the specific conditions of two or more of these causes of action are met.

The Court of Cassation did not resist, and confirmed this interpretation on several occasions. ${ }^{172}$ One indirect way of resisting, suggested by some French scholars, ${ }^{173}$ would have been for the Court of Cassation to take advantage of the exception allowing actions based on fault alternatively to actions based on the articles on product liability, and define fault in a very broad manner. ${ }^{174}$ The

\footnotetext{
${ }^{170}$ ECJ, 25 April 2002, supra note 155, para. 22; ECJ, 14 March 2006, supra note 162, para 31.

${ }^{171} \mathrm{Id}$.

${ }^{172}$ Cass. Com., 26 May 2010, Bull. Civ. nº 08-18545. RTD civ. 2010.790, obs. Patrice Jourdain; Cass. Civ. $1^{\text {re }}, 15$ May 2007, Bull. Civ. nº 05-17947; JCP 2007.I.185, nº 8, obs. Ph. Stoffel-Munck; D.2007.1593, obs. I. Gallmeister; RTD civ. 2007.580, obs. Patrice Jourdain.

${ }^{173}$ Geneviève Viney, L'interprétation par le CJCE de la directive du 25 juillet 1985 sur la responsabilité du fait des produits défectueux, JCP 2002.I.177; L. Grynbaum, comment to ECJ, 10 January 2006, C-402/03, Bilka

Lavprisvarehus A/S v.Jette Mikkelsen, Michael Due Nielsen, in JCP G 2006.II.10082; Philippe Stoffel-Munck, JCP G 2006.I.166, n $n^{0} 12$.

${ }^{174}$ As it had done in the previously cited 1972 decision (supra note 151).
} 
Court of Cassation, however, followed the spirit of the 2002 decision of the European Court of Justice, and refused to equate the mere defectiveness of a product with delictual fault. ${ }^{175}$

Another interesting sign of flexibility shown by the European Court of Justice came after the Court of Cassation carefully requested a preliminary ruling on a matter involving the interpretation of article 1386-2 [now 1245-1] of the Civil Code. ${ }^{176}$ The Product Liability Directive, when defining the types of damage to property that can be compensated, only mentions goods intended for personal use or consumption. However, article 1386-2 [1245-1] of the Civil Code did not and still does not have such a limitation, thus allowing victims to also claim damage caused to property intended for professional use. This was a disparity that was not mentioned by the Commission in any of the previously mentioned infringement proceedings, and that is why this case was brought before the European Court of Justice only in 2009, by way of a request for a preliminary ruling. ${ }^{177}$ This time, however, the Court of Justice found no issue with the implementation of the Product Liability Directive, and decided that, although damage caused to goods intended for professional use is outside of the scope of the directive, it is possible for the Court of Cassation to interpret article 1386-2 [1245-1] so as to also allow recovery for damage caused to goods intended for professional use. ${ }^{178}$ Finally, in 2011, the European Court of Justice allowed the parallel existence of a strict liability system, designed by administrative courts, for public hospitals in cases of damage caused by defective products used by the hospital. ${ }^{179}$ Public hospitals, as service providers, fall outside the scope of the directive, which deals with the liability of producers and suppliers, ${ }^{180}$ so the decision was logical and not all that surprising. However, it shows that the goal of maximum harmonization does not preclude, in some circumstances, the existence of concurrent strict liability regimes for damage caused by defective products.

\footnotetext{
${ }^{175}$ Cass. Com., 26 May 2010, supra note 172.

${ }^{176}$ Cass. Com., 24 June 2008, Bull. civ. n ${ }^{0}$ 07-11744; JCP G 2008.I.186, nº 7, obs. Ph. Stoffel-Munck; D.2008.1895, obs. I. Gallmeister; D.2008.2318, note J.S. Borgetti; RTD civ. 2008.685, obs. Patrice Jourdain.

${ }^{177}$ CJEU, 4 June 2009, C-285/08, Moteurs Leroy Somer v. Dalkia France, Ace Europe; D.2009.1731, note J.S. Borghetti; D.2010.49, obs. Philippe Brun \& O. Gout; RTD civ. 2009.738, obs. Patrice Jourdain; JCP G 2009.I.248, $\mathrm{n}^{\circ}$ 5, obs. Ph. Stoffel-Munck; JCP G 2009.II.26, obs. F. Picod; JCP G 2009.II.82, note Patrice Jourdain; See also, Judith Rochfeld, Les ambiguités des directives d'harmonisation totale : la nouvelle répartition des compétences communautaire et interne, D.2009.2047 (Chron.).

${ }^{178}$ CJEU, 4 June 2009, supra note 177, at para. 32.

${ }^{179}$ CJEU, 21 December 2011, C-495/10, Centre hospitalier universitaire de Besançon v. Thomas Dutrueux, Caisse primaire d'assurance maladie du Jura; D.2012.926, note J.S. Borghetti; D.2012.1558, note P. Véron \& F. Vialla; RTD civ. 2012.329, obs. Patrice Jourdain; ECLI:EU:C:2011:869.

${ }^{180} \mathrm{Id}$. at para. 28.
} 
4. Nuisance (troubles de voisinage)

The term trouble de voisinage is the French equivalent for what in English is generically called the "law of nuisance". ${ }^{181}$ Within the French legal system, this area of the law is particularly hard to map within the general framework of liability because it lies at the intersection of property and tort. In terms of its legal basis, nuisance in France is a jurisprudentially-created cause of action which is entirely autonomous, ${ }^{182}$ the Court of Cassation moving away from both the Civil Code articles on property (especially article 544) and the articles on tort liability [particularly articles 1240-1241 and article 1242 (1)].

The Civil Code did not, and still does not, contain any articles dealing with the law of nuisance. ${ }^{183}$ For the non-industrialized, largely agricultural, society of 1804, fault-based liability, the law of servitudes (especially legal servitudes), the law of possession, and the law of contract provided sufficient legal tools to solve most, if not all, problems arising at that time between neighbours. Also, it is worth noting that the Civil Code emphatically defined private ownership in terms that allowed the owner to "enjoy and dispose of his property in the most absolute manner". ${ }^{184}$ The law of nuisance, as well as the doctrine of "abuse of rights", was to challenge this assertion of absoluteness, especially in the $20^{\text {th }}$ and $21^{\text {st }}$ centuries. ${ }^{185}$

However, for all practical purposes, the law of nuisance began to take on a life of its own with a decision of the Court of Cassation from 1844. ${ }^{186}$ Although the Court did not find in that particular case that a nuisance was present, it did recognize that when the noise emanating from a factory is

\footnotetext{
${ }^{181}$ For the purposes of this subchapter the author is using the English term "nuisance" as a translation of "troubles de voisinage", although perhaps a novel term should be coined to translate this French legal concept. A reason to use a different terminology is the fact that some French authors distinguish between the French term "nuisance" and "trouble de voisinage". See Francis CABALLERO, ESSAI SUR LA NOTION JURIDIQUE DE NUISANCE 197-99 (L.G.D.J. 1981).

182 Valérie Gaillot-Mercier, Troubles de voisinage, $\mathrm{n}^{\circ} 22-23$, in ENCYCLOPÉDIE DALLOZ. RÉPERTOIRE DE DROIT CIVIL (updated 2015).

${ }^{183}$ All the recent French reform projects which contain provisions regarding tort law contain, however, at least one provision regarding the law of nuisance. See Art. 1361 of the Catala Project, supra note 120; Art. 24 of the Terré Project, supra note 121; Art. 1244 of the Projet de réforme de la responsabilité civile (Ministère de la justice, March 2017), available online at

http://www.justice.gouv.fr/publication/Projet_de_reforme_de la responsabilite_civile_13032017.pdf A translation in English prepared by Simon Whittaker, in consultation with Jean-Sébastien Borghetti, is available online at http://www.textes.justice.gouv.fr/art_pix/reform_bill_on_civil_liability_march_2017.pdf [hereinafter Chancery Reform Project]

${ }^{184}$ CIVIL CoDE, Art. 544 (Fr.) (emphasis added).

${ }^{185}$ The most famous decision of the Court of Cassation, considered by many the cornerstone of both doctrines, was decided in 1915. Cass. Req., 3 August 1915, DP 1917.1.79. See also, Gaillot-Mercier, supra note 182, at no 21. ${ }^{186}$ Cass. Civ., 27 November 1844, DP 1845.1.13.
} 
unbearable for the neighbours, reparation is justified. ${ }^{187}$ The pillars for actions based on a trouble de voisinage were in place, and a principle was emerging: some inconveniences from neighbours had to be accepted, whilst above a certain threshold liability would ensue.

An interesting detail about this 1844 decision was the fact that the Court of Cassation relied on both articles 1382-1383 [now 1240-1241] and on article 544. ${ }^{188}$ The Court of Cassation always felt relatively bound to identify a legislative basis for its decisions, and that is why it was only in 1986 that the step was made to proclaim a general principle of troubles de voisinage without relying on or quoting articles 1382-1383 [now 1240-1241] and 544. ${ }^{189}$

Because of its long interplay with fault-based liability, it is hard to determine exactly when liability based on troubles de voisinage became strict. It is clear, however, that with time, the law of nuisance was invoked in more and more cases, and became much more attractive to victims, because compensation was dependent on the abnormal character of the disturbance, and not on fault. Especially in terms of proof, the link with articles 1382-1383 [now 1240-1241] has arguably always been merely declarative. Full certainty came in 1992, when the Court of Cassation made it abundantly clear that fault was simply not an element in nuisance cases, having found that even if it is proven that the author of the nuisance is not at fault, liability could still follow on the basis of troubles de voisinage. ${ }^{190}$

The evolution and expansion of the doctrine of nuisance in France did not stop there. Strict as it was, two main developments made this form of liability even broader: (1) the courts interpreted the term "neighbour" in an expansive manner; and (2) rather recently, the interpretation of "abnormal disturbance" has been invoked in fascinating new situations of mere risk.

Today, for the purposes of nuisance law, the term "neighbour" includes any person living or carrying out an activity or work in the vicinity of the land or building affected. Therefore, a victim can direct its action against co-owners, lessees, or usufructuaries, ${ }^{191}$ franchisors, ${ }^{192}$ and even "occasional neighbours", such as a company performing some construction work on the adjacent

\footnotetext{
${ }^{187} \mathrm{Id}$.

${ }^{188} \mathrm{Id}$.

${ }^{189}$ Cass. 2e civ., 19 November 1986, Bull. Civ. II, n 172: "nul ne doit causer à autrui un trouble de voisinage" ["no person can cause to another a nuisance (trouble de voisinage)"]; D. 1988.16, note A. Robert.

${ }^{190}$ Cass. Civ. $3^{\text {e }}, 12$ February 1992, Bull. Civ. III, $n^{\circ} 44$.

${ }^{191}$ LE TOURNEAU ET AL., supra note 77 , at $1782, \mathrm{n}^{\circ} 7161$.

${ }^{192}$ Cass. Civ. 2e 21 May 1997, D.1998.150, note B. Fages.
} 
property. ${ }^{193}$ Also, an owner need not effectively live on the adjacent property where the nuisance originates from. ${ }^{194}$ The Court of Cassation also allowed a victim to bring an action against the owner of a neighbouring apartment for the disturbance created not by the owner himself, but by his lessee. ${ }^{195}$ What counts as a "neighbour" in terms of space, or radius, is not yet clear, but there seems to be a tendency to relax the conditions in this regard as well, especially in the jurisprudence of administrative courts. ${ }^{196}$

More fundamentally, the nature of what can be considered "abnormal" in relationships between neighbours has recently undergone substantial transformation. The most spectacular developments of this area of the law are in a way still unfolding, as they began surfacing only in the $21^{\text {st }}$ century. Up until the end of the $20^{\text {th }}$ century, the undeniable element of any nuisance action was the element of damage. Not only did the victim have to prove damage, the victim also had to prove that the damage suffered went beyond a certain threshold of what is normal in relationships between neighbours. A series of decisions in the early 2000's, however, opened the way for remedies based on the doctrine of troubles de voisinage in cases where no damage had occurred, but there was a demonstrable risk of future harm. ${ }^{197}$ Then, some lower courts took this one step further, ${ }^{198}$ and

${ }^{193}$ Cass. Civ. 3e 11 May 2000, Bull. Civ. III, no 106, D.2001.2231, obs. Patrice Jourdain. But see Cass. Civ. 3e, 21 May 2008, D.2008.1550, obs. Bigot de la Tuanne; D.2008.2458, obs. Mallet-Bricout \& Reboul-Maupin; D.2008.2894, obs. Philippe Brun \& Patrice Jourdain ; RTD civ. 2008.496, obs. Patrice Jourdain ; Cass. Civ. $3^{e}$, 9 February 2011, Bull. Civ. III, n 21. These last two decisions restricted the domain of "occasional neighbour" only to the actual (material) authors of the nuisance.

${ }^{194}$ Cass. Civ. $2^{\mathrm{e}}$, 29 June 1995, Bull. civ. II, nº 222, D.1996.59, obs. A. Robert.

${ }^{195}$ Cass. Civ. 2e, 17 March 2005, Bull. civ. II, no 73; D.2005.2357, obs. Mallet-Bricout \& Reboul-Maupin.

${ }^{196}$ See LE TOURNEAU ET AL., supra note 77, at 1781-82, $\mathrm{n}^{0} 7160$.

${ }^{197}$ Cass. Civ. 2e, 10 June 2004, Bull. civ. II, no 291; D.2004.2477; D.2005.185, obs. Philippe Delebecque, Patrice Jourdain \& Denis Mazeaud; RTD civ. 2004.738, obs. Jourdain (risk of damage to the owner of a house neighbouring a gold course); Cass. Civ. $2^{\mathrm{e}}$, 24 February 2005, Bull. Civ. II, n 50; JCP 2005.I.149, obs. Geneviève Viney; JCP 2005.II.10100, note Trébulle (in this case, the defendant was found liable for trouble de voisinage because he was depositing straw very close to the neighbouring house inhabited by the plaintiff, thus creating an increased risk of fire).

${ }^{198}$ Tribunal de Grande Instance ["TGI"] Grasse, 17 June 2003, JurisData 2003-221748 ; This decision was approved by Cour d'appel ["CA"] Aix-en-Provence, 8 June 2004, D. 2004.2678, note Mathilde Boutonnet; D.2005.186, obs. Denis Mazeaud; Michel Cannarsa et al., France (report), in EuroPEAN TORT LAW 2004, at 297 (Helmut Koziol \& Barbara C. Steininger eds., Springer 2005). In this case, the lower court based its decision on the precautionary principle, whereas the Court of Appeals relied on the law of nuisance and article 544 of the Civil Code (this being the article that defines ownership). Later on, another more famous case was decided by the Court of Appeals from Versailles: CA Versailles, 4 February 2009, D. 2009.499; D. 2009.819, note Mathilde Boutonnet; J-Ph. Feldman, Le trouble voisinage du principe de precaution, D. 2009 Chron. 1369; Olivier Moréteau, France (report), in EUROPEAN TORT LAW 2009, at 199 (Helmut Koziol \& Barbara C. Steininger eds., De Gruyter 2010). For the decision of the lower court see TGI Nanterre, 18 September 2008, D. 2008.2916, note Mathilde Boutonnet. Here, the lower court relied on both the precautionary principle and the law of nuisance, whereas the Court of Appeals based its decision only on nuisance law. 
issued remedies on the basis of doctrines of nuisance, whether or not coupled with the newly constitutionalized precautionary principle, ${ }^{199}$ in cases where the risk of harm was only hypothetical. ${ }^{200}$ The first line of cases, where the risk of future harm is quantifiable and proven, has been approved and crystalized in the jurisprudence, ${ }^{201}$ but the relay antenna cases that made up the second line of cases have been much more controversial and the jurisprudence was divided. ${ }^{202}$ Moreover, the jurisprudential divide went beyond the control of the Court of Cassation. Parallel to what the civil law courts were doing, administrative courts were developing their own jurisprudence under the guidance of the Conseil d'État, in the sense that lawfully installed relay antennas could not be removed. ${ }^{203}$ In the end, the relay antenna problem was solved procedurally: the Tribunal des conflits ${ }^{204}$ was asked to resolve the jurisdictional problem between the civil courts and the administrative order on this matter, and reached a decision that severely curtailed the jurisdiction of civil courts. ${ }^{205}$ In practical terms, this meant that, from that point on, relay antenna operators would have the certainty that they could not be forced to remove lawfully-installed relay antennas.

The jurisprudential line of cases that allowed neighbours to seek remedies for the hypothetical damage that the relay antennas would produce died off due to lack of jurisdiction. However, this left the substantive legal problem unsolved, at least for now. It is uncertain whether the

\footnotetext{
${ }^{199}$ See article 5 of the Environmental Charter, which received Constitutional value in 2005: Loi constitutionnelle 2005-205 du 1 mars 2005 - Loi constitutionnelle relative à la Charte de l'environnement, JORF, 2 March 2005, p. 3697.

${ }^{200}$ For details on the history of these cases see Alexandru-Daniel On, Prevention and the Pillars of a Dynamic Theory of Civil Liability. A Comparative Study on Preventive Remedies 51-60 (Master's thesis, Louisiana State University, Spring 2013). See also Olivier Moréteau \& Alexandru-Daniel On, France (report) in EuROPEAN ToRT LAW 2013, at 229, 240 (Ken Oliphant \& Barbara C. Steininger eds., De Gruyter 2013).

${ }^{201}$ This author has no knowledge of any decisions running contrary to those cited supra in note 197.

${ }^{202}$ See the cases identified in LE TOURNEAU ET AL., supra note 77, at 1790, n.1, $\mathrm{n}^{\circ} 7170$.

${ }^{203}$ Conseil d'État ["CE"], 19 July 2010, no. 328687, JurisData 2010-012229.

${ }^{204}$ The Tribunal de conflits decides on conflicts of jurisdiction between the Cour de Cassation and the Conseil d'État.

${ }^{205}$ Civil courts now have jurisdiction in cases involving relay antennas only if:

(1) the claim is for damages and stems from the lawful installation or operation of the relay antenna, provided it is not a public work (ouvrage public), subject to the possibility of a preliminary ruling on jurisdiction; or (2) the claim is to order the cessation of nuisance (trouble anormal de voisinage) caused (i) by installation or operation which does not comply with administrative regulations, or (ii) by regular installation or operation, but where the interest harmed is not related to public health or interference of the radio waves.

Tribunal des conflits [TC] May 14, 2012, 6 decisions, JurisData 2012-010164, 2012-010165, 2012-010166, 2012010169, 2012-010170, 2012-010172; D. 2012 Jur. 1930, notes G.J. Martin \& J.-C. Msellati; Moréteau \& On, supra note 200, at 241-42. See also Sophie Moreil, Antennes relais: que reste-t-il au juge judiciaire?, D. 2012 Chron. 2978.
} 
precautionary principle can be used in conjunction with the theory of troubles de voisinage, and on a more general level, it has yet to be clearly determined whether an uncertain risk can support an action based on the law of nuisance.

The law of nuisance is inextricably linked with the evolution of society. It is, in the end, not all that surprising that this area of tort law has been extremely dynamic and in constant expansion. The legal system simply reacted to an ever more crowded and urbanized France, where the proper balance of interests and the boundaries set between conflicting rights became more and more delicate. In many ways, the law of nuisance is no longer about how absolute or relative property rights are. Expanding the notion of "neighbourhood" (voisinage) and allowing actions based on risks of damage, real or hypothetical, shows that the discourse in this area of the law is today more about lifestyle than ownership. For this reason, one author was able to affirm that the law of nuisance is a corollary to a personality right: the right to live in peace and tranquillity, ${ }^{206}$ and the European Court of Human Rights has tied actions in nuisance to article 8 of the Convention dealing with the right to privacy. ${ }^{207}$

\section{Strict Liability in Special Legislation}

\section{Overview}

The Civil Code is home to general principles that together make up the basic architecture of French tort law, and indeed, most delictual actions brought before French courts are based on these general norms. Nevertheless, a substantial number of legislative acts have been adopted since 1804 for situations that seemed, in the eyes of the French legislature, to require derogating norms, thus creating many liability regimes outside of the Code.

The first non-Code strict liability regime was mentioned earlier in the context of liability for things. ${ }^{208}$ A law adopted on 21 April 1810 made the concessionary of a mine liable to the owner for damage caused to the surface, and the strict character of the liability envisaged by this law was declared by the Court of Cassation in an 1862 case. ${ }^{209}$

\footnotetext{
${ }^{206}$ LE TOURNEAU ET AL., supra note 77, at 1781, $\mathrm{n}^{\circ} 7158$.

${ }^{207}$ ECHR, 21 February 1990, Powell and Rayner v. United Kingdom, no 9310/81; [1990] 12 EHRR 355, [1990] ECHR 2; ECHR, 9 December 1994, Lopez Ostra v. Spain, n 16798/90; RTD Civ. 1996.507, obs. Marguénaud.

${ }^{208}$ Supra Part C. 1 of this chapter.

${ }^{209}$ Cass. Ch. Réun., 23 July 1862, D.1862.1.257.
} 
Then, a law from 9 April 1898 created a compensation regime for work accidents. ${ }^{210}$ This law arguably went much further than simply creating a form of strict liability, because as long as the accident could be characterized as a "work accident" within the meaning of the law, compensation was guaranteed. This was a law that was concerned less with responsibility (or liability), and more with speedy guaranteed compensation, thus creating a social security type of compromise, mandating reparation in all cases. However, the payments were periodic and there was usually a cap set on the maximum amount received by the victim. It comes as no surprise then that, in time, the solutions provided by this law were incorporated in the Code of Social Security. ${ }^{211}$

During the $20^{\text {th }}$ century, non-Code strict liability and compensation regimes began to multiply at an accelerated pace. The following non-exhaustive list ${ }^{212}$ provides a chronological overview of the enactments containing liability regimes that have at least some elements of strict liability:

- 19 December 1917: ${ }^{213}$ making establishments that are "dangerous, inconvenient or unsanitary" strictly liable for the damage caused to their neighbours.

- 3 May 1921: ${ }^{214}$ making industrial establishments (public or private) that work for the national army (la défense nationale) liable for accidents harming third parties.

- 31 May 1924:215 making the operator of any type of aircraft liable for the damages caused by said aircraft on the ground.

- 8 July 1941: ${ }^{216}$ regarding damage caused by cable cars. According to article 6 of this law, the person installing the cable car (whilst the cable car is being installed), and the operator of the cable car (after installation), are made strictly liable for all damage caused to third parties by the cabin of the cable car, its cables, or other component

\footnotetext{
${ }^{210}$ Loi du 9 Avril 1898 sur les responsabilités des accidents dont les ouvriers sont victimes dans leur travail, BULLETIN DE L'INSPECTION DU TRAVAIL, $\mathrm{n}^{\circ}$ 2, 1898, also available online at http://travailemploi.gouv.fr/IMG/pdf/Loi du 9 avril 1898.pdf

${ }^{211}$ Articles L. 411-1 to L. 482-5 and R.412-1 to R.482-3 of the French Social Security Code.

${ }^{212}$ The chronological arrangement of these special laws is based on a similar list provided in: LE TOURNEAU ET AL., supra note 77 , at $2026, \mathrm{n}^{\circ} 8052$.

${ }^{213}$ Loi du 19 décembre 1917 relative aux établissements dangereux, insalubres ou incommodes, available online at http://www.legifrance.gouv.fr/affichTexte.do?cidTexte=LEGITEXT000006074238\&dateTexte=19761231; This law was modified a number of times, and then replaced by a new law in 1976, which was later incorporated in the Environmental Code (articles L.511-1 to L.517-2). LE TOURNEAU ET AL., supra note 77, at 2026, $\mathrm{n}^{\circ} 8052$.

${ }^{214}$ Loi du 3 mai 1921, accidents corporels ou matériels du fait des établissements travaillant pour la défense nationale : droit à réparation, JORF du 5 mai 1921, p. 5474.

${ }^{215}$ Loi du 31 mai 1924 relative à la navigation aérienne, JORF du 3 juin 1924, p. 5046. This law was incorporated in 1967 into the Code of Civil Aviation.

${ }^{216}$ Loi du 8 juillet 1941, servitudes de survol au profit des téléphériques, JORF du 27 août 1941, p. 3614.
} 
parts that get detached from the cable car (including objects thrown out by passengers $^{217}$ ).

- 1 July 1964: ${ }^{218}$ making the State liable for any damage that results from mandatory vaccination. Today, under this regime, as long as the vaccine is mandatory, the State is liable even if the vaccination is provided by a private clinic. ${ }^{219}$

- 12 November $1965^{220}$ and 29 November $1968:^{221}$ imposing strict liability of operators of nuclear vessels. 222

- 12 November $1965^{223}$ and 30 October 1968: ${ }^{224}$ these laws published the provisions of the Paris Convention on Third Party Liability in the Field of Nuclear Energy of 29th July $1960 .{ }^{225}$ Needless to say, under the Paris Convention, nuclear energy operators are strictly liable for the damages caused by nuclear incidents.

- 18 June $1966:^{226}$ making the organizer of the cruise by sea strictly liable for the acts of other persons providing various services during the cruise. This form of vicarious liability is a species of what some French legal scholars call, more generally, “contractual vicarious liability" (responsabilité contractuelle du fait d'autrui). ${ }^{227}$

- 26 May 1977.228 in the application of the Brussels Convention on Civil Liability for Oil Pollution Damage (29 November 1969), ${ }^{229}$ this law makes the owner of a ship

\footnotetext{
${ }^{217}$ LE TOURNEAU ET AL., supra note 77, at 2101, no 8302.

${ }^{218}$ Loi n ${ }^{\circ}$ 64-643 du 1 juillet 1964 relative à la vaccination antipoliomyélitique obligatoire et à la répression des infractions à certaines dispositions du code de la santé publique, JORF du 2 juillet 1964, p. 5762.

${ }^{219}$ See art. L. 3111-9 of the Public Health Code (Code de la santé publique).

${ }^{220}$ Loi n ${ }^{\circ}$ 65-956 du 12 novembre 1965 sur la responsabilité civile des exploitants de navires nucléaires, JORF du 13 novembre 1965, p. 9996.

${ }^{221}$ Loi n ${ }^{\circ}$ 68-1045 du 29 novembre 1968 responsabilité des accidents d'origine nucléaire, JORF du 30 novembre 1968, p. 11229.

${ }^{222}$ Adopted after France ratified the Brussels Convention on The Liability of Operators of Nuclear Ships from the $25^{\text {th }}$ May 1962; subsequently modified in 1988, these laws were eventually codified in the French Code of Transport (Code des transports) (article L.5122-1 and the following).

${ }^{223}$ Loi n ${ }^{\circ} 65-956$ du 12 novembre 1965 responsabilité des accidents d'origine nucléaire, JORF du 13 novembre 1965, p. 9996.

${ }^{224}$ Loi n ${ }^{\circ} 68-943$ du 30 octobre 1968 relative à la responsabilité civile dans le domaine de l'énergie nucléaire, JORF du 31 octobre 1968, p. 10195.

${ }^{225}$ The Paris Convention on Third Party Liability in the Field of Nuclear Energy of 29th July 1960, as amended by the Additional Protocol of 28th January 1964 and by the Protocol of 16th November 1982, is available online at http://www.oecd-nea.org/law/nlparis conv.html

${ }^{226}$ Loi n ${ }^{\circ} 66-420$ du 18 juin 1966 sur les contrats d'affrètement et de transport maritime, JORF du 24 juin 1966 p. 5206.

227 See VinEY ET AL., CONDITIONS..., supra note 20, 1100-1140, no 814-841.

${ }^{228}$ Loi n ${ }^{\circ} 77-530$ du 26 mai 1977 relative à la responsabilité civile et à l'obligation d'assurance des propriétaires de navires pour les dommages résultant de la pollution par les hydrocarbures, JORF du 27 mai 1977 p. 2993.

${ }^{229}$ Available online at http://www.admiraltylawguide.com/conven/civilpol1969.html
} 
carrying oil strictly liable for damage caused by pollution resulting from the escape or discharge of oil from ships.

- 5 July 1985 (loi Badinter): ${ }^{230}$ regarding road traffic liability (presented infra in extenso).

- 20 December $1988.2^{231}$ this law protects persons who volunteer to be test subjects in bio-medical research or experiments. According to its provisions, the person who profits from the research conducted is liable for the damage that could result from the experiments conducted. However, this is not a pure strict liability regime, the law establishing only a rebuttable presumption of fault. ${ }^{232}$

- 13 July 1992:233 making travel agents vicariously liable for the manner in which other service providers perform their obligations to the client during the arranged trip. Again, the liability envisaged by this law is strict, and can be seen as a form of contractual vicarious liability.

- 15 July 1994:234 this law, modifying the Mining Code, makes the explorers, operators, or owners of mining rights strictly liable for damages caused by the exploration or the mining operations. Also, if the responsible party cannot pay, the State guarantees the compensation of the damages caused.

In the $21^{\text {st }}$ century, the evolution of the law seems to continue down the same path, with two meaningful reforms that were adopted in the areas of medical and environmental liability:

- 4 March $2002^{235}$ and 30 December 2002.236 establishing a framework for the compensation of medical accidents, with various liability regimes, often coupled with direct insurance schemes, and subsidiary compensation funds. When a responsible

\footnotetext{
${ }^{230}$ Loi no $85-677$ du 5 juillet 1985 tendant à l'amélioration de la situation des victimes d'accidents de la circulation et à l'accélération des procédures d'indemnisation, JORF du 6 juillet 1985, p. 7584.

${ }^{231}$ Loi no88-1138 du 20 décembre 1988, dite Huriet, relative à la protection des personnes qui se prêtent a des recherches biomédicales, JORF du 22 décembre 1988, p. 16032.

${ }^{232}$ VINEY ET AL., INTRODUCTION..., supra note 14, at 37, no 24.

${ }^{233}$ Loi no 92-645 du 13 juillet 1992 fixant les conditions d'exercice des activités relatives à l'organisation et à la vente de voyages ou de séjours, JORF nº162 du 14 juillet 1992, p. 9457.

${ }^{234}$ Loi no 94-588 du 15 juillet 1994 modifiant certaines dispositions du code minier et l'article L. 711-12 du code du travail, JORF n ${ }^{\circ} 163$ du 16 juillet 1994, p. 10239.

${ }^{235}$ Loi n ${ }^{\circ} 2002-303$ du 4 mars 2002 relative aux droits des malades et à la qualité du système de santé, JORF du 5 mars 2002, p. 4118.

${ }^{236}$ Loi n ${ }^{2} 2002-1577$ du 30 décembre 2002 relative à la responsabilité civile médicale, JORF du 31 décembre 2002, p. 22100 .
} 
party can be identified, the compensation mechanism is similar to the strict liability regime established by the Law Badinter (5 July 1985) on traffic liability, and when the responsible party cannot be identified, the damages are covered by a compensation fund. $^{237}$

- 1 August 2008: $:^{238}$ regarding environmental liability. This law deals with the prevention and reparation of pure environmental damage (dommages environnementaux purs), and transposes Directive 2004/35/CE on environmental liability with regard to the prevention and remedying of environmental damage. ${ }^{239}$ As a consequence of this transposition, article 161-1 (1) was added to the Environmental Code, which stipulates that the operators listed in a subsequent decree ${ }^{240}$ are strictly liable for damage caused to the environment, on the basis of the "polluter pays" principle. ${ }^{241}$

The term "special delicts" (délits spéciaux) has been coined by some French scholars to designate these special liability regimes, ${ }^{242}$ because generally they create particular types of tort liability. Quite exceptionally, the legislature will go one step further and announce that a certain liability regime transcends the distinction between contract and tort. ${ }^{243}$ However, most of these laws create special forms of liability for the acts of things or nuisance.

The vast majority of the liability regimes that exist outside of the Civil Code are strict, and fault plays no role whatsoever. But that is not always the case. The law from 20 December 1988 cited above protecting persons who volunteer to be test subjects in bio-medical research or experiments creates only a rebuttable presumption of fault, which means that at least theoretically its foundation is fault. Also, while article 161-1 (1) of the Environmental Code creates a strict liability regime for environmental damage in general, article 161-1 (2) of the same code creates an exception for damage caused to protected species and natural habitats, in which case liability is fault-based.

\footnotetext{
${ }^{237}$ LE TOURNEAU ET AL., supra note 77, at 2167, no 8571.

${ }^{238}$ Loi n ${ }^{\circ} 2008-757$ du 1er août 2008 relative à la responsabilité environnementale et à diverses dispositions d'adaptation au droit communautaire dans le domaine de l'environnement, JORF nº179 du 2 août 2008, p. 12361. ${ }^{239}$ Directive 2004/35/CE of the European Parliament and of the Council of 21 April 2004 on environmental liability with regard to the prevention and remedying of environmental damage, OFFICIAL JOURNAL L 143, 30.04.2004, at 54-75.

${ }^{240}$ See Décret n² 2009-468 du 23 avril 2009 relatif à la prévention et à la réparation de certains dommages causés à l'environnement, JORF nº098 du 26 avril 2009, p. 7182.

${ }^{241}$ LE TOURNEAU ET AL., supra note 77, at 2190, no 8635.

${ }^{242}$ LE TOURNEAU ET AL., supra note 77, at 2028, no 8054.

${ }^{243}$ See, e.g., Art. 1 of Loi no $85-677$ du 5 juillet 1985 tendant à l'amélioration de la situation des victimes d'accidents de la circulation et à l'accélération des procédures d'indemnisation, JORF du 6 juillet 1985, p. 7584.
} 
There seems to be something more than just a proliferation of strict liability regimes within the French legal system. While a majority of these non-Code provisions were enacted with the purpose of creating strict liability regimes, the historical pattern seems to point toward a more significant overall shift from private law to public law, and in some cases toward an interplay between private law remedies and public law compensation and prevention schemes. On the one hand, the law of civil liability is being replaced in some circumstances with social security mechanisms and compensation funds. The compensation of workers injured while on the job is an example of the former, while a series of laws creating compensation funds for victims of violent crimes, ${ }^{244}$ terrorism, ${ }^{245}$ or asbestos ${ }^{246}$ are examples of the latter. On the other hand, there is a tendency to combine the law of torts with mandatory insurance, ${ }^{247}$ administrative regulation, ${ }^{248}$ guarantee funds, ${ }^{249}$ and/or criminal penalties.

\section{Traffic accidents}

For the French law of torts, the most significant non-Code piece of legislation is what is known as the loi Badinter, ${ }^{250}$ aimed at creating a compensation system for victims of traffic accidents.

As we have already seen, ${ }^{251}$ the problem of road traffic accidents was initially addressed jurisprudentially, through the Jand'heur ${ }^{252}$ and Desmares ${ }^{253}$ cases, by way of making liability for

\footnotetext{
${ }^{244}$ Loi n ${ }^{\circ} 77-5$ du 3 janvier 1977 garantissant l'indemnisation de certaines victimes de dommages corporels résultant d'une infraction, JORF du 4 janvier 1977, p. 77.

${ }^{245}$ Loi n ${ }^{\circ} 86-1020 \mathrm{du} 9$ septembre 1986 relative à la lutte contre le terrorisme et aux atteintes à la sûreté de l'État, JORF nº210 du 10 septembre 1986, p. 10956.

${ }^{246}$ Loi no 2000-1257 du 23 décembre 2000 de financement de la sécurité sociale pour 2001, JORF n²98 du 24 décembre 2000, p. 20558

${ }^{247}$ Mandatory insurance covers today over 120 types of activities. LE TOURNEAU ET AL., supra note 77, at 49, no 59 .

${ }^{248}$ E.g. Loi no 2003-699 du 30 juillet 2003 relative à la prévention des risques technologiques et naturels et à la réparation des dommages, JORF n 175 du 31 juillet 2003, p. 13021.

${ }^{249}$ E.g. Loi nº 2006-1772 du 30 décembre 2006 sur l'eau et les milieux aquatiques, JORF nº303 du 31 décembre 2006, p. 20285.

${ }^{250}$ Loi no $^{\circ} 85-677$ du 5 juillet 1985 tendant à l'amélioration de la situation des victimes d'accidents de la circulation et à l'accélération des procédures d'indemnisation, JORF du 6 juillet 1985, p. 7584 [Referred to in this study as Loi du 5 juillet 1985].

${ }^{251}$ Supra Part C.1 of this chapter.

${ }^{252}$ Cass. Ch. Réun, 13 February 1930, DP 1930.1.57, note Georges Ripert, rapport Le Marc'hadour, conclusions P. Matter ; S.1930.1.121, note Paul Esmein.

${ }^{253}$ Cass. Civ. 2e, 21 July 1982, D. 1982. 449, concl. Charbonnier, note Larroumet ; JCP 1982. II. 19861, note

Chabas; Defrénois 1982. 1689, obs. Aubert ; RTD civ. 1982. 607, note G. Durry.
} 
things stricter. ${ }^{254}$ In fact, the Desmares decision was the final trigger (or provocation) for reform, ${ }^{255}$ the 1985 law regarding compensation for traffic accidents being a reaction to the Court of Cassation's bold decision.

A significant role was played by academia as well. Beginning in the middle of the 1960's, the debate within French academia regarding the reform of the law of traffic accidents was marked by the two very well argued legislative proposals made by Professor André Tunc (and other French scholars under his direction), one in $1966,{ }^{256}$ and the other in $1981 .{ }^{257}$ Professor Tunc's proposals were much more revolutionary than the current framework established through the loi Badinter, because he envisaged a system of automatic compensation, where fault (including the fault of the victim) would play no part. The gist of the critique of traditional tort law was that compensation through tort mechanisms is very slow, especially in a context where insurance companies had the tendency to delay compensation and prefer litigation, and where the simple fault of the victim was a defence. Given the uphill battle they faced-since the interest groups of both lawyers and insurance companies had a stake in keeping the tort system unchanged ${ }^{258}$ — it is impressive how influential these proposals proved to be.

While the academic movement led by Professor André Tunc proved to be persuasive on the Court of Cassation, which decided in Desmares that the fault of the victim can no longer be used as a defence in case of liability for things, ${ }^{259}$ it was less cogent for the legislature. The 1985 reform of traffic liability is a compromise and hybrid between automatic compensation and traditional tort law, including fault-based liability. This special law $^{260}$ establishes mainly a compensation system,

\footnotetext{
${ }^{254}$ Before the proliferation of individually owned motor vehicles, of course, the problem of road traffic accidents involved mainly horse-driven carriages, and in that context, the question fell under the field of liability for the act of animals. See Geneviève Viney \& Anne Guégan-Lécuyer, The development of traffic liability in France, in THE Development of Traffic Liability 50, at 60 (Wolfgang Ernst ed., Cambridge University Press 2010).

${ }^{255}$ See Jean-Luc Aubert, L'arrêt Desmares : une provocation ... a quelles réformes?, D.1983.1 (Chron.). ${ }^{256}$ ANDRÉ TUNC, LA SÉCURITÉ ROUTIÈRE. ESQUISSE D’UNE LOI SUR LES ACCIDENTS DE LA CIRCULATION (Dalloz 1966).

${ }^{257}$ ANDRÉ TUNC ET AL., POUR UNE LOI SUR LES ACCIDENTS DE LA CIRCULATION (Economica 1981).

${ }^{258}$ See FABRE-MAGNAN, supra note 9, at 283.

${ }^{259}$ Cass. Civ. 2e, 21 July 1982, supra note 253.

${ }^{260}$ The Court of Cassation interpreted the law in an autonomous manner as a special liability and compensation regime, derogating from the general law of torts and in particular article 1384 (1). The autonomy achieved is rather limited, as many times the Court of Cassation needed to refer back to the law of torts, particularly when dealing with issues of fault or causation. See LE TOURNEAU ET AL., supra note 77, at 2032-33, no 8064, and 2046, no 8103.

Moreover, there is one remarkable exception to the special and derogating character of the loi Badinter: in case of accidents caused by employees, only employers will be liable under the conditions of the loi Badinter, the
} 
and distances itself from the law of torts particularly through a laxer requirement of causation: first, the law requires only that a vehicle be "involved" in an accident in order to trigger compensation; ${ }^{261}$ and second, drivers are not allowed the defence of force majeure or the act of a third party. ${ }^{262}$ This is indeed reflective of a victim-oriented and victim-friendly philosophy. However, for personal injury, ${ }^{263}$ the law then goes on and distinguishes between non-driver victims and victims that drive vehicles involved in an accident. The first category of victims is privileged because, in principle, automatic compensation operates irrespective of their fault, except for their "inexcusable fault", and only if said inexcusable fault is the sole cause of the accident. ${ }^{264}$ Furthermore, if the non-driver victim is less than 16 years old, or more than 70 years old, or has a recognized incapacity or disability of at least $80 \%$, the "inexcusable fault" defence is inapplicable. ${ }^{265}$ However, if the victim is also a driver, the victim's fault will limit or exclude their right to compensation. ${ }^{266}$ This has been a highly criticized distinction in French academia, ${ }^{267}$ which made the 1985 law on traffic accidents less victim-friendly than the legislative proposals of André Tunc, or the Desmares jurisprudence for that matter.

In the current system, non-driver victims benefit from a system that goes well beyond strict liability, while driver victims benefit from something akin to a rebuttable presumption of fault (particularly in cases of collisions between two or more vehicles). Both the Catala and the Terré reform projects for the law of torts envisaged erasing this distinction, thus allowing driver victims automatic compensation, except for their "inexcusable fault," just like non-driver victims. ${ }^{268}$

It is hard to understand the rules of the loi Badinter, and the proposals to change it, without seeing the bigger picture of compensation for damage caused as a result of traffic accidents in France.

employees still benefit from the immunity they have under the interpretation of article 1384 (5) as expressed in the Costedoat case (Cass. Ass. Plén., 25 February 2000, supra note 92). Cass. Civ. 2e, 28 May 2009, nº 08-13310, Bull. civ., II, $n^{\circ}$ 128; JCP 2009.92, note J. Mouly; D.2009.1606, obs. I. Gallmeister; D.2009.2667, note N. Pierre; D.2010.55 obs. Philippe Brun; RTD civ.2009.541, obs. Patrice Jourdain.

${ }^{261}$ Art. 1 of Loi du 5 juillet 1985.

${ }^{262}$ Art. 2 of Loi du 5 juillet 1985.

${ }^{263}$ In cases of damage to property, the fault of the victim is always a defence. Art. 5 of Loi du 5 juillet 1985.

${ }^{264}$ Art. 3 (1) of Loi du 5 juillet 1985.

${ }^{265}$ Art. 3 (2) of Loi du 5 juillet 1985.

${ }^{266}$ Art. 4 of Loi du 5 juillet 1985.

${ }^{267}$ LE TOURNEAU ET AL., supra note 77, at 2057, no 8147 ; FRANÇOIS CHABAS, LE DROIT DES ACCIDENTS DE LA CIRCULATION APRĖS LA RÉFORME DU 5 JUILLET 1985, at 160-65 (2 $2^{\text {nd }}$ ed., Gazette du Palais \& Litec 1988); Hubert Groutel, La faute du conducteur victime dix ans après, D.1995.335 (Chron.); Fabrice Leduc, La sanction de la faute du conducteur victime en question, RCA 2011, Étude 12, no 10 (October 2011).

${ }^{268}$ Art. 1385-2 of the Catala Project, supra note 120; Art. 26 of the Terré Project, supra note 121. 
The shift from fault-based standards to strict liability, and then automatic compensation, must be read as simply a point in a complex nexus of legislation. The compensation of damage is almost never secured from the pocket of the individual driver, considering the fact that France has a mandatory insurance system in place for traffic accidents. ${ }^{269}$ Losses stemming from nonintentional traffic accidents are therefore being spread through such a scheme on all the participants to traffic. That being said, one might wonder if strict liability or automatic compensation would lead to an efficient distribution of costs and questions might be asked in regard to the incentives such a system creates. However, looking at the bigger picture, it would be a misjudgement to say that abandoning a fault-based standard for traffic accidents means giving up on prevention and deterrence. The response offered by French law to the problem of traffic accidents is much more complex than just its system of compensation. Prevention and deterrence are being served by rules stemming from administrative law (road signals, information and education of the public, stringent procedures for obtaining driving permits, etc.), criminal law (many delicts and contraventions deal with traffic violations), and contract law (clumsy drivers have to pay higher insurance premiums). In addition, one ought not to forget that intentional acts fall outside of the scope of the law on traffic accidents, and the law does not protect actors who act recklessly (by committing an inexcusable fault), so the risk of encouraging reckless behaviour through such a system is practically non-existent.

With all its inconsistencies, and although heavily criticized, the 1985 reform of the law of traffic accidents in the end largely achieved its declared purpose of simplifying the law of traffic accidents and accelerating compensation procedures for victims, ${ }^{270}$ and looking at the bigger picture, it did so without sacrificing the goals of prevention and deterrence of future traffic accidents.

\footnotetext{
${ }^{269}$ Loi n $58-208$ du 27 février 1958, institution d'une obligation d'assurance en matière de circulation de véhicules terrestres à moteur, JORF du 28 février 1958, p. 2148.

${ }^{270}$ FABRE-MAGNAN, supra note 9, at 284.
} 


\section{CHAPTER III}

\section{STRICT LIABILITY IN ENGLAND}

A. The Common Law Tradition and the Growth of Trespass and Negligence

1. The early common law

As opposed to the French legal system, where the legal framework of the law of delicts, or la responsabilité civile délictuelle, is based on general principles established mainly through legislation, the English law of torts seems much more fragmented, with specific, judge-made rules that are still closely in touch with the facts that led to their creation. The idea of a "law of torts" (or wrongs), as opposed to a "law of delict" or a "law of responsibility", can be said to be specific to the common law tradition. Instead of relying on general principles, the English law of torts is divided into various actions, some covering very specific and narrow sets of facts (for instance, libel and slander, the former dealing with defamatory statements in writing, while the latter with oral defamation), and others covering a vast variety of possible cases (the tort of negligence and nuisance being the best examples).

The best explanation is once again historical: for many centuries, redress for wrongs was dependent on procedure more than on the existence of a set of substantive norms. The development of the English law of torts goes all the way back to the development of the first forms of action, the building blocks of the common law. The forms of action, of course, were abolished in 1852, ${ }^{1}$ but Maitland's famous words resonate strongly in the law of torts: "The forms of action we have buried, but they still rule us from the grave."

The origins of the English common law and of the various forms of action are hard to identify though, at least with great precision. The evolution of English law has always been one of incremental development, ${ }^{3}$ and this process began long before an English nation or state took shape.

\footnotetext{
${ }^{1}$ Common Law Procedure Act, 1852,15 \& 16 Vict., c. 76.

${ }^{2}$ Frederic William Maitland, Equity, also The Forms of aCtion at Common law 296 (Cambridge University Press 1909, repr. 1929).

${ }^{3}$ Or, in the words of Patrick Glenn, "incremental change". H. PATRICK GLENN, LEGAL TRAdITIONS OF THE WorLD $253\left(4^{\text {th }}\right.$ ed., Oxford University Press 2010).
} 
Even the Norman Conquest (1066), which contributed perhaps the most to the development of a distinct legal tradition on the English island, did not make tabula rasa of the old customs of the conquered Anglo-Saxon population. William the Conqueror took the throne of England through war, but based the legitimacy of his reign on his blood right, and claimed to be king by lawful succession. ${ }^{4}$ It made sense for him not to make changes that would be seen as too sweeping in order to reinforce the idea of continuity that comes with lawful succession. Also, he found a system of laws in place that was relatively well-developed for that time. ${ }^{5}$ England was, politically at least, already a relatively unified nation, ${ }^{6}$ with an incipient bureaucracy that operated through written documents under the king's seal, and with local sheriffs enforcing the king's law and will in the territory.

The essential element brought by the new Norman court was a "taste for strong government and [...] flair for administration", 7 which led to the early development of centralized royal power. Within a century after the conquest, two great institutions of the state with Norman $\operatorname{roots}^{8}$ were created: the Chancery ${ }^{9}$ and the Exchequer. ${ }^{10}$ At the same time, the King's Bench began to take shape. ${ }^{11}$

Initially, the Conqueror and his successors did not implement sweeping changes in matters regarding the resolution of disputes. The vast majority of cases were decided still by the old local

\footnotetext{
${ }^{4}$ J.H. BAKER, AN InTRODUCtion to ENGLISH LEGAL History 14 (3rd ed., Butterworths 1990).

${ }^{5}$ Maitland even goes as far as to suggest that the Anglo-Saxon laws were more developed and refined than the laws of Normandy. The Norman conquerors did not have any written laws of their own and were, in Maitland's harsh words, "a less civilized race than were those English whom they came to subjugate." FREDERIC WILLIAM MAITLAND \& Francis C. Montague, A Sketch of English Legal History 26 (James F. Colby ed., The Lawbook Exchange 2010).

${ }^{6}$ The unification of England began under Alfred of Wessex (899 A.D.) and was completed during the $10^{\text {th }}$ century. BAKER, supra note 4 , at 3.

${ }^{7} I d$. at 14 .

${ }^{8}$ See Amable Floquet, EsSAi historique SUR L'ÉCHIQUIER DE NoRMANDIE 5-6 (Rouen - Édouard Frère 1840) (discussing the origins of the Exchequer).

${ }^{9}$ The Chancery began as the secretariat for the king, and not as a court of law (which was a role it developed progressively). Its initial mission was to hold recordings of royal writs and charters and the chancellor had custody of the great seal of England. Its role as a court of extraordinary jurisdiction developed progressively due to the very important role played by the chancellor in the administrative apparatus of the king. For more information about the evolution of the jurisdiction of the Chancery, see George Spencer, The History of the Court of Chancery in 2 SELECT ESSAYS IN ANGLO-AMERICAN LEGAL History 219 (Little, Brown and Co. 1908, repr. The Lawbook Exchange 1992).

${ }^{10}$ The "Exchequer" took shape during the reign of Henry I as a powerful central tribunal and financial bureau, controlled by the king's ministers. MaitLand \& MONTAGUE, supra note 5, at 29.

${ }^{11}$ See George Burton Adams, The Origin of the English Courts of Common Law, 30 YaLE L.J. 798; George A. Bonner, The History of the Court of King's Bench, 11 BeLL YARD: J.L. SOC'Y SCH. L. 3 (1933).
} 
courts, called "shire moots" and "hundred moots," 12 to which newly created seigniorial courts were added. ${ }^{13}$ The king's court was busy mainly with protecting and enforcing royal rights and settling disputes between the king's barons and, in the rare occasion, a court of last resort for the persistent litigant. ${ }^{14}$ Slowly, however, the communal and seigniorial courts started to be replaced by a centralized justice system under the control of the king. During the reign of Henry II, the king's court was opened to all litigants, and the king's bench of professional justices began their "circuits", which meant that they would appear periodically in all the counties as Justices in Eyre (or Itinerant Justices). ${ }^{15}$

With defined boundaries, a relatively homogenous population, a professional judiciary, and a centralized system of government, England can very well be called "the first discernable state [that] came into being in Europe." 16 By the time the Corpus Juris Civilis was rediscovered in the $12^{\text {th }}$ and $13^{\text {th }}$ centuries, England already had the makings of its own original legal system. The early development of a centralized system of government, coupled with an early "inoculation"17 with elements of Roman law, and the development of a centralized court system run by professional judges, allowed the English common law to resist the temptation of completely reforming its law on Roman foundations like the rest of Europe. The royal judges of England had already created a substantial body of precedents and hence a strong corpus of law by the time the Corpus Juris Civilis was rediscovered.

\section{The writ}

It is truly remarkable that the body of judge-made law that generated the early common law was able to provide a workable alternative to Justinian's compilation. The fact that English law took a different turn as compared to the law on the Continent has been described as an accident

\footnotetext{
12 The shire moots were assemblies that met twice a year to discuss the affairs of a certain region in the country (the shire), be it judicial, administrative or legislative. The shires were divided in smaller units called "hundreds", and the hundred moots were assemblies that met monthly to discuss the judicial and administrative problems of the community. For more details on the shire and the hundred moots see BAKER, supra note 4, at 4-9.

${ }^{13}$ Maitland \& MonTAgUe, supra note 5, at 30.

${ }^{14} I d$.

$15 \mathrm{Id}$. at 31 .

${ }^{16}$ GLENN, supra note 3, at 238.

${ }^{17}$ See Heinrich Brunner, The Sources of English Law in 2 SELECT EsSAYS IN ANGLO-AMERICAN LEGAL HiSTORY 7 , 36, 42 (The Lawbook Exchange 1992; originally Little, Brown and Co. 1908).
} 
or "chance" of history, ${ }^{18}$ and in many ways it was. English law at the time of the rediscovery of the Corpus Juris Civilis was nowhere near as sophisticated as the late Roman law which was encapsulated in it. However, the seeds of a separate legal tradition were already in place. When the Corpus Juris Civilis saw its last days in the Roman Empire, the kingdoms of England began writing down their own customs, ${ }^{19}$ and the written word was a key ingredient in the legal tradition that was about to emerge. The habit of writing down not just laws, but also the king's orders to his sheriffs, and later, the recording of decisions of the king's court and of his Justices in Eyre, made the early common law develop into a tradition of its own. Writing down rules and the orders of kings is a legacy that goes back all the way to the Anglo-Saxon kings. In fact, the first known text in the English language is also the earliest surviving piece of legislation, dating back to Æthelbert I of Kent, around 600 A.D. ${ }^{20}$

Ironically though, what allowed the English common law to resist the influence of the Corpus Juris Civilis was the fact that by the end of the $12^{\text {th }}$ century, it unintendedly developed very much like the early Roman $l^{21} w^{21}$ in a praetorian fashion. The difference was the Romans relied on formulas, the English on the "writ." The two centuries that followed the Norman conquest were essential for the creation of the common law, because that is when all the ingredients of the old Anglo-Saxon law and the newer Norman laws and institutions fused at an accelerated pace, giving English law its distinct flavour. It was also the time when the writs became the backbone of the justice system in England.

The word "writ" itself means "written document" (a "writing"). ${ }^{22}$ In the most general terms, access to the king's justice was premised upon the issuance of such a written document, and indeed "[w]here there was no writ, there was no right" in the early common law. ${ }^{23}$

\footnotetext{
${ }^{18}$ R.C. van CAenegem, The Birth of the English Common LaW 108 ( $2^{\text {nd }}$ ed., Cambridge University Press 1988). Pollock and Maitland described the Norman conquest as a "catastrophe which determines the whole future history of English law". Frederick Pollock \& Frederick William Maitland, 1 The History of ENGLish LaW Before THE TIME OF EDWARD I, at 57 (Cambridge University Press 1895).

${ }^{19}$ BAKER, supra note 4 , at 2.

${ }^{20}$ Maitland \& Montague, supra note 5, at 3;

${ }^{21}$ See Fritz Pringsheim, The Inner Relationship Between English and Roman Law, 5 CAMBRIDGE LAW JouRnAL 347, 358 (1935).

${ }^{22}$ BLACK'S LAW DiCTIONARY, vo writ, 1845 (Brian A. Garner ed., $10^{\text {th }}$ ed., Thomson Reuters 2014) (hereinafter BLACK'S LAW DICTIONARY).

${ }^{23}$ R.F.V. Heuston \& R.S. Chambers, SAlmond and Heuston on the Law of Torts 1 (Sweet \& Maxwell 1981).
} 
Initially a "writ" issued by the king or in the king's name was not a judicial document at all, but an executive order. Plaintiffs sought out writs in order to avoid going to the only courts that were available to them, and those were the local courts: hundred moots, shire moots and manorial courts. It is quite understandable that a direct executive order from the king was seen as much more advantageous than the procedure in the local courts, which involved proof by oath and various ordeals (trial by water or by fire), and where judgment usually preceded proof (once the local court decided that a party must pass an ordeal, there was little left to decide other than see if that party passed the ordeal). ${ }^{24}$

The issuance of executive writs had its downfalls, because usually only one party to the dispute presented the case; no witnesses or jurors were heard, no documents inspected, no experts consulted, and it was entirely possible that multiple, contradictory, or self-defeating writs could be sought for the same issue. ${ }^{25}$ Litigants even began to ask for writs that would safeguard against other writs. $^{26}$

By the time of Henry II, royal intervention in the affairs brought before the king and his justices transformed into a truly judicial affair, and this transformative process brought about various procedural rules, guarantees, and a fair examination of the merits of claims that was based on and followed the presentation of evidence. ${ }^{27}$ A simple change in the language of the writs brought about this extraordinary transformation in procedure: whereas in the older writs the king simply ordered the addressee to do something, the newer writs, known as the "original writs", while still maintaining the appearance and some effects of the executive writs, ${ }^{28}$ added the option for the party to whom they were addressed to appear before the king or his justices and present reasons why the order was opposed and defend his own rights. This possibility, of "returning the writ" 29

\footnotetext{
${ }^{24}$ BAKER, supra note 4 , at 6.

${ }^{25}$ VAN CAENEGEM, supra note 18 , at 36.

${ }^{26} \mathrm{Id}$. at 37.

${ }^{27}$ Id. at 39; See also Doris Mary Stenton, English Justice BetweEn the NoRman Conquest AND the GREAT CHARTER, 1066-1215, at 51-53 (The American Philosophical Society 1964).

${ }^{28}$ The wording of the original writs began with a first part that contained an order for the defendant to carry out a command from the king (just like an executive writ), but with the possibility of returning the writ this order became only a relic from the past; that being said, this relic from the past carried with it some financial consequences, as a losing defendant was liable to payment of a fine on account of disrespecting the king's orders contained in the writ. VAN CAENEGEM, supra note 18, at 52-53.

${ }^{29}$ See BAKER, supra note 4, at 64-65.
} 
to the king or his justices meant that both parties would now have the chance to be heard and be allowed to present evidence before a remedy became final.

The procedural rules laid down in the writs varied from case to case, according to the matter that was brought for resolution, and new fact patterns required the issuance of new writs. In the formative years of the common law, many new writs were issued by the Chancery. From the time of Glanvill (around 1189) to the reign of Edward I (1272-1307) the number of writs increased, according to Arthur Hogue, from 39 to over $400 .{ }^{30}$ However, this rapid expansion did not continue indefinitely. Even though there was no a priori doctrine to this effect, the original formulae of the writs had the innate tendency to become fixed. Plaintiffs were not allowed to write or formulate their own complaints freely, as was the case in the local courts, but had to either rely on already existing writs or apply for a new writ to be created. ${ }^{31}$ It was, of course, much more convenient, expedient and cheaper to rely on an existing writ than to ask for a new one to be created. Still, despite this tendency, the uninhibited proliferation of new writs became a problem by the middle of the $13^{\text {th }}$ century. In order to curtail the discretionary creation of new writs, the Chancellor was sworn not to issue any unprecedented writs without first securing the assent of the king's council, through the Provisions of Oxford in $1258 .^{32}$ The original writs thus became fixed precedents, and claimants needed to find a suitable existing writ in order to enforce their rights. In fact, a right did not even exist without a writ to back it up. Procedure trumped substance; or, in the more elegant words of Maine: "Substantive law has at first the look of being gradually secreted in the interstices of procedure". 33

The limits placed on the creation of new writs did not inhibit the development of the common law. The original writs provided a rich basis for an evolution that gradually shifted focus from formal procedure to substantive claims by way of stretching the ambit of original writs that proved more flexible. From a substantive angle, much like what we have seen earlier with France, the story of English tort law has been one of a constant expansion of liability rules, and it all began with the action of trespass.

\footnotetext{
${ }^{30}$ ARThUR R. Hogue, ORIGINS OF THE COMmON LAW 13 (Indiana University Press 1966, repr. Liberty Fund 1986).

${ }^{31}$ BAKER, supra note 4 , at 65 .

${ }^{32} I d$. at 66 .

${ }^{33}$ Henry Sumner Maine, DisSertations on Early LaW and Custom 389 (Henry Holt and Company 1886).
} 


\section{The early action for trespass}

The reader must first understand the context from which the action for trespass grew. The world of the $13^{\text {th }}$ century and the legal thinking of that time were very different from modern conceptions of the world and of the law. Looking into the early cases on trespass with the eyes of the present, arguably, one might see an evolution from a broad rule of absolute liability ${ }^{34}$ towards fault-based liability, and many authors have deduced such a conclusion from the early case law. ${ }^{35}$ Others have argued that the English common law has always been based on standards of negligence. ${ }^{36}$ If, however, one puts the early case law on trespass into context, the more likely evolution seems to be from no, or very little, civil liability to an ever expanding law of torts. ${ }^{37}$ The wronged English subject of the $13^{\text {th }}$ century was more likely to find no justice at all than a favourable absolute liability rule. In the words of Percy Winfield: "It must be recollected that the age was a rough one, stricken with poverty, that it had a hard task in wrestling with the intentional evil-doer, and that mere negligence, even if it inflicted bodily injury, was not much accounted unless it resulted in death." 38 Seeking the king's justice was not easy by modern standards, nor was it cheap, and we have already seen that a substantive claim meant very little without a writ to

\footnotetext{
${ }^{34}$ It has been debated whether or not the nature of liability in the early action for trespass was absolute. Compare, for instance, John Henry Wigmore, Responsibility for Tortious Acts: Its History in 3 SELECT ESSAYS IN ANGLOAmERICAN Legal History 480 (Little, Brown and Co. 1909) (this essay first appeared in the Harvard Law Review, 1894, vol. VII, at 315, 383, 442), with Oliver Wendell Holmes, THe Common LAW 53 (Little, Brown, and Company 1881, repr. Holmes Press 2012), and Percy H. Winfield, The Myth of Absolute Liability, 42 L. Q. Rev. 37 (1926).

35 Theodore F.T. Plucknett, A Concise History of the Common Law 463-64 ( $5^{\text {th }}$ ed., Little, Brown \& Co. 1956, repr. Liberty Fund 2010); M.A. Millner, Negligence In Modern LaW 203 (Butterworth \& Co. 1967); James Barr Ames, Law and Morals, 22 HARV. L. Rev. 97, 99 (1908); Morris S. Arnold, Accident, Mistake, and Rules of Liability in the Fourteenth-Century Law of Torts, 128 U. PA. L. REV. 361, 364, 368-74 (1979); John H. Wigmore, Responsibility for Tortious Acts: Its History III, 7 HARV. L. REV. 441, 442 (1894).

${ }^{36}$ C.H.S. FifoOt, History AND SOURCES OF THE COMMON LAW 187-95 (Greenwood Press 1970; originally Stevens \& Sons Ltd. 1949); S.F.C. Milsom, Historical Foundations of THE COMMON LAW 295-300 (2 ${ }^{\text {nd }}$ ed., Butterworths 1981); See also Stephen C. Gilles, Inevitable Accident in Classical English Tort Law, 43 EMORY L. J. 575 (1994) (arguing, however, that the centrality of the inevitable accident defence in the early common law and the fact that the defence referred not only to the defendant having taken customary reasonable care, but also to have taken all possible practical care, taking into consideration his abilities and skill, thus indicating that the early cases may have been grounded on subjective negligence).

${ }^{37}$ This applies not only to the early development of tort law. It is also true for the development of liability rules in the $19^{\text {th }}$ and the $20^{\text {th }}$ century. The law of product liability is a perfect example, having evolved from a no-liability rule (no recovery due to a lack of privity of contract), to fault liability, and then strict liability. See Robert L. Rabin, The Historical Development of the Fault Principle: A Reinterpretation, 15 GA. L. REV. 925 (1980-1981) (providing, in addition to the product liability example, other illustrations of the same trend in cases of trespass to land, or industrial injuries).

${ }^{38}$ Percy H. Winfield, The History of Negligence in Torts, 42 L. Q. REV. 184, 185 (1926).
} 
back it up. Also, the king's justice was still either a question of personal favour or, later on, an alternative, be it a very attractive one, to the justice of the local courts.

The birth of trespass as a cause of action largely coincides also with the birth of the idea that claimants could recover damages for wrongs committed against them, especially when dispossessed of property. ${ }^{39}$ Initially all actions for damages took the same form ostensurus quare, which is a variety of the original writs whereby the King ordered the sheriff to summon the defendant to the royal court so that the defendant might explain why he had done certain things. ${ }^{40}$ For that purpose, the early action for trespass never required fault, either in the form of intent or negligence. ${ }^{41}$ The act simply had to be voluntary, and to this day this has not changed for trespass to land. ${ }^{42}$

The action for trespass initially combined what in the eyes of a modern lawyer look like elements of criminal law and private law. The modern distinction between tort law and criminal law was not in place when the action for trespass began to take shape, and the possibility for the victim to recover damages in actions for trespass was accessory to the main issue, which was the breach of the king's peace, with the use of force and arms. ${ }^{43}$ Looking just at trespass, the law seems to evolve from the initial primacy of criminal law toward more and more enforcement through private law. ${ }^{44}$ But if one were to go all the way back to Anglo-Saxon rule and then look at English law as a whole, the situation seems reversed: older customs invited parties to settle and submit their disputes to arbitration, even in cases of murder, whereas after the Norman conquest there seems to be a growing trend for the crown to actively investigate crimes and submit criminals to the king's justice. ${ }^{45}$ From this point of view, the development of the action for trespass is an exception. The action for trespass grew in its ambit by turning the conditions that gave it a public law flavour into fictions.

\footnotetext{
${ }^{39}$ The first reported case where damages were awarded under the assise of novel disseisin was traced back to 1198 . George E. Woodbine, The Origins of the Action of Trespass, 33 Yale L.J. 799, 807 (1924).

${ }^{40}$ PLUCKNETT, supra note 35 , at 370.

${ }^{41}$ Percy H. Winfield \& Arthur L. Goodhart, Trespass and Negligence, 49 L. Q. REV. 359, 359-362 (1933).

${ }^{42}$ See infra Part B.9 of this chapter.

${ }^{43}$ André Tunc, Introduction in 11 InTERNATIONAL ENCYCLOPEDIA OF COMPARATIVE LAW, TORTS, Ch. I at 37 (I-67) (André Tunc ed., J.C.B. Mohr (Paul Siebeck) \& Martinus Nijhoff Publishers 1983).

${ }_{44}^{44}$ PluCKNETT, supra note 35, at 423, 465.

${ }^{45} \mathrm{Id}$. at 423 .
} 
Two public law elements are discernible in the early action for trespass: (1) the breach of the king's peace; and (b) the use of force and arms (vi et armis). The "breach of the king's peace" seems to have always been a jurisdictional matter more than a definitional one for the tort of trespass: determining which trespasses were actionable in the royal courts, not what kind of action constituted a trespass. ${ }^{46}$ The notion itself was so malleable ${ }^{47}$ that a breach of the king's peace did not have to be proven in any way: it was not something that had to really exist, but had to simply be stated as an allegation by the plaintiff. ${ }^{48}$ Most importantly, the requirement of the use of force and arms in time lost its initial meaning, and became a mere fiction. ${ }^{49}$ Generally, the writ of trespass had to formally contain allegations of use of force and arms, but proof of such allegations was not essential for the success of the action. ${ }^{50}$

In the vernacular of the $13^{\text {th }}$ century, the word "trespass" itself simply meant "wrong", but by the 1270 s the word acquired a very specific meaning as a term of art in the law courts. ${ }^{51}$ Despite the narrow initial interpretation of what a trespass initially meant in the royal courts, i.e. a wrongful interference with a person's property by use of force, this old tort remedy in many ways became the primordial source of all modern actions in tort, thus living up to the broad meaning it had for laymen. Maitland poetically called trespass that "fertile mother of actions" ${ }^{52}$ From the early action of trespass have grown the modern actions of trespass to land, battery, and conversion, ${ }^{53}$ and alongside it the action for trespass "on the case" developed and expanded, and in time became the modern tort of negligence.

\footnotetext{
${ }^{46}$ DAVid IbBetson, A Historical Introduction to the LaW of Obligations 39 (Oxford University Press 2001).

${ }^{47}$ Although we have an early definition of the king's peace that seems very precise: "The king's peace shall extend thus far from this gate, where he is in residence, in all four directions from that place, that is to say, three miles, three furlongs, the breath of three acres, nine feet, the breath of nine hands and of nine grains of barley." IBBETSON, supra note 46 , at 39 .

${ }^{48} I d$.

${ }^{49}$ Id. at $40-41$.

${ }^{50}$ Some early writs were accepted in royal courts even without this allegation $I d$. That being said, the fact that the writs contained fictitious allegations of use of force and arms was sometimes a problem for plaintiffs, because it distracted juries from what the real issue was in a case. Id. at 50.

${ }^{51}$ IBBETSON, supra note 46, at 39 .

${ }^{52}$ MaitLAND, supra note 2, at 342 .

${ }^{53}$ Fascinatingly, to this day, the modern forms of trespass - trespass to land and battery - have kept some key characteristics from the $13^{\text {th }}$ century: liability is still based on voluntariness of the act (although only in the case of trespass to land), and these two torts are also crimes (although the burden of proof is now different in the criminal action, and trespass to land is not a criminal offence as a rule - a special statute is needed to make trespass to land criminal). See infra Part B.9 of this chapter.
} 


\section{The tort of negligence}

Up until the beginning of the $19^{\text {th }}$ century, there were no significant developments in the law of trespass as such. ${ }^{54}$ The most significant developments from the $15^{\text {th }}$ to the $19^{\text {th }}$ century had to do with the action in case. The original quare actions were very diverse and, out of that diversity, trespass was the first action to acquire an independent existence. ${ }^{55}$ All the other quare actions either fell out of use, or developed into separate independent actions. ${ }^{56}$ What was left was a large group of miscellaneous actions, all of which had in common just the fact that they did not meet the criteria for actions in trespass. ${ }^{57}$

The line between trespass and case was only drawn with some level of precision in the $15^{\text {th }}$ century. According to some authorities, trespass emerged at this time as dealing with damage that is caused through the direct use of force, while case was left with damage that is consequential (or indirect) ${ }^{58}$ According to other authors, the distinction becomes one between misfeasance (actively breaching a duty), which corresponds to the action for trespass, and nonfeasance (breaching a duty through omissions), corresponding to case. ${ }^{59}$ It is only toward the end of the $18^{\text {th }}$ century and the beginning of the $19^{\text {th }}$ century that the action in case starts to be seen as an action sanctioning negligent behaviour. ${ }^{60}$

This is the point in history when the industrial revolution began to show its effects in England. Here we also catch up with the starting point of the description of French law from the previous chapter. The $19^{\text {th }}$ century was a century of reform and rapid development of the law of torts in England, both jurisprudentially and through statutory enactment.

\footnotetext{
${ }^{54}$ PLUCKNETT, supra note 35, at 468.

${ }^{55} \mathrm{Id}$.

${ }^{56} I d$. at 469.

${ }^{57} I d$.

${ }^{58}$ William Blackstone, 3 Commentaries on the Laws of England. In Four Books 208 (Clarendon Press 1768, repr. Forgotten Books 2012): "[I]n general, any misfeasance, or act of one man whereby another is injuriously treated or damnified, is a transgression, or trespass in it's [sic] largest sense; for which we have already seen, that whenever the act itself is directly and immediately injurious to the person or property of another, and therefore necessarily accompanied with some force, an action for trespass vi et armis will lie; but, if the injury is only consequential, a special action of trespass on the case may be brought."

See also Blackstone's dissent in Scott v Shepherd, [1773] 96 Eng. Rep. 525.

${ }^{59}$ PLuCKNETT, supra note 35, at 469.

${ }^{60}$ PluCKNETT, supra note 35, at 471.
} 
England was "the world's first industrialized nation", ${ }^{61}$ and the industrial revolution was much faster and more dramatic in England than in France. ${ }^{62}$ Of course, this rapid industrialization came with new risks and new harms, but the response of the law, in particular the law of torts, was very different in England. The law did not evolve toward a proliferation of strict liability regimes, like it did in France. To the contrary. The story of the $19^{\text {th }}$ and the $20^{\text {th }}$ century law of torts in England is a story of the dominance of the tort of negligence.

Society at the end of the $18^{\text {th }}$ century was still to a large extent rural, and there was no real need to coordinate the regulation of risks at a national level. At that time, the paradigmatic tort law case found the victim on his property (land or home), and the tortfeasor was infringing the exclusive right the owner had over his property. ${ }^{63}$ What the industrial revolution and the rapid urbanization of the $19^{\text {th }}$ century brought about was a drastic increase in harms that happened outside of one's property, and the paradigmatic case soon became the personal injury case instead of the traditional trespass.

The beginning of the $19^{\text {th }}$ century finds the law of torts still focused on procedure more than substance, and the consequence was, of course, that the law at that time seemed incoherent. However, with the changes in society came also a change in the intellectual approach to tort law. In the minds of judges and jurists of the $19^{\text {th }}$ century, substance began to transcend form. The action on the case was so broad a form that a variety of wrongs could be brought under the same cause of action: slander and libel, trover, nuisance or negligence. Judges began to slowly see the substantive separation between the different wrongs as more important than the use of the correct form, and began to distinguish different substantive requirements for the different causes of action that could be allowed under the writ of trespass or case. ${ }^{64}$ Legal scholars also began to see the possibility of describing the law of torts in terms of substance, ${ }^{65}$ and perhaps even to deal with it

\footnotetext{
${ }^{61}$ Michael Lobban, Part four: Tort in The OXford History of THE Laws of England. Volume XII (1820-1914). PrIVATE LAW 879 (William Cornish et al. eds., Oxford University Press 2010).

${ }^{62}$ Marcel Gillet, Au XIXe siècle: industrialisation linéaire ou industrialisation par bonds?, 23 REVUE ÉCONOMIQUE 723,724 (1972).

63 "The paradigm problem in this world was that of the Englishman in his home, whose private domain was invaded by the unauthorized intrusion of another. Since his neighbour had no right to walk across his land, or let his cattle stray there, or interfere with his easements, the fact that he was careful counted for nothing." Lobban, supra note 61, at 889 .

${ }^{64}$ Sometimes it was not clear to judges which writ had to be brought, but they would grant a remedy as long as they were sure of the cause of action. Lobban, supra note 61 , at 888.

${ }^{65}$ The most notable first effort in this regard can be attributed to Blackstone, who treated the law of torts as a law of wrongs, and gave the title 'Private Wrongs' to Book 3 of his treatise. See Blackstone, supra note 58.
} 
coherently. ${ }^{66}$ Especially after the abolition of the forms of action by the Common Law Procedure Act of 1852, many jurists began to treat the law of torts in a scientific manner. ${ }^{67}$ At the end of the century, Frederick Pollock, and just a few years before him, Oliver Wendel Holmes in the United States, began to even articulate first principles of the law of torts, and to arrange the various torts in a comprehensive manner. The cross-influence over the Atlantic is well-known, as the two great authors studied each other's work and were in correspondence. ${ }^{68}$ For Pollock, the law of torts was divided according to three types of duties: "[...] to abstain from wilful injury, to respect the property of others, and to use due diligence to avoid causing harm to others". ${ }^{69}$ In his view, there was a general universal duty to take care not to harm others. The most important competing treatise to Pollock's was written by John Salmond, who argued that there was no general duty of care, but a number of different and "specific rules prohibiting certain kinds of harmful activity, and leaving all the residue outside the sphere of legal responsibility". ${ }^{70}$ At the end of the $19^{\text {th }}$ century, Salmond's generalization seemed to describe the law better than Pollock's, but Pollock was soon to be vindicated, in 1932, when the famous Donoghue $v$ Stevenson case ${ }^{71}$ was decided.

In practice, the law of negligence did not await the abolition of the forms of action or the classifications of jurists. Negligence standards began their development early in the $19^{\text {th }}$ century, ${ }^{72}$ and their evolution was not linear. The early $18^{\text {th }}$ century saw a rapid expansion of the law of negligence, which was, however, reined in from the 1850 s onwards. ${ }^{73}$ The year 1932 saw a new expansion and the beginning of the modern law of negligence in England, and the law of negligence saw its broadest form in the 1960s and 1970s, only to be then narrowed down again after the Caparo $^{74}$ decision.

\footnotetext{
${ }^{66}$ Attempts to deal with the law of torts in a coherent manner, based on principles, only truly begin after the publication in the United States of America of Holmes's “The Common Law". See HoLmES, supra note 34.

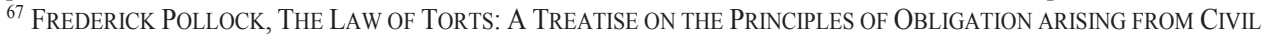
Wrongs In THE COMMON LAW, at vii ( $3^{\text {rd }}$ ed., Stevens and Sons Ltd. 1892).

${ }^{68}$ Lobban, supra note 61, at 890-91. Pollock's introduction to his treatise on torts is in fact addressed as a letter to his friend Oliver Wendell Holmes. PoLlOCK, supra note 67, at v-viii.

${ }^{69}$ POLLOCK, supra note 67, at 22.

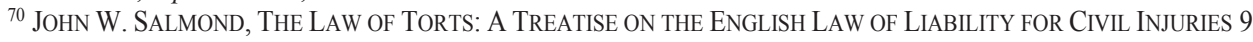
(2d ed., 1910).

${ }^{71}$ Donoghue v Stevenson, [1932] UKHL 100, [1932] A.C. 562.

${ }^{72}$ Lobban, supra note 61 , at 888.

${ }^{73} \mathrm{Id}$. at 991-992.

${ }^{74}$ Caparo Industries plc v Dickman, [1990] UKHL 2, [1990] 2 A.C. 605.
} 
Unlike the unitary treatment of fault under French law, issues of fault under English law were, from early on, broken down by judges into two distinct elements that had to be proven by the plaintiff: first, there must have been a duty of care owed by the defendant to the plaintiff; and second, that duty must have been breached by the defendant. It was the first element that always proved to be more restrictive under English law, and the ups and downs of the law of negligence are very much linked to how judges perceived the notion of duty.

The neminem laedere principle embodied in article 1382 of the French Civil Code, and advocated by Pollock in his treatise on the law of torts, ${ }^{75}$ was never part of English law as such. Up until 1932, judges did not see negligence as an independent tort, but as one way in which a wrong could be committed, meaning that there were many separate duties with different standards, some more strict, some less, that had to be found to exist, before analysing whether those duties had been breached. ${ }^{76}$

A unifying principle for the law of negligence found its way into the English law of torts in Lord Atkin's speech from Donoghue v Stevenson, holding that there was "some general conception of relations giving rise to a duty of care, of which the particular cases found in the books are instances. [...] You must take reasonable care to avoid acts or omissions which you can reasonably foresee would be likely to injure your neighbour." 77 The timing of this decision is remarkable, particularly when compared to the development of a general fault principle in French law. Between the time Domat was writing and Napoleon's empire (preceded by the adoption of the Civil Code), France reached the apex of its power, and the territory of France reached its most extensive point during Napoleon's reign. Great Britain reached the apex of its power and reached the highest point of the British empire's geographical expansion in the $1920 \mathrm{~s} .{ }^{78}$ This comparison is a strong reinforcement of Paul Mitchell's intuition that around the 1920s, English law needed formulations that proved the universal validity of English law, and its suitability for application throughout the empire. ${ }^{79}$ The same is true for France. The search for universal validity was pervasive in the natural law school that Domat was part of, and the earlier quotations of the exposé des motifs to the French

\footnotetext{
${ }^{75}$ PoLLOCK, supra note 67, at 12.

${ }^{76}$ Lobban, supra note 61, at 926.

${ }^{77}$ Donoghue v Stevenson, [1932] UKHL 100, [1932] A.C. 562, at 580.

${ }^{78}$ PAUl Mitchell, A History OF TORT LAW 1900-1950, at 15 (Cambridge University Press 2015)

${ }^{79} \mathrm{Id}$.
} 
Civil Code prove that the drafters of the Code were indeed searching for expressions of a morality that could claim a propensity for universality.

The law of negligence is to a great extent similar to French fault-based liability, but there are a few significant differences. Lord Atkin's formulation was by all means general, broad, and capable of universal application, but it still imposed two important limits on the element of duty: proximity and foreseeability:

At present I content myself with pointing out that in English law there must be, and is, some general conception of relations giving rise to a duty of care, of which the particular cases found in the books are but instances. The liability for negligence, whether you style it such or treat it as in other systems as a species of 'culpa, 'is no doubt based upon a general public sentiment of moral wrongdoing for which the offender must pay. But acts or omissions which any moral code would censure cannot in a practical world be treated so as to give a right to every person injured by them to demand relief. In this way rules of law arise which limit the range of complainants and the extent of their remedy. The rule that you are to love your neighbour becomes in law, you must not injure your neighbour; and the lawyer's question, Who is my neighbour? receives a restricted reply. You must take reasonable care to avoid acts or omissions which you can reasonably foresee would be likely to injure your neighbour. Who, then, in law is my neighbour? The answer seems to be-persons who are so closely and directly affected by my act that I ought reasonably to have them in contemplation as being so affected when I am directing my mind to the acts or omissions which are called in question. $^{80}$

Lord Atkin's speech was different from that of his peers on the bench, and arguably the other judges did not envisage such a broad liability rule. ${ }^{81}$ Nor did the legal profession see Donoghue v Stevenson as an expression of such a broad principle. In fact, this is a case that now stands for something very much different from what it originally represented for the legal profession. ${ }^{82}$ Most judges and practitioners saw the ruling of the case as being quite narrow, i.e. that a manufacturer of a defective product owed a duty of care to a third party if there was no opportunity for the third

\footnotetext{
${ }^{80}$ Donoghue v Stevenson, [1932] UKHL 100, [1932] A.C. 562, at 580.

${ }^{81}$ In fact, they actively opposed such a broad liability rule. Id. at 578 (Lord Buckmaster).

${ }^{82}$ MitCHELL, supra note 78, at 4.
} 
party consumer to detect that the product was defective. ${ }^{83}$ It was only in 1978 that Lord Atkin's test for determining the duty of care element in negligence gained traction, ${ }^{84}$ with the reception of the Atkinian principle in Anns $v$ Merton $L B C$ (and particularly in Lord Wilberforce's speech). ${ }^{85}$ For personal injuries and damage to property caused by acts (as opposed to omissions) the Atkinian principle remains, to this day, the law of the land in England. ${ }^{86}$ However, the expansion of the law of negligence to novel cases was curtailed by a new limiting element in Caparo Industries Plc v Dickman: ${ }^{87}$ judges can, after this decision, control the recognition of new duties not only on the basis of proximity and foreseeability, but also by asking whether it is fair, just and reasonable to impose a duty on the defendant under the circumstances of the case at hand. ${ }^{88}$ One recent authority even elevates the Caparo test as the test for duty in all potential claims based on negligence. ${ }^{89}$

Despite the limits placed on the notion of duty, the tort of negligence remains the broadest and most important tort under English law and is perhaps the closest thing to a default rule for liability, ${ }^{90}$ if one could possibly attribute such a rule to the English law of torts.

Many of the situations encountered earlier under French law as instances of strict liability would be dealt with under the tort of negligence across the channel. However, one should not think that there is an equivalence of results. The fact that the claimant must prove fault in such circumstances effectively means that his chances of being awarded compensation are lower. Moreover, the limits placed on the duty of care element of fault-based liability (foreseeability, proximity, and the just, fair and reasonable limitation) lead to a number of cases where compensation is denied in England, whereas in France the claimant would most likely succeed.

At this time, under English law, there is no general rule of strict liability for things. With the exception of products, animals, and the narrow rule of Rylands $v$. Fletcher, no other specific strict

\footnotetext{
${ }^{83}$ See, e.g., the 1937 decision of Dransfield v. British Insulated Cables Ltd. [1937] 4 All ER 382, 386-87.

${ }^{84}$ See IBBETSON, supra note 46, at 190-95.

${ }^{85}$ Anns v Merton LBC [1978] A.C. 728, at 751-52.

${ }^{86}$ See SimOn DEAKIN ET AL., MARKESINIS AND DEAKIN's TORT LAW 169, 172 ( $5^{\text {th }}$ ed., Oxford University Press 2003); CeEs VAN Dam, European TORT LAW 109 ( $2^{\text {nd }}$ ed., Oxford University Press 2013).

${ }^{87}$ Caparo Industries Plc v Dickman, [1990] UKHL 2, [1990] 2 A.C. 605.

${ }^{88}$ Id. at 617 (per Lord Bridge): "[T] he situation [ought to] be one in which the court considers it fair, just and reasonable that the law should impose a duty of care of a given scope on the one party for the benefit of the other."

${ }^{89}$ See Robinson v Chief Constable of West Yorkshire Police, [2014] EWCA Civ 15, at 40 (per Hallett LJ): stating that the Caparo test "applies to all claims in the modern law of negligence."; Connor v Surrey CC, [2010] 3 W.L.R. 1302; [2010] EWCA Civ 286; [2011] Q.B. 429, at 469 (per Laws LJ): "though it is no rulebook, [the Caparo test] represents the modern backdrop against which to judge any putative negligence claim."

${ }^{90}$ RODOLFO SACCO, LA COMPARAISON JURIDIQUE AU SERVICE DE LA CONNAISSANCE DU DROIT 83 (Economica, 1991).
} 
liability rules can be found in the case law either. Most importantly, liability for traffic accidents, perhaps one of the most important areas in terms of annual injuries and fatalities, ${ }^{91}$ is governed by the law of negligence. However, traffic accidents are a special category of cases that deserves special attention, due to the fact that the standard of care required is much higher than in other cases of negligence, making liability for traffic accidents relatively close to a strict regime of liability.

Traffic accidents in a way derogate from the general standard applied for the breach of duty element of negligence: the reasonable person in similar circumstances. ${ }^{92}$ Any error, however slight, on the part of the driver of a motor vehicle seems sufficient in order to find that a duty of care was breached in cases of traffic accidents. ${ }^{93}$ The higher standard of care is not all that surprising seeing how liability for traffic accidents is closely intertwined with insurance ${ }^{94}$ (and a higher level of danger). Third party liability insurance is mandatory in England, ${ }^{95}$ and many cases of traffic accidents do not even reach the courts. The heightened standard of care, similar to the strict liability system of France, makes the outcome of such cases easier to predict, and that in turn makes it easier to settle claims swiftly, without applying for a remedy in court. And indeed, in England, despite fault-based rules, participants in traffic accidents rarely confront each other in court, the claims of victims being handled most of the time by the insurance companies amongst themselves, often by way of "knock-for-knock" agreements. ${ }^{96}$ However, when cases do end up in court, it is

\footnotetext{
${ }^{91}$ In 2015, road traffic accidents accounted for 1,775 fatalities, 22,807 seriously injured, and 169,895 slightly injured persons in the United Kingdom. Department for Transport, Transport Statistics Great Britain 2015, at 16, available online at https://www.gov.uk/government/uploads/system/uploads/attachment data/file/489894/tsgb2015.pdf

${ }^{92}$ The standard authority for the standard of care required under English law is the oft-cited phrase of Alderson B from Blyth v Birmingham Waterworks Co.: "Negligence is the omission to do something which a reasonable man, guided upon those considerations which ordinarily regulate the conduct of human affairs, would do, or doing something which a prudent and reasonable man would not do." Blyth v Birmingham Waterworks Co. (1856) 11 Ex. 781 , at 784 .

${ }^{93}$ DEAKIN ET AL., supra note 86, at 169, 172.

${ }^{94}$ See Morris v Ford Motor Co. Ltd. [1973] Q.B. 792, at 798 (per Lord Denning): “The damages are expected to be borne by the insurers. The courts recognize this every day. They would not find negligence so readily - or award sums of such increasing magnitude - except on the footing that the damages are to be borne, not by the man himself, but by an insurance company."

${ }^{95}$ Liability insurance has been compulsory since 1930 (Road Traffic Act 1930), and its scope has been expanded ever since [See Road Traffic Act 1934; Motor Vehicle (Passenger Insurance) Act 1971 and the various acts implementing Motor Insurance directives]. Roderick Bagshaw, The Development of Traffic Liability in England and Wales, in The Development of Traffic Liability 12, 43-45 (Wolfgang Ernst ed., Cambridge University Press 2010).

${ }^{96}$ In England and Wales insurance companies are the real defendants in nine out of ten personal injury claims, and insurance companies pay $94 \%$ of tort compensation for personal injury. Richard Lewis, Insurers and Personal
} 
possible to avoid liability if the judges find that the claimant was not driving unreasonably. The law applicable to traffic accidents in England is not functionally equivalent to the strict liability we have seen in France. Far from it, and two good illustrations are the cases of Moore v Poyner ${ }^{97}$ and Mansfield $v$ Weetabix. ${ }^{98}$ In Moore $v$ Poyner, the defendant, who was driving through a residential district at 30 miles per hour on a Sunday afternoon, struck a child who ran out from behind a coach that was parked on a curb. At trial, the defendant was found to be liable on account of the fact that he was aware that children played in that area. A majority of the Court of Appeal reversed the trial judge's decision, arguing that the behaviour of the defendant was reasonable in the circumstances, and a too high standard of care ought not to be imposed in such cases. Mansfield $v$ Weetabix was a case in which the defendant, at the time of the incident, had a malignant insulinoma which resulted in him developing a hyperglycaemic state. Unaware of his condition, the defendant drove his lorry into a shop owned by the claimant. The Court of Appeal once again found that there was no breach of duty. In the words of Legatt LJ:

In my judgment, the standard of care that Mr Tarleton was obliged to show in these circumstances was that which is to be expected of a reasonably competent driver unaware that he is or may be suffering from a condition that impairs his ability to drive. To apply an objective standard in a way that did not take account of Mr Tarleton's condition would be to impose strict liability. But that is not the law. ${ }^{99}$

English law also does not recognize a general strict liability rule for the acts of others. In fact, the contrary can be stated. The default is fault-based liability. However, there is one exception with tremendous practical implications: employers are strictly liable under English law for the acts of their employees. ${ }^{100}$ The effect of this arrangement is that parents will be liable for the acts of their children based on a standard negligence analysis, ${ }^{101}$ and the same applies to teachers and artisans for their students or pupils. ${ }^{102}$ Also, any institution in charge of educating or providing care for

\footnotetext{
Injury Litigation: Acknowledging "the Elephant in the Living Room”, [2005] JOURNAL OF PERSONAL INJURY LAW 1; Bagshaw, supra note 95 , at 43 ;

${ }^{97}$ Moore v Poyner [1975] R.T.R. 127.

${ }^{98}$ Mansfield v Weetabix Ltd, [1998] 1 W.L.R. 1263.

${ }^{99} \mathrm{Id}$. at 1268 .

${ }^{100}$ See infra Part B.4 of this chapter.

${ }^{101}$ Jean-Pierre Le Gall, Liability for Persons under Supervision, in 11 INTERNATIONAL ENCYCLOPEDIA OF Comparative Law, ToRTs, Chapter 3, at 7, para. 3-18 (André Tunc ed., J.C.B. Mohr (Paul Siebeck) \& Martinus Nijhoff Publishers 1983).

${ }^{102} I d$.
} 
others will only be held liable for its own faulty actions or omissions, and not vicariously for the actions of persons placed under its control and supervision. ${ }^{103}$

The overall picture of English tort law has a different structure and composition from French law. It is not possible to identify any default rule, but, if one were to analogize loosely, the principles of the tort of negligence would constitute the closest thing to such a rule. Strict liability regimes are special and derogative, and do indeed occupy less "territory" than they do in France. In addition, England has a number of enacted compensation systems, but they are far fewer in number and less generous in scope than their French equivalents.

In the following, we look into more detail at the existing English strict liability regimes, starting with (1) the rule from Rylands $v$ Fletcher, followed by (2) nuisance, (3) product liability, (4) vicarious liability of employers for the acts of their employees, (5) breach of non-delegable duty, (6) liability for animals, (7) breach of statutory duty, and (8) other strict liability torts created by statute. This chapter will then return to (9) the original trespass torts and (10) the tort of conversion. (11) The tort of defamation and a small number of (12) equitable wrongs will then complete our list of strict liability torts. Lastly, section $\mathrm{C}$ briefly discusses existing compensation schemes in England.

\section{B. Strict Liability Torts in Modern English Law}

\section{Rylands $v$ Fletcher}

Rylands $v$ Fletcher ${ }^{104}$ has been, but arguably no longer is, a cornerstone for the law of strict liability in England. In the mind of an English solicitor or barrister, it is usually the first case that comes to mind when strict liability is mentioned. That being said, the evolution of the rule from Rylands $v$ Fletcher reveals, perhaps more than anything else, the hostility of English law toward a broad rule of strict liability.

The facts of the case were as follows: the defendants, Mr Ryland and Mr Horrocks, hired independent contractors to construct a reservoir on land adjacent to a mill they were operating. Unbeknownst to the defendants, the independent contractors found beneath the site of the reservoir

\footnotetext{
${ }^{103}$ See, e.g., Dorset Yacht v Home Office [1970] AC 1004; Ellis v Home Office [1953] 2 Q.B. 135. But, see infra Part B.5 of this chapter.

${ }^{104}$ Fletcher v Rylands, (1865) 3 H \& C 774, 159 ER 737 (Court of Exchequer); Fletcher v Rylands, (1866) LR 1 Ex. 265 (Court of Exchequer Chamber); Rylands v Fletcher, (1868) LR 3 HL 330 (House of Lords).
} 
disused shafts leading to the coal mines known as the Red House Colliery that belonged to the plaintiff, and failed to seal the mine shafts properly. ${ }^{105}$ On 11 December 1860, shortly after the reservoir was filled for the first time, water from the reservoir burst through the unsealed shafts and flooded the plaintiff's mine, causing substantial damage. ${ }^{106}$

After a three-stage procedural saga, the defendants were held liable for the damage caused to the plaintiff's mine, despite the fact that they were not personally at fault. The Court of Exchequer initially found for the defendants, but the decision was reversed by the Court of Exchequer Chamber, and subsequently the House of Lords upheld the latter decision.

At that time, the existing torts were not able to provide the plaintiffs with a remedy. The law of negligence was still underdeveloped, and there was no recognized duty of care for the acts of independent contractors. ${ }^{107}$ Also, the law of nuisance required at the time that the activity be continuous or recurring, as opposed to a one-time act. ${ }^{108}$ By holding in favour of the plaintiff, a new tort was coming into being, and its principle is encapsulated in Blackburn J's formulation from the Court of Exchequer Chamber's decision:

We think that the true rule of law is, that the person who for his own purposes brings on his lands and collects and keeps there anything likely to do mischief if it escapes, must keep it at his peril, and, if he does not do so, is prima facie answerable for all the damage which is the natural consequence of its escape.

In the House of Lords, Lord Cairns LC concurred with the decision reached by the Court of Exchequer Chamber, but added to the above cited principle that liability would only rest for a "non-natural use" of land. ${ }^{109}$ It is very probable that Lord Cairns did not intend to add a new element, but simply to clarify that the rule applied only to things collected by the defendant, and not to things that naturally exist or accumulate on land (like rainwater). ${ }^{110}$ This was most likely already implied in Blackburn J's formulation, but subsequent case law has given a different interpretation to "non-natural use", making it a veritable added element. In Rickards $v$ Lothian, "non-natural use" was interpreted to mean a "special use bringing with it increased danger to

\footnotetext{
${ }^{105}$ Rylands v Fletcher, (1868) LR 3 HL 330, at 331.

${ }^{106} I d$. at 332.

${ }^{107}$ DEAKIN ET AL., supra note 86, at 532.

${ }^{108} \mathrm{Id}$.

${ }^{109}$ Rylands v Fletcher, (1868) LR 3 HL 330, at 339.

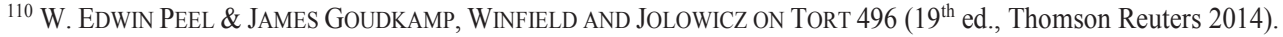


others"111 and which "must not merely be the ordinary use of land or such a use as is proper for the general benefit of the community." 112 Subsequent case law reinforced this interpretation, and even restricted the ambit of the tort further. ${ }^{113}$ Also, given that in the meantime the tort of negligence had come to the forefront, special rules had been enacted for the liability of occupiers for the damage caused on their premises, ${ }^{114}$ and the law of nuisance had been expanded to include new situations, ${ }^{115}$ the practical importance of the rule from Rylands $v$ Fletcher was severely diminished. Although some plaintiffs were able to recover for damage caused by a variety of things, ${ }^{116}$ like fire, ${ }^{117}$ gas, ${ }^{118}$ electricity, ${ }^{119}$ noxious fumes, ${ }^{120}$ blasting with explosives, ${ }^{121}$ munition, ${ }^{122}$ a rusty wire from a decaying fence, ${ }^{123}$ or even vibrations, ${ }^{124}$ in the $20^{\text {th }}$ century comparatively few successful claims were brought under the strict liability principle of Rylands. ${ }^{125}$

\footnotetext{
${ }^{111}$ Rickards v Lothian, [1913] A.C. 263.

${ }^{112} \mathrm{Id}$.

${ }^{113}$ Read v J Lyons \& Co Ltd, [1947] A.C. 156; [1946] 2 All E.R. 471; Cambridge Water Co Ltd v Eastern Counties Leather Plc, [1994] 2 W.L.R. 53, [1994] 2 A.C. 264.

${ }^{114}$ See Occupiers Liability Act (1957), c. 31 (Regnal. 5_and_6_Eliz_2) and Occupiers Liability Act (1984), c. 3.

${ }^{115}$ See infra Part B.2 of this chapter.

${ }^{116}$ The rule has been used not only for things, but also for disturbances created by persons living on the defendant's land: Attorney-General v Corke, [1933] Ch. 89 (The owner of the land allowed persons to bring caravans on his land and the occupants of the caravans committed acts which amounted to a nuisance and a menace to the health of the neighbourhood).

${ }^{117}$ Jones v Festiniog Ry (1866) L.R. 1 Ex. 265; Powell v Fall (1880) 5 Q.B.D. 597; Musgrove v Pandelis [1919] 2
} K.B. 43; Job Edwards Ltd. V Birmingham navigations [1924] 1 K.B. 341; Balfour v Barty-King [1957] 1 Q.B. 496. The Fires Prevention (Metropolis) Act 1744, section 86, provides that no action can be brought against anyone in whose building or on whose estate a fire accidentally started. The statute was interpreted restrictively, to cover only accidents "produced by mere chance or incapable of being traced to any cause." Filliter v Phippard, (1847) 11 Q.B. 347, at 357 (per Denman CJ). Thus, fires caused by negligence or which constitute a nuisance still give rise to a cause of action. PEEL \& GOUDKAMP, supra note 110, at 517. The statute's relationship with the rule from Rylands v Fletcher is rather uncertain, but the case law seems to suggest that if the prima facie requirements of Rylands are met, the statute does not bar recovery. See Mason v Levy Auto Parts of England Ltd, [1967] 2 Q.B. 530, at 540-41; but see Lewison LJ's opinion in Stannard v Gore, [2012] E.W.C.A. Civ. 1248; [2014] Q.B. 1 (arguing that the statute defeated any liability under Rylands v Fletcher; his opinion was not shared, however, by the other members of the court).

${ }^{118}$ Batcheller v Tunbridge Wells Gas Co (1901) 84 L.T. 765.

${ }^{119}$ National Telephone Co v Baker [1893] 2 Ch. 186; Eastern and South African Telegraph Co Ltd v Cape Town Tramways Companies Ltd, [1902] A.C. 381; Hillier v Air Ministry, [1962] C.L.Y. 2084.

${ }^{120}$ West v Bristol Tramways Co [1908] 2 K.B. 14.

${ }^{121}$ Miles v Forest Rock Co (1918) 34 T.L.R. 500.

${ }^{122}$ Reinham Chemical Works Ltd v Belvedere Fish Guano Co Ltd [1921] 2 A.C. 465 (to be more exact, the case involved the storing of nitrate of soda and dinitrophenol, used for the manufacture of munition; the two substances ignited due to a fire and a strong explosion followed).

${ }^{123}$ Firth v Bowling Iron Co (1878) 3 C.P.D. 254.

${ }^{124}$ Hoare \& Co v McAlpine [1923] 1 Ch. 167.

${ }^{125}$ Peel \& GoudKAMP, supra note 110, at 498; Civil Liability for Dangerous Things and Activities (1970) Law Com. No.32, at 7. See also Transco Plc v Stockport MBC [2003] U.K.H.L. 61; [2004] 2 A.C. 1, 39 (per Lord Hoffmann): "It is hard to escape the conclusion that the intellectual effort devoted to the rule by judges and writers over many years has brought forth a mouse." 
The situation has been quite different in the United States, where on the basis of Rylands $v$ Fletcher, in the vast majority of states, the case law moved toward a general strict liability rule for abnormally dangerous activities. ${ }^{126}$

The broad formulation of the principle from Rylands $v$ Fletcher could have provided a solid ground for the growth of strict liability in England as well. However, the subsequent case law did not expand the rule to apply to all abnormally dangerous activities. To the contrary, the rule was narrowly construed and the list of requirements for its application expanded. Also, damages for death and personal injury are not covered by the rule. ${ }^{127}$ At present, in order to establish a prima facie case under Rylands, a plaintiff must show that: ${ }^{128}$

1) the defendant is an owner or occupier of land;

2) the defendant brought, kept, or collected an exceptionally dangerous or mischievous thing on his land;

3) the defendant recognized, or ought reasonably to have recognized, judged by the standards appropriate at the relevant place and time, that there is an exceptionally high risk of danger or mischief if that thing should escape, however unlikely the escape may have been thought to be;

4) the defendant's use of land has been extraordinary and unusual, having regard to all the relevant circumstances of time and place;

5) the thing escaped the property of the defendant into or onto the property of another; and

6) the escape caused damage of a relevant kind to the rights and enjoyment of the claimant's land.

Liability under the Rylands rule is strict because none of the requirements mentioned above are based on fault. Recognized defences include, of course, acts of God ${ }^{129}$ and acts of a stranger, ${ }^{130}$

\footnotetext{
${ }^{126}$ JOHN C.P. GOLDBERG \& BENJAMIN C. ZIPURSKY, THE OXFORD INTRODUCTIONS TO US LAW. TORTS 259-63 (Oxford University Press 2010).

${ }^{127}$ Transco Plc v Stockport MBC [2003] U.K.H.L. 61; [2004] A.C. 1.

${ }^{128}$ Following the conditions laid down in PEEL \& GoUDKAMP, supra note 110, at 500.

${ }^{129}$ Nichols v Marsland, (1876) 2 Ex.D. 1. See also, however, Greenock Corp v Caledonian Ry, [1917] A.C. 556 (this case does not impact the rule that an act of God may be used as a defence, but shows a narrower interpretation of what counts as an act of God, by comparison to Nichols v Marsland).

${ }^{130}$ Box v Jubb, (1879) 4 Ex.D 76; Rickards v Lothian, [1913] A.C. 263; see also, Perry v Kendricks Transport Ltd, [1956] 1 W.L.R. 85.
} 
but it is likely that the fault of the claimant can also be used as a defence, although there is to this author's knowledge no case law on the matter.

One might wonder why the case law evolved in such a manner. The ground was fertile at the end of the $19^{\text {th }}$ century for the expansion of strict liability to all manner of dangerous things and activities. The fact that the law did not yet have a general negligence principle, and the fact that the law of nuisance was still focused on property rights over immovables, perhaps would have justified expanding the strict liability rule developed in Rylands. But that would be true only if we assume that the English legal elite had the same attitude to the industrial revolution and the changes brought about by it as their French counterparts. That was obviously not the case. In a legal system where at that time it was debated even whether negligence standards ought to be applied generally, it was very unlikely that a strict liability rule would be interpreted broadly. The rule from Rylands $v$ Fletcher remained enclosed within the limited confines of disputes between landowners, involving extraordinary and unusual uses of land, using things that were perceived as unusual or dangerous in themselves. The creation of strict duties on industrial activities that involve the use of dangerous things and materials could not have become the function of a tort that ended up, due to Lord Goff's speech in Cambridge Water Co Ltd. v Eastern Counties Leather plc., ${ }^{131}$ as nothing more than a narrow "sub-species of nuisance". ${ }^{132}$

\section{Nuisance}

The law of nuisance comprises two separate, but loosely connected, torts: private nuisance and public nuisance. Although both torts are common law creations that go back to the earliest forms of action, private nuisance is today mainly a civil action, while public nuisance is first and foremost a common law crime. However, both private and public nuisance are actionable for the purpose of obtaining a private law remedy, and both may be considered strict liability torts.

\section{a. Private nuisance}

A private nuisance regulates competing uses of land between private parties and, as such, has been designed mainly for the purposes of protecting interests in land and, conversely, of limiting the power and freedom land users have under the law. Generally, private nuisance is

\footnotetext{
${ }^{131}$ Cambridge Water Co Ltd v Eastern Counties Leather Plc, [1994] 2 W.L.R. 53, [1994] 2 A.C. 264.

${ }^{132}$ Phrase used by Lord Bingham in Transco Plc v Stockport MBC, [2003] U.K.L.H. 61; [2004] 2 A.C. 1, at 9.
} 
therefore defined as “the unlawful interference with a person's use or enjoyment of land, or some right over, or in connection with it."133

The starting point for analysing the law of private nuisance is the fact that modern life can rarely, if ever, afford land users absolute rights, in the sense of rights that offer absolute protection from any interference or that offer absolute freedom to do any and all types of activities on one's own property. ${ }^{134}$ The crowded life of our times requires reasonable tolerance between neighbours. That is why the most basic rule of the law of nuisance is one of non-liability: not every infringement or disturbance is actionable; a certain level of disturbance between neighbours must be considered normal. ${ }^{135}$ As a consequence, in order to have a cause of action in nuisance, one ought to prove that the disturbance to one's use or enjoyment of land is both substantial and unreasonable. ${ }^{136}$ These are context-dependent standards ${ }^{137}$ which exist for the purpose of attaining a fair balance between the interests of the claimant and the defendant. ${ }^{138}$

The tort of private nuisance is a separate tort from both trespass to land and the tort of negligence. It differs from trespass in that it deals with indirect infringements as opposed to direct infringements. It also differs from the tort of negligence, although both torts deal with indirect infringements. However, the fact that the law of nuisance has, at its core, a standard of reasonableness makes it rather difficult to draw clear distinctions. ${ }^{139}$ Also, a good number of factual situations that give rise to a nuisance might also be actionable in negligence, and sometimes the negligent act of the defendant is taken into consideration by courts when deciding whether a

\footnotetext{
133 PEEL \& GOUDKAMP, supra note 110 , at 450.

134 There are, however, some rights that seem to be protected at common law even when their exercise may cause substantial damage to a neighbour or his property. For instance, the right to extract subterranean water by landowners is protected even if it can lead to personal injury or the subsidence of buildings. Prenn v Simmonds, [1971] 1 W.L.R. 1381, at 1387.

${ }_{135}$ See Bamford v Turnley, (1862) 3 B. \& S. 62, at 83; Kennaway v Thompson [1981] Q.B. 88, at 94.

${ }^{136}$ Christian Witting, Street ON TORTs 431 (14 ${ }^{\text {th }}$ ed., Oxford University Press 2015).

${ }^{137}$ All the circumstances of the case ought to be taken into consideration in determining whether a nuisance was committed, including the time and place when the nuisance was allegedly committed, the seriousness of the disturbance, whether it is temporary or permanent, occasional or continuous, as well as the manner in which the harm was committed, and even the defendant's motive. See Bamford v Turnley, (1862) 3 B. \& S. 62, at 79 (per Pollock CB).

${ }^{138}$ Sedleigh-Denfield v O’Callaghan, [1940] AC 880, at 903 (per Lord Wright): “A balance has to be maintained between the right of the occupier to do what he likes with his own, and the right of his neighbour not to be interfered with."

${ }^{139}$ Some authors have even stated that it seems "difficult to support the proposition that $[\ldots]$ the modern law of nuisance involves any general rule of strict liability for damage done.” PEEL \& GOUDKAMP, supra note 110, at 465.
} 
nuisance must be remedied. ${ }^{140}$ However, in the most general terms, negligence is concerned with the reasonableness of the defendant's conduct, whereas nuisance is concerned with the reasonableness of the resulting interference. Thus, the standard of reasonableness in nuisance cases refers not to the defendant's conduct as such, but to the outcome of his conduct. ${ }^{141}$ That is why it can be concluded that the tort of private nuisance is a strict liability tort. However, the line between reasonableness in conduct and reasonableness in the result of conduct is very thin, and because of this, elements of negligence often make their way into the discourse of lawyers and judges. Overall, the case law is very confusing on this issue. Lord Reid's Privy Council speech in The Wagon Mound (No 2) is perhaps the most perplexing:

Nuisance is a term used to cover a wide variety of tortious acts or omissions and in many negligence in the narrow sense is not essential. An occupier may incur liability of the emission of noxious fumes or noise although he has used the utmost care in building and using his premises. . . [A]lthough negligence may not be necessary, fault of some kind is almost always necessary and fault generally involves foreseeability. ${ }^{142}$

Lord Reid most probably intended to limit the scope of nuisance to damage of a type that is foreseeable, but the use of the term "fault" in such a context is most unfortunate. A better phrasing was later offered by Lord Goff in Cambridge Water Co Ltd v Eastern Counties Leather Plc, although his formulation may also lead to confusion because of the analogy made with the development of the tort of negligence:

[T] he fact that the defendant has taken all reasonable care will not of itself exonerate him [...] But it by no means follows that the defendant should be held liable for damage of a type which he could not reasonably foresee; and the development of the law of negligence in the past 60 years points strongly towards a requirement that such foreseeability be a prerequisite of liability in damages for nuisance, as it is of liability in negligence. ${ }^{143}$

The fact that the defendant is liable only for foreseeable damage does not mean that fault is in some way a requirement in nuisance cases. Neither negligence, nor intent, need to be shown in

\footnotetext{
${ }^{140}$ Goldman v Hargrave, [1967] 1 AC 645, at 657 (per Lord Wilberforce): A nuisance "may comprise a wide variety of situations, in some of which negligence plays no part, in others of which it is decisive."

${ }^{141}$ WiTTING, supra note 136 , at 432.

142 [1967] 1 A.C. 617 , at 639 (emphasis added).

143 [1994] 2 A.C. 264 , at 300.
} 
order for a claimant to be successful in a nuisance claim. This is not to say, however, that the negligence of the defendant plays no role in nuisance cases. There are various situations where the negligence of the defendant is of paramount importance. If, for instance, a nuisance may be prevented by taking reasonable steps, the cost of which is not very high, but the defendant has not taken such steps, it is likely that a court will find that a nuisance was committed. Also, in some cases, the defendant's malice may transform an activity that is otherwise tolerable into a nuisance. ${ }^{144}$ However, one ought to remember that in such cases the negligent conduct or the motive of the defendant is one of the factors that the court takes into account, and not the basis for liability.

The only cases where nuisance can properly be considered fault-based are those where the defendant is continuing a nuisance created by a third party or by an act of nature. Because the defendant cannot be considered responsible for the initial creation of the nuisance, in such cases he will only be liable if he had knowledge of the nuisance and failed to take reasonable precautions to abate it. ${ }^{145}$

We have seen that the tort of nuisance shares the requirement of foreseeability of harm with the tort of negligence. Also, although liability is strict, contributory negligence on the part of the claimant is a valid defence. ${ }^{146}$ In addition, and as opposed to the tort of negligence, two other important limitations exist in the law of nuisance: first, only persons with an interest in land may sue on the basis of private nuisance; ${ }^{147}$ and second, personal injury is not recoverable. ${ }^{148}$ Because the tort of nuisance protects interests in land, the diminution in the value of land is remedied, ${ }^{149}$ and not any interests in the person of the claimant. Relatives of the occupier, guests, lodgers and

\footnotetext{
${ }^{144}$ See Christie v Davey, [1893] 1 Ch. 316 (this was a case where the defendant, who was exasperated by the noise coming from the music lessons given by the claimant on his property, disturbed the lessons by knocking on the wall, beating on trays, whistling and shrieking); Hollywood Silver Fox Farm Ltd v Emmett, [1936] 2 K.B. 468 (in this case the defendant, out of pure spite, caused guns to be fired on his own land in order to scare the claimant's foxes during breeding time); But, see Allen v Flood, [1898] A.C. 1 and Bradford (Mayor of) v Pickles, [1895] A.C. 587 (holding that a bad motive will not make wrongful an otherwise legal act).

${ }^{145}$ See Sadleigh-Denfield v O'Callaghan, [1940] A.C. 880 (nuisance created by a trespasser); Goldman v Hargrave, [1967] 1 A.C. 645 (fire spreading from a tree that was hit by lightning); Leakey v National Trust, [1980] Q.B. 485 (damage resulting from movement of land onto the adjoining land).

${ }^{146}$ WITTING, supra note 136, at 465.

${ }^{147}$ Hunter v Canary Wharf Ltd, [1997] A.C. 655 (it is important to note, however, Lord Cooke's dissent in this case, which in part relies on article 8 of the ECHR).

${ }^{148} I d$. at 706 (per Lord Hoffmann, although this part of his speech is only dictum, therefore not binding as a precedent).

${ }^{149}$ Peel \& GoudKamp, supra note 110 , at 467.
} 
employees therefore do not have standing. ${ }^{150}$ Also, the measure of damages is determined by calculating the diminution in the value of the claimant's land. However, the impact of the nuisance on the persons living in the premises is taken into consideration by courts. ${ }^{151}$

Lastly, the existence of actual damage is not a requirement for the tort of private nuisance. In some circumstances, when the occurrence of damage in the future is certain or very likely, courts may presume the existence of damage. ${ }^{152}$ In addition, the tort of nuisance may be remedied not only by way of compensatory damages, but also by way of injunction. In rare cases, when the damage is both imminent and almost certain to occur, a claimant may even obtain a quia timet injunction. ${ }^{153}$ Such a remedy requires not the proof of damage that has occurred, but of a strong probability that damage will occur in the future. Quia timet injunctions are aimed at preventing legal wrongs, not at correcting them. When dealing with quia timet injunctions, the distinction between fault liability and strict liability plays no part, because the courts have discretion when deciding whether or not to issue such an injunction. ${ }^{154}$

\section{b. Public nuisance}

A public nuisance (or common nuisance) is a tort whereby the unlawful act or omission of the defendant causes harm to the lives, comfort, property, or common interests of the public. ${ }^{155} \mathrm{~A}$ wide variety of situations may fall within the broad definition of a public nuisance. ${ }^{156}$ To give but a few examples, the obstruction of a public highway, carrying on an offensive trade, selling food

\footnotetext{
${ }^{150} \mathrm{Id}$.

${ }^{151}$ Dobson v Thames Water, [2009] 3 All E.R. 319; [2009] H.R.L.R. 19; [2009] EWCA Civ 28, at 33.

${ }^{152}$ Fay v Prentice, (1845) 1 C.B. 828.

${ }^{153}$ PeEL \& GoudKamp, supra note 110, at 478.

${ }^{154}$ As an equitable remedy, an injunction is discretionary, but the case law is, of course, not arbitrary. Judges have been developing criteria and elements to be taken under consideration. The reason why the distinction between fault and strict liability plays no part in such cases is because the criteria are flexible, and the questions judges have to answer in such cases do not fit the traditional paradigm of tort cases, being focused on prevention of harm, and not compensation. For more information about quia timet injunctions see Ken Oliphant, Injunctions and Other Remedies in THE LAW OF TORT 297, 318-319 (Andrew Grubb ed., Butterworths 2002); JOSEPH STORY \& W.H. LYON, 2 COMMENTARIES ON EQUiTY AS ADMINISTERED IN ENGLAND AND AMERICA 525 (14 th $\mathrm{ed}$., Little Brown \& Co. 1918). ${ }^{155}$ See John Frederick Archbold, Criminal Pleading, Evidence And Practice 2529 (59 ${ }^{\text {th }}$ ed., P.J.

Richardson ed., Sweet \& Maxwell 2002): "A person is guilty of a public nuisance [...] who (a) does an act not warranted by law, or (b) omits to discharge a legal duty, if the effect of the act or the omission is to endanger the life, health, property or comfort of the public, or to obstruct the public in the exercise or enjoyment of rights common to all Her Majesty's subjects."

This definition was endorsed by the House of Lords in R v Rimmington; R v Goldstein, [2006] 1 A.C. 456.

${ }^{156}$ In the words of Lord Denning, it "covers a multitude of sins, great and small". Southport Corp v Esso Petroleum Co Ltd, [1954] 2 Q.B. 182, at 196.
} 
unfit for human consumption, or lighting up fireworks in the street; all fall within the ambit of the tort of public nuisance. ${ }^{157}$

Although public nuisance was initially just a common law crime, it has subsequently evolved to allow civil remedies to be obtained as well. There are three types of civil remedies that can be obtained in cases of public nuisance: (a) relator actions, which are injunction proceedings brought by the Attorney General on behalf of a private citizen; (b) actions by local authorities under the Local Government Act 1972; and (c) actions brought by a private citizen who has suffered "special damage." 158 The third of these actions is a tort action by nature. Therefore, the tort of public nuisance deals with situations where an act or omission brings about a disturbance to the public in general, and the claimant suffers "special damage", i.e. damage that goes beyond that suffered by other members of the public. ${ }^{159}$

Public nuisance differs from private nuisance, although the same action or activity may give rise to both a public nuisance and a private one. ${ }^{160}$ Also, the main standard for establishing whether a public nuisance was committed is that of reasonableness. ${ }^{161}$ In addition, as in cases of private nuisance, it has long been established that the claimant suffering from a public nuisance can ask not only for damages, but also for injunctive relief. ${ }^{162}$ The main difference between public nuisance and private nuisance lies in the nature of the rights and interests that are protected: private nuisance protects private interests in land, whereas public nuisance protects public rights, which are not personal to the claimant, being common and shared with the rest of the public. ${ }^{163}$ What singles out the claimant from the general public in order to obtain a remedy is not the nature of his interest, but the extent of the damage suffered. Thus, because the nature of the interest protected is not

\footnotetext{
${ }^{157}$ PEEL \& GoudKAMP, supra note 110 , at 448.

158 WiTTING, supra note 136 , at 469.

${ }^{159} \mathrm{Id}$.

${ }^{160}$ PEEL \& GOUDKAMP, supra note 110 , at 450.

161 See id.

${ }^{162}$ See Spencer v London and Birmingham Rly Co, (1836) 8 Sim 193.

${ }^{163}$ See the example given by Lord Rodger in R v Rimmington and R v Goldstein, [2006] 1 A.C. 456, at para. 48: "Suppose $[\ldots]$ that someone makes a series of obscene telephone calls to people living in a village or neighbourhood. In that situation each call is heard, and is intended to be heard, only by the recipient. Of course, as the calls mount up, more and more residents will be affected and the general peace of the neighbourhood may be disturbed. But each telephone call affects only one individual, not the community in the village or neighbourhood. Therefore, it does not have that quality which is the hallmark of the crime of public nuisance."
} 
decisive, as opposed to private nuisance, public nuisance allows for the recovery of damages for personal injury. ${ }^{164}$

Whether liability for public nuisance is strict or based on fault is an interesting question, to which no clear answer can be given. The fundamental question in public nuisance cases seems to boil down, similar to private nuisance cases, to the reasonableness of the activity of the defendant, and it does seem that the act of the defendant need not be in itself unlawful, as long as its effects are deemed unreasonable. However, because public nuisance is also a crime, knowledge or presumptive knowledge of the nuisance is required in order to satisfy the mens rea requirement. ${ }^{165}$

\section{Liability for defective products}

The liability for defective products is regulated in the Consumer Protection Act 1987, the first part of which implements the 1985 European Directive on Product Liability. ${ }^{166}$ The directive is, as mentioned before in the analysis of the equivalent legislation from France, ${ }^{167}$ a maximum harmonization piece of European legislation, which mandates all European states to implement a strict liability regime for personal injury and personal property damage caused by defective products. $^{168}$

The United Kingdom was the first European state to implement the directive. ${ }^{169}$ This might come as a surprise, considering the fact that the English common law has been and still is relatively averse to strict liability. However, it seems that the implementation of the directive and its application was more difficult in states like France, which by 1985 had already developed a set of contractual and tortious remedies that were more generous to consumers.

English law was not as generous to consumers at the time of the enactment of the Consumer Protection Act, but the evolution of the law of contract and tort in England was moving toward more serious consumer protection. Before 1893, when the first Sale of Goods Act was

\footnotetext{
${ }^{164}$ Claimants in Corby Group Litigation v Corby BC, [2008] EWCA Civ 463; [2009] 2 W.L.R. 609.

${ }^{165}$ ARCHBOLD, supra note 155, at 2530; R v Shorrock, [1994] Q.B. 279; R v Rimmington; R v Goldstein, [2006] 1 A.C. 456 .

${ }^{166}$ Council Directive 85/374/EEC of 25 July 1985 on the approximation of the laws, regulations and administrative provisions of the Member States concerning liability for defective products, Official Journal L 210, 07/08/1985, p. 29-33 [Referred to in this study as the Product Liability Directive].

167 Supra Chapter II Part C.3.

168 Thus, damage to business or commercial property and pure economic loss cannot be recovered under the strict liability rules of the Consumer Protection Act 1987 (see s. 5 (1) of the Act).

${ }^{169}$ VAN DAM, supra note 86 , at 421.
} 
introduced, ${ }^{170}$ England had in fact offered little to no protection to consumers of goods. ${ }^{171}$ The law of contract had a firmly established privity rule and the default rule that applied to buyers in sales contracts was caveat emptor (let the buyer beware). This means that final consumers often could not sue manufacturers because the goods were bought from an intermediary, and even when they wanted to sue the seller himself, they often had no cause of action because the default caveat emptor rule placed the duty to verify whether the goods are in conformity with the contract on the buyer. The Sale of Goods Act of 1893 offered more protection to buyers by implying, in some exceptional circumstances, warranties for the quality or fitness for purpose of the goods sold. ${ }^{172}$ The most important exception to the privity of contract rule, applicable in cases of defective products, found its way into English law in 1932 in the Donoghue $v$ Stevenson case. ${ }^{173}$

Subsequent legislation reinforced consumer protection, particularly in the area of contract law, ${ }^{174}$ whereas subsequent case law refined and further developed the law of negligence. ${ }^{175}$ However, what really paved the way for the introduction of strict liability for defective products were the parallel developments in U.S. law ${ }^{176}$ and the two reports generated by the Law Commission ${ }^{177}$ and the Royal Commission on Civil Liability and Compensation for Personal Injury, ${ }^{178}$ which both recommended a strict liability regime.

The protection offered through the strict liability regime of the 1985 Product Liability Directive, as implemented through the Consumer Protection Act 1987, does not change the common law of contract or the law of negligence, offering instead an alternative cause of action. Thus, consumers may choose whether to bring a claim based on contract, the tort of negligence, or the Consumer Protection Act, Part I.

\footnotetext{
${ }^{170}$ See Sale of Goods Act 1893, 56 \& 57 VICT., available online at http://www.legislation.gov.uk/ukpga/1893/71/pdfs/ukpga 18930071 en.pdf.

${ }^{171}$ WiTTING, supra note 136, at 410.

172 Section 14 of the Sale of Goods Act 1893.

${ }^{173}$ Donoghue v Stevenson, [1932] UKHL 100, [1932] A.C. 562. In fact, although Donoghue v Stevenson is known mainly for Lord Atkin's speech which established the roots of the modern law of negligence, the holding of the case, and the point on which the majority agreed on, was that privity of contract did not bar the claimant from bringing an action directly against the manufacturer of the product, where the manufacturer was guilty of negligence.

${ }^{174}$ See Sale of Goods Act 1979; Supply of Goods and Services Act 1982; Unfair Contract Terms Act 1977.

${ }^{175}$ See supra Part A.4 of this chapter.

176 See Greenman v. Yuba Power Products Inc., 59 Cal. 2d 57, 377 P.2d 897, 27 Cal. Rptr. 697 (1963).

${ }^{177}$ Law Commission \& Scottish Law Commission, Liability for Defective Products (1977), available online at http://www.scotlawcom.gov.uk/files/8812/7989/7339/rep45.pdf.

${ }^{178}$ Royal Commission on Civil Liability and Compensation for Personal Injury (1978) (Command 7054-I).
} 
The implementation of the Product Liability Directive into English law stands out because of the wording of the provisions from the Consumer Protection Act. First, the verbose style of English statutes was adopted also for the implementation of the directive. ${ }^{179}$ English statutes are generally more detailed and verbose when compared to legislation from the Continent, but in the case of the Consumer Protection Act it can be said that the legislature was truly overly zealous. What is striking, but not necessarily surprising, is the fact that the different wording of the Consumer Protection Act, as well as its verbosity, are detrimental to consumer-victims and beneficial to producers. England erred on the side of business in implementation, as opposed to France, where we have already seen that the errors in implementation were more "consumer-friendly."

English legal scholars have been pointing out the various differences in implementation, ${ }^{180}$ but for the most part the Act did not undergo any major reforms, except for some small revisions that were triggered by the fact that the directive itself was modified. ${ }^{181}$

A first set of noteworthy differences between the directive and the implementing act concern definitional matters. For instance, while the directive uses the term "movable" in the definition of a product, the Consumer Protection Act employs the more restrictive term "goods." Also, the phrase "put into circulation" from the directive has been replaced by "supply" in the Consumer Protection Act.

A second major difference is the fact that the Consumer Protection Act excludes claims for damage caused by a defective component to the product in which it has been incorporated before the sale. ${ }^{182}$ For instance, if a consumer buys an automobile with a defective radio that catches fire and damages the automobile or other parts of the automobile, the consumer has no claim based on the Act. ${ }^{183}$ However, consumers in such cases may have a more advantageous claim under the Sale of Goods Act, making the difference almost insignificant in practice. ${ }^{184}$

Lastly, perhaps the most controversial issue regarding the implementation of the directive in the United Kingdom has to do with the manner in which the development risk defence was drafted in

\footnotetext{
${ }^{179}$ Compare, for instance, art. 6 (1) of the Directive (55 words), with section 3 of the Consumer Protection Act (225 words).

${ }^{180}$ See Jane Stapleton, A Personal Evaluation of the EEC Directive on Products Liability, 1 TORTS LAW JOURNAL 90, 93-94 (1993).

${ }^{181}$ See Consumer Protection Act 1987 (Product Liability) (Modification) Order 2000 (SI 2000/2771).

${ }^{182}$ Section 5 (2) of the Consumer Protection Act 1987.

${ }^{183}$ PEEL \& GOUDKAMP, supra note 110 , at 311.

${ }^{184}$ See Stapleton, supra note 180, at 94.
} 
the Consumer Protection Act. According to article 7 of the directive, a producer is not liable if "the state of scientific and technical knowledge at the time when he put the product into circulation was not such as to enable the existence of the defect to be discovered." 185 The Consumer Protection Act however allows a defendant to escape liability upon proof that "the state of scientific and technical knowledge at the relevant time was not such that a producer of products of the same description as the product in question might be expected to have discovered the defect if it had existed in his products while they were under his control." "186 The seemingly more generous test from the Consumer Protection Act was not deemed contrary to the goals of article 7(e) of the Product Liability Directive by the European Court of Justice when this matter was brought before it. ${ }^{187}$ Most importantly, though, English courts later decided in the relevant case law to interpret article 4(1)(e) of the Consumer Protection Act as referring to the objective state of scientific knowledge at the time the product was put into circulation, ${ }^{188}$ despite the fact that the literal wording of the Act suggests a more subjective approach. It is, indeed, laudable that English courts give preference to the English version of the directive as opposed to the literal wording of the Consumer Protection Act when there is a conflict between the two. In the end, the practical application of the directive does not fundamentally differ from the practice of other member states, and it is safe to conclude that the strict liability regime applicable to defective products in England does not, in practice, differ much from the equivalent French regime, discussed in the previous chapter.

\section{Vicarious liability}

The vicarious liability of employers for the acts of their employees is one of the oldest strict liability torts in English law, having been around, in its strict form, for at least two centuries.

Before the beginning of the $18^{\text {th }}$ century, employers were found liable for the acts of their employees only if the acts of an employee were done at the express command of the employer. ${ }^{189}$ This was more of a form of personal liability than vicarious liability. However, at the beginning

\footnotetext{
${ }^{185}$ Art. 7(e) of the Product Liability Directive.

${ }^{186}$ Art. 4(1)(e) of the Consumer Protection Act 1987.

${ }^{187}$ European Commission v UK, Case C-300/95, EuROPEAN COURT REPORTS, p. I-02649 (1997); [1997] All ER (EC) 481.

${ }^{188}$ Richardson v LRC Products Ltd, [2000] Lloyd's Rep Med 280; A v National Blood Authority [2001] 3 All ER 289.

${ }^{189}$ PeEL \& GoudKAMP, supra note 110 , at 641.
} 
of the $18^{\text {th }}$ century the liability of employers was expanded to implied commands, ${ }^{190}$ and since the implied commands could be inferred from the general authority given to the employee due to his employment alone, the idea of a personal liability became more and more fictitious. ${ }^{191}$ Due to this gradual evolution, it is hard to determine with precision when the liability of employers became truly vicarious, but it can safely be said that employers became strictly liable for the acts of their employees by the middle of the $19^{\text {th }}$ century, when, in Reedie $v$ London and North Western Ry, ${ }^{192}$ it was decided that the relationship between the employer and the employee was sufficient in order to find the employer liable, as long as the employee's wrongful act was done in the course of employment.

Until very recently, the law of vicarious liability was synonymous with, and limited to, the liability of employers for the acts of their employees. In the last seven years, however, this area of the law has evolved and expanded in remarkable ways.

The initial steps outside the boundaries of employment relationships were made in 2012 and 2016, with Catholic Child Welfare Society v Institute of the Brothers of the Christian Schools ${ }^{193}$ (hereinafter Christian Brothers) and Cox v Minister of Defence. ${ }^{194}$ These two cases made the first steps toward opening up the category of vicarious liability, but were not in any way revolutionary. The notion of "employment" used in the context of vicarious liability was always understood to be broader than in the area of employment law, and the existence of an employment contract was never a requirement. ${ }^{195}$ The novelty brought by the Christian Brothers case is the fact that it expanded the notion of vicarious liability to also cover relationships "akin to employment" ${ }^{196}$ In this case, a religious institution (taking the legal form, in this case, of an unincorporated association) was found vicariously liable for the acts of abuse of children perpetrated by a parish priest. The priest in question was not employed by the church or religious order he was affiliated

\footnotetext{
${ }^{190} \mathrm{Id}$.

${ }^{191} I d$.

192 Reedie v London and North Western Ry, (1849) 4 Exch. 244.

${ }^{193}$ Catholic Child Welfare Society v Various Claimants and the Institute of the Brothers of the Christian Schools, [2012] UKSC 56; [2013] 2 A.C. 1.

${ }^{194}$ Cox v Ministry of Justice [2014] EWCA Civ 132.

195 See John Davies, Tort, in 2 English Private Law 519 [no 14.371] (Peter Birks ed., Oxford University Press 2000); VAN DAM, supra note 86, at 508.

196 [2012] UKSC 56, para. 47, 49.
} 
with, and he was also not remunerated for his work. ${ }^{197}$ Notwithstanding, the Supreme Court held that, for tort law purposes, any time work is done by a person and that work furthers the purposes of another, the resulting relationship may be sufficient in order to activate strict vicarious liability. ${ }^{198}$ The court applied a Caparo-like test (asking whether it was fair, just, and reasonable to impose vicarious liability in the circumstances of the case) on the basis of five factors, namely: (i) whether the "employer" is more likely to have the means to compensate the victim than the tortfeasor; (ii) whether the tort was committed as a result of activity undertaken by the tortfeasor on behalf of the employer; (iii) whether the tortfeasor's activity is likely to be part of the business activity of the "employer"; (iv) whether the "employer" created the risk of the tort being committed by assigning a particular task to the tortfeasor; and (v) whether the tortfeasor was, to a greater or lesser degree, under the control of the employer. ${ }^{199}$

Cox reinforced the open-textured approach from Christian Brothers, ${ }^{200}$ and took the law one small step further. ${ }^{201}$ This case involved a prisoner who, while working in the prison kitchens, out of negligence, fell and dropped a sack of kitchen supplies on the claimant. The Ministry of Justice was found liable for the negligent act of the prisoner, again, despite the fact that the prisoner was not an employee. The holding from Cox goes a step further than the holding from Christian Brothers because the relationship between the prison service and the prisoner was not voluntary. According to the applicable prison rules, ${ }^{202}$ convicted prisoners were required to do useful work for up to ten hours a day. Nevertheless, despite the prisoner in question performing prison service work as a matter of penal policy, the Supreme Court went through the factors from Christian Brothers and found that a relationship sufficiently akin to employment existed between a prisoner and the prison authorities, because the prison authorities benefitted from the work done by the prisoner, and the activity he engaged in was an integral part of the defendant's business. ${ }^{203}$

\footnotetext{
${ }^{197}$ Priests belonging to the brotherhood must donate all the money they receive for their work to the religious order they belong to, and in exchange the institute covers all their day-to-day material needs and looks after them after retirement. [2012] UKSC 56, at para. 9.

198 [2012] UKSC 56, at para. 61.

${ }^{199} \mathrm{Id}$. at para. 35.

${ }^{200}$ Cox v Ministry of Justice, [2016] UKSC 10.

${ }^{201}$ See Marianne Tutin, Vicarious Liability: An Ever Expanding Concept?, 45 InduSTRIAL LaW JouRnal 556 (2016).

${ }^{202}$ Rule 31(1) of the Prison Rules 1999 (SI 1999/728).

${ }^{203}$ Cox v Ministry of Justice, [2016] UKSC 10.
} 
An even bigger leap forward was made in the case of Armes v Nottinghamshire County Council, decided on 18 October 2017. ${ }^{204}$ In this case, the Supreme Court ruled that a local authority was liable for the torts committed by foster parents against a child who was placed in their care. Similar to Christian Brothers and Cox, the relationship between a local authority and foster parents was certainly not one of employment. However, it is even more of a stretch to say that the activities of foster parents are "akin to employment". Foster parents are paid an allowance and receive training from local authorities to perform their duties, but do not work for the local authorities. Nevertheless, a majority of the court considered the factors from Christian Brothers and found that: the tortious acts of the foster parents were committed "in the course of an activity carried on for the benefit of the local authority" 205 (see above, the second criterion from Christian Brothers); the foster parents were not "carrying out an independent business of their own" (see the third criterion); ${ }^{206}$ and the local authority had "powers of approval, inspection, supervision and removal without any parallel in ordinary life" (see the fifth criterion). ${ }^{207}$ Also, a local authority was more likely to have the means to compensate the victims (first criterion). ${ }^{208}$

The dissenting opinion in this case belongs to Lord Hughes, who considered that the activity of foster parents is more similar to the activity of independent contractors than that of employees. ${ }^{209}$ He also argued that the rule endorsed by the majority could also apply to situations where children are placed with family members or friends, and consequently local authorities would be deterred from making such placements. ${ }^{210}$ And finally, he expressed concern that the majority's ruling creates a standard too strict for local authorities, ${ }^{211}$ and may encourage undesirable litigation of family life activities in the courts. ${ }^{212}$ Lord Reed responded to these arguments and suggested, in dicta, that when local authorities place children with their parents the resulting relationship is not one which can give rise to vicarious liability, because when parents are raising their own children

\footnotetext{
${ }^{204}$ Armes v Nottinghamshire County Council, [2017] UKSC 60.

${ }^{205} \mathrm{Id}$. at para. 60.

${ }^{206} I d$. at para. 59.

${ }^{207}$ Id. at para. 62.

${ }^{208} \mathrm{Id}$. at para. 63.

${ }^{209} \mathrm{Id}$. at para. 76.

${ }^{210} \mathrm{Id}$. at para. 87-89.

${ }^{211} \mathrm{Id}$. at para. 90.

${ }^{212} I d$.
} 
they engage in activities which can be distinguished more clearly from the childcare services carried out by a local authority. ${ }^{213}$

From a comparative perspective, the facts and the reasoning adopted by the Supreme Court in Armes ring similar to the French Blieck case. ${ }^{214}$ However, a general principle of liability for the acts of third parties like what we have seen in France will probably not be recognized in English law anytime soon. It is doubtful that the holding from Armes will reach further than relationships between public bodies and persons who engage in activities sufficiently connected to the mission of such public bodies, and the Supreme Court will most likely continue expanding the doctrine of vicarious liability only incrementally. However, from Christian Brothers to Armes, it can be said that English law has gone down a slow path of (spontaneous) convergence with French law on the matter of vicarious liability.

The notions of "employment" and "akin to employment" most certainly will not extend to the work done by independent contractors. The existing case law distinguishes between "contracts of service" (falling within the notion of employment) and "contracts for services" (involving independent contractors). ${ }^{215}$ In cases of "contracts for services," the freedom enjoyed by the independent contractor in deciding how to perform his duties makes the relationship too weak to be described as employment or "akin to employment" for the purposes of vicarious liability. Therefore, the liability of independent contractors is usually determined on the basis of the tort of negligence, but also, exceptionally, on the basis of breach of a non-delegable duty (which is also a strict liability tort). ${ }^{216}$

Another area which seems to belong exclusively to the law of negligence is the liability of parents for the acts of their minor children. Although there is a surprising lack of authorities at the appellate level dealing with this issue in England, ${ }^{217}$ it seems to be generally accepted that parents can only be held liable if they breach their duty of care in supervising or controlling their children. ${ }^{218}$ In fact, resorting exclusively to the tort of negligence in such situations seems to be characteristic for

\footnotetext{
${ }^{213} I d$. at para. $71-72$.

214 See supra Chapter II Part C.2.e.

215 See, e.g., Lee v Cheung [1990] 2 A.C. 374; Express and Echo Publications Ltd v Tanton [1999] I.R.L.R. 367.

${ }^{216}$ See infra Part B.5 of this chapter.

${ }^{217}$ See VAN DAM, supra note 86, at 469.

${ }^{218}$ DEAKIN ET AL., supra note 86, at 153-154.
} 
the common law tradition as a whole. English scholars sometimes $\operatorname{refer}^{219}$ to the Australian case of Smith v Leurs, ${ }^{220}$ and in the United States, there is abundant case law supporting the principle that parents are only liable if they breach their duty to supervise and control their children. ${ }^{221}$ Vicarious liability was never really considered an option in such cases, and Armes will probably not have any impact in this area of tort law. In Armes, the defendant had parental authority over the victim, not over the tortfeasor, and the tortfeasor was an adult, not a child. Also, having parental authority is not the same thing as having a relationship "akin to employment". Armes did not abolish or modify the test from Christian Brothers, and proving the mere existence of a parentchild relationship is not enough to fulfil the five factors from the Christian Brothers case.

Moving on to the requirements for liability, the generally accepted test for vicarious liability is the two-stage test laid down by Lord Phillips in Christian Brothers: ${ }^{222}$ in a first stage, it must be determined whether the relationship between the defendant and the person for whom he is brought to answer is a relationship capable of giving rise to vicarious liability; and in a second stage, it must be determined whether the conduct of the employee falls within the "scope of his employment". The fault of the employer is never a factor or a condition for its liability. However, in most cases the fault of the employee (or the person for whom the principal is liable) will have to be established as a precondition for vicarious liability will be that the employee himself must have committed a tort (and in the vast majority of cases that tort is the tort of negligence).

Finally, it must be noted that the employee does not benefit in England from any form of immunity when the employer is found vicariously liable, although the employer's deeper pockets might de facto insulate the employee from liability. As the law stands, employees are jointly liable with their employees in such cases, so the victim of a tort committed by an employee can direct his or her action against both the employer and the employee and recover from either one. ${ }^{223}$ Moreover, employers even have the possibility of recovering from the employee, either under the provisions

\footnotetext{
${ }^{219} I d$. at 154 .

${ }^{220}$ Smith v Leurs, (1945) 70 CLR 256. In Smith v Leurs the claim against the parents of a 13-year-old child who injured another child while playing with a shanghai was dismissed. The court recognised that a duty to take due care in the supervision of children exists for parents, but found that in the circumstances of the case that duty was not breached.

${ }^{221}$ See R.D. Mawdsley, Intentional Tortious Acts of Children and Parental Responsibility: The U.S. Common Law and Statutory Approaches to this Issue, 42 DE JuRE 14 (2009); RESTATEMENT (SECOND) OF TORTS, VOL. 2 § 316 (American Law Institute 1965).

222 [2012] UKSC 56; [2013] 2 A.C. 1, at [21].

${ }^{223}$ DEAKIN ET AL., supra note 86, at 595.
} 
of the Civil Liability (Contribution) Act $1978^{224}$ or at common law under the rule established in Lister $v$ Romford Ice and Cold Storage Co. ${ }^{225}$ The rule from Lister was later analysed in an interdepartmental committee, and immediately after the report was published, employers' liability insurers entered into a "gentleman's agreement" not to take advantage of the possibility open to them to recover from employees unless there was evidence of collusion or wilful misconduct. ${ }^{226}$

5. Breach of a "non-delegable" duty

The general rule under English law is that a person will not be held liable for the acts of independent contractors. Vicarious liability is limited to the acts of employees, as defined above, and does not extend to independent contractors (hired under a "contract for services"). However, it is possible for the principal to be held liable for an act of an independent contractor in cases where he owes the claimant a "non-delegable" duty. It must be stressed, however, that the liability that ensues from a breach of such a duty is not vicarious, but personal to the defendant who owes the non-delegable duty. ${ }^{227}$

The typical cases involving breaches of non-delegable duties are cases of contractual liability. For instance, if A contracts to perform work carefully for B, he will be liable for any damage that is caused to B by the negligent acts of an independent contractor hired to perform the work that $\mathrm{A}$ has promised.

Nonetheless, liability for breach of non-delegable duties may be based not only on contract. In some exceptional cases, liability in tort may also arise because the law itself imposes non-delegable duties. Two types of scenarios can be identified in the case law. ${ }^{228}$ The first typical situation is that of a person employing an independent contractor to perform work which is inherently hazardous or likely to become so. ${ }^{229}$ The relevant precedent for such cases is Honeywill and Stein Ltd v Larkin Bros $L t d,{ }^{230}$ where the principle was established that an employer cannot escape liability by delegating the performance of "acts which, in their very nature, involve in the eyes of the law special dangers to others" ${ }^{231}$ to an independent contractor. The principle from Honeywill and Stein

\footnotetext{
${ }^{224}$ Ch. 22.

${ }^{225}$ Lister v Romford Ice and Cold Storage Co, [1957] A.C. 555; [1957] 1 All E.R. 125.

${ }^{226}$ PEEL \& GOUDKAMP, supra note 110 , at 665.

${ }^{227}$ D\&F Estates Ltd. v Church Commissioners, [1989] A.C. 177 (per Lord Bridge).

${ }^{228}$ See PEEL \& GOUDKAMP, supra note 110, at 667.

${ }^{229} \mathrm{Id}$.

${ }^{230}$ Honeywill and Stein Ltd v Larkin Bros Ltd, [1934] 1 K.B. 191.

${ }^{231} \mathrm{Id}$. at 197.
} 
was, however, criticized recently by the Court of Appeal, first, because of its inconsistency with the ruling from Read $v$ Lyons, ${ }^{232}$ and second, because it is very difficult to distinguish between situations where work is inherently hazardous and situations where it is not. ${ }^{233}$ The Court therefore concluded that the application of the principle ought to be kept as narrow as possible. ${ }^{234}$ The second type of cases concerns defendants who are deemed to have assumed responsibility for the exercise of due care, irrespective of whether they perform their duties or delegate to an independent contractor. It has long been held that employers owe a non-delegable duty of care toward their employees in regard to safety in the workplace. ${ }^{235}$ Also, it was recently held in Woodland v Essex $C C$ that an educational authority owes a non-delegable duty to school children. ${ }^{236}$ Moreover, dicta from the same case indicates that patients in hospitals, prisoners and residents in care homes may be owed the same type of duty. ${ }^{237}$ The requirements for liability were also laid down in Woodland $v$ Essex CC by Lord Sumption:

(1) The claimant is a patient or a child, or for some other reason is especially vulnerable or dependent on the protection of the defendant against the risk of injury. . . . (2) There is an antecedent relationship between the claimant and the defendant, independent of the negligent act or omission itself, (i) which places the claimant in the actual custody, charge or care of the defendant, and (ii) from which it is possible to impute to the defendant the assumption of a positive duty to protect the claimant from harm, and not just a duty to refrain from conduct which will foreseeably damage the claimant. . . . (3) The claimant has no control over how the defendant chooses to perform those obligations, i.e. whether personally or through employees or through third parties. (4) The defendant has delegated to a third party some function which is an integral part of the positive duty which he has assumed towards the claimant; and the third party is exercising, for the purpose of the function thus delegated to him, the defendant's custody or care of the claimant and the element of control that goes with it. (5) The third party has been negligent not in some collateral respect but in

\footnotetext{
${ }^{232}$ Read v J Lyons \& Co Ltd, [1947] A.C. 156; [1946] 2 All E.R. 471 [holding that a person is not strictly liable (i.e. absent negligence) for dangerous things, such as shell cases filled with explosives].

${ }^{233}$ Biffa Waste Services Ltd v Maschinenfabrik Ernst Hese GmbH, [2008] EWCA Civ 1238; [2009] Q.B. 725.

${ }^{234} \mathrm{Id}$.

${ }^{235}$ Wilson and Clyde Coal Co v English, [1938] A.C. 57. See also Employers' Liability (Defective Equipment) Act 1969, section 1(1).

${ }^{236}$ Woodland v Essex CC, [2013] UKSC 66; [2014] A.C. 537.

${ }^{237} I d$. at [23] (per Lord Sumption).
} 
the performance of the very function assumed by the defendant and delegated by the defendant to him. ${ }^{238}$

Liability for breach of a non-delegable duty is strict. The absence of fault as a requirement is not due to the strictness of the duty owed by the defendant to the claimant. It may very well be that the defendant only owed a duty of care to the claimant. However, the fact that the defendant will be held liable because of the fault of another (the independent contractor), and not due to his personal fault, means that liability in such a case is triggered irrespective of the defendant's fault. In other words, in order for the claimant to succeed in his action, the defendant's personal fault need not be proven (for instance, by way of proving that he erred in delegating the performance to an inexperienced or incompetent contractor). As long as the duty is breached by the independent contractor delegated to perform, the defendant will be held liable irrespective of how reasonable its own behaviour was.

\section{Liability for animals}

Another traditional area of English law where strict liability rules were developed as early as the $14^{\text {th }}$ century ${ }^{239}$ is that of liability for animals. ${ }^{240}$ Nowadays, the sedes materiae for strict rules of liability for animals is the Animals Act $1971 .{ }^{241}$ However, this statute is but a patch in the legal landscape regulating liability for animals that are considered dangerous, replacing an older common law action called the "scienter action" liability for injury done by dogs to livestock, and modernizing the rules on liability for straying livestock. The full picture of liability for animals is complex and cannot be reduced to the 1971 Act. The damage caused by animals may trigger liability based on a variety of torts, such as negligence, ${ }^{242}$ nuisance, ${ }^{243}$ assault and battery, ${ }^{244}$

\footnotetext{
${ }^{238} I d$.

${ }^{239}$ HeUston \& R.S. CHAMBERS, supra note 23, at 315.

${ }^{240}$ For comprehensive studies on liability for animals in English law see PETER NORTH, CIVIL LIABILITY FOR Animals (Oxford University Press 2012) and Glanville L. Williams, Liability for Animals (Cambridge University Press 1939).

${ }^{241}$ Animals Act 1971, c. 22.

${ }^{242}$ Fardon v. Harcourt-Rivington, (1932) 146 L. T. 391, 392 (per Lord Atkin); Searle v Wallbank, [1947] A.C. 341, at 359-60 (per Lord du Parcq).

${ }^{243}$ Aldred's case, (1610), 9 Co. 57b; Wheeler v JJ Saunders Ltd, [1996] Ch. 19 (both cases dealing with the disturbance created by the stench of pigs); Leeman v Montague, [1936] 2 All E.R. 1677 (crowing of cockerels); Farrer v Nelson, (1885) 15 Q.D.B. 258 (damage to crops by pheasants);

${ }^{244}$ See Roberts v CC Kent, [2008] EWCA Civ 1588; [2009] Po. L.R. 8 [the action in this case failed though, because the release of the dog by a police officer was lawful pursuant to the Criminal Law Act 1967 s.3(1)].
} 
trespass, ${ }^{245}$ and potentially even defamation. ${ }^{246}$ The 1971 Act operates on top of these common law actions, and a claimant may choose between reliance on the Act or another cause of action if he meets the requirements of both.

At common law, under the old scienter rule, the keeper of an animal was strictly liable for damage caused by the animal if: (1) the animal belonged to a dangerous species (was ferae naturae); or (2) the animal did not belong to a dangerous species (mensuetae naturae) but its owner had knowledge of its dangerous propensities. ${ }^{247}$ The Animals Act 1971 basically maintains this old distinction, but modifies on a number of points the old common law rules. ${ }^{248}$

Liability for animals belonging to a dangerous species is regulated by section 2(1) of the Act. This rule is fairly straightforward, making the keeper strictly liable for any damage caused by such an animal. ${ }^{249} \mathrm{~A}$ dangerous species is defined as a species "(a) which is not commonly domesticated in the British Islands; and (b) whose fully grown animals normally have such characteristics that they are likely, unless restrained, to cause severe damage or that any damage they may cause is likely to be severe." ${ }^{250}$ A person is considered a keeper of the animal if:

(a) he owns the animal or has it in his possession; or (b) he is the head of a household of which a member under the age of sixteen owns the animal or has it in his possession; and if at any time an animal ceases to be owned by or to be in the possession of a person, any person who immediately before that time was a keeper thereof by virtue of the preceding provisions of this subsection continues to be a keeper of the animal until another person becomes a keeper thereof by virtue of those provisions. ${ }^{251}$

\footnotetext{
${ }^{245}$ A very common form of trespass is "cattle trespass", and one variety of such trespass (the straying of livestock) is dealt with in section 4 of the Animals Act.

${ }^{246}$ See the hypothetical examples provided in PEEL \& GoUDKAMP, supra note 110, at 520 and DEAKIN ET AL., supra note 86 , at 549 .

${ }^{247}$ PeEL \& GoudKAMP, supra note 110, at 521.

${ }^{248}$ For instance, no escape or attack is necessary under the wording of the act, whereas the older cases required such a condition. $I d$. At 522.

249 "Where any damage is caused by an animal which belongs to a dangerous species, any person who is a keeper of the animal is liable for the damage, except as otherwise provided by this Act." Section 2(1) of the Animals Act 1971.

${ }^{250}$ Section 6(2) of the Animals Act 1971.

${ }^{251}$ Section 6(3) of the Animals Act 1971.
} 
The liability for animals that do not belong to a dangerous species is anything but straightforward. This provision has been criticized on multiple occasions for its obscurity ${ }^{252}$ and drafting style. ${ }^{253}$ In order to establish the defendant's liability under this provision, the following elements (most of them problematic) must be shown: (a) the animal, although not belonging to a dangerous species, has abnormal characteristics (not normally found in animals of the same species), or characteristics which are not normally present, except at particular times or in particular circumstances; (b) the damage caused by the animal was foreseeably ${ }^{254}$ likely to occur or was likely to be severe; and (c) the keeper had knowledge of the above-mentioned characteristics of the animal, or a person who at that time had charge of the animal or another keeper of the animal who is a member of the keeper's household and under the age of 16 had knowledge of the abnormal characteristics of the animal. ${ }^{255}$ It is hard to say if this provision establishes a genuine strict liability rule due to the knowledge requirement. The claimant must prove that the defendant had actual (not constructive) knowledge of the vicious characteristic of the animal, ${ }^{256}$ except, of course, for the situations where another keeper or a member of the principal keeper's household had charge of the animal, in which case their knowledge can be imputed upon the principal keeper of the animal. ${ }^{257}$ The mental element required by section 2(2)(c) of the Animals Act (knowledge of the dangerous propensities of the animal) is different from a requirement to show negligence or intention. The keeper is liable irrespective of whether he intended the damage, or the damage was caused by some imprudence (behaviour that falls short of the standard of a reasonable person). However, the presence of a mental element among the conditions for liability implies some form of fault in a broader sense (the damage is imputed to the keeper because he knew about the dangerous propensity). That being

\footnotetext{
${ }^{252}$ See Mirvahedy v Henley, [2003] UKHL 16; [2003] 2 A.C. 491, at [9].

${ }^{253}$ See Turnbull v Warrener, [2012] EWCA Civ 412; [2012] P.I.Q.R. P16, at [4].

${ }^{254}$ Curtis v Betts, [1990] 1 W.L.R. 459, at 469.

${ }^{255}$ Section 2(2) of the Animals Act 1971: "Where damage is caused by an animal which does not belong to a dangerous species, a keeper of the animal is liable for the damage, except as otherwise provided by this Act, if (a) the damage is of a kind which the animal, unless restrained, was likely to cause or which, if caused by the animal, was likely to be severe; and (b) the likelihood of the damage or of its being severe was due to characteristics of the animal which are not normally found in animals of the same species or are not normally so found except at particular times or in particular circumstances; and (c) those characteristics were known to that keeper or were at any time known to a person who at that time had charge of the animal as that keeper's servant or, where that keeper is the head of a household, were known to another keeper of the animal who is a member of that household and under the age of sixteen."

${ }^{256}$ Chauhan v Paul, [1998] C.L.Y. 3990, CA. When the characteristic is common in the species in some circumstances [the second thesis of section 2(2)(b)], it is sufficient that the keeper knows that animals of that type may react in a way which led to the damage, and it is not necessary to show that the keeper had additional knowledge about that particular animal. Welsh v Stokes, [2007] EWCA Civ 796; [2008] 1 W.L.R. 1224. ${ }^{257}$ PeEL \& GoudKamP, supra note 110 , at 527.
} 
said, it is the opinion of this author that liability can still be catalogued as strict in such a case because, once the element of knowledge is established, the level of precautions taken is irrelevant - the keeper will be held liable even if he took reasonable precautions.

The Act also tackles the liability of keepers of dogs for the damage resulting from attacks on livestock (section 3 of the Animals Act), the liability for straying livestock (section 4 of the Animals Act), and the liability for damage and expenses due to horses on land in England without lawful authority. ${ }^{258}$ In all the circumstances covered by sections 3, 4 and 4A of the Act, liability is strict.

The exclusive fault of the claimant is a defence ${ }^{259}$ and contributory negligence is also a partial defence for all forms of strict liability covered by the Act. ${ }^{260}$ Section 5 of the Act contains other detailed provisions regarding more specific defences (e.g. assumption of risk in case of liability under section 2, or lawful use of the highway in case of liability under section 3).

7. Breach of statutory duty

When a person breaches a duty imposed by a statute, it is possible, in exceptional circumstances, for a private action to arise as a consequence of that breach. The tort of breach of statutory duty is an autonomous and separate tort in England, ${ }^{261}$ and is, stricto sensu, triggered by a breach of duty arising from a statute that is primarily regulatory or criminal. ${ }^{262}$ Other statutes, such as the Occupiers Liability Act 1957 or Part I of the Consumer Protection Act 1987, regulate tortious liability exclusively, and under a broader definition (breach of statutory duty lato sensu) such statutes can also be said to create causes of action based on a breach of statutory duty. ${ }^{263}$ In this subsection, only the traditional, stricto sensu, tort of breach of statutory duty is analysed.

The predilect interests protected by the tort of breach of statutory duty are health and safety in the workplace, the health and safety of consumers, the safety of road-users, and the protection of

\footnotetext{
${ }^{258}$ Section 4A was inserted by the Control of Horses Act 2015, c. 23, ss. 4(1), 5(1).

${ }^{259}$ See section 5 of the Animals Act 1971.

${ }^{260}$ See section 10 of the Animals Act 1971.

${ }^{261}$ See London Passenger Transport Board v Upson, [1949] A.C. 155, at 168 (per Lord Wright): "[A] claim for damages for breach of a statutory duty is [...] a specific common law right which is not to be confused in essence with a claim for negligence." By contrast, in the United States, the breach of a duty enshrined in a statute gives rise to either a presumption of negligence or a finding of negligence per se, the law of negligence being applied and not a separate tort. DEAKIN ET AL., supra note 86, at 359.

262 PEEL \& GoudKAMP, supra note 110 , at 207.

${ }^{263}$ K.M. Stanton, New Forms of the Tort of Breach of Statutory Duty, 120 L.Q.R. 324, 324 (2004).
} 
certain types of property and financial interests. ${ }^{264}$ In addition, breaches of European Union law by individuals are actionable in England as breaches of statutory duty. ${ }^{265}$

Not all statutes create duties that give rise to a civil action for breach of statutory duty. In order for the tort to operate, Parliament must have, either explicitly ${ }^{266}$ or by implication, intended for the statutory duty to give rise to an action in tort. When the statute is not explicit, a claimant must satisfy a two-part test: (1) he must show that the statute was created with the intention of protecting the class of persons to which he belongs; and (2) the Parliament envisaged that such a claimant could be allowed a remedy for the infringement of his interests. ${ }^{267}$ However, statutory construction and the identification of parliamentary intent is not always straightforward. In most cases, statutes are either silent, or their language is not crafted with precision, ${ }^{268}$ and therefore interpretation can go one way or another. Courts have been taking various factors into account, including the purpose of the legislation as a whole, ${ }^{269}$ whether the statute already has a remedial system in place, the type of injury, and the literal wording or the structure of the statute, but none of these factors individually or in any combination offers a definitive answer. That is why Lord Denning harshly criticized the legislature for having left the courts with a "guess-work puzzle", ${ }^{270}$ while other legal scholars compared the interpretation work of the courts with acts of divination, ${ }^{271}$ and others even argued for the abolition of the tort of breach of statutory duty altogether. ${ }^{272}$

Whether liability is strict or based on fault in cases of a breach of statutory duty is a matter that depends on the construction of the duty created by the statute. A large number of such duties are

\footnotetext{
${ }^{264}$ DEAKIN ET AL., supra note 86 , at 358.

${ }^{265}$ See Garden Cottage Foods v Milk Marketing Board, [1983] 3 W.L.R. 143; [1984] A.C. 130, 141 (per Lord Diplock): "A breach of the duty imposed by article 86 not to abuse a dominant position in the common market or in a substantial part of it, can thus be categorised in English law as a breach of statutory duty that is imposed not only for the purpose of promoting the general economic prosperity of the common market but also for the benefit of private individuals to whom loss or damage is caused by a breach of that duty."

But, see the opposing view of Stanton, supra note 263, at 329-330: "The Eurotort is simply to be classified as a tort in domestic proceedings and the repeated references to breach of statutory duty are a redundancy."

${ }^{266}$ E.g. Sex Discrimination Act 1975, c. 65; section 38 of the Building Act 1984, c. 55; section 103 of the Copyright Designs and Patents Act 1988, c. 48; sections 71 and 150 of the Financial Services and Markets Act 2000, c. 8.

${ }^{267}$ WitTING, supra note 136, at 501.

${ }^{268}$ See Glanville L. Williams, The Effect of Penal Legislation in the Law of Tort, 23 M.L.R. 233, 243 (1960): "[T]he language used in legislation seems to be largely haphazard."

${ }^{269}$ R. v Deputy Governor of Brixton Prison Ex p. Hague, [1992] 1 A.C. 58 at 171; Morrison Sports Ltd v Scottish Power, [2010] UKSC 37; [2010] 1 W.L.R. 1934.

${ }^{270}$ Ex p. Island Records, [1978] Ch. 122, at 134-135 (per Denning MR).

${ }^{271}$ PEEL \& GOUDKAMP, supra note 110, at 223.

${ }^{272}$ See Williams, supra note 268.
} 
strict, ${ }^{273}$ but quite often the duties created by some statutes amount to nothing more than special duties of care $^{274}$ that can give rise to standards similar to those based on presumptions of negligence ${ }^{275}$ (whether de facto such duties lead to strict liability depends on how easy it is for the defendant to rebut the presumption). In addition, it is worth adding that all statutory tortious duties created by Parliament are non-delegable, ${ }^{276}$ therefore their breach by a third party might also lead to a form of strict liability on the part of the person owing the duty.

\section{Other statutory strict liability torts}

Some statutes go to further lengths to spell out the liability of certain categories of persons in very specific circumstances, and thus regulate much more than just their statutory duties. We have seen earlier that the tort of breach of statutory duty corresponds to the narrow, stricto sensu, interpretation of the phrase "breach of statutory duty" and does not cover statutes that spell out the conditions for civil action (where the phrase breach of statutory duty may also be used, lato sensu). In this section, the most important statutes that create strict liability causes of action are briefly analysed. In addition to Part I of the Consumer Protection Act 1987, ${ }^{277}$ which was analysed at

\footnotetext{
${ }^{273}$ Williams, supra note 268, at 331; WiTTING, supra note 136, at 499; R. A. Buckley, Liability in Tort for Breach of Statutory Duty, 100 L.Q.R. 204, 223 (1984). In London Passenger Transport Board v Upson, [1949] A.C. 155, 168, Lord Wright even made the general statement that breach of statutory duty is "a common law action ... [that] belongs to the category often described as that of cases of strict or absolute liability." See also Galashiels Gas Co v Millar, [1949] A.C. 275 (Section 22, sub-section 1 of the Factories Act, 1937 imposed an absolute duty, and therefore proof of any failure in the mechanism of a hoist or lift establishes a breach of the statutory duty, despite the fact that it was impossible to anticipate the failure before the event and that reasonable steps have been taken to provide a suitable hoist or lift and to maintain it properly); John Summers \& Sons Ltd v Frost, [1955] 2 W.L.R. 825; [1955] A.C. 740 [The duty of the factory owner to fence the grinding wheel securely (under section 14(1) of the Factories Act, 1937) was absolute, and the fact that compliance with the statute might have rendered the machine unusable did not absolve the factory owner from such a duty].

${ }^{274}$ See Read v Croydon Corporation, [1938] 4 All E.R. 631 (The Waterworks Clauses Act 1847 required the defendant corporation to provide a "supply of pure and wholesome water." The court interpreted this obligation to be limited to "the exercise of all reasonable care and skill to ensure that the water provided accord[ed] with the provisions of the Act." Id. at 650-51). The language of some statutes only requires measures to be taken that are "reasonably practicable," or "practicable", standards that seem very close to that of negligence, and definitely imply some form of fault. See, e.g., Sections 11(2)(a) \& (b), Provision and Use of Work Equipment Regulations 1998 (SI 1998/2306).

${ }^{275}$ See Baker v Quantum Clothing Group Ltd, [2011] UKSC 17; [2011] 1 W.L.R. 1003 [holding that "safety," for the purposes of section 29(1) of the Factories Act 1961 (now repealed by Workplace (Health, Safety and Welfare) Regulations 1992/3004 Sch.2(I) para.1), was a relative concept which had to be judged according to the general knowledge and standards of the time, by reference to what might reasonably have been foreseen by a reasonable and prudent employer).

${ }^{276}$ Stanton, supra note 263, at 338 .

${ }^{277}$ Supra Part B.3 of this chapter.
} 
length above, in this category we can include the Harbours, Docks and Piers Clauses Act 1847, ${ }^{278}$ the Carriage by Air Act 1961, ${ }^{279}$ the Nuclear Installations Act $1965,{ }^{280}$ the Gas Act $1965,{ }^{281}$ the Civil Aviation Act 1982, ${ }^{282}$ the Environmental Protection Act 1990, ${ }^{283}$ the Water Industry Act $1991,{ }^{284}$ the Merchant Shipping Act 1995, ${ }^{285}$ and the Environmental Damage (Prevention and Remediation) Regulations 2009. ${ }^{286}$

9. Trespass in modern law

The development of the law of negligence and the various modern forms of strict liability are symptoms of a layer-by-layer expansion of English tort law in the last two centuries. The law of torts in England grew organically, with small incremental changes, brought about by the nuances in the case law or the patchwork done through various statutes. What happened then to the old action for trespass?

The action for trespass went through a process of refinement and subdivision over the past couple of centuries. Thus, three main forms of trespass can now be distinguished in the modern law: trespass to the person, trespass to land, and trespass to chattels. Trespass to the person is further subdivided into the actions for battery, assault, and false imprisonment.

\footnotetext{
${ }^{278}$ Section 74, Harbours, Docks and Piers Clauses Act 1847, c. 27 (Regnal. 10 and 11 Vict.): "The owner of every vessel or float of timber shall be answerable to the undertakers for any damage done by such vessel or float of timber, or by any person employed about the same, to the harbour, dock, or pier, or the quays or works connected therewith, and the master or person having the charge of such vessel or float of timber through whose wilful act or negligence any such damage is done shall also be liable to make good the same; and the undertaker may detain any such vessel or float of timber until sufficient security has been given for the amount of damage done by the same: Provided always, that nothing herein contained shall extend to impose any liability for any such damage upon the owner of any vessel, where such vessel shall at the time when such damage is caused be in charge of a duly licensed pilot whom such owner or master is bound by law to employ and put his vessel in charge of."

Section 74 of the Harbours, Docks and Piers Clauses Act 1847 has had a fascinating life in the case law, posing many questions of statutory construction that divided the law lords over the years. What is clear, however, is the fact that the statute does impose a form of vicarious strict liability upon the owner of a vessel. See River Wear Commissioners v Adamson, (1877) App. Cas. 743; The Mostyn, [1928] A.C. 57.

${ }^{279}$ Carriage by Air Act 1961, c. 27 (Regnal. 9 and 10 Eliz 2), giving effect to the Convention concerning international carriage by air known as "the Warsaw Convention as amended at The Hague, 1955."

${ }^{280}$ Nuclear Installations Act 1965, c. 57, which implements the provisions of the 1960 Paris Convention of Third Party Liability in the field of Nuclear Energy and the 1963 Brussels Convention Supplementary to the Paris Convention.

${ }^{281}$ Gas Act 1965, c. 36, Section 14.

${ }^{282}$ Civil Aviation Act 1982, c. 16, Section 76(2).

${ }^{283}$ Environmental Protection Act 1990, c. 43, Sections 33(1), 63(2), 73(6).

${ }^{284}$ Water Industry Act 1991, c. 56, Section 209.

${ }^{285}$ Merchant Shipping Act 1995, c. 21 (see especially Sections 153 \& 154).

${ }^{286}$ Environmental Damage (Prevention and Remediation) Regulations 2009, SI 2009/153, implementing Directive 2004/35/CE of the European Parliament and of the Council of 21 April 2004 on environmental liability with regard to the prevention and remedying of environmental damage.
} 
The trespass to the person torts have seen a very important transformation in the $20^{\text {th }}$ century. While they might have once been strict liability torts, in the sense that they did not require proof of intent or negligence, ${ }^{287}$ after the decisions in Fowler v Lanning ${ }^{288}$ and Letang v Cooper, ${ }^{289}$ it is now commonly held that trespass to the person torts require proof of intent. ${ }^{290}$ The intent required is not intent to cause damage, and damage need not even be proven, as all three torts are actionable per se. ${ }^{291}$ The intent required by the trespass torts is intent to commit the act of force, not intent to cause a certain consequence. ${ }^{292}$

The tort of trespass to land is a strict liability tort, ${ }^{293}$ despite it being sometimes categorized as an "intentional" tort. ${ }^{294}$ This form of trespass sanctions any unjustifiable interference with the possession of land. ${ }^{295}$ What is considered unjustifiable is (a) any voluntary act of interference that is direct; and (b) any involuntary act of direct interference that is caused negligently. In the case of voluntary acts of interference, there is a form of intent present: the intent to enter upon land or otherwise interfere with the possession of land. ${ }^{296}$ Entry upon another person's land is considered trespass even if the tortfeasor did not know that he was trespassing. ${ }^{297}$ Therefore, the innocent

\footnotetext{
${ }^{287}$ See the various cases identified in Winfield \& Goodhart, supra note 41, at 359-362, which show that, even as late as the year 1891, it was not necessary to prove intent or negligence for a successful claim in trespass to the person.

${ }^{288}$ Fowler v Lanning, [1959] 1 Q.B. 426.

${ }^{289}$ Letang v Cooper, [1964] 3 W.L.R. 573; [1965] 1 Q.B. 232. See especially Lord Denning's speech: "[W]hen the injury is not inflicted intentionally, but negligently, I would say that the only cause of action is negligence and not trespass." Id. at 240.

290 DEAKIN ET AL., supra note 86, at 415; PEEL \& GoudKAMP, supra note 110, at 57; WiTTING, supra note 136, at 252. See also F. A. Trindade, Intentional Torts: Some Thoughts on Assault and Battery, 2 OXF. J. LEG. STUD. 211 (1982).

${ }^{291}$ PEEL \& GOUDKAMP, supra note 110, at 57.

${ }^{292}$ W. V. H. ROGERS, THE LAW OF TORT 134 (Sweet \& Maxwell 1989).

${ }^{293}$ DEAKIN ET AL., supra note 86, at 448: "[L]iability in trespass is strict in the sense that it does not depend upon intention or negligence as to the consequences of the act"; JENNY STEELE, TORT LAW: TEXT, CASES AND MATERIALS 899 (4th ed., Oxford University Press 2017): "Trespass liability is 'strict'."

${ }^{294}$ See, e.g., DAN B. DoBbS, The LAW OF TORTS 98 ( $3^{\text {rd }}$ ed. repr., West 2004); AdRIAN TAMBA, InTENTIONAL TORTS. O CERCETARE A COMMON LAW-ULUI AMERICAN - COMMON LAW, EQuity, TORTS LAW 276 (Hamangiu 2015) (both authors write about U.S. law, not English law, and both admit that the kind of "intent" required in trespass to land is merely "intent to enter or commit an equivalent to entry").

${ }^{295}$ PEeL \& GoudKAMP, supra note 110, at 427.

${ }^{296}$ There are various ways of committing a trespass other than physically entering on someone's property. See Lavender v Betts, [1942] 2 All ER 72 (removing doors and windows); Rashid v Sharif, [2014] EWCA Civ 377 (rebuilding a shared wall); Westripp v Baldock, [1938] 2 All ER 779 (affd [1939] 1 All ER 279) (placing a ladder against a wall); Simpson v Weber, (1925) 133 LT 46 (driving nails into a wall); Beckwith v Shordike, (1767) 4 Burr 2092 (encouraging a dog to run onto a person's land); British Waterways Board v Seven Trent Water, [2002] Ch. 25 (CA) (discharging water into the flowing watercourse of the claimant).

${ }^{297}$ Conway v George Wimpey \& Co Ltd, [1951] 2 K.B. 266, at 273-74; Jolliffe v Willmett \& Co, [1971] 1 All ER 478.
} 
belief a defendant might hold that he is passing through his own land is not an excuse. ${ }^{298}$ However, when the defendant enters another person's land through no act of his own, such as when one is pushed or thrown by someone into the claimant's land, he will not be held liable in trespass. ${ }^{299}$ The use of the term voluntary, instead of "intentional," is deliberate. The state of mind that is required in cases of trespass to land differs from the state of mind required to commit a battery. For instance, if a person suddenly turns around without knowing that another person is standing behind him or her (or mistakenly believes that it is not a person, but for instance a door behind him or her) and, in so turning, directly hits such a person, English courts would likely conclude that the act in such a case was not intentional. In the case of trespass to land, however, we have seen that a trespasser will be held liable even if he is not aware of the fact that he is trespassing, and the exculpatory situations found in the case law seem to suggest that in those cases the trespassory act was simply involuntary. The best example for proving this assertion is Gilbert $v$ Stone ${ }^{300}$ where the defendant was found liable despite the fact that he had been forced to enter the claimant's land by threats. The voluntariness of the act of stepping onto somebody else's land is thus sufficient, even if the defendant did not want to commit the trespass. In fact, it is possible for a defendant to be found liable for trespass even in cases where the entry upon land was involuntary, as long as the involuntary entry is a consequence of a prior negligent act. For instance, it is possible to hold a defendant liable for trespass if, following a car accident, he enters land adjoining the highway, but only if the claimant proves that the defendant was negligent in so doing. ${ }^{301}$ Similarly, the owner of a pack of hounds may be held liable in trespass when, knowing that there was a real risk that the hounds would enter the claimant's land, he failed to exercise proper control over his hounds. ${ }^{302}$ Trespass to chattels (also called "trespass to goods") is much more difficult to qualify, and it is not clear whether the tort is nowadays strict or fault-based. The traditional opinion is that once it is proven that the goods have been interfered with in a direct manner, the claimant has a prima facie case, and it rests upon the defendant to prove that the interference was caused by an "inevitable accident." ${ }^{303}$ However, it is possible, after the decision from Fowler $v$ Lanning, ${ }^{304}$ that proof of

\footnotetext{
${ }^{298}$ Basely v Clarkson, (1681) 3 Lev 37.

${ }^{299}$ Smith v Stone, (1647) Style 65.

${ }^{300}$ Gilbert v Stone, (1647) Style 72.

${ }^{301}$ See PeEL \& GoUdKAMP, supra note 110, at 428.

${ }^{302}$ League Against Cruel Sports v Scott, [1986] Q.B. 240, 252 (per Park J).

${ }^{303}$ PEEL \& GOUDKAMP, supra note 110 , at 539.

${ }^{304}$ Fowler v Lanning, [1959] 1 Q.B. 426.
} 
negligence might be required in cases of trespass to goods as well, but the problem has not yet been settled in the case law.

\section{Conversion}

The protection of moveable property in English common law is realised through a number of causes of action, ${ }^{305}$ including trespass to goods, which was dealt with above, replevin, ${ }^{306}$ and the tort of conversion. Conversion is the broadest in scope amongst the torts that protect interests in goods, covering a myriad of situations which include: wrongfully taking possession of goods, wrongfully misusing goods, wrongfully destroying them, and wrongfully refusing to give them up when required. ${ }^{307}$ No matter how conversion is realised, liability is always strict. In the words of Lord Diplock:

At common law, one's duty to one's neighbour who is the owner, or entitled to possession, of any goods is to refrain from doing any voluntary act in relation to his goods which is a usurpation of his proprietary or possessory rights in them. . . [I] t matters not that the doer of the act of usurpation did not know, and could not by the exercise of any reasonable care have known, of his neighbour's interest in the goods. The duty is absolute; he acts at his peril. $^{308}$

\section{Defamation}

Defamation is an umbrella term, designating two separate, but similar, torts: slander and libel. Traditionally, the distinction between slander and libel was drawn based on whether the defamatory statement was made orally or in writing, but the more modern interpretation is that slander applies to statements made in non-permanent form, whereas libel applies to statements taking on a permanent form. ${ }^{309}$ The practical importance of the distinction between slander and

\footnotetext{
${ }^{305}$ Some of the older causes of actions have been completely replaced by more modern forms: the old action of "trover" evolved into the modern action of conversion; also, "distress" (a self-help remedy whereby a party, in certain cases, is entitled to seize and retain goods until satisfaction is obtained) has been replaced by statutory remedies (See Part 3 of the Tribunals, Courts and Enforcement Act 2007, c. 15).

${ }^{306}$ Replevin is a very old cause of action that offers a form of interim relief for the victim of a trespassory taking of goods, but which has lost its practical importance since Section 4 of the Torts (Interference with Goods) Act 1977, c. 32 introduced a more attractive form of interim relief.

${ }^{307}$ PEel \& GoudKAMP, supra note 110 , at 541.

${ }^{308}$ Marfani \& Co Ltd v Midland Bank Ltd, [1968] 1 W.L.R. 956, 970-71.

${ }^{309}$ PeEL \& GoudKAMP, supra note 110, at 361.
} 
libel today is minimal. ${ }^{310}$ The main difference in terms of legal consequences is the fact that libel is actionable per se (without proof of damage), ${ }^{311}$ whereas slander usually requires proof of actual damage (although there are some exceptions when slander is also actionable per se). ${ }^{312}$

Defamation is difficult to place in one of the two major categories of liability (fault and strict liability). Slander and libel are extremely complex and technical torts. Their core was developed by the courts of common law, but many scattered statutes also govern some important aspects (the most important statutes being the Defamation Act $1996^{313}$ and the Defamation Act $2013^{314}$ ). The purpose of statutory reform in the law of defamation has not been the complete replacement of the rules developed by the common law courts. Rather, the various statutes patch up the elements and defences of defamation for specific situations. Because of this complexity, it is very difficult to identify any general principles underlying the whole set of rules making up the law of defamation. The weight given to the defendant's state of mind, in particular, will depend on the interplay between prima facie elements, defences, the rules regarding the burden of proof, and the choices made by the parties.

However, it is not impossible to determine those instances when liability is strict and those when liability is fault-based. As a general rule, and based on its prima facie elements alone, defamation can be characterized as a strict liability wrong. If the plaintiff has standing, all he needs to show is that: (1) a defamatory statement was made, (2) the statement was published, and (3) the statement can be said to have been referring to the claimant. ${ }^{315}$ In addition, in the case of slander, as a general

\footnotetext{
${ }^{310}$ Historically, the main distinction between the two torts of defamation was that libel was also a common law crime. The crime of defamatory libel was abolished, however, by s. 73 (b) of the Coroners and Justice Act 2009. c. 25. PEEL \& GOUDKAMP, supra note 110 , at 372.

${ }^{311}$ This rule that libel is actionable per se has not been curtailed in any significant way by the enactment of section 1 of the Defamation Act 2013, which provides that a statement is defamatory only if its publication causes "serious harm." Case law subsequent to the enactment of the Defamation Act 2013 supports the view that libel is still actionable per se, because the seriousness of harm can be inferred from the nature of the publication. See, e.g., Lachaux v Independent Print Ltd, [2015] EWHC 2242 (Q.B.); Sobrinho v Impresa Publishing SA, [2016] EWHC 66 (Q.B.). Also, commentary on this text seems to indicate that its impact is trivial, the text being aimed only at preventing trivial claims from being brought to court. See Alastair Mullis \& Andrew Scott, Tilting at Windmills: the Defamation Act 2013, 77 MODERn LAW REV. 87, 106 (2014) ("it is likely that section 1 will make only the most marginal of differences to the existing law").

${ }^{312}$ Id. at $372-73$.

313 Defamation Act 1996 c. 31.

${ }^{314}$ Defamation Act 2013 c. 26.

${ }^{315}$ See DEAKIN ET AL., supra note 86, at 651-66.
} 
rule, actual or "special" damage must also be shown. ${ }^{316}$ The interpretation of the first element, in particular, supports the conclusion that liability in defamation is strict. The test for what counts as a defamatory statement is whether "the words tend to lower the plaintiff in the estimation of rightthinking members of society generally." 317 There is an objective standard underlying this test, but it is a standard very much different from the reasonable person standard we find in the tort of negligence. The focus in defamation is on the material or words published and the potential impact of the publication, and not the level of care taken by the defendant. The judge must put himself not in the shoes of the defendant, but in the shoes of a reasonable member of society, in order to determine whether the published material negatively impacts the esteem of the plaintiff in the eyes of such a reasonable person. This results in a relative disregard for the defendant's intentions and precautions. Based on the existing case law, a claimant may recover for defamation even if the defendant did not know and could not have known under the circumstances that: (1) his words can be construed as referring to the claimant, (2) what he said was not true, or (3) his words could be understood by others in a defamatory sense. ${ }^{318}$

A partial resemblance with a fault-based tort is triggered by the second element, requiring publication. The defamatory statement must be communicated to one or more persons other than the plaintiff in order to establish this element. However, the defendant will be allowed to show that he took reasonable care in relation to the publication, and did not know, and had no reason to believe, that what he did caused or contributed to the publication of a defamatory statement. In the abstract, this means that the publication requirement is fulfilled only if the publication by the defendant was done intentionally or negligently. ${ }^{319}$ One is negligent in this regard if one should have foreseen that some other person would read, hear or otherwise access the defamatory

\footnotetext{
${ }^{316}$ Proof of damage is not required in cases of slander if the publication suggests that: (1) the claimant is guilty of a criminal offence punishable with imprisonment in the first instance, or (2) the (female) claimant was unchaste, or (3) the claimant is suffering from a contagious disease, or (4) the publication has a negative impact on the claimant's reputation in relation to his (or her) office, professional trade, or business. DEAKIN ET AL., supra note 86, at 650. ${ }^{317}$ Sim v Stretch, [1936] 2 All E.R. 1237 (per Lord Atkin); See also Skuse v Granada Television Ltd, [1996] E.M.L.R. 278, at 286; Dee v Telegraph Media Group Ltd, [2010] E.M.L.R. 20; [2010] 4 WLUK. 472, at 513 (applying the same test).

${ }^{318}$ W. V. Horton Rogers, Fault under English law, in Unification OF TORT LAW: FaUlt 65, 66 (Pierre Widmer ed., Kluwer Law International 2005); W. V. Horton Rogers, England in UNIFICATION OF TORT LAW: STRICT LIABILITY 101, 102 n.1 (B.A. Koch \& H. Koziol eds., Kluwer Law International 2002); Donal Nolan \& John Davies, Torts and Equitable Wrongs, in English Private Law 927, 999 ( $3^{\text {rd }}$ ed., Andrew Burrows ed., Oxford University Press 2013).

${ }^{319}$ Peel \& GoudKAmP, supra note 110, at 370.
} 
information. ${ }^{320}$ That being said, it is important to understand that the relevant state of mind is determined not in relation to the harm suffered by the plaintiff, but simply in relation to the act of publication. The presumption of intention or negligence does not impact the nature of defamation as a whole, being limited to the act of publication. In defamation, it is not necessary to establish that the defendant was negligent toward the plaintiff (nor is this type of negligence presumed). From making a defamatory statement to the act of publication only a first part of the causal chain that leads to the infringement of the plaintiff's rights is covered, and only for this portion of the causal chain is it necessary for the defendant to (reasonably) foresee the consequences of his acts.

A true exception to the general prima facie rule of strict liability emerged in the context of the liability of "distributors" 321 and other persons who play a minor or passive role in the process of publication. ${ }^{322}$ As opposed to authors, editors, and publishers, the liability of distributors (and others) is not strict, but based on a presumption of negligence. The rule originates from the 1885 case of Emmens $v$ Pottle, ${ }^{323}$ but has since been incorporated in the Defamation Act 1996, which provides in section 1(1) that:

In defamation proceedings a person has a defence if he shows that-(a) he was not the author, editor or publisher of the statement complained of, (b) he took reasonable care in relation to its publication, and (c) he did not know, and had no reason to believe, that what he did caused or contributed to the publication of a defamatory statement. ${ }^{324}$

More exceptions to the strict nature of defamation can be identified if defences are also taken into account. The technical complexity of defamation is owed in large part to the numerous defences available to defendants. These defences include: (1) justification (or "truth"); (2) absolute privilege; (3) qualified privilege; (4) fair comment on a matter of public interest; (5) publication not made intentionally or negligently; (6) honest opinion; (7) offer of amends; (8) consent; and the now relatively obsolete defence of (9) apology and payment into court. Also, the operators of internet websites benefit from an additional defence for statements posted on a website by other

\footnotetext{
${ }^{320} I d$.

${ }^{321}$ On this topic, but also for other potential inroads of fault-based notions into the law of defamation, see Eric Descheemaeker, Protecting Reputation: Defamation and Negligence, 29 OXF. J. LEG. STUD. 603, 627-39 (2009).

${ }^{322}$ See section 1 (3) of the Defamation Act 1996, c. 31.

323 (1885) 16 QBD 354.

${ }^{324}$ Section 1 (1) of the Defamation Act 1996, c. 31.
} 
persons than the operator of the website. ${ }^{325}$ Some of the defences listed above, such as justification, absolute privilege, or fair comment, when proven, defeat liability entirely. Others make it necessary for the claimant to show malice in order to succeed in his action for defamation. More specifically, malice defeats the defence of qualified privilege, ${ }^{326}$ offer of amends, ${ }^{327}$ and the defence of operators of internet websites. ${ }^{328}$ Also, under the Rehabilitation of Offenders Act 1974, the defence of justification may also be defeated by malice, when the defendant relied on a "spent conviction" (a sufficiently old conviction) in his defence. ${ }^{329}$ Finally, malice may also play a role in the determination of damages, as a criterion for increasing the amount of damages, but only if the claimant's feelings are hurt as a result of the defendant's malicious act. ${ }^{330}$ Arguably, however, when malice is used as criteria for determining damages, there is no necessary impact on the ground for liability. ${ }^{331}$ Liability may still be strict, and only the determination of the remedy will depend upon proof of malice.

Malice is not the same thing as negligence, and malice-based causes of action do not fit squarely within the fault-based paradigm. Negligence designates a mental state inferred from a person's failure to take reasonable care, the object of which are the consequences of one's actions. Malice is a term which designates a different kind of mental state, the object of which are the motives of the defendant, and not his attitude towards the consequences of his acts. Despite their different natures, there is a connection between negligence and malice, which surfaces very clearly in defamation cases: an improper motive generally reveals a careless disregard for the consequences of one's actions. The publication of a defamatory statement is malicious when its motives are improper, and an improper motive reveals a careless disregard for the truth that goes further than a mere failure to take reasonable care. In other words, a strong implication of carelessness may be derived from proven malice. Therefore, proving malice may be a more demanding task than

\footnotetext{
325 See section 5 of the Defamation Act 2013, c. 26.

${ }^{326}$ See Clarke v Molyneux, (1877) 3 Q.B.D. 237; Horrocks v Lowe, [1975] A.C. 135; section 6(6) of the Defamation Act 2013, c. 26.

${ }^{327}$ Section 4(3) of the Defamation Act 1996, c. 31; Milne v Express Newspapers, [2004] E.M.L.R. 24.

${ }^{328}$ Section 5(11) of the Defamation Act 2013, c. 26.

${ }^{329}$ See Section 8 of the Rehabilitation of Offenders Act 1974, c. 53.

${ }^{330}$ Rookes v Barnard, [1964] A.C. 1122.

${ }^{331}$ Older defamation cases where damages were increased due to the defendant's malice were concerned more with the character of the wrong, and not just the defendant's loss, but that line of case law was reversed by Rookes $v$ Bernard (supra note 330). For a very good historical account see PAUL MiCHELL, THE MAKING OF THE MODERN LAW OF DEFAMATION 64-70 (Hart Publishing 2005).
} 
proving negligence, malice residing in acts which display a higher level of disregard for consequences than acts that simply breach a duty of care.

We can conclude, based on the above, that defamation is most of the time a strict liability wrong. However, in limited circumstances and only after the defendant successfully invokes a defence which can be defeated by proof of malice on the part of the claimant, defamation can also be seen as a fault-based tort. Exceptionally, a person who is not an author, editor, or publisher of a defamatory statement will incur liability based on a rebuttable presumption of fault.

\section{Equitable strict liability wrongs}

The English common law lato sensu is split in the mind of English jurists between equity and common law stricto sensu. This is a division of the law's substance, based on a parallel and anachronistic procedural division: the division between the courts of common law and the courts of equity. The term "equity" is sometimes used in a much more abstract sense to denote that which is fair, just, or moral, ${ }^{332}$ but in this context we are referring to "that body of rules administered by [...] English courts of justice which, were it not for the operation of Judicature Acts, would be administered only by those courts which would be known as Courts of Equity."333

The Courts of Equity emerged between the $14^{\text {th }}$ and the $16^{\text {th }}$ centuries. The first and most important court of equity was the Chancery, ${ }^{334}$ but it is worth mentioning that municipal courts also applied equity in London (the Mayor's Court and the Duchy Chamber), in the cinque ports, in the palatinate of Durham, and in Lancashire. ${ }^{335}$

The Chancery as an institution first emerged as the secretariat for the king's business, and hence also for the English royal court. ${ }^{336}$ The head of this institution, the chancellor, held one of the most important positions at court, being the king's personal chaplain, principal advisor and secretary, and keeper of the great seal of England (used to authenticate royal documents) ${ }^{337}$ In terms of

\footnotetext{
332 Jill E. MARTin, HANBuRy \& MARTin - Modern Equity 3 (18 $18^{\text {th }}$ ed., Sweet \& Maxwell/Thomson Reuters 2009); See also OXFORD ENGLISH DictionaRY OnLINE, vo equity (n.), I. (Oxford University Press, July 2018). http://www.oed.com/view/Entry/63838? redirectedFrom=equity (last accessed on 29 October 2018); 1 WEBSTER's THIRD NEW INTERNATIONAL DiCTIONARY UNABRIDGED 769 [v ${ }^{0}$ equity, 1a] (Encyclopedia Britannica 1986). ${ }^{333}$ MAITLAND, supra note 2, at 1.

${ }^{334}$ For further details on the emergence of Chancery as a court of equity, see J. E. A. JOLLIFFE, THE Constitutional History of MedieVal England from the English Settlement to 1485, at 466-68 (Adam and Charles Black 1937).

${ }^{335}$ PLUCKNETT, supra note 35, at 675-76.

${ }^{336}$ BAKER, supra note 4 , at 114.

${ }^{337}$ BAKER, supra note 4, at 114-115.
} 
judicial functions, the Chancery's first preoccupation was the issuance of writs, a task which included the production of original writs (used by claimants to initiate proceedings), as well as the issuance of judicial writs (aimed at guiding the procedure after the commencement of a trial). ${ }^{338}$ In an ironic twist of fate, the chancellor came to preside over a court of his own only because his prerogative to issue new writs was severely curtailed in the $13^{\text {th }}$ century. ${ }^{339}$ Initially, when a person made a novel complaint to the king or the chancellor, the problem was addressed by issuing a new writ. When the chancellor's power to issue new writs was limited, the judiciary gained more independence from the king and his chancellor and the common law became more predictable and stable, but the same process also opened the door for the chancellor's exceptional jurisdiction. In the $13^{\text {th }}$ century, the common law was already a relatively well-developed and comprehensive system of rules. However, there were gaps in the law, and the mechanism of justice provided by the royal courts sometimes worked unfairly. ${ }^{340}$ Thus, as the common law system began to crystallize, it also lost much of its initial flexibility and reputation as a just forum. Common law judges slowly gave up their discretion in favour of a more faithful application of precedent and principle, enforced strict rules of pleading and proof, and limited the list of available remedies. The king retained, however, a residual power to impart justice to his subjects. Those litigants who could not obtain relief from the courts of common law or were treated unfairly addressed the king or his council directly praying for relief or a fair hearing. ${ }^{341}$ The king first delegated matters not covered by the common law writs, or where the common law was deficient and led to unjust results, to Parliament, to his council, or to individual councillors, such as the chancellor, the admiral, and the marshal. ${ }^{342}$ Not long after, litigants learned to address their matters to the appropriate authority directly. ${ }^{343}$ The chancellor fully embraced his new role in the justice system and was willing to hear a diverse assortment of cases. He had a number of justifications to intervene in judicial affairs, such as the protection of the weak against the strong, the preservation of order,

\footnotetext{
${ }^{338}$ HoGUE, supra note 30 , at 166.

${ }^{339}$ In 1258, through the Provisions of Oxford, the Chancellor was sworn not to issue any unprecedented writs without first securing the assent of the king's council. Supra note 32 and accompanying text.

${ }^{340}$ See JOLLIFFE, supra note 334, at 410: "Lords invent trespasses on the part of their enemies and secure commissions of oyer and terminer for justices who are favourable to them. They influence the sheriffs to appoint days of trial without warning the defendants, and so they lose their case by non-appearance. They appoint places of trial in remote districts where their victims dare not come, and have juries empanelled which know nothing of the cause. In suits of land great lords maintain each other, so that the opposing parties dare not proceed."

${ }^{341}$ MAITLAND, supra note 2, at 3.

${ }^{342}$ BAKER, supra note 4 , at 113.

${ }^{343} I d$.
} 
the need to solve the enforcement problems of the common law, or the need to correct defects and fill in gaps in the common law. ${ }^{344}$

Despite the initially broad justifications of the chancellor's jurisdiction, equity evolved to cover only a small and eclectic fraction of English law. The historical explanation is that between the $13^{\text {th }}$ and the $18^{\text {th }}$ centuries the chancellor's justice went through a process of rapid and drastic transformation. Aspects such as the cost of litigation, the length and sophistication of the proceedings, the types of cases brought before the chancellor, and the chancellor's normgenerating power, changed in remarkable ways.

Starting with the costs, length, and number of cases heard in Chancery, the evolution cannot be said to have been positive. Justice in Chancery was slowly undermined by its own popularity. What was initially perceived as a forum for inexpensive and swift justice became known in early modernity as "a byword for costly delay". ${ }^{345}$ From the $13^{\text {th }}$ to the $15^{\text {th }}$ century, bringing a case to Chancery was appealing for all English subjects. The poor, the oppressed, and those who feared the corruption of sheriffs and juries were particularly attracted to the type of justice offered by the chancellor. There was no need for claimants to purchase original writs, the proceedings were relatively informal and inexpensive, there was no jury, and the Chancery was always open for business. ${ }^{346}$ The chancellor had the power to order the discovery of evidence, he could stay proceedings which were commenced in the common law courts, order the parties not to pursue their common law rights in the regular courts, enforce oral contracts, and ensure that fiduciary obligations were discharged. ${ }^{347}$ This was an avenue for justice which often had more powerful mechanisms for redress than the common law, was more claimant-friendly and, most importantly, was cheaper and faster. However, many of the initial advantages of bringing cases to Chancery were short lived. As more and more litigants brought their disputes to the chancellor, it became increasingly difficult for chancellors and their staff to manage their caseload. Already in 1579 the Chancery began rejecting cases which it deemed too trivial. ${ }^{348}$ Then, in the $17^{\text {th }}$ and $18^{\text {th }}$ centuries, the backlog of cases grew exponentially, and with it the amount of time and money necessary to see a case through. By some accounts, there were a number of cases brought before the chancellor

\footnotetext{
344 PLUCKNETT, supra note 35 , at 684.

${ }^{345}$ Maitland \& MonTAgUe, supra note 5, at 122.

${ }^{346}$ BAKER, supra note 4, at 119.

${ }^{347}$ Id. at $119-20$.

${ }^{348} I d$. at 121, citing the case of Hamby v Northage, (1579) Cary 76.
} 
during this period which lasted over 30 years and totalled costs of up to $£ 20,000 .{ }^{349}$ Early in the $19^{\text {th }}$ century, a series of reforms partially addressed these problems by creating new offices for vice-chancellors to take over part of the chancellor's work. The problem, nonetheless, persisted until the Judicature Acts unified the courts of equity with the courts of common law.

Parallel to the growth of the Chancery's judicial business, the type of cases brought before Chancery also changed over time. At the very beginning, the Chancery was preoccupied with any civil or commercial matter it could justify hearing, but the bulk of the cases brought before the chancellor concerned wrongs: assaults, land grabbing, and other violent acts. ${ }^{350}$ In time, however, the common law courts prevailed in this domain. Faced with competition from the courts of equity, the common law courts adapted, and took over almost the entire domain of civil wrongs by expanding the action of "trespass on the case". ${ }^{351}$ This did not mean, however, that fewer cases were brought before the chancellor or that equity lost its practical importance. It simply meant that equity developed in a different direction and ended up covering a different domain. From wrongs, the focus of the chancellor's jurisdiction shifted toward property rights. Trusts and fiduciary relationships emerged as the main subject matter dealt with in the Chancery and, with this shift, the profile of the claimant in equity also changed, the poor and the oppressed being replaced by rich landholders. Maitland and Montague described this episode in English legal history very well:

It seems possible that this nascent civil jurisdiction of the chancellor would have come to naught but for a curious episode in the history of our land law. In the second half of the fourteenth century many causes were conspiring to induce the landholders of England to convey their lands to friends, who, while becoming the legal owners of those lands, would, nevertheless, be bound by an honourable understanding as to the uses to which their ownership should be put. There were feudal burdens that could thus be evaded, ancient restrictions which could thus be loosened. The chancellor began to hold himself out as willing to enforce these honourable understandings, these "uses, trusts, or confidences, " as they were called, to send to prison the trustee who would not keep faith. ${ }^{352}$

\footnotetext{
${ }^{349}$ Id. at 129.

${ }^{350}$ Maitland \& MonTAgue, supra note 5, at 122.

${ }^{351}$ Discussed supra in Part A.4 of this chapter.

${ }^{352}$ Maitland \& Montague, supra note 5, at 122-23.
} 
A great part of the domain of equity is still, to this day, made up of rules which apply to trusts and other fiduciary relationships. Beside fiduciary relationships, the rules of equity address only a small number of miscellaneous events for which equitable remedies are made available: specific performance (for breach of contract, and only exceptionally), injunctions (for a narrow list of wrongs and threatened wrongs), and gain-based damages (also for a limited number of wrongs and unjustified enrichment claims).

That we even have today a body of rules dealing with trusts and various other issues is owed to a third parallel development: the transformation of the power of the chancellor to create norms. The chancellor's orders and decrees initially had a narrow normative impact, seeing how prior decrees were most likely not considered binding, and there are no reports of cases heard in the Court of Chancery before $1557 .{ }^{353}$ His decisions were binding in "conscience," or in "equity," not in law. That did not mean, of course, that a person had to do only what their own subjective conscience dictated. Not respecting the chancellor's orders often meant imprisonment. To their addressees, the chancellor's orders were as binding as the decisions of the courts of common law, if not more so. Still, during the formative years of equity, the chancellor did not create binding rules of general application. He enjoyed extensive discretion, was not bound by precedent, and his decisions were only rarely reported. ${ }^{354}$ However, with time, "equity hardened into law". ${ }^{355}$ Chancellors developed a practice of binding themselves to precedents in order to deal with commonly recurring petitions and better deal with the ever-increasing number of cases brought before them. ${ }^{356}$ Also, in the $16^{\text {th }}$ century the Chancery began recording its decrees in rolls and its orders in books. ${ }^{357}$ Collections of decisions and reports of decisions from Chancery were published for the first time just a century later. ${ }^{358}$ During the $17^{\text {th }}$ and $18^{\text {th }}$ centuries, most chancellors strove to bring order and coherence into equity, and from their efforts a definite, principled, and consistent body of rules emerged. ${ }^{359}$ Although the chancellor's intervention was technically discretionary, his discretion was bound by precedent and general principles. The learned chancellors of the $18^{\text {th }}$ and $19^{\text {th }}$ centuries fought hard

\footnotetext{
${ }^{353}$ MAITLAND, supra note 2 , at 8.

${ }^{354}$ See Maitland \& Montague, supra note 5, at 126; Franz Metzger, The Last Phase in Medieval Chancery, in LAW-MAKING AND LAW-MAKERS IN BRITISH History 79, 87 (Alan Harding ed., Royal Historical Society 1980).

${ }^{355}$ BAKER, supra note 4, at 127.

${ }^{356} I d$.

${ }^{357}$ PluCKNETT, supra note 35, at 693.

${ }^{358} I d$.

${ }^{359} \mathrm{Id}$. at 692.
} 
to dispel John Selden's well-known and humorous critique of equity, according to which the measure of the chancellor's justice is the length of his foot. ${ }^{360}$ Lord Eldon's words, uttered at the beginning of the $19^{\text {th }}$ century, reflect not only his ambitions, but those of many chancellors that came before him:

The doctrines of this court ought to be as well settled, and made as uniform almost as those of the common law, laying down fixed principles, but taking care that they are to be applied according to the circumstances of each case. I cannot agree that the doctrines of this court are to be changed with every succeeding judge. Nothing would inflict on me greater pain, in leaving this place, than the recollection that I have done anything to justify the reproach that the equity of this court varies like the Chancellor's foot. ${ }^{361}$

The $19^{\text {th }}$ century was a century of reform. During the first part of the century, the reforms were piecemeal and rather timid, being limited to conferring some common law powers to the courts of equity and equitable powers to the courts of common law. ${ }^{362}$ However, the seventh decade of the $19^{\text {th }}$ century saw the adoption of "the most sweeping reform in the history of English courts." 363 The Judicature Acts of 1873-1875 364 abolished the distinction between courts of equity and courts of common law, and unified the English court system with the creation of the Supreme Court of Judicature. The newly created Supreme Court of Judicature incorporated the Court of Queen's Bench (known as the King's Bench when the Sovereign was male), the Court of Common Pleas, the Court of Chancery, the Court of Exchequer, the High Court of Admiralty, and the Courts of Probate and Divorce. ${ }^{365}$ The Judicature Act of 1973 also provided in section 25(11) that "where there is a conflict or variance between the Rules of Equity and the Rules of the Common Law with

\footnotetext{
${ }^{360}$ John SELDEN, TABLE TALK: BeING THE DISCOURSES OF JOHN SELDEN $43-44$ (E. Smith 1689; Israel Gollancz ed., repub. J.M. Dent and Co. 1898), available online at https://archive.org/details/tabletalkbeingd00milwgoog/: "Equity is a Roguish thing: for Law we have a measure, know what to trust to; Equity is according to the Conscience of him that is Chancellor, and as that is larger or narrower, so is Equity. 'Tis all one as if they should make the Standard for the measure we call a Foot, a Chancellor's Foot; what an uncertain Measure would be this. One Chancellor has a long Foot, another a short Foot, a Third an indifferent Foot: 'Tis the same thing in the Chancellor's Conscience." ${ }^{361}$ Gee v Pritchard, (1818) 2 Swan 402, at 414.

${ }^{362}$ Patrick Polden, Mingling the Waters. Personalities, Politics and the Making of the Supreme Court of Judicature, 61 CAMBRidge L. J. 575, 576-77 (2002).

${ }^{363}$ Robert Stevens, The Final Appeal: The Reform of the House of Lords and Privy Council 1867-1876, 80 L. Q. REV. 343, 351 (1964).

${ }^{364}$ Supreme Court of Judicature Act 1873, 36 \& 37 Vict c. 66; Supreme Court of Judicature Act 1875, 38 \& 39 Vict c. 77.

${ }^{365}$ ARThur Wilson, The Supreme Court OF Judicature ACTS, 1873 AND 1875, at 7 (Stevens and Sons 1875), available online at https://archive.org/details/supremecourtofju00wils.
} 
reference to the same matter, the rules of Equity shall prevail."366 This mischievous and ineffective ${ }^{367}$ provision gave rise to much confusion in regard to the substantive effects of the Judicature Acts.

The traditional view is that the administrative merger between the courts of common law and the courts of equity did not lead to a parallel merger of substantive law. ${ }^{368}$ Traditionalists believe that, at a substantive level, the doctrines of equity did not blend and should not blend with the doctrines of common law; or, as the famous metaphor goes: "[t]he two streams of jurisdiction, though they run in the same channel, run side by side and do not mingle their waters." ${ }^{369}$ The more modern view is that the substantive effect of the Judicature Acts was a "fusion" of common law and equity. ${ }^{370}$ The noun "fusion" may be confusing. ${ }^{371}$ The verb, in its continuous form, describes better the dynamic at play: the common law and equity are fusing. As a historical process, the fusion of common law and equity is best understood as an unfinished process with many moving parts, and not the uno ictu result of the Judicature Acts. The Judicature Acts did not dictate a substantive unification of common law and equity, ${ }^{372}$ but they did open up the possibility of merging the two systems into one.

There is also a normative aspect to the fusion debate. Pro-fusion scholars and judges have argued that substantive fusion will bring more order and simplicity into the law, ${ }^{373}$ English jurists should not be the prisoners of history, ${ }^{374}$ like cases should be treated alike and therefore inconsistencies

\footnotetext{
${ }^{366}$ Section 25 (11) of the Supreme Court of Judicature Act 1873, 36 \& 37 Vict c. 66.

${ }^{367}$ See MAITLAND, supra note 2, at 16: "the clause [...] has been practically without effect."

368 See RoDERICK PITT MEAGHER ET AL., EQUiTY, DOCTRINES AND REMEDIES 44-63 (2 $2^{\text {nd }}$ ed., Butterworths 1984); ALASTAIR HUdSON, EQUiTY AND TRUSTS 8-9, 1306-23 (8 $8^{\text {th }}$ ed., Routledge 2015).

369 DENNIS BROWNE, ASHBURNER's PRINCIPLES OF EQUITY 18 (2 $2^{\text {nd }}$ ed., Butterworths 1933).

${ }^{370}$ See, e.g., MARTIN, supra note 332, at 22; RoBert A. PEARCE \& John SteVens, The LAW OF TRUSTS AND

EQuitable OBligations 11-17 (4 ${ }^{\text {th }}$ ed., Oxford University Press 2006); Alfred ThOMPSON DenNing,

LANDMARKS IN THE LAW 86 (Butterworths 1984); PAUl M. PERELl, THE Fusion OF LAW AND EQUiTY

(Butterworths 1990); Andrew Burrows, We Do This at Common Law but That in Equity, 22 OXF. J. LEG. STUD. 1, at 3 et seq. (2002); Joshua Getzler, Patterns of Fusion, in The Classification OF OBligations 157-192 (Peter Birks ed., Clarendon Press 1997); P. V. Baker, The Future of Equity, 93 L. Q. REV. 529 (1977); United Scientific Holdings Ltd. v Burnley BC, [1978] AC 904, at 925 (per Lord Diplock).

${ }^{371}$ Fusion is defined as "the union or blending together of different things (whether material or immaterial) as if by melting, so as to form one whole." OXFORD ENGLISH DiCTIONARY ONLINE, vo fusion (n.), 3.a. (Oxford University Press, July 2018), http://www.oed.com/view/Entry/75786?redirectedFrom=fusion\& (last accessed on 29 October 2018)

372 Burrows, supra note 370 , at 4.

${ }^{373}$ See Walton Stores (Interstate) Ltd v Maher, (1988) ALR 513, at 556 (per Deane J) (Australia).

${ }^{374}$ Burrows, supra note 370 , at 4.
} 
should be removed, ${ }^{375}$ reasoning from common law to equity and vice versa is necessary for a coherent development of the law, ${ }^{376}$ and the doctrines of common law and equity should be rearranged under a common taxonomy. ${ }^{377}$ Conversely, those who arduously defend a strict substantive separation between common law and equity have argued that equity is better equipped than the law to deal with social complexity and chaos, ${ }^{378}$ some doctrines can be made coherent only by developing the notion of "conscience" as a grounding feature of equity, ${ }^{379}$ fusion will bring an end to what is "said to be the genius of the English case law system", 380 or a unified taxonomy would "produce artificiality". 381

The pro-fusion arguments are more convincing but, unfortunately, they did not have a great deal of impact on legal practice. If one were to look only at the case law developed by English courts since the Judicature Acts, it would be fair to say that if the common law and equity are fusing, they are doing so at a very slow pace. At the level of legal categories and doctrines, there is hardly any fusion at all. The distinctions drawn between legal ownership and equitable ownership, legal rights and equitable rights, tracing at common law and tracing in equity, and between common law damages and compensation in equity, still stand and produce important legal effects. ${ }^{382}$ In some cases, judges were confronted with conflicting rules stemming from the common law, on the one hand, and from equity, on the other, and found it necessary to eliminate the resulting inconsistencies. ${ }^{383}$ A significant number of contradictions and inconsistencies have survived nonetheless. ${ }^{384}$ Today, equity is made up of a miscellany of causes of action and remedies which share only a common lineage with the case law of the Courts of Equity.

\footnotetext{
${ }^{375} I d$.

${ }^{376} I d$.

${ }^{377}$ See Peter Birks, Equity in the Modern Law: An Exercise in Taxonomy, 26 U.W. AusTL. L. REV. 1 (1996).

${ }^{378}$ See HudSON, supra note 368, at 1313-17.

${ }^{379}$ Id. at 9.

${ }^{380}$ MEAGHER ET AL., supra note 368 , at 63.

${ }^{381}$ Derek Davies, Restitution and Equitable Wrongs: an Australian Analogue, in CONSENSUS AD IDEM, ESSAYS ON CONTRACT In HonOur OF GuENTER TREITEL 158, 176 (F.D. Rose ed., Sweet \& Maxwell 1996) (speaking specifically about the distinction between equitable wrongs and torts).

382 MARTIN, supra note 332, at 23-24.

${ }^{383}$ See Boyer v Warbey, [1953] 1 Q.B. 234, especially at 245-46; Australian Blue Metal Ltd v Hughes, [1963] A.C.

74, especially at 102; Napier and Ettrick (Lord) v Hunter, [1993] A.C. 713; Tinsley v Milligan, [1994] 1 A.C. 340; Coulthard v Disco Mix Club Ltd, [2000] 1 W.L.R. 707, especially at 727-35; Sempra Metals Ltd (formerly

Metallgesellschaft Ltd) v Inland Revenue Commissioners, [2008] 1 A.C. 561.

${ }^{384}$ For examples see Burrows, supra note 370, at 7.
} 
Navigating the seas of equity is difficult, particularly because of the eclectic subject-matter it covers, i.e. an amalgam of property relationships, contracts, wrongs, unjustified enrichment claims, and exceptional remedies. Identifying and organizing the various civil wrongs which belong to equity is even more challenging. To start with, it is not always clear whether the duties protected through equitable remedies stem from wrongs, contract, or unjustified enrichment. A breach of trust, for instance, can potentially stem from any one of the three sources of obligations. Also, only a very small number of events which can be characterized as wrongs, and for which a legal remedy is available, belong to equity. We have already seen that wrongs were once the principal focus of the chancellor's justice, but the core of this area of the law has long been claimed by the common law. ${ }^{385}$ The way the common law of torts is conceptualized and studied is also part of the problem. Many taxonomical and doctrinal problems English legal scholars face today with regard to equitable wrongs are aggravated by the fact that, traditionally, treatise writers on tort excluded equitable wrongs from their purview. ${ }^{386}$

Nevertheless, in recent years, a number of scholars have made an effort to extract and categorize those wrongs which were born in equity and are distinguishable from common law wrongs. According to Andrew Burrows, there are four categories of equitable wrongs: breach of fiduciary duty, breach of confidence, dishonestly procuring or assisting a breach of fiduciary duty, and some forms of estoppel (in particular proprietary estoppel). ${ }^{387}$ James Edelman also counts four equitable wrongs: breach of fiduciary duty, breach of confidence, knowing participation in a breach of fiduciary duty, and fraud (encompassing deceit and bribery). ${ }^{388}$ The Law Commission, ${ }^{389}$ by contrast, in a report from 1997, identified only three equitable wrongs: breach of fiduciary duty

\footnotetext{
${ }^{385}$ See supra the text following note 350.

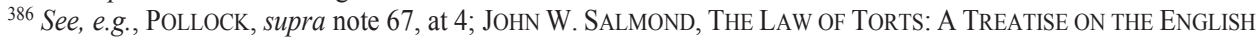
LAW OF LiabiLity FOR Civil InJURIES 5-6 (Stevens and Haynes 1907); THOMAS ATKINS STREet, THE THEORY AND PrinciPles of TORT LAW xxviii (Edward Thompson Co. 1906, repr. Beard Books 1999); PERCy H. WinfiELD, THE Province of the LAW OF TORT (TAgORe LAW LeCtURES DELIVERED IN 1930), at 32 (Cambridge University Press 1931). By way of contrast, contract law scholars have been more active in integrating equitable doctrines in the general law of contracts. See, e.g., the extensive treatment of promissory and proprietary estoppel, and specific performance in EDWIN PEEL, TREITEL ON THE LAW OF CONTRACT 135-158, 1091-1130 (13 ${ }^{\text {th }}$ ed., Sweet \& Maxwell / Thomson Reuters 2011), ChitTy ON CONTRACTS. Volume 1. General Principles 384-431, 1905-62 (31 ${ }^{\text {st }}$ ed., Hugh G. Beale gen. ed., Sweet \& Maxwell / Thomson Reuters 2012).

${ }^{387}$ Burrows, supra note 370 , at 8 .

388 James EdELman, Gain-Based Damages CONTRACt, TORT, EQUity AND InTELlectual Property 191 (Hart Publishing 2002).

389 The Law Commission "is the statutory independent body created by the Law Commissions Act 1965 to keep the law of England and Wales under review and to recommend reform where it is needed." https://www.lawcom.gov.uk/
} 
(including breach of trust), knowing assistance in breach of fiduciary duty, and breach of confidence. $^{390}$

Breach of fiduciary duty is considered equity's main, and perhaps only, strict liability wrong. ${ }^{391}$ To be more precise though, a breach of fiduciary duty may be either a fault-based or a strict liability wrong, depending on the type of fiduciary duty that has been breached. There is not just one fiduciary duty with a well-determined nature. The term "fiduciary duty" is generic, designating a set of duties which can be subdivided in many different ways. If we arrange the sets of duties according to the nature of liability, we arrive at two types of duties: duties of care and duties of loyalty. ${ }^{392}$ Liability is strict for breach of fiduciary duty only when the fiduciary breaches his duties of loyalty. ${ }^{393}$

The typical fiduciary relationship is the relationship between a trustee and the beneficiary of the trust property, but other relationships, such as the relationship between a solicitor and his client, between a company director and the company he represents, and between an agent and his principal, are also fiduciary in the sense envisaged here. ${ }^{394}$ There is no exhaustive list of fiduciary relationships, and there is ample scope for judicial discretion in this regard. As Peter Birks pointed out, the term "fiduciary" is often used as a vehicle for analogy in order to apply the rules of trust law to other relationships which require the same degree of altruism. ${ }^{395}$

To a certain extent, the idea of altruism shapes the normative content of all fiduciary duties. ${ }^{396}$ Generally speaking, fiduciaries are required to promote the interests of another in a disinterested manner, in the sense that the pursuit of any conflicting interests is incompatible with their duties. ${ }^{397}$ Trustees, for instance, must administer the trust property only in the best interest of the beneficiary; solicitors must have the best interest of their clients in mind when they give advice or represent

\footnotetext{
${ }^{390}$ Law Commission, Aggravated, Exemplary and Restitutionary Damages Report, LC247 (16 December 1997), at 106, 112, 185 (available online at https://s3-eu-west-2.amazonaws.com/lawcom-prod-storage11 jsxou24uy7q/uploads/2015/04/LC247.pdf).

${ }^{391}$ Nolan \& Davies, supra note 318, at 1011; GraHAm VIRGO, ThE PRINCIPLES OF EQUiTY \& TRUSTs 503 (2 $2^{\text {nd }}$ ed., Oxford University Press 2016).

${ }^{392} I d$. at 1013 .

${ }^{393}$ When fiduciaries breach their duties of care, liability is negligence-based. See Henderson v Merrett Syndicates Ltd., [1994] W.L.R. 761, [1995] 2 A.C. 145, 205 (per Lord Browne-Wilkinson); Bristol and West Building Society v Mothew, [1998] Ch. 1, 16-18 (per Millett L.J.); Hilton v Barker Booth Eastwood, [2005] U.K.H.L. 8, [2005] 1 W.L.R. 567, at [29] (per Lord Walker);

${ }^{394}$ Nolan \& Davies, supra note 318 , at 1011-12.

395 Peter Birks, Lionel Cohen Lecture: The Content of Fiduciary Obligation, 34 ISR. L. REV. 3 (2000).

${ }^{396}$ In Birksian taxonomy "positive-and-disinterested altruism". See id. at 20-22.

${ }^{397}$ Id. at 20 .
} 
them; company directors the best interest of the company; and agents the best interest of their principals. What all these relationships have in common is the fact that "circumstances $[\ldots]$ are such that one party is entitled to expect that the other will act in his interest in and for the purposes of the relationship." 398 That is why fiduciaries are bound not only to act in accordance with an objective standard of skill and care (the duty of care), ${ }^{399}$ but also to avoid any conflicts of interest or temptations that may detract them from their altruistic mission (the duty of loyalty, or "fidelity" $"$ "00).

There are two scenarios that the duty of loyalty is designed to prevent: (a) conflicts of interest, and (b) the taking of unauthorized profits. ${ }^{401}$ Liability is strict in both situations because the mere existence of a conflict of interest or the accumulation of unauthorized profits from the fiduciary relationship are sufficient for liability to ensue.

The leading case for breach of fiduciary duty is the $18^{\text {th }}$ century case of Keech $v$ Sandford ${ }^{402}$ (also known as the Rumford Market case). This case, although rather cryptic and "reported with frustrating brevity", ${ }^{403}$ has rightfully gained its notoriety, as it is still a good illustration of what the duty of loyalty entails. The defendant in this case was a trustee who held the profits of a lease over Rumford market for an infant cestui que use. When the lease expired, the landlord refused to renew the lease in favour of the infant. Then, the trustee, instead of trying to renew the lease as a trustee for the benefit of the infant, secured the lease for himself. The chancellor, Lord King, decided that the trustee was in breach of his duties, and argued as follows:

[I]f a trustee, on the refusal to renew, might have a lease to himself, few trustestates would be renewed to cestui que use; though I do not say there is a fraud in this case, yet he should rather have let run out, than to have had the lease to himself. This may seem hard, that the trustee is the only person of all mankind who might not have the lease: but it is very proper that rule should be strictly pursued, and not

\footnotetext{
${ }^{398}$ Paul D. Finn, The Fiduciary Principle, in EQUITY, FIDUCIARIES, AND TruST 1, 46 (T. G. Youdan ed., Carswell 1989).

${ }^{399}$ Birks, supra note 395, at 11.

${ }^{400}$ See Birstol \& West Building Society v Motthew, [1998] Ch. 1 (CA), at 18.

${ }^{401}$ See Nolan \& Davies, supra note 318, 1013; Matthew Conaglen, The Nature and Function of Fiduciary Loyalty, 121 LEG. Q. ReV. 452, 467 (2005); John Mowbray ET AL., LewIN ON Trusts 437 (17 ${ }^{\text {th }}$ ed., Sweet \& Maxwell 2000).

402 (1726) Sel. Cas. t. King 61; 25 E.R. 223.

403 Joshua Getzler, Rumford Market and the Genesis of Fiduciary Obligations, in MAPPING THE LAW: ESSAYS IN Memory of Peter BiRKs 577, 581 (Andrew Burrows \& Alan Rodger eds., Oxford University Press 2006)
} 
in the least relaxed; for it is very obvious what would be the consequence of letting trustees have the lease, on refusal to cestui que use. ${ }^{404}$

Subsequent case law solidified the principle that a trustee is not allowed to derive any profits from the trust property. ${ }^{405}$ Trustees are also not allowed to use trust property for their own business, take bribes or commissions for the performance of certain acts which are in their power as trustees, accept employment offered because of their position as trustees, or use the opportunity and special knowledge that comes with being a trustee in order to acquire property from a third party. ${ }^{406}$ Also, trustees may not put themselves in situations of conflict. For instance, they are also strictly liable when they start up a business which competes with the business carried out by the trust. ${ }^{407}$

These prohibitions do not apply only to trustees. The no-profits and no-conflict duties were extended during the $19^{\text {th }}$ and $20^{\text {th }}$ centuries to other fiduciary relationships, such as the relationship between partners, ${ }^{408}$ between solicitors and clients, ${ }^{409}$ between beneficiaries of the same trust, ${ }^{410}$ and between directors and the companies they run. ${ }^{411}$

Moving on to other equitable wrongs, knowing participation in a breach of fiduciary duty (which includes knowing assistance in breach of fiduciary duty) and fraud are fault-based. For the former, usually an aggravated standard of negligence, i.e. "dishonesty", is sufficient, ${ }^{412}$ whereas the latter is an intentional wrong.

Breach of confidence and proprietary estoppel are more difficult to categorize. Breach of confidence is problematic because the standard for liability is not clear. ${ }^{413}$ To prevail in an action

\footnotetext{
404 (1726) Sel. Cas. t. King 61, at 62-63; 25 E.R. 223, 223-34.

${ }^{405}$ Getzler, supra note 403, at 589.

${ }^{406}$ Edwin Simpson, Conflicts, in Breach of Trust 75, 79 (Peter Birks \& Arianna Pretto eds., Hart Publishing 2002) (and the cases cited there); MowBRAY ET AL., supra note 401, at 453-59.

${ }^{407}$ Simpson, supra note 406, at 79-80 (citing Re Thomson, [1930] 1 Ch. 203).

${ }^{408}$ Crawshay v Collins, (1808) 15 Vesey Junior 218, 229; 33 ER 736, 741 (applying the rule to a partnership); Getzler, supra note 403, at 589.

${ }^{409}$ Boardman v Phipps, [1967] 2 A.C. 46.

${ }^{410} I d$.

${ }^{411}$ Regal (Hastings) Ltd v Gulliver [1967] 2 A.C. 134.

412 EDELMAN, supra note 388, at 195.

${ }^{413}$ In addition to the more general "conceptual confusion" which surrounds the topic [see Gareth Jones, Restitution of Benefits Obtained in Breach of Another's Confidence, 86 LEG. Q. REV. 463 (1970)] and uncertainty regarding the application of equitable or tort principles to breach of confidence [see Law Commission, Breach of Confidence, Law Com. No. 110, (October 1981), at 85 [no 5.2], available online at http://www.lawcom.gov.uk/app/uploads/2016/08/LC.-110-BREACH-OF-CONFIDENCE-REPORT-ON-AREFERENCE-UNDER-SECTION-3le-OF-THE-LAW-COMMISSIONS-ACT-1965.pdf; Law Commission,
} 
for breach of confidence, a claimant must show, prima facie, that: the disclosed information is confidential in nature, the claimant disclosed that information to the defendant in circumstances that create a duty to respect the confidentiality of the information, and the defendant breached his duty by disclosing or misusing the information. ${ }^{414}$ Based on its elements alone, breach of confidence seems to be a strict liability wrong. The claimant does not have to prove that the defendant breached a duty of care. Also, it has been argued that the underlying duty of breach of confidence is fiduciary in nature, ${ }^{415}$ and we have seen above that fiduciary duties of loyalty are indeed strict. However, going over the case law, the breach in question is most of the time not merely negligent, but actually intentional. ${ }^{416}$ Seager $v$ Copydex is the main authority that supports the idea that breach of confidence is a strict liability wrong. ${ }^{417}$ In this case, the defendants "honestly [...] and unconsciously made use of confidential information given to them by the plaintiff as a spring-board for activities detrimental to him, thereby infringing a duty of confidence."418 However, the term "unconscious" is used by lords Denning ${ }^{419}$ and Winn ${ }^{420}$ in the sense of "not intentional," and not in any sense that would involve a lack of capacity on the part of the defendants to understand the consequences of their actions. The facts of the case were the following: the claimant invented a carpet grip, took out a patent for it, and then negotiated with the defendants with a view to their marketing the grip for more than one year. During the negotiations, the claimant also mentioned an alternative grip and explained the details of its design. The defendants knew that information regarding the alternative grip was given to them in confidence, but when the negotiations broke down, they made a carpet grip which was based on the claimant's explanations regarding the alternative grip. The defendants took great care to ensure the patent was

Working Paper No 58 - Breach of Confidence (October 1974), at 35-36 [para. 40], available online at https://s3-euwest-2.amazonaws.com/lawcom-prod-storage-11jsxou24uy7q/uploads/2016/08/No.058-Breach-of-Confidence.pdf. ${ }^{414}$ Coco v. AN Clark (Engineers) Ltd. [1968] F.S.R. 415, p. 419-421 (per Megarry J); FRANCIS GURRY, BREACH OF CONFIDENCE 4-5 (Oxford University Press 1984).

415 Daniel Bayliss, Breach of Confidence as a Breach of Fiduciary Obligations: A Theory, 9 AucKLAND U. L. REV. 702 (2002).

${ }^{416}$ See, e.g., Prince Albert v Strange, (1849) 41 E.R. 1171; Pollard v Photographic Co, (1888) 40 Ch. D. 345; Liquid Veneer Company v Scott, (1912) 29 R.P.C. 639; Lord Ashburton v Pape, [1913] 2 Ch 469; Saltman Engineering Co v Campbell Engineering Co, (1948) 65 R.P.C. 203; Douglas v Hello! Ltd (No. 5), [2003] EWHC 786 (Ch).

${ }^{417}$ Seager v Copydex Ltd, [1967] 1 W.L.R. 923. See also Terrapin Ltd. V Builders Supply Co (Hayes) Ltd., [1967]

R.P.C. 375; National Broach \& Machine Co. v Churchill Gear Machines Ltd., [1965] R.P.C. 61. Francis Gurry relied on the three cases cited above to conclude that liability for breach of confidence is strict. GURRY, supra note 414, at 264-66.

418 Seager v Copydex Ltd, [1967] 1 W.L.R. 923, at 924.

${ }^{419} I d$. at 931 .

${ }^{420} I d$. at 939. 
not infringed by their new grip, but were not aware that the information provided in confidence by the claimant was protected by the law. The case seems to have been one in which the defendants did not know they were infringing the claimant's rights, but ought to have known, and therefore were negligent. The object of their ignorance was the law, not the consequences of their actions. ${ }^{421}$ The judges of the Court of Appeal in this case perhaps could not have inferred, from the evidence presented, an intention to cause damage to the claimant, but there was certainly enough in the facts of the case to infer negligence. The holding in Seager suggests that the defendant should have known that his actions were in breach of the claimant's rights.

Proprietary estoppel raises a more fundamental taxonomical issue. Proprietary estoppel may indeed lead to a form of redress which is not based on the defendant's fault, but most of the time it is doubtful that we can truly speak of liability for wrongs when discussing proprietary estoppel. Like its sibling from the law of contract (promissory estoppel), proprietary estoppel generates rights (personal or property rights) in order to protect a person's reasonable reliance on the promise or conduct of another. ${ }^{422}$ The essence of a proprietary estoppel claim is that a promissee's reasonable expectations regarding the transfer of a property right have been disregarded by the promissor. ${ }^{423}$ As a reliance-based mechanism, proprietary estoppel can be said to have closer links with the logic of contracts and pre-contractual arrangements than the logic of torts. Also, the remedies available aim more towards the enforcement of the rights derived from the initial promise or reliance-creating conduct than towards the recognition and redress of a wrong (independently of any promise, made or implied). That being said, there are exceptional situations in which the victim's reasonable expectations regarding the transfer of a property right are disregarded not by the transferor, but by a third party, and in such situations proprietary estoppel can be understood

\footnotetext{
${ }^{421} I d$. at 932 (per Lord Denning): "They were quite innocent of any intention to take advantage of him. They thought that, as long as they did not infringe his patent, they were exempt. In this they were in error. They were not aware of the law as to confidential information. They were not at liberty to make use of any confidential information he gave them without paying for it." (emphasis added)

${ }^{422}$ Susan Bright \& Ben McFarlane, Proprietary Estoppel and Property Rights, 64 CAMBridge L. J. 449, 452 (2005).

${ }^{423}$ For this reason, the Law Commission did not include promissory estoppel in the list of equitable wrongs. Law Commission, supra note 390, at 112 .
} 
as a tort remedy. ${ }^{424}$ It is remarkable, but perhaps unsurprising, that in such situations, if there is no direct representation made by the third party, negligence is a requirement. ${ }^{425}$

In modern equity, therefore, the only obvious strict liability wrong is breach of fiduciary duty (when the defendant breaches his duties of loyalty). Also, despite the lack of a clear precedent, there is potential to view breach of confidence as a strict liability wrong because its prima facie elements permit the imposition of liability irrespective of the defendant's fault.

\section{Compensation Schemes}

Ideally, the social security system would fill some gaps left by the tort law system, but because the tort system and the social security system evolved separately and in an uncoordinated manner, in England many harms end up being over-compensated, while others are left entirely uncompensated. ${ }^{426}$ Compensation schemes are a form of social security, and therefore do not form part of the English law of wrongs. However, they are important to mention from a functional perspective because they share with civil wrongs the incidental function of compensating certain types of harm.

Compensation schemes and strict liability torts have in common the irrelevance of fault, because the benefits provided by the former are, almost without exception, ${ }^{427}$ attributed without any need for the beneficiary to show that the harm suffered was caused by anybody's fault. That being said, it must be acknowledged that compensation schemes, although more advantageous because of

\footnotetext{
424 Olivier Moréteau, L’estopPel et la Protection de la Confiance Légitime: ElÉments D’un Renouveau du DROIT DE LA RESPonsabilité (DROIT ANGLAIS ET DROIT FranÇAIS), at 354, 398-423 (Thèse pour le doctorat d'état en droit, Universite Jean Moulin - Lyon III 1990) available online at https://digitalcommons.law.lsu.edu/faculty scholarship/12/; Olivier Moréteau, Revisiting the Grey Zone between Contract and Tort: The Role of Estoppel and Reliance in Mapping out the Law of Obligations, in EUROPEAN TORT LAW 2004, at 60, 69-70, 76 (H. Koziol \& B. Steininger eds., Springer 2005);

${ }^{425}$ See, e.g., Lickbarrow v. Mason, 2 T.R. 63 (1787); The Mercantile Bank of India, Ltd. vs The Central Bank Of India, [1938] A.C. 287 (P.C.); Central Newbury Car Auctions Ltd v. Unity Finance Ltd, [1957] 1 Q.B. 371; Mercantile Credit Co Ltd v Hamblin, [1965] 2 Q.B. 242; Sargent (Garages) Ltd v. Motor Auctions (West Bromwich) Ltd, [1977] R.T.R. 121 (C.A.); Moorgate Mercantile Co Ltd v Twitchings, [1977] A.C. 890. See also A. L. Pickering, Estoppel by Conduct, 55(3) L. Q. REV. 407 (1939).

${ }^{426}$ DEAKIN ET AL., supra note 86, at 46. See also Lord Chancellor's Department: Royal Commission on Civil Liability and Compensation for Personal Injury [Pearson commission], Cmnd. 7054 (1978), Vol. I, para. 271: "the two systems have for too long been permitted to develop in isolation from each other, with regard to the fact that, between them, they meet many needs twice over and others not at all."

${ }^{427}$ The only exception this author was able to identify is from the Mesothelioma Act 2014, where the victim's claim can be based on either negligence or breach of statutory duty. The statute attempts to compensate victims of negligence or breach of statutory duty who cannot recover under the tort system because of dissolution of the employer or loss of insurance records. As far as the victim relies on a negligence claim, it could be said that the statutory benefits of the compensation scheme are also fault-based.
} 
their lower administrative costs, ${ }^{428}$ offer far lower levels of financial support than the tort system. $^{429}$

Compensation schemes are, in any event, rare birds in the landscape of English law. They constitute special regimes within the social security system, providing an extra layer of protection in addition to the general safety net provided through the various social security benefits, which are usually at subsistence rate, ${ }^{430}$ and the largely free-of-charge medical service provided through the National Health Service (NHS). The following compensation schemes can be identified in the statutes:

- The Criminal Injuries Compensation Scheme: administered by the Criminal Injuries Compensation Authority, this compensation scheme is designed to provide compensation according to a statutory tariff to victims of crimes of violence. ${ }^{431}$

- The Industrial Injuries Scheme: this compensation scheme applies in situations where the injury or disease arises from the workplace, and provides benefits for disablement caused by a work accident or on the occurrence of certain diseases associated with work. $^{432}$

- The Victims of Overseas Terrorism Compensation Scheme 2012: provides compensation through the Criminal Injuries Compensation Authority to victims who have suffered from acts of terrorism outside of the United Kingdom. ${ }^{433}$

- The Vaccine Damage Payments Act 1979: provides for lump-sum payments to be made to persons who suffer severe disablement as a result of vaccination against any of the diseases to which the Act applies. ${ }^{434}$

- The Mesothelioma Act 2014: compensates victims of negligence or breach of statutory duty by their employer that lead to their exposure to asbestos, and who cannot recover

\footnotetext{
${ }^{428}$ Also called "transfer payments" by some economists. See DEAKIN ET AL., supra note 86, at 47.

${ }^{429}$ PEEL \& GoudKAMP, supra note 110, at 29.

${ }^{430}$ WiTTING, supra note 136 , at 725.

${ }^{431}$ Criminal Injuries Compensation Act 1995, c. 53. For a detailed presentation of the scheme set up by the 1995 Act and its history, see DEAKIN ET AL., supra note 86, at 48-50.

432 Social Security Contributions and Benefits Act 1992, c. 4.

${ }^{433}$ The Scheme was created by Sections 47-54 of the Crime and Security Act 2010, c. 17. See also Ministry of Justice, The Victims of Overseas Terrorism Compensation Scheme 2012, available online at https://www.gov.uk/government/uploads/system/uploads/attachment_data/file/243508/9780108512124.pdf.

${ }^{434}$ Vaccine Damage Payments Act 1979, c. 17.
} 
under the tort system because of dissolution of the employer or because the insurance records cannot be found or no longer exist. ${ }^{435}$

- The Pneumoconiosis etc. (Workers' Compensation) Act 1979: provides for lump-sum payments to victims (or their dependents, if the victims died) who become disabled by work-related pneumoconiosis, byssinosis or diffuse mesothelioma. ${ }^{436}$

${ }^{435}$ Mesothelioma Act 2014, c. 1.

${ }^{436}$ Pneumoconiosis etc. (Workers' Compensation) Act 1979, c. 41. 


\section{Chapter IV}

\section{The Elements of Strict Liability}

\section{A. Problems Raised by the Standard Definition of Strict Liability}

The history and the evolution of strict liability in France and England sketched in the previous two chapters shows that while there may be many differences between these two jurisdictions at the level of detail, there are remarkable similarities at the highest level of generality, or principle. In both the civil law and the common law, at least since the mid-19 ${ }^{\text {th }}$ century, ${ }^{1}$ tort law has been intellectually organized around two major categories: fault (consisting of intentional and negligent behaviour) and strict liability. In both France and England, despite the suspicion with which strict liability regimes are regarded by the English and the more positive attitude of the French, strict liability regimes have flourished and have multiplied over time, although to a different extent and in different ways. Also, in both jurisdictions, the default rules of liability are fault-based, and strict liability rules are special and narrower in scope by comparison.

Fault liability rules have a vocation for universal application in both France and England, and have remarkably sprung into existence in both jurisdictions at a time when French and English law were aiming at the creation of liability rules of universal application, due to their power and territorial reach. The fault liability principle that emerged in France and England is at its core almost identical: a tortfeasor must repair damage caused to a victim only when his/her behaviour fails to live up to the objective standard of a reasonable person (or bonus pater familias). This similarity at the level of principle can be framed partly in terms of normative equivalence. In both France and in England, fault liability rules have, amongst others, the two interrelated normative functions of (i) sanctioning wrongful behaviour, ${ }^{2}$ i.e. behaviour that is unreasonable, and (ii) compensating

\footnotetext{
${ }^{1}$ James Gordley, Foundations of Private LaW: Property, ToRT, Contract, UnJust EnRichment 174-75, 180-81 (Oxford University Press 2006).

${ }^{2}$ For the same functional interpretation see Franz Werro \& Erdem Büyüksagis, The Bounds Between Negligence and Strict Liability, in Comparative Tort LaW: Global Perspectives 201, 201 (Mauro Bussani \& Anthony J. Sebok eds., Edward Elgar Publishing 2015); Stig Jørgensen, Liability and Fault, 49 TUL. L. REV. 329, 338 (1974-1975): "The central element of the concept of negligence today is whether the behaviour diverges from recognised patterns of behaviour"; David Howarth, Many Duties of Care-Or A Duty of Care? Notes from the Underground, 26 OXF. J. OF LEG. STUD. 449, 472 (2006): "negligence law deals not in rights to compensation but in judging the reasonableness of conduct." There are, of course, also other functional interpretations proposed by legal scholars. See, e.g., Andrew Robertson, On the Function of the Law of Negligence, 33 OXF. J. OF LEG. STUD. 31, 32 (2012):
} 
the victim of that wrongful behaviour. ${ }^{3}$ The normative functions of strict liability are, by contrast, not at all as obvious, and this has to do, or at least partly, with the way in which strict liability has been defined and conceptualized.

Strict liability is most often defined in relation to fault or, to be more precise, by opposition to fault-based liability, as "liability without fault." The language of this traditional definition is somewhat misleading, and has been often criticized. ${ }^{5}$ The absence of fault is not a necessary precondition of liability. ${ }^{6}$ The law never requires a plaintiff to prove that the defendant was not at fault in order to win his case. Strict liability encompasses fault liability, but goes beyond it, in the sense that although most of the time when a defendant is found strictly liable he is also at fault, it is possible to have some cases where a defendant is liable even though his behaviour is irreproachable. The law simply "does not inquire into whether or not the defendant was at fault or not." "7 The necessary absence of fault is therefore to be identified not at the level of the tortfeasor's

\footnotetext{
"the law of negligence serves a broader community welfare purpose, which is perhaps best understood as the maintenance of civil peace through the provision of civil recourse for particular interpersonal wrongs." Dan Priel, Tort Law for Cynics, 75(5) THE MOdern LAw REviEw 703, 708 (2014): "cynicism . . . argues that as a matter of fact negligence law does not always (or even often) treat violations of duties of care as behaviours that should be avoided, but rather as behaviours for which one should pay damages [...]".

To see the law of negligence in functional terms is, of course, a choice that not all authors make. Ernest Weinrib is perhaps the most over proponent of the non-functionalist view, but even he sees an essential role for behavioural wrongs in his account of negligence. See ERNEST WeinRIB, THE IDEA of Private LaW 56, 147-152 (Oxford University Press 2012).

For a brief presentation of a wide array of justifications for fault liability see Pierre Widmer, Comparative Report on Fault as a Basis of Liability and Criterion of Imputation (Attribution), in UNIFICATION OF TORT LAW: FAULT 331, 334-35 (Pierre Widmer ed., Kluwer Law International 2005).

${ }^{3}$ Moreover, function and justification are tied together in the area of fault liability because the unreasonableness of the tortfeasor's behaviour constitutes the main reason for the imposition of liability.

${ }^{4}$ Cees van Dam, European Tort Law 297 ( $2^{\text {nd }}$ ed., Oxford University Press 2013); Jules L. Coleman, The Morality of Strict Tort Liability, 18 WM. \& MARY L. REV. 259, 271 (1976-1977). For a long time, in fact, "liability without fault" and "strict liability" have been used interchangeably by legal scholars. See, e.g., Ezra Ripley Thayer, Liability without fault, 29 HARV. L. REV. 810 (1916); John B. Waite, Liability without fault, 18 Mich. L. REV. 316 (1920); Kenzo Takayanagi, Liability without Fault in the Modern Civil and Common Law, 16 ILL.L.R. 163 (19211922); Kenzo Takayanagi, Liability without Fault in the Modern Civil and Common Law - II, 16 ILL.L.R. 268 (1921-1922); Kenzo Takayanagi, Liability without Fault in the Modern Civil and Common Law - III, 17 ILL.L.R. 187 (1922-1923); Kenzo Takayanagi, Liability without Fault in the Modern Civil and Common Law - IV, 17 ILL. L. R. 416 (1922-1923); Rufus C. Harris, Liability Without Fault, 6 TUL. L. REV. 337 (1931-1932); Fowler V. Harper, Liability Without Fault and Proximate Cause, 30 Mich. L. Rev. 1001 (1931-1932); William H. McBratney, New Trends Toward Liability Without Fault, 26 RocKY MNTN. L. Rev. 140 (1953-1954) ; Rev. Francis E. Lucey, Liability Without Fault and the Natural Law, 24 TENN. L. REV. (1955-1957); Cornelius J. Peck, Negligence and Liability Without Fault in Tort Law, 46 WASH. L. REV. 225 (1970-1971); Richard Shields, Liability Without Fault. Rylands v. Fletcher Revitalised, 2 TRINITY C.L. REV. 124 (1999).

${ }^{5}$ W. EDWin Peel \& James GoudKamp, Winfield AND Jolowicz ON TORT 53 (19 $9^{\text {th }}$ ed., Thomson Reuters 2014); W. Page Keeton et Al., Prosser and Keeton on Torts 534 ( $5^{\text {th }}$ ed., West 1984); Peter Cane, Responsibility IN LAW AND MORALITY 82 (Hart Publishing 2002).

${ }^{6}$ CANE, supra note 5 , at 39 .

${ }^{7}$ Christian WitTing, StReEt On TORTs 15 (14 th ed., Oxford University Press 2015).
} 
behaviour, but at the level of analysis of the conditions required for liability to ensue. The perspective is that of a lawyer (and not that of the private actors to whom the liability rule is addressed), and the emphasis is always put on fault as a condition or requirement for liability. Consequently, a more precise formulation of strict liability would be "liability regardless of fault", "liability irrespective of fault", 9 or "liability that does not depend on proof of negligence or intent to do harm", ${ }^{10}$ Such formulations make it clear that fault may be present in strict liability cases, but is not a requirement; therefore, liability may ensue even in its absence.

Both the traditional definition and its more modern version are phrased in the negative, and provide a perspective on the notion of strict liability which is dependent on the notion of fault and the normative structures of fault liability. When fault is present in the list of elements, liability is faultbased; when absent, liability is strict. What we have seen, however, by looking at the historical origins of liability regimes is that strict liability forms either pre-existed the concept of "fault", being imbedded in older actions giving rise to liability which survived into modernity (although often in a distorted or modified form) or grew as a reaction against some of the inequities of fault liability. The common law action for trespass to land, the tort of nuisance, and the French rules regarding liability for animals ${ }^{11}$ belong to the former category, while rules of vicarious liability, product liability (in both jurisdictions), liability for things, and liability for road traffic accidents in France and breach of (strict) statutory duties in England belong to the second. Nevertheless, despite the heterogeneous origins of strict liability norms, it is the logic of the second category of strict liability norms that prevailed in the legalistic attempts to define strict liability as a category within the law of tort.

\footnotetext{
${ }^{8}$ Id.; CANE, supra note 6, at 39. See also Gregory C. Keating, Is There Really No Liability Without Fault: A Critique of Goldberg \& Zipursky, 85 FORDHAM L. REV. RES GESTAE 24, 26 (2016-2017) ("liability without regard to fault"). ${ }^{9}$ PeEl \& GoudKamp, supra note 5, at 53.

${ }^{10}$ BlacK's LaW Dictionary 1055, vo liability (10 ${ }^{\text {th }}$ ed., Bryan A. Garner ed., Thomson Reuters 2014).

${ }^{11}$ In Chapter II the liability of a keeper for the damage caused by animals under his custody (art. 1243 French Civil Code) has been discussed only in respect to its evolution after the enactment of the Napoleonic Code. However, it is useful to remark that the action against the keeper for damage caused by animals under his custody evolved from a stricter form towards the fault-based rule envisaged by the drafters of the Civil Code, and then again towards a strict liability rule at the end of the $19^{\text {th }}$ century. The history of rules regarding liability for the acts of animals goes back a long way, in a form very similar to the present rule, at least up to the Law of the XII Tables in Ancient Rome and the actio de pauperis. In Roman law, the actio de pauperis was based on a strict liability rule, as proof of fault was not required in order for the victim of damage caused by animals to be compensated or be offered noxal surrender by the owner of the animal. See Ferdinand F. Stone, Chapter 5. Liability for Damage Caused by Things, in 11 INTERNATIONAL ENCYCLOPEDIA OF COMPARATIVE LAW, TORTS at 11-12, (sections 5-39 to 5-41) (André Tunc ed., J.C.B. Mohr (Paul Siebeck) \& Martinus Nijhoff Publishers 1983); Jérôme Julien, Responsabilité du fait des animaux, at no 1 (Published as part of the RÉPERTOIRE DE DROIT CIVIL, Dalloz, last updated 2014).
} 
What follows from this is that the existing, fault-centred, conceptualization of strict liability tells us more about what strict liability is not (it is not fault liability), and offers very little towards a true understanding of its nature. ${ }^{12}$ This is problematic mainly because when fault liability is taken as a starting point, the foundations of strict liability become obscure, and the category itself risks being reduced to a miscellanea of "weird" rules. To truly understand what strict liability is about, one ought to overcome the initial shock of not seeing fault among its elements, and see what exactly, if anything, replaces fault. This requires us to stay within the lawyer's perspective and identify the elements of strict liability. One can depart from the phrasing in the negative and the fault-centricity of traditional definitions of strict liability by tracing the commonalities of the element or elements that replace fault.

The elements of a tort (taking the form of prima facie requirements and defences) are encoded arguments about what is necessary from a factual and normative perspective in order to find that a given defendant is liable for a particular claimant's harm. Therefore, identifying, analysing, and categorizing the elements of strict liability norms may reveal the arguments that have been put forward and have been accepted, in one or both of the jurisdictions we are analysing, for holding someone strictly liable for harm. Following this line of inquiry, this chapter begins with a taxonomical exercise aimed at identifying a way of ordering strict liability regimes around their elements. What emerges is an image of a spectrum of rules, with a paradigmatic or ideal type form, where fault is typically replaced by at least one other requirement, which we generically refer to as "the strict element."

This theoretical model presupposes that, at some level of generality, fault and strict liability have some features and structures in common which allow us to relate liability rules with each other and order them according to rank. At the same time, at lower levels of generality one can identify more and more differences between the various liability rules, and such differences must be susceptible to quantification, even though the process of quantification may be somewhat imprecise. From a doctrinal perspective, fault and strict liability legal norms are structurally similar in that they rely on prima facie elements and defences. Also, fault and strict liability are substantively similar because both sets of rules presuppose the background principle that losses

\footnotetext{
12 Peter Cane, Atiyah's Accidents, Compensation And the Law 91 ( $8^{\text {th }}$ ed., Cambridge University Press 2013): "The phrase 'liability without fault' merely eliminates fault as a necessary condition of liability; it does not put anything else in its place."
} 
ought to lie where they fall. ${ }^{13}$ Once the analysis moves to a lower level of generality, the differences begin to emerge because not all liability rules have the same prima facie elements and the same list of available defences. However, liability rules do tend to cluster around two combinations of elements which can be taken as paradigmatic. Thus, fault and strict liability usually share the elements of causation and damage, as well as certain defences like contributory negligence and force majeure. The main difference between fault and strict liability, it will be argued, ${ }^{14}$ lies in the nature of the wrong they sanction, and the analysis of wrongfulness is encoded in the element of fault, on the one hand, and a generic element we have termed "the strict element", on the other.

So far, strict liability regimes have been identified, collected and explained from within the laws of France and England. Now we can take our repository of forms of strict liability and organize them into categories based on their prima facie requirements and available defences. A useful tool to organize strict liability forms based on their elements, as found in section B, is the often-used image of a spectrum starting from the most demanding set of elements for a plaintiff to prove and ending with the most victim-friendly forms of liability. Within this spectrum of rules, we then in section $\mathrm{C}$ further distinguish between fault-based rules with a reversed burden of proof, regimes which we will call "de facto strict liability" rules; and in section D, examine liability rules where fault is never a consideration, which we will call "de jure strict liability".

\section{B. The Elements of Strict Liability}

Despite strict liability having always been defined as "that which is not fault-based liability", it is not, in practice, easy to draw a clear separation between fault liability and strict liability. Western legal systems fiddle with liability rules in many ways in order to adjust the strictness of liability. We have seen, for instance, that even within the fault paradigm, there are remarkable variations. Liability for road traffic accidents in England is premised upon a much stricter duty of care than in other cases of negligence. ${ }^{15}$ Also, some categories of persons, usually professionals in a particular field, obey a stricter standard of care, the law taking into consideration the specialized knowledge they possess. ${ }^{16}$ Lastly, adjusting the rules of evidence, making use of

\footnotetext{
${ }^{13}$ For a more detailed discussion of this principle see infra Part B of this chapter.

${ }^{14}$ Infra Chapter V.

${ }^{15}$ Supra Chapter III Part A.4.

${ }^{16}$ VAN DAM, supra note 4, at 267-69.
} 
presumptions, and limiting defences in tort cases may also lead to stricter forms of fault liability. Therefore, a rule may pay lip service to the fault principle, but in fact be closer in results to strict liability rules.

It has been suggested that a useful and accurate theoretical approach to deal with such complexity would be to arrange the rules of liability on a spectrum ${ }^{17}$ (a continuum of standards from the strictest forms of liability to the most fault-based),${ }^{18}$ instead of relying on the traditional dichotomy (fault/strict liability). Thus, within such a spectrum, between the paradigmatic forms of fault liability and strict liability, a good number of intermediate positions would be taken by rules that in some form or another combine fault and strict liability.

It is unsurprising that comparatists feel very comfortable employing this theoretical mechanism because they are usually confronted with a higher degree of diversity resulting from their inquiries into multiple legal systems. Acknowledging this diversity is, of course, a major advantage of the spectrum-based approach. But there is at least one other, subtler, advantage that is worth mentioning. Arranging liability rules on a spectrum reflects how easy or burdensome it is for someone to be held liable or for the victim to obtain compensation. On the lower end of the spectrum (toward fault) it is harder for a victim to prove his or her case and easy for the tortfeasor to avoid liability. In addition, this pragmatic way of ordering liability rules has a formal quality to it because it offers no allegiance to any normative theory justifying the rules so ordered. The reasons justifying the liability rules can be very diverse. Consequently, the distribution of underlying rights and duties, and hence the position of the various rules on the spectrum, may differ substantially between various legal systems. Nevertheless, this way of ordering liability rules does show allegiance to one, overarching, default principle which creates the background of the spectrum: that losses ought to lie where they fall, in the absence of a compelling reason to shift

\footnotetext{
${ }^{17}$ Franz Werro et al., Strict Liability in European Tort Law: An Introduction, in THE BoundARIES OF STRICT Liability in European Tort LaW 3, 7 (Franz Werro \& Vernon Valentine Palmer eds., Staempfli Publishers, Carolina Academic Press \& Bruylant 2004); Vernon Valentine Palmer, Trois Principes de la Responsabilité sans faute, 39(4) R.I.D.C. 825, 827 (1987).

${ }^{18}$ Peter Cane, Fault and Strict Liability for Harm, in THE SEARCH FOR PRINCIPLE: ESSAYS IN HONOUR OF LORD GOFF OF CHIEVELEY 171, 172 (William Swadling \& Gareth Jones eds., Oxford University Press 1999); IZHAK Englard, The Philosophy of Tort Law 21 (Dartmouth Pub. Co. 1993). See also Walter Wilburg, The DEVELOPMENT OF A FLEXIBLE SYSTEM IN THE AREA OF PRIVATE LAW : INAUGURAL ADDRESS AS RECTOR MAGNIFICUS OF THE KARL-FrANZENS UNIVERSITY IN GRAZ ON NOVEMBER 22, 1950 (Herbert Hausmaninger trans., Manzsche Verlags- und Universitätsbuchhandlung 2000).
} 
them to another party. ${ }^{19}$ The rules of liability which fill the spectrum derogate from this default principle, and the ordering of liability rules on the spectrum is an arrangement showing the ease or difficulty of defeating the default principle.

The spectrum approach is not the only descriptive theory of strict liability. An interesting and contrasting theoretical approach was proposed by Jules Coleman. Inspired by an earlier paper published by Guido Calabresi, ${ }^{20}$ Coleman offered a way of theorizing liability rules on the basis of a symmetrical dichotomy between fault and strict liability: where the former begins with the default principle that losses ought to lie with the victim unless there is a compelling reason to shift it to the tortfeasor, and the latter is based on the symmetrically opposite rule that "in the absence of a sound reason for leaving a loss with the victim, it ought to be transferred to the injurer". ${ }^{21}$ The sound reason Coleman had in mind was a person's fault. When the default principle places losses on the victim, the victim may shift his or her burden by showing that the injurer was at fault. When the default rule places the loss on the injurer, he may escape liability by proving that the victim was at fault. Coleman thus ended up defining all liability as strict: fault liability being characterized as strict victim liability and strict liability as strict tortfeasor liability. ${ }^{22}$ Thus, in cases of strict victim liability (fault liability) the victim will be strictly liable a priori, but could 'defend' by proving the fault of the tortfeasor, whereas in cases of strict liability the tortfeasor will bear the $a$ priori burden unless he can show fault on the part of the victim.

Despite the beauty of its symmetry, as a descriptive theory, Coleman's strict liability theory is based on a false premise. It is important to note from the outset that Coleman did not see his representation of liability forms as an ideal to which existing rules should aspire. Coleman clearly saw a descriptive element in his theory and seemed to believe that existing forms of strict tortfeasor liability operated the way he explained them. He even exemplified what he meant by strict injurer liability by reference to liability for defective products. ${ }^{23}$ As it so happens, liability for defective

\footnotetext{
${ }^{19}$ This is a principle famously phrased by Oliver Wendell Holmes as a starting point for his theory of negligence. Oliver Wendell Holmes, The Common Law 62 (Little, Brown, and Company 1881, repr. Holmes Press 2012). His principle, however, as shown in the text above is valid also for strict liability.

${ }^{20}$ Guido Calabresi, Optimal Deterrence and Accidents: To Fleming James, Jr., 84 YALE L.J. 656, 664-66 (19741975).

${ }^{21}$ Jules L. Coleman, The Morality of Strict Tort Liability, 18 WM. \& MARY L. ReV. 259, 260 (1976-1977);

${ }^{22}$ Id. at 274. One should note that Coleman extended his theory also to two non-paradigmatic forms of liability, and thus he also identified the categories of "(3) strict injurer liability with no defense of plaintiff misconduct" and "(4) strict victim (plaintiff) liability with no defense of injurer wrongfulness." Id.

${ }^{23} I d$. at 260.
} 
products is, in fact, a very suitable example to demonstrate how his theory fails as a descriptive endeavour. In all European jurisdictions, and the same will hold also for the jurisdictions in the United States, ${ }^{24}$ a "victim" suffering damage from a supposedly defective product is not entitled to compensation merely by showing that he or she has suffered some damage. The victim must first show that the damage suffered is a legally relevant type of damage. ${ }^{25}$ In addition, the victim must also show that: the product was indeed defective under the standard imposed by law, ${ }^{26}$ the defendant is a producer, again according to what the legal definition of a producer is, ${ }^{27}$ and the defect of the product caused the relevant damage. ${ }^{28}$ Unless the victim can prove, cumulatively, all the elements mentioned above, he or she will remain uncompensated for the loss suffered. Therefore, the "losses ought to lie where they fall" principle applies just as well to cases of strict tortfeasor liability, including liability for defective products. There is no a priori rule that the producer shoulders the losses of victims. Just because fault did not play a role in the victim's prima facie case does not automatically mean that the burden was a priori shifted to the producer. In addition, upon closer inspection, Coleman's theory also loses its symmetrical beauty. Under faultbased rules, the defendant, even if already proven to be at fault, can still invoke the contributory negligence of the victim. The fact that the "sometimes innocent" defendant can defend by invoking the contributory negligence of the victim cannot be paralleled to fault as a prima facie element. Invoking the defence of contributory negligence is, in a significant way, a different kind of argument than the argument behind the prima facie element of fault. When A proves that B was at

\footnotetext{
${ }^{24}$ See American Law Institute, Restatement of the Law (Third). Torts. Products Liability, at 5 (§1).

${ }^{25}$ What kind of damage is compensated by the strict liability rule may be limited. In the case of the Product Liability Directive (Council Directive 85/374/EEC of 25 July 1985 on the approximation of the laws, regulations and administrative provisions of the Member States concerning liability for defective products, O. J. L 210, 07/08/1985, p. 29-33), for instance, according to Article 9, only damage "caused by death or by personal injuries," and property damage (other than the defective product itself) which is "above the threshold of 500 ECU, provided that the item of property: (i) is of a type ordinarily intended for private use or consumption, and (ii) was used by the injured person mainly for his own private use or consumption."

${ }^{26}$ See Article 6 of the Product Liability Directive: "A product is defective when it does not provide the safety which a person is entitled to expect, taking all circumstances into account, including: (a) the presentation of the product; (b) the use to which it could reasonably be expected that the product would be put; (c) the time when the product was put into circulation."

${ }^{27}$ See Article 3 (1) of the Product Liability Directive: "'Producer' means the manufacturer of a finished product, the producer of any raw material or the manufacturer of a component part and any person who, by putting his name, trade mark or other distinguishing feature on the product presents himself as its producer. 2. Without prejudice to the liability of the producer, any person who imports into the Community a product for sale, hire, leasing or any form of distribution in the course of his business shall be deemed to be a producer within the meaning of this Directive and shall be responsible as a producer."

${ }^{28}$ See Article 4 of the Product Liability Directive: "The injured person shall be required to prove the damage, the defect and the causal relationship between defect and damage" (emphasis added).
} 
fault, $\mathrm{A}$ is in fact showing that $\mathrm{B}$ disregarded the interests of $\mathrm{A}$ in a legally significant way. When $\mathrm{B}$, however, defends by saying that A was contributorily negligent, he is saying that A disregarded its own interests, not B's, in a legally significant way. ${ }^{29}$ That suggests that the fault invoked in the defence of contributory negligence is of a slightly different nature and the justification of contributory negligence is different from the justifications of both fault and strict liability rules. ${ }^{30}$ Finally, there is a problem with the use of the terms "victim" and "injurer" in Coleman's theory. In the law of torts, a person is a "victim" and another is an "injurer" only once all the elements of liability are met. Not all persons who suffer a loss are victims for the purposes of the law of torts, and not all persons who breach some pre-existing duties are injurers. That is why it makes very little sense to say that an initial liability rule for strict liability is that "the injurer bears the costs of accidents unless he can show some defect in the victim's conduct [...]". ${ }^{31}$ A person becomes an "injurer" only by the joint operation of the prima facie elements and the failure of available defences. And the same goes for the victim. A person becomes a victim, for the purposes of tort law, only when all the elements of liability are met. Conceptually, in tort law, the victim and the injurer become victim and injurer simultaneously. ${ }^{32}$

Coleman himself later changed his views on the default rule in tort law, although it is not entirely clear to what extent. In his remarkable book Risks and Wrongs, he begins his chapter on fault and strict liability with a Holmesian premise: "In each case the burden of establishing the relevant conditions for shifting losses have been met typically falls to the victim. Thus, liability rules apply in response to the initial liability rule that victims are responsible for the costs of accidents"

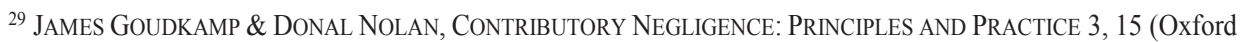
University Press 2018); James Goudkamp, Rethinking Contributory Negligence, in CHALLENGING ORTHODOXY IN TORT LAW 309, 311 (Erika Chamberlain et al. eds., Hart Publishing 2013); Ulrich Magnus \& Miquel Martín-Casals, Comparative Conclusions, in UNIFICATION OF TORT LAW: CONTRIBUTORY NEGLIGENCE 259, 260-61 (Ulrich Magnus \& Miquel Martín-Casals eds., Kluwer Law International 2004); Richard W. Wright, The Standards of Care in Negligence Law, in PhilosophiCal Foundations of TorT LaW 249, 259 (David G. Owen ed., Oxford University Press 1995, repr. 2001). See also Froom v Butcher, [1976] Q.B. 286, 291 (CA) (per Lord Denning MR): "Contributory negligence is a man's carelessness in looking after his own safety" (emphasis added).

${ }^{30}$ See Goudkamp, supra note 29, at 325-327; Kenneth W. Simons, Contributory Negligence: Conceptual and Normative Issues, in PhilosophiCAL Foundations OF TORT LAW 462, 468-481 (David G. Owen ed., Oxford University Press 1995, repr. 2001); Kenneth W. Simons, The Puzzling Doctrine of Contributory Negligence, 16 CARDOZO L. REV. 1693, 1707-1711, 1725-1728 (1994 - 1995).

${ }^{31}$ Coleman, supra note 21 , at 272.

${ }^{32}$ In other words, the victim and the tortfeasor acquire their roles because of a unitary relationship created by the law. Ernest Weinrib was right in saying that "the basic unit of analysis" in private law is the legal relationship. See WEINRIB, supra note 2, at 24-25.
} 
(emphasis added). ${ }^{33}$ The change is slightly suspicious because of his addition of the word "typically". The initial burden of establishing the relevant conditions for shifting losses in tort law always falls on the victim.

With regard to strict liability in particular, Coleman clearly abandoned the idea that strict liability was premised on a default principle placing the burden of repair on the injurer. ${ }^{34}$ Such a default principle was never necessary for his moral argument, and abandoning it actually gave more strength and credibility to the idea he was advancing - that the choice between fault and strict liability should ultimately be phrased as a choice regarding who should bear the costs of accidents when both parties to a dispute are innocent. ${ }^{35}$ We will come back to Coleman's justification of fault and strict liability. For now, it is sufficient that we have established that, as a matter of positive law, the law of torts relies on a default rule that losses should be borne by those who suffer them, unless a good reason is put forward that someone else should compensate the victim for the loss suffered.

It is important to keep in mind that Holmes's default principle that "losses ought to lie where they fall" is addressed not to victims, but to any person that may have suffered a loss. Tort liability rules create a legal bond that links the person who has suffered a loss to another person who can, after all the conditions of liability are met, be said to have caused (in a legal sense) the loss. Meeting the requirements of liability makes the person who has suffered a loss properly a "victim" in tort because it entitles him or her to a remedy from the person who can now be called an "injurer". The idea of arranging liability rules on a spectrum looks precisely at what it takes to move from the default principle to a tort liability rule, and tries to quantify and rank-order liability rules based on a comparison of their "elements": the conditions for liability and available defences.

What would such a spectrum look like? If one were to move from fault towards strict liability, the rules of liability based on a subjective standard of fault can be placed at the bottom of the spectrum because liability premised on such rules is less strict than all other forms of liability. When a rule based on subjective fault liability is applicable to a case, the tortfeasor is in the best possible situation, as he/she will be subject to a standard fully personalized to his own set of subjective

\footnotetext{
33 JULES COLEMAN, RiSKS AND WRONGS 213 (Oxford University Press 1992, repr. 2003).

${ }^{34} \mathrm{Id}$. at 227: "So the fault liability rule holds that the initial presumption in favour of victim liability is overcome if the victim can show that the injurer is at fault. This differs from the strict liability rule in that under strict liability the same presumption is overcome if the victim can show that the injurer caused the victim's loss" (emphasis added).

${ }^{35} I d$. at 229.
} 
circumstances: his/her habits, talents, physical and mental attributes, etc. Conversely, the victim is in the worst possible position, his/her recovery being dependent on proving that the tortfeasor's behaviour fails to meet the above-mentioned personalized standard. Such rules are rare, and one might even venture to say non-existent, in modern law. There are, however, a number of intermediate rules where an objective standard is tempered by some select number of personal circumstances, such as the young age of the tortfeasor, ${ }^{36}$ or, exceptionally, the existence of a serious physical impairment or handicap, or a mental disease. ${ }^{37}$ Then there is the paradigmatic form of fault liability which is based on an objective standard: that of an adult reasonable person. One step higher, we find rules which are still fault-based, but where the burden of proof for the fault element shifts from the plaintiff to the defendant. When such rules apply, it is no longer incumbent upon the plaintiff to show that the defendant was at fault; the defendant must show that he was not at fault. Another step higher on the spectrum we find the paradigmatic form of strict liability. This is a form of liability where the defendant does not have the option to show that he was not at fault, and thus considerations of his own fault are fully removed from the elements of liability. However, the defendant may still show that the plaintiff was contributorily negligent, or that the damage was caused by an irresistible act of nature or of a third party. Beyond this form of liability there are a number of even stricter, sometimes called "absolute", forms of liability. The term "absolute" is not very appropriate, though. These rules of liability either relax the requirements of causation in the plaintiff's prima facie case or eliminate some of the traditional

\footnotetext{
${ }^{36}$ For example, in England, the rule is that children are judged against a standard of a child of the same age. PeEL \& GOUDKAMP, supra note 5, at 769; VAN DAM, supra note 4, at 227. In France, however, children's behaviour is judged against the standard of a reasonable adult person. Id. at 272-73. The few cases where French judges have taken the age of the defendant into consideration are rare and regarded as inconsequential exceptions. GENEVIÈVE

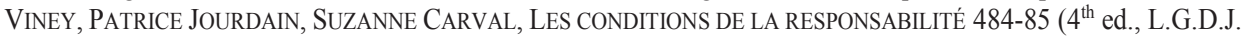
2013). The rule in England is therefore, more subjective than its French counterpart.

${ }^{37}$ Under English law, generally, "no allowance is made in determining the qualities of the reasonable person for the fact that the defendant was, for example, blind, deaf, intoxicated, dim-witted or insane." PEEL \& GouDKAMP, supra note 5, at 146. In a number of exceptional cases, however, it was held that a physical or mental impairment can be taken into account when deciding whether a defendant was negligent. See Waugh v James K. Allan Ltd [1964] 2 Lloyd's Rep 1 (lorry driver who lost control of the vehicle as a result of a heart attack); Mansfield v Weetabix [1998] 1 W.L.R. 1263 (lorry driver crashed into the plaintiff's shop while being in a hypoglycaemic state); See also Goldman v Hargrave [1967] 1 A.C. 645, 663 (although in this case the defendant was, in the end, held liable, the Privy Council advised, in dicta, that infirmity may be taken into account when analysing the liability of a person who failed to stop a fire which started on his land due to natural causes). French law, although very strict in applying a uniform objective standard also to children and the mentally ill, does, as a rule, take into account physical impairments. VINEY ET AL., supra note 36, at 485-86.
} 
defences available to the defendant, such as contributory negligence or force majeure, but do not impose a liability that is all-encompassing.

The image below illustrates how such a spectrum might be imagined graphically, with the main categories of liability being highlighted:

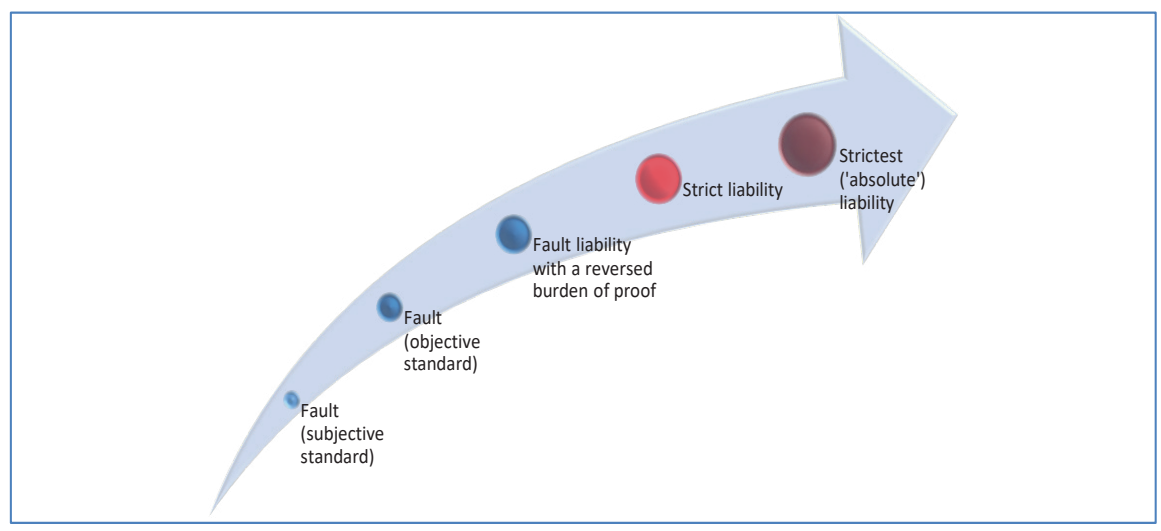

Representing liability rules on a spectrum does not preclude taxonomy. In fact, a basic taxonomy is useful and necessary within such a spectrum, especially for the purpose of identifying the paradigmatic form of strict liability (highlighted in red as "strict liability" in the image above). Taxonomy may also help explain how this paradigmatic form of strict liability relates to fault liability with a reversed burden of proof and the strictest ("absolute") forms of liability.

Based on the legal elements, or conditions of liability, of various strict liability regimes, we can roughly distinguish two major forms of strict liability: de facto strict liability, i.e. fault liability with a reversed burden of proof; and de jure strict liability - liability regardless of fault, the latter being the characteristic form of strict liability (where the law does not concern itself with the defendant's conduct at all). Within the second category, further distinctions can then be made. The ideal type that emerges from French and English legal practice is represented by rules which (1) require proof of a strict element, causation and damage, and allow the defences of contributory 
negligence $^{38}$ and force majeure ${ }^{39}$. It will be shown that although most strict liability regimes replace fault-based standards with other elements of liability, some go even further, and (2) also eliminate the requirement of causation. In addition, whether the claimant's own negligence or force majeure are allowed as defences may also be used to differentiate between the ideal type form of strict liability and (3) other, even stricter, often called "absolute", strict liability regimes.

\section{De facto Strict Liability, or "Fault Liability with a Reversed Burden of Proof"}

Fault liability with a reversed burden of proof is not easy to categorize. Depending on the question being asked and the criteria for classification, this form of liability can be seen as belonging to fault liability, strict liability, or making up its own category (sui generis).

It might seem odd at first sight to include fault liability with a reversed burden of proof among the types of strict liability. By its very name, this is still a form of "fault liability". Describing this form of liability as strict is particularly puzzling for Continental lawyers, who would find, at least for the purposes of taxonomy, the grounds for liability more important than its effects. As long as the reasons behind the liability rule are couched in the language of fault, it matters very little that in practice the rule makes it possible to hold a person liable even if that person was not at fault. A French lawyer would speak of responsibility based on "risk," "guarantee," "control," or "solidarity" 40 as an alternative to fault-based liability, more often than "liability without fault" or responsabilité objective. Strict liability is not conceived of in the French nomos independently from its foundation. Also, the reversal of the burden of proof has been, historically, perceived as a procedural solution, not a substantive one, meant to deal with the injustice of obligating some categories of victims to prove fault without displacing the ordering role of the fault principle. In the common law, by contrast, some scholars find it very natural to conceptualize strict liability as "liability without proof of fault". ${ }^{41}$ Such a broad definition would include liability based on a presumption of fault in the category of strict liability. It should be noted though that when common

\footnotetext{
${ }^{38}$ For the purposes of this chapter the exclusive fault of the victim as well as his/her partial fault are encompassed in the notion of "contributory negligence".

${ }^{39}$ Also, within the notion of force majeure we include both irresistible acts of nature (usually called in the common law "acts of God") and the irresistible acts of a third party.

${ }^{40}$ See Muriel Fabre-Magnan, 2 Droit Des obligations. Responsabilité CiVILE ET QuASI-CONTRATs 63-66 (3 ${ }^{\text {rd }}$ ed., PUF 2007) ; PhilipPe LE TOURNEAU ET AL., DROIT DE LA RESPONSABILITÉ ET DES CONTRATS. RÉGIMES D'INDEMNISATION 45-74, $\mathrm{n}^{\mathrm{0}}$ 50-103 (10 $0^{\text {th }}$ ed., Dalloz 2014).

${ }^{41}$ Dan B. DobBS ET AL., HornBoOK ON TORTs 5, 777 (2 $2^{\text {nd }}$ ed., West 2016); JOHN COOKE, LAW OF TORT 9 (9 $9^{\text {th }}$ ed., Pearson Education Ltd. 2009); VIVIENNE HARPWOOD, PRINCIPLES OF TORT LAW 10 (4 ${ }^{\text {th }}$ ed., Cavendish Publishing Ltd. 2000, repr. 2002).
} 
law scholars say that liability does not require proof of fault, they most likely mean by this that liability is not fault-based (i.e. fault is simply not an element). In all circumstances where fault is a basis for liability in the common law, and especially in the English common law, the burden of proof is on the plaintiff. The English legal system does not make use of presumptions of fault in the same way as the French legal system, and the only mechanism that comes even remotely close is the res ipsa loquitur doctrine, which falls just short of being a veritable presumption of fault.

Regimes based on rebuttable presumptions of fault fall into the strict liability category only when the focus shifts from foundations to outcomes. It is undisputed that fault-based rules with a reversed burden of proof lead to different outcomes than traditional fault-based rules. At the same time, these results are closer to the outcomes one would expect if the rule were clearly one of strict liability (where fault is not required as an element, nor as a foundation). ${ }^{42}$ In essence, the liability regimes discussed in this section spare the plaintiff from the burden of proving fault, and place on the defendant's shoulders the task of proving that he was not at fault, i.e. that he took all reasonable precautions. The "not at fault" defence allowed to the defendant is very difficult to establish, if not almost impossible, in some cases. That is why, if we set out to find rules of liability where a defendant who is not at fault may still be held liable, fault-based rules with a reversed burden of proof would undoubtedly have to be included, as they clearly allow such outcomes.

In France, very few rules of fault liability with a reversed burden of proof still exist in the positive law. The only surviving example can be found in a law from 20 December $1988^{43}$ that was recently integrated in the Public Health Code (Code de la santé publique), protecting persons who volunteer to be test subjects in biomedical research or experiments. According to the provisions of this legislative act, the person who profits from the research conducted is prima facie liable for the damage that could result from the experiments conducted. The law makes, however, a distinction between research with a direct therapeutic purpose and research without such a purpose, and only in the case of the former, may the person conducting the research escape liability by showing that he was not at fault. ${ }^{44}$

\footnotetext{
${ }^{42}$ Franz Werro et al., supra note 17, at 13.

${ }^{43}$ Loi no88-1138 du 20 décembre 1988, dite Huriet, relative à la protection des personnes qui se prêtent a des recherches biomédicales, JORF du 22 décembre 1988, p. 16032.

${ }^{44}$ Art. L209-7 of the Public Health Code (Code de la santé publique).
} 
Liability based on rules presuming fault once held a place of great importance. Most of the existing strict liability regimes identified in France have once been grounded on fault. ${ }^{45}$ In the transition from fault liability to stricter forms, there was usually an intermediary jurisprudential step when courts held onto the old fault-based paradigm, but aimed at the outcomes of strict liability, and achieved this by reversing the burden of proof (making it incumbent on the defendant to prove that he was not at fault). ${ }^{46}$ In some other European legal systems, such as Germany, Austria, Spain, Portugal, Italy, ${ }^{47}$ and Belgium, ${ }^{48}$ many liability regimes included in civil codes (like the liability of employers for the acts of their employees, or of parents for their minor children) are still, to date, fault-based with a reversed burden of proof.

Historically, fault-based rules with a reversed burden of proof were either present in the civil code from the outset, or developed during the industrial revolution out of, and as a reaction to, the injustice of the fault system, which required plaintiffs to always prove the defendant's fault, even in situations where such proof was hard to come by or where the defendant was the only one who had access to the relevant information and proof. ${ }^{49}$ The practical reality was that if proof of fault was at times difficult to come by, it was very likely that in many cases where the defendant was at fault, the victim would remain uncompensated. Every system of civil procedure suffers in some way from epistemological shortcomings, but perhaps this problem is more pressing in a civil law jurisdiction like France, which, in the $19^{\text {th }}$ century (and, to a large extent, even now), did not make use of "discovery" mechanisms. ${ }^{50}$

A fault-based system where proof of fault is required sacrifices at its margins some categories of victims who will not be able to prove their case even if the defendant is at fault. Reversing the burden of proof ensures that all worthy victims receive compensation. However, within a

\footnotetext{
45 Supra Chapter II Part C.

${ }^{46}$ For a general, but not very detailed, overview see supra Chapter II Parts C.1 \& C.2. The evolution of liability for things is perhaps the most illuminating in this regard, and the slow move from fault-based to presumed fault and then no-fault in the case law of the French Court of Cassation is very well-presented in F.H. LAWSON \& BASIL S. MARKESINIS, 1 TORTIOUS LiABILITY FOR UNINTENTIONAL HARM IN THE COMMON LAW AND THE CIVIL LAW 148-152 (Cambridge University Press 1982).

${ }^{47}$ Franz Werro et al., supra note 17, at 28.

${ }^{48}$ In Belgium, the liability of parents, teachers, and artisans are still based on rebuttable presumptions of fault (art. 1384 subs. 2 and 4 of the Belgian Civil Code). Herman Cousy \& Dimitri Droshout, Belgium, in UnIFICATION OF TORT LAw: Strict Liability 43, 46 (B.A. Koch \& H. Koziol eds., Kluwer Law International 2002).

${ }^{49}$ See GENEVIÈVE VINEY, INTRODUCTION À LA RESPONSABILITÉ 26-28 (3 ${ }^{\text {rd }}$ ed., L.G.D.J. 2008); FABRE-MAGNAN, supra note 40 , at $62-63$.

${ }^{50}$ See Emmanuel Hayaux du Tilly et al., France, in 2 EUROPEAN Civil PraCTICE $139,164, n^{\circ} 51.078$ ( $2^{\text {nd }}$ ed., Alexander Layton et al. eds., Thomson/Sweet \& Maxwell 2004).
} 
normative framework where liability is still justified only by the concept of fault, it sacrifices some categories of defendants who might not be at fault and are unable to rebut the presumption set against them.

In England, the solution of reversing the burden of proof in negligence cases is quasi-inexistent. A legal system that had a very advanced system of discovery in place, and which did not care much about foundational unity in its law of torts, evolved rules of negligence and strict liability independently, at least for the most part. There is, however, a doctrine that operates within the tort of negligence and has a very similar function and effect to the Continental fault-based rules with a reversed burden of proof: the doctrine of res ipsa loquitur. Res ipsa loquitur (translated as "the thing speaks for itself") is a doctrine that allows judges to infer negligence from the circumstances in which the accident occurred. ${ }^{51}$ Based on the presumption that "certain happenings do not usually occur in the absence of negligence", 52 res ipsa loquitur allows for inferences of negligence mainly in situations where the means by which the damage was inflicted were under the defendant's sole control, or where, at a first glance no other explanation than negligence on the part of the defendant seems likely. ${ }^{53}$ It is possible for the defendant to displace the inference of negligence that res ipsa loquitur creates by offering evidence backing up an explanation that is consistent with due care. ${ }^{54}$ It cannot be said that the burden of proof shifts from the claimant to the defendant ${ }^{55}$ because the presumption of negligence is born out of facts and circumstances that make negligence very likely, and which by themselves still need to be proven. Consequently, it is less likely that a no-fault case would slip through the cracks by comparison to the scenarios where a veritable presumption of fault is at play, but nonetheless such slippages are still theoretically possible.

\section{De jure Strict Liability or "Liability regardless of Fault"}

Liability "regardless of fault", where considerations regarding the defendant's fault are never brought up by any of the parties to a case, are from a lawyer's perspective truer forms of strict liability (de jure forms of strict liability). But before we taxonomize these rules further, we should first ask if "irrespective of fault" means the same thing in the two jurisdictions we are

\footnotetext{
${ }^{51}$ PEEL \& GOUdKAMP, supra note 5, at 159.

52 Roe v Minister of Health, [1954] 2 Q.B. 66, at 87 (per Morris L.J.).

${ }^{53}$ SimOn DEAKIn ET AL., MARKESINIS AND DEAKIN's TORT LAW 182 ( $5^{\text {th }}$ ed., Oxford University Press 2003$)$.

${ }^{54}$ Henderson v Henry E Jenkins \& Sons [1970], A.C. 282, at 310 (per Lord Pearson).

${ }^{55}$ PEEL \& GoudKAMP, supra note 5, at 160; Ng v Lee, [1988] R.T.R. 296.
} 
analysing. In other words, does the French concept of strict liability differ from the English concept of strict liability?

If we take for granted that the essential characteristic of all the rules included in the category of strict liability is the absence of the element of fault in determinations of liability, their similarity across jurisdictions depends on what various legal systems make of the concept of fault. And indeed, it does seem that the core characteristics of the concept of fault are similar, at least across the two jurisdictions we are comparing. While there are certain minor differences between fault in England and fault in France, ${ }^{56}$ from a bird's eye view, there seems to be a core common understanding of fault: as an act of a person that is wrongful due to the lack of care, judged under an objective standard (bonus pater familias in France, or a reasonable person in England). ${ }^{57}$

At the most fundamental level then, not inquiring into fault means not making any judgments about the behaviour of the defendant (and therefore not making a comparison between the behaviour of the defendant and an ideal standard of behaviour).

The French legal system relies heavily on rules of liability which do not look into the behaviour of the defendant. De lege lata, the rules in the Civil Code on liability for things [art. 1242(1) (former art. 1384 (1))], liability for other persons [art. 1242(1) (former art. 1384 (1))], liability for animals [art. 1243 (former art. 1385)], liability for dilapidated buildings [art. 1244 (former art. 1386)], liability of parents for their minor children [art. 1242(4) (former art. 1384(4))], liability of employers for their employees [art. 1242(5) (former art. 1384(5))], liability of artisans for the apprentices they instruct [art. 1242(6) (former art. 1384(6))], and liability for defective products [arts. 1245 to $1245-17$ (former arts. 1386-1 to 1386-18)] are all free of any consideration of the defendant's fault. ${ }^{58}$ Liability in nuisance is also strict in the same sense. ${ }^{59}$ Outside the Civil Code, strict liability rules can be found in the areas of liability for traffic accidents, work accidents, mining, damage caused by aircraft, nuclear vessels, nuclear installations, cable cars, damage

\footnotetext{
${ }^{56}$ See the discussion supra in footnotes 36 and 37, regarding the liability of children, the elderly, the mentally ill and those suffering from a physical impairment, injury, or illness.

${ }^{57}$ See supra the discussions regarding fault-based liability in Chapter II Part B, Chapter III Part A.4, and in Part A of this chapter.

${ }^{58}$ See supra Chapter II Parts C.1, C.2 and C.3.

${ }^{59}$ See supra Chapter II Part C.4.
} 
caused by mandatory vaccination, medical accidents, and a number of special statutes dealing with specific nuisances and environmental liability in general. ${ }^{60}$

Although England has comparatively fewer strict liability rules than France, a close look reveals an impressive number: the rule in Rylands $v$ Fletcher, the tort of nuisance, the vicarious liability of employers for the acts of their employees, liability for defective products (Part I of the Consumer Protection Act), some forms of breach of non-delegable duty and breach of statutory duty, liability for dangerous species of animals, trespass to land, conversion, and a few statutory torts (section 74 of the Harbours, Docks and Piers Clauses Act 1847, the Carriage by Air Act 1961, the Nuclear Installations Act 1965, the Merchant Shipping Act 1995, and the Environmental Damage Regulations 2009). ${ }^{61}$

The fact that liability rules are best analysed on a spectrum is also true for the rules of strict liability analysed here. Some liability rules are stricter than others. The inventory of the various strict liability rules in France and England we have made so far reveals a very eclectic set, and it is not easy to place these rules on such a spectrum. However, if one were to go over the elements of each rule, there is (1) a common pattern, a common physiognomy of strict liability rules to which we can identify two meaningful exceptions: (2) liability without causation, and (3) strict liability without certain traditional defences like contributory negligence or force majeure ("absolute" liability rules). ${ }^{62}$ Both exceptions make liability stricter than it is in typical situations, and it may even be possible to combine liability without causation with strict liability without the traditional defences of contributory negligence and force majeure, the best example being the rules of the French loi Badinter on liability for road-traffic accidents.

\section{The ideal type}

The ideal type or archetypical form of (de jure) strict liability is encompassed in rules which are not grounded in fault, do not require proof of fault, and do not allow for a "no fault" defence on the part of the defendant. In other words, these are rules where the defendant's fault is

\footnotetext{
${ }^{60}$ See supra Chapter II Part D.

${ }^{61}$ See supra Chapter III Part B.

${ }^{62}$ The list could, of course, be further extended to other atypical situations that cross over the fault-strict liability divide. For instance, a number of torts are actionable per se (e.g. battery, assault, or trespass to land), and that means that liability in such cases may occur even in the absence of quantifiable damage.
} 
simply not a consideration. However, the claimant's own fault may be a relevant consideration, and most often it is accepted as a valid defence.

The archetypical form of strict liability relies on the requirements of causation and damage, just as in the case of fault liability, but replaces the element of fault with some other considerations in which the behaviour of the defendant is irrelevant. We can call this element, or set of elements, the strict element. Thus, we can draw an analytical parallel between fault-based liability and the archetypal form of strict liability: fault-based analysis requires investigation into the elements of fault, causation and damage; strict liability typically requires investigation into the strict element, causation, and damage.

\section{Elements of fault-based liability}

Fault $[$ faute $(\mathrm{FR}) /$ duty of care + breach of duty The strict element $(\mathrm{EN})]$

Causation

Damage

\section{Elements of strict liability}

Causation

Damage

A couple of examples may be illuminating as to what the strict element consists of, and how it characteristically replaces fault as an element of analysis.

Let us take liability for defective products as a first example. A producer is liable under the rules governing liability for defective products if he puts a defective product on the market which causes relevant damage to the claimant. The prima facie case is therefore usually broken down into the following elements: the defectiveness of the product at the time it was put into circulation, causation, and damage. ${ }^{63}$ Analysing whether or not the given product is defective substitutes for the fault-based analysis, which would have looked into whether or not the producer's actions were reasonable (by comparison to an objective standard of behaviour). What becomes relevant instead is whether the product was defective, irrespective of the producer's behaviour. Therefore, the

\footnotetext{
${ }^{63}$ It does not make any difference for the elements of liability if we base our analysis on Part I of the Consumer Protection Act or on articles 1386-1 to 1386-18 of the French Civil Code. The basic requirements for liability are identical.
} 
defectiveness of the product is the strict element which must be causally linked to the damage suffered by the claimant. In a society that relies on mass production, a certain number of defective products is unavoidable, but nevertheless a manufacturer will be potentially liable for each defective product which causes damage. To take a simplistic example, let us say, for instance, that the defendant in a product liability case is a manufacturer producing ten thousand units of vacuum cleaners per year, and on average five of his units every year are found to be defective. Let us also suppose that it can be shown at trial that the defendant is the most careful manufacturer on the market, having taken extraordinary steps to minimize defects in his products. All the other otherwise prudent companies are averaging ten units of defective products of the same type relative to the same number of units produced (ten thousand). Based on such facts, under a fault-based rule it would be reasonable to conclude that the first manufacturer acted reasonably, and has taken reasonable precautions, and under a fault-based rule the manufacturer would not be liable. However, the degree of care taken by a manufacturer is irrelevant in strict product liability cases. The wrong, if any, lies within the product itself, and not in the manufacturer's behaviour. As long as the product is characterized as defective, and the defective product causes damage, it matters very little that the producer acted reasonably. The producer will be liable for any damage caused by any of his five defective products. However, if he can show that the product used by the claimant was not defective (when it was put into circulation), then the manufacturer will escape liability.

Other strict liability torts can be analysed in a similar manner. For the law of nuisance, the strict element is that of "unreasonable use" (England) or "abnormal use" (France) of land; for the rule in Rylands v Fletcher it is "non-natural use of land"; in the case of liability for things (France) it is the "act of a thing" (when the thing is actively used) or its "abnormal characteristics" (when it is passive); in the case of liability for animals the strict element is the act of the animal; the dilapidated state of a building in the case of liability for buildings; and the list can go on. In vicarious liability cases, the strict element consists of the existence of a certain kind of relationship (employer-employee, parent-child, artisan-apprentice, etc.), to which sometimes a second element is added, which narrows down the circumstances in which the actions of the primary tortfeasor are relevant (in the case of the liability of employers for the acts of their employees, only acts which occurred "in the course of employment" trigger the vicarious liability rule). For the loi Badinter, the strict element is simply the occurrence of a road traffic accident involving at least one motor 
vehicle. ${ }^{64}$ For each strict liability regime, there is at least one element which replaces fault, thus narrowing down what kind of considerations allow a shift from the victim to some other person of the legal responsibility for the harm that occurred.

The vast majority of existing strict liability regimes fit the three-part model consisting of a strict element (or elements), causation, and damage. The strictness of a liability rule, however, also depends on the available defences, and it is useful to identify what the typical defences are in strict liability cases. More often than not, final determinations of liability also take into consideration the plaintiff's own sphere of responsibility, and that is why typically the fault of the victim is a valid defence. Also, the defendant can usually defend by showing that the damage was a result of force majeure (thus denying that there is causation between the strict element and the claimant's damage).

Not all strict liability rules follow this ideal model. Derogations from the ideal type can be found in relation to both prima facie elements and available defences. The following sections will discuss these deviations, first by looking in subsection 2 at strict liability regimes which do not rely on causation and then in subsection 3 at strict liability regimes with more limited defences.

\section{Strict liability regardless of causation}

It is frequently assumed that no responsibility, and especially no legal responsibility, can be attached to a person in the absence of causation. ${ }^{65}$ However, a closer and more careful look into

\footnotetext{
${ }^{64}$ If it can be shown that the accident was intentionally caused by one of the drivers, recovery will be based on article 1240 (former 1382) of the Civil code. See Article 1 of Loi no 85-677, 5 July 1985 tendant à l'amélioration de la situation des victimes d'accidents de la circulation et à l'acceleration des procédures d'indemnisation, JO 6 July 1985, p. 7584 ; LE TOURNEAU ET AL., supra note 40, at 2033-35, nº 8070.

${ }^{65}$ See,e.g., Marta Infantino \& Eleni Zervogianni, The Place and Space of Causation, in CAuSATION IN EuROPEAN TORT LAW 3 (Marta Infantino \& Eleni Zervogianni eds., Cambridge University Press 2017): "No matter what the legal system, no matter what the ground for litigation, it is a firm tenet of tort law that there can be no liability without causation. The success of a plaintiff's claim is always said to be dependent upon whether, and to what extent, a causal link is established between the defendant's activity and the plaintiff's loss." Mauro Bussani \& Marta Infantino, Tort Law and Legal Cultures, 63 AM. J. ComP. L. 77 (2015): "It is a general rule, valid everywhere, that liability in tort requires (proof of) causation"; A. M. Honoré, Causation and Remoteness of Damage, in 11 InTERNATIONAL ENCYClOPEDia OF COMPARATIVE LAW, TORTS [Ch.7], at 7 (André Tunc ed., J.C.B. Mohr (Paul Siebeck) \& Martinus Nijhoff Publishers 1983) (see also the literature cited by Honoré in his footnote 47).

See also Michael S. Moore, Causation and Responsibility: An EsSay in LaW, Morals, and Metaphysics 3 (Oxford University Press 2009); Judith Jarvis Thomson, Remarks on Causation and Liability, 13 PHILOSOPHY \& PUBLIC AFFAIRS 101 (1984) (Moore only states explicitly that "causation matters to legal liability", so it might seem unfair to attribute to him the stronger statement that he assumes that there is a need for causal inquiries in all liability determinations; however, his overall rhetoric seems to imply that causation plays an essential role in most, if not all,
} 
legal practice will show that some persons may be held liable even in the absence of causation, or that causation may be replaced in some circumstances with other less stringent concepts.

The most important liability regime that operates in the absence of causation is vicarious liability. ${ }^{66}$ This is a form of liability for another. Vicarious liability attaches legal responsibility to a person not due to a causal link between that person's acts and the damage suffered by the victim, but because of the relationship the defendant shares with another person who caused the damage. For France and England, the vicarious liability of employers for the acts of their employees operates in an almost identical manner, and in both cases liability is strict and causation is not a requirement. Three requirements must be met in order to trigger an employer's liability: (a) a tort committed by an employee; (b) an employer-employee relationship; and (c) the act of the employee must be committed by him or her in the course of employment. Causation may be a requirement within the first condition because in almost all circumstances an employee is considered to have committed a tort only when his or her acts were the cause of the damage suffered by the victim. However, the liability of the employer is born simply by virtue of the relationship between the employer and the tortfeasor and of the circumstances in which the tort was committed (in the course of employment). None of these conditions imply the existence of an act on the part of the employer which is causally effective.

One possible way of salvaging the notion of causation is by moving the normative inquiry further into the past. One might argue that the employer did act at some point in the past when he hired his employee. ${ }^{67}$ That is indeed (factually) a prior cause, and one might draw a link between the harm suffered by the victim and the distant past act of hiring the primary tortfeasor. This construction is, however, fictitious and unilluminating. In France and England, for the purposes of vicarious liability, the law does not attach any normative significance to the act of hiring a person. ${ }^{68}$

\footnotetext{
judgments of legal responsibility; Thomson, on the other hand, clearly and explicitly argues for the necessity of causation).

${ }^{66}$ See also H. L. A. Hart \& TONy Honoré, CAuSATION In the LAW 85 (2 ${ }^{\text {nd }}$ ed., Oxford University Press 1985, repr. 2002).

${ }^{67}$ The French Court of Cassation dismissed the possibility of basing the liability of employers on their fault in the selection of the employee already at the beginning of the $20^{\text {th }}$ century. Cass. Crim., 20 juin 1924, D.1925.1.94; See also HENRI MAZEAUD ET AL., 1 TRAITÉ THÉORIQUE ET PRATIQUE DE LA RESPONSABILITÉ CIVILE DÉLICTUELLE ET CONTRACTUELLE 1008, $\mathrm{n}^{\circ} 931$ ( $6^{\text {th }}$ ed., Montchrestien 1965)].

${ }^{68}$ In this regard, it is useful to contrast the strict vicarious liability of France and England with the fault liability with a reversed burden of proof regime reflected by section 831 of the German Civil Code, where the act of hiring the employee is normatively relevant, precisely because fault requires reference to the employer's behaviour (according
} 
Factually, many other prior causes might have led to the damage suffered by the victim: for instance, some other employer might have given the employee a first chance and due to this first chance he had the required work experience to be hired by the defendant; or a university might have given the employee a degree that allowed him to apply for the job that linked him with the defendant, etc. All of these prior acts are causes in fact (at least, on the basis of a simple "but for" test) but are normatively insignificant. The employer does not "cause" the victim's injury in any legally significant way simply by hiring an employee, the same way the prior employer or the university does not "cause" that same harm. The law inquires only into the existence and quality of the employer-employee relationship, not into the existence or quality of the prior act of hiring the employee. The act of hiring the employee is therefore not relevant for the determination of the employer's liability. Of course, in order for such a relationship to exist, it must have been forged sometime in the past, but that past moment is irrelevant from a normative perspective. The relevant moment for the attribution of liability is the moment when the tortious act of the employee was committed. All the elements of liability are analysed at that moment and that moment only. The person causing the victim's damage must have been an employee at that moment and must have been operating in the course of his employment at that time.

Although in England the only form of vicarious liability is the liability of employers for the acts of their employees, the French legal system, while sharing a similar approach to the liability of employers for the acts of their employees, ${ }^{69}$ knows three other vicarious liability regimes.

The first such regime of vicarious liability is the general vicarious liability rule recognized in the Consorts Blieck case ${ }^{70}$ on the basis of article 1384(1) of the French Civil Code. This general vicarious liability norm is based on the relationship between a person who accepts to permanently "organize, direct and control" "1 the life of another and that other person. No act on the part of the

to $\S 831 \mathrm{BGB}$, the employer can defend by proving that he exercised reasonable care in the selection and supervision of the employee). See Christian VON BAR, 1 THE COMMON EUROPEAN LAW OF TORTS 198, 202-07 [nos 179-80, 185-90] (Oxford University Press 1998); vAN DAM, supra note 4, at 502.

${ }^{69}$ While the conditions for liability are identical, it is important to note, however, that in France the employees are immunized from liability. Thus, when an employee commits a tort within the scope of the functions attributed to him through his employment, in England the victim can recover from both the employer and the employee, and the employer has a recursive action against the employee, while in France the employer alone is liable, and no recursive action is allowed.

${ }^{70}$ Cass. Ass. Plén., 29 March 1991, no 89-15.231, Bull. ass. plén., no 1; D.1991.324, note Larroumet; Somm. 324, obs. Aubert; JCP 1991.II.21673, concl. Dontenwille, note Ghestin; Gaz. Pal. 1992.2.513, obs. Chabas; RTD civ. 1991.312, note J. Hauser; RTD civ. 1991.541, note Patrice Jourdain.

${ }^{71}$ Id. 
vicariously liable person is required in order for liability to ensue. The case law looks only at the act of the person under supervision and at the quality of the relationship between that primary tortfeasor and the person or institution organizing, directing and controlling the life of the primary tortfeasor.

A second noteworthy rule of vicarious liability that exists in France, but not in England, is the liability of parents for the acts of their minor children. ${ }^{72}$ The Bertrand case $^{73}$ made it abundantly clear that the liability of parents for the acts of their children is based on the relationship between them, and not on any pre-existing fault in supervision or education. Also, the jurisprudential tendency to relax the condition of co-habitation between the parent and the minor child who caused injury to the victim, and to analyse it in abstracto $^{74}$ (the mere possibility of co-habitation being sufficient), proves that the relationship between the parent and the minor child is the essential element for liability, and the co-habitation requirement is but a relic of the past.

Lastly, the liability of artisans for the acts of the apprentices they mentor ${ }^{75}$ may be added to the list, although this liability regime has almost no practical importance nowadays. The legal regime of this form of liability is assimilated into the liability of parents for their minor children, ${ }^{76}$ and thus the argument made for the liability of parents applies mutatis mutandis.

All forms of vicarious liability, whether we are speaking of the French and of the English liability of employers for the acts of their employees, or the general rule of vicarious liability (which only exists in France), the liability of parents for their minor children or the liability of artisans for their apprentices (also only exists in France), share the characteristic that they do not require an act or an omission on the part of the vicariously liable person. Consequently, liability in such cases follows in the absence of causation and is based on the relationship between the vicariously liable person and the primary tortfeasor.

\footnotetext{
${ }^{72}$ See a more detailed presentation of this liability regime supra in Chapter II Part C.2.b.

${ }^{73}$ Cass. Civ. 2e, 19 February 1997, Bull. civ. II, no 56; D.1997.265, note Patrice Jourdain; JCP.1997.II.22848, concl. R. Kessous, note Geneviève Viney; Gaz. Pal., 3 October 1997, note François Chabas (arrêt Bertrand). ${ }^{74}$ Geneviève Viney ET AL., TRAité DE DROIT CIVIL. LeS CONDITIONS DE LA RESPONSABILITÉ $1196, n^{\circ} 876$ ( $4^{\text {th }}$ ed., L.G.D.J. 2013).

${ }^{75}$ Presented in more detail supra Chapter II Part C.2.c.

${ }^{76}$ VINEY ET AL., supra note 74, at 1222, no 893.
} 
A second set of liability rules which are not premised on a strict notion of causation are the liability rules of the loi Badinter. ${ }^{77}$ There is a significant difference, however, between vicarious liability and liability for road traffic accidents (in France) when it comes to the absence of causation. If for vicarious liability causation is simply not a consideration, the inquiry being focused on the relationship between the person responsible and the person who can properly be said to have caused the damage, causation in the case of the loi Badinter is replaced by a concept which resembles causation, but is looser, thus allowing for broader ascriptions of liability. The operative element replacing causation is the "involvement of the vehicle" in the accident (implication du véhicule). ${ }^{78}$ In practice, this means that the driver or owner of a vehicle can be held liable even if the vehicle was stationary, ${ }^{79}$ correctly parked ${ }^{80}$ or was in the proximity of the victim at the time of the accident, even if there was no contact, as long as the vehicle played some kind of active role in the accident. ${ }^{81}$ Moreover, force majeure and the act of a third party are not valid defences for the driver or keeper when it is established that the vehicle was involved in the accident. ${ }^{82}$ Thus, the involvement of a vehicle as an element of liability cannot be countered by showing that someone else or an act of nature was the actual cause of the accident, as would be the case if liability were premised on causation.

Another interesting and controversial example from French law of liability absent causation is the solution in the well-known Perruche case. ${ }^{83}$ The Perruche case was a wrongful life case (or, in

\footnotetext{
${ }^{77}$ Loi n ${ }^{\circ}$ 85-677 du 5 juillet 1985 tendant à l'amélioration de la situation des victimes d'accidents de la circulation et à l'accélération des procédures d'indemnisation, JORF du 6 juillet 1985, p. 7584.

${ }^{78}$ LE TOURNEAU ET AL., supra note 40, at 2045-46, $\mathrm{n}^{\text {os }} 8102-03$.

${ }^{79}$ Cass. Civ. 2e 17 June 1990, RTD civ. 1990. 507, obs. Patrice Jourdain.

${ }^{80}$ Cass. $2^{\text {e }}$ Civ., 23 March 1994, D. 1994.299, comm. Hubert Groutel; RTD civ. 1994. 627, obs. Patrice Jourdain; Cass. $2^{\mathrm{e}}$ Civ., 25 January 1995, Bull. civ. II, no. 27; RTD. Civ. 1995. 382, obs. Patrice Jourdain; Cass $2^{\mathrm{e}}$ Civ., 12 June 1996, D. 1996 IR 175.

${ }^{81}$ Cass. $2^{\text {e }}$ Civ., 3 October 1990, RTD civ. 1991. 354, obs. Patrice Jourdain; Cass $2^{\text {e } ~ C i v ., ~} 8$ June 1994, Bull. civ. II, no. 147; D. 1994 IR 181; Cass 2e civ., 13 January 1997, JCP 1997.II.22883.

${ }^{82}$ Art. 2 of Loi n ${ }^{\circ} 85-677$ du 5 juillet 1985, supra note 77 : "Les victimes, y compris les conducteurs, ne peuvent se voir opposer la force majeure ou le fait d'un tiers par le conducteur ou le gardien d'un véhicule mentionné à l'article ler." (The defences of force majeure or the act of a third party cannot be raised by the driver or the keeper of a vehicle mentioned in article 1 against the victim, even if the victim is a driver.)

${ }^{83}$ Cass. Ass. Plén., 17 November 2000, pourvoi no 99-13.701, Bull. civ. 2000, JCP G 2000, II, 10438, concl. SainteRose, rapp. P. Sargos, note F. Chabas ; D. 2001, 332, note D. Mazeaud; D. 2001, 336, note P. Jourdain.
} 
other words, a case of "prenatal harm" ${ }^{\text {} 84}$ ), hotly debated in the French ${ }^{85}$ and international media, ${ }^{86}$ as well as the legal literature of the time. ${ }^{87}$ Procedurally, the case was a jurisprudential saga that went on for eight years until it was finally decided by the Plenary Assembly (Assemblé plénière) of the Court of Cassation. ${ }^{88}$ The facts of the case were as follows: in 1982, one of the plaintiffs in the case, Josette Perruche, had reasons to believe she had contracted rubella (also known as the German measles) from her four-year-old daughter. Josette was at that time one month pregnant. Knowing that her unborn child might suffer from birth defects if she was indeed infected with rubella, Josette underwent testing at a local hospital. She explained to her physician that if she was infected with rubella, due to the risk of giving birth to a child suffering from a severe handicap, she would opt for interrupting her pregnancy. Her physician negligently misinterpreted the results of her two blood tests, and informed Josette that she had not contracted the disease and her son was safe. On 14 January 1983, Nicholas Perruche was born. He came into the world deaf, partially blind, suffering from heart problems, and with significant mental retardation.

What makes the case interesting from the perspective of causation is the fact that the physician who misinterpreted the results was held liable towards the child, in solidum with the laboratory and their insurers, even though the child would have been born with the same handicap had the doctor not been negligent in interpreting the results. The only other causal alternative would have

\footnotetext{
${ }^{84}$ See VAN DAM, supra note 4, at 198.

${ }^{85}$ See e.g. Jacques Julliard, Ne ricanons pas!, Le Nouvel ObSERVATEUR, 23 November 2000 ; Catherine LabrusseRiou et al., La vie humaine comme prejudice?, LE MONDE, 24 November 2000; Jean-Yves Nau, Le préjudice de vivre, LE MONDE, 26 November 2000; Denys de Bechillonet et al., L'arrêt Perruche, le droit et la part d'arbitraire, LE MONDE, 21 December 2000.

${ }^{86}$ Marlise Simons, French Uproar Over Right to Death for Unborn, New York Times, available online at http://www.nytimes.com/2001/10/19/world/french-uproar-over-right-to-death-for-unborn.html? _r=0

87 Gérard Mémeteau, L'action de vie dommageable, JCP 2000.II.279; Geneviève Viney, Brèves remarques à propos d'un arrêt qui affecte l'image de la justice dans l'opinion, JCP 2001.I.286; Michelle Gobert, La Cour de cassation méritait-elle le pilori?, PetiTtes AfFiches, at 4 (8 December 2000); Laurent Aynès, Préjudice de l'enfant, né handicapé : la plainte de Job devant la Cour de cassation, D.2001.492 ; Jean-Luc Aubert, Indemnisation d'une existence handicapée qui, selon le choix de la mère, n'aurait pas dû être, D.2001.489; François Terré, Le prix de la vie, JCP 2000, Act., at 2267; Yves Saint-Jours, Handicap congénital - Erreur de diagnistie prenatal - Risque thérapeutique sous-jacent, D.2001.1263; Pierre Kayser, Un arrêt de l'Assemblée plénière de la Cour de cassation sans fondement juridique?, D.2001.1889; Yvonne Lambert-Faivre, La réparation de l'accident médical, obligation de sécurité : oui ; aléa thérapeutique : non, D.2001.570; Basil Markesinis, Réflexions d'un comparatiste anglais sur et à partir de l'arrêt Perruche, RTD civ. 77 (2001).

${ }^{88}$ The case was first decided by the Tribunal de grande instance of Évry. The decision of the first instance court went through appeal at the Court of Appeals in Paris, and then cassation by the first chamber of the Court of Cassation (Cass. 1re civ., 26 March 1996, no 94-11.791 94-14.158, Bull. civ. 1996). The Court of Cassation sent the case back to the Court of Appeals of Orleans, which resisted the decision of the first chamber of the Court of Cassation. It was after this second decision by the Court of Appeals of Orleans that the case was brought before the Plenary Assembly of the Court of Cassation. Julia Field Costich, The Perruche case and the issue of compensation for the consequences of medical error, 78 HEALTH POL'Y 8, 11 (2006).
} 
been an early abortion, which the mother could have decided to undertake had she been correctly informed. By allowing the child's claim, the highest French court departed significantly from the core meaning attributed by French law to the concepts of causation and damage, and many authors reacted critically to the decision. ${ }^{89}$ The critiques were justified, and were endorsed a couple of years later by the French legislature, which enacted a bill that retroactively ${ }^{90}$ disavowed the solution of the Perruche case..$^{91}$ The same bill created a mandate for the implementation of a compensation system for children born with a handicap based on national solidarity, ${ }^{92}$ and that might have been what the Court of Cassation wanted all along. ${ }^{93}$ The Perruche case highlighted the inadequacy of the existing social security measures aimed at providing care to citizens suffering from very serious disabilities. ${ }^{94}$ Nevertheless, living up to its own mandate proved challenging for the French legislature. The new compensation system was created only in $2005^{95}$ and it only covers the most basic needs (and significantly less than what the tort law system would have provided in terms of compensation).

The Perruche case demonstrates that liability absent causation can also be associated with a faultbased rule. The fault of the doctor and of the laboratory he worked for were essential for the

\footnotetext{
${ }^{89}$ Mémeteau, supra note 87; Aubert, supra note 87; Terré, supra note 87 ; Saint-Jours, supra note 87; see also Brigitte Feuillet, The Perruche Case and French Medical Liability, 4 DreXel Law Rev. 139 (2011).

${ }^{90}$ The retroactivity of the "anti-Perruche" bill created further complications. After two condemnations by the European Court of Human Rights (ECHR, 6 October 2005, Maurice v France, no 11810/03; (2005) 42 EHRR 885; ECHR, 6 October 2005, Draon v France, no 1513/03) and a decision of the Constitutional Court (Cons. const., 11 June 2010, n² 2010-2 QPC, JORF, p.10847; D. 2010., 1976, obs. I. Gallmeister, note Daniel Vigneau, D. 2010, 1980, note Valérie Bernaud et Laurence Gay; D. 2011, 2565, obs. Anne Laude; RTD civ. 2010, 517, obs. Pascal Puig), the Court of Cassation finally settled on the rule that children born before the enactment of the "antiPerruche" law are entitled to compensation in tort, whereas children born after 7 March 2002 are not. Cass. 1re civ., 15 December 2011, D. 2012, 297, note Nicolas Maziau; D. 2012, 323, note I. Gallmeister.

${ }^{91}$ Loi 2002-303 du 4 mars 2002 relative aux droits des malades et à la qualité du système de santé, JORF du 5 mars 2002, p. 4118, Art. 1 (I).

${ }^{92} \mathrm{Id}$. at art. 1 (II) and (III).

${ }^{93}$ An interesting phenomenon can be observed in French judicial and parliamentary practice that can only be described as a form of subtle (and somewhat passive-aggressive) dialogue. The Court of Cassation is usually very protective of the French doctrinal system, guarding its integrity and guiding all lower courts towards coherent interpretations of legal doctrines. So, when the Court of Cassation makes such bold moves as in the Perruche case, one can reasonably interpret this departure from usual practice as a cry for reform. Jean-Luc Aubert was the first to point out this subtle form of dialogue as applied to the reform of road traffic liability. Before the law of 15 July 1985 (supra note 77), the Court of Cassation forced the hand of the legislature to intervene in the area of traffic accidents through its decision in the Desmares case. See Cass. Civ. 2e, 21 July 1982, D. 1982. 449, concl. Charbonnier, note Larroumet ; JCP 1982. II. 19861, note Chabas; Defrénois 1982. 1689, obs. Aubert ; RTD civ. 1982. 607, note G. Durry; Jean-Luc Aubert, L'arrêt Desmares: une provocation... à quelles réformes?, D. 1983 Chron. 1.

${ }^{94}$ Feuillet, supra note 89 , at 145.

${ }^{95}$ Loi 2005-102 du 11 février 2005 pour l'égalité des droits et des chances, la participation et la citoyenneté des personnes handicapées, JORF du 12 février 2005, p. 2353.
} 
ascription of responsibility. Nevertheless, because the fault identified in this case was not causally linked to the damage suffered by the claimant, one may reasonably conclude that the liability rule created by the Court of Cassation is a strict liability rule, and as a strict liability rule, it is perhaps the strictest liability rule we know of. Causation in this case is not replaced by a looser notion like "implication", or by a special type of relationship. It is simply absent.

It is true that the life of the liability rule from Perruche was short-lived in France due to the legislature's intervention. From a comparative perspective, however, discussing the Perruche decision is still relevant and important. At least in one other jurisdiction, the highest court has reached the same conclusion and adopted a rule similar to the one affirmed by the French Court of Cassation in the Perruche case, without being reversed by the legislature, and that jurisdiction is the Netherlands. The Dutch Supreme Court decided in a very similar case (the baby Kelly case) that a child born with a handicap does have a cause of action against the negligent doctors who misdiagnosed the mother while she was pregnant. ${ }^{96}$ It should be noted, however, that the Dutch example is rather singular, and other European legal systems having refused to create a cause of action for a child in such circumstances. The German Supreme Court, for instance, denied a child's claim because to do so would violate his human dignity (the reasoning being that to recognize his damage would imply that a life lived with a severe handicap is a worse condition than being dead), ${ }^{97}$ and in a similar but much older English case, the child's claim was dismissed because the judges did not consider it just to create a duty of care for the doctors towards the child in such circumstances. ${ }^{98}$

Finally, there is one strict liability rule which escapes not only the requirement of causation, but also that of damage. The English tort of trespass to land is a strict liability tort where the plaintiff is not required to show anything other than the fact that the defendant entered his land without authorization. As already discussed in Chapter III, ${ }^{99}$ trespass sanctions any unjustifiable

\footnotetext{
${ }^{96}$ HR 18 March 2005, ECLI:NL:HR:2005:5213, NJ 2006/606 (baby Kelly); See also Ivo Giesen, The Use and Influence of Comparative Law in Wrongful Life Cases, 8:2 UtRECHT LAW REvIEW 35 (2012). Marc A. Loth, Corrective and Distributive Justice in Tort Law. On the Restauration of Autonomy and a Minimal Level of Protection of the Victim, 22:6 MAASTRICHT JOURNAL OF EUROPEAN AND COMPARATIVE LAW 788, 790 (2015). ${ }^{97}$ BGH 18 January 1983, ENTSCHEIDUNGEN DES BUNDESGERICHTSHOF IN ZIVILSACHEN 86, 240; See also BASIL S. MARKESINIS \& HANNES UnBerath, THE GERMAN LAW OF TORTS: A COMPARATIVE TREATISE 156-163 (Hart Publishing 2002).

${ }^{98}$ McKay and Another v Essex Area Health Authority [1982] 2 All ER 771 (CA).

${ }^{99}$ Supra Chapter III Part B.9.
} 
interference with the possession of land, ${ }^{100}$ and what is considered unjustifiable is: (a) any voluntary act of interference that is direct; and (b) any involuntary act of direct interference that is caused by the defendant's prior negligence. In the case of voluntary acts of interference, the form of intent required is the intent to enter upon land or otherwise interfere with the possession of the plaintiff's land. ${ }^{101}$ As to involuntary acts of interference, it is possible to hold a defendant liable for trespass even though their entry upon land is involuntary, if the entry is a consequence of a prior negligent act. ${ }^{102}$ Trespass is actionable "per se," which means that no proof of damage is required. ${ }^{103}$ In addition, seeing how damage is not a requirement, there is also no need to show a causal link since there is nothing to link the defendant's act to. The act of entry upon land is all that is required in order for the plaintiff to make his prima facie case. Of course, only unjustified entry upon land will constitute trespass, but it is in the realm of defences that justifications such as consent, or adverse possession, properly belong.

What all the examples discussed above show is that the strictness of liability may be fine-tuned by fiddling with prima facie elements, and the element that seems most susceptible to being modified or replaced is the element of causation. The same effect may also result from changes made to the list of available defences, and to this problem we now turn our attention.

\section{Strict liability with limited defences}

We have already seen that the ideal type for strict liability rules can typically be broken down, prima facie, into the following elements: "the strict element", causation, and damage. The cumulative operation of these prima facie elements provides reasons which, absent any countervailing reasons to the contrary, allow to shift responsibility for the harm suffered by the claimant onto the defendant. The formulation of such countervailing reasons takes the form of

\footnotetext{
${ }^{100}$ PEEL \& GOUDKAMP, supra note 5, at 427.

${ }^{101}$ There are various ways of committing a trespass other than physically entering onto someone's property. See Lavender v Betts, [1942] 2 All ER 72 (removing doors and windows); Rashid v Sharif, [2014] EWCA Civ 377 (rebuilding a shared wall); Westripp v Baldock, [1938] 2 All ER 779 (affd [1939] 1 All ER 279) (placing a ladder against a wall); Simpson v Weber, (1925) 133 LT 46 (driving nails into a wall); Beckwith v Shordike, (1767) 4 Burr 2092 (encouraging a dog to run onto a person's land); British Waterways Board v Seven Trent Water, [2002] Ch. 25 (CA) (discharging water into the flowing watercourse of the claimant).

${ }^{102}$ If, following a car accident, the defendant entered land adjoining the highway, and the claimant proves that the defendant was negligent in so doing, the defendant will be liable for trespass. PEEL \& GoUDKAMP, supra note 5, at 428. Similarly, the owner of a pack of hounds may be held liable in trespass when, knowing that there was a real risk that the hounds would enter the claimant's land, he failed to exercise proper control over his hounds. League Against Cruel Sports v Scott, [1986] Q.B. 240, 252 (per Park J).

${ }^{103}$ PeEl \& GoudKamp, supra note 5, at 428.
} 
legally recognized defences, and the strictness of a liability regime depends just as much on the type and number of defences as it does on the prima facie elements.

The list of available defences differs among the various strict liability rules, but there is, once again, a common pattern. Most strict liability rules allow two defences which counter the prima facie element of causation: contributory negligence and force majeure. All vicarious liability rules we have identified (in both France and England), the liability for the acts of things (France), as well as the narrower rules on liability for the acts of animals and for dilapidated buildings (France), the rules governing the law of nuisance (in both France and England), breaches of non-delegable duties and probably all forms of breach of statutory duty (England), as well as the liability for defective products (in both France and England), follow this pattern.

For most of these strict liability rules, the defences of contributory negligence and force majeure are also the only recognized defences. The law of product liability is, however, a significant exception. The Product Liability Directive ${ }^{104}$ lists a number of defences in article 7 which relate to the strict element (the defectiveness of the product at the time it was put into circulation). Thus, when the producer did not put the product into circulation [art. 7(a)], when it is probable that the defect did not exist at the time when the product was put into circulation, or that the defect came into being at a later stage [art. 7 (b)], if the product was not manufactured for sale or any form of distribution for economic purposes, nor manufactured or distributed in the course of the producer's business [Art. 7 (c)], or the defect was due to compliance of the product with mandatory regulations issued by the public authorities [Art. 7 (d)], or the state of scientific knowledge was such that the defect could not have been discovered at the time the product was put into circulation (development risk defence) [art. 7 (e)], ${ }^{105}$ the producer can defeat the argument that he should be held accountable because the product in question was defective. With regard to defences related to causation, the contours of causation in product liability claims are, in principle, governed by national law, and therefore the defences to causation should also be found, by default, in national law. Nevertheless, the directive addresses the defences of contributory negligence [art. 8(2)] and

\footnotetext{
${ }^{104}$ Council Directive 85/374/EEC of 25 July 1985 on the approximation of the laws, regulations and administrative provisions of the Member States concerning liability for defective products, OFFICIAL JOURNAL L210, 07.08.1985, at 29-33.

${ }^{105}$ The directive also contains a superfluous defence in art. 7(f): "in the case of a manufacturer of a component, that the defect is attributable to the design of the product in which the component has been fitted or to the instructions given by the manufacturer of the product."
} 
the act of a third party [art. 8(1)]. The directive allows the former as a defence, while disallowing the latter when the act of a third party is a partial cause of the damage. In other words, a producer may avoid or reduce his liability when the damage is caused (at least partly) by the act of the victim or of a person for whom the victim is responsible, as well as in the situation where the damage was caused exclusively by the act of a third party, but not when the damage is caused by both the defective product and the act of a third party. In the latter scenario, the producer and the third party will be solidarily liable, ${ }^{106}$ and the respective rights of recourse will be governed by national law. ${ }^{107}$ Force majeure is not mentioned by the directive or the implementing acts (Part I of the Consumer Protection $\mathrm{Act}^{108}$ or the Law no. 98-389, adopted on 19 May $1998^{109}$ ), but there is doctrinal support for the idea that force majeure is an available defence in product liability cases. ${ }^{110}$

The category of "de facto strict liability" departs from the ideal model of strict liability toward regimes representing the fault paradigm because it allows, in addition to contributory negligence and force majeure, the further defence that the defendant was not at fault (thus rebutting the initial presumption of fault). ${ }^{111}$

Toward the other end of the spectrum, the strictest forms of liability depart from the ideal type by removing the possibility of using one of the typical defences or both. An interesting example is the liability of the keeper of dangerous animals in England under the Animals Act 1971, which supresses the defence of force majeure, but allows defences of contributory negligence. ${ }^{112}$ In France, the liability of the person installing a cable car (whilst the cable car is being installed), and the operator of the cable car (after installation) similarly allows the defence of contributory negligence, ${ }^{113}$ while excluding force majeure. ${ }^{114}$ The same holds true for liability for damage

\footnotetext{
${ }^{106}$ LE TOURNEAU ET AL., supra note 40, at 2140, nº 8450.

${ }^{107}$ Article 8(1) of the Product Liability Directive.

${ }^{108}$ Consumer Protection Act 1987 c. 43.

${ }^{109}$ Loi no 98-389 du 19 mai 1998 relative à la responsabilité du fait des produits défectueux, JORF n 117 du 21 mai 1998 , p. 7744.

${ }^{110}$ LE TOURNEAU ET AL., supra note 40, at 2140, $\mathrm{n}^{\circ} 8452$. For a court decision suggesting the contrary solution (that the list of defences is limited to the defences mentioned in the implementing act), see CA Toulouse, 14 décembre 2004, JCP E 2005 Pan. 926.

${ }^{111}$ Supra Part C of this chapter.

112 Peter North, Civil Liability for Animals 88, s. 2.165 \& 2.166 (Oxford University Press 2012); Nichols v Marsland, (1875) LR 10 Exch 255, 260; Baker v Herbert, [1911] 2 KB 633, 647.

${ }^{113}$ Article 6(2) of Loi du 8 juillet 1941, servitudes de survol au profit des téléphériques, JORF du 27 août $1941, \mathrm{p}$. 3614.

${ }^{114}$ LE TOURNEAU ET AL., supra note 40, at 2101, nº 8302.
} 
caused by aircraft in France ${ }^{115}$ and in England. ${ }^{116}$ Also, in France, under the provisions of the loi Badinter, when both the claimant and the defendant are drivers, the defendant may invoke the contributory negligence of the claimant, but not force majeure. ${ }^{117}$

Other liability regimes do not eliminate the defence of force majeure entirely, but severely limit its sphere of application. For instance, in France ${ }^{118}$ and in England, ${ }^{119}$ the strict liability for oil pollution only allows the defendant to invoke acts of war, hostility or insurrection, as well as exceptional, irresistible and inevitable natural phenomena, the intentional act of a third party, or that the damage was due wholly to the negligence or wrongful act of a government or other authority in exercising its function of maintaining lights or other navigational aids for the maintenance of which it was responsible. ${ }^{120}$

Some liability regimes limit the ambit of both contributory negligence and force majeure, and the best example for such limitations is given by the liability of operators of nuclear installations, who may only invoke in their defence gross negligence ("reckless disregard for the consequences of the act or omission" in England and "faute grave" in France) and the intentional fault of the victim, and may only invoke force majeure events such as acts resulting from armed conflicts, hostilities, civil war, or insurrection. ${ }^{121}$ This excludes acts of negligence which are not sufficiently serious, acts of third parties, as well as any other force majeure events. ${ }^{122}$

Finally, the strictest forms of liability in terms of defences can be found in the loi Badinter, when the victim of a traffic accident (in which a motor vehicle was involved) is a pedestrian, passenger or cyclist. In such cases, the defence of force majeure is not available, and the defence of contributory negligence is severely curtailed, the defendant being allowed only the defence of

\footnotetext{
115 Article L6131-2 of the CODE DES TRANSPORTS (Transport Code).

${ }^{116}$ Section 6 of the Carriage by Air Act 1961, c. 27 (Regnal. 9 and 10 Eliz 2).

${ }^{117}$ One arrives at this solution by corroborating articles 2 and 4 of Loi ${ }^{\circ} 85-677,5$ July 1985 tendant $\grave{a}$

l'amélioration de la situation des victimes d'accidents de la circulation et à l'acceleration des procédures

d'indemnisation, JO 6 July 1985, p. 7584.

${ }^{118}$ LE TOURNEAU ET AL., supra note 40, at 2108, $\mathrm{n}^{\circ} 8325$.

${ }^{119}$ Section 155 of the Merchant Shipping Act 1995, c. 21.

${ }^{120}$ The French and English provisions are based on Article III Sections $2 \& 3$ of the International Convention on Civil Liability for Oil Pollution Damage, 1992, available online at

http://www.iopcfunds.org/uploads/tx iopcpublications/Text of Conventions e.pdf.

${ }^{121}$ For France, see LE TOURNEAU ET AL., supra note 40, at 2179, $\mathrm{n}^{\circ} 8605$; For England see section 13 (4), (4A) \& (7) of the Nuclear Installations Act 1965, c. 57. See also Article 9 of the Convention on Third Party Liability in the Field of Nuclear Energy of 29th July 1960, as amended by the Additional Protocol of 28th January 1964, the Protocol of 16th November 1982, and Protocol of 12th February 2004.

${ }^{122} I d$.
} 
inexcusable fault, if the inexcusable fault of the victim was the sole cause of the accident. ${ }^{123}$ Furthermore, when the victim is under the age of 16 , older than 70 , or was more than $80 \%$ disabled before the accident took place, only the intentional act of the victim is allowed as a defence. ${ }^{124}$

\section{E. A Partial Conclusion}

The intention behind this chapter was to order and taxonomize the various forms of strict liability previously identified in the tort systems of France and England. For this purpose, we first broke down strict liability rules into their constitutive elements (prima facie and defences), and then tried to represent them on a spectrum where all liability rules, including fault-based rules, are understood as attempts by the law to balance the interests of the parties. The result was an ordered cluster of rules which gravitate around typical forms.

In its typical form, strict liability can be characterized as a rule according to which the plaintiff must establish one or more strict element(s), causation, and damage, and the defendant can generally reduce or deny his liability by invoking two alternative defences: contributory negligence or external cause (force majeure / act of God).

There are a number of strict liability rules which do not fit the typical form and depart from it by adding or subtracting one or more elements. In some cases, liability is made stricter by removing the element of causation, meaning that a defendant may be found liable even though his actions or omissions did not cause the plaintiff's damage (see vicarious liability rules in both France and England, or road traffic liability in France). Furthermore, there is at least one strict liability rule which does not require proof of either causation or damage (see the tort of trespass). In other situations, stricter forms of liability are obtained by removing one or more defences (the defence of contributory negligence, external cause, or both). On the other side of the spectrum, between typical rules of strict liability and typical rules of fault liability, there are a few liability rules which are less strict than the typical form of strict liability, but which also sit uncomfortably in the category of fault-based liability. We have described these rules as "de facto strict liability rules" because the plaintiff's prima facie case is not dependent upon a showing of fault. The plaintiff benefits from a rebuttable presumption of fault, which means that he is granted an additional

\footnotetext{
${ }^{123}$ Article 3 (1) of Loi no 85-677, 5 July 1985 tendant à l'amélioration de la situation des victimes d'accidents de la circulation et à l'acceleration des procédures d'indemnisation, JO 6 July 1985, p. 7584.

${ }^{124}$ Article 3 (3) of Loi no 85-677, 5 July 1985 tendant à l'amélioration de la situation des victimes d'accidents de la circulation et à l'acceleration des procédures d'indemnisation, JO 6 July 1985, p. 7584.
} 
defence to what is typical for strict liability rules, being allowed to show that he was not at fault in causing damage to the plaintiff. As defendants usually find it very difficult to rebut the presumption of fault operating in the plaintiff's favour, these fault-based rules operate in practice almost identically to strict liability rules.

We have also seen that the line between fault-based liability and strict liability is further blurred by the existence of fault-based rules where the standard of care is heightened (as is the case with certain categories of professionals when damage is caused in the exercise of their profession), and by mechanisms which allow a judge to infer the defendant's fault from the circumstances of the accident he was involved in and which led to the plaintiff's damage (see the doctrine of res ipsa loquitur). These rules prove that there are also variations in the fault-based area of the spectrum, and that some fault-based rules are based on stricter duties of care than others.

An interesting generalization emerges from these findings. Looking at all the forms of strict liability we have identified in the French and English systems of tort law, the only clear common pattern we can identify from the various arrangements of elements which lead to liability is that strict liability is never exclusively causation-based. We have not found a single liability rule where a defendant is liable only because his actions or omissions can be said to have caused damage to the plaintiff (not even prima facie).

What this means is that the absence of the requirement of fault from the list of elements does not translate into attributions of liability based on causation and damage alone. The element of fault is, in all of the examples we have found, replaced with one or more elements (which we have generically termed "the strict element" in this chapter). What is more, causation is not only insufficient for liability, it is not even always necessary (vicarious liability rules, the tort of trespass, and the liability rules of the loi Badinter providing powerful examples of liability rules which do not rely on the element of causation in ascribing liability).

Two rather common (and related) assumptions about strict liability are therefore not reflected in current tort law practice. First, the assumption that strict liability is based on causation alone ${ }^{125}$ is

\footnotetext{
${ }^{125}$ See, e.g., Hans-Bernd Schäfer \& Andreas Schönenberger, Strict Liability versus Negligence: An Economic Analysis, in The Boundaries of Strict Liability in European TorT LAW 37, 56 (Franz Werro \& Vernon Valentine Palmer eds., Staempfli Publishers, Carolina Academic Press \& Bruylant 2004): "Strict liability is based on causation alone."
} 
false. For most forms of strict liability, causation is not sufficient and, in some situations, it is not even a necessary element. Therefore, what are termed "general," 126 or "pure"127 theories of strict liability, often associated with libertarian scholars, ${ }^{128}$ clash with the historical evolution of tort law and offer little to no descriptive appeal. ${ }^{129}$ For the same reason, using terms such as "causal

See also ColEman, supra note 33, at 227: "[T]he fault liability rule holds that the initial presumption in favor of victim liability is overcome if the victim can show that the injurer is at fault. This differs from the strict liability rule in that under strict liability the same presumption is overcome if the victim can show that the injurer caused the victim's loss."

${ }^{126}$ This is the term used by Izhak Englard and Stephen Perry, in Izhak Englard, Can Strict Liability be Generalized?, 2 OXF. J. LeG. STUD. 245 (1982) \& Stephen R. Perry, The Impossibility of General Strict Liability, 1 CAN. J. L. \& JURISPRUDENCE 147 (1988).

${ }^{127}$ Term used by Eric Claeys, in Eric R. Claeys, On the "Property" and the "Tort" in Trespass, in PHILOSOPHICAL FOUNDATIONS OF THE LAW OF TORTS 122, 133 (John Oberdiek ed., Oxford University Press 2014).

${ }^{128}$ The most well-known causation-based, libertarian theory of tort law is usually considered to be reflected in Richard Epstein's early work. Richard A. Epstein, A Theory of Strict Liability, 2 J. LEGAL STUD. 151 (1973); However, it should be noted that Epstein's thoughts later evolved towards rejecting the idea of a generalized strict liability rule for tort law. In his more mature work, he maintains his initial commitment to the idea that strict (causal) liability should be the default rule for personal injury and property damage, but accepts that it is not the only ground for tort liability, there being situations where intention or negligence play a decisive role. See Richard A. Epstein, Defenses and Subsequent Pleas in a System of Strict Liability, 3 J. LegAL StUD. 165 (1974); Richard A. Epstein, Intentional Harms, 4 J. Legal Stud. 391 (1975); Richard A. Epstein, Medical Malpractice: The Case for Contract,

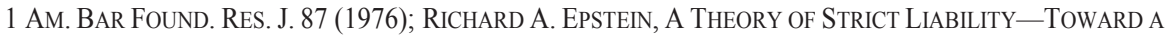

Reformulation OF TORT LAW (Cato Institute, San Francisco 1980); Richard A. Epstein, Toward a General Theory of Tort Law: Strict Liability in Context, 3 J. TORT L. [Art. 6] (2010). The writings of perhaps one of the most famous libertarians, Robert Nozick, provides good evidence that libertarians often assume that responsibility ought to be attributed only on causal grounds. See also ROBERT NozICK, ANARCHY, STATE AND UTOPIA 57-84 (Basic Books 1974) (Nozick's repeated use of the "boundary-crossing" metaphor and the way he defines boundary-crossings (at page 57) suggest that for him liability is also attributed solely on causal grounds).

${ }^{129}$ Epstein's way of theorizing about tort law is in two important ways very different from the account we presented above. First, Epstein codifies arguments about liability not by way of cumulative prima facie "elements" and standalone "defences," but as a set of pleadings, going back and forth between the parties (the plaintiff makes a claim, to which the defendant can then respond, followed by a further claim by the plaintiff, a new response, etc. until none of the arguments can be advanced further). Second, and as a consequence of the first point, causation for Epstein is not an element of liability. He rejects any "test" for causation, and conceptualizes causation as a generic term which refers to four causal paradigms which are sufficient for a prima facie cause of action: (1) the application of force to a person or a thing (e.g. "A hits B."); (2) frightening or shocking another person (e.g. "A frightened B"); (3) compelling a person to commit (1) or (2) (e.g. "A compelled B to hit C"); and (4) the creation of dangerous conditions which cause harm. See especially Epstein, A Theory of Strict Liability, supra note 128, at 160-89; Epstein, Defenses and Subsequent Pleas in a System of Strict Liability, supra note 128. Thus conceived, Epstein's causation-based account is much better suited to describe a large number of tort law rules coherently than any possible causation-based theory in which causation is conceptualised as an element of liability. However, even with these differences in mind, none of Epstein's four causal paradigms is up to the task of explaining the prima facie case for some important and well-established liability rules, such as vicarious liability [where the employer does not hit the plaintiff, does not frighten him, does not compel his employee to hit or frighten the plaintiff, and does not (necessarily) create a dangerous condition]. Nor was Epstein ever able to convincingly explain how his causal paradigms relate to the notion of duty. The four causal paradigms only capture a prima facie ground for liability if causation is in some way determinative of duty. However, Epstein conceded that questions of duty always come before questions of causation when an explanation is sought for liability, and not causation [see Epstein, Toward a General Theory of Tort Law: Strict Liability in Context, supra note 128, at 10; and Joshua Getzler, Richard Epstein, Strict Liability and the History of Torts, 3 J. Tort L. [Art. 3] at 4, n. 14 (2010) (Epstein was responding to Getzler 
liability" or "causal responsibility"130 as synonyms for strict liability is misleading. Second, strict liability cannot be equated with unlimited liability, in the sense of liability for everything. Actual strict liability rules do not make a defendant liable "simply for being active". ${ }^{131}$ The fear that strict liability rules have the potential to lead to an infinite enlargement of the sphere of responsibilities of the individual ${ }^{132}$ is based on a misinterpretation of strict liability. Only strict liability understood as a general principle capable of replacing in its entirety fault-based liability is susceptible to this type of critique. However, strict liability is better understood as a generic term, designating a large number of relatively heterogenous rules which concern themselves only with narrow pockets of human activity, and not as a standalone general principle. Understood in this manner, strict liability still threatens the hegemony of fault-based liability, and strict liability rules do indeed expand the legal responsibility of individuals in comparison to fault-based liability rules, but they do so only in a more limited and contained manner, challenging fault and expanding liability only within the respective "pockets" in which they have developed.

when he made this concession)]. It is not possible to make causal ascriptions without a background of responsibility norms (of ex ante rights and duties, marking what is expected of persons before they interact in a tortious manner). I believe Benjamin Zipursky was making a similar point when he affirmed that Epstein's paradigms of causation are "neither explicable nor defensible nor cogent unless one person's causing a loss to another is understood in terms of one person's being responsible for the loss another suffered" (Benjamin C. Zipursky, Richard Epstein and the Cold War in Torts, 3 J. TORT L. [Art. 5], at 16 (2010)\}; Epstein, however, interpreted this statement as an argument that drawing inferences from causation to responsibility is circular. See Epstein, Toward a General Theory of Tort Law: Strict Liability in Context, supra note 128, at 17.

Despite Epstein's insistence on causal attribution, it appears that the real foundations for tortious responsibility in his theory of strict liability are a set of universal negative duties (and the correlative rights attached to them) which demand forbearance from any and all interference with the person or property of another. (Epstein explicitly formulates the underlying duties in such a manner in Toward a General Theory of Tort Law: Strict Liability in Context, supra note 128, at 10).

${ }^{130}$ The term "responsabilité causale" (causal responsibility) is sometimes used to refer to strict liability. See Pierre Widmer, Détermination et réduction de la réparation en droit suisse, in THE LiMITS OF LIABILITY. KEEPING THE FloOdGates Shut 137, 141 (J. Spier ed., Kluwer Law International 1996); KONRAD ZWEIGERT \& HEIN KöTZ, 2 AN Introduction to COMParative LaW. The Institutions of Private LaW 312 (Tony Weir trans., North-Holland Publishing Co. 1977).

${ }^{131}$ Ernest Weinrib, for instance, seems to equate strict liability with liability for simply being active. WEINRIB, supra note 2, at 181: "Strict liability, however, implies that the very production of external effects - an indispensable part of agency - can itself be a violation of the equality of agents. ... To ascribe liability to an action, regardless of culpability, for whatever harmful effects it has had simply because they are its effects, is to hold the agent liable for being active."

${ }^{132}$ Similar objections to Weinrib's were raised by well-known French authors such as Marcel Planiol and Georges Ripert (See Marcel Planiol \& Georges Ripert, 6 Traité PratiQue De Droit Civil Français 644-46 (2 $2^{\text {nd }}$ ed., Paul Esmain ed., L.G.D.J. 1952), as well as Henri and Léon Mazeaud, and André Tunc [HENRI MAZEAUD ET AL., 1 TRAITÉ THÉORIQUE ET PRATIQUE DE LA RESPONSABILITÉ CIVILE DÉLICTUELLE ET CONTRACTUELLE 431-446, $\mathrm{n}^{\text {os }} 339$ $355\left(6^{\text {th }}\right.$ ed., Montchrestien 1965)]. 
To sum up, at this point in our analysis we can already say much more about strict liability rules than the fact that they do not inquire into the defendant's fault (which was our starting point). After first identifying a large number of liability rules in French and in English law which fit such a description, and then breaking them down into their constitutive elements (prima facie and defences), we found that fault is not absent from the list of elements tout court; in all circumstances, there is one or several prima facie elements (generically the strict element) which fill the vacuum left by the absence of fault. The mere existence of such elements rebuts a few common mistaken assumptions about strict liability: (1) strict liability cannot be reduced to liability simply for causing harm, and therefore (2) strict liability rules do not necessarily lead to an indefinite enlargement of personal responsibility (liability simply for being active). More importantly though, the presence of one or more strict elements in all strict liability rules opens up the possibility to ask new questions about the substance of strict liability rules. In what way exactly are strict liability norms different from equivalent fault-based norms? Are there any commonalities between the various elements which replace fault (in other words, can the normative differences be generalized)? We next turn our attention to these questions. 


\section{Chapter V}

Tertium Comparationis: Civil Wrongs and Strict Liability

\section{A. Introduction: The Comparative Method}

From a birds-eye perspective, both the French and the English legal systems have experienced an internal process of proliferation and expansion of strict liability relative to faultbased liability. ${ }^{1}$ From the same standpoint, however, it is also obvious that the evolution of strict liability in the two jurisdictions has been remarkably different. De lege lata, there are more rules of strict liability in France than in England, and the scope of French strict liability rules is also much broader when compared to similar English rules. The process of expansion of strict liability has been so much slower in England than in France that the two legal systems look like polar opposites in their attitude and treatment of strict liability. In fact, from a broader European perspective, the two jurisdictions seem to represent two extremes, or two opposed ends of a spectrum, where jurisdictions receptive to strict liability norms resemble the French model, and jurisdictions with less strict liability gravitate toward the English model. ${ }^{2}$

For two legal systems with a similar level of economic development, ${ }^{3}$ employing relatively similar principles of fault liability in the background, ${ }^{4}$ the different degree of reception of strict liability and the accompanying attitudes toward strict liability which led to such drastic divergence are

\footnotetext{
${ }^{1}$ The overall trend is clear despite the fact that, at the level of detail, some few examples can be found of the opposite phenomenon, of contraction. For instance, in France, we have already seen that the liability of teachers and educators shifted from fault-based with a reversed burden of proof to simply fault-based, the evolution being then toward a less strict regime. In England, the same point can be made by looking at Rylands v Fletcher, which was interpreted narrowly by subsequent case law, thus evolving from what seemed like a broad liability principle toward an atypical form of nuisance.

${ }^{2}$ This is the overall picture one gets from reading the 15 country reports from the Unification of tort law project (with the caveat that 3 of the reports are not European; nevertheless, even the non-European jurisdictions-Israel, South Africa and the United States - fall somewhere between the France and England in their approaches to strict liability). See UnificATION OF Tort Law: StRict Liability (B.A. Koch \& H. Koziol eds., Kluwer Law International 2002).

${ }^{3}$ For instance, in terms of GDP per capita, the United Kingdom and France rank 40 and 41 with the exact same score, according to the estimates for the year 2017. See https://www.cia.gov/library/publications/the-worldfactbook/rankorder/2004rank.html.

${ }^{4}$ See Pierre Widmer, Comparative Report on Fault as a Basis of Liability and Criterion of Imputation (Attribution), in UNIFICATION OF TORT LAW: FAULT 331, $339-40$ (Pierre Widmer ed., Kluwer Law International 2005); EUROPEAN Group ON TORT LAW, PRINCIPLES OF EUROPEAN TORT LAW: TEXT AND COMMENTARY 65 (Springer 2005).
} 
question-begging. ${ }^{5}$ All comparatists who turned their attention to the nature of liability rules in France and England have acknowledged that the number and breadth of strict liability rules differ significantly between the two jurisdictions. That being said, not all authors see this as a sign of divergence. Some scholars see it as a mere formal and surface-level distinction with little consequential effect, based on a presumption that similar cases will be decided in the same way regardless of the legal basis of the decision (praesumptio similitudinis). ${ }^{6}$ More recent research, conducted on the basis of the factual method, has shown, however, that the preference for fault over strict liability and vice versa does have an impact on the resolution of disputes. ${ }^{7}$ The divergence is therefore real and consequential. That is why, in more recent comparative law work, various scholars have advanced a set of interesting reasons for the different balance found in France and England, such as the existence of deep cultural differences between French and English jurists, ${ }^{8}$ different policy choices,${ }^{9}$ or different ways of framing arguments: French jurists focusing

\footnotetext{
${ }^{5}$ Not all legal scholars find the divergent ways of balancing fault and strict liability question-begging. Saul Levmore, for instance, has argued that since both fault and strict liability norms can (under the assumptions of economic analysis) lead to efficient deterrence, variety is to be expected. The essence of the argument seems to be based on the assumption that the laws of various legal systems, modern or ancient, will generally be uniform when compelled by utilitarian necessity, but divergent where different rules are equally efficient. In the case of fault and strict liability, since the two rules have similar incentive effects on behaviour and are both Pareto optimal, the choice of one rule or another is not compelled by utilitarian efficiency considerations. See Saul Levmore, Rethinking Comparative Law: Variety and Uniformity in Ancient and Modern Tort Law, 61 TuL L. REv. 235, 238, 240-48 (1986-1987).

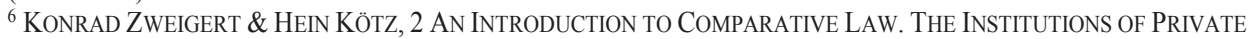
LAW 312 (Tony Weir trans., North-Holland Publishing Co. 1977): "What happens in practice is that liability for fault imperceptibly shades into strict liability, and it is often a meaningless question whether a particular legal system, with regard to accidents of a particular type, adopts the principle of fault or causal liability"; See also Nils Jansen, Duties and Rights in Negligence: A Comparative and Historical Perspective on the European Law of Extracontractual Liability, 24 OXF. J. LEG. STUD. 443, 467 (2004): "From a comparative point of view, rules of strict liability and negligence are largely equivalent."

${ }^{7}$ See THe BOUNDARIES OF Strict LiabiLity In EUROPEAN ToRT LAW (Franz Werro \& Vernon Valentine Palmer eds., Bruylant/Staempfli/Carolina Academic Press 2004), especially the comparison between the solutions offered on pages 124-26 (Engalnd) and 142-44 (France); Compare also the answers from W. V. Horton Rogers, England in UNIFICATION OF TORT LAW: STRICT LiABILITY 101, 124-25 (B.A. Koch \& H. Koziol eds., Kluwer Law International 2002), with Suzanne Galand-Carval, France in UnificATION OF TORT LAW: StRICT LiabiLITY 127, 143-44 (B.A. Koch \& H. Koziol eds., Kluwer Law International 2002).

${ }^{8}$ See Cees van Dam, Who is Afraid of Diversity? Cultural Diversity, European Co-operation, and European Tort Law, 20 KING'S LAW JouRnaL 281, 288-89, 295-99 (2009), also available at http://www.ceesvandam.info/default.asp?fileid=460.

${ }^{9}$ CEes VAN DAM, EuROPEAN TORT LAW 9 (2nd ed., Oxford University Press 2013): “[...] France and England represent two opposite policy approaches to tort law. Whereas French tort law primarily focuses on compensation for the victim, rules of strict liability, and the principle of distributive justice, the predominant focus of English tort law is on the defendant's conduct and the principle of corrective justice and barely considers rules of strict liability."
} 
on the plaintiff's plight (damnum) and English jurists focusing on the defendant's conduct (iniuria). ${ }^{10}$

In the remainder of this study we will slowly unravel a different reason for the disparity by building an argument that the choice of more or for less strict liability is also reflective of an underlying commitment to different conceptions of (distributive) justice. To this end, we will now move on from the doctrinal method employed in previous chapters and reflect on strict liability first on the basis of comparative law methodology, and then on the basis of normative legal theory.

The argument will extend over three chapters. The present chapter presents the framework for the comparative exercise which follows in Chapter VI. Chapter VI focuses on comparing the norms inherent to fault-based and strict liability rules covering the same domain, and on identifying recurring patterns so as to make positive generalizations about the differences between fault and strict liability wrongs. The penultimate chapter of this book, Chapter VII, will then discuss the implications of choosing one form of liability over the other in the light of the overarching internal goals of the practice of tort law.

B. In Search of a Different Point of Outlook

If we take the English law of torts, together with the portion of equity dealing with wrongs, and the French law of responsabilite civile délictuelle to be roughly similar practices, and within these practices we assume the relative similarity of fault-based liability, ${ }^{11}$ the occasion arises to use comparative law and comparative methodologies in order to better understand the differences between strict liability and fault-based liability from a standpoint that transcends the two legal systems. Differences in the domain of strict liability translate into a determinable number of situations in which one legal system will employ a strict liability rule while the other will resort to fault liability for the resolution of the same liability problem. These situations provide the opportunity to discover recurring normative similarities and differences between fault and strict liability rules governing similar domains. Uncovering and understanding these general similarities

\footnotetext{
${ }^{10}$ See F.H. LAWSON \& BASIL S. MARKESINIS, 1 TORTIOUS LiABILITY FOR UNINTENTIONAL HARM IN THE COMMON LAW AND THE CIVIL LAW 182, 186 (Cambridge University Press 1982).

${ }^{11}$ Of course, fault-based liability is not identical in the two jurisdictions. In contrast to the French legal system, English legal system does not know of a general fault-based principle, employs fault-based criteria in a large number of causes of action (torts), distinguishes between intentional and negligent infringements of rights, and makes frequent use of control mechanisms to limit negligence-based liability on policy grounds (typically under the "duty of care" element). Nevertheless, an overall similarity of principle can be assumed.
} 
and differences will later provide the building blocks for our argument regarding the different conceptions of justice reflected in a sustained commitment to fault liability over strict liability and vice versa.

It is important, though, to first explain the framework for the comparisons that this study has been building up towards. What was referred to above as a "transcendent perspective" is simply a point of view that goes beyond the internal perspective of the French and the English legal systems, and not some mysterious out-of-this-world construction. Such a standpoint is necessary in order to make cogent and meaningful comparisons between the French and the English legal systems. ${ }^{12}$ The standard term used to designate the external frame within which comparative analysis is conducted is tertium comparationis. ${ }^{13}$

The challenge is to find a standpoint that is external to the French and the English legal systems, but nevertheless internal to the practice of tort liability and responsabilité civile délictuelle. We are looking for a framework which will be familiar and recognizable for both French and English jurists, yet not bound to either of the two legal systems.

There are numerous possible standpoints external to national legal systems which are capable of doing the work of an "invariant element", ${ }^{14}$ or tertium comparationis. Most often, the invariant element is taken to be a function, often assumed to be served by the legal doctrine or rule which prompted the comparison, and which functional equivalents are being searched for by the comparatist in other legal systems. Some of the most well-known comparative law studies employed this method in order to identify "equivalents" to common law doctrines such as consideration ${ }^{15}$ or trusts ${ }^{16}$ in the civil law (mostly in French or German law). In regard to strict

\footnotetext{
${ }^{12}$ See John C. Reitz, How to Do Comparative Law, 46 AM. J. CoMP. L. 617, 622 (1998): "In large measure, the notion of a common point of departure seems inherent in the process of comparison. Either one legal system has the same legal rule or legal institution as another, or it has different rules or institutions which perform the same function, or it provides different results for a particular problem, or it does not seem to address that problem at all." ${ }^{13}$ Reitz, supra note 12, at 822-23; MiChaEl BogDan, Comparative LAW 58 (Kluwer/Norstedts Juridik/Tano 1994).

${ }^{14}$ Ralf Michaels, The Functional Method of Comparative Law, in THE OXFoRd HANDBOOK OF COMPARATIVE LAW 339, 367 (Mathias Reimann \& Reinhard Zimmermann eds., Oxford University Press 2006).

${ }^{15}$ Arthur T. von Mehren, Civil Law Analogues to Consideration: An Exercise in Comparative Analysis, 72 HARV. L.

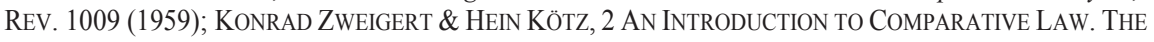
Institutions of Private LaW 60-71 (Tony Weir trans., North-Holland Publishing Co. 1977); Basil S. Markesinis, Cause and Consideration: A Study in Parallel, 37 CAMBRIDGe L.J. 53 (1978).

${ }^{16}$ HeIn KÖtZ, TRUST UND TREUHAND : EINE RECHTSVERGLEICHENDE DARSTELLUNG DES ANGLO-AMERIKANISCHEN TRUST UND FUNKTIONSVERWANDTER INSTITUTE DES DEUTSCHEN RECHTS (Vandenhoeck \& Ruprecht 1963); Henry
} 
liability, the classic example of functionalist comparative law methodology applied to the problem of strict liability is the chapter written by Konrad Zweigert and Hein Kötz in their Introduction to Comparative Law. ${ }^{17}$ The same methodological roots can be found in the comparative law treatment of strict liability in the works of Cees van Dam, ${ }^{18}$ Raymond Youngs, ${ }^{19}$ Harry Lawson and Basil Markesinis, ${ }^{20}$ and in the contributions to the International Encyclopedia of Comparative Law. ${ }^{21}$ Moreover, the primary method employed by the European Group on Tort Law in its broader study on strict liability was also functionalism. ${ }^{22}$

Another conception of the tertium comparationis often employed by comparatists results from the construction of a more or less detailed fact pattern, which can either be purely fictitious or inspired by real events. Under this "factual approach", the fact pattern is usually presented to a group of national reporters as a case to be solved. They then have to give an opinion or attempt to formulate the right solution to the case under their positive national law in much the same way a national judge would decide the case. On the basis of the reports, the comparatist tries to determine how similar or different the arguments presented and the solutions to the case are. This factual methodology, made famous by Schlesinger's comparative analysis on the formation of contracts

Hansmann \& Ugo Mattei, The Functions of Trust Law: A Comparative Legal and Economic Analysis, 73 N.Y.U. LAW REV. 434 (1998).

${ }^{17}$ ZWEIGERT \& KÖTZ, supra note 865 , at 309-40.

${ }^{18}$ VAN DAM, supra note 9, at 297-306.

${ }^{19}$ Raymond Youngs, English, French \& GERman COMPARATIVE LAW 353-62 (2 ${ }^{\text {nd }}$ ed., Routledge Cavendish 2007).

${ }^{20}$ LAWSON \& MARKESINIS, supra note 10, at 142-77. See also another project in which Basil Markesinis collaborated with Michael Coester, Guido Alpa and Augustus Ullstein, also based, for the most part on functionalist methodology: BASIL S. MARKESINIS ET AL., COMPENSATION FOR PERSONAL INJURY IN ENGLISH, GERMAN AND ITALIAN LAW: A COMPARATIVE OUTLINE (Cambridge University Press 2005).

${ }^{21}$ See especially Jean-Pierre Le Gall, Liability for Persons under Supervision, in 11 INTERNATIONAL ENCYCLOPEDIA of COMParative Law, TORTs [Ch. 3] (André Tunc ed., J.C.B. Mohr (Paul Siebeck) \& Martinus Nijhoff Publishers 1983); Ferdinand F. Stone, Liability for Damage Caused by Things, in 11 INTERNATIONAL ENCYCLOPEDIA OF COMPARAtive Law, TORTs [Ch. 5] (André Tunc ed., J.C.B. Mohr (Paul Siebeck) \& Martinus Nijhoff Publishers 1983); A. M. Honoré, Causation and Remoteness of Damage, in 11 InTERNATIONAL ENCYCLOPEDIA OF Comparative Law, TorTs [Ch. 7] (André Tunc ed., J.C.B. Mohr (Paul Siebeck) \& Martinus Nijhoff Publishers 1983); and André Tunc, Traffic Accident Compensation Law and Proposals, in 11 InTERNATIONAL ENCYCLOPEDIA of COMParative Law, ToRTs [Ch. 14] (André Tunc ed., J.C.B. Mohr (Paul Siebeck) \& Martinus Nijhoff Publishers 1983).

${ }^{22}$ UnificATION OF TORT LAW: Strict LiABiLITY (B.A. Koch \& H. Koziol eds., Kluwer Law International 2002) (this work was done in preparation for the drafting of the PETL by the European Group on Tort Law). 
(work also known as the "Cornell project"), ${ }^{23}$ and later also championed by Basil Markesinis, ${ }^{24}$ was adopted by the Trento Group (the Common Core of European Private Law project), ${ }^{25}$ and was also partly employed by the European Group on Tort Law, in their respective comparative law studies on strict liability. ${ }^{26}$

Upon a closer look, the "factual approach" 27 is also, in essence, functional. ${ }^{28}$ The different legal doctrines on which a national reporter must rely in order to provide a solution to the fact pattern he was presented with are functional equivalents. They perform the same broad function of generating legal consequences in response to the specific fact pattern presented. Therefore, the fact pattern alone does not constitute the tertium comparationis in any of the studies relying on the "factual approach". The real tertium comparations is an unarticulated, sometimes hidden, but also open-ended, notion of a legal rule or doctrine which applies to the carefully crafted fact pattern. The factual approach is interesting, and the insights resulting from it are so valuable, precisely because of the unstated and open-ended character of its tertium comparationis: the doctrines applicable to the fact pattern may be quite different, the legal consequences they entail can also be extremely varied. Also, by applying national rules to a clear fact pattern, the "factual approach" is apt to fill in the gap between the law-in-the-books and law-in-action and reduce the risk of bias or error in interpretation. ${ }^{29}$

The point of this short digression is that, in the end, in the field of comparative law, the tertium comparationis usually consists of a problem defined in functional terms (if "function" is

\footnotetext{
${ }^{23}$ Formation of CONTRACts. A Study of THe COMmOn CORE OF Legal Systems (Rudolf B. Schlesinger gen. ed., Oceana Publications/Stevens \& Sons 1968, 2 vols.).

${ }^{24}$ See Basil S. Markesinis, Comparative Law-A Subject in Search of an Audience, 53 Modern Law Review 1

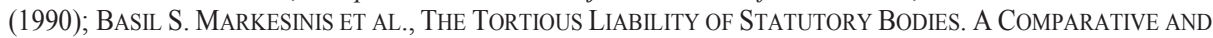
ECONOMIC ANALYSIS OF FIVE CASES (Hart Publishing 1999), also published in BASIL S. MARKESINIS, ALWAYS ON the Same Path: Essays on Foreign LaW and Comparative Methodology. Volume II, at 219-304 (Hart Publishing 2001).

${ }^{25}$ The Boundaries of Strict Liability in European Tort LaW (Franz Werro \& Vernon Valentine Palmer eds., Bruylant/Staempfli/Carolina Academic Press 2004) (Part of the Common Core of European Private Law project, also known as the "Trento Project");

${ }^{26}$ UNIFICATION OF TORT LAW: STRICT LIABILITY, supra note 22.

${ }^{27}$ This seems to be a standard way of referring to the method promoted by Schlesinger. See, e.g., Mauro Bussani \& Ugo Mattei, The Common Core Approach to European Private Law, 3 Colum. J. EuR. L. 339, 344 (1997); EsIN ÖRÜCÜ, THE ENIGMA OF COMPARATIVE LAW. VARIATIONS ON A THEME FOR THE TWENTY-First CENTURY 52 (Springer-Science/Business Media 2004)

${ }^{28}$ See Geoffrey Samuel, An Introduction to Comparative Law Theory and Method 71 (Hart Publishing 2014).

${ }^{29}$ See Bussani \& Mattei, supra note 27, at 343.
} 
understood in a broad sense). The need to identify a tertium comparationis, therefore, arises when functionalist methodologies are employed. ${ }^{30}$

\section{Functionalism and Aristotelian Finalism}

Functionalism is widely recognized as the standard method for making micro-comparisons within the field of comparative law. ${ }^{31}$ There are, however, many flavours of functionalism, and many ways in which the idea of function is used in comparative law scholarship. A very useful taxonomy of functionalism was elaborated by Ralf Michaels who, after carefully combing through a large number of comparative law studies, identified seven broad categories of functionalism: (1) finalism; (2) adaptionism; (3) classical functionalism; (4) instrumentalism; (5) refined functionalism; (6) epistemological functionalism; and (7) equivalence functionalism. ${ }^{32}$ From his list, two conceptions of functionalism would be appropriate for the analysis we intend to make in this chapter: finalism and equivalence functionalism. As indicated in the introductory chapter, ${ }^{33}$ this study fits best within the category of (Aristotelian ${ }^{34}$ ) finalism. However, for the purposes of

\footnotetext{
${ }^{30}$ Functionalism is not, of course, the only game in town for comparative law: macro-comparisons at the level of the legal family or legal tradition, the comparative the study of legal culture, as well as comparative legal history, the study of legal transplants, and newer, "fringe," methodological approaches like numerical comparative law, have also been enriching this field of study [for a description of numerical comparative law see especially Mathias Siems, Numerical Comparative Law - Do We Need Statistical Evidence in Law in Order to Reduce Complexity?, 13 CARDOZO J. InT'L \& COMP. L. 521 (2005); MATHIAS Siems, Comparative LAW 146-187 (Cambridge University Press 2014)].

${ }^{31}$ The classic formulation of the tenets of comparative law functionalism is generally attributed to Konrad Zweigert and Hein Kötz. See Konrad Zweigert \& Hein Kötz, 1 An Introduction to Comparative Law 23-41 (NorthHolland Publ. Co. 1977); Konrad Zweigert, Méthodologie du droit comparé, in 1 MÉLANGES OFFERTS À JACQUES MAURY (Dalloz 1960); Konrad Zweigert, Des solutions identiques par des voies différentes (Quelques observations en matière de droit comparé), 18 R.I.D.C. 5 (1966).

Much more has been written about functionalism since, and many nuances brought to the method. See Michaels, supra note 14; James Gordley, The Functional Method in Methods of Comparative LaW 107 (Pier Giuseppe Monateri ed., Edward Elgar 2012); Olivier Moréteau, Premiers pas dans la comparaison des droits in JuRILINGUISTIQUE: ENTRE LANGUES ET DROITS 419 (Jean-Claude Gémar \& Nicholas Kasirer eds., Thémis 2005); Béatrice Jaluzot, Méthodologie du droit comparé. Bilan et perspective, 57 R.I.D.C. 29, 39-41 (2005); Michele Graziadei, The Functionalist Heritage, in Comparative Legal Studies: TRADITIONS AND TRANSITIONS 31-45 (Pierre Legrand \& Roderick Munday eds., Cambridge University Press 2003); Mathias Reimann, The Progress and Failure of Comparative Law in the Second Half of the Twentieth Century, 50 AM. J. ComP. L. 671, 679 (2002); Reitz, supra note 12; Günter Frankenberg, Critical Comparisons: Re-thinking Comparative Law, 26 HARV. INT'L. L. J. 411, 428-29, 434-40 (1985).

${ }^{32}$ Michaels, supra note 14 , at 343-360.

${ }^{33}$ Supra Chapter I Part C.1.

${ }^{34}$ Michaels' conception of finalism is broad enough to encompass both Aristotelian and neo-Kantian comparative law scholarship. See Michaels, supra note 14, at 345-47. There are important differences, however, between the two traditions. Kantian comparatists see legal institutions as imperfect embodiments of the ideal law, a universal law based on reason alone. "Is" and "ought" are perfectly separated, and therefore the ideal law cannot be derived from the study of existing institutions. The concept of tertium comparationis requires the articulation of the ideal law
} 
our comparisons, equivalence functionalism would have done the job just as well. Since equivalence functionalism is by far the most widely used method of comparative law, it is perhaps useful to explain briefly what finalism entails, and why it fits the overall goals of this study better than equivalence functionalism.

The differences between Aristotelian finalism and equivalence functionalism can be reduced to how the concept of function is understood. The starting point for the two methods is similar. Both methods regard function as a relationship between a problem and a legal institution. Also, for both methods, the problem is always considered a constant (the problem needs to be universal or, at the very least, common), whereas legal institutions or legal norms are seen as contingent. ${ }^{35}$ Equivalence functionalism, however, makes no further assumptions and places no constraints on the type of function the comparatist needs to identify. Any plausible function will do. Aristotelian finalism, by contrast, requires the identification of the causa finalis, the telos, of the compared legal institutions. Finalism is therefore a much more demanding version of functionalism. It is, in essence, equivalence functionalism with a commitment to a teleological understanding of legal institutions. Consequently, finalism requires the comparatist, at the very least, to put forward an argument regarding the telos of the institutions he is comparing. From this commitment to a teleological understanding of legal institutions, one important limitation on the types of functions which are appropriate as tertium comparationis emerges: because Aristotelian finalism looks only for legal institutions with a shared purpose, understood as causa finalis, or telos, functions which are merely incidental and do not belong to the nature of a legal institution must be excluded.

\section{Our tertium comparations: Defining and Correcting Civil Wrongs}

If the purpose of this study had been just to make interesting comparisons, it would have been sufficient to define a neutral concept or a neutral framework and explain its functional structure. That is why equivalence functionalism would have been sufficient. If all we had wanted to do is compare fault and strict liability regimes from France and England, a tertium

\footnotetext{
(what "ought"), and the function of existing legal institutions (what "is") is to strive toward the ideal. In the Aristotelian tradition, "is" and "ought" are not independent, but related, and reflection on existing legal institutions may yield insights into their nature. The telos of things, including legal institutions, is understood to be part of their nature. Therefore, the concept of tertium comparationis for Aristotelians requires the articulation of the telos of the compared legal institutions, and institutions are functionally equivalent when they exist for the same purpose.

${ }^{35}$ Michaels, supra note 14 , at 346.
} 
comparationis could have been constructed ${ }^{36}$ without any further justification. It would have been enough to argue that the identified function is a plausible function of tort law.

However, our thesis is that the definition and correction of civil wrongs is not just a plausible function but the very aim of the social practice which falls under the domains of tort law, equitable wrongs, and responsabilité civile délictuelle. It will be argued in Chapter VII that this social practice has two interrelated aims: to justly define inter-personal legal wrongs (or civil wrongs) and to provide just corrective mechanisms for such wrongs. In other words, defining civil wrongs and correcting them is part of the nature of tort law as an institution. A legal institution that does something else than define and correct wrongs is not recognizable as tort law. It is an altogether different institution.

The argument is necessary because the aims of tort law are hotly contested in contemporary legal scholarship. Without engaging with the underlying argument at this point, it is important to clarify already what our position is in this debate. Much of the controversy and confusion that surrounds this topic is due to the elevation of incidental functions to the status of aims of the practice. Compensation and deterrence in particular are often singled out as the aims or goals of tort law. ${ }^{37}$ When they are not lumped together as the joint aims of tort law, they are seen as rival aims, and much ink has been spilled on whether a compensation principle or a deterrence principle underlies tort law. ${ }^{38}$ However, if by the aim of tort law one means telos, purpose, or causa finalis, then the first contention (that compensation and deterrence are the aims of tort law) is wrong, and the second (that the aim of tort law is either compensation or deterrence) is ill-framed. The telos of tort law is neither the compensation of victims, nor the deterrence of tortfeasors. Tort law, or the law of delict, exists to respond to the problem of civil wrongs, i.e. wrongs between private parties,

\footnotetext{
${ }^{36}$ See Michaels, supra note 14, at 368-69.

${ }^{37}$ See, e.g., André Tunc, Introduction in 11 InTERnational Encyclopedia of COMParative LaW, TORTS, Ch. I at 87 (I-154) (André Tunc ed., J.C.B. Mohr (Paul Siebeck) \& Martinus Nijhoff Publishers 1983); JoHN CoOKE, LAW OF TORT 12-14 ( $9^{\text {th }}$ ed., Pearson Education Ltd. 2009); MuRIEL FABRE-MAgnan, 2 DroIT DES OBLIGATIONS. RESPONSABILITÉ CIVILE ET QUASI-CONTRATS 53-56 ( $3^{\text {rd }}$ ed., PUF 2007); HELMUT KOZIOL, BASIC QUESTIONS OF TORT LAW FROM A GeRMANIC PERSPECTIVE, 75-82 (nos 3/1-3/11) (Jan Sramek Verlag 2012); Olivier Moréteau, Basic Questions of Tort Law from a French Perspective, in BASIC QuESTIONS OF TORT LAW FROM A COMPARATIVE PersPeCtive 3, 24-27 (n ${ }^{\text {os }}$ 1/64-1/71) (Jan Sramek Verlag 2015); Ken Oliphant, Basic Questions of Tort Law from the Perspective of England and the Commonwealth, in BASIC QuESTIONS OF TORT LAW FROM A COMPARATIVE PersPeCtive 355, 380 ( $n^{\circ}$ 5/56) (Jan Sramek Verlag 2015); Helmut Koziol, Comparative Conclusions, in BASIC Questions OF TORT LAW FROM A COMPARATIVE PERSPECTIVE 685, 746-750 ( $\mathrm{n}^{\text {os }}$ 8/146-8/154) (Jan Sramek Verlag 2015).

${ }^{38}$ See infra Chapter VII Part A.2.
} 
to define what constitutes a civil wrong and how the law responds to the commission of such wrongs. Compensation and deterrence are part of what tort law is about, but in teleological terms they represent only incidental functions of tort law. This means that tort law also performs the functions of compensating victims and deterring wrongdoers, but these functions do not define what tort law is about. The compensation of unfortunate victims of accidents or the deterrence of socially undesirable conduct may be worthwhile goals. However, this does not mean that either compensation and/or deterrence are (or ought to be) the defining goals of tort law as a practice. The law can define civil wrongs and respond to the wrongs so defined without necessarily providing for compensation to victims and without achieving any level of deterrence.

\section{E. Civil Wrongs}

Looking for legal institutions in different legal systems that have the same telos opens up a creative space for the formulation of new concepts and ideas, and for inventing a new terminology binding foreign institutions together. However, the same can be said of functionalism generally. The search for an appropriate point of departure, or tertium comparationis, very often leads to new ideas and the discovery or creation of enlightening general concepts. The concept of a civil wrong is one of these general concepts that can frame and structure the comparisons we intend to make.

As pointed out by John Reitz, "the real power of comparative analysis arises precisely from the fact that the process of comparing 'apples' and 'oranges' forces the comparatist to develop constructs like "fruit'." What "fruit" is for apples and oranges, "civil wrong" is for torts and equitable wrongs on the one hand, and responsabilité civile délictuelle on the other. This general concept is where we will turn our attention next because even if, for the moment, we take it for granted that the telos of the practice we associate with tort law and responsabilité civile délictuelle is the definition and correction of civil wrongs, one may still legitimately ask: what exactly are civil wrongs anyway?

In order to answer this question, in the following, we: (1) briefly review the history and tradition of the category of civil wrongs in Roman, French and English private law, (2) define the concept of civil wrongs, and then (3) explain the normative structure of civil wrongs.

\footnotetext{
${ }^{39}$ Reitz, supra note 12 , at 625.
} 


\section{The history of the idea of 'civil wrongs'}

The concept of "civil wrongs," as defined and explained in the following sections, is derived mainly from the work of Peter Birks, ${ }^{40}$ Eric Descheemaeker, ${ }^{41}$ Ernest Weinrib, ${ }^{42}$ Benjamin Zipursky, and John Goldberg, ${ }^{43}$ but with some modifications, which hopefully will improve its understanding.

The idea that there are events in the world which are wrongs, and that some of these events belong to an area of the law which we call the civil law (hence civil wrongs) long pre-dates any of the authors indicated above. The concept of civil wrongs was born and evolved through the interweaving of two long-lasting traditions of inquiry. The first tradition was kick-started by Aristotle and focuses on the moral question of "how should we treat each other?", whereas the second was initiated by the Roman jurists of the Classical period and revolves around the legaldoctrinal question of "what are the sources of legal obligations"?

Although civil wrongs are a legal category, the first seed of the idea originates, as mentioned above, in Aristotle's moral philosophy. Aristotle believed that the starting point for all philosophical inquiry, including inquiry on moral issues, is our experience of the world as we find it (as it appears to us). ${ }^{44}$ For us human beings, our "being in the world" involves a certain level of interaction with others. We are, by nature, social creatures, ${ }^{45}$ living in concrete communities. We come into this world already within a family, a village or city, a state, and we later join or form new communities (a school, a chess club, a professional community). In the communities we inhabit, our lives become entangled with the lives of others in many different ways over the course of a lifetime. We interact with others, and through those interactions we forge bonds, or relationships. There is, therefore, an important social aspect to a life that is distinctively human.

\footnotetext{
${ }^{40}$ Peter Birks, The Concept of a Civil Wrong, in Philosophical Foundations of Tort Law 31 (David G. Owen ed., Oxford University Press 1995).

${ }^{41}$ ERic DescheEmaeker, THe Division of Wrongs: A Historical Comparative Study 15-38 (Oxford University Press 2009).

${ }^{42}$ ERnest WeInRIB, THe IDEA OF PRIVATE LAW 1-22, 56-84, 114-145 (Oxford University Press 1995, repr. 2012); ERNeSt J. WeinRIB, CORRECTIVE Justice 1-81 (Oxford University Press 2012).

${ }^{43}$ John C. P. Goldberg \& Benjamin C. Zipursky, Torts as Wrongs, 88 TEX. L. REV. 917 (2010); Benjamin C. Zipursky, Rights, Wrongs, and Recourse in the Law of Torts, 51 VAND. L. REV. 1 (1998).

${ }^{44}$ Christopher Shields, Aristotle, in THE STANFORd ENCYCloPedia OF PHILOSOPHY (Edward N. Zalta ed., 2016), available online at https://plato.stanford.edu/archives/win2016/entries/aristotle/: "When he goes to work, Aristotle begins by considering how the world appears, reflecting on the puzzles those appearances throw up, and reviewing what has been said about those puzzles to date."

${ }^{45}$ See Aristotle, Politics [1253a1-2], in The BASIC Works of Aristotle 1127, at 1129 (Richard Mckeon ed., The Modern Library 2001).
} 
Only by relating to others can we love, trade, argue, learn, teach, work, fight, have conversations, make friends, and so on. But not all interactions with other members of the communities we inhabit are necessarily good. From a positive standpoint, if we want to live well in an environment which is inescapably social, we must learn how to relate to others in a good way, and learning how to do that is essential for having a good (social) life. Conversely, from a negative outlook, if we are to at least cope with social life as we find it (and for human beings it is, for the most part, inescapably social), we must avoid wronging those others with whom we come in contact.

Aristotle's moral philosophy is keenly preoccupied with answering relational questions, such as "how should we treat each other?", "which interactions are good and allowed in a community and which are wrongful and forbidden?", or "when we wrong each other, what does it take to make things right again?" Moreover, he was perhaps the first philosopher to frame all issues of justice around relational questions. ${ }^{46}$ In the Nicomachean Ethics, Aristotle discusses a variety of wrongful interactions between persons, and inquires into the conditions that make an interaction unjust. He never articulates the category of civil wrongs explicitly and, as a matter of fact, even the concept of a "wrong," or something equivalent, never really appears in Aristotle's writings. Aristotle did, however, bring together many examples of what we would today call civil wrongs as examples of unjust acts. In his discussion on corrective (or commutative) justice, he first distinguished between voluntary (hekosia) and involuntary (akosia) transactions (synallagma) between persons, ${ }^{47}$ and then discussed different examples of unjust involuntary transactions, such as stealing, killing, or adultery. ${ }^{48}$ He was also the first to introduce the distinction between voluntary and involuntary conduct, and discussed the importance of the distinction for morality. He reasoned that only voluntary acts can be said to be unjust acts and therefore only voluntary acts can attract blame or praise, but that some result or event can be said to be unjust even if an agent's acts are involuntary. ${ }^{49}$ The Aristotelian concepts of corrective and distributive justice, voluntary and involuntary transactions, as well as voluntary and involuntary conduct, have survived to this day and constitute the starting point for much of the existing theoretical and doctrinal scholarship on morality, justice, private law, and in particular contract law and tort law. Aristotle, however, cannot

\footnotetext{
${ }^{46}$ Aristotle's summa divisio of justice is between distributive and corrective justice. Distributive justice deals with the relationship between persons and the larger communities they inhabit, whereas corrective justice deals with relationships persons have with each other.

${ }^{47} \mathrm{NE} 1131 \mathrm{~b} 25-26$.

${ }^{48}$ NE Book V Ch. 4 1132a (p. 73).

${ }^{49}$ NE Book V Ch. 4 1135a-1135b (p. 79-80).
} 
be credited with inventing anything like the idea of civil wrongs. His examples of unjust involuntary transactions were bundled together with examples of injustice in voluntary exchange (contracts), ${ }^{50}$ and no further categories were identified within involuntary transactions. What he can legitimately receive credit for is asking the right questions and launching a tradition of moral and legal inquiry centred around the investigation of relational events (interactions).

Something like the concept of a tort, delict, or civil wrong surfaced much later, in the work of the Roman jurists of the Classical period. The earliest articulation of a private law category concerned with the problem of wrongs most likely belongs to the second century jurist Gaius. ${ }^{51}$ He developed an account of the law of his time centred around the concept of the civil obligation (obligatio): ${ }^{52} \mathrm{a}$ relational and correlative concept consisting of a legal bond between two persons where one is obligated to the performance of something for the benefit of the other. ${ }^{53}$ Gaius asked himself what triggers the creation of such legally enforceable bonds, and concluded in his Institutes that there are two main sources of obligations: contractus (contract), and delictum (delict or wrong). ${ }^{54}$ However, he also identified a number of situations that did not fit into the categories of contract or delict. Therefore, a third residual category of "other causal events" 55 is implicit in Gaius's Institutes. ${ }^{56}$ Gaius was able to label this third residual category only in a later text, the Res cottidianae, a text which is known to us only through excerpts reproduced in the Digest of the Corpus Iuris Civilis. ${ }^{57} \mathrm{He}$ concluded that these were obligations borne "by operation of law" (proprio quodam iure) and that there are many different forms that these obligations take, some resembling contracts (quasi ex contractu) and others resembling delicts (quasi ex maleficio). ${ }^{58}$

\footnotetext{
${ }^{50}$ NE Book V Ch. 4 1133a (p. 74-75).

${ }^{51}$ Birks, supra note 40, at 31.

${ }^{52}$ For details on the likely origins of the concept of "obligation" see CHRISTIAN VON BAR, 1 THE COMMON EUROPEAN LAW OF TORTS 5 (Oxford University Press 1998).

${ }^{53}$ The civil obligation was defined in the Corpus Iuris Civilis as follows: Obligatio est iuris vinculum, quo necessitate adstringimur alicuius solvendae rei secundum nostrae civitatis iura ("An obligation is a legal tie which binds us to the necessity of making some performance in accordance with the laws of our state"). J.3.13 pr (Peter Birks \& Grant McLeod trans., Duckworth 1987).

${ }^{54}$ G.3.88 (W.M. Gordon \& O.F. Robinson trans., Cornell University Press 1988): Omnis enim obligatio vel ex contractu nascitur vel ex delicto ("All obligations arise from a contract or from a delict").

${ }^{55}$ See Birks, supra note 40, at 31.

${ }^{56}$ DESCHEEMAEKER, supra note 41 , at 57-58.

${ }^{57} \mathrm{Id}$.

${ }^{58} \mathrm{Id}$. at 58-59 (these pages contain also the relevant texts in Latin and translated into English).
} 
By asking "where do civil obligations come from?" and structuring his answer into distinct categories, Gaius provided legal science with a new kind of "software" legal materials. Many legal scholars since Gaius have been asking the same basic question before structuring their work on private law (but have never stopped tinkering with his answer).

With time, the doctrinal classification of the sources of obligations became more and more sophisticated. By the time the Corpus Iuris Civilis was written (in the $6^{\text {th }}$ century, during the reign of the emperor Justinian), Gaius's threefold taxonomy had developed into a fourfold division: contract, quasi-contract ("as though" from a contract), delict (wrong), and quasi-delict ("as though" from a delict). ${ }^{60}$ The fourfold classification enjoyed a relatively long life, and survived from Justinian's time to the time of the major codifications of the $19^{\text {th }}$ century in the civil law nomos. In fact, to this day, the fourfold Roman classification remains a staple of civil law taxonomy. In a modified form, and via the $18^{\text {th }}$ century legal scholar Robert Pothier, ${ }^{61}$ it even made its way into the French Civil Code of 1804 (and from there into many other European civil codes). However, it should be noted that the late Roman classification was not favoured by many influential natural law scholars writing before the enactment of the French Civil Code, ${ }^{62}$ and was

\footnotetext{
${ }^{59}$ The metaphor belongs to Peter Birks. Peter Birks, Introduction, in 1 ENGLISH PRIVATE LAW xlvii (Peter Birks ed., Oxford University Press 2000).

${ }^{60}$ J.3.13.2 (Peter Birks \& Grant McLeod trans., Cornell University Press, 1987): Sequens divisio in quattuor species deducitur: aut enim ex contractu sunt aut quasi ex contractu aut ex maleficio aut quasi ex maleficio ("[O]bligations arise from a contract, as though from a contract, from a wrong, or as though from a wrong"). See also DESCHEEMAEKER, supra note 56, at 57-59; Birks, supra note 40, at 31.

${ }^{61}$ It is through the work of Robert Pothier that the Roman law categories made their way into the French Civil Code. He more or less followed the Roman law classification, but added a fifth residual source of obligations, and saw contracts as a primary (or, at the very least, more important) source of obligations. See ROBERT J. POTHIER, 1 TRAITÉ DES OBLIGATIONS, SELON LES RĖGLES TANT DU FOR DE LA CONSCIENCE QUE DU FOR EXTÉRIEUR 5 [n ${ }^{\circ} 2$ ] (les frères Debure \& la veuve Rouzeau-Montaut 1774) : Les causes des obligations sont les contrats, les quasi-contrats, les délits, les quasi-delits, quelquefois la loi ou l'équité seule. ["The causes of obligations are contracts, quasicontracts, delicts, quasi-delicts and sometimes law or equity alone"]. A similar translation can be found in ROBERT J. POTHIER, 1 A TREATISE ON OBLIGATIONS, CONSIDERED IN A MORAL AND LEGAL VIEW 3 (N. C. Newbern trans., Martin and Ogden 1802) ("The causes of obligations are contracts, quasi-contracts, torts, quasi-torts; sometimes the law or equity alone.")

${ }^{62}$ Hugo Grotius, for instance, preferred a tripartite classification. See HugONIS GROTII, DE IURE BELLI AC PACIS LIBRI TRES : IN QUIBUS JUS NATURAE, GENTIUM, ITEM JURIS PUBLICI PRAECIPUA EXPLICANTUR 201 (Guilielmum Blaeu 1632), available online at https://archive.org/details/hugonisgrotiidei00grot: Supra diximus ejus quod nobis debetur fontes esse tres, pactionem, maleficium, legem. ["We have said above that there are three sources of what is owed to us, agreement, wrong, and statute." The translation is taken from F.H. LAWSON \& BASIL S. MARKESINIS, 1 TORTIOUS LIABILITY FOR UNINTENTIONAL HARM IN THE COMMON LAW AND THE CIVIL LAW 40 (Cambridge University Press 1982)].

Jean Domat, by contrast, preferred a two-fold classification based on the Aristotelian distinction between voluntary and involuntary transactions, and thus divided transactions (engagements) between strangers into contractual and non-contractual transactions. See JEAN DOMAT, LES LOIX CIVILES DANS LEUR ORDRE NATUREL, LE DROIT PUBLIC ET
} 
more or less abandoned by most French scholars writing after the enactment of the Code $^{63}$ (being replaced by more sophisticated taxonomies). ${ }^{64}$ It was also recently removed from the French Civil Code and replaced with a much more modern set of categories. Thus, in the recent reform of the law of obligations ${ }^{65}$ article 1100 was introduced, which reads: "Obligations arise from juridical acts, from juridical facts, or from the authority of the law alone." (Les obligations naissent d'actes juridiques, de faits juridiques ou de l'autorité seule de la loi). The category of "juridical facts" was further subdivided in article 1100-2 (2) into "non-contractual liability" (responsabilité extracontractuelle) and a residual category of "other sources of obligations" (autres sources d'obligations). ${ }^{66}$

Despite the taxonomical heterogeneity of the sources of obligations found in civil law legal doctrine and legislation, in every scheme that has been proposed since Gaius the category of wrongs (or delicts) has been ever-present. At a core level, there is a high level of continuity in the practice of imposing legal obligations on the basis of interpersonal wrongs within the civil law tradition.

The modern category of non-contractual liability (responsabilité extracontractuelle) has obvious links with the combined Roman categories of delicts and quasi-delicts, and the concept of a "civil

\footnotetext{
LEGUM DELECTUS, at vi, 147 (nouvelle ed., Savoye 1756) available online at https://gallica.bnf.fr/ark:/12148/bpt6k117556w. For the English translation see JEAN DOMAT, 1 THE CIVIL LAW IN ITS NATURAL ORDER (Cuther S. Cushing trans., Little, Brown \& Co., 1853).

${ }^{63}$ With the notable exception of the treatise written by Aubry and Rau (itself a translation, for the most part, of Zachariae von Lingenthal's work, which perhaps explains the strict adherence to the Roman law taxonomy). See ChARles AubrY \& CHARLES-FrÉDÉRIC RAU, COURS DE DROIT CIVIL FRANÇAIS (F. Lagier 1839-1846, 5 vols.). ${ }^{64}$ See, e.g., Charles-Bonaventure-Marie Toullier, 11 Le Droit CiVIL FRANÇAis SUIVANT L'OrdRe DU Code 10-11 [n ${ }^{\circ}$ 9] (4th ed., Warée oncle et Warée fils aîné 1824), available online at https://gallica.bnf.fr/ark:/12148/bpt6k119157k; ALEXANDRE DURANTON, 10 COURS DE DROIT FRANÇAIS SUIVANT LE CODE CIVIL 11-18 [n $\mathrm{n}^{\text {os }}$ 19-30] (Alex-Gobelet 1830), available online at https://gallica.bnf.fr/ark:/12148/bpt6k9763850r; RENÉ DEMOGUE, 1 DES OBLIGATIONS EN GÉNÉRAL 21-50 ( ${ }^{\text {os }} 11$ 17bis) (A. Rousseau 1923), available online at https://gallica.bnf.fr/ark:/12148/bpt6k65173531; NOOMAN M. K. GomaA, ThÉorie des Sources de L'obligation (L.G.D.J. 1968); MARCEL Planiol, 2 Traité ÉlÉMENTAire de DROIT CIVIL 259-261 [n ${ }^{\text {os }}$ 805-809] (5th ed., L.G.D.J. 1909) ; HeNRI MAZEAUd ET AL., 2 LEÇONS DE DROIT CIVIL. OBLIGATIONS. THÉORIE GÉNÉRALE 12 [nº 17], 44-48 [n ${ }^{\text {os }} 45-51$ ] ( $8^{\text {th }}$ ed., Montchrestien 1991); FrANÇOIS TERRÉ ET AL., Droit Civil. Les Obligations $23-25$ [ $\mathrm{n}^{\text {os }}$ 15-16] (10th ed., Dalloz 2009); PhilipPE MaLAURIE ET AL., Droit DES OBLigations $17-18$ [ $\mathrm{n}^{0} 10$ ] ( $8^{\text {th }}$ ed., L.G.D.J. 2016); MuRIEl FABRE-MAGNAN, 1 DROIT DeS OBLigations. CONTRAT ET ENGAGEMENT UNILATÉRAL 7-14 [n $\left.{ }^{\text {os }} 7-11\right]$ ( $4^{\text {th }}$ ed., P.U.F. 2016).

${ }^{65}$ Loi n $^{\circ}$ 2018-287 du 20 avril 2018 ratifiant l'ordonnance ${ }^{\circ}$ 2016-131 du 10 février 2016 portant réforme du droit des contrats, du régime général et de la preuve des obligations, JORF n 93 du 21 avril 2018. An English translation is available online at http://www.textes.justice.gouv.fr/art pix/Translationrevised2018final.pdf

${ }^{66}$ The text of the new article 1100-2 (2) reads as follows: Les obligations qui naissent d'un fait juridique sont régies, selon le cas, par le sous-titre relatif à la responsabilité extracontractuelle ou le sous-titre relatif aux autres sources d'obligations.
} 
wrong" still captures the common core of these legal categories. The modern practice of responsabilité extracontractuelle does differ, however, from its Roman precursor in some ways. Perhaps the most important difference is the fact that the modern practice, in France at least, is devoid of any retributive or penal considerations. The separation between public law and private law and between civil law and criminal law is much stricter today than it was in Roman times. In Ancient Rome, the obligation to pay damages was seen as a form of personal punishment for the tortfeasor (poena), and what victims sought was not necessarily compensation, but a form of revenge or "economic retaliation" ${ }^{67}$ Therefore, the victim's form of redress was both compensatory and retributive, with an emphasis on the latter. That is why it was possible for a victim to cumulate damages from multiple tortfeasors when the wrongful act was committed by more than one person. ${ }^{68}$ It is also why, when a tortfeasor died, his heirs did not inherit the obligation to pay damages and had to compensate the victim only if they were enriched by the tortfeasor's unlawful act. ${ }^{69}$ Today, in France, the victim's redress is almost always compensatory. The obligation to pay damages is construed as a duty to repair the victim's loss for the tortfeasor and, correlatively, as a right to full compensation for the victim. In exceptional circumstances, damages can surpass the value of the victim's loss, but only in order to disgorge the profits made by the tortfeasor. ${ }^{70}$ Also exceptionally, preventive orders can be issued by a court to prevent the occurrence of damage. ${ }^{71}$ However, the general rule is that a victim cannot ask for punishment of the tortfeasor. ${ }^{72}$ It is perhaps true that judges sometimes infuse compensatory damages with a punitive element when they evaluate non-pecuniary loss (préjudice moral). ${ }^{73}$ However, the fact

\footnotetext{
${ }^{67}$ Nils Jansen, Duties and Rights in Negligence: A Comparative and Historical Perspective on the European Law of Extracontractual Liability, 24 OXF. J. LEG. STUD. 443, 448 (2004).

${ }^{68} I d$.

69 Id.

${ }^{70}$ The most common examples involve infringements of intellectual property rights. See CODE DE LA PROPRIÉTÉ INTELLECTUELLE, art L.615-7: Pour fixer les dommages et intérêts, la juridiction prend en considération distinctement: $1^{\circ}$ Les conséquences économiques négatives de la contrefaçon, dont le manque à gagner et la perte subis par la partie lésée; $2^{\circ}$ Le préjudice moral causé à cette dernière ; $3^{\circ}$ Et les bénéfices réalisés par le contrefacteur, y compris les économies d'investissements intellectuels, matériels et promotionnels que celui-ci a retirées de la contrefaçon. (allowing judges to take into account the benefit of the tortfeasor when calculating damages for patent infringements).

${ }^{71}$ See CYRIL Bloch, LA CESSATION DE L'ILLICITE. RECHERCHE SUR UNE FONCTION MÉCONNUE DE LA RESPONSABILITÉ CIVILE EXTRACONTRACTUELLE (Dalloz 2008); CYRIL SINTEZ, LA SANCTION PRÉVENTIVE EN DROIT DE LA RESPONSABILITÉ CIVILE : CONTRIBUTION À LA THÉORIE DE L'INTERPRÉTATION ET DE LA MISE EN EFFET DES NORMES (Dalloz 2011).

${ }^{72}$ Oliver Moréteau, Basic Questions of Tort Law from a French Perspective, in BASIC QUESTIONS OF TORT LAW FROM A COMPARATIVE PerSPECTIVE 3, 17 (Helmut Koziol ed., Jan Sramek Verlag 2015): "French law, like other continental systems, does not recognize claims for punitive damages."

${ }^{73}$ SuZANNE CARVAL, LA RESPONSABILITÉ CIVILE DANS SA FUNCTION DE PEINE PRIVÉE 289 [nº 256] (L.G.D.J. 1995).
} 
that punishment enters the law of tort in this indirect form only strengthens the principle that victims cannot ask for punishment. The state's monopoly in the area of punishment is understood in a broad sense in France, extending also to the initiative to punish, not just the performance of punishment. Consequently, it is considered that the proper domain for punitive measures is within criminal and administrative law, and not private law.

Moving on to English law, we have already seen that the English law of wrongs developed for the most part in isolation, and without a very strong influence from Roman law. ${ }^{74}$ In its early days, the only tool for organizing legal material in the English common law was the alphabet, ${ }^{75}$ and what was available to be organized was just a miscellanea of procedural writs and court decisions. That being said, the evolution of English law was very similar to that of Roman law, ${ }^{76}$ and legal scholarship and thinking about English law has been undoubtedly influenced by the modes of thinking and taxonomizing the law which emerged from the study of Roman law. ${ }^{77}$ As a result, today one can easily recognize in the landscape of English law which areas are concerned with the problem of civil wrongs because those areas have been separated from other parts of the law in precisely the same way as they have been in the civil law tradition.

Like Roman law, English law began as a formulary system, with substance hidden within the "interstices of procedure". ${ }^{78}$ Procedural law and substantive law were one and the same, and there was no abstract division of the sources of claims, and therefore no distinction made between claims arising out of contracts or wrongs. Also, the early remedies of the common law were more retributive than compensatory, as the early common law did not separate what we now understand as civil and criminal law matters. The way English law changed in time also mirrors the development of Roman law (and the civil law afterlife of Roman law), the law slowly rearranging itself along substantive categories. What is truly remarkable though is the fact that not only did English law rearrange itself along substantive categories, it rearranged itself along strikingly similar substantive categories to those of the Roman law inspired civil law tradition. Gradually,

\footnotetext{
${ }^{74}$ Supra Chapter III Part A.1.

${ }^{75}$ Descheemaeker, supra note 56, at 190, 193.

${ }^{76}$ Fritz Pringsheim, The Inner Relationship Between English and Roman Law, 5 CAMBrIDGE LAW JouRNAL 347, 358 (1935).

${ }^{77}$ Heinrich Brunner, The Sources of English Law in 2 SELECT EsSAYS IN ANGLO-AMERICAN LeGAL History 7, 36, 42 (The Lawbook Exchange 1992/ originally Little, Brown and Co. 1908).

${ }^{78}$ Henry Sumner Maine, Dissertations on EARly LaW AND Custom 389 (Henry Holt and Company 1886).
} 


\section{Chapter V}

civil law matters were separated from criminal law matters, ${ }^{79}$ procedural law was separated from substantive law, ${ }^{80}$ and a law of contract emerged as distinct from the law of wrongs (torts). ${ }^{81}$

It should be noted though that the resulting categories are more fluid in the common law than they are in the civil law, and that all these processes are somewhat unfinished. Some civil wrongs, such as battery or assault, bear the same name and have similar elements to the common law crimes they separated from, ${ }^{82}$ punitive damages can be imposed for civil wrongs (torts), ${ }^{83}$ and it is still possible in England for a private party to institute and conduct criminal proceedings. ${ }^{84}$ Also, while the forms of action have been abolished, the different wrongs recognized in English law still draw much of their substance from the requirements of the old forms of action. ${ }^{85}$ Even the distinction between contract and tort is somewhat unclear. Some breaches of contract can also constitute breaches of duties in tort, and in such situations English law gives the victim a choice between claiming compensation in tort or on the basis of breach of contract. ${ }^{86}$ French law, by contrast, operates within a stricter separation between contractual and delictual liability and does not, in principle, allow a victim to choose between them. Generally speaking, under French law, an event is either a delict or a failure to perform a contract, but not both at the same time (the rule of noncumul). ${ }^{87}$ All of these differences, however, do not diminish the fact that the broadest categories in which civil law and common law lawyers think are roughly the same.

The credit for these developments must go primarily to the English treatise writers. As many of them were familiar with the Corpus Iuris Civilis and some even had a sophisticated understanding of Roman law and its categories, it should come as no surprise that the divisions of the law they

\footnotetext{
${ }^{79}$ A process that seems to have been envisaged by English scholars from as early as the $12^{\text {th }}$ century. See FrEDERICK Pollock \& FRederic William Maitland, 2 The History of ENGlish LaW Before the Time OF EDWARd I, at 570 (Cambridge University Press 1895) (making reference to a passage from Glanvill).

${ }^{80}$ The abolition of the forms of action during the middle of the $19^{\text {th }}$ century is the main cut off point for this process.

${ }^{81}$ For a detailed historical account see A. W. BRIAN SIMPSON, A HisTORY OF THE COMMON LAW OF CONTRACT: THE RISE OF THE ACTION OF AsSUMPSIT (Oxford University Press 1975, repr. 2005).

${ }^{82}$ W. EDWIn PeEl \& JAMES GOUdKAMP, Winfield AND Jolowicz ON TORT 11 (19 $9^{\text {th }}$ ed., Thomson Reuters 2014).

${ }^{83}$ See Vanessa Wilcox, Punitive Damages in England, in Punitive Damages: Common LaW And Civil LaW PeRSPECTIVES 7 (Helmut Koziol \& Vanessa Wilcox eds., Springer 2009).

${ }^{84}$ See Section 6 of the Prosecution of Offences Act 1985, c. 23;

${ }^{85}$ See Frederic William Maitland, Equity, also The Forms of Action at Common LaW 296 (Cambridge University Press, reprinted 1929/ originally published in 1909): "The forms of action we have buried, but they still rule us from the grave."

${ }^{86}$ Henderson v Merrett Syndicates Ltd., [1994] W.L.R. 761, [1995] 2 A.C. 145; ANDREW BuRROws, UNDERSTANDING THE LAW OF OBLIGATIONS: ESSAYS ON CONTRACT, TORT AND RESTITUTION 17 (Hart Publishing 1998).

${ }^{87}$ The rule of non-cumul has been relaxed in recent years, particularly in the field of medical malpractice. See Cass Civ., 1re, 3 June 2010, D. 2010. 1522 (note P. Sargos).
} 
employed mirrored the pre-existing Roman law categories. Already in the $13^{\text {th }}$ century, Bracton organized his De Legibus et Consuetudinibus Angliae in accordance with Roman law categories. ${ }^{88}$ He followed the institutional scheme and divided his work into persons, things, and actions, then subdivided the law of actions into actions in personam, in rem, and mixed. ${ }^{89}$ The law of wrongs (ex maleficio) he located within the category of actions in personam, alongside the law of contract (ex contractu).${ }^{90}$ Much later, in the $18^{\text {th }}$ century, William Blackstone structured English law along similar lines in his Commentaries on the Laws of England, dividing the subject-matter into persons, things, and wrongs. ${ }^{91}$ The law of wrongs was further subdivided by Blackstone into wrongs that are private in nature and wrongs that are public. ${ }^{92}$ Under the heading of "private wrongs", he discussed many topics, a large part of which coincide with what today would be called torts (such as battery, false imprisonment, slander, trespass, or nuisance). However, also included under the heading of "private wrongs" was an extensive discussion on various procedural matters (such as jurisdiction, the methods of trial, of judgments, appeal proceedings, and the organization of the various courts), ${ }^{93}$ and even a small section on equitable wrongs. ${ }^{94}$ Therefore, Blackstone's category of wrongs is in many ways closer to Bracton's category of delicts (delictum or maleficium) than to the modern notion of torts.

The modern legal category of "tort" and the "law of torts" as an autonomous subject of study surfaced somewhere between the mid- $18^{\text {th }}$ and the early $19^{\text {th }}$ century, and took hold definitively a century later, when authors such as Addison ${ }^{95}$ and Pollock ${ }^{96}$ wrote their well-known treatises. The

\footnotetext{
${ }^{88}$ Henry de Bracton, De Legibus Et Consuetudinibus Angliæ (George Woodbine ed., Samuel E. Thorne trans.) available online in bilingual format at http://bracton.law.harvard.edu/.

${ }^{89}$ Id. at 290 (vol. 2): Et sciendum quod omnium actionum sive placitorum, ut inde utatur aequivoce, haec est prima divisio, quod quaedam sunt in rem, quaedam in personam et quaedam mixtae. Item earum quae sunt in personam alia criminalia alia civilia, secundum quod descendunt ex maleficiis vel contractibus. ("The first classification of actions or pleas (to use these terms synonymously) is this, that some are in rem, some in personam and some mixed. Of those in personam, [some] descend ex maleficio, [others] ex contractu. [Of those ex maleficio], some are criminal, others civil").

${ }^{90} I d$.

${ }^{91}$ William Blackstone, Commentaries on the Laws of England (4 vols., $15^{\text {th }}$ ed., A. Strahan 1809 , republished by Forgotten Books 2012).

${ }^{92} I d$. (volume 3 deals with private wrongs, whereas volume 4 is concerned with public wrongs).

${ }^{93}$ William Blackstone, 3 COMMENTARIES ON THE LAWS OF ENGLAND 22-86, 270-455 [Ch. III-VI, and XVIIIXXVII] (15 ${ }^{\text {th }}$ ed., A. Strahan 1809, republished by Forgotten Books 2012).

${ }^{94} \mathrm{Id}$. at $426-455$.

${ }^{95}$ Charles G. AdDison, Wrongs AND their Remedies: Being a TREATISE ON THE LAW OF TORTS (V. and R. Stevens and Sons 1860).

${ }^{96}$ Frederick Pollock, The LaW of Torts: A Treatise on the Principles of Obligation ARISING From Civil WrONGS IN THE COMMON LAW (Stevens and Sons 1887).
} 
term "tort" is a synonym for "wrong" 97 , but what has emerged as the subject-matter of the $19^{\text {th }}$ century treatises are only those wrongs which are private (thus excluding the category of crimes, or public wrongs). Furthermore, only the wrongs which emerged from the case law of the courts of common law were included in the "law of torts", thus excluding those which were dealt with by the courts of equity before they were merged with the regular courts.

In the $20^{\text {th }}$ century, the number of treatises, monographs and journal articles on English tort law grew exponentially, and the cross-influences with the civil law world became even more pronounced. The law of torts as a subject of study solidified its boundaries, and that is why equitable wrongs are rarely given treatment in a monograph or treatise dealing with the law of torts. However, as this is clearly an unfortunate remnant of past procedural divisions, which ought to be ignored, the law of civil wrongs in England is best understood as including both torts and equitable wrongs. ${ }^{98}$

Today, debates and proposals on how to substantively structure English law are more fiery and imaginative than ever. ${ }^{99}$ It is hard to tell whether tort law as a subject of inquiry and study will end up incorporating equitable wrongs, and it is equally hard to know whether the way private law is classified in England will resemble more the categories we find on the Continent. Most likely, differences will remain. Nevertheless, the question that is being asked is the same. That there is a law of torts to speak of today in England, and that this law is seen as different from the law of

\footnotetext{
${ }^{97}$ The word "tort" is derived from the Latin tortus, which means "twisted", or "wrong". ROBERT STEVENS, TORTS AND Rights 2 (Oxford University Press 2007); WiLliam L. Prosser, LAW OF TORTS 2 (4th ed., West 1971).

${ }^{98}$ The Concept of a Civil Wrong, supra note 40, at 35; Descheemaeker, supra note 56, at 206-207.

${ }^{99}$ See e.g. Patrick S. Atiyah, Contracts, Promises and the Law of Obligations, 94 L. Q. REv. 193, 220-23 (1978) \& PATRICK S. ATYAH, THE Rise AND FALL OF THE FREEDOM OF CONTRACT 4, 768, 778-9 (Oxford University Press 1979) (arguing that the law of obligations should be divided into "reliance-based" and "benefit-based" liabilities); Steve Hedley, Contract, Tort and Restitution: or, On Cutting the Legal System Down to Size, 8 LEG. STUD. 137 (1988) (arguing that the division between contract, tort and restitution should be replaced with a division based on the eight types of assets protected in the law of obligations); Jane Stapleton, A new 'Seascape' for Obligations: Reclassification on the Basis of Measure of Damages, in The Classification OF OBLIGATIONS 193 (Peter Birks ed., Clarendon Press 1997) (arguing that the law should be categorised based on measure of damages). But see also Peter Birks, An Introduction to the Law of Restitution 28-49 (Clarendon Press 1985, repr. 1996); Peter Birks, Restitution and Wrongs, 35 CLP 53 (1982); Peter Birks, Six Questions in Search of a Subject-Unjust Enrichment in a Crisis of Identity, [1985] JURID. REVIEW 227; Peter Birks, Unjust Enrichment-A Reply to Mr. Hedley, 5 Leg. Stud. 67 (1985); Peter Birks, Definition and Division: A Meditation on Institutes 3.13 in THE Classification of Obligations 1 (Peter Birks ed., Clarendon Press 1997); Andrew Burrows, Contract, Tort and Restitution -A Satisfactory Division or Not?, 99 L. Q. REv. 217 (1983); BURRows, supra note 86, at 1-15 (defending the traditional division between contract, tort and restitution);
} 
contract and restitution, is by itself proof that the days when the common law's structure was dictated only by the alphabet are long forgotten. ${ }^{100}$

\section{A tentative definition}

We have talked about the history of the idea of civil wrongs, but we have not yet defined what exactly civil wrongs are. It was suggested already that civil wrongs are relational wrongs which are dealt with in the part of the law we call private law. ${ }^{101}$ This was a good starting point for our historical introduction, but we can now attempt to formulate a more detailed and useful definition. In particular, we can better differentiate civil wrongs from other relational events with which private law is concerned, and we can explain what relational wrongs are from a legalnormative perspective (i.e. what is the role of legal rights and duties in understanding civil wrongs). The following tentative definition will be our starting point: a civil wrong is an involuntary interaction which consists of an infringement or violation by one person of another's legally protected interest (and therefore also a breach of a legal duty owed to that other person), the occurrence of which triggers ${ }^{102}$ the creation of a civil obligation. ${ }^{103}$

What the English call liability in tort, the portion of English equity dealing with equitable wrongs, and what the French call responsabilité civile délictuelle, can all be understood as parts of the law concerned with the problem of civil wrongs as defined above. What the definition excludes are voluntary interactions (contracts), lawful involuntary interactions which give rise to legal obligations, and non-legal wrongs.

Contracts and other juridical acts fall into the category of voluntary interactions. Like civil wrongs, contracts also have the potential to give rise to remedial obligations, but the legal relationship in

\footnotetext{
${ }^{100}$ See also Descheemaeker, supra note 56, at 31: "The traditional alternative structure of the common law, the alphabet, has been moved on from." Contra, see Peter Birks' pessimistic pronouncement, in Birks, Definition and Division: A Meditation on Institutes 3.13, supra note 99, at 2: "The alphabet has [recently] taken back what little ground it had ever surrendered.".

${ }^{101}$ Supra Part E.1 of this chapter.

${ }^{102}$ In this context, "triggers" should be understood as "constitutes the reason for."

${ }^{103}$ Similar conceptualizations of the civil wrongs can be found in ERIC DESCHEEMAEKER, THE DIVISION OF WRONGS: A HistoricAl COMPARATIVE STUDY 17 (Oxford University Press 2009): "our starting point will be to define a wrong as the violation of a right, and therefore a breach of duty"; and Birks, supra note 40, at 33: "A civil wrong is $[\ldots]$ a breach of legal duty owed to a plaintiff."

Descheemaeker's definition is preferable because it does not make any reference to "plaintiffs" or "defendants." Civil wrongs exist also outside of civil proceedings, and that is why it is unnecessarily restrictive to say that plaintiffs are the passive subjects of the duties in question.

See also BLACKSTONE, supra note 93, at 2: "[private wrongs] are an infringement or privation of the private or civil rights belonging to individuals, considered as individuals."
} 
contractual situations is voluntary, i.e. it is born out of the parties' will. Involuntary interactions give rise to remedial obligations regardless of the parties' intentions to be bound. It is a common characteristic of tort law, equitable wrongs, and the responsabilité civile délictuelle that, when the parties interact, they do not have a common intention to enter into a legal relationship. The legal relationship is born from the wrongful involuntary interaction between them, irrespective of what the parties intended. This means that, in contrast to voluntary interactions, the parties do not seek, by common accord, to be bound. To be more precise, the parties' will to be bound does not count among the reasons for the imposition of any legal obligations between them.

That being said, things are not always so clear cut. There are situations in which legal obligations can be derived from both voluntary and involuntary interactions. When a breach or nonperformance of a contract is also a breach of a primary duty fixed by the law, both the voluntary interaction (the contract) and the involuntary interaction (the wrong) can simultaneously be sources of obligations. In such situations, as already mentioned, ${ }^{104}$ the English legal system gives the obligor a choice between the two legal bases, whereas in France we find a stricter separation between contractual and non-contractual liability (and the contractual avenue is usually preferred). ${ }^{105}$ There is also the possibility of not relying on the categories of tort and contract altogether and of creating an entirely different legal regime for such events. Both France and England know of at least one such sui generis liability regime, and that is the strict liability regime for damage caused by defective products. ${ }^{106}$

Not all involuntary transactions between persons are wrongful, and this is true even for a number of involuntary transactions that give rise to civil obligations. In both the civil law and the common law traditions, legal obligations may arise from events and acts which are perfectly lawful and cannot be characterized as infringements of rights and breaches of legal duties. In the civil law tradition, the traditional category of "quasi-contracts" covers these kinds of interactions [broken down into the sub-categories of unjustified enrichment (l'enrichissement sans cause), payment of a debt not owed (le paiement de l'indu), and management of the affairs of another (la gestion d'affaires)], ${ }^{107}$ whereas the common law groups these events under the law of restitution

\footnotetext{
${ }^{104}$ Supra Part E.1 of this chapter.

${ }^{105}$ With a few exceptions. See supra note 87.

${ }^{106}$ See supra Chapter II Part C.3 and Chapter III Part B.3.

107 TERRÉ ET AL., supra note 64 , at $1029-70$ ( ${ }^{\text {os }} 1026$ to $\left.1074-1\right)$.
} 
(particularly when restitutionary remedies are available for events which cannot be characterized as wrongs). ${ }^{108}$

Also excluded from the category of civil wrongs are non-legal wrongs, i.e. wrongs which do not consist of a breach of a legal duty (or infringement of a legal entitlement), and which do not lead to the creation of legal obligations. Civil wrongs are a sub-category of legal wrongs, which means that the normative system which determines which duties are owed and which rights are protected is the law (le droit). Non-legal wrongs are those wrongful relational events which are not legally relevant, cannot be characterized as breaches of duties or infringements of rights, and do not give rise to civil obligations. For instance, if I fail to show up for a blind date, one can legitimately say that I wronged the person who was eagerly expecting me, but that person will not, under normal circumstances, have any recourse in court because my actions are not constitutive of a legal wrong.

3. The normative structure of civil wrongs

a. The two-tier structure

There are two sets of duties and entitlements which make up the normative structure of civil wrongs. The definition provided in the previous section emphasizes this "two-tier"109 structure. The set of facts that can be characterized as a breach of a legal duty (or the violation of a legally protected interest) also triggers the birth of a new duty and a new right. The wrongful or tortious event bridges "first order" duties and "second order" (or "remedial") duties (and their correlative rights or entitlements). ${ }^{110}$

First order and second order duties are linked in a very specific way: the violation or infringement of the first order duty is a source for the remedial duty. To phrase this differently, the remedial duty is born because the first order duty was breached.

The two-tier structure is readily observable in the English tort of negligence: the breach of a duty of care owed to the victim (the primary duty) triggers a claim for compensation (the remedial duty)

\footnotetext{
108 See Andrew Burrows, The LAw OF Restitution 9 ( $3^{\text {rd }}$ ed., Oxford University Press 2002) (naming this group of events "restitution of an unjust enrichment," as opposed to "restitution for wrongs"); PETER BIRKS, AN INTRODUCTION TO THE LAW OF RESTITUTION 25-27 (Clarendon Press 1985, repr. 1996) (placing this group of causal events under the generic heading of "unjust enrichment by subtraction").

${ }^{109}$ Birks, supra note 40, at 37.

${ }^{110} \mathrm{Id}$. at 37-38; Descheemaeker, supra note 56, at 20-23; See also JOHN AUSTIN, LECTURES ON JURISPRUDENCE 44$47,796-96$ ( $2^{\text {nd }}$ ed., Burt Franklin 1970).
} 
against the tortfeasor. Another transparently two-tiered tort is breach of statutory duty. This is a tort premised upon the existence of a pre-existing statutory duty, and it is the breach of any such pre-existing statutory duties that gives rise to the remedial duties to compensate the victim. In the case of other torts and equitable wrongs, the same structure may not always be articulated explicitly, but it is there nonetheless. The tort of battery, for instance, consists of (1) a primary duty not to intentionally touch another in an unlawful way ${ }^{111}$ (most often this means a harmful, offensive, or unconsented to contact), and (2) a remedial duty (usually to pay damages) in case the primary duty is breached. Similar constructions can be made for the torts of conversion, trespass to goods, trespass to land, nuisance, product liability, ${ }^{112}$ and so on.

The two-tier structure also underlies French non-contractual liability regimes. In fact, the idea of a two-tier structure was, as far as we know, first articulated by the French legal scholar Robert Pothier, ${ }^{113}$ who is considered "one of the fathers of the civil code" 114 and whose scholarly work has been one of the main sources of inspiration for the provisions of the Code Napoléon. ${ }^{115}$ Pothier's two-tier structure was later endorsed by one of the most influential French scholars of the $20^{\text {th }}$ century, ${ }^{116}$ Marcel Planiol, ${ }^{117}$ and by two of the most well-respected contemporary tort scholars, Geneviève Viney and Patrice Jourdain. ${ }^{118}$ However, most other French legal scholars have been reluctant to discuss the structure of delictual liability, and seem to avoid at all costs the recognition of primary duties and entitlements. Even Viney and Jourdain structured their work around the "requirements (or elements) of liability" (les conditions de la responsabilité) and the

\footnotetext{
${ }^{111}$ As well as the correlative entitlement to be free from such acts.

${ }^{112}$ See Goldberg \& Zipursky, supra note 43, at 938.

${ }^{113}$ Pothier, 1 Traité Des Obligations..., supra note 61, at 209-212 [n ${ }^{\text {os }}$ 183-185]; PothieR, 1 A Treatise ON the LAW OF OBLIGATIONS..., supra note 61, at 111-13.

${ }^{114}$ Claude Michaud, Review of ROBERT-JOSEPH POTHIER D'HIER ET D'AUJOURD'HUI (Joël Moneger et all. Eds., Economica 2001), 34 DiX-HUITIÈME SIĖCLE 666, 667 (2002), available online at https://www.persee.fr/doc/dhs 0070-6760 2002 num 3412517 t1 066600003.

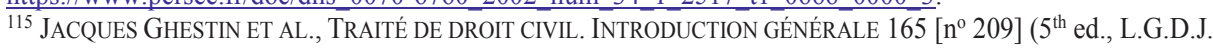
2018).

${ }^{116}$ As a side note, it is due to John Austin's familiarity with the work of Pothier that the two-tier structure entered the English juridical nomos. See Birks, supra note 40, at 38.

${ }^{117}$ Planiol defined faute (which for him was the only basis for liability) as a "breach of a pre-existing obligation", which gives rise to a second-order obligation to repair the damage caused to another. PLANIOL, supra note 64, at 280 [n $\left.{ }^{\circ} 863\right]$ : La faute est un manquement à une obligation préexistante, dont la loi ordonne la réparation quand il a causé un dommage à l'autrui.

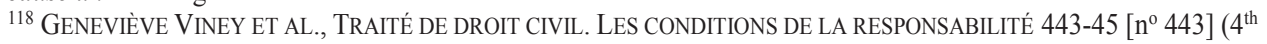
ed., L.G.D.J. 2013)
} 
"effects" thereof (les effets de la responsabilité), ${ }^{119}$ and not primary and secondary duties and rights.

One can only speculate as to why contemporary French academia steers clear of the idea of primary rights and duties. One possible explanation has to do with the history of the debate in the $20^{\text {th }}$ century. The two major figures at the beginning of the century, Marcel Planiol and Louis Josserand, developed opposing theories of liability, but had a common understanding of what their theories had to specify. Planiol's fault-based theory and Josserand's risk-based theory share a preoccupation with formulating pre-existing duties. The point of contention was about the content of these pre-existing duties. Planiol in particular made an effort to explicitly articulate the normative component of his theory by defining fault as any "breach of a pre-existing obligation". ${ }^{120}$ His contribution was initially well received and proved very influential. ${ }^{121}$ However, throughout the second half of the $20^{\text {th }}$ century his theory of fault was met with heavy criticism, and this might have dissuaded other authors from following him down the path he opened. Scholars such as Louis Bach, ${ }^{122}$ Jacques Flour, Jean-Luc Aubert, and Éric Savaux ${ }^{123}$ chastised Planiol for twisting the meaning of "obligation" and for introducing a "useless element" into the analysis of fault, and Philippe Malaurie, Laurent Aynès, and Philippe Stoffel-Munck ${ }^{124}$ argued that Planiol's definition was too vague to be of any use. Most of these arguments, however, are disputable. In fact, only the first argument has any real bite. The use of the term obligation by Planiol in this context is indeed unfortunate because it risks depicting pre-existing first order duties as equivalent to civil obligations (which are always remedial in the law of delict). Had he used the term devoir (duty) instead, he could have avoided the first critique. As for the second argument, it is unlikely that Planiol intended to add another element or requirement to fault-based liability. The notion of obligation (or duty) that he employed served only an analytical purpose, ${ }^{125}$ and he most

\footnotetext{
${ }^{119}$ VineY ET AL., LeS CONDITIONS..., supra note 119 \& GENEVIÈVE VINEY ET AL., TRAiTÉ DE DROIT CIVIL. LES EFFETS DE LA RESPONSABILITÉ (4 ${ }^{\text {th }}$ ed., L.G.D.J. 2017).

${ }^{120}$ PLANIOL, supra note 64, at 280 [nº 863].

${ }^{121}$ See the many sources cited in VINEY ET AL., LES CONDITIONS..., supra note 119, at 443, n.33 [n ${ }^{\circ} 443$ ].

${ }^{122}$ Louis Bach, Reflexions sur le problème du fondement de la responsabilité civile en droit français, RTD civ. 1977.17.

${ }^{123}$ JACQUES FlOUR ET AL., 2 Droit CIVIL. LeS OBLiGATIONS. LE FAIT JURIDIQUE 119 [nº 98] (14 ${ }^{\text {th }}$ ed., Dalloz 2011).

${ }^{124}$ MALAURIE ET AL., supra note 64, at 43 [n ${ }^{\circ}$ 51].

${ }^{125}$ Understanding his definition as an analytical tool impacts the correct way of understanding what he meant by "pre-existing obligation." It is not that the duties must be pre-existing in a temporal sense, i.e. be determined by the legal system in advance. What Planiol meant is that duties pre-exist their breach analytically (one must first have a duty in order to be in breach of it), and only a breach of duty constitutes a fault.
} 
surely did not intend to add a control mechanism that would do any work not done already by the concept of fault. ${ }^{126}$ This does not, however, make the notion of a pre-existing duty useless, nor does it make his definition vague. Planiol's definition is helpful because it focuses the attention of jurists on the normative aspects hidden within the elements of liability. The purpose of his definition was not so much to unravel the content of fault, but its structure and nature. He makes the point that there is an ought implicit in the idea of fault: to say that someone was at fault is to say that he ought to have acted differently (he had a duty to act differently). ${ }^{127}$ As to the content of fault, he believed that in order to unravel the content of fault one had to very carefully study legal sources (especially legislation and court decisions), because the ought implied by the idea of fault was a legal ought, determined by legal practice. ${ }^{128}$

A different explanation for the reluctance of contemporary French scholars to structure civil wrongs along primary and secondary rights and duties might be the fact that silence on this matter serves a rhetorical purpose in normative arguments. Most, if not all, French legal scholars are aware of the normative space colouring the elements of liability (the existence of primary duties and entitlements), but prefer to focus their discourse on a higher level of abstraction, that of the foundations of liability (les fondements de la responsabilité civile), leaving the space between foundations and legal requirements (elements) ambiguous. Often enough, the discourse on the foundations of French tort law is itself relatively unstructured, and based on abstract and vague ideas, such as: the moral idea of faute (he who is at fault must pay), risque crée (he who introduces a risk in society must pay), ${ }^{129}$ la garantie $^{130}$ (some rights are guaranteed against infringement and he who infringes them must pay), or droit à la sûreté (everybody has a subsidiary right to security and he who infringes this right must pay). ${ }^{131}$ The obvious advantage of this abstract approach is that it creates a large space for creativity in formulating the guiding normative ideas of the law of delict. Also, without the need to spell out the primary rights and duties of the parties, general

\footnotetext{
${ }^{126}$ Unlike English law, French law does not have a control mechanism performing the same function as the "duty of care" element.

${ }^{127}$ PlANIOL, supra note 64, at 280 [n $\left.{ }^{\circ} 863\right]$.

${ }^{128} I d$. at 281 [n $\left.\mathrm{n}^{\circ} 863 \mathrm{bis}\right]$

${ }^{129}$ LOUIS JOSSERAND, DE LA RESPONSABILITÉ DU FAIT DES CHOSES INANIMÉES (Arthur Rousseau 1897).

${ }^{130}$ BORIS STARCK, ESSAI D’UNE THÉORIE GÉNÉRALE DE LA RESPONSABILITÉ CIVILE CONSIDÉRÉE EN SA DOUBLE FONCTION DE GARANTIE ET DE PEINE PRIVÉE (L. Rodstein 1947).

${ }^{131}$ Ch. Radé, Réflexions sur les fondements de la responsabilité civile. 1 L'impasse, D. 1999. Chron. 313 ; Ch. Radé, Réflexions sur les fondements de la responsabilité civile. 2 Les voies de la réforme : la promotion du droit à la sûreté, D. 1999. Chron. 323.
} 
theories like those we have enumerated are more appealing for any reform-minded legal actors. The theoretical discussions on the foundations of liability have the potential to influence the development of the law in a variety of ways, and the normative arguments that follow from these general ideas can take on almost any form: e.g., to change the elements of liability, to interpret them in a different manner, or even to create entirely new liability regimes. The downside is that without the structure imposed by the two tiers of relational rights and duties, many general theories lack some much-needed balance. Planiol's insistence on fault as the sole basis for liability, for instance, is too defendant-friendly (which translates in today's social environment as also too "business-friendly"), whereas Starck's théorie de la garantie and Radé's droit à la sûreté are too plaintiff-friendly (and hence victim- and consumer-friendly). Luckily, the excesses in these general theories rarely make their way into legal practice. French courts act in a pragmatic manner, adapting rules and doctrines to changing social needs, not changing doctrinal winds. The general picture of the law of delict in the end does not match any of the foundational theories put forward, even though some theories have influenced individual doctrines adopted by the highest court and some specific legislative acts. ${ }^{132}$

\section{b. Correlativity}

The duties and entitlements within each of the two normative tiers are correlative, i.e. linked to each other to create (legal) relationships among persons. The idea of "wrong" by itself, or of a "breach of duty imposed by the law", does not necessarily imply correlativity. The idea of correlativity comes from narrowing down the category of wrongs to civil (or private) wrongs. Civil wrongs are about what we owe others, not about what we owe society in general, or what we owe to ourselves. ${ }^{133}$ In the words of Peter Birks: "[a] civil wrong is one in respect of which a citizen may make his own complaint, on his own account and not on behalf of the citizenship to which he belongs." 134 From an analytical perspective, this is what truly differentiates civil wrongs from

\footnotetext{
132 See PhilipPe le Tourneau ET AL., Droit DE LA RESPONSABILITÉ ET DES CONTRATS. RÉGIMES D’INDEMNISATION $45,50-54$ [ $\left.\mathrm{n}^{\mathrm{o}} 72-82\right]$ (10 ${ }^{\text {th }}$ ed., Dalloz 2014); FLOUR ET AL., supra note 123, at 82-85 [ $\left.{ }^{\text {os }} 71-72\right]$ (describing the court decisions and legislative acts influenced by risk theories).

${ }^{133}$ Goldberg \& Zipursky, supra note 43, at 918: "[T] from injuring (or to protect from injury) that are owed by certain persons to others: duties that, when breached, constitute wrongs to those others, as opposed to wrongs to the world. Second, precisely because torts are private wrongs, they provide the basis for a private response. For a wrong to be a tort it must in principle generate for its victim a private right of action: a right to seek recourse through official channels against the wrong-doer." See also, Zipursky, supra note 43, at 59-63 (discussing the analytical structure of relational wrongs). ${ }^{134}$ Birks, supra note 40, at 40.
} 
criminal wrongs, ${ }^{135}$ and not only the compensatory function of the former, as opposed to the punitive function of the latter (as it is sometimes argued). ${ }^{136}$ Civil wrongs may contain a punitive remedial layer, and as a matter of fact punitive measures are sometimes imposed on certain tortfeasors. While in France, and perhaps on the whole Continent, the idea of punishment has been ousted from civil law relationships, in England it is still present in the remedy of punitive damages. ${ }^{137}$ Whether punitive measures should be imposed in the civil law is a different matter entirely, one to be decided not by resorting to the analytical distinction between civil law and criminal law, but through normative argument. ${ }^{138}$ For instance, one could argue that empowering private parties to exact punishment from other private parties encourages vindictive behaviour, and for that reason, it is better to leave retribution in the hands of an abstract entity, such as the state. Or, alternatively, even if the punishment of the tortfeasor and a retributive response by the victim (within the bounds set by law) are considered socially desirable, there is no good reason why the victim of a wrong should be enriched simply because he or she suffered a wrong. ${ }^{139}$

Furthermore, the resulting correlative notions are structured binomially. Someone must owe a duty to someone else (or, conversely, someone is entitled to something from someone else). Normative discourse regarding civil wrongs paradigmatically refers to a relationship between two persons.

Remedial rights and duties (taking the form of civil obligations or claims) are binomial in a very straightforward way, taking the form of person $A$ has an obligation toward person $B$ or person $A$ is entitled to something (usually compensation) from person $B$. They are born after the event which

\footnotetext{
${ }^{135} \mathrm{Id}$.

${ }^{136}$ See, e.g., MAZEAUD ET AL., supra note 64, at 349-50 [n 375]; FLOUR ET AL., supra note 123, at 70.

${ }^{137}$ Awards of punitive damages are not as common in England as they are in the United States, being "grudgingly allowed only in very limited circumstances." Andrew Tettenborn, Punitive Damages - A View from England, 41 San Diego L. Rev. 1551, 1552 (2004). See also Renée Charlotte Meurkens, Punitive Damages. The Civil REMEDY In AMERICAN LAW, LESSONS AND CAVEATS FOR CONTINENTAL EUROPE 333-42 (Kluwer 2014).

${ }^{138}$ Nor is it an option to resort to the relational structure of civil wrongs and build a purely structural argument devoid of normative considerations. Punitive measures may not necessarily violate the "structural principle of bilateral justification for legal consequences so fundamental to all private law" [see KOZIOL, BASIC QUESTIONS OF TORT LAW FROM A GERMANIC PERSPECTIVE, supra note 37 , at 53 [n ${ }^{\circ} 2 / 58$ ] (relying primarily on a theoretical argument developed by Franz Bydlinski; See id. n.182); Helmut Koziol, Punitive Damages-A European Perspective, 68 LA. L. Rev. 741, 751-53 (2008)]. It is not impossible to imagine a type of justification of punishment that takes into account the bilateral aspect of civil wrongs. A relational event may be considered sufficiently egregious as a relational event (and not simply as an act by the defendant) that the law would be willing to empower the victim to exact punishment, not just compensation, from the wrongdoer.

${ }^{139}$ For such an argument, see, e.g., MeURKENS, supra note 137, at 203-04; Michael L. Wells, A Common Lawyer's Perspective on the European Perspective on Punitive Damages, 70 LA. L. REv. 557, 566 (2010); Dan B. Dobbs, Ending Punishment in "Punitive" Damages: Deterrence-Measured Remedies, 40 ALA. L. REV. 831, 856-57, 888-90 (1998).
} 
qualifies as a wrong, when the active and passive subjects of the remedial duties (the victim and the tortfeasor) can be identified; in other words, when it is known who wronged who. In the law, obligations arising out of civil wrongs are always constructed as relationships between two parties, one owing a remedial obligation and the other having a remedial right. This is true even if there are multiple victims or multiple tortfeasors. When there are multiple victims of the same wrong for which just one person is responsible, the responsible person owes each one of the victims a remedial obligation. Conversely, when there are multiple tortfeasors and one victim, the victim has a remedial right (or claim) against each one of the tortfeasors. And finally, the same pairing is obtained when there are multiple victims and multiple tortfeasors.

Primary duties and entitlements are also binomial, but in a different way. The existence of first order duties implies the existence of correlative first order entitlements (protected rights and interests). However, first order duties and entitlements are usually formulated in very general terms, some duties being owed by all persons to all others, others by members of a class or group to members of the same or of another class or group, and others still by members of a class or group to all other persons, or by all persons to members of a class or group. ${ }^{140}$ Many misunderstandings about strict liability spring from the assumption that correlative primary duties can only be formulated as universal duties (duties owed by all persons to all others). ${ }^{141}$ This way of framing primary duties and entitlements projects an overly-simplifying individualism on our understanding of civil wrongs, which has contributed perhaps more than anything else to the mystification of strict liability. Strict liability is typically based on duties which are owed by members of a class or group to members of the same or of another class or group, by members of a class or group to all other persons, or by all persons to a class or group. We will come back to this aspect later, after explicitly comparing strict liability regimes with similar fault-based regimes. ${ }^{142}$ The contrast between the principles of fault liability and those of strict liability will more clearly bring to light the different options we have of framing primary duties and entitlements. For now, it suffices to comment that one of the most damaging effects of framing all

\footnotetext{
${ }^{140}$ It is theoretically possible to have primary duties taking the form of person A owes person $B$ something, but it would be difficult to actually find any such duties in any positive law.

${ }^{141}$ For examples of theories which rely on universal duties see WEINRIB, THE IDEA OF PRIVATE LAW, supra note 42, at 84-113, 122-36; Goldberg \& Zipursky, supra note 43, at 945 (the latter authors do note, however, that some relational wrongs are not defined in terms of universal duties in footnote 140, on the same page).

${ }^{142}$ Infra Chapter VI Part D.
} 
primary duties as duties owed by all persons to all others is the rather common, but fallacious, belief that primary strict liability duties are duties of extreme or impossible care. ${ }^{143}$

Nothing about how we defined civil wrongs implies that one must necessarily do wrong or commit a wrong in order to be liable for a civil wrong. ${ }^{144}$ Correlativity need not be tied with "doing and suffering" $" 145$ out of analytical necessity.

A large number of authors who believe (correctly) that the law of torts is best understood as a law of wrongs, assume (wrongly) that primary duties are duties of right or wrong conduct. ${ }^{146}$ This usually leads them to exclude from the outset strict liability regimes from the domain of civil wrongs, and to characterize them as peripheral and insignificant exceptions. ${ }^{147}$ The reduction of civil wrongs to wrongful conduct or acts of wrongdoing is based on a narrow understanding of what we owe others and of what others owe us in return: that is, that only our personal acts and omissions can form the object of primary duties. It is true, of course, that often primary duties direct persons to behave in a certain way toward others. In essence, that is what fault-based liability is all about: a person is at fault for breaching a standard of conduct. Also, even beyond fault

\footnotetext{
${ }^{143}$ See, e.g., Alan Brudner, The Unity of the Common LaW 190 (University of California Press 1995): "[S]trict liability means that I have a right that you be governed in all your actions by concern for my welfare, and you have the same right over me. No doubt there is a mutuality of care here; but it is the mutual care of extreme altruists who, because they claim no worth as independent slaves, can neither give nor receive confirmation of worth and hence can require no valid right to care. By contrast a fault [i.e. negligence] requirement establishes a reciprocity of care between selves."

See also WeINRIB, THE IDEA OF PRIVATE LAW, supra note 42, at 182-83: "[The Kantian principle of right] requires that the freedom of one agent be capable of coexisting with the freedom of another. Both strict liability and the subjective standard are inconsistent with that principle. In strict liability, the protection of the plaintiff's right cuts off the defendant's moral power to actualize his or her purposive capacity, so that the vindication of the plaintiff's agency comes at the price of denying the defendant's."

${ }^{144}$ Contra see Birks, supra note 40, at 41: "One commits a wrong or does a wrong. The requirement of conduct, meaning either acts or omissions, could possibly have turned out to be attributable to the accompanying verb, not to the intrinsic notion of a wrong. But that is not so. A wrong necessarily involves acts or omissions by the alleged wrongdoer. It is not possible for a person to be in breach of duty, and a fortiori not possible for him to have committed a wrong, except by his own acts and omissions."

See also Goldberg \& Zipursky, supra note 133, at 944: "For every tort, there is an inquiry into the nature of the tortfeasor's actions (whether intentional in some sense or careless), the nature of the setback suffered by the victim, and the connection between the two."

${ }^{145}$ WeinRIB, The Idea OF Private LaW, supra note 42, at 65, 78, 81, 83, 145; Weinrib, Corrective Justice, supra note 42, at 43, 87; Ernest J. Weinrib, The Monsanto Lectures: Understanding Tort Law, 23 VAL. U. L. REV. 485, 514 (1989).

${ }^{146}$ Birks, supra note 40, at 41; Goldberg \& Zipursky, supra note 43, at 919, 935, 941; WeINRIB, THE IDEA OF PRIVATE LAW, supra note 42, at 171.

${ }^{147}$ This is the strategy of John Goldberg and Benjamin Zipursky - see Goldberg \& Zipursky, supra note 43, at 952; Ernest Weinrib, and to a certain extent Peter Birks as well, attempted instead to re-interpret existing strict liability rules (from the common law) as rules of right conduct. See WeINRIB, THE IDEA OF PRIVATE LAW, supra note 42, at 184-203; Birks, supra note 40, at 41.
} 
liability, some strict duties may be framed as behavioural duties. For instance, the duty not to trespass on someone else's land is strict, but what it prohibits is an act: the act of entering upon land. Nevertheless, nothing about the concept of a breach of a relational duty, by itself, can lead us to such a narrow understanding of the object of primary duties. Many liability rules can be found in the positive laws of France and England which prove that our responsibilities may extend beyond personal conduct. We may owe duties for the acts of others (see all the forms of vicarious liability we discussed), or for the damage caused by the things we have under our sphere of control [see, e.g., the liability of manufacturers for defective products, or the liability for the acts of things in France]. Moreover, a person may owe another a duty to achieve a certain result, irrespective of whether such a result is even possible to achieve through personal conduct. ${ }^{148}$ For instance, a manufacturer may be liable for damage caused by a defective product even if it is impossible to produce only non-defective products. Also, an employer may be liable for the acts of an employee even if there is no measure that could have been lawfully taken by the employer to prevent the employee from acting in the way he did. ${ }^{149}$

To sum up, most strict liability regimes are not based on duties to behave in a certain manner, and even when strict liability rules are based on behavioural duties, those duties are not duties of care. John Gardner was perfectly on point when he observed that:

\footnotetext{
${ }^{148}$ In John Gardner's terminology, a person might have a duty "to succeed", not just "to try." John Gardner, Obligations and Outcomes in the Law of Torts, in RELATING TO RESPONSIBILITY. ESSAYS FOR TONY HONORÉ ON HIS Eightieth BirThDAY 111, 117- 20 (Peter Cane \& John Gardner eds., Hart Publishing 2001); See also John Gardner, The Purity and Priority of Private Law, 46 U. ToronTo L.J. 459, 486 (1996).

${ }^{149}$ See, however, Peter Birks' rather bizarre argument that vicarious liability in fact shows that a wrong can only be committed by one's own acts and omissions. Birks, supra note 40, at 41: "Vicarious liability shows that the law can make one person liable for the wrong of another, but it also shows, in the word 'vicarious' itself, that one cannot commit a wrong or be in breach of duty except by one's own acts or omissions. A 'vicarious' liability is a liability which one person takes over from another, and as such not his but that other's, just as a 'vicar' was originally a person in holy orders who occupied a place which was not his but the rector's whose substitute he was."

The problem with this understanding of vicarious liability is that it denies the existence of a relationship of pre-existing primary rights and duties between the victim and the vicariously liable person. This makes at least one of the main features of vicarious liability unintelligible: how is it that the person who is vicariously liable must answer with their own patrimony, alongside the main tortfeasor? In England, a civil obligation is born between the vicariously liable person and the victim directly, and the vicariously liable person is not just a sort of agent or representative of the actual tortfeasor. The tortfeasor and the vicariously liable party are both bound (jointly and severally) to remedy the wrong suffered by the victim. The French vicarious liability of employers for the acts of their employees becomes even more mysterious, because in French law the vicariously liable person is the only one who will be obligated to compensate the victim when the requirements for the employer's liability are met, the employee benefitting in such situations from immunity.
} 
[W] hen strict liability is at stake... the law does not give two hoots either way about the care that D took. The most inhuman lack of care does not count against her but by the same token the most superhuman investment of care does not count in her favour. It is this doubleedged obliviousness to D's precautions that lawyers have in mind when they call liability by the evocative name "strict". 150

\section{F. Summary}

The English law of torts, together with the portion of equity dealing with wrongs, and the French law of responsabilité civile délictuelle are areas of human activity, or practices, which have in common the fact that they grapple with problems regarding the definition and correction of civil wrongs. In this chapter, we have posited that finding answers to such problems is the common aim of all these practices. While we have left the argument supporting this proposition for later, we have tried in this chapter to clarify what the proposition means by defining the term "civil wrongs".

To sum up, civil wrongs were defined above as involuntary interactions which consist of infringements or violations by one person of another's legally protected interest (and therefore also a breach of a legal duty owed to that other person), the occurrence of which constitutes the reason for the creation of a civil obligation. ${ }^{151}$ On the basis of this definition, we first distinguished civil wrongs from other interpersonal interactions which are also legally recognized and produce legal effects, such as contracts and unjustified enrichment, and then tried to unravel the normative structure of civil wrongs. With regard to the normative structure of civil wrongs, two aspects in particular were emphasized. First, civil wrongs have a two-tier normative structure. This means that there are two sets of duties and entitlements which make up the normative architecture of civil wrongs. In order to be characterized as a civil wrong, an event must, on the one hand, constitute a breach of duty (and, correlatively, the violation of a legally protected interest) and, on the other hand, trigger the birth of a new duty and a new right. The two tiers are linked, the violation or infringement of a first order duty being the reason why a remedial duty is born. Second, civil wrongs have a correlative normative structure, and this applies to both normative levels. Each individual duty is correlated with a right or entitlement. Furthermore, the correlation is binomial,

\footnotetext{
${ }^{150}$ Gardner, supra note 148 , at 113.

${ }^{151}$ Supra Part E.2 of this chapter.
} 
normative discourse regarding civil wrongs being built around concepts which refer to the relationship between two persons.

The overall aims of the practices we lumped together around the category of civil wrongs are reflected in a relatively straightforward manner in the "two tier" structure of individual civil wrongs. The goal of defining civil wrongs (i.e. determining what constitutes, according to the law, a civil wrong and what does not) is embodied and specified in the formulation of primary duties and entitlements. Only events which can be characterized as breaches of primary duties (and infringements of the correlative primary entitlements) will count as civil wrongs. Therefore, a just definition of civil wrongs corresponds to a just determination of the content of primary duties and entitlements in the case of each individualized civil wrong. The remedial layer of rights and obligations is, of course, also necessary for a civil wrong to exist, because a relational wrong which does not create legal obligations is not a civil wrong. However, the determination of the content of remedial rights and obligations can be somewhat dissociated from the question of what counts as a civil wrong. A relational wrong will be a civil wrong if it leads to the creation of any second order relational rights and obligations, irrespective of their actual content. ${ }^{152}$ The content of remedial rights and duties is more connected to the second aim, that of the just correction of civil wrongs (i.e. the determination of legal responses to already defined civil wrongs). The justice of legal responses to civil wrongs corresponds to a just determination of the content of remedial rights and duties in the case of each individualized civil wrong.

However, even if we take it as a given that parts of English law and French law share a preoccupation with the definition and correction of civil wrongs, this does not necessarily imply that the two legal systems define civil wrongs in the same manner, or that they correct the wrongs so defined with the same mechanisms. In fact, the practices associated with tort law and equitable wrongs (in England), and responsabilité civile délictuelle (in France), do sometimes differ when it comes to normative content. In the search for just ways of defining civil wrongs and just corrective mechanisms, the French and the English legal systems can go, and have gone, down different roads. The extent to which the two legal systems employ rules of strict liability relative to fault-based liability is simply one of the more striking and puzzling differences.

${ }^{152}$ See Birks, supra note 40, at 36-37, 47. 
Chapter VI 


\section{CHAPTER VI}

\section{STRICT LIABILITY AND ITS FUNCTIONAL EQUIVALENTS}

\section{A. Introduction}

In previous chapters, we identified which rules fall under the category of strict liability in France and England, and discussed the ambit of each rule identified. ${ }^{1}$ Even from afar, it is immediately obvious that there are some circumstances in which French law and English law apply similar strict liability rules, and there are other circumstances in which one legal system applies strict liability while the other applies fault-based liability or even a no-liability rule. This chapter takes a closer look at these circumstances in order to identify when and how exactly the two legal systems are similar or different. Everything is now in place to make such explicit and detailed comparisons between the two legal systems. We know when strict liability arises in both jurisdictions, i.e. under what circumstances, and we also identified our tertium comparationis, a common function and aim that our two legal systems share: the just definition and correction of civil wrongs.

How English law and French law define civil wrongs in circumstances that give rise, at least in one of the two jurisdictions, to strict liability will be emphasized more in this chapter than how these two legal systems respond to (or correct) civil wrongs. This is because when both France and England impose strict liability, the remedial response is almost invariably the same, and when the two systems diverge (one opting for strict liability while the other opting for fault), the choice of one regime over the other does not usually lead to noteworthy differences at the remedial level. The English and the French legal systems always respond to civil wrongs by creating personal obligations (or claims), and most often these remedial obligations are designed to provide full monetary compensation to the victim. ${ }^{2}$ Derogations from the principle of full compensation are rare. They exist, for instance, when caps are set on the amount of compensation in order to limit

\footnotetext{
${ }^{1}$ See supra Chapters II and III.

${ }^{2}$ Full monetary compensation is understood in both systems as returning the victim to the situation he or she was in before the wrong occurred. See Andrew Burrows, Judicial Remedies, in PRINCIPLES OF THE ENGLISH LAW OF Obligations 323, 345 [n 4.14] (Andrew Burrows ed., Oxford University Press 2015); GeNEVIĖVE VINEY \& PATRICE JourdaIN, TRAITÉ DE DROIT CIVIL. LES EFFETS DE LA RESPONSABILITÉ 111-13 [nº 57] (2 ${ }^{\text {nd }}$ ed., L.G.D.J. 2001).
} 
the liability exposure of certain actors. Also, limits may be set on the actionability of claims when they do not exceed a minimum threshold. However, when such minimum or maximum limits exist, they exist in both legal systems. Thus, for instance, both France and England limit the applicability of strict product liability in cases of property damage to claims exceeding a minimum threshold ( $£ 275$ in England, $€ 500$ in France), ${ }^{3}$ and both France and England cap the amount of compensation in cases of nuclear accidents. ${ }^{4}$ It is true that there are also differences, but these differences are truly marginal. For instance, English law allows claims for punitive damages, i.e. damages that go beyond full compensation, whereas French law does not. However, punitive damages are very rarely awarded in cases of strict liability, ${ }^{5}$ or in any of the fault-based wrongs we have identified below as functionally equivalent to a rule of strict liability. ${ }^{6}$ Thus, the availability of punitive damages in England, and their absence from French tort law, play a negligible role in the comparisons we make in this chapter. Remedial obligations may sometimes take other forms than monetary compensation, such as the restitution of property or injunctions, but in this regard, again, the differences between France and England are not significant. ${ }^{7}$ Perhaps the only caveat worth mentioning is that the French legal system is theoretically more inclined to impose reparations in natura, but in practice victims usually ask for and receive monetary compensation, and therefore non-compensatory remedies remain marginal. ${ }^{8}$ All of this being said, when truly significant differences exist between French and English law at the remedial level, these differences will be highlighted.

Thus, the main question answered in the following sections will be: how are the French and English legal systems similar in their definitions of civil wrongs, and how are they different, in those circumstances in which at least one of the two legal systems applies strict liability? Or, to rephrase the question in terms of primary entitlements and duties, under what circumstances does French

\footnotetext{
${ }^{3}$ Section 5(4) of the Consumer Protection Act 1987, c. 43; Art. 1245-1 (2) of the French Civil Code.

${ }^{4}$ Section 16 of the Nuclear Installations Act 1965, c. 57; Art. 4 of Loi no 68-943 du 30 octobre 1968 relative à la responsabilité civile dans le domaine de l'énergie nucléaire, JORF du 31 octobre 1968, p. 10195.

${ }^{5}$ The only noteworthy exception is the tort of nuisance. See Bell v. Midland Ry. Co., 142 Eng. Rep. 462,463 (C.P. 1861).

${ }^{6}$ While it is possible, in principle, for a court to award punitive damages on the basis of the tort of negligence, examples of such awards are very difficult to find. See Andrew Tettenborn, Punitive Damages - A View from England, 41 SAN DieGo L. ReV. 1551, 1558-60 (2004).

${ }^{7}$ See Walter Van Gerven et Al., CaSes, Materials and TeXt on National, Supranational and INTERNATIONAL TORT LAW 847-48, 862 (Hart Publishing 2000).

${ }^{8}$ See Olivier Moréteau, Basic Questions of Tort Law from a French Perspective, in BASIC QuESTIONS OF TORT LAW from a Comparative Perspective 3, 90 [nº 1/210] (Jan Sramek Verlag 2015); Viney \& Jourdain, Les efFets De LA RESPONSABILITÉ, supra note 2, at 25-26 [nº 14].
} 
law confer the same primary duties and entitlements as English law, and under what circumstances do the primary duties and entitlements differ? We first look in section B at areas where strict liability wrongs are defined in a similar manner, then in section $\mathrm{C}$ at areas where one legal system employs strict liability while the other employs, partially or totally, a fault-based equivalent, and finally, in section D we summarize and reflect on our findings.

\section{B. Similarities}

Starting with the similarities between the French and the English legal systems, there are at least four strict liability regimes which confer similar primary duties and entitlements: (1) the liability of producers for harm caused by the defective products they have put on the market; (2) the liability of nuclear operators for harm caused by the operation of nuclear facilities; (3) the liability of employers for the civil wrongs of their employees; and (4) the liability of neighbours for nuisance (trouble de voisinage). In addition, we discuss in (5) the very high level of functional equivalence between the strict liability tort of trespass to land (in England) and the civil wrongs which trigger a référé possessoire (in France).

The high degree of convergence of primary duties and entitlements in cases of product liability and nuclear accidents is due to the common European and international commitments of France and England. The liability of employers for the civil wrongs of their employees, the liability of neighbours for nuisance, and the liability for trespass to land is, by contrast, the result of bottomup, or spontaneous, convergence.

\section{Product liability}

The liability of producers for harm caused by defective products introduced into the European market has been harmonized on the basis of the 1985 European Directive on Product Liability. ${ }^{9}$ Articles 1245 to $1245-17$ of the French Civil Code and Part I of the Consumer Protection Act 1987 implement the directive into French and English law respectively. Within the scope of the directive, there are no differences between the two legal systems with regard to the formulation of primary duties and entitlements. The primary duty rests on producers, whereas the primary entitlement is conferred upon any natural person who may suffer personal injury or damage to

\footnotetext{
${ }^{9}$ Council Directive 85/374/EEC of 25 July 1985 on the approximation of the laws, regulations and administrative provisions of the Member States concerning liability for defective products, Official Journal L 210, 07/08/1985, p. 29-33 [Referred to in this study as the Product Liability Directive].
} 
property. ${ }^{10}$ A subsidiary primary duty is owed by suppliers and importers. A supplier owes the same duty as a producer when he does not indicate to the injured person who supplied him the product, whereas importers owe the same duty as producers if the product does not indicate the identity of the producer or the product is imported from outside of the EU. ${ }^{11}$ The primary entitlement enjoyed by natural persons is to be free of damage caused by a defective product, and conversely, the primary duty of producers is not to cause damage due to the defectiveness of products they have put on the market. Not all damage, however, falls within the ambit of these first order duties and entitlements. The directive only applies to personal injury and damage to property which is intended for private use or consumption. ${ }^{12}$ However, an interesting point of divergence can be observed in the implementations of the directive with regard to the type of damage covered. The Consumer Protection Act adheres to the solution of the directive, ${ }^{13}$ whereas the French Civil Code contains a broader definition which includes also professional or commercial property. ${ }^{14}$ This is an interesting discrepancy between the Civil Code articles and the provisions of the directive, which has gone unnoticed by or perhaps was of no concern to the Commission, ${ }^{15}$ and was later deemed acceptable by the Court of Justice of the European Union. ${ }^{16}$ Another potential source of divergence is latent within the requirement of a causal relationship. While the elements of damage and defectiveness of the product are harmonized, causation is not. Causation is governed by national law, and France and England do sometimes arrive at different solutions to causation problems. ${ }^{17}$ To take just one example from within the law of product

\footnotetext{
${ }^{10}$ Often, the person suffering damage will be a consumer, but the directive and the implementing acts do not limit the class of plaintiffs to consumers. A third party who suffers damage caused by a defective product purchased by a consumer also has a claim for product liability. Juridical persons, however, seem to be excluded, because only damage which consists of physical injury or damage to property intended for personal use or consumption (as opposed to commercial use) falls within the ambit of the directive. See Art. 9 of the Product Liability Directive. ${ }^{11}$ Art. 3, paras. (2) and (3) of the Product Liability Directive; Arts. $1245-5$ para. $2\left(1^{\circ}\right)$ and 1245-6 para. 1 of the French Civil Code; sections 2 (2) and 2 (3) of the Consumer Protection Act 1987 c. 43.

${ }^{12}$ Art. 9 of the Product Liability Directive.

${ }^{13}$ Sections 5(1) and 5(3) of the Consumer Protection Act 1987 c. 43.

${ }^{14}$ Art. 1245-1 para. 2 of the French Civil Code.

${ }^{15}$ See Jean-Sébastien Borghetti, The Development of Product Liability in France, in The DeVelopment oF Product Liability 87, 109 (Simon Whittacker ed., Cambridge University Press 2010).

${ }^{16}$ CJEU, 4 June 2009, C-285/08, Moteurs Leroy Somer v. Dalkia France, Ace Europe; D.2009.1731, note J.S. Borghetti; D.2010.49, obs. Philippe Brun \& O. Gout; RTD Civ. 2009.738, obs. Patrice Jourdain; JCP G 2009.I.248, $\mathrm{n}^{0} 5$, obs. Ph. Stoffel-Munck; JCP G 2009.II.26, obs. F. Picod; JCP G 2009.II.82, note Patrice Jourdain.

${ }^{17}$ For a very good comparative study on causation in European legal systems, see UNIFICATION OF TORT LAW: CAUSATION (J. Spier ed., Kluwer Law International 2000). The study's conclusions are that generally European legal systems have relatively similar theoretical approaches to causation, but differ when it comes to how they deal with specific causation issues, and that this is due to divergent doctrinal solutions, lack of clarity in the solutions
} 
liability, French courts sometimes presume that damage is caused by the defectiveness of a product even in the absence of scientific proof, as long as the presumptions are serious, precise, and consistent (graves, précises et concordantes). ${ }^{18}$ No English court has applied, to date, anything even resembling such a presumption.

Another set of differences between France and England with regard to product liability can be identified by looking at the relation between the statutory provisions implementing the Product Liability Directive and other competing liability regimes. The Court of Justice of the European Union held in 2002 that, based on article 13 of the directive, general strict liability rules cannot be applied concurrently to cases which fall within the ambit of the directive. ${ }^{19}$ This meant that French courts could not circumvent the application of articles 1245 to 1245-17 (former 1386-1 to 138618) by applying the second thesis of article 1242 (1) which refers to liability for things. However, the same decision leaves open the concurrent application of special strict liability regimes. This rule was confirmed in 2011 when the Court of Justice, in response to a request for a preliminary ruling, decided that a patient who suffers injuries due to a defective product may also rely on the special French strict liability regime which makes public hospitals liable for the damage suffered by a person who is undergoing treatment or surgery in the hospital. ${ }^{20}$ This particular liability regime formally belongs to public law, being created mainly by the jurisprudence of the French administrative courts, but the principle established by the Court of Justice extends also to liability

\footnotetext{
identified, and the fact that some causation issues remain unresolved. Jaap Spier \& Olav A Haazen, Comparative Conclusions on Causation, in UnifiCATION Of TORT LAw: CAUSATION 127, at 127 (J. Spier ed., Kluwer Law International 2000).

${ }^{18}$ Cass Civ. $1^{\text {re }}, 22$ May 2008, no 06-10.967, Bull. Civ. I, no 149; D.2008 AJ 1544, obs. I. Gallmeister; D.2008 2894, obs. Ph. Brun \& P. Jourdain; RTD civ. 2008. 492, obs. P. Jourdain; Cass. Civ. $1^{\text {re }}, 25$ June 2009, n $^{\circ} 08-12.781$, Bull. civ. I, no 141; D.2009 AJ 1895; Cass. Civ. ${ }^{\text {re }}$, 9 July 2009, nº 08-11.073, Bull. civ. I, n 176; D.2009 AJ 1968, obs. I. Gallmeister; D.2010 Pan. 49 n 2 , obs. Ph. Brun ; RTD civ. 2009. 723, obs. P. Jourdain; Cass. Civ. $1^{\text {re }}, 26$ September 2012, no 11-17.738, Bull. civ. I, no 187; D.2012. 2853, obs. I. Gallmeister, note J.-S. Borghetti ; D. 2012. 2376, entretien C. Radé; D.2013. 40, obs. Ph. Brun \& O. Gout; D.2013. 2802, obs. Ph. Delebecque, J.-D. Bretzner \& I. Darret-Courgeon; RTD civ. 2013. 131, obs. P. Jourdain; Cass. Civ. $1^{\text {re }}, 10$ July 2013, n $12-21.314$, Bull. civ. I, nº 157; D.2013. 2311; D.2013. 2306, avis conforme C. Mellottée; D.2013. 2312, note Ph. Brun; D.2013. 2315, note J.-S. Borghetti; D.2014. 47, obs. Ph. Brun \& O. Gout. See also CJEU, 21 June 2017, C-621/15, N.W., L.W., C.W. v Sanofi Pasteur MSD SNC, Caisse primaire d'assurance maladie des Hauts-de-Seine, Carpimko, ECLI:EU:C:2017:484.

${ }^{19}$ ECJ, 25 April 2002, C-183/00, Maria Victoria González Sánchez v Medicina Asturiana SA, ECLI:EU:C:2002:255; ECJ, 25 April 2002, C-52/00, Commission v France [2002] ECR I-3827, ECLI:EU:C:2002:252; ECJ, 25 April 2002, C-154/00 Commission v Greece [2002] ECR I-3879, ECLI:EU:C:2002:254.

${ }^{20}$ CJEU, 21 December 2011, C-495/10, Centre hospitalier universitaire de Besançon v. Thomas Dutrueux, Caisse primaire d'assurance maladie du Jura; D.2012.926, note J.S. Borghetti; D.2012.1558, note P. Véron \& F. Vialla; RTD civ. 2012.329, obs. Patrice Jourdain; ECLI:EU:C:2011:869.
} 
regimes which fall under private law. The case involved a thirteen-year-old boy who suffered burns caused by a defect in the heated mattress of the hospital bed he was laid on during surgery. The hospital was not the producer of the mattress, nor the supplier, being solely a service provider. Because the directive does not cover the liability of service providers, the Court of Justice concluded that article 13 of the directive was not an obstacle to a concurrent claim against the hospital. ${ }^{21}$ Arguably, the same principle ought to apply to the liability of any service providers, including medical practitioners and hospitals who are subject to the strict liability regimes established through the legislative acts adopted on 4 March $2002^{22}$ and 30 December $2002 .^{23}$ In England, this problem does not arise because there is no special strict liability regime that can compete with the statutory tort of product liability. Plaintiffs may, of course, choose to file claims on the basis of the tort of negligence when damage is suffered due to the defectiveness of a product against any negligent party, including producers, suppliers and service providers. However, since the strict liability regime from the Consumer Protection Act 1987 is more advantageous for victims, the tort of negligence only becomes appealing when the wrong suffered by the victim falls outside of the scope of the Act (for instance, in cases of damage to commercial property or pure economic loss, or in cases where the claim is against a service provider). Therefore, outside of the scope of the Product Liability Directive, there are cases where, although damage is caused by a defective product, French law allows certain strict liability claims while under English law faultbased claims are the only option.

\section{The liability of nuclear operators}

The liability of operators of nuclear installations, in both France and England, is governed by legislation implementing the 1960 Paris Convention of Third Party Liability in the field of Nuclear Energy ${ }^{24}$ and the 1963 Brussels Convention Supplementary to the Paris Convention. ${ }^{25}$ The

\footnotetext{
${ }^{21} I$. at para. $27-29,39$.

${ }^{22}$ Loi n 2002-303 du 4 mars 2002 relative aux droits des malades et à la qualité du système de santé, JORF du 5 mars 2002, p. 4118.

${ }^{23}$ Loi n ${ }^{\circ}$ 2002-1577 du 30 décembre 2002 relative à la responsabilité civile médicale, JORF du 31 décembre 2002 , p. 22100.

${ }^{24}$ The Paris Convention on Third Party Liability in the Field of Nuclear Energy of $29^{\text {th }}$ July 1960, as amended by the Additional Protocol of $28^{\text {th }}$ January 1964 and by the Protocol of $16^{\text {th }}$ November 1982, available online at http://www.oecd-nea.org/law/nlparis conv.html.

${ }^{25}$ Convention of $31^{\text {st }}$ January 1963 Supplementary to the Paris Convention of 29th July 1960, as amended by the additional Protocol of $28^{\text {th }}$ January 1964 and by the Protocol of $16^{\text {th }}$ November 1982, available online at https://www.oecd-nea.org/law/nlbrussels.html.
} 
provisions of the two French statutes regulating this matter $\left(\mathrm{n}^{\circ} 65-956\right.$ from the $12^{\text {th }}$ of November $1965^{26}$ and $n^{\circ} 68-943$ from the $30^{\text {th }}$ of October 1968) ${ }^{27}$ and of the Nuclear Installations Act $1965^{28}$ impose a similar primary duty on the operator of a nuclear installation: not to cause damage to third parties by nuclear accidents which occur on the installation, or in the course of transportation of a nuclear substance, or as a consequence of exposure to nuclear matter which has been on the installation or has been carried on the nuclear operator's behalf by another. Any person who may suffer damage as a consequence of such nuclear accidents holds the correlative entitlement. The most obvious difference between the French and the English strict liability regimes for nuclear accidents regards the definition of damage. Under French law, personal injury claims have priority, but once personal injury claims are satisfied, any kind of damage, including pure economic loss, may trigger the application of the strict liability regime. ${ }^{29}$ In England, the Nuclear Installations Act 1965 covers only personal injury, damage to property, economic loss which arises from personal injury and damage to property, and environmental damage. ${ }^{30}$ Pure economic loss, therefore, is not recoverable under the Nuclear Installations Act $1965 .^{31}$

3. The liability of employers for the civil wrongs committed by their employees

The vicarious liability of employers for the acts of their employees developed in a spontaneous manner along similar lines in France and England. In both jurisdictions, the liability of employers for the acts of their employees is premised upon (i) the existence of a civil wrong committed by the employee; (ii) the existence of an employer-employee relationship; and (iii) the employee's civil wrong must have occurred in the course of his employment. Therefore, the rough

\footnotetext{
${ }^{26}$ Loi n ${ }^{\circ 65-956}$ du 12 novembre 1965 responsabilité des accidents d'origine nucléaire, JORF du 13 novembre 1965 , p. 9996.

${ }^{27}$ Loi n ${ }^{\circ}$ 68-943 du 30 octobre 1968 relative à la responsabilité civile dans le domaine de l'énergie nucléaire, JORF du 31 octobre 1968, p. 10195.

${ }^{28}$ Nuclear Installations Act 1965, c. 57.

${ }^{29}$ Art. 13 of the Loi n ${ }^{\circ}$ 68-943 du 30 octobre 1968 relative à la responsabilité civile dans le domaine de l'énergie nucléaire, JORF du 31 octobre 1968, p. 10195, as modified by Loi $\mathrm{n}^{\circ}$ 2006-686 du 13 juin 2006 relative à la transparence et à la sécurité en matière nucléaire, JORF du 14 juin 2006, p. 8946.

${ }^{30}$ Sections $7 \& 12$ of the Nuclear Installations Act 1965, c. 57, as amended by The Nuclear Installations (Liability for Damage) Order 2016 (S.I. 2016/562). See also Explanatory Memorandum to the Nuclear Installations (Liability for Damage) Order 2016, No 562, available online at https://www.legislation.gov.uk/uksi/2016/562/pdfs/uksiem_20160562_en.pdf; Maria Lee, Civil Liability of the Nuclear Industry, 12 JournaL OF ENVIRONMENTAL LAW 317, 320-21 (2000).

${ }^{31}$ See Merlin and Another v British Nuclear Fuels Plc., [1990] 2 Q.B. 557, [1990] 3 W.L.R. 383 (high levels of radioactivity in a house near the Sellafield plant reduced the value of the claimant's property almost by half, but the claimants did not suffer any personal injury and the physical characteristics of the house were not altered; therefore, the court characterized the damage as pure economic loss and dismissed the claim).
} 
lines of the primary rights and duties created by this complex civil wrong ${ }^{32}$ are also the same: the employer has a duty to ensure that his employees do not commit wrongs in the course of their employment, and potential victims hold the correlative right of being free from such wrongs committed by said employees in the course of their employment. The duty is strict in both jurisdictions in the sense that employers must ensure a certain result (that their employees do not commit civil wrongs in the course of their employment) and the mere taking of reasonable precautions does not absolve them of liability. Potentially, every time a civil wrong is committed by an employee in the course of employment, the liability of the employer can ensue.

However, upon a closer look, there are a few important differences which affect the scope and nature of the primary duties owed by employers and of the correlative rights held by (potential) victims.

First, because employers are liable for the civil wrongs committed by their employees, the scope of employers' liability is very much dependent on the types of civil wrongs which can be ascribed to their employees. In England, under the doctrine of vicarious liability, employers can be held liable for the commission of any tort by their employees in the course of their employment. Most often, it is the tort of negligence that triggers the liability of the employee, but any other tort will do just as well: battery, assault, trespass to land, conversion, etc. ${ }^{33}$ (and even an equitable wrong). In France, however, the matter is not clearly settled yet. There is an ongoing debate regarding the underlying civil wrongs which may trigger the liability of employers for the acts of their employees. Some authors argue that only when the employee commits a fault (faute) can the

\footnotetext{
${ }^{32}$ Some authors, such as Horton Rogers and Peter Birks, claim that vicarious liability is not truly a civil wrong (not a "tort"). See W. V. Horton Rogers, England in UnifiCATION OF TORT LAW: STRICT LiabiLITY 101, 106 (B.A. Koch $\&$ H. Koziol eds., Kluwer Law International 2002); Peter Birks, The Concept of a Civil Wrong, in PHILOSOPHICAL FOUNDATIONS OF TORT LAW 31, 41 (David G. Owen ed., Oxford University Press 1995). Against Birks' argument, see supra note 149. Rogers' claim that vicarious liability is merely a "general ancillary doctrine" was made only in passing in order to explain why it is not instinctive to think of vicarious liability as "strict liability". However, vicarious liability only comes into play when employees commit civil wrongs, and not when they are on the passive side of a restitutionary claim or in cases of contractual non-performance. Therefore, as an ancillary doctrine, vicarious liability is only ancillary to another civil wrong, and not to any other juridical fact. Therefore, both the victim's right and the employer's obligation to compensate are born from a wrong. If a tort or a civil wrong is defined as a breach of a pre-existing duty giving rise to a civil obligation, then vicarious liability definitely fits the description of a civil wrong. Vicarious liability is indeed a complex wrong because the employer's breach of duty is premised upon the breach of a different duty by one of his employees in the course of employment, but it is a wrong nonetheless.

${ }^{33}$ Cees van Dam, European Tort Law 509 (2 $2^{\text {nd }}$ ed., Oxford University Press 2013).
} 
employer be held vicariously liable. ${ }^{34}$ Others believe that any civil wrong, be it fault-based or strict, can trigger the vicarious liability of the employer, as long as the employee could have otherwise been held liable on that basis (the act is "imputable au préposé"). ${ }^{35}$ The latter doctrinal interpretation is both preferable and more in line with the jurisprudence of the Court of Cassation. The Court of Cassation does indeed refer very often to fault-based standards when assessing the existence of an "act of the employee", ${ }^{36}$ but it has also found employers liable for acts of their employees which fall under the ambit of the loi Badinter. ${ }^{37}$ As shown above, liability under the loi Badinter is not only not based on fault: it is extremely strict, being premised on the mere involvement in a road traffic accident of the vehicle driven by the defendant. ${ }^{38}$ The liability of employers for road traffic accidents in which a vehicle driven by an employee was involved clearly does not require proof of the employee's fault. French courts in such circumstances seem content with finding that a motor vehicle driven by the employee was involved in the accident, and that also triggers the vicarious liability of the employer when the employee was acting in the course of his employment. ${ }^{39}$ The entire matter would be clarified once and for all if a case were to arise in which the employer's liability was premised on the liability of the employee for a thing under his custody [in other words, a case in which the employer was held liable on the basis of article 1242 (5), but on the premise that the employee could have been held liable under the second thesis of 1242 (1)]. However, such a case has not yet been brought before the Court of Cassation. ${ }^{40}$ The reason is that, most of the time, the person who has the custody of things used by employees in the course of their employment is the employer himself. ${ }^{41}$ Therefore, when damage is caused by

\footnotetext{
${ }^{34}$ PhilipPE LE TOURNEAU ET AL., DRoIT DE LA RESPONSABILITÉ ET DES CONTRATS. RÉGIMES D'INDEMNISATION

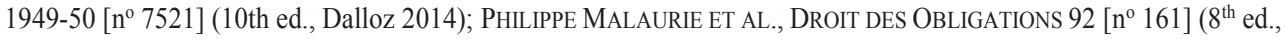
L.G.D.J. 2016); HENRI MAZEAUD ET AL., 1 TRAITÉ THÉORIQUE ET PRATIQUE DE LA RESPONSABILITÉ CIVILE DÉLICTUELLE ET CONTRACTUELLE 995 [n ${ }^{\circ}$ 916] (6 $6^{\text {th }}$ ed., Montchrestien 1965)]. See also VAN DAM, supra note 33, at 506 .

${ }^{35}$ GENEVIÈVE Viney ET AL., TRAité DE DROIT CIVIL. LeS CONDITIONS DE LA RESPONSABILITÉ 1074-75 (nº 807) (4th

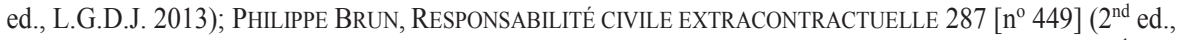
LexisNexis Litec 2009); FranÇOIS TerRé ET AL., Droit Civil. Les Obligations 1129 [nº 1064] (12 ${ }^{\text {th }}$ ed., Dalloz 2018).

${ }^{36}$ See e.g., Olympique de Marseille: Cass. Civ. 2e 8 April 2004, nº 03-11.653, Bull. civ. II, $\mathrm{n}^{0}$ 194; RTD Civ. 2004.217, obs. Patrice Jourdain; D.2004.2601, note Serinet; JCP 2004.II.10131, note Imbert.

${ }^{37}$ VINEY ET AL., LeS CONDITIONS..., supra note 35, at 1075 (nº 807), n.210; Cass. Civ. $2^{\mathrm{e}}$, 18 November 1987, Bull civ. II, n ${ }^{\circ} 235$, p. 130; and Cass. Civ. 2e, 11 April 2002, Bull. civ. II, nº 72, p. 60.

${ }^{38}$ See supra Chapter II Part D.2.

${ }^{39}$ Cass. Civ. $2^{\mathrm{e}}$, 18 November 1987, Bull. civ. II, nº 235, p. 130.

${ }^{40}$ Viney ET AL., LeS CONDITIONS..., supra note 35, at 1075 ( $\mathrm{n}^{\circ}$ 807). See, however, MALAURIE ET AL., supra note 34, at $92\left(n^{\circ} 161\right)$ [arguing that a decision of the Court of Cassation from 1936 settled the matter (Cass. Civ., 30 December 1936, DP 1937.1.5, rap. L. Josserand, note R. Savatier; S. 1937.1.137, note H. Mazeaud)].

${ }^{41}$ VINEY ET AL., LeS CONDITIONS..., supra note 35, at 1075 (n $\left.{ }^{\circ} 807\right)$.
} 
things, the victim usually has the choice of basing their cause of action against the employer either on article 1242 (1) (liability for things) or article 1242 (5) (the liability of employers for the acts of their employees). ${ }^{42}$

Therefore, despite the similar formulation of primary duties of employers for the acts of their employees, we can conclude that the scope of vicarious liability in England is reduced when compared to the same primary duties owed by employers in France. The extremely frequent need to prove the elements of the tort of negligence in order to establish the commission of a tort by the employee in the course of employment is the main reason for the reduced ambit of vicarious liability in England as opposed to France. The contrast is most evident when employees injure others while driving motor vehicles or operate tools or machinery. In France, in cases of road traffic accidents, the victim can rely on an underlying civil wrong of strict liability in order to show that the employee committed a civil wrong: the regime from the loi Badinter. Also, in cases of damage caused by things operated by employees, vicarious liability may be bypassed entirely. The employer is almost always considered to be the gardien of the thing and, in that capacity, he may be held liable under the general rule on liability for things. ${ }^{43}$ In England, in all such cases, the victim must show that the employee was at least negligent as a pre-condition for holding the employer vicariously liable.

Second, there is a strong divergence between France and England on the issue of the relationship between the liability of employers for the civil wrongs of their employees and the liability of the employees themselves for said wrongs. In England, employees can be held liable for the wrongs they commit in the course of employment. Employees and their employers are held jointly liable when both the requirements for personal liability and those for vicarious liability are met, ${ }^{44}$ and moreover, employers have a right of recourse against their employees. ${ }^{45}$ That being said, judgments against employees have rarely been enforced, and the right of recourse is almost never exercised (the main reason being the fact that liability insurers have entered into a gentlemen's agreement not to take advantage of the right of recourse without the consent of the employer, unless there is evidence of wilful misconduct or collusion). ${ }^{46}$ In France, employees are now

\footnotetext{
${ }^{42}$ LE TOURNEAU ET AL., supra note 34, at 1957 [n $\left.\mathrm{n}^{\circ} 7556\right]$.

${ }^{43}$ VINEY ET AL., LES CONDITIONS..., supra note 35, at $1075\left(\mathrm{n}^{\circ} 807\right)$.

44 Simon DeAKIN ET AL., Markesinis AND DeAKIN's TorT LaW 595 ( $5^{\text {th }}$ ed., Oxford University Press 2003$)$.

${ }^{45} \mathrm{Id}$.

${ }^{46}$ W. Edwin PeEl \& JAMEs GoudKAMP, Winfield AND JOLOWICZ ON TORT 665 (19 ${ }^{\text {th }}$ ed., Thomson Reuters 2014).
} 
virtually immunized from liability when committing civil wrongs in the course of their employment. Until the beginning of the $1990 \mathrm{~s},{ }^{47}$ the rules regarding the liability of employees for wrongs committed in the course of employment and the employer's right of recourse were similar to the rules we still find today in England. ${ }^{48}$ Whenever an employee committed a wrong in the course of his employment, the employer and the employee were both liable, in solido, but on different grounds, and the employer had a right of recourse against the employee. ${ }^{49}$ However, in the year 2000, the plenary assembly of the Court of Cassation completely revolutionized the interplay between the liability of employers and that of employees in the Costedoat decision. ${ }^{50}$ Costedoat immunizes the employee from the consequences of liability as long as he did not exceed the limits of his functions. ${ }^{51}$ Therefore, as the law stands today, while the victim still has to prove the elements of a civil wrong committed by the employee, ${ }^{52}$ in almost every case only the employer owes a secondary obligation to compensate the victim's harm. Also, employers cannot recover from their employees by way of recursory action. Before Costedoat, employers rarely made use of recursory actions, ${ }^{53}$ but now this is not even a theoretical option.

Arguably, the French legal system developed a form of liability that deserves the name of "vicarious liability" more than its twin from across the Channel. The original term "vicar" was used for a member of clergy who occupied a position as a substitute for another. ${ }^{54}$ Yet, under

\footnotetext{
${ }^{47}$ Although the turning point was the year 2000 when Costedoat was decided, there were earlier signs that the winds were changing. Parts of French legal doctrine advocated various solutions aimed at reducing or eliminating the liability of employees since the 1970s (M. T. Rives-Lange, Contribution a l'étude de la responsabilité des maîtres et commetants, JCP 1970.1.2309; MAZEAUD ET AL., supra note 34, at 1002-05 [no 927]; VINEY ET AL., LES CONDITIONS..., supra note 35, at 1079 [n 811-1]). However, courts only began to address the inequity of holding employees liable for faults committed in the course of employment in the 1990s. The Court of Cassation's commercial chamber made the first move in 1993 (Cass. Com., 12 October 1993, Bull. civ. IV, n 338, p. 245 ; D. 1994.124, note Geneviève Viney; RTD civ. 1994.111), followed by a more timid and nuanced decision rendered by the first chamber of the Court of Cassation in 1995 (Cass. Civ. $1^{\text {re }}, 30$ October 1995, Bull. civ. I, $n^{\circ} 383$, RTD civ. 1996.136, obs. Patrice Jourdain).

${ }^{48}$ VINEY ET AL., LES CONDITIONS..., supra note 35, at 1078-79 ( $\left.{ }^{\circ} 811\right)$.

${ }^{49}$ The right of recourse existed in theory only because, since 1930, insurers of employers held vicariously liable were only allowed to use the recursory action against the responsible employee when the employee acted with malice (malveillance). VINEY ET AL., LES CONDITIONS..., supra note 35, at 1080 ( ${ }^{0}$ 811-1).

${ }^{50}$ Cass., Ass. Plén., 25 February 2000, n 97-20.152, Bull. ass. plén., nº 2; D.2000.673, note Brun; JCP

2000.II.10295, concl. Kessous, note Billiau; Gaz. Pal. 2000.2.1462, note Rinaldi.

${ }^{51}$ The language used by the court is unequivocal: "The employer that acts within the limits of the task assigned to him by the employer shall not be liable toward third parties." ([N]'engage pas sa responsabilité à l'égard des tiers le préposé qui agit sans excéder les limites de la mission qui lui a été impartie par son commettant).

52 See the case Olympique de Marseille: Cass. Civ. 2e, 8 April 2004, nº 03-11.653, Bull. civ. II, n 194; RTD Civ. 2004.217, obs. Patrice Jourdain; D.2004.2601, note Serinet; JCP 2004.II.10131, note Imbert.

${ }^{53}$ VineY ET AL., LES CONDITIONS..., supra note 35, at $1080\left(\mathrm{n}^{\circ} 811-1\right)$.

${ }^{54}$ Birks, supra note 51 , at 41.
} 
English law, employers are liable alongside their employees and do not fully substitute for them, whereas under French law, after Costedoat, employers became truly liable in their employees' stead.

The immunization from liability of employees in France does not mean, however, that the responsibility of employees is entirely effaced. The consequences of liability are indeed shifted entirely on the employer, but the law continues to signal what constitutes a relational wrong between the employee and the victims, the commission of a civil wrong by the employee still being a pre-condition for the liability of the employer.

From a comparative perspective, the English tort system does not appear to be more generous to victims than the French system, despite it having a rule of joint liability, because employers are almost always the more solvent debtors and very often have liability insurance. Therefore, the additional cause of action against the employee is of little to no importance to the victim. However, the English tort system is comparatively harsh toward employees, over whom the prospect of liability (either to the victim or to the employer on the basis of the recursory action) always looms in the background, threatening financial devastation. The Costedoat jurisprudence, by contrast, achieves something truly remarkable: the simultaneous protection of victims and of employees without sacrificing much at all, the parallel liability of employees being superfluous in a system where taking out liability insurance by employers is commonplace.

\section{Private nuisance and trouble de voisinage}

The tort of private nuisance (in England), including the rule from Rylands $v$ Fletcher, and the general principles applicable to troubles de voisinage (in France) have a similar scope and nature. They apply to relationships between neighbours, in situations where one of the neighbours causes an inconvenience to at least one other neighbour. These cases are solved in both jurisdictions through the interplay of two broad principles. The default position is one of mutual tolerance: neighbours must put up with each other's activities, sounds, smells, etc. However, if the interference is abnormal, in the sense that it is sufficiently substantial and unreasonable, then liability ensues irrespective of fault. The reasonableness standard is result-orientated, being applied directly to the interference, and not to the defendant's conduct. Therefore, the primary rights and duties can be formulated along similar lines in France and England: potential victims have a right 
to be free from unreasonable interference from their neighbours, and the correlative duty is to refrain from an abnormal interference.

Despite a common core, in recent years, the scope of the general principle applicable to troubles de voisinage in France has been expanding faster than the scope of equivalent rules in England. In France, nuisance principles are today focused more on lifestyle than property rights, ${ }^{55}$ whereas the English tort of nuisance is still heavily focused on property rights. For instance, the French Cour de Cassation interprets the notion of "neighbour" in a broad sense, including also "occasional neighbours", such as the employees of a company performing construction work on property adjacent to that of the defendant. ${ }^{56}$ In England, as a general rule, only persons with rights to land may sue their neighbours in nuisance. ${ }^{57}$ "Occasional neighbours", therefore, do not have standing to sue in nuisance. In addition, French courts seem willing to infuse the doctrine of troubles de voisinage with the tenets of the precautionary principle, and therefore expand its reach to uncertain risks. ${ }^{58}$ In England, there has not yet been a case in which nuisance principles were applied to uncertain risks, and it is unlikely that any English court would take such a step in the near future. In fact, there is clear authority that there is no liability when the possibility of interference could not reasonably have been foreseen by a reasonable person in the defendant's situation. ${ }^{59}$

\section{Trespass to land and the référé possessoire}

Although it is less obvious, there is also a very high level of functional equivalence between the strict liability tort of trespass to land (in England) and the civil wrongs that ground a référé possessoire (in France). Trespass to land is a tort that sanctions any unjustifiable interference with

\footnotetext{
${ }^{55}$ Supra Chapter II Part C.4.

${ }^{56}$ Cass. Civ. $3^{\mathrm{e}}$, 11 May 2000, Bull. civ. III, no 106, D.2001.2231, obs. Patrice Jourdain; Cass. Civ. 3e, 21 May 2008, D.2008.1550, Obs. Bigot de la Tuanne; D.2008.2458, obs. Mallet-Bricout \& Reboul-Maupin ; D.2008.2894, obs. Philippe Brun \& Patrice Jourdain ; RTD civ. 2008.496, obs. Patrice Jourdain ; Cass. Civ. 3 ${ }^{\text {e }} 9$ February 2011, Bull. Civ. III, $\mathrm{n}^{\circ} 21$.

${ }^{57}$ Hunter v Canary Wharf Ltd, [1997] A.C. 655. See also Paula Giliker, Relationships Between Neighbours: England and Wales 1850-2000, in The DeVELOPMENT OF LiaBILITY BETWEEN NEIGHBOURS 29, 45 (James Gordley ed., Cambridge University Press 2010).

${ }^{58}$ Tribunal de Grande Instance ["TGI"] Grasse, 17 June 2003, JurisData 2003-221748 ; Cour d'appel ["CA"] Aixen-Provence, 8 June 2004, D. 2004.2678, note Mathilde Boutonnet; D.2005.186, obs. Denis Mazeaud; Michel Cannarsa et al., France (report), in EuROPEAN TORT LAW 2004, at 297 (Helmut Koziol \& Barbara C. Steininger eds., Springer 2005); TGI Nanterre, 18 September 2008, D. 2008.2916, note Mathilde Boutonnet; CA Versailles, 4 February 2009, D. 2009.499; D. 2009.819, note Mathilde Boutonnet; J-Ph. Feldman, Le trouble voisinage du principe de précaution, D. 2009 Chron. 1369; Olivier Moréteau, France (report), in EUROPEAN TORT LAW 2009, at 199 (Helmut Koziol \& Barbara C. Steininger eds., De Gruyter 2010).

${ }^{59}$ Cambridge Water Co Ltd v Eastern Counties Leather Plc, [1994] 2 W.L.R. 53, [1994] 2 A.C. 264; PEEL \& GOUDKAMP, supra note 46, at 464.
} 
the possession of land. ${ }^{60}$ The référé possessoire is not in itself a civil wrong. It is a fast, cheap, and simple procedure which is aimed at providing possessors of immovables a remedy in cases of unlawful interference with their possession of land. However, the acts which may trigger a référé possessoire are civil wrongs. In fact, they are the same types of wrongs that usually trigger liability for trespass to land in England.

The reason why the equivalence is not obvious is because in France the protection of possession has traditionally been studied as an appendix to property law, not an integral part of civil liability law. Moreover, the référé possessoire has only recently become the primary legal response to acts of interference with possession. For more than 200 years (from the enactment of the Civil Code to the enactment of the new reforms in 2015), the protection of possession was provided by a set of procedures known as actions possessoires (possessory actions) ${ }^{61}$ Possessory actions were based on a general principle that all persons having factual possession of an immovable, including tenants and other "precarious possessors" (détenteurs), as well as possessors in bad faith, are entitled to legal protection when their possession is disturbed by another. ${ }^{62}$ The starting point for the analysis of possessory actions was always on the passive side (that of the possessor), and not on the active side (that of the person infringing possession), and because of this fault never played a role in possessory actions. However, it is beyond any doubt that possessory actions were meant to redress voluntary acts of interference with the possession of land. Such acts were seen as unlawful, and their commission led to the creation of a novel remedial obligation. There were three types of possessory actions, each with a different legal regime: (1) the complainte, (2) the dénonciacion de nouvel oeuvre, and (3) the action en réintégration. The complainte was the most general possessory action, where the possessor, after proving that he suffered from a present interference with his possession (trouble actuel), was entitled to ask the court to order the defendant to stop interfering and, if and when it was deemed necessary, remove any works that caused the interference. ${ }^{63}$ The dénonciacion de nouvel oeuvre was a preventive action, allowing the possessor to ask for the suspension of works which could potentially have interfered with his possession. ${ }^{64}$

\footnotetext{
${ }^{60}$ PeEl \& GoudKamp, supra note 46 , at 427.

${ }^{61}$ For the origins, history, and evolution of possessory actions in France during this interval see Raffaele Caterina, The Evolution of Possessory Actions in France and Italy, in THE CONSEQUENCES OF POSSESSION 95, 98 -102 (Eric Descheemaeker ed., Edinburgh University Press 2014).

${ }^{62}$ Christian Atias, Droit CIVIL. LES BIENS 354 [n $\left.{ }^{\circ} 469\right]$ (12 $2^{\text {th }}$ ed., LexisNexis 2014).

${ }^{63}$ FranÇOIS Terré \& PhiliPPe Simler, Droit CIVIL. LeS BIENS 194 [n $\left.{ }^{\circ} 211\right]\left(9^{\text {th }}\right.$ ed., Dalloz 2014$)$.

${ }^{64} \mathrm{Id}$. at 195 [n $\left.\mathrm{n}^{\circ} 211\right]$.
} 
Lastly, the action en réintégration protected the possessor against the most serious infringements, encompassing acts of violence and manifestly illegal acts, and allowed him to ask the court for any form of redress necessary in order to restore the possessor to the same situation he would have been in had the infringement never occurred. ${ }^{65}$

A recent reform abolished these traditional forms of redress for unlawful interference with possession, and replaced them with the référé possessoire. ${ }^{66}$ The possibility to make use of the référé (fast and cheap procedure, relatively similar to the English injunction) ${ }^{67}$ in order to protect possessory interests was recognized by the Court of Cassation long before the reform, in $1996 .{ }^{68}$ From 1996 to 2015, the référé possessoire and possessory actions coexisted as alternative avenues for the protection of possession. However, during this time, possessory actions lost their appeal. The référé possessoire proved to be a faster, cheaper, and more flexible procedure. Moreover, possessory actions presented a number of disadvantages when compared with the référé possessoire. The most significant inconvenience was the fact that in possessory actions it was not possible to bring arguments regarding the existence or exercise of a real right, due to the rule of "non-cumul du possessoire et du pétitoire". ${ }^{69}$ Also, the complainte and the dénonciacion de nouvel oeuvre were not available to those who had been in possession for less than one year at the moment when the infringement occurred. ${ }^{70}$ By contrast, issues regarding the existence of a real right can be raised in the référé possessoire procedure, ${ }^{71}$ and there is no limit set on the duration of the claimant's possession. ${ }^{72}$ For these reasons, academics also became disenchanted with possessory actions. In 2009, a report published by the working group on the reform of property law, sponsored by the Henri Capitant Association, concluded that possessory actions were excessively complex and lacked any real utility and thus proposed they be abolished. ${ }^{73}$ And indeed, in 2015 all

\footnotetext{
${ }^{65} \mathrm{Id}$.

${ }^{66}$ Loi n ${ }^{0}$ 2015-177 du 16 février 2015 relative à la modernisation et à la simplification du droit et des procédures dans les domaines de la justice et des affaires intérieures, JORF n ${ }^{0} 40$ du 17 février 2015, p. 2961.

${ }^{67}$ As opposed to the English injunction, however, in the référé possessoire the powers of the judge extend to any necessary measure that will stop and/or redress the infringement of possession, including damages.

${ }^{68}$ Cass. Ass. Plén., 28 June 1996, D.1996.497, concl. Jean-François Weber, note Jean-Marie Coulon; RTD civ. 1997.216, obs. Jacques Normand; RTD civ. 1997.463, obs. Frédéric Zenati.

${ }^{69}$ JeAn CarbonNiER, 3 Droit CiVIL. Les Biens 320 [nº 203] (19 ${ }^{\text {th }}$ ed., P.U.F. 2000);

${ }^{70}$ PhilipPe Malaurie \& LaURent Aynès, Les BIENS 156 [n $\left.{ }^{0} 507\right]$ ( $5^{\text {th }}$ ed., Defrénois 2013); ATIAS, supra note 62 , at 353-54 [n 468]; TERRÉ \& SIMLER, supra note 63, at 191 [nº 205].

${ }^{71}$ Cass., $3^{\mathrm{e}}$ civ., 24 February 1999, $\mathrm{n}^{\circ}$ 96-18.742, D.1999.79 (I.R.).

72 There is no temporal requirement in art. 809 of the French Code of Civil Procedure which sets out the requirements of the référé procedure.

${ }^{73}$ Proposition de L’ASSOCIATION HENRI CAPITANT POUR UNE RÉFORME DU DROIT DES BIENS (Hugues PérinetMarquet dir., Litec 2009).
} 
possessory actions were abolished by the French legislature and the référé possessoire became the only procedural avenue for the protection of possession. ${ }^{74}$

The référé possessoire is an autonomous protective mechanism, and not just a faster and cheaper possessory action in disguise. ${ }^{75}$ This is why the non-cumul du possessoire et du pétitoire principle and the requirement of being in possession for at least one year before the infringement occurred are inapplicable in the référé procedure. Judges enjoy a great degree of discretion in référé proceedings, and for this reason it is hard to say what the substantive requirements of a claim are. What exactly constitutes an infringement of possession (trouble possessoire) is left open to argument, thus making the référé possessoire much more flexible than the pre-existing possessory actions. There is only some form of general guidance in the Code of Civil Procedure, in which articles 808 and 809 of the Code of Civil Procedure lay down the requirements for all claims in référé, including the référé possessoire. According to these provisions, the claimant has to show that either the infringement of his possession is likely to cause him imminent damage ("[...] pour prévenir un dommage imminent") or the infringement is manifestly against the law ("[...] pour faire cesser un trouble manifestement illicite").

Although the référé possessoire and an action for trespass to land are very different from a procedural standpoint, the exclusive reliance on the référé brings French law much closer to English law with regard to the substantive requirements of a claim for the infringement of possession. The admissibility of the tort of trespass to land does not depend on the claimant being able to show that he has been in possession for a minimum amount of time, and English judges are not at all disconcerted by the prospect of a party invoking the existence of a property right in trespass cases. Both trespass to land and the référé possessoire are flexible with regard to the nature of the claim that can be brought to court, requiring only that the claimant prove that his possession was disturbed by the defendant's act. And most importantly, both trespass to land and the civil wrongs that ground a référé possessoire serve the same function at the level of primary entitlements and duties, namely of protecting a possessor's interest to peacefully enjoy the possession of his land.

\footnotetext{
${ }^{74}$ Loi n ${ }^{\circ}$ 2015-177 du 16 février 2015, supra note 66.

75 NAdÈGe Reboul-Maupin, Droit DES BIENS 287 [n³24] (6 $6^{\text {th }}$ ed., Dalloz 2016)
} 


\section{Differences}

There are also some strong differences between the French and the English legal systems when it comes to the definition of civil wrongs. Most of the time, when French law and English law differ in their definitions of civil wrongs, it is because a certain domain is governed by a strict liability rule in France, whereas in England a fault-based rule governs the field (or a combination between strict liability and fault-based liability). This is the case particularly (1) when a thing is involved in the causation of damage, (2) in most cases of liability for the civil wrongs committed by another, (3) in cases of road traffic accidents, and (4) partly in cases of damage caused by animals. There are, however, quite exceptionally, also liability problems to which English law responds with strict liability, whereas French law resorts only to fault-based liability (or a combination between strict liability and fault-based liability). These include civil wrongs dealing with (5) the protection of entitlements over movable property, and (6) defamation.

This list is not exhaustive, but it covers most of the areas where French and English law sharply diverge, in the sense that one jurisdiction opted for fault, while the other for strict liability. In the following, the solutions to each of these liability problems are briefly compared, with an emphasis on the key differences regarding the definition of primary entitlements and duties.

\section{Liability for things}

The second thesis of article 1242 (1) of the French Civil Code, establishing a general principle of liability for the acts of things, is one of the most distinctive provisions of French tort law and, one could even say, of French legal culture as a whole. From all the liability rules we have identified in France and England, the liability of a gardien for the acts of things is by far the broadest in scope. It is the broadest strict liability rule in Europe, and perhaps even worldwide. ${ }^{76}$ It encompasses all objects, movable or immovable, except those for which there are more specific liability provisions (animals, buildings, motor vehicles), and it does not require that the thing be defective, dangerous, or even "guided by a human hand". ${ }^{77}$ Any person who has factual custody (la garde) of a thing that causes damage to another may be held liable on the basis of this rule,

\footnotetext{
${ }^{76}$ See Franz Werro, Liability for Harm Caused by Things, in TowARDS A EUROPEAN Civil CODE 921, 922 (4 ${ }^{\text {th }}$ ed., Arthur Hartkamp et al. eds., Wolters Kluwer/Ars Aequi Libri 2011).

${ }^{77}$ Suzanne Galand-Carval, France in Unification OF Tort LAW: Strict Liability 127, 132 (B.A. Koch \& H. Koziol eds., Kluwer Law International 2002).
} 
without the victim being required to show that the custodian was negligent and without any possibility of exoneration upon proof of absence of fault by the custodian. ${ }^{78}$

The English common law does not have any comparable rule or principle. What in France is dealt with under liability for things, in England would most often be dealt with under the tort of negligence. Only exceptionally, torts such as battery, ${ }^{79}$ nuisance, ${ }^{80}$ or breach of statutory duty ${ }^{81}$ may also be used when a victim suffers damage due to the "act of a thing". However, the involvement of a thing is not characteristic of any common law torts. The torts of negligence, battery, nuisance, and breach of statutory duty can be committed without things being involved in the causation of damage, and where things are involved, what matters is the human agency that makes use of such things and not the involvement of the thing itself. Moreover, because of the broad scope of article 1242 (1) of the French Civil Code, there are a number of cases in which liability would ensue on the basis of the general rule on liability for things in France, whereas under English law the same factual scenarios would not lead to any liability at all. In England, if no-one is deemed to have been negligent in the use of a thing, or to have had the intent to touch another with the thing in question, or to have caused a private or public nuisance, or to have breached a statutory duty, most likely there will be no other basis for liability available to a person who suffered damage after coming into contact with a thing.

Therefore, the functional equivalence between the rule from article 1242 (1) of the French Civil Code and the torts mentioned above is, at best, only partial. In fact, when it comes to liability for the acts of things, the divergence between English law and French law stands out more than any partial functional equivalence. From a bird's-eye perspective, it would not be wrong to say that English law relies mainly on negligence standards when things play a role in the causation of injury, whereas French law relies on strict liability. This is an uncontroversial, well-known and

\footnotetext{
${ }^{78}$ Muriel Fabre-Magnan, 2 Droit Des Obligations. Responsabilité CIVILE ET QUASI-CONTRATS 244-45 (3 ${ }^{\text {rd }}$ ed., PUF 2007).

${ }^{79}$ See e.g., Scott v Shepherd, [1773] 96 Eng. Rep. 525 (a squib); Fagan v Metropolitan Police Commissioner, [1969] 1 QB 439, [1968] 3 All ER 442, [1968] 3 WLR 1120 (a motor vehicle); Breslin v McKenna, [2009] NIQB 50 (a bomb).

${ }^{80}$ As already mentioned in Chapter III, Rylands v Fletcher [(1868) LR 3 HL 330 (House of Lords)] is nowadays treated as a sub-category of nuisance. The cases where the rule from Rylands $v$ Fletcher is applied, but also Rylands $v$ Fletcher itself, represent very good examples of situations where damage is caused by the "act of a thing" (as it would be understood under French law), but liability is based on a different rationale.

${ }^{81}$ See e.g., Atkinson v Newcastle Waterworks Co, (1877) 2 Ex. D. 441 (water pipes); Groves v Lord Wimborne, [1898] 2 QB 402 (a steam winch with revolving cog-wheels); Lochgelley Iron \& Coal Co v M'Mullan, [1934] AC 1 (the roof of a building).
} 
often-cited difference between French and English law. ${ }^{82}$ The other potential torts that may come into play in England (battery, nuisance, or breach of statutory duty) apply too rarely to have much of an impact on the overall picture.

Different ideas of what may constitute an interpersonal civil wrong lie at the root of this divergence between English law and French law. In particular, two differences regarding how the underlying wrong is defined stand out: first, the French liability rule for the acts of things defines the subject of the underlying duty in a narrower, more definite manner than the tort of negligence; and second, the ascription (or imputation) of a civil wrong to a custodian is done in two steps, bypassing any reference to the behaviour of the custodian, whereas under the tort of negligence the ascription of the wrong is direct and unmediated, being focused on the behaviour of the tortfeasor.

Starting with the first difference, under French law, the primary duty is owed by custodians of things, i.e. persons who have direction and control over a corporeal object. This primary duty is owed to the world at large, and therefore the correlative right is held by all other persons. Therefore, the characteristic primary duty which underlies the French rule on liability for things belongs to the category of duties which are owed by a class of persons to all others. In England, although the duty of care element in the tort of negligence is relational and is often established on a case-by-case basis, ${ }^{83}$ there is no a priori limitation as to who can be a claimant and who can be a respondent in a negligence case. The duty of care in negligence has the potential to bind all persons to all others ${ }^{84}$ In other words, the primary duty of the tort of negligence has a propensity

\footnotetext{
${ }^{82}$ VAN DAM, supra note 33 , at 404 ; FABRE-MAGNAN, supra note 78 , at 268-69.

${ }^{83}$ See Caparo Industries Plc v Dickman, [1990] UKHL 2, [1990] 2 A.C. 605, 618 (per Lord Bridge): "Whilst recognizing, of course, the importance of the underlying general principles common to the whole field of negligence, I think the law has now moved in the direction of attaching greater significance to the more traditional categorization of distinct and recognizable situations as guides to the existence, the scope and the limits of the varied duties of care which the law imposes."

${ }^{84}$ The most well-known formulations of the duty of care element in negligence come from Lord Atkin's speech in Donoghue v Stevenson and Lord Bridge's speech in Caparo Industries plc v Dickman.

See Donoghue v Stevenson, [1932] UKHL 100, [1932] A.C. 562, 580 (per Lord Atkin): “At present I content myself with pointing out that in English law there must be and is some general conception of relations, giving rise to a duty of care, of which the particular cases found in the books are but instances.... The rule that you are to love your neighbour becomes in law you must not injure your neighbour; and the lawyer's question 'Who is my neighbour?' receives a restricted reply. You must take reasonable care to avoid acts or omissions which you can reasonably foresee would be likely to injure your neighbour. Who then in law is my neighbour? The answer seems to be persons who are so closely and directly affected by my act that I ought reasonably to have them in contemplation as being so affected when I am directing my mind to the acts or omissions which are called in question."

Caparo Industries Plc v Dickman, [1990] UKHL 2, [1990] 2 A.C. 605, 617-18 (per Lord Bridge): "What emerges is that, in addition to foreseeability of damage, necessary ingredients in any situation giving rise to a duty of care are
} 
to universality. However, this does not mean that in positive English law every person owes a duty of care to all others in every circumstance. There are relational limits placed on the duty of care, but the limits themselves also have an impersonal character. Criteria such as "foreseeability", "proximity", or "whether it is fair, just and reasonable for the law to impose a duty of care" do not imply an ex ante exclusion of any particular category of claimants or defendants.

To sum up, the active side of the primary duty is better defined and has a higher level of specificity in the case of the civil wrong envisaged by the French principle of liability for things, when compared to the tort of negligence. Under any formulation, the active side of the duty always excludes as potential tortfeasors those who do not have direction and control over a corporeal object.

Before moving on to the second difference, it is perhaps useful to first clarify what constitutes "an act of a thing" under French law. It is definitely not the case that French law attributes any kind of agency to inanimate things. There are examples in medieval law ${ }^{85}$ of a different kind of "thing responsibility" ${ }^{\prime 66}$ where punishment or vengeance was sought against the thing itself, as if the thing had agency or was possessed by a mysterious entity with agency (for instance, a demon). The kind of thing responsibility we see nowadays in France is not a responsibility of the thing itself, but a responsibility for things, which rests on those who have legal personality under French law, i.e. natural and legal persons.

The concept of an "act of a thing" is a fiction, which operates as a nexus point in the ascription of liability. The primary duty and the correlative entitlement that bind the custodian to the victim have a complex structure, being based on the correct identification of two connected relationships: the relationship between the victim and the thing and the relationship between the thing and its custodian. First, the relationship between the victim and a thing must be of the right kind. Not every involvement of a thing in the causation of injury falls within the scope of article 1242 (1).

\footnotetext{
that there should exist between the party owing the duty and the party to whom it is owed a relationship characterized by the law as one of 'proximity' or 'neighbourhood' and that the situation should be one in which the court considers it fair, just and reasonable that the law should impose a duty of a given scope on the one party for the benefit of the other."

${ }^{85}$ In medieval times a surprisingly large number of cases were brought against animals and insects. See EDWARD Payson Evans, The Criminal Prosecution and Capital Punishment of Animals (E. P. Dutton and Company 1906).

${ }^{86}$ Ferdinand F. Stone, Liability for Damage Caused by Things, in 11 InTERNATIONAL ENCYClOPEDIA OF Comparative LaW, TorTs [Ch.5], at 3 (André Tunc ed., J.C.B. Mohr (Paul Siebeck) \& Martinus Nijhoff Publishers 1983).
} 
French courts distinguish between things in motion and things that are stationary. There is usually no difficulty in identifying an "act of a thing" when the thing was in motion and caused the victim's damage, but for stationary things a mere causal role is insufficient: a stationary thing must also be abnormal in its construction, functioning, sturdiness, or positioning. ${ }^{87}$ Second, the right kind of relationship between the defendant and the thing must be present. Only a person that has the use, direction and control ${ }^{88}$ (le pouvoir d'usage, de direction et de contrôle) of a thing can be considered a custodian for the purposes of article 1242 (1). The behaviour of the custodian is irrelevant for the determination of his liability. All that matters are his powers of control and direction over the thing. By contrast, the structure of imputation under the tort of negligence is unmediated, and the behaviour of the person having a primary duty (the duty of care) is of paramount importance. The only relevant relationship when determining liability under the tort of negligence is the causal relationship between the behaviour of the wrongdoer and the damage suffered by the victim.

2. Liability for another (when the other is not an employee)

De lege lata, strict vicarious liability encompasses in France also the liability of parents for the acts of their minor children, the liability of artisans for the acts of their apprentices, and the general principle of liability for the acts of others. The liability of parents for their minor children, based on article 1242 (4) of the Civil Code, has been strict since the Bertrand case, decided by the Court of Cassation in 1997. ${ }^{89}$ The liability of artisans for the acts of their apprentices, based on article 1242 (6) of the Civil Code, has traditionally been fault-based with a reversed burden of proof, ${ }^{90}$ but French commentators have argued that after the Bertrand case the liability of artisans will likely follow either the regime applicable to employers for the acts of their employees, ${ }^{91}$ or the regime applicable to parents for the acts of their minor children. ${ }^{92}$ Last but not least, the general

\footnotetext{
${ }^{87}$ LE TOURNEAU ET AL., supra note 34, at 1989 [n 7804].

${ }^{88}$ Cass. Ch. Réunies, 2 December 1941, DC 1942.25, note Ripert; S.1941.1.217, note H. Mazeaud; JCP 1942.II.1766 note Mihura (arrêt Franck); Cass. Civ 2e, 14 January 1999, nº 97-11.527, Bull. civ. II, nº 13; D. 1999. IR 50.

${ }^{89}$ Cass. Civ. 2e, 19 February 1997, Bull. civ. II, no 56; D.1997.265, note Patrice Jourdain; JCP.1997.II.22848, concl. R. Kessous, note Geneviève Viney; Gaz. Pal., 3 October 1997, note François Chabas (arrêt Bertrand); Christophe Radé, Le renouveau de la responsabilité du fait d'autrui, D.1997.279 (Chron.).

${ }^{90}$ VINEY ET AL., LES CONDITIONS..., supra note 35, at 1223 [n ${ }^{\circ} 893$ ].

${ }^{91}$ LE TOURNEAU ET AL., supra note 34, at 1940 [n 7472].

${ }^{92}$ Id., at 1223-24, no 893; See also PhILIPPE BRUN, ReSPONSABILITÉ CIVILE EXTRACONTRACTUELLE 301-302 [n ${ }^{\circ}$ 467] ( $2^{\text {nd }}$ ed., LexisNexis - Litec 2009) [presenting three alternatives: (1) artisans will be assimilated to parents; (2) they will be assimilated to employers; or (3) their liability will follow the general regime of 1384 (1)]; But see FABRE-MAGNAN, supra note 9, at 389 (who presents the liability of artisans as still based on a presumption of fault).
} 
principle of liability for the acts of others, based on the judicial re-interpretation of article 1242 (1) of the French Civil Code, has been part of French positive law since the Consorts Blieck case, decided in $1991 .^{93}$

In England, until very recently, vicarious liability was synonymous with the liability of employers for the torts committed by their employees. However, since 2012, the law of vicarious liability has been transforming and expanding at a rapid pace. ${ }^{94}$ The UK Supreme Court has shown in cases such as Christian Brothers, ${ }^{95}$ Cox $^{96}$ and Armes $^{97}$ a progressive attitude toward the doctrine of vicarious liability, and allowed new kinds of relationships to fall within its scope. It is now part of positive English law that: a church or religious entity is liable for the wrongs committed by the priests who belong to that church or religious order (Christian Brothers), prison authorities are liable for the wrongs committed by prisoners while performing prison service work (Cox), and local authorities are liable for the wrongs committed by foster parents against children placed in their care (Armes).

That being said, what these cases mean for the present and future scope of vicarious liability is still relatively unclear. No clear-cut general rules or general principles of vicarious liability have emerged from these recent cases, and it is hard to predict whether this progressive trend will continue (and if it continues, where it will stop). ${ }^{98}$ The expansion has been incremental, careful, and inconclusive. There is a purposeful lack of clarity and precision in these recent judgments, ${ }^{99}$ and it is likely that the determination of liability in similar novel cases will rest on what judges find fair, just and reasonable under the specific circumstances of each case. ${ }^{100}$ In this regard, the

\footnotetext{
${ }^{93}$ Cass. Ass. Plén., 29 March 1991, no 89-15.231, Bull. ass. plén., no 1; D.1991.324, note Larroumet; Somm. 324, obs. Aubert; JCP 1991.II.21673, concl. Dontenwille, note Ghestin; Gaz. Pal. 1992.2.513, obs. Chabas; RTD civ. 1991.312, note J. Hauser; RTD civ. 1991.541, note Patrice Jourdain; Geneviève Viney, Vers un élargissement de la catégorie des "personnes dont on doit répondre": la porte entrouverte sur une nouvelle interprétation de l'article 1384, alinéa 1er, du code civil, D.1991.157 (Chron.); Pierre Bon, La responsabilité du fait des personnes dont on a la garde : sur un rapprochement des jurisprudences administrative et judiciaire, RFDA 1991.991.

${ }^{94}$ Lord Philips' last judgment as the President of the UK Supreme Court contained, in hindsight, some truly prophetic words: "The law of vicarious liability is on the move". Catholic Child Welfare Society v Various Claimants and the Institute of the Brothers of the Christian Schools, [2012] UKSC 56; [2013] 2 A.C. 1 ${ }_{95}^{95}$.

${ }^{96}$ Cox v Ministry of Justice, [2016] UKSC 10, [2016] A.C. 660.

${ }^{97}$ Armes v Nottinghamshire County Council, [2017] UKSC 60, [2018] A.C. 355.

${ }^{98}$ See Lord Reed's statement in Cox v Ministry of Justice, [2016] UKSC 10, [2016] A.C. 660, at 664: "[Vicarious liability] has not yet come to a stop."

${ }^{99}$ Mohamud v WM Morrison Supermarkets plc, [2016] UKSC 11, [2016] A.C. 677, at 695 (per Lord Dyson): "To search for certainty and precision in vicarious liability is to undertake a quest for a chimaera."

${ }^{100}$ Catholic Child Welfare Society v Various Claimants and the Institute of the Brothers of the Christian Schools, [2012] UKSC 56; [2013] 2 A.C. 1, at 15.
} 
flexible set of factors set out by Lord Philips in the Christian Brothers case have been used to test whether it is fair, just and reasonable to hold a particular defendant vicariously liable under a specific set of circumstances. These factors are: (1) whether the defendant is more likely to have the means to compensate the victim than the tortfeasor; (2) whether the tort was committed as a result of activity undertaken by the tortfeasor on behalf of the defendant; (3) whether the tortfeasor's activity is likely to be part of the business activity of the defendant; (4) whether the defendant created the risk of the tort being committed by assigning a particular task to the tortfeasor; and (5) whether the tortfeasor was, to a greater or lesser degree, under the control of the defendant. ${ }^{101}$

The factors from Christian Brothers are not cumulative and do not have equal weight. ${ }^{102}$ However, the civilian reader should not be fooled by the flexibility and open-endedness of the existing test. Armes, the last and perhaps boldest of all the decisions cited above, is replete with dicta inviting caution, distinguishing its facts from other similar instances, and highlighting the unique factual and normative circumstances that justified the imposition of vicarious liability. ${ }^{103}$ The test from Christian Brothers is not meant to be broad and over-inclusive, and it does not create a general liability principle. Its flexibility is only supposed to make it easily adaptable to the infinite set of circumstances that may arise in future cases. ${ }^{104}$

There is an obvious similarity between the general principle of liability for the acts of others which emerged from the Consorts Blieck case ${ }^{105}$ in France and the English cases on vicarious liability we have highlighted above. However, seeing how reluctant English judges are, and will probably remain, to create a general principle of vicarious liability, there is only a partial overlap between the vicarious liability doctrines of our two jurisdictions. It is hard to tell how extensive the enlargement of vicarious liability will prove to be under English law. So far, only the relationship between a priest and his religious order, between a prison authority and a prisoner performing work during his sentence, and between foster parents and local authorities have been recognized under the doctrine of vicarious liability next to employment relationships, but the scope of

\footnotetext{
${ }^{101}$ Catholic Child Welfare Society v Various Claimants and the Institute of the Brothers of the Christian Schools, [2012] UKSC 56; [2013] 2 A.C. 1, at 15.

${ }^{102}$ Cox v Ministry of Justice, [2016] UKSC 10, [2016] A.C. 660, at 669; Armes v Nottinghamshire County Council, [2017] UKSC 60, [2018] A.C. 355 , at 377.

${ }_{103}$ Armes v Nottinghamshire County Council, [2017] UKSC 60, [2018] A.C. 355, at 378-79, 380, 382-83.

${ }^{104}$ See Cox v Ministry of Justice, [2016] UKSC 10, [2016] A.C. 660, at 669.

${ }^{105}$ Supra note 93.
} 
vicarious liability should be much broader. Based on the factors mentioned in Christian Brothers and Armes, there is some potential for a much more extensive doctrine of vicarious liability. In France, liability based on article 1242 (1) of the French Civil Code may be imposed on any person who is under a duty to organize, direct, and control in a permanent or temporary manner the dayto-day life of another person ${ }^{106}$ who committed a civil wrong. ${ }^{107}$ Thus, the broader French rules apply to a more diverse set of relationships, including the relationship between a rugby club and one of the players who was a member, ${ }^{108}$ the relationship between an association of cheerleaders and one of the cheerleaders, ${ }^{109}$ the relationship between a municipal centre for the homeless and one of the homeless persons it was hosting, ${ }^{110}$ or the relationship between an association organizing a holiday camp for children and one of the participating children. ${ }^{111}$

Most of the relationships governed by article 1242 (1) of the French Civil Code are not covered by the doctrine of vicarious liability in England. Instead, the torts of negligence and breach of nondelegable duty usually apply when such relationships exist.

With regard to the tort of negligence, an instructive case is Home Office v Dorset Yacht Co Ltd. ${ }^{112}$ The case involved a group of borstal trainees who were working in a harbour, under the control of officers employed by the Home Office. Seven of the borstal trainees escaped one night, boarded a yacht, navigated it, and collided with a second yacht which belonged to the plaintiffs. The key issues in this case were whether any of the employees of the Home Office owed a duty of care to the owner of the damaged yacht and, if they did, whether they breached such a duty of care. However, the officers working for the Home Office failed precisely in their duties to control and supervise the borstal trainees. In France this would have been an easy case of vicarious liability based on article 1242 (1) of the Civil Code because the prison authority organizes, directs and controls the life of the borstal trainees. In England, however, the duty to control and supervise was

\footnotetext{
${ }^{106} I d$.

${ }^{107}$ Moreover, a similar principle is applied by administrative courts in situations where a public body organises, directs and controls the daily life of another. LE TOURNEAU ET AL., supra note 34, at 1914-15 [ $\left.\mathrm{n}^{\circ} 7355\right]$.

${ }^{108}$ Cass. Civ. 2e 22 May 1995, JCP 1995.II.22550, comm. Mouly, JCP 1995.I.3893, obs. Geneviève Viney, RTD civ. 1995. 899, obs. Patrice Jourdain.

${ }^{109}$ Cass. Civ. 2e 12 December 2002, Bull. civ. II. n 289; RTD civ. 2003. 305, obs. Patrice Jourdain, JCP

2003.I.154, n 49, obs. Geneviève Viney.

${ }^{110}$ Cass. Civ. 2e, 22 May 1995, D.1996.453.

${ }^{111}$ CA Paris, 9 June 2000, Resp. civ. et assur. 2001, comm. n 76; VINEY ET AL., LES CONDITIONS..., supra note 35, at $1022\left[n^{\circ} 789-24\right]$.

${ }^{112}$ Home Office v Dorset Yacht Co Ltd, [1970] UKHL 2, [1970] AC 1004.
} 
interpreted as a sub-category of the duty of care, the breach of which triggers the application of the tort of negligence. ${ }^{113}$ Whether the Home Office or its employees were vicariously liable for the acts of the borstal boys was never even raised as an issue. The Home Office was held vicariously liable, though, on the basis of the traditional employer-employee relationship. There is no equivalence with a general principle of vicarious liability, however, because it is much more difficult to establish that employees of the prison authority were negligent toward the owner of the damaged yacht than it would be to establish the negligence of the borstal boys. Home Office $v$ Dorset Yacht Co Ltd. highlights instead the centrality of the tort of negligence within the English law of torts. The duties of control and supervision follow, by default, the logic of the tort of negligence, and not that of vicarious liability. That is why in this case, the persons who had powers of control, direction and supervision over the borstal boys (the employees of the Home Office) were deemed to have owed a duty of care, and not a duty to respond vicariously for the torts committed by the borstal trainees.

With regard to breach of a non-delegable duty, the recent case of Woodland v Essex CC stands out. ${ }^{114}$ In this case, it was held that a school owes a non-delegable duty to pupils taking swimming classes - which meant that it owed not only a duty to take reasonable care of the pupils itself, but also to provide that reasonable care is taken of the pupils by a third party. Thus, the defendant, a school which had the obligation to provide swimming lessons according to the national curriculum, was held liable for the damage suffered by a pupil during a swimming lesson which took place off-site at a local pool, under the instructions of an independent teacher. ${ }^{115}$ Dictum from the same case indicates that patients in hospitals, prisoners and residents in care homes may be owed the same type of duty. ${ }^{116}$ Thus, the English common law seems to achieve similar results to French law when such relationships are present, the defendant being held strictly liable for the negligence of another. The difference is that in France the defendant would be considered liable for the acts of another, whereas in England the defendant is considered personally liable. However, the

\footnotetext{
${ }^{113} I d$. at 1055: "The Borstal boys were under the control of the defendants' officers, and control imports responsibility. The boys' interference with the boats appears to have been a direct result of the defendants' officers' failure to exercise proper control and supervision. Problems may arise in other cases as to the responsibility of the defendants' officers for acts done by Borstal boys when they have completed their escape from control and are fully at large and acting independently. No such problem faces the plaintiffs in this case." (emphasis added).

${ }^{114}$ Woodland v Essex CC, [2013] UKSC 66; [2014] A.C. 537.

${ }^{115} \mathrm{Id}$.

${ }^{116} I d$. at [23] (per Lord Sumption).
} 
existence of a direct primary duty might be just a handy fiction. Some authors have suggested that the development of the doctrine of breach of non-delegable duty has been driven, at least in part, by the need to overcome some of the legal barriers to vicarious liability. ${ }^{117}$ In older common law cases, breach of non-delegable duty was used as a substitute for vicarious liability when the victim was an employee who was barred from bringing a vicarious liability claim due to the doctrine of common employment. ${ }^{118}$ In newer cases, such as Woodland, it works as a substitute for vicarious liability in relationships that are characterized by a higher level of independence than the relationship between an employer and an employee, but where it would still be just to hold the party who sub-contracted or delegated its activities liable. ${ }^{119}$

The torts of negligence and breach of non-delegable duty are not perfect functional equivalents to more general rules of vicarious liability. Both the tort of negligence and the tort of breach of nondelegable duty lead to the personal liability of the defendant, ${ }^{120}$ thus ignoring the very relationships that trigger the application of article 1242 (1) of the Civil Code in France. The underlying duties owed are personal duties, relating the tortfeasor directly to the victim. The primary duties and entitlements of vicarious liability regimes work differently. They have a different structure, relating the (vicarious) tortfeasor to the victim by way of two connected relationships: the relationship between the victim and the primary tortfeasor, and the relationship between the primary tortfeasor and the vicariously liable person. Nevertheless, the general impression one gets from the comparisons made above is that French and English tort law are moving in the same direction and are converging.

A completely different picture is revealed when one looks for functional equivalents to the vicarious liability of parents for the acts of their minor children [article 1242 (4) of the French Civil Code] and the liability of artisans for the acts of their apprentices [article 1242 (6) of the

\footnotetext{
${ }^{117}$ Paula Giliker, Vicarious Liability in Tort: A Comparative PersPective 118-21, 122 (Cambridge University Press 2010); JoHn G. Fleming, THE LAW OF TORTS 360 ( $6^{\text {th }}$ ed., The Law Book Company Ltd 1983); For a historical account see also DAVID IBBETSON, A HiSTORICAL INTRODUCTION TO THE LAW OF OBLIGATIONS 183 (Oxford University Press 2001).

${ }^{118}$ GILIKER, supra note 117, at 118-21.

${ }^{119}$ In this context, "newer cases" means cases from the $20^{\text {th }}$ and $21^{\text {st }}$ centuries. The use of the doctrine of breach of a non-delegable duty as a substitute for vicarious liability is a phenomenon that began manifesting itself long before Woodland. Patrick Atiyah, for instance, noticed this evolution in the case law five decades ago. See PATRICK S. ATIYAH, VICARIOUS LIABILITY IN THE LAW OF TORTS 338 (Butterworths 1967).

${ }^{120}$ D\&F Estates Ltd. v Church Commissioners, [1989] A.C. 177 (per Lord Bridge) (discussing breach of a nondelegable duty).
} 
French Civil Code]. Even in France, the latter liability rule is considered more of a relic from the past, and that is why we will not attempt to find its functional equivalents under English law in a systematic manner. An educated guess would be that a modern-day artisan would be liable either vicariously (because the artisan-apprentice relationship would probably qualify as an employment relationship or, at the very least, as a relationship akin to employment), or under the tort of negligence (when the relationship would not fall within the scope of vicarious liability ${ }^{121}$ ). With regard to the liability of parents, it seems to be generally accepted that under English law parents can only be held liable on the basis of the tort of negligence, for breach of their duty of care in supervising or controlling their minor children. ${ }^{122}$ In France, however, according to the postBertrand interpretation of article 1242 (4) of the French Civil Code, the liability of parents for the acts of their minor children is strict.

A comparison between the primary duties and entitlements of parents under the tort of negligence and under the strict liability regime of article 1242 (4) of the French Civil Code resembles most the comparison we have made in the previous section between the tort of negligence and liability for the acts of things. ${ }^{123}$ This is because article 1242 (4) of the French Civil Code no longer follows the logic of any other forms of vicarious liability. In fact, the liability of parents can hardly be categorized today as vicarious liability, as it functions more like a form of personal liability.

In general, when contrasted with the tort of negligence, all forms of vicarious liability have at least three aspects in common with liability for the acts of things. First, primary duties and entitlements are non-universal (they are not owed by all persons to all others, as would be the case with fault or negligence-based duties of care and their correlative entitlements). The defendant must be an employer, a parent, an artisan, or a person with duties of control, direction and supervision. In other words, the defendant must be related in the right way to the primary tortfeasor, for whose wrongs he will be deemed responsible. When a person is not related in the right way with the primary tortfeasor, that person will not owe a primary duty to the victim (at least not under vicarious liability). Second, in cases of vicarious liability, as in the case of liability for the acts of

\footnotetext{
${ }^{121}$ Based on Lord Philips' test from Catholic Child Welfare Society v Various Claimants and the Institute of the Brothers of the Christian Schools, [2012] UKSC 56; [2013] 2 A.C. 1, at 15.

${ }^{122}$ DEAKIN ET AL., supra note 44, at 153-54; Jean-Pierre Le Gall, Liability for Persons under Supervision, in 11 INTERNATIONAL ENCYClOPEDIA OF COMPARATIVE LAW, TORTS, Chapter 3, at 26-27, para. 87-93 (André Tunc ed., J.C.B. Mohr (Paul Siebeck) \& Martinus Nijhoff Publishers 1983). See also Donaldson v McNiven, [1952] 1 All E.R. 1213 (C.A.).

${ }^{123}$ Supra Part C.1 of this chapter.
} 
things, the behaviour of the defendant is irrelevant for establishing liability. Third, the primary duties and entitlements have a mediated structure, and depend on the existence of two connected relationships: the relationship between the defendant and the primary tortfeasor and the relationship between the primary tortfeasor and the victim.

Vicarious liability, however, differs fundamentally from liability for the acts of things in how it constructs the second relationship. The primary tortfeasor is a person endowed with agency and legal personality, and not an inanimate thing. Thus, he must truly be characterized as a tortfeasor in the sense that he must have committed a civil wrong himself. A mere causal role (as is the case with liability for things) is insufficient to trigger the application of vicarious liability. The liability of parents on the basis of article 1242 (4) of the French Civil Code, however, does not require proof of the child's subjective or objective fault, or even objective unlawfulness (acte objectivement illicite). ${ }^{124}$ The child's mere causal role is sufficient. ${ }^{125}$ That is why it cannot be said, de lege lata, that parents are called to answer vicariously for their children. Under French law, parents are treated more like guarantors for the damage their children may cause to others, ${ }^{126}$ and children are assimilated to things (for the purposes of liability). ${ }^{127}$ Many French legal scholars find it problematic to treat children like objects (la réification de l'enfant) and have severely criticized this development in jurisprudence, ${ }^{128}$ suggesting that the child's acts must be at the very least capable of being categorized as abnormal, if not (at least objectively ${ }^{129}$ ) a civil wrong. For now, their calls for a jurisprudential shift have remained unanswered by the Court of Cassation. However, the reform project initiated by the Chancery of the Ministry of Justice, published in

\footnotetext{
${ }^{124}$ The Court of Cassation's jurisprudence evolved from first requiring proof of the child's fault to being satisfied with the objective unlawfulness of the child's act. See VINEY ET AL., LES CONDITIONS..., supra note 35, at 1199$1202\left[\mathrm{n}^{\text {os }} 878-879-1\right]$

${ }^{125}$ Cass. Ass. Plén., 9 May 1984, Bull. ass. plén., no 4; D.1984.525, concl. J. Cabannes, note François Chabas ; JCP 1984.II.20255, obs. N. Dejean de la Bâtie (2 $2^{\text {nd }}$ case); JCP 1984.II.20291, Rapport Fedou; RTD civ. 508 (1984), obs. J. Huet (arrêt Fullenwarth); Cass. Civ. 2 19 February 1997, Bull. civ. II, nº 56; D.1997.265, note Patrice Jourdain; JCP.1997.II.22848, concl. R. Kessous, note Geneviève Viney; Gaz. Pal., 3 October 1997, note François Chabas (arrêt Bertrand) ; Cass. Civ. 2e 10 May 2001, no 99-11287, Bull. civ. II, nº 76; D. 2001.2851, rapp. Guerder, note Tournafond; D.2002.1315, obs. D. Mazeaud ; JCP 2001.II.10614, note J. Mouly ; RTD civ. 2001.601, obs. Patrice Jourdain (arrêt Levert); Cass. Ass. Plen., 13 December 2002, nº 00-13787, Bull. ass. plen., no 4; D.2003.231, note Patrice Jourdain; JCP 2003.II.10010, note Hervio-Lelong; JCP 2003.I.154, obs. Geneviève Viney; Cass. Ass. Plen., 17 January 2003, $\mathrm{n}^{\circ}$ 00-13787; D.2003.591, note Patrice Jourdain.

${ }^{126}$ VINEY ET AL., LES CONDITIONS..., supra note 35, at 1199 [n 877].

${ }^{127}$ FABRE-MAGNAN, supra note 78, at 359.

${ }^{128}$ LE TOURNEAU ET AL., supra note 34, at 1934-36 [ $\mathrm{n}^{\text {os }}$ 7434-7435]; JACQUES FlouR ET AL., 2 DroIT CIVIL. LeS OBLIGATIONS. Le FaIT JURIDIQUE 246 [ $\left.\mathrm{n}^{\circ} 197-1\right]$ ( $14^{\text {th }}$ ed., Dalloz 2011).

129 "Objectively" is used here in the sense that the facts would be categorized as a civil wrong if an abstract adult person had performed the same act.
} 
March 2017, ${ }^{130}$ contains the rule in article 1245 (2) that in all cases of vicarious liability, including the liability of parents for the acts of their minor children, the act which is the direct cause of damage to the victim must be capable of being categorized as a civil wrong. ${ }^{131}$

\section{Road Traffic Accidents}

The starting point for our comparative observations regarding the definition of civil wrongs in cases of road traffic accidents is the French loi Badinter. ${ }^{132}$ This means that the following pages do not discuss the problem of road traffic accidents lato sensu, which would include non-relational accidents (e.g. one driver losing control of his vehicle and crashing into a wall, injuring himself only) and traffic accidents which occur without the involvement of at least one motor vehicle (e.g. when a person riding a bicycle collides with a person on a skateboard).

The loi Badinter only deals with liability questions involving two categories of relationships: (i) between a driver or keeper of a motor vehicle and another driver or keeper of a second motor vehicle; and (ii) between a driver or keeper of a motor vehicle and other road users (usually cyclists, pedestrians, or passengers). Therefore, in all cases, the active side of the relationship is limited to two classes of defendants: drivers and custodians of motor vehicles. ${ }^{133}$ Cases against other categories of defendants must be based on other, usually more general, tort law provisions. On the passive side, the category of victims who may receive compensation under the loi Badinter is much broader, encompassing any person who may be harmed due to a traffic accident (including especially other motorists or keepers of motor vehicles, pedestrians, passengers, and cyclists). The

\footnotetext{
${ }^{130}$ Ministère de la justice, Projet de réforme de la responsabilité civile (March 2017), available online at http://www.justice.gouv.fr/publication/Projet de reforme de la responsabilite civile 13032017.pdf. A translation in English prepared by Simon Whittaker, in consultation with Jean-Sébastien Borghetti, is available online at http://www.textes.justice.gouv.fr/art_pix/reform_bill_on_civil_liability_march_2017.pdf ["Chancery Reform Project"]. Also, a translation made by Olivier Moréteau can be found in EUROPEAN TORT LAW. BASIC TEXTS 127-39 ( $2^{\text {nd }}$ ed., Ernst Karner et al. eds., Jan Sramek Verlag 2018).

${ }^{131}$ The exact wording of the article is: Cette responsabilité suppose la preuve d'un fait de nature à engager la responsabilité de l'auteur direct du dommage (translated as "This liability rests on proof of an action of a nature to engage liability in the direct author of the harm").

${ }^{132}$ Loi no $85-677$ du 5 juillet 1985 tendant à l'amélioration de la situation des victimes d'accidents de la circulation et à l'accélération des procédures d'indemnisation, JORF du 6 juillet 1985, p. 7584 ["Loi du 5 juillet 1985”].

Translations in English of its most important provisions can be found in EUROPEAN TORT LAW. BASIC TEXTS 125-27

( $2^{\text {nd }}$ ed., Ernst Karner et al. eds., Jan Sramek Verlag 2018) and in ThE MaAstricht Collection. Volume IV: COMPARATIVE Private LAW 56-57 (6 ${ }^{\text {th }}$ ed., Sascha Hardt \& Nicole Kornet eds., Europa Law Publishing 2019). ${ }^{133}$ See Art. 2 of Loi du 5 juillet 1985 (Les victimes, y compris les conducteurs, ne peuvent se voir opposer la force majeure ou le fait d'un tiers par le conducteur ou le gardien d'un véhicule mentionné à l'article ler) (emphasis added).
} 
underlying primary duties and entitlements therefore relate the narrow composite group of drivers and keepers with the relatively broader group of other road users.

Liability is always strict under the loi Badinter. However, this is not a typical form of strict liability. In all cases that fall within the scope of this special law, in addition to the fact that fault is not a prima facie requirement, the element of causation is replaced by the mere involvement of a motor vehicle in the accident, ${ }^{134}$ and the defences of force majeure and the act of a third party are excluded. ${ }^{135}$ The behaviour of the driver or keeper of a motor vehicle is, therefore, of no importance for the determination of liability.

Moreover, in some situations, even the defence of contributory negligence is excluded, being replaced by narrower and more victim-friendly defences. In accidents where both the plaintiff and the defendant are motorists, the defence of contributory negligence applies without modifications and leads to a reduction of liability, ${ }^{136}$ but when the victim is a pedestrian, cyclist or passenger, the driver or custodian of the motor vehicle can only escape liability if he can prove that the victim committed an inexcusable fault ${ }^{137}$ and that the victim's inexcusable fault (faute inexcusable) is the sole cause of the accident. ${ }^{138}$ If, however, the victim is a person under the age of 16 , a person older than 70 , or a person who already suffers from a more than $80 \%$ disability, then the driver or custodian only benefits from a defence if the victim intentionally sought the damage he suffered (la victime a volontairement recherché le dommage qu'elle a subi). ${ }^{139}$

The possibility of defendants invoking contributory negligence on the basis of article 4 of the loi Badinter, coupled with the frequent applicability of the contributory negligence defence in cases of collisions between two or more motor vehicles, translates into a weaker level of protection for victim-drivers when compared to other categories of road users. However, the Court of Cassation has done its best, through its jurisprudence, to mitigate the negative consequences for victimdrivers of article 4 of the loi Badinter by creating exceptions which derogate from the usual effects of the contributory negligence defence. That is why, on multiple occasions, the Court decided that even if the victim-driver's fault was the sole cause of the accident, the victim-driver can still be

\footnotetext{
${ }^{134}$ Art. 1 of Loi du 5 juillet 1985.

${ }^{135}$ Art. 2 of Loi du 5 juillet 1985.

${ }^{136}$ Art. 4 of Loi du 5 juillet 1985.

${ }^{137}$ Art. 3 (1) of Loi du 5 juillet 1985.

${ }^{138}$ Cass. Civ. 2e 8 November 1993, Bull. civ. II, n ${ }^{0} 316$, JCP 1994.IV.84.

${ }^{139}$ Arts. 3 (2) and 3 (3) Loi du 5 juillet 1985.
} 
awarded partial compensation. ${ }^{140}$ Nevertheless, the solution from article 4 of the loi Badinter remains one of the most severely criticized tort law provisions in modern French legal literature ${ }^{141}$ and all recent reform projects have sought to address the issue by eliminating the defence of contributory negligence in cases of personal injury. ${ }^{142}$

The structure of the primary duties and entitlements underlying the liability rules of the loi Badinter is in some ways similar to the structure of the general principle of liability for things. Similar to liability for the acts of their things, the primary duty and the correlative entitlement that bind the driver or custodian to the victim have a complex structure, being based on the identification of two connected relationships: the relationship between the victim and the motor vehicle and the relationship between the victim and the driver or custodian. However, there are also two essential differences between liability based on the loi Badinter and liability for the acts of things. The first difference can be found in how the first relationship is constructed: the relationship between the victim and the motor vehicle is based on the involvement of the motor vehicle, and not on causation. The notion of involvement is broader, encompassing also cases in which the motor vehicle in question was stationary, ${ }^{143}$ correctly parked, ${ }^{144}$ or there has been no contact between the motor vehicle and the victim. ${ }^{145}$ The second difference regards the second relationship, which connects the motor vehicle to either the driver or the custodian, whereas the

\footnotetext{
${ }^{140}$ Cass. Ch. Mixte, 28 March 1997, D.1997.294, comm Hubert Groutel; Cass. Civ. 2e, 6 May 1997, D.1997.503. comm. Hubert Groutel; Cass. Civ. 2e, 2 July 1997, D.1997.183.

${ }^{141}$ FRANC,OIS CHABAS, LE DROIT DES ACCIDENTS DE LA CIRCULATION APRÈS LA RÉFORME DU 5 JUILLET 1985, at 160 [ $\left.{ }^{0} 179\right]$ ( $2^{\text {nd }}$ ed., Litec 1988); François Chabas, La situation faite au conducteur fautif de véhicule terrestre à moteur, Gaz. Pal. (3 February 1994) ; Hubert Groutel, La faute du conducteur victime dix ans après, D. 1995.335 (Chron.) ; Fabrice Leduc, La sanction de la faute du conducteur victime en question, RCA 2011, Étude 12, no 10 (October 2011); LE TOURNEAU ET AL., supra note 34, at 2057 [no 8147].

${ }^{142}$ See Art. 1287 of the Chancery Reform Project; Art. 1385-2 of the Catala Project [Rapport à Monsieur Pascal Clément Garde des Sceaux, Ministre de la Justice, Avant-projet de réforme du droit des obligations (Articles 1101 à 1136 du Code civil) et du droit de la prescription (Articles 2234 à 2281 du Code civil) at 157 (22 September 2005) available online at http://www.justice.gouv.fr/art pix/RAPPORTCATALASEPTEMBRE2005.pdf]; Art. 26 of the Terré Project [Proposition de textes. Chapitre des délits in POUR UNE RÉFORME DU DROIT DE LA RESPONSABILITÉ CIVILE (François Terré coord., ed. Dalloz, 2011), also available online at http://www.textes.justice.gouv.fr/art pix/1 proposition texte responsabilite civile 20111018.pdf]

${ }^{143}$ Cass. Civ. $2^{\mathrm{e}}$, 17 June 1990, RTD civ. 1990, 507, obs. Patrice Jourdain.

${ }^{144}$ Cass. Civ. 2e 23 March 1994, D. 1994.299, comm. Hubert Groutel; RTD civ. 1994, 627, obs. Patrice Jourdain; Cass. Civ. 2e 25 January 1995, Bull. civ. II, no. 27; RTD. Civ. 1995, 382, obs. Patrice Jourdain; Cass Civ. 2 e 12 June 1996, D. 1996 IR 175.

${ }^{145}$ Cass. Civ. $2^{\mathrm{e}}$, 3 October 1990, RTD civ. 1991.354, obs. Patrice Jourdain; Cass Civ. 2 ${ }^{\mathrm{e}}, 8$ June 1994, Bull. civ. II, no. 147; D. 1994 IR 181; Cass. Civ. 2e, 13 January 1997, JCP 1997.II.22883.
} 
general principle of liability for the acts of things only triggers liability against the custodian of the thing.

In England, the same types of accidents, involving the same categories of actors, are usually dealt with under the tort of negligence. This means that, at least in theory, there is no special significance attached to accidents caused by the operation of motor vehicles: the primary duties of drivers or keepers of motor vehicles are ordinary duties of care, and victims of road traffic accidents receive the same treatment as the victims of other civil wrongs. The duty of care which underlies the tort of negligence has the potential to bind all persons to all others, and the existence of such a duty of care, as well as the breach of that duty, are prima facie elements that must be proven by the plaintiff-victims of road traffic accidents. Moreover, causation is an element of the prima facie case, connecting the behaviour of the driver with the damage suffered by the victim. Finally, the situation for victims in England is weaker compared to France also when it comes to defences, because defendant-drivers can rely on the defences of act of God (force majeure) and contributory negligence. ${ }^{146}$ There are no privileged or super-privileged categories of victims in England, nor is there any principled difference between drivers and other categories of road users.

A closer look at the practice of liability for road traffic accidents shows, however, that road traffic accident cases are situated somewhat uncomfortably within the law of negligence. First, the doctrine of res ipsa loquitur ${ }^{147}$ can sometimes dispense the claimants from some of the more difficult aspects of proving negligence. ${ }^{148}$ Second, the level of care required from motorists is much higher than the level of care required by law in other contexts. In most cases of road traffic accidents, even the slightest error on the part of a driver is considered sufficient in order to find that a duty of care was breached. ${ }^{149}$ This is because the standard of care leans more toward the idealized behaviour of a "skilled, experienced and careful driver" 150 proposed by Lord Denning than the "ordinary driver" standard proposed by Lord Salmon in Nettleship v Weston. ${ }^{151}$ Moreover, the standard of care for drivers is different even from the standard of care applied to other road

\footnotetext{
146 See VAN DAM, supra note 33, at 415.

147 The doctrine is explained in detail supra in Chapter IV Part C.

${ }^{148}$ See, e.g., Worsley v Hollins, [1991] RTR 252 (CA); See, however, also Henderson v Henry E Jenkins \& Sons [1970], A.C. 282; NG Chun Pui v Lee Chuen Tat, [1988] R.T.R. 298 (Privy Council) (in which the res ipsa loquitur inference of negligence was successfully rebutted).

${ }^{149}$ DEAKIN ET AL., supra note 44, at 169, 172.

${ }^{150}$ Nettleship v Weston, [1971] 2 Q.B. 691, at 702 (per Lord Denning).

${ }^{151} I d$. at 703 (per Lord Salmon).
} 
traffic participants. For instance, the inexperience of a driver is considered irrelevant in setting the required standard of care, whereas the inexperience of a pedestrian is usually taken into account when determining contributory negligence. ${ }^{152}$ Also, the applicable standards of care require drivers to anticipate careless driving by others, as well as the carelessness of pedestrians, whereas pedestrians are not required to anticipate the carelessness of drivers. ${ }^{153}$ Lastly, more weight is attributed to non-compliance with provisions of the Highway Code when the negligence of drivers is being determined as opposed to when the negligence of pedestrians is at stake. ${ }^{154}$

Quite exceptionally, the tort of breach of statutory duty may also apply in cases of road traffic accidents involving motor vehicles. On multiple occasions, English courts held that the mere breach of a statutory road traffic rule is not sufficient in order to apply the tort of breach of statutory duty. ${ }^{155}$ English judges wanted to avoid creating "isolated pockets of strict liability into an area generally governed by negligence". ${ }^{156}$ However, on the very rare occasions when the tort of breach of statutory duty was applied, liability was strict, not negligence-based. There are two main precedents in which a claimant, following a road traffic accident, successfully claimed compensation on the basis of breach of statutory duty: Monk $v$ Warbey ${ }^{157}$ and London Passenger Transport Board v Upson. ${ }^{158}$ Monk $v$ Warbey involved a claim against the owner of a vehicle who allowed an uninsured driver (who was also destitute) to use the vehicle, when the driver's negligent driving caused damage to the plaintiff. The owner violated section 35-1 of the Road Traffic Act $1930,{ }^{159}$ which stipulated that it was unlawful for the owner of a vehicle to permit another person to use a motor vehicle on the road, unless that other person was also covered by liability insurance or some similar security covering third-party risks. The court considered that this section of the Road Traffic Act was enacted with the aim of protecting victims of road traffic accidents, who are

\footnotetext{
${ }^{152}$ Roderick Bagshaw, The Development of Traffic Liability in England and Wales, in THE DEVELOPMENT OF TRAFFIC LiABILITY 12, 46 (Wolfgang Ernst ed., Cambridge University Press 2010).

${ }^{153} \mathrm{Id}$.

${ }^{154} \mathrm{Id}$.

${ }^{155}$ Philips v Britannia Hygienic Laundry Co, [1923] 2 K.B. 832; Clark v Brims, [1947] K.B. 497; Coote v Stone, [1971] 1 W.L.R. 279; Exel Logistics Ltd. v Curran, [2004] EWCA Civ 1249.

${ }^{156}$ PEEL \& GOUDKAMP, supra note 46, at 216.

157 [1935] 1 K.B. 75.

158 [1949] A.C. 155.

${ }^{159}$ Section 35-1 of the Road Traffic Act 1930, c. 43 (later repealed and replaced by newer road traffic regulations): “ [...] it shall not be lawful for any person to use, or to cause or permit any other person to use, a motor vehicle on a road unless there is in force in relation to the user of the vehicle by that person or that other person, as the case may be, such a policy of insurance or such a security in respect of third-party risks as complies with the requirements of this Part of this Act."
} 
likely to find it difficult to enforce their claims against uninsured drivers. ${ }^{160}$ The owner was held liable not for having caused the claimant to be injured, but for having "caused the claimant to be in a position where his claim against the driver was worthless." ${ }^{161}$ With the driver lacking insurance and the means to provide compensation, the owner, who permitted such a driver to operate his motor vehicle, was called to answer almost like a subsidiary insurer. In London Passenger Transport Board $v$ Upson, the driver of a bus was held strictly liable for the damage caused to a pedestrian who was crossing the street while the traffic lights showed red for pedestrians. The relevant statutory duty required the driver to "proceed at such speed as to be able if necessary to stop before reaching such crossing." 162 The speed of the bus was approximately $15 \mathrm{mph}$ when the pedestrian emerged at the crossing from behind a stationary taxi. ${ }^{163}$ These were circumstances in which it was clear that the driver was not negligent, and the court acknowledged this fact. ${ }^{164}$ However, this did not have any bearing on the claim for breach of statutory duty because the language of the statute did not refer to any level of care. The duty it created was result-orientated, and thus the only thing that truly mattered was the fact that even at $15 \mathrm{mph}$, the driver was not able to stop the bus in time (in order to avoid colliding with the claimant).

Despite its marginal role, the tort of breach of statutory duty adds another interesting colour to the kaleidoscopic picture of road traffic liability in England. The relevant contrast, from a comparative perspective, is not just between the quasi-absolute liability regime of the loi Badinter and the faultbased tort of negligence. The tort of breach of statutory duty, the doctrine of res ipsa loquitur, and the many derogations from the usual standard of care that apply only to drivers show that the chasm between French and English law with regard to road traffic liability is not as deep as it seems. Liability ranges in England from classical negligence, to negligence with special standards, to quasi-presumptions-of-fault (res ipsa loquitur), and all the way to strict liability. On top of all this, there is one ingredient missing from the big picture that is apt to narrow the gap even further: mandatory insurance.

\footnotetext{
${ }^{160}$ Monk v Warbey, [1935] 1 K.B. 75, at 79-80.

${ }^{161}$ PeEL \& GoudKAMP, supra note 46, at 216.

${ }^{162}$ The Pedestrian Crossing Places (Traffic) Regulations 1941, reg. 3 [replaced in 1971 by the 'Zebra' Pedestrian Crossings Regulations 1971 (SI 1971 No. 1524)].

${ }^{163}$ London Passenger Transport Board v Upson, [1949] A.C. 155, at 157.

${ }^{164} \mathrm{Id}$. at 162.
} 
In both France and England, drivers must carry mandatory third-party insurance. ${ }^{165}$ The insurance system is grafted on top of the existing liability system and is logically dependent on the system of liability rules. The obligation of the insurer to pay is born only when liability is established. At least, that is how the theory goes. There is a gap between the abstract rights and obligations that govern the relationship between victims of road traffic accidents and third-party liability insurers and their actual enforcement. Insurance companies deal with most road traffic accidents on the basis of an out-of-court and bureaucratized set of procedures that enable the quick settlement of claims. The French loi Badinter even imposes an obligation on insurance companies to make an offer for settlement to the victims of a traffic accident within eight months from the moment the accident occurred. ${ }^{166}$ Insurance companies can be sanctioned if the offer is made too late or the compensation offered is manifestly insufficient. ${ }^{167}$ In England there is no such legal obligation, but some studies suggest that insurance companies rarely contest liability once a claim is made by a victim, particularly when the claims are of low value. ${ }^{168}$ Moreover, in France and England, insurance companies often enter into reciprocal agreements not to litigate certain categories of claims. ${ }^{169}$ The resulting effect is that in both France and England a large number of claims are settled out of court, and these settlements do not necessarily follow the same principles for determining liability or the amount of compensation as those used by courts. ${ }^{170}$

The liability system itself is also, in a way, dependent on the mandatory insurance system. First, without mandatory insurance it is doubtful that the tort systems of both jurisdictions would have

\footnotetext{
${ }^{165}$ Introduced in France through Loi n58-208 du 27 février 1958, institution d'une obligation d'assurance en matière de circulation de véhicules terrestres à moteur, JORF du 28 février 1958, p. 2148; and in England through the Road Traffic Act 1930, c. 43.

${ }^{166}$ Art. 12 of Loi du 5 juillet 1985.

${ }^{167}$ Geneviève Viney \& Anne Guégan-Lécuyer, The Development of Traffic Liability in France, in THE DEVElopMent OF TRAFFiC Liability 50, 72 (Wolfgang Ernst ed., Cambridge University Press 2010).

${ }^{168}$ Richard Lewis, Insurers and Personal Injury Litigation: Acknowledging the Elephant in the Living Room, [2005] JouRnal OF PERSONAL InJURY LAW 1, at 3; See also Bagshaw, supra note 152, at 47.

${ }^{169}$ Richard Lewis, Insurers Agreements Not to Enforce their Strict Legal Rights, (1985) 48 MLR 275; LE TOURNEAU ET AL., supra note 34, at 2081 [n 8239].

${ }^{170}$ See Richard Lewis, Insurers and Personal Injury Litigation..., supra note 168, at 3. In France, the risk of applying different criteria in such settlements is reduced when compared to England because the settlement process is extensively regulated. Aspects ranging from pre-contractual information duties to the steps to be followed during the settlement procedure, the content of the settlement offer, and withdrawal rights are regulated in a detailed manner in the Insurance Code (Code des assurances) and the loi Badinter. For details on the regulation of the settlement procedure see LE TOURNEAU ET AL., supra note 34, at 2082-92 [n $\mathrm{n}^{\text {os }} 8241-62$ ].
} 
survived. ${ }^{171}$ The high number of annual victims of road traffic accidents and the high level of damages that are usually at stake in such cases would likely have led to an inoperable system, which would have bankrupted many defendants, and would have left many victims without compensation (even if they had been entitled to it under the law). The introduction of insurance in the equation led to a workable distribution of costs and risks, as well as a significant reduction in administrative court costs. Second, the existence of mandatory liability insurance has led to a change in the identity of the parties who litigate road traffic accident cases. In England, insurance companies are the real defendants in nine out of ten personal injury cases and pay $94 \%$ of all personal injury tort compensation. ${ }^{172}$ Also, on the claimant side, it is estimated that "legal expenses insurers" play an important role in $80 \%$ of cases. ${ }^{173}$ In France the numbers are even higher, with at least $80 \%$ of cases being settled out of court and most litigation involving one insurance company against another. ${ }^{174}$

The cost-spreading power of insurance also explains, at least partly, why liability rules in this area of the law are stricter than liability rules governing other types of accidents. In England, the best proof of the impact liability insurance had on liability rules are the candid statements made by Lord Denning in Morris v Ford Motor Co. Ltd:

The damages are expected to be borne by the insurers. The courts recognise this every day. They would not find negligence so readily - or award sums of such increasing magnitude - except on the footing that the damages are to be borne, not by the man himself, but by an insurance company. ${ }^{175}$

In France, Charbonnier's statements as Advocate General in the Desmares case followed the same line of reasoning:

Since the defendant is no longer practically harmed by the consequences of his act, and since the insurer is not harmed either (since the latter varies the premiums in

\footnotetext{
${ }^{171}$ See FLEMING, supra note 117, at 11: “[...] without liability insurance the tort system would long ago have collapsed under the weight of the demands put on it and been replaced by an alternative, and perhaps more efficient, system of accident compensation."

172 Richard Lewis, Insurers and Personal Injury Litigation..., supra note 168, at 2-3.

${ }^{173}$ Richard Lewis, Insurers and Personal Injury Litigation ..., supra note 168, at 3.

${ }^{174}$ See Loi BADINTER : LE BILAN DE 20 ANS D'APPLICATION (Philippe Brun \& Patrice Jourdain eds., L.G.D.J. 2007); GENEVIÈVE VINEY, L'INDEMNISATION DES VICTIMES D'ACCIDENTS DE LA CIRCULATION 111 (L.G.D.J. 1992).

${ }^{175}$ Morris v Ford Motor Co. Ltd., [1973] Q.B. 792, at 798.
} 
accordance with the number of materialized risks), from now on attention is focused on the victim. And in a world dominated notably by the - sometimes contradictory - values of individual happiness and social solidarity, our contemporaries have the tendency both to concern themselves over the fate of victims and to hope that they obtain more complete compensation $[\ldots]^{176}$

The added layer of mandatory insurance, coupled with the practices and policies of insurance companies described above, make the comparison between primary rights and obligations in road traffic accidents relatively different from the comparisons made in previous sections. For one, based on the methods we employed for this study, a significant portion of this area of practice is difficult to compare between our chosen two jurisdictions because the actual norms and outcomes are determined by the internal policies and procedures of insurance companies and not by the legal system. Second, for those cases that do benefit from court adjudication, the cost-distributive effect of insurance cannot be ignored. The primary entitlements and duties that shape civil wrongs in cases of road traffic accidents have, because of the existence of a mandatory insurance system, a depersonalized, socialized character. The individual driver (or, when applicable, the custodian) of a motor vehicle owes a primary duty to other participants in traffic, but the class of drivers deals with the consequences of its breach, not the individual driver. Liability under the loi Badinter is channelled to the driver or custodian and drivers are treated differently within the English law of negligence because, as a class, drivers and custodians are also required by the system to socialize their potential losses.

All this being said, the primary duties and correlative entitlements that are socialized through mandatory insurance remain dependent on the prima facie elements and available defences of the underlying tort. In England, what is almost invariably being shared by drivers is a behavioural duty - the duty to drive carefully in order not to cause damage to other participants in traffic. In France, custodians and drivers share all the risks to other persons that their motor vehicles create. Put differently, what the law considers "wrong" in England are behavioural errors in traffic, whereas in France the "wrong" is the road traffic accident itself.

\footnotetext{
${ }^{176}$ Cass. Civ. 2e, 21 July 1982, D. 1982. 449, concl. Charbonnier, note Larroumet ; JCP 1982. II. 19861, note Chabas; Defrénois 1982. 1689, obs. Aubert ; RTD civ. 1982. 607, note G. Durry; the English translation of which is taken from Viney \& Guégan-Lécuyer, supra note 167, at 66.
} 


\section{Damage caused by animals}

The comparison between French liability rules that apply to damage caused by animals and their functional equivalents in England provides another illustration (next to liability for road traffic accidents) of only partial divergence, owed mainly to the diversity of liability regimes that govern these civil wrongs in England.

In France, the liability of custodians of animals for the "acts" of their animals is governed by a special, yet broad, strict liability principle. Custodians of animals are, in essence, strictly liable the same way custodians of things are liable for the acts of things. The only thing that is special about the liability for animals is the different textual basis in the Civil Code (article 1243); ${ }^{177}$ in every other respect, the regime applicable to animals is identical to the regime applicable to things in general.

In England, the landscape is messier. There is no unifying principle governing liability for animals, and the existing rules do not have a common legal nature. Some liability rules are strict, some are fault-based, and others are somewhere in between. When animals cause damage, liability may be triggered on the basis of a variety of torts, including negligence, ${ }^{178}$ nuisance, ${ }^{179}$ assault and battery, ${ }^{180}$ trespass, ${ }^{181}$ and even defamation. ${ }^{182}$ However, the most important causes of action can be found in a statute: the Animals Act 1971. ${ }^{183}$ The Animals Act 1971 is positioned alongside other common law causes of action, as an alternative. Thus, a claimant who meets the requirements of a common law tort as well as the requirements of the statutory tort may choose between the two causes of action.

\footnotetext{
${ }^{177}$ LE TOURNEAU ET AL., supra note 34, at 2008 [n $\left.{ }^{0} 7954\right]$.

${ }^{178}$ Fardon v. Harcourt-Rivington, (1932) 146 L. T. 391, 392 (per Lord Atkin); Searle v Wallbank, [1947] A.C. 341, at 359-60 (per Lord du Parcq).

${ }^{179}$ Aldred's case, (1610), 9 Co. 57b; Wheeler v JJ Saunders Ltd, [1996] Ch. 19 (both cases dealing with the disturbance created by the stench of pigs); Leeman v Montagu, [1936] 2 All E.R. 1677 (crowing of cockerels); Farrer v Nelson, (1885) 15 Q.D.B. 258 (damage to crops by pheasants).

${ }^{180}$ See Roberts v CC Kent, [2008] EWCA Civ 1588; [2009] Po. L.R. 8 [the action in this case failed though, because the release of the dog by a police officer was lawful pursuant to Criminal Law Act 1967 s.3(1)].

${ }^{181}$ A very common form of trespass is "cattle trespass", and one variety of such trespass (the straying of livestock) is dealt with in section 4 of the Animals Act.

${ }^{182}$ See the hypothetical examples provided in PEEL \& GOUdKAMP, supra note 46, at 520 and DEAKIN ET AL., supra note 44 , at 549 .

${ }^{183}$ Animals Act 1971, c. 22.
} 
According to the Act, the liability for animals belonging to a dangerous species is strict, ${ }^{184}$ and so is the liability for dogs (but only when the dogs cause damage to livestock), ${ }^{185}$ as well as the liability for trespassing livestock, ${ }^{186}$ and the liability for damage and expenses caused by horses who are on land in England without lawful authority. ${ }^{187}$ As a general (or default) rule, liability for non-dangerous species is not covered by the Animals Act 1971, and therefore will most often be negligence-based. However, the Animals Act 1971 created a special strict liability cause of action that may be applicable when non-dangerous animals cause damage, but only when the following conditions are met: (a) the animal, although not belonging to a dangerous species, has abnormal characteristics (not normally found in animals of the same species), or characteristics which are not normally present, except at particular times or in particular circumstances; (b) the damage caused by the animal was foreseeably ${ }^{188}$ likely to occur or was likely to be severe; and (c) the keeper had knowledge of the above-mentioned characteristics of the animal, or a person who at that time had charge of the animal or another keeper of the animal who is a member of the keeper's household and under the age of 16 had knowledge of the abnormal characteristics of the animal. ${ }^{189}$

In all cases of strict liability for animals we have identified, the primary duties are owed either by a class or group to all others (see the general strict liability rule for animals from article 1243 of the Civil Code, the liability for animals belonging to a dangerous species from section 2(1) of the Animals Act 1971, and the liability for non-dangerous animals from section 2(2) of the Animals Act 1971), or by a class or group to another class or group (see the liability for trespassing livestock from section 4 of the Animals Act 1971 and the liability for damage and expenses caused by horses who are on land in England without lawful authority from section 4A of the Animals Act 1971). When fault-based torts apply, particularly the tort of negligence, the primary duties

\footnotetext{
${ }^{184}$ Section 2(1) of the Animals Act 1971, c. 22.

${ }^{185}$ Section 3 of the Animals Act 1971, c. 22.

${ }^{186}$ Section 4 of the Animals Act 1971, c. 22.

${ }^{187}$ Section 4A of the Animals Act 1971, c. 22 [inserted by the Control of Horses Act 2015 (c. 23), ss. 4(1), 5(1)].

${ }^{188}$ Curtis v Betts, [1990] 1 W.L.R. 459, at 469.

${ }^{189}$ Section 2(2) of the Animals Act 1971: "Where damage is caused by an animal which does not belong to a dangerous species, a keeper of the animal is liable for the damage, except as otherwise provided by this Act, if(a) the damage is of a kind which the animal, unless restrained, was likely to cause or which, if caused by the animal, was likely to be severe; and (b) the likelihood of the damage or of its being severe was due to characteristics of the animal which are not normally found in animals of the same species or are not normally so found except at particular times or in particular circumstances; and (c) those characteristics were known to that keeper or were at any time known to a person who at that time had charge of the animal as that keeper's servant or, where that keeper is the head of a household, were known to another keeper of the animal who is a member of that household and under the age of sixteen."
} 
have the same propensity to universality we discussed above. ${ }^{190}$ In terms of how the subjects of the primary duty are linked with the subjects of the correlative entitlement, all the strict liability provisions mentioned above follow the same relational structure we identified earlier for liability for things, ${ }^{191}$ with two connected relationships: the relationship between the custodian and the animal, and between the "act" or "behaviour" of the animal and the damage suffered by the victim. Even the special strict liability regime for damage caused by non-dangerous animals follows this structure. The only difference is that both relationships are narrowed down more than in other cases of strict liability for animals. First, in order to establish the right kind of relationship between the keeper and the animal, the claimant must also prove an additional objective element (that the animal has abnormal characteristics or characteristics which are not normally present) and a subjective element (that the keeper had knowledge of the abnormal characteristic). Second, the causal relationship between the behaviour of the animal and the damage caused is also limited to causes which were either foreseeably likely to occur or likely to be severe. The effect of this double limitation is to increase the applicability of the tort of negligence to damage caused by nondangerous animals when the requirements of section 2(2) of the Animals Act 1971 are not met, because in such situations the tort of negligence is the only avenue open to victims.

\section{Interference with movable property}

One of the truly surprising findings that emerged from methodically identifying all forms of strict liability in both France and England is that there are also situations in which English law responds to a set of facts through strict liability whereas France responds, at least partly, with a fault-based equivalent or even a rule of no-liability. Liability rules dealing with interference with movable property provide us with a first set of examples of such unusual situations where English law is stricter than French law.

Under English law, entitlements over movable property are protected through several torts: the tort of conversion, the tort of trespass to goods, the tort of reversionary injury, and a small number of statutory actions and remedies. ${ }^{192}$ From this list, the torts of conversion and trespass to goods are

\footnotetext{
${ }^{190}$ Supra Part C.1 of this chapter.

${ }^{191} I d$.

${ }^{192}$ Some older causes of action and remedies, such as "detinue" and "replevin", have been completely abolished or replaced by more modern equivalents [See section 2(1) of the Torts (Interference with Goods) Act 1977, c. 32 (abolishing detinue); Part 3 of the Tribunals, Courts and Enforcement Act 2007, c. 15, especially section 65 (abolishing replevin); See also section 144 and schedule 1 of the County Courts Act 1984, c. 28].
} 
the most general and important civil wrongs that protect against interference with movable property, and this section focuses on these two torts and their functional equivalents.

The tort of conversion protects "the current superior possessory interest in personal property"193 against actions that exclude the person who holds that current superior possessory interest from using or possessing his property. ${ }^{194}$ It covers situations such as wrongfully taking possession of goods, wrongfully misusing goods, wrongfully destroying them, and wrongfully refusing to give them up when required. ${ }^{195}$ A successful claim for conversion requires proof that (1) the claimant has a superior possessory right; (2) the claimant was deprived of the full benefit of that right; and (3) the defendant appropriated (or assumed) that right. ${ }^{196}$

The tort of trespass to goods partly overlaps with conversion, but has a different aim and different requirements. The aim of trespass to goods is the protection of possessory interests against any direct and wrongful interference, ${ }^{197}$ and a successful claim of trespass to goods is based on proof that the defendant's (1) act of physical interference with possession was (2) direct and (3) unlawful. ${ }^{198}$ The overlap between the two torts was explained very succinctly by Andrew Tettenborn with the following example:

[I]f D takes P's bottle of wine and drinks it, be commits both [conversion and trespass to goods]. But they remain distinct. If D merely moves the bottle from one shelf to another, he commits trespass but not conversion, since there is no appropriation. Conversely, if $D$ is a bailee of the bottle and proceeds wrongfully to drink the contents he commits conversion but not trespass: he has consumed the wine, but has not interfered with P's possession (since $P$ was not in possession at the relevant time). ${ }^{199}$

\footnotetext{
${ }^{193}$ Sarah Green \& John Randall, The Tort OF Conversion 46, 51,58 (Hart Publishing 2009).

${ }^{194}$ See Simon Douglas, The Nature of Conversion, 68(1) CAMBridGE L. J. 198, 209, 211-15 (2009).

${ }^{195}$ Peel \& GoudKAMP, supra note 46, at 541; William L. Prosser, Nature of Conversion, 42 CoRnELL L.Q. 168, 174-84 (1956-57).

${ }^{196}$ GREEN \& RANDALL, supra note 193 , at 75.

${ }^{197} \mathrm{Id}$. at 47 .

${ }^{198}$ PeEL \& GOUDKAMP, supra note 46, at 538.

${ }^{199}$ Andrew Tettenborn, Wrongful Interference with Goods, in CLERK \& LINDSELL ON TORTS 1003, 1005 [para. 17$02]$ (19 ${ }^{\text {th }}$ ed., Anthony M. Dugdale et al. eds., Sweet \& Maxwell 2006); Also quoted in GREEN \& RANDALL, supra note 193 , at 47 .
} 
Liability for conversion is always strict. ${ }^{200}$ A person who appropriates someone else's movable property is liable for conversion even if he does not know his actions are inconsistent with the second person's superior possessory right. ${ }^{201}$

The tort of trespass to goods is partly strict and partly fault-based. When the defendant intended to touch or interfere with the claimant's thing, liability is strict, in the sense that there is no need to show that the defendant failed to exercise sufficient care (and absence of fault is also not a defence). ${ }^{202}$ However, when the defendant interferes with the claimant's thing unintentionally (for instance, without being aware that he is interfering with another's property) he can escape liability by proving that he exercised sufficient due care. ${ }^{203}$ Also, collisions on the highway have long been dealt with under the tort of negligence instead of trespass to goods, irrespective of the intentional or negligent character of the interference. ${ }^{204}$

Both torts require a voluntary act, but not intention to cause harm, nor intention to interfere with the claimant's interests. ${ }^{205}$ In other words, the requisite intention is not relational. Conversion requires intention to appropriate the asset belonging to the claimant and trespass to goods requires intention to touch the asset belonging to the claimant. Thus, in all cases of conversion and trespass to goods, the characteristic form of intention relates the defendant with a thing, not with a person (the claimant). Moreover, conversion is actionable without proof of damage (actionable per se), ${ }^{206}$ and contributory negligence is not a defence. ${ }^{207}$ Trespass to goods differs slightly from conversion in this regard, being actionable per se only when the defendant touched the claimant's thing deliberately. ${ }^{208}$ When the defendant touched the thing through a careless or unintended act, proof of damage is required. ${ }^{209}$

\footnotetext{
${ }^{200}$ See Hollins v Fowler, (1875) LR 7 HL 757; Fine Art Society v Union Bank of London, (1886) LR 17 QBD 705; Consolidated Co v Curtis \& Sons, [1892] 1 QB 495; Marfani \& Co Ltd v Midland Bank Ltd, [1968] 1 W.L.R. 956, 970-71 (per Lord Diplock); GREEN \& RANDALL, supra note 193, at 67; Douglas, supra note 194, at 215.

${ }^{201}$ See especially Hollins v Fowler, (1875) LR 7 HL 757.

202 DEAKIN ET AL., supra note 44, at 436.

${ }^{203}$ Id. at 436-37; National Coal Board v JE Evans \& Co (Cardiff) LD, [1951] 2 KB 861 (During an excavation, the defendants damaged a cable belonging to the claimant without knowing the cable would be located under their land. The court held that the accident was not caused by the defendant's negligence or wilful act and was "utterly without his fault," and for that reason there was no liability for trespass to goods).

${ }^{204}$ DEAKIN ET AL., supra note 44, at 436.

${ }^{205}$ See PEEL \& GOUDKAMP, supra note 46, at 539, 558.

${ }^{206}$ GREEN \& RANDALL, supra note 193 , at 58.

${ }^{207}$ Section 11(1) of the Torts (Interference with Goods) Act 1977, c. 32.

${ }^{208}$ DEAKIN ET AL., supra note 44, at 437.

${ }^{209} \mathrm{Id}$.
} 
In France, the protection of entitlements over movable property is achieved through a combination of tortious, contractual, and property law mechanisms. ${ }^{210}$ The main and default protective mechanism is tortious. All acts of interference with movable property that lead to damage fall under the general fault liability provisions of the Civil Code (articles 1240-1241 of the Civil Code). When damage to a movable is caused by a thing, however, liability will be strict [article 1242 (1) of the Civil Code]. Depending on the circumstances, strict vicarious liability provisions might also apply [particularly articles 1242 (1), 1242 (4) and 1242 (5) of the Civil Code]. The second layer of protection is provided by a set of property law remedies. Owners of movable property can rely on the revendicatory action (action en revendication de la propriété), an action that draws its main characteristics from the Roman vindicatio. ${ }^{211}$ However, the revendicatory action is not conceptualized as a remedy for a civil wrong. It is an action that belongs to the owner who is not in possession against the possessor who is not the owner, ${ }^{212}$ irrespective of how the latter came to possess the movable in question (lawfully or unlawfully). However, insofar as we can analogize with a liability rule, the revendicatory action follows the logic of a strict liability rule - the defendant's behaviour is irrelevant, the plaintiff being required only to prove that he has a better title than the defendant in order to recover his property. ${ }^{213}$ Other property rights which derive from ownership and confer the right to use (usus), or a combination of the right to use (usus) and the right to natural and civil fruits of the property (fructus), are protected through similar petitory actions, called actions confessoires. Lastly, some specific facts which are characterized as conversions in England would not fall under tort or property in France, being dealt with under contract law instead. Specifically, when a bailor interferes with the possession of a bailee, in English law the bailor's acts of interference are constitutive of the tort of convergence, ${ }^{214}$ whereas in equivalent situations French law responds with contractual remedies which exclude the application of the law of torts. ${ }^{215}$ The tort of conversion and the contractual remedies available in

\footnotetext{
${ }^{210}$ François Terré \& PhilipPe Simler, Droit CiVIL. LeS BIENS 397 [n 502$]$ (10 ${ }^{\text {th }}$ ed., Dalloz 2018).

${ }^{211}$ See JEAN-LOUIS HALPERIN, HistoIRE DU DROIT DES BIENS 25-26 (Economica 2008).

212 TERRÉ \& SIMLER, supra note 210, at 399 [n 506].

213 JeAn-Louis Bergel et AL., Traité DE DROIT CiVIL. LeS BIENS 500-502 [n $\left.{ }^{\text {os }} 439-441\right]$ (2 ${ }^{\text {nd }}$ ed., L.G.D.J. 2010).

${ }^{214}$ GREEN \& RANDALL, supra note 193, at 48.

215 The common law term "bailment" refers to a broad set of contractual relationships that involve the transfer of possession over movables, but which roughly correspond to the pre-existing Roman categories of depositum (the gratuitous deposit of a movable), mandatum (the essence of which is the fact that the mandatary performs acts for the principal, but he may also receive possession from the principal of certain movables in order to perform such acts), commodatum (gratuitous loan for use), pignus (the pledge or pawn of a movable as security for a debt), locatio
} 
France are close equivalents because, under French law, when the owner of a movable is under a contractual obligation to ensure peaceful possession, his contractual liability is also strict. ${ }^{216}$

The overall picture we get is that, by default, English law protects entitlements over movables with strict liability norms, whereas French law equivalents can be either fault-based or strict. The default rule in France is one of fault liability. Strict liability exists in pockets and is exceptional. Important differences between French law and English law arise particularly in those situations when general tort liability and petitory actions apply in France, and the torts of conversion and trespass to goods apply in England. French law relies heavily on fault-based liability when a thing is stolen, misused, damaged or destroyed, whereas English law relies on strict liability in such circumstances. Also, petitory actions do not exist in English law, whereas in France they are the strongest tools protecting property rights. For instance, when a person refuses to return property that belongs to another or does not acknowledge that person's ownership right, in France the owner can recover his property through the revendicatory action. In England, in the same circumstances, the owner, but also any other person that has a current possessory interest, is in principle entitled only to damages, the restitution of property being granted by courts only when the property has some special value to the claimant. ${ }^{217}$

The key to understanding these differences between England and France can be found, once again, in the different design of primary rights and entitlements and their correlative duties. The entitlements protected by the torts of conversion and trespass to goods are different in nature from

\footnotetext{
(the onerous loan for use), and mutuum (a contract in which the obligor receives a specified quantity of fungible goods and later must return the same quantity of goods of the same quantity and quality). See Michael H. Rubin, Bailment and Deposit in Louisiana, 35 LA. L. REV. 825, at 825 (1975). With the exception of pignus, which has been replaced by a narrower set of contracts which create recognized security rights, all the other types of Roman law contracts that involved the transfer of possession over movables have survived, evolved, and transformed into the modern-day contracts of dépôt, mandat, commodat (prêt à usage), bail (specifically one of its subspecies, the location de meubles), and mutuum (prêt de consommation).

${ }^{216}$ This is particularly the case for the special contract of location de meubles, which, like any other bail, confers a personal right to possess and enjoy the property (droit de jouissance) and a warranty against eviction (garantie d'éviction). See François Collart-Dutilleul \& Philippe DelebecQue, Contrats civils et commerciaux 432-33, 435-36 [n $\left.{ }^{\text {os }} 496-97,500-01\right]$ (7th ed., Dalloz 2004).

${ }^{217}$ Whiteley Limited v Hilt, [1918] 2 K.B. 809, at 809: "[T] he power vested in the Court to order the delivery up of a particular chattel is discretionary, and ought not to be exercised when the chattel is an ordinary article of commerce and of no special value or interest, and not alleged to be of any special value to the plaintiff, and where damages would fully compensate."

See also Tanks and Vessels Industries Ltd v Devon Cider Company Ltd, [2009] EWHC 1360 (Ch), at para. 55; Blue Sky One Ltd v Mahan Air, [2009] EWHC 3314 (Comm), at para. 309; Tettenborn, Wrongful Interference with Goods, in CLERK \& LINDSELL ON TORTS, supra note 199, at 1048-49 [para. 17-84].
} 
the entitlements in movable property protected by general fault liability and the revendicatory action.

The tort of trespass to goods protects "possession", ${ }^{218}$ and the tort of conversion protects "the current superior possessory interest in personal property". ${ }^{219}$ Although no clear attempt at a definition can really be identified in English legal practice, possession in the context of trespass to goods must be understood broadly, as what a layman would understand by the term: having the use and control of the movable property in question. For the civil law reader, the "possession" protected by trespass to goods is equivalent to the corpus aspect of the civil law concept of possession. Moving on to conversion, the term "possessory interest" is more precise, but still very broad, being either a component of a broader property right, a contractual right, an equitable right, or a legally protected interest of a person who does not have any title at all. Most often, possession is protected by conversion not as a factual state of affairs, but as one of rights (or interests) that belongs to the bundle which constitutes a property right, a contractual right, or an equitable right. 220 However, a finder's (or even a thief's) possession is protected by the tort of conversion as long as the finder's interest in possession is superior to that of the defendant. ${ }^{221}$ The general rule is that conversion protects only those entitlements to possess which are current (not future), and which supersede any entitlement to possess that the defendant might have.

In France, the general entitlement to be free from loss caused by the intentional or negligent act of another protects possession and property interests only insofar as the infringements to possession or property rights constitute damage (i.e. a legally recognized loss). This general entitlement protects against acts such as theft, misuse of goods, or destruction of goods (acts which in England would constitute conversions). The destruction or damaging of goods may also be caused by the "act of a thing", in which case the custodian of the thing will be strictly liable. Here, once more, the entitlement is to be free from loss (only this time, loss caused by a thing, not by a person's fault). However, when a person merely touches a thing that belongs to another, the latter does not have an action under French law unless he can show that he suffered some form of recognized

\footnotetext{
${ }^{218}$ PEEL \& GOUDKAMP, supra note 46, at 540.

${ }^{219}$ GREEN \& RANDALL, supra note 193, at 46, 51, 58.

${ }^{220}$ See GREEN \& RANDALL, supra note 193, at 46, at 90-106 (going over all the possible scenarios, from property rights, to bailments, finders of movable property, and equitable rights).

${ }^{221}$ Id. at 92 .
} 
damage (in England, the same facts would constitute prima facie trespass to goods, even if no proof of damage can be brought).

Petitory actions protect the right of ownership and other real rights derived from ownership (démembrements). There are two types of petitory actions that allow the holder of a property right to recover possession: revendicatory actions and actions confessoires. Revendicatory actions are applicable in situations where a person refuses to return property that belongs to another or does not acknowledge that person's ownership right. In England, the same acts constitute conversions. However, the tort of conversion protects not only the possessory interests of owners, but also bailees and other persons who have property rights which confer possessory interests. In fact, a person who has a current possessory interest can even sue the initial owner for conversion. The initial owner, by creating a right which contains a current possessory interest, is left only with a reversionary possessory interest. A reversionary possessory interest is a future interest, and as such is not protected through the tort of conversion. A person who suffers damage due to an infringement of a future possessory interest will have to rely on the tort of reversionary injury or the tort of negligence instead. In France, a person who leases personal property or keeps it under a deposit contract does not even have a property right over the thing in question, ${ }^{222}$ and therefore does not have access to any petitory action. ${ }^{223}$ However, a person that holds a secondary property right that confers a current right to use the property, such as an usufructuary, can rely on the action confessoire in order to recover possession from any third party (including the naked owner). ${ }^{224}$

In France, the mere possession of movable property is not protected through an action of its own. In the French legal system, possession is a very well-defined term of art, designating the factual situation where a person has corpus (physical control of a thing) and animus (the intention to behave as an owner toward the thing). The possession of movables serves, first and foremost, an evidentiary purpose: the possessor is presumed to be the owner of the movable he possesses. ${ }^{225}$ However, in some circumstances, the possession of a movable may lead to the acquisition of ownership. These circumstances are worth dwelling upon for a moment, because they showcase the sharpest divergence between France and England in this area of the law. It is a rather hidden

\footnotetext{
${ }^{222}$ Such contracts generate only obligations and correlative credit rights (créance), not property rights.

223 TERRÉ \& SIMLER, supra note 210, at 706 [nº 778].

${ }^{224}$ Id. at 719 [n $\left.\mathrm{n}^{\circ} 795\right]$.

${ }^{225}$ Art. 2276 (1) of the French Civil Code.
} 
divergence, not only because the solutions are so different, but also because a different area of private law comes into play in such situations: tort law in England and property law in France. The circumstances we are referring to are those in which a third party in good faith acquires a corporeal movable from a non-owner. In such circumstances, the rule in France is that the third party in possession and in good faith is protected, whereas in England the rule is that the third party in possession and in good faith is liable for conversion. According to article 2276 (1) of the French Civil Code, when a person acquires a movable from a non-owner on the basis of an onerous contract and in good faith, that person becomes the owner of the movable the moment he comes into possession of the movable. However, this provision only applies to situations where the initial owner voluntarily passes the movable on to the non-owner seller, because article 2276 (2) stipulates that when the movable was stolen or lost, the initial owner has the possibility to revendicate the thing within three years from the moment the thing was lost or stolen. ${ }^{226}$ Thus, under French law, if A, the owner of a movable, voluntarily leaves his movable property with B, and $\mathrm{B}$ transfers ownership to $\mathrm{C}$ through an onerous contract and $\mathrm{C}$ is in good faith (does not know that $\mathrm{B}$ is not an owner), $\mathrm{C}$ acquires ownership and $\mathrm{A}$ has no remedy against him. In England, under the same facts, C, although innocent, would be liable for conversion. ${ }^{227}$ This is probably the only example where French law resorts to a rule of no liability, whereas English law employs a rule of strict liability.

\section{Defamation}

Another example where the common law makes use of strict liability whereas French law employs, at least in part, fault-based liability regimes can be found in the law of defamation. However, as the following lines will demonstrate, the differences between French and English law in this regard are not as pronounced as they might seem at first sight.

As already mentioned in Chapter III, the two English defamation torts, slander and libel, are both strict liability wrongs. ${ }^{228}$ In the typical defamation suit, the plaintiff is required, prima facie, to prove only that: (1) a defamatory statement was made; (2) the defamatory statement was published by the defendant; (3) and the defamatory statement can be said to have been referring to the

\footnotetext{
${ }^{226}$ This rule is further nuanced by the provisions of article 2277 of the Civil Code. According to this article, if the current possessor obtained the movable from a fair, a market, or from a public auction, the initial owner can revendicate the thing only if he reimburses the current possessor the price he paid.

${ }^{227}$ Hollins v Fowler, (1874-75) LR 7 HL 757.

${ }^{228}$ Supra Chapter III Part B.11.
} 
claimant. ${ }^{229}$ The test for what counts as a defamatory statement is whether "the words tend to lower the plaintiff in the estimation of right-thinking members of society generally." ${ }^{230}$ The focus in defamation is on the material or words published and the potential impact of the publication, and not the level of care taken by the defendant. ${ }^{231}$ Therefore, a plaintiff may recover for defamation even if the defendant did not know and could not have known under the circumstances that: (1) his words can be construed as referring to the claimant, (2) what he said was not true, or (3) his words could be understood by others in a defamatory sense. ${ }^{232}$

The functional equivalents to the defamation torts in France can be found in article 9 of the French Civil Code and the provisions of an 1881 statute regulating freedom of the press. ${ }^{233}$ Articles 1240 1241 apply, in theory, when there is no special provision dealing with defamation (or protecting a correlative right). However, the Court of Cassation has almost fully excluded the applicability of articles 1240-1241 of the Civil Code in defamation cases. The key decision is the affaire Erulin, in which the Court of Cassation declared that: "[...] abuses of freedom of expression sanctioned by the law of 29 July 1881 cannot be repaired on the basis of article 1382 [now 1240] of the Civil Code". ${ }^{234}$ The practical effect of the line of jurisprudence started by the affaire Erulin has been the virtual exclusion from the ambit of articles 1240-1241 of the Civil Code of all defamatory statements directed at a person (natural or legal). ${ }^{235}$ The only cases applying article 1240 in the last 20 years involved situations where the defendant insulted or defamed a thing that belonged to the plaintiff, such as the wine produced by the defendant ${ }^{236}$ or the defendant's trademark. ${ }^{237}$

\footnotetext{
${ }^{229}$ See DEAKIN ET AL., supra note 44, at 651-66.

${ }^{230}$ Sim v Stretch, [1936] 2 All E.R. 1237 (per Lord Atkin); See also Skuse v Granada Television Ltd, [1996]

E.M.L.R. 278, at 286; Dee v Telegraph Media Group Ltd, [2010] E.M.L.R. 20, [2010] 4 WLUK 472, at 513 (applying the same test).

${ }^{231}$ See supra Chapter III Part B.11.

${ }^{232}$ W.V. Horton Rogers, Fault under English law, in UnifiCaTION OF TORT LaW: FaUlt 65, 66 (Pierre Widmer ed., Kluwer Law International 2005); W. V. Horton Rogers, England in UnIFICATION OF TORT LAW: STRICT LIABILITY 101, 102 n.1 (B.A. Koch \& H. Koziol eds., Kluwer Law International 2002); Donal Nolan \& John Davies, Torts and Equitable Wrongs, in English PRIVATE LAW 927, 999 (3rd ed., Andrew Burrows ed., Oxford University Press 2013).

${ }^{233}$ Loi du 29 juillet 1881 sur la liberté de la presse, JORF du 30 juillet 1881, p. 4201.

${ }^{234}$ Cass. Ass. Plén., 12 July 2000, no 98-10160, Bull. ass. plén., nº 8; D.2000.463, obs. Patrice Jourdain; RTD civ. 2000.842, obs. Patrice Jourdain; RTD civ. 2000.845, obs. Patrice Jourdain.

${ }^{235}$ LE TOURNEAU ET AL., supra note 34, at 686-87 [ $\left.\mathrm{n}^{\circ} 1645\right]$.

${ }^{236}$ Cass. Civ. $2^{\mathrm{e}}$, 7 October 2004, $\mathrm{n}^{\mathrm{o}}$ 02-18.995, Bull. civ. II, $\mathrm{n}^{\mathrm{o}}$ 445; D.2004.2692; Cass. Civ. $2^{\mathrm{e}}, 16$ June 2005, $\mathrm{n}^{\mathrm{o}}$ 03-18.625, Bull. civ. II, $\mathrm{n}^{\circ}$ 156; D.2005.1805, obs. J. Daleau; Cass. Civ. $1^{\text {re }}, 7$ July 2006, nº 05-16.614, Bull. civ. I, $\mathrm{n}^{0} 356$.

${ }^{237}$ Cass. Civ. $1^{\text {re }}, 8$ April 2008, no 07-11.251, Bull. civ. I, $n^{\circ}$ 104, D.2008.2402, obs. S. Lavric, note Laurent Neyret; RTD civ. 2008.489, obs. Patrice Jourdain.
} 
Article 9 of the Civil Code deals with defamation only partly and incidentally. This provision protects the right to private life, which implies also a correlative duty to respect a person's privacy, and because some acts of defamation may cause infringements of privacy, it governs, as lex specialis, part of defamation law in France. The liability rule from article 9 of the Civil Code is strict because whenever the right to private life is infringed, the victim of the infringement is automatically entitled to monetary compensation or any other form of redress that may prevent or stop potential or existing privacy infringements. ${ }^{238}$ The rule is somewhat stricter and broader in scope than any of its English equivalents ${ }^{239}$ because the cause of action is focused exclusively on the primary entitlement (the right to privacy). The characteristics of the defendant's statements are not essential. Thus, for instance, the truth defence does not apply when there is an infringement of privacy $^{240}$ because someone's privacy may well be infringed even if a statement is true.

Whenever an act of defamation infringes other protected interests, the legal basis for liability is the 1881 freedom of the press act (loi sur la liberté de la presse). Article 29 of the loi sur la liberté de la presse distinguishes between defamation proper (diffamation) and insults (injure). Diffamation and injure are first and foremost criminal delicts. The French loi sur la liberté de la presse is primarily a regulatory and criminal law statute, and criminal penalties play a much more important role in practice than civil liability in cases when defamatory statements are published. ${ }^{241}$ In fact, the role of criminal law is so important in this area of the law that the corresponding civil actions generally mimic the conditions and requirements of the crimes defined in the loi sur la liberté de la presse. ${ }^{242}$ This includes, for instance, even the very short three-month prescriptive period which applies to the criminal action for defamation. The same short prescriptive period governs not only civil actions that are accessory to criminal actions, but also any independent civil

\footnotetext{
${ }^{238}$ Art. 9 (2) of the French Civil Code: "Without prejudice to compensation for injury suffered, the court may prescribe any measures, such as sequestration, seizure and others, appropriate to prevent or put an end to an invasion of personal privacy; in case of emergency those measures may be provided for by interim order" (Les juges peuvent, sans préjudice de la réparation du dommage subi, prescrire toutes mesures, telles que séquestre, saisie et autres, propres à empêcher ou faire cesser une atteinte à l'intimité de la vie privée : ces mesures peuvent, s'il y a urgence, être ordonnées en référé).

${ }^{239}$ The English common law does not recognize a right to privacy as such, interests in privacy being protected indirectly trough other torts, such as slander and libel, deceit, malicious falsehood, breach of confidence, or the tort of negligence, and statutes such as the Defamation Act 1952, the Protection from Harassment Act 1997 and the Human Rights Act 1998. See VAN DAM, supra note 33, at 188; DEAKIN ET AL., supra note 44, at 701-20.

${ }^{240}$ Art. 35 (3) (a) of Loi du 29 juillet 1881 sur la liberté de la presse, JORF du 30 juillet 1881, p. 4201.

${ }^{241}$ Dominique Mondoloni, Legal Divisions: French versus English Libel Laws, 43(2) INDEX ON CENSORSHIP 84, at 86 (2014), available online at https://journals.sagepub.com/doi/pdf/10.1177/0306422014537174.

${ }^{242}$ GENEVIÈVE VINEY, TRAITÉ DE DROIT CIVIL. INTRODUCTION À LA RESPONSABILITÉ 284,335 [n $\left.{ }^{\text {os }} 116,145\right]$ ( $3^{\text {rd }}$ ed., L.G.D.J. 2008).
} 
liability claims in which the defendant's fault corresponds to any of the crimes regulated by the 1881 act. $^{243}$ Across the Channel, the relationship between civil law and criminal law with regard to defamation looks entirely different. In England, criminal penalties play no role whatsoever, the offence of defamatory libel having been abolished by the Coroners and Justice Act $2009 .{ }^{244}$ Thus, defamation in England is sanctioned only through civil law mechanisms.

Under French law, the definitions of the crimes of defamation proper (diffamation) and insult (injure) are very broad. Defamation proper is defined as "any allegation or imputation of a fact that infringes the honour or public standing of a person". ${ }^{245}$ Insults are defined as "any outrageous expression, contemptuous term, or invective that does not encompass the imputation of a fact". 246 Defamation proper was initially conceived as an intentional wrong. ${ }^{247}$ However, when it comes to both civil and criminal liability, French courts presume that intention is present once the defamatory character of the statement is proven. ${ }^{248}$ The presumption is rebuttable, the defendant being allowed to prove he made the statement in good faith. Thus, the actual character of defamation as a civil wrong depends on the jurisprudential interpretation of the defence of "good faith" (bonne foi). The defence of good faith is based on an objective standard of behaviour: the defendant must prove facts that show that he behaved correctly in the given circumstances (for instance, by showing that the author had a legitimate interest, researched the facts seriously, carefully, and prudently, and the writing itself was also moderate and prudent). ${ }^{249}$ Therefore, defamation proper (diffamation) can best be characterized as a form of liability based on presumed fault. An action for defamation proper may also be defeated by showing that the defendant benefits from a privilege or spoke the truth (exceptio veritatis). ${ }^{250}$ Regarding the exceptio veritatis defence, in a case decided in 2010, the Court of Cassation held that the defendant can even rely on facts discovered after the publication of his statements in order to demonstrate the veracity of said

\footnotetext{
${ }^{243} I d$. at $335\left[\mathrm{n}^{\circ} 145\right]$ (especially the decisions cited in note 823$)$.

${ }^{244}$ Coroners and Justice Act 2009, c. 25 section 73.

${ }^{245}$ Article 29 (1) of Loi du 29 juillet 1881 sur la liberté de la presse, JORF du 30 juillet 1881, p. 4201: Toute allégation ou imputation d'un fait qui porte atteinte à l'honneur ou à la considération de la personne ou du corps auquel le fait est imputé est une diffamation.

${ }^{246}$ Article 29 (3) of Loi du 29 juillet 1881 sur la liberté de la presse, JORF du 30 juillet 1881, p. 4201 : Toute expression outrageante, termes de mépris ou invective qui ne renferme l'imputation d'aucun fait est une injure. ${ }^{247}$ LE TOURNEAU ET AL., supra note 34, at 798 [n 1986].

${ }^{248}$ Id. at 798 [n ${ }^{\circ}$ 1987]; CA Paris, 10 February 1999, D. 2000.226, note Nathalie Mallet-Poujol.

${ }^{249}$ LE TOURNEAU ET AL., supra note 34, at 798-99 [n 1988] ; Nathalie Mallet-Poujol, supra note 248.

${ }^{250}$ See Arts. 41 (immunities) and 35 (truth defence) of Loi du 29 juillet 1881 sur la liberté de la presse, JORF du 30 juillet 1881, p. 4201.
} 
statements. ${ }^{251}$ Thus, the way the truth defence works highlights once again the insignificance of the defendant's state of mind in defamation suits: it is possible, based on the interplay of prima facie elements and defences, for a defendant to intend to defame the plaintiff, yet later find out that his statements are true and escape liability. Equally, it is possible for a defendant not to intend to defame but nevertheless still be found liable. Insults (injures) generally follow the same principles, with the caveat that the truth defence and the defence of good faith do not apply to insults. Instead, the characteristic defence for insults is "provocation", the author of an insult being exempt from liability if the insult was preceded by an act or statement infringing his honour, reputation, or any of his legally protected pecuniary or moral interests. ${ }^{252}$

There is no real equivalent to the civil wrong of insult (injure) in the English common law, but the civil wrong of diffamation has many more aspects in common with the torts of slander and libel than aspects that set them apart. All three civil wrongs focus on the objective characteristics of the statement (or statements) made by the defendant; in all three civil wrongs the state of mind of the defendant at the time the statement was made is not of any significance; all three allow the exceptio veritatis defence; and in both France and England the liability of "distributors" and other persons who play a minor or passive role in the process of publication is based on a presumption of fault. ${ }^{253}$ Nevertheless, due to the defence of good faith, the French diffamation is, by its very nature, less strict than its English equivalents (even after taking into account the large number of defences available under English law). Finally, at the remedial level, it is worth mentioning that the amount of damages recoverable for defamation in England seems to be much higher than in France. ${ }^{254}$ However, this may be explained by the fact that criminal actions are often filed together with tort actions in France, and the fines are not at all negligible (going up to EUR 45,000 in some cases).

\section{Recurring Patterns and Conclusions}

Contrasting strict liability and fault-based liability wrongs through the lens of comparative law has proven to be an endeavour fraught with nuance.

\footnotetext{
${ }^{251}$ See Emmanuel Dreyer, Droit de la presse et droits de la personnalité, D.2011.780, at 786, discussing Cass. Civ. $1^{\text {re }}, 25$ February 2010, $n^{\circ} 09-12.641$.

${ }^{252}$ LE TOURNEAU ET AL., supra note 34, at 802 [n 1992].

${ }^{253}$ See supra Chapter III Part B.11.

${ }^{254}$ Mondoloni, supra note 241, at 86.
} 
On the one hand, we have seen that even when France and England define strict liability wrongs in a similar manner, some of the details of these definitions still diverge in important ways. France and England define primary duties and their correlative entitlements very similarly in the areas of product liability, liability for nuclear accidents, vicarious liability of employers for the acts of their employees, nuisance, and trespass to land. Yet, in the area of product liability, there are differences with regard to what counts as damage, how causation may be proved, and the relationship between product liability and other liability regimes. In the area of liability for nuclear accidents, there are differences with regard to the recoverability of pure economic loss, and in the area of vicarious liability of employers for the acts of their employees there is an important divergence with regard to the definitions of the underlying civil wrongs committed by employees, and with regard to the liability exposure of employers when their employers are held vicariously liable. In the area of private nuisance, there are subtle differences regarding the definition of the term "neighbour" and the treatment of uncertain risks, and lastly, with regard to acts of interference with the possession of land, there are conceptual and procedural differences between the English tort of trespass to land and the French référé possessoire.

On the other hand, in some areas where the definitions of civil wrongs fundamentally differ-one jurisdiction opting for strict liability and the other for (mainly) fault-based liability-we nevertheless found a number of subtle points of convergence. We have seen, for instance, that the law of vicarious liability in England has been expanding and now partly overlaps with the French general principle of liability for others, and that although in France liability is strict and in England the tort of negligence dominates the area of liability for road traffic accidents, drivers are nevertheless held to a higher standard of care in England. Petitory actions, which are not even conceived as remedies for wrongs in France, seem to protect possessory interests in a similar manner to the torts of conversion and trespass to goods, and in France, the applicability of faultbased liability (articles 1240-1241 of the Civil Code) in defamation cases has been restricted jurisprudentially to such an extent that fault-based liability has become almost inconsequential, making French law just about as strict as English law in this area.

Despite these nuances, two recurring characteristics of strict liability norms emerged from the comparisons made in this chapter: first, strict liability norms are non-universal, in the sense that primary duties and entitlements take other forms than the all against all form that is characteristic to fault-based norms; and second, the link between potential tortfeasors and victims is mediated, 
the ascription of liability typically requiring the identification of at least two connected relationships. Both characteristics emerged as patterns, which became recognizable when strict liability was contrasted to paradigmatic forms of fault liability.

In order to explain the non-universal nature of strict liability norms, perhaps the best place to start is with its opposite, the universal nature of fault-based liability. For instance, the primary duty of the tort of negligence, the duty of care, is a duty with universal undertones, and so is the general principle encoded in article 1240 of the French Civil Code. As already mentioned, although the duty of care element in the tort of negligence is relational and is often established on a case-bycase basis, there is no a priori limitation as to who can be a claimant and who can be a respondent in a negligence case. ${ }^{255}$ Abstracted from policy considerations, the duty of care in negligence has the potential to bind all persons to all others. ${ }^{256}$ The general principle of article 1240 of the French Civil Code is even enunciated as binding every person ("[t]out fait quelconque de l'homme") to all others ("qui cause à autrui"). ${ }^{257}$ This all to all universality is happily married to an extreme form of individualism and atomization: fault liability's primary duties (and correlative entitlements) being conferred upon individuals qua individuals. Strict liability duties and correlative entitlements are non-universal in precisely the sense that they are narrower and more targeted with regard to the subjects they address. Strict liability duties are still general duties, but they address, on either the passive or the active side, or on both sides at the same time, only a

\footnotetext{
${ }^{255}$ Supra Part C.1 of this chapter.

${ }^{256}$ The most well-known formulations of the duty of care element in negligence come from Lord Atkin's speech in Donoghue v Stevenson and Lord Bridge's speech in Caparo Industries plc v Dickman.

See Donoghue v Stevenson, [1932] UKHL 100, [1932] A.C. 562, 580 (per Lord Atkin): “At present I content myself with pointing out that in English law there must be and is some general conception of relations, giving rise to a duty of care, of which the particular cases found in the books are but instances. . . . The rule that you are to love your neighbour becomes in law you must not injure your neighbour; and the lawyer's question 'Who is my neighbour?' receives a restricted reply. You must take reasonable care to avoid acts or omissions which you can reasonably foresee would be likely to injure your neighbour. Who then in law is my neighbour? The answer seems to be persons who are so closely and directly affected by my act that I ought reasonably to have them in contemplation as being so affected when I am directing my mind to the acts or omissions which are called in question."

Caparo Industries Plc v Dickman, [1990] UKHL 2, [1990] 2 A.C. 605, 617-18 (per Lord Bridge): "What emerges is that, in addition to foreseeability of damage, necessary ingredients in any situation giving rise to a duty of care are that there should exist between the party owing the duty and the party to whom it is owed a relationship characterized by the law as one of 'proximity' or 'neighbourhood' and that the situation should be one in which the court considers it fair, just and reasonable that the law should impose a duty of a given scope on the one party for the benefit of the other."

${ }^{257}$ The primary duty created by article 1240 is also relational and limited in scope, but the limitations surface only in the jurisprudence of French courts (for instance, by declaring that a causal chain is too indirect when the damage caused to the victim was not reasonably foreseeable).
} 
group or class of persons. The characteristic subject of a strict liability rule is not the individual qua individual, but the individual qua member of a group or class.

These general, yet non-universal, duties that make up the primary level of strict liability wrongs can be further divided into three categories: (i) duties owed by members of a group or class to all others; (ii) duties owed by all persons to members of a group or a class of persons; and (iii) duties owed by members of a group or class to members of another group or class. The liability for the acts of things (in France), the liability for animals (in France), the liability for nuclear accidents (in both France and England), and all forms of vicarious liability (in both France and England) belong to the first set of duties (i.e. owed by a group or class to all others). Only a gardien of a thing, a gardien of an animal, a nuclear operator, an employer, a parent, or a person who exercises a sufficient degree of control and direction over another person's life can be held strictly liable under these liability regimes, whereas the potential victim can be any person whatsoever. The English tort of trespass to land and its French equivalents (the wrongs which form the basis for a référé possessoire), as well as the torts of conversion and trespass to goods fall into the second category (duties owed by all to members of a class or group). These civil wrongs can be committed by any person but protect only members of that group or class of persons who possess land, buildings or goods, or have a right to possess goods. Lastly, the characteristic duties of product liability (in both France and England), liability for road traffic accidents under the loi Badinter (in France), as well as nuisance and trouble de voisinage, belong to the third category (i.e. duties owed by members of a group or class to members of another group or class). With regard to product liability, the primary duty rests on producers, suppliers, or importers, whereas the primary entitlement is held by any natural person who may suffer personal injury or damage to property (usually consumers). The loi Badinter contains three sets of primary duties: (1) duties owed by drivers to other drivers; (2) duties owed by drivers to privileged victims (pedestrians, cyclists and passengers); and (3) duties owed by drivers to super-privileged victims (pedestrians, cyclists or passengers who are under the age of 16 , older than 70 , or more than $80 \%$ disabled). The English tort of nuisance and the French trouble de voisinage are also based on duties owed by members of a group or class to members of a group or class, but in a different way. These civil wrongs do not create primary duties connecting persons from different groups, as in the cases of product liability 
and road traffic accidents. Instead, the potential claimants and defendants in nuisance cases belong to the same self-referential relational group: they must be neighbours. ${ }^{258}$

There are exceptions to the universality of primary duties and entitlements even within the domain of fault-based liability, but the exceptions tend only to reinforce the correlation between strict liability and the non-universality of primary duties, rather than falsify it. Thus, even within the typically universalist fault-based paradigm, there are circumstances in which a group or class of persons is singled out, especially on the active side, and slightly different primary duties are ascribed to that group or class. However, in such situations, the primary duties owed by the group or class are almost invariably stricter than the general duty of care. For instance, the liability of drivers under the tort of negligence is based on a primary duty which is more demanding than the general duty of care, drivers being held to the standard of a "careful and experienced driver" and not the standard of a "reasonable driver". ${ }^{259}$ Also, another group which is often singled out is that of professionals, who owe stricter duties of care because their advanced qualifications in a specific field are taken into account when the victim's damage was caused while they were exercising their specialized functions. ${ }^{260}$ To sum up this idea, we can say that in the right kind of circumstances, the fact that the tortfeasor was a driver, a lawyer, a notary, a doctor, or an accountant, matters for the definition of primary duties and entitlements, but it matters in precisely the sense that the standards these groups of individuals are held to is higher than the ordinary standard of care.

Moving on to the mediated structure of strict liability norms, the contrast with fault-based liability norms provides once more a good point of departure. Fault-based liability links tortfeasors and victims in a straightforward ("direct" or "un-mediated") manner. The only relevant relationship when determining liability under fault-based norms is the causal relationship between the behaviour of the wrongdoer and the damage suffered by the victim. Strict liability norms, however,

\footnotetext{
${ }^{258}$ It should be noted, however, that the category of the neighbour in nuisance cases differs very much from the kind of "neighbour" Lord Atkin had in mind in Donoghue v Stevenson, in the context of the tort of negligence. Lord Atkin's neighbour is a universal category that does not exclude any person ab initio. It is an abstract idea, of all the persons one should take into account when performing an action (hence its two coordinates, of proximity and foreseeability). The idea of the neighbour in nuisance is much more concrete, evoking the idea of a spatial and temporal limitation, thus excluding ab initio those who do not live within the enclave of "neighbours".

${ }^{259}$ See supra Chapter III Part A.4 and Part C.3 of the present Chapter; DEAKIN ET AL., supra note 86, at 169, 172.

${ }^{260}$ See PEEL \& GOUDKAMP, supra note 46, at 147, 149; VINEY ET AL., LES CONDITIONS..., supra note 35, at 488-89 [no 471]; VAN DAM, supra note 33, at 267-69; Panayotis J. Zepos \& Phoebus Christodoulou, Professional Liability, in 11 InTERNATIONAL ENCYCLOPEDIA OF COMPARATIVE LAW, TORTS, Chapter 6, at 5, para. 9-10 (André Tunc ed., J.C.B. Mohr (Paul Siebeck) \& Martinus Nijhoff Publishers 1983).
} 
typically link tortfeasors and victims by way of two connected relationships held together by a nexus point. The elements of liability combine to form a narrative of two relationships: one relationship between the tortfeasor and the nexus point and a second relationship between the nexus point and the victim. It is therefore through the mediation of a nexus point that potential tortfeasors can be said to owe a duty to potential victims.

The best examples of liability regimes with a mediated structure were discussed at length in this chapter: the French general principle of liability for the acts of things and all the different rules of vicarious liability from both France and England. With regard to liability for things, we have seen that the primary duty and the correlative entitlement that bind the custodian of a thing to the victim are based on the correct identification of two connected relationships: the relationship between the victim and the thing and the relationship between the thing and its custodian. Therefore, the nexus point in the ascription of liability is the idea of an "act of a thing". With regard to vicarious liability, the first relationship is between the victim and the primary tortfeasor and the second relationship is between the primary tortfeasor and the vicariously liable person, the nexus point being "the civil wrong committed by the primary tortfeasor". 261

The same mediated structure can also be identified with ease in the areas of liability for animals, product liability, liability for nuclear accidents, and liability for road traffic accidents under the loi Badinter. Also, even though it is perhaps less obvious, the torts of trespass to land, trespass to goods, conversion, and defamation also have a mediated normative structure. Similar to the liability for the acts of things, the French rule on liability for animals is based on the identification of the right kind of relationship between the victim and the animal and the right kind of relationship between the animal and its custodian, the nexus point being the "act of the animal". Product liability is dependent on the identification of the right kind of relationship between the victim and a product, and between that product and its manufacturer (or supplier/importer, depending on the circumstances), and the nexus point is the "defective product". The liability for nuclear accidents is premised on the relationship between the victim and nuclear material and the relationship between that nuclear material and a "nuclear operator", the nexus point being the "nuclear accident", the "transport of nuclear matter", or "exposure to nuclear matter". Liability under the

\footnotetext{
${ }^{261}$ With one notable exception - the liability of parents for the acts of their minor children in France [art. 1242 (4) of the French Civil Code], where the nexus point is the act of the child (analysed similarly to the "act of a thing"). See supra Part C.2 of this chapter for a more extensive discussion and critique of this rule.
} 
loi Badinter is based on the relationship between the victim and a motor vehicle, and between the motor vehicle and its driver, the nexus point being the "road traffic accident". The tort of trespass to land is based on the relationship between the victim-possessor and his land and between that same land and the trespasser, the nexus point being the "voluntary act of entering or making contact with the land". The torts of trespass to goods and conversion require a first relationship between the person who is in possession (trespass) or has the current superior right to possess (conversion) and a movable, and a second relationship between the movable and the tortfeasor, the nexus point being the "act of interference with possession or the right to possess". The tort of defamation requires the right kind of relationship between the tortfeasor and a published statement coupled with the right kind of relationship between the published statement and the victim, the nexus point being the "defamatory nature of the statement".

The mediated structure of their primary duties and entitlements is what allows strict liability regimes to bypass judgments regarding the quality of the defendant's behaviour. The locus of the wrong or, in other words, the problem that the liability rule is trying to address, is not in the behaviour of the tortfeasor, but in the nexus point, which is always somewhat removed and independent from the tortfeasor's decision-making process. There is a sort of imputability distance implied in all strict liability wrongs. In the context of some strict liability wrongs, such as vicarious liability or liability for the acts of things, the tortfeasor is not liable because of something he did, but because of who he is, i.e. how he relates to the real or primary culprit (who may be a thing or another person). In the context of other torts, such as trespass to land, trespass to goods or conversion, the tortfeasor is liable for something he did, but something he did to someone's land or goods, and not something he did to the victim of the tort directly. The distance is created in the latter examples on the passive side of the primary duty, the victim being entitled to a remedy not because something was done to him or her, but because of his or her relationship to the property which was being interfered with.

These two structural characteristics of strict liability norms (their non-universality and mediated structure) ought to be taken seriously because of what they imply for the existing debates regarding the adoption, expansion, and even justification of strict liability regimes. There is more at stake when legal systems choose strict liability regimes over fault-based liability than a slight preference for security over freedom and a corresponding "victim-friendly" narrative (which is often 
contrasted to the "business-friendliness" of fault-based liability). ${ }^{262}$ Strict liability's imputability distance, combined with its non-universal nature, point towards a deeper and subtler ideological rift. These characteristics suggest that, in any given area of tort law, what the proponents of faultbased liability and the proponents of strict liability disagree about is not how the law should respond to the same problem (by favouring potential victims over risk-takers or the other way around) or how legal responses can be made more efficient, ${ }^{263}$ but about what the problem is to start with. Because the normative differences between fault and strict liability operate on the primary level of duties and entitlements, the move from fault to strict liability requires a powerful shift in the way events are perceived by legal actors.

Perhaps a couple of examples can shed more light on this idea. A clear contrast and therefore a good example of this shift in perception comes from the area of road traffic liability, where proponents of fault-based liability would normally see a problem with individual behaviour (i.e. the problem of sub-standard driving), whereas proponents of strict liability would see a problem with the traffic system as a whole, a problem shared by all the groups participating in the traffic system (i.e. the problem being the road traffic accident itself). Another good example is product liability, where the proponents of fault-based liability would locate the problem in the behaviour of producers and would inquire into the level of precautions adopted by the producer, whereas strict liability proponents would locate the problem in the product itself and would ask questions about the level of safety expected from that product.

To sum up, the key differences between fault and strict liability are differences in the normative narrative shaping our perceptions of the interpersonal problems that ought to be remedied by the legal system. In the interpretation we have offered, the choice between fault and strict liability implies a choice between two different ways of defining civil wrongs, i.e. two different ways of

\footnotetext{
${ }^{262}$ A shift to the victim's perspective is the starting point, for instance, of Boris Starck's théorie de la garantie. BORIS STARCK, ESSAI D’UNE THÉORIE GÉNÉRALE DE LA RESPONSABILITÉ CIVILE CONSIDÉRÉE EN SA DOUBLE FONCTION DE GARANTIE ET DE PEINE PRIVÉE (L. Rodstein 1947).

${ }^{263}$ What comes to mind immediately is the famous clash of the two law and economics titans, Guido Calabresi and Richard Posner, who seemed to agree on the problem (both extoling welfare maximization and cost reduction as the goals of tort law practice), but reached opposite conclusions with regard to which liability regime is more efficient. Guido Calabresi argued that strict liability is the more efficient liability regime for dealing with "accidents", whereas Posner argued towards the contrary conclusion - that fault liability is more efficient. See GUIDO CALABRESI, THE Costs of ACCIDENTS: A Legal AND ECONOMiC ANALYsis ( ${ }^{\text {nd }}$ ed., Yale University Press 1970); Guido Calabresi \& Jon T. Hirschoff, Toward a Test for Strict Liability in Torts, 81 YALE L.J. 1055 (1972); Richard A. Posner, Strict Liability: A Comment, 2 Journal of Legal Studies 205 (1973); Richard A. Posner, A Theory of Negligence, 1 JoURNAL OF LEGAL STUDIES 29 (1972).
} 
formulating primary duties and their correlative entitlements. However, this interpretation, as well as the comparisons made in this chapter and the insights derived from these comparisons, only hold true if our initial assumption, that the telos of tort law is the just definition and correction of civil wrongs, is correct. That is why in the following chapter, we will turn our attention to the debate and the arguments regarding the final aims of tort law, and of civil wrongs more generally. 


\section{CHAPTER VII}

\section{STRICT LiABILITY AND JUSTICE}

\section{A. The Two Problems with Strict Liability in Normative Tort Law Theory}

According to Gregory Keating, the topic of strict liability has been an "embarrassment" for most of the theories developed by contemporary normative legal theorists, particularly for those who purport to provide "moral" and "internal" accounts of tort law. ${ }^{1}$ This diagnostic may perhaps seem harsh at first sight, but the more one looks into the relevant legal literature the more one has to acknowledge that Keating's strong words may not be too far from the truth. For various reasons, strict liability has been conveniently forgotten, summarily dismissed, or grossly mischaracterized by a surprising number of legal theorists, many of whom have otherwise built impressive and original internal accounts of the practice of tort law, or of private law more generally.

The problem, according to Keating, is that most of the "moral" theories of tort law, i.e. theories that are not "economic", have been unable or unwilling to characterize strict liability torts as interpersonal wrongs. ${ }^{2}$ There is a pervasive assumption in this body of literature that strict liability is best explained as a kind of "pay as you go" 3 form of liability (i.e. a form of liability where the defendant is obligated to pay for the costs created by certain activities he engages in, activities that are otherwise lawful, perhaps even useful, from a societal perspective). ${ }^{4}$ Because of this, moral

\footnotetext{
${ }^{1}$ Gregory C. Keating, Strict Liability Wrongs, in Philosophical Foundations of THE LaW OF ToRTs 292, 294 (John Oberdiek ed., Oxford University Press 2014).

${ }^{2} I d$. at 294-95.

${ }^{3}$ Id. at 293 (attributing this phrase to Arthur Ripstein); See, therefore, also Arthur Ripstein, Tort Law in a Liberal State, 1 J. TORT L. [ii], 28, 29 (2007).

${ }^{4}$ See John C.P. Goldberg \& Benjamin C. ZiPuRSKY, ReCognizing Wrongs 191 (The Belknap Press of Harvard University Press 2020); John C.P. Goldberg \& Benjamin C. Zipursky, The Strict Liability in Fault and the Fault in Strict Liability, 85 FORDHAM L. REV. 743, 762-64, 768 (2016) (arguing that true strict liability regimes are licensingbased rather than wrongs-based).

The idea that strict liability is a kind of "pay as you go" or "licence-based" form of liability is often implied in the law and economics literature. The idea of ascribing strict liability to the "cheapest cost avoider", for instance, implies that liability is simply part of the cost of doing business for the cheapest cost avoider (and not necessarily the result of an inter-personal wrong). See Guido CALABRESI, The Costs of ACCIDENTS: A LeGAL AND ECONOMIC ANALYSIS 135 (2d ed., Yale University Press 1970); Guido Calabresi \& Jon T. Hirschoff, Toward a Test for Strict Liability in Torts, 81 YALE L.J. 1055, 1060 (1972).

Last, but not least, the same assumption underlies the Restatement (Second) of Torts' justification of liability for abnormally dangerous activities. See RESTATEMENT (SECOND) OF TORTS, VOL. 3 § $509 \mathrm{cmt}$. d (1977): "[Liability] is founded upon a policy of the law that imposes upon anyone who for his own purposes creates an abnormal risk of
} 
theorists either cannot make sense of strict liability or, even worse, try to fit "the round peg" of existing forms of strict liability into "the square hole" of fault-based liability. ${ }^{5}$

Keating's criticism is justified, but his diagnosis of the problem is aimed at too narrow a target. The difficulties in dealing with strict liability stem from two deeper problems: first, there is no agreement, and a great deal of confusion amongst moral theorists of tort law with regard to what counts as "strict liability" in the law of torts; and second, there is no agreement with regard to the aims and outline of tort law as a practice, making it difficult to determine whether, and to what extent, if at all, strict liability should be part of the tort law system. The first problem operates at the ground level, the level of legal doctrine and taxonomy. The second problem is normative, operating at the level of general principles and normative frameworks. Any tort law theorist that sets out to work back and forth between doctrinal accounts and general principles ${ }^{6}$ will find that both ends of the reflection process need to be attended to, and the space between the two ends is riddled with treacherous paths.

1. The doctrinal problem - the definition of strict liability

At the doctrinal level, different ways of distinguishing between fault and strict liability generated a high degree of equivocation with regard to the boundary between these two principal forms of liability. ${ }^{7}$ The emergence, in tort law doctrine, of at least four rival conceptions of strict liability is the root cause of this taxonomical predicament. The conception we embraced in this study was that strict liability is liability "irrespective of fault", in the sense that fault is not an element taken into account for determining liability (at least not prima facie). However, besides this conception of strict liability, one can find in modern tort law scholarship at least three alternative conceptions which ought to be rejected either as downright mischaracterizations or as normatively indefensible. They are: first, the idea that strict liability is synonymous with liability based on causation alone; second, the view that all tortious liability is, at least prima facie, strict;

\footnotetext{
harm to his neighbors, the responsibility of relieving against that harm when it does in fact occur. The defendant's enterprise, in other words, is required to pay its way by compensating for the harm it causes, because of its special, abnormal and dangerous character." (emphasis added).

${ }^{5}$ Keating, supra note 1, at 293-94.

${ }^{6}$ We already indicated in Chapter I that the method of reflective equilibrium guided our approach to the topic. See supra Chapter I Part C.2.

${ }^{7}$ In a recent study, Allan Beever also pointed out that this is a problem. See ALLAN BEEVER, A THEORY OF TORT LIABILITY 28-33 (Hart Publishing 2016).
} 
and third, the notion that all liability not based on personal and subjective fault falls under the category of strict liability.

The most prevalent mischaracterization, discussed already in Chapter IV, is the idea that strict liability is synonymous with liability based on causation alone. ${ }^{8}$ This conception of strict liability has been forcefully attacked by a large number of authors, holding relatively diverse normative commitments, and has been explicitly and forcefully defended, at least to this author's knowledge, only by Richard Epstein. ${ }^{9}$ Yet, even amongst those who criticize Epstein's conception of strict liability, there is often an implicit assumption that strict liability is correctly defined as liability based on causation alone. One of the most well-known arguments against causation-based strict liability comes from Oliver Wendell Holmes's The Common Law. ${ }^{10}$ Holmes argued that fault was a necessary requirement for liability because without it, liability would arise for all the negative consequences caused by a person's mere existence. ${ }^{11}$ Liability for Holmes was either fault-based or causation-based, and the latter was both unjustified and lacked any support in legal precedent. ${ }^{12}$ Later, in 1951, Glanville Williams argued that any general theory of strict liability is incompatible with the idea of corrective justice. ${ }^{13}$ Also, in the decades before World War II in France, Marcel Planiol ${ }^{14}$ and the Mazeaud brothers ${ }^{15}$ raised forceful objections against causation-based general

\footnotetext{
${ }^{8}$ See supra Chapter IV Part E.

${ }^{9}$ Richard A. Epstein, A Theory of Strict Liability, 2 J. LEGAL STUD. 151 (1973).

${ }^{10}$ Oliver Wendell Holmes JR., The Common LaW (Dover Publications 1881 / Little, Brown and Company 1923 repr.).

${ }^{11} I d$. at 94-95 (citations omitted): "The general principle of our law is that loss from accident must lie where it falls, and this principle is not affected by the fact that a human being is the instrument of misfortune. But relatively to a given human being anything is accident which he could not fairly have been expected to contemplate as possible, and therefore to avoid. In the language of the late Chief Justice Nelson of New York: "No case or principle can be found, or if found can be maintained, subjecting an individual to liability for an act done without fault on his part. . . . All the cases concede that an injury arising from inevitable accident, or, which in law or reason is the same thing, from an act that ordinary human care and foresight are unable to guard against, is but the misfortune of the sufferer, and lays no foundation for legal responsibility." If this were not so, any act would be sufficient, however remote, which set in motion or opened the door for a series of physical sequences ending in damage; such as riding the horse, in the case of the runaway, or even coming to a place where one is seized with a fit and strikes the plaintiff in an unconscious spasm. Nay, why need the defendant have acted at all, and why is it not enough that his existence has been at the expense of the plaintiff? The requirement of an act is the requirement that the defendant should have made a choice. But the only possible purpose of introducing this moral element is to make the power of avoiding the evil complained of a condition of liability. There is no such power where the evil cannot be foreseen."

${ }^{12} \mathrm{Id}$. at 95.

${ }^{13}$ Glanville Williams, The Aims of the Law of Tort, 4 CURRENT LEGAL ProBS. 137 (1951).

${ }^{14}$ Marcel Planiol, 2 Traité ÉLÉMentaire De DROIT CIVIL 282-83 [n $\left.{ }^{\circ} 863\right]$ ( $9^{\text {th }}$ ed., L.G.D.J. 1923).

${ }^{15}$ HENRI MAZEAUD ET AL., 1 TRAITÉ THÉORIQUE ET PRATIQUE DE LA RESPONSABILITÉ CIVILE DÉLICTUELLE ET CONTRACTUELLE 93-96 [n $\left.{ }^{\text {os }} 90,91,91-2\right]$ (6 ${ }^{\text {th }}$ ed., Montchrestien 1965).
} 
theories of strict liability, with arguments that were similar to those earlier advanced by Holmes. ${ }^{16}$ Later, after the publication of Richard Epstein's A Theory of Strict Liability, ${ }^{17}$ the attacks against the causation-based conception of strict liability multiplied exponentially in the English-speaking world. In response to Richard Epstein's causation-based theory of strict liability: Stephen Perry argued very convincingly that there is no plausible justification for such a form of liability, and that even if one could be found, a general theory of strict liability is not even possible, because it would be unable to generate determinate results, ${ }^{18}$ Ernest Weinrib argued that it is a form of liability that violates the bilateral and correlative structure of tort law; being focused exclusively on formulating "a sacrosanct domain of autonomy" 19 for the plaintiff, causation-based strict liability would be unable to offer an "intelligible conception of the defendant's duty" 20 (in other words, it "has right without a [correlative] duty"21); and finally, other authors, such as Izhak Englard, ${ }^{22}$ Joshua Getzler, ${ }^{23}$ and Benjamin Zipursky ${ }^{24}$ criticized Epstein's theory for its circularity. Richard Epstein himself ended up disavowing to a certain extent his initial definition. ${ }^{25}$

Instructive as this debate has been, its object is and always has been a mythical creature, a mischaracterization of what strict liability is. Examples of liability based on causation alone do not exist, never existed, and never will exist in legal practice. Although most authors disavow this form of liability, the existing attacks on causal strict liability ended up solidifying the idea that strict liability is synonymous with "liability based on causation", thus obscuring the fact that real, existing forms of strict liability pose a more pressing challenge to accounts of tort law that are based on wrongdoing, or fault, alone. Strict liability as an over-encompassing, causation-based,

\footnotetext{
${ }^{16}$ It should be noted though that the general theories of strict liability they were responding to were more sophisticated, being based not on causation alone, but on causation and risk (théorie du risque), or on causation and the moral idea that "he who profits from introducing a risk into society must pay when the risk is actualized" (théorie du risqué-profit).

${ }^{17}$ Epstein, supra note 9.

${ }^{18}$ Stephen R. Perry, The Impossibility of General Strict Liability, 1 CAN. J. L. \& JURISPRUdENCE 147 (1988).

${ }^{19}$ ERnest J. WeinRiB, The IdEA OF Private LAW 178 (Oxford University Press 2012).

${ }^{20} \mathrm{Id}$. at 179 .

${ }^{21} \mathrm{Id}$. at 178 .

${ }^{22}$ Izhak Englard, Can Strict Liability be Generalized?, 2 OXF. J. LEG. STUD. 245, 251-53 (1982).

${ }^{23}$ Joshua Getzler, Richard Epstein, Strict Liability and the History of Torts, 3 J. TORT L. [Article no. 3], at 4, n. 14 (2010).

${ }^{24}$ Benjamin C. Zipursky, Richard Epstein and the Cold War in Torts, 3 J. ToRT L. [Article no. 5], at 16 (2010).

${ }^{25}$ See Richard A. Epstein, Defenses and Subsequent Pleas in a System of Strict Liability, 3 J. Legal Stud. 165 (1974); Richard A. Epstein, Intentional Harms, 4 J. LEgAL STUD. 391 (1975); Richard A. Epstein, Medical Malpractice: The Case for Contract, 1 AM. BAR Found. Res. J. 87 (1976); RICHARD A. EPSTEIN, A THEORY OF Strict Liability - Toward a Reformulation of Tort LaW (Cato Institute, San Francisco 1980); Richard A. Epstein, Toward a General Theory of Tort Law: Strict Liability in Context, 3 J. TORT L. [Article no. 6] (2010).
} 
general principle of liability is too easy of a target for authors who argue that strict liability has no place in the law of torts. ${ }^{26}$ In such arguments, causation-based strict liability plays, even inadvertently, the role of a convenient "bogeyman." Like the bogeyman, this type of liability does not exist, has never existed, and cannot possibly exist in the law, but can scare away those "naughty" enough to challenge the orthodox individualist paradigm, which equates the law of interpersonal wrongs with the "law of wrongdoing." Normative legal theorists who want to ignore the problem of strict liability need only summon its causation-based conception and the argument is won, because next to it, fault-based liability always emerges as the (often only) sensible practical solution.

The second misconception, the idea that all tortious liability is strict (also discussed in a previous chapter ${ }^{27}$ ), was defended most eloquently by Jules Coleman. ${ }^{28}$ The premise of the argument is that tort law deals with risk and loss allocation within a bilateral structure. ${ }^{29}$ The starting point is that losses happen, and the law must allocate these losses (in some manner and to some person). ${ }^{30}$ Also, tort law's structure is such that decisions on the allocation of losses typically involve two parties, the victim and the tortfeasor. According to Coleman, liability is always strict because no matter what kind of rule applies to the victim-tortfeasor relationship, an innocent party (i.e. a party whose conduct is irreproachable) will have to prima facie bear the loss. What most legal doctrine would call fault-based liability, Coleman argues is better understood as victim strict liability. Victim strict liability begins with the default strict liability principle that losses ought to lie with the victim, unless the victim can show that the tortfeasor was at fault, in which case liability is shifted.

\footnotetext{
${ }^{26}$ See, e.g., WEINRIB, THE IDEA OF PRIVATE LAW, supra note 19, at 177: "Whereas corrective justice treats the litigants as equals, strict liability and the subjective standard center themselves on only one of the parties - the former on the plaintiff, the latter on the defendant. The inequality in strict liability emerges from the principle that the defendant is to be liable for any penetration of the plaintiff's space. What is decisive for the parties' relationship is the demarcation of the domain within which the law grants the plaintiff immunity from the effects of the actions of others; the activity of the defendant is then restricted to whatever falls outside of this sphere. Thus the interests of the plaintiff unilaterally determine the contours of what is supposed to be a bilateral relationship of equals."

This scathing critique follows an extensive presentation of Epstein's theory of strict liability (see Id. at 173-176), and is obviously a response to Epstein.

${ }^{27}$ Supra Chapter IV Part B.

${ }^{28}$ Jules L. Coleman, The Morality of Strict Tort Liability, 18 WM. \& MARY L. REV. 259 (1976-1977); JuLeS L. COLEMAN, RISKS AND WRONGS 229-33 (Oxford University Press 1992).

The origins of the idea can be traced back to a paper published in 1975 by Guido Calabresi. Guido Calabresi, Optimal Deterrence and Accidents: To Fleming James, Jr., 84 YALE L.J. 656, 664-66 (1974-1975).

${ }^{29}$ Coleman, The Morality of Strict Liability, supra note 28, at 272. COLEMAN, RISKS AND WrONGS, supra note 28, at 223.

${ }^{30} \mathrm{Id}$.
} 
Conversely, what most doctrinal scholars would call strict liability is best described as strict tortfeasor liability, i.e. the symmetrically opposite rule that in the absence of victim fault the loss ought to be allocated to the injurer. ${ }^{31}$ Thus, in cases of strict victim liability (fault liability) the victim will be strictly liable a priori, but could 'defend' by proving the fault of the tortfeasor, whereas in cases of strict liability the tortfeasor will bear the a priori burden unless he can prove the victim's fault. Thus, for Coleman, the moral choice between strict victim liability and strict tortfeasor liability should ultimately be rephrased as a choice regarding who should bear the costs of accidents when both parties to a dispute are innocent. ${ }^{32}$ There are several problems with Coleman's account. One problem we already discussed ${ }^{33}$ is that it is only through the requirements for liability that we are able to determine who is a victim and who is a tortfeasor. In the law of torts, a person is a "victim" and another is an "injurer" only after all the elements of liability are met. Not all persons who suffer a loss are victims for the purposes of the law of torts, and not all persons who breach some pre-existing duties are injurers. That is why it makes very little sense to say that an initial liability rule for strict liability is that "the injurer bears the costs of accidents unless he can show some defect in the victim's conduct [...]." ${ }^{34}$ A person becomes an "injurer" only by the joint operation of the prima facie elements and the failure of available defences, and the same goes for the victim. A person becomes a victim, for the purposes of tort law, only when all the elements of liability are met. Conceptually, in tort law, the victim and the injurer become victim and injurer simultaneously. ${ }^{35}$ Second, the symmetry between strict victim liability and strict tortfeasor liability breaks down once all of the elements of liability are accounted for. The principle that "losses ought to lie where they fall" is really the starting point for all forms of liability, not just for strict victim liability. A person who suffers a loss will, by default, have to bear that loss even in cases of strict tortfeasor liability if he or she cannot prove the prima facie elements of liability. ${ }^{36}$ Also, upon closer inspection, strict victim liability is not as strict on the victim side as strict tortfeasor liability is on the tortfeasor side. Under the rules Coleman associates with strict

\footnotetext{
${ }^{31}$ Coleman, The Morality of Strict Liability, supra note 28, at 260 (1976-1977);

${ }^{32}$ COLEMAN, RiskS AND WRONGS, supra note 28, at 229.

${ }^{33}$ The following lines only summarise the argument made supra in Chapter IV Part B.

${ }^{34}$ Coleman, The Morality of Strict Liability, supra note 28, at 272.

${ }^{35}$ In other words, the victim and the tortfeasor acquire their roles because of a unitary relationship created by the law. Ernest Weinrib was right to say that "the basic unit of analysis" in private law is the legal relationship. See WEINRIB, THE IDEA OF PRIVATE LAW, supra note 19, at 24-25.

${ }^{36}$ See supra Chapter IV Part B, where the argument is accompanied by an illustration from the law of product liability.
} 
victim liability (the tort of negligence, for instance), the defendant, even if already proven to be at fault, can still invoke the contributory negligence of the victim. Therefore, if we were to follow Coleman's logic all the way, strict victim liability is really more of a sequential "double-fault" liability - the victim can initially shift losses by proving the tortfeasor's negligence, and the tortfeasor can then shift at least part of those losses back to the victim by proving contributory negligence. The same move is not available under strict tortfeasor liability. The "shifting of losses" stops under strict tortfeasor liability with the defence of contributory negligence. The victim cannot continue to re-shift liability onto the tortfeasor by proving that the tortfeasor was negligent. Moreover, tortfeasor negligence and contributory negligence encapsulate different ideas of fault and cannot be equated. When A proves that B was at fault, A is showing that B disregarded the interests of $\mathrm{A}$ in a legally significant way. When B, however, defends by saying that $\mathrm{A}$ was contributorily negligent, he is saying that A disregarded his own interests in a legally significant way, not B's. ${ }^{37}$ Therefore, the fault invoked in the defence of contributory negligence is of a different nature than the fault encapsulated in prima facie negligence. Finally, Coleman's initial premise, that the law of torts deals with the allocation of risks and losses, casts the net too widely. Tort law allocates losses ex post and risks ex ante, but it does so only as an effect of how it defines and corrects civil wrongs. In other words, tort law does not deal with losses tout court. Outside of the context of those bilateral and correlative interactions between persons following which one party can rightfully be characterized as a victim and the other as a tortfeasor, tort law has nothing to say about loss allocation. Allocative decisions with regard to risks and losses are not, and need not be, the province of tort law alone. The shifting of losses from one party to another can be, and is often, realized through practices that have very little to do with private law: administrative procedures, compensation funds, relief funds, etc. Moreover, losses are not even a necessary component of tort law. There are some civil wrongs that are actionable without the need for the victim to have suffered a loss (e.g. the torts of trespass to land, trespass to goods, or battery).

\footnotetext{
37 James GoudKamp \& DOnal Nolan, CONTRibutory Negligence: Principles AND Practice 3, 15 (Oxford University Press 2018); James Goudkamp, Rethinking Contributory Negligence, in CHALLENGING ORTHODOXY IN TORT LAW 309, 311 (Erika Chamberlain et al. eds., Hart Publishing 2013); Ulrich Magnus \& Miquel Martín-Casals, Comparative Conclusions, in UNIFICATION OF TORT LAW: CONTRIBUTORY NEGLIGENCE 259, 260-61 (Ulrich Magnus \& Miquel Martín-Casals eds., Kluwer Law International 2004); Richard W. Wright, The Standards of Care in Negligence Law, in PhilosophiCal Foundations of TorT Law 249, 259 (David G. Owen ed., Oxford University Press 1995, repr. 2001). See also Froom v Butcher, [1976] QB 286, 291 (CA) (per Lord Denning MR): "Contributory negligence is a man's carelessness in looking after his own safety" (emphasis added).
} 
Lastly, the third source of confusion and equivocation regarding the legal boundary between fault and strict liability in the law of torts stems from a related ambiguity regarding the definition of fault-based liability. Some legal and moral theorists have argued that what most legal scholars see as the paradigmatic fault-based tort, the tort of negligence, is in fact strict. ${ }^{38}$ The authors who arrive at such a broad conception of strict liability usually do not contest that strict liability is "liability regardless of fault", but insist on constraining the meaning of "fault" to its personal and subjective sense. In common parlance and within the discipline of moral philosophy, fault is indeed often understood in its subjective sense, which is much more closely linked to other related moral concepts such as "blame", "desert" and "discredit". 39 In normal parlance, when we say that someone is at fault we usually understand fault to refer to a subjective failure, i.e. a failure that originates in the human mind and is proof of a character defect. However, in tort law (especially in France and England), fault-based liability refers to "fault in conduct", ${ }^{40}$ not to fault in the mind or character of the tortfeasor. When tort lawyers say that a person committed a fault or is at fault, they mean only that that person's behaviour failed to live up to an objective standard of care. This is why tortious fault is often described as an "objective fault" (faute objective) ${ }^{41}$ Fault is "personal" in the law of torts only in the sense that the tortfeasor himself must have failed to live up to the requisite standard of care; it is not personal in the sense that we can draw any moral inferences regarding the moral worth of the tortfeasor as a person. Therefore, we cannot raise any objections with regard to the soundness of this third conception of strict liability. The problem is simply one of "translation". What moral philosophers think fault is differs from what lawyers think fault is,

\footnotetext{
${ }^{38}$ TONY HonORÉ, ResPonsibILity AND FAUlt 14, $30-31$ (Hart Publishing 1999); Avihay Dorfman, Reasonable Care: Equality as Objectivity, 41 LAW \& PHIL. 369 (2012); Heidi M. Hurd, Finding No Fault with Negligence, in PhilosophicAl Foundations OF THE LAW OF TORTS 387 (John Oberdiek ed., Oxford University Press 2014); Larry Alexander \& Kimberly Kessler Ferzan, Confused Culpability, Contrived Causation, and the Collapse of Tort Theory, in Philosophical Foundations of THE LAW OF TORTS 406, 408-16 (John Oberdiek ed., Oxford University Press 2014).

${ }^{39}$ HONORÉ, supra note 38, at 14.

${ }^{40}$ Wolfgang Gaston Friedmann, Legal Theory 329 ( $2^{\text {nd }}$ ed., Stevens \& Sons/Martinus Nijhoff 1949); Roscoe Pound, Philosophy of Law and Comparative Law, 100 U. PA. L. REV. 1, 9 (1951); Franco Ferrari, Comparative Remarks on Liability for One's Own Acts, 15 Loy. L.A. INT. \& ComP. L.J. 813, 830 (1993); Benjamin Zipursky, The Restatement (Third) and the Place of Duty in Negligence Law, 54 VAND. L. REV. 657, 665 (2001). See also, Dan B. Dobbs, 1 The LaW of TorTs 269 (West Group 2001); Robert E. KeEton ET AL., CASES AND MATERIALS ON TORT AND ACCIDENT LAW 173 (West Group 1998).

For an interesting objection to this way of defining "fault-based liability," see Hurd, supra note 38, at 391.

${ }^{41}$ See, e.g., Henri Mazeaud, La "faute objective" et la responsabilité sans faute, D. 1985 Chron. 13; Patrice Jourdain, Retour sur l 'imputabilité, in LES DROITS ET LE DROIT, MÉLANGES DÉDIÉS À B. BOULOC 511 (Dalloz 2007); GENEVIĖVE VINEY ET AL., TRAITÉ DE DROIT CIVIL. LES CONDITIONS DE LA RESPONSABILITÉ $447-48$ [nº 444] (4th ed., L.G.D.J. 2013); Philippe Pierre, La place de la responsabilité objective. Notion et rôle de la faute en droit français, REVUE JURIDIQUE DE L'OUEST 403, 405, 412 (2010).
} 
and because of this mismatch, strict liability also appears to be a much broader concept to some moral philosophers (at least when compared to the conception widely shared by lawyers and doctrinal scholars).

The conceptions of strict liability discussed above, instead of clarifying the boundary between fault and strict liability, end up undermining the "fault-strict liability" dichotomy altogether. Under the first conception, all liability ends up being fault-based, because purely causal strict liability neither fits any existing forms of liability, nor can it be justified in an intelligible manner. Under the second and third conceptions, all tort liability ends up being strict. Under Coleman's “allocative" account, liability is prima facie always strict for one of the interacting parties (and always fault-based once the analysis moves beyond the prima facie allocation). When fault liability is understood only in a subjective, psychological sense, almost all liability ends up being strict once again because in England no tort in existence is based on subjective fault, and in France liability based on subjective fault, even under the most generous interpretation, plays only an exceptionally marginal role. ${ }^{42}$

There is a fourth way of understanding strict liability, according to which strict liability refers to those civil wrongs in which the legal element of fault is absent. This is the conception that prevails amongst textbook and treatise writers, as well as most legal practitioners, and it is also the conception that we have relied on in previous chapters in order to identify strict liability wrongs. ${ }^{43}$ At first glance, this way of defining strict liability may seem to draw only a formal line between fault and strict liability. ${ }^{44}$ However, because the fault element is never simply absent, but is usually replaced by other elements carrying normative weight, ${ }^{45}$ this potential objection fails. There are significant substantive differences between fault-based and strict liability regimes. The comparisons made in the previous chapter even allowed us to generalize the existing substantive differences, and we have shown that: first, civil wrongs where the element of fault is absent are based on non-universal primary duties and entitlements, binding members of a group to all other

\footnotetext{
${ }^{42}$ The only exception is liability in "duty to rescue" cases. See, e.g., CA Versailles, 26 June 1989, D.1989.247 (IR). In France, the standard of care in duty to rescue cases contains some strong subjective elements, in derogation from the usual standard which is purely objective (the regular standard of care has been objectified to such an extent that an infant is judged by the same standard of reasonableness as an adult person; VINEY ET AL., supra note 41, at 700$703\left[\mathrm{n}^{0} 593\right]$.

This problem does not arise in England. In England, it has long been the rule that there is no "duty to rescue" in tort, and therefore no person can be held liable for failing to rescue a fellow human being.

${ }^{43}$ Specifically, Chapters II and III.

${ }^{44}$ This is the conclusion drawn by Allan Beever. See BEEvER, supra note 7, at 32.

${ }^{45}$ See supra Chapter IV Part D.1.
} 
persons, or members of a group to members of the same or a different group, as opposed to faultbased liability which typically relies on primary duties and entitlements that bind all persons to all others; and second, in the case of strict liability torts, the ascription of liability is not based on a direct causal link between the behaviour of the tortfeasor and the damage suffered by the victim, but on the identification of two (or more) connected relationships, usually of a different nature. These substantive differences are by no means trivial. When combined, they reveal that the normative choice between fault-based liability and strict liability is never a straightforward choice between rival solutions to a commonly agreed problem, but a more fundamental choice about what the problem is to start with. ${ }^{46}$

2. The normative problem - the justification of strict liability

The historical and doctrinal accounts of Chapters II and III, the definition of strict liability offered in Chapter IV, the tertium comparations identified in Chapter V, and the comparative findings from Chapter VI are all based on a set of assumptions regarding the practice of tort law that are not entirely uncontroversial. In fact, the ethical tradition upon which our account builds is, as James Gordley rightly pointed out, "out of fashion" ${ }^{\text {47 }}$ nowadays (at least in legal circles). ${ }^{48} \mathrm{We}$ are referring, of course, to that same tradition that Gordley valiantly defended despite it being unfashionable - the "Aristotelian tradition".

It was from within a distinctly Aristotelian moral framework that we first assumed that the set of practices that form the doctrinal areas of tort law, equitable wrongs, and la responsabilite civile délictuelle are best understood as dealing with interpersonal wrongs. Also from within this framework, we assumed that these practices are purposive social practices, i.e. that they have a telos (purpose), and that without that purpose, or with a different one, they would no longer be recognizable; they would constitute some other social practice(s) [in order to simplify our references to these practices, we refer to them generically as the practice of tort law]. Finally, we assumed that the practice of tort law has a composite telos, with two connected components: to

\footnotetext{
${ }^{46}$ See supra Chapter VI Part D.

${ }^{47}$ James Gordley, Foundations of Private LaW. Property, Tort, CONTRACt, UnJust EnRichment 7 (Oxford University Press 2006).

${ }^{48}$ Aristotelian accounts of private law are quantitatively dwarfed by utilitarian, Kantian, or Hegelian accounts. However, the interest in Aristotelian ethics is growing in both moral philosophy and in legal theory.
} 
justly define and justly correct civil wrongs. Therefore, in Aristotelian terms, the practice of tort law has a plural aim, both corrective and distributive justice playing an ordering role within it.

Among modern tort law theorists, there is no clear agreement with regard to the first thesis (that the practice of tort law is best understood as dealing with wrongs); there is some hesitation with regard to the second, i.e. the purposive nature of the practice of tort law; and there is no agreement, and perhaps not even a prospect of future agreement, with regard to the aims of tort law's constituent practices. Before moving on to the debate around the aims of tort law, which will occupy the remainder of this chapter, we can swiftly mention the main challenges faced by the first two theses: that the practice of tort law is concerned with interpersonal wrongs, and that it is a teleological (or purposive) practice.

Starting with the first thesis, the main alternative to understanding tort law as a law of wrongs ${ }^{49}$ can be found in theories of tort law which conceptualize the practice of tort law as a tool for allocating the societal costs of accidents. ${ }^{50}$ The focus on losses has some descriptive strength, and

\footnotetext{
${ }^{49}$ The present paragraph relies very heavily on the research and arguments expounded in John C. P. Goldberg \& Benjamin C. Zipursky, Torts as Wrongs, 88 TEX. L. REv. 917 (2010). Also in support of the "torts-as-civil-wrongs" thesis see WeInRIB, THe IdEA OF PRIVATE LAW, supra note 19, at 134-35; RoBert SteVENS, ToRTS AND Rights 23 (Oxford University Press 2007); John Gardner, What is Tort Law for? Part 1: The Place of Corrective Justice, 30 Law and Philosophy 1, 22 (2011); Peter Birks, The Concept of a Civil Wrong, in Philosophical Foundations OF TORT LaW 31 (David G. Owen ed., Oxford University Press 1995); A. M. Dugdale, Principles of Liability in Tort, in Clerk \& LindSELl ON TORTS 1-2 [para. 1-02] (19 ${ }^{\text {th }}$ ed., Anthony M. Dugdale et al. eds., Sweet \& Maxwell

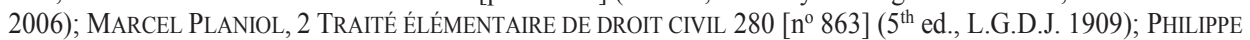
BRUN, RESPONSABILITÉ CIVILE EXTRACONTRACTUELLE 1-2 ( $2^{\text {nd }}$ ed., LexisNexis - Litec 2009).

Many of the early treatise writers, such as Blackstone, Addison, Pothier, Aubry and Rau, to take but a few examples, also conceptualized the field as a law of wrongs (where "wrong" is understood as the breach of an inter-personal duty). See William Blackstone, 3 Commentaries on the Laws of England. In Four Books (Clarendon Press 1768, repr. Forgotten Books 2012) (this entire volume deals with the topic of "private wrongs"); CHARLES G. AdDISON, Wrongs AND THEIR REMEDIES: BEING A TREATISE ON THE LAW OF TORTS (V. and R. Stevens and Sons 1860); ROBERT J. POTHIER, 1 TRAITÉS SUR DIFFÉRENTES MATIERES DE DROIT CIVIL, APPLIQUÉES À L'USAGE DU BARREAU ; ET DE JURISPRUDENCE FRANÇOISE 53 [n ${ }^{\circ} 116$ ] (Jean Debure \& la veuve Rouzeau-Montaut 1773), available online at https://bibliotheque-numerique-patrimoniale.u-psud.fr/collection/item/4760-redirection; ROBERT J. POTHIER, 1 TRAITÉ DES OBLIGATIONS, SELON LES REGLES TANT DU FOR DE LA CONSCIENCE QUE DU FOR EXTÉRIEUR 137-38 [ $\mathrm{n}^{\text {os }} 116-117$ ] (les frères Debure \& la veuve Rouzeau-Montaut 1774) ; CHARLES AUBRY \& CHARLESFRÉDÉRIC RAU, 3 COURS DE DROIT CIVIL FRANÇAIS 539, 547 [n $\left.{ }^{\text {os }} 443,446\right]$ ( $3^{\text {rd }}$ ed., Cosse 1856), available online at https://gallica.bnf.fr/ark:/12148/bpt6k57900391.

${ }^{50}$ See, e.g., GUIDO CALABRESI, THE COSTS OF ACCIDENTS: A LEGAL AND ECONOMIC ANALYSIS 239, 312 (2d ed., Yale University Press 1970); Richard A. Posner, ECONOMIC ANALYSIS OF LAW 8, 10 (Wolters Kluwer 2014); JoHN G. FLEMING, THE LAW OF TORTS 3 ( $6^{\text {th }}$ ed., The Law Book Company Ltd 1983): "The law of torts, then, is concerned with the allocation of losses incident to man's activities in modern society.” W. PAGE KEETON ET AL., PROSSER AND KEETON ON TORTS 6 ( $5^{\text {th }}$ ed., West 1984): "The law of torts, then, is concerned with the allocation of losses arising out of human activities"; PATRICK S. ATIYAH, ACCIDENTS, COMPENSATION AND THE LAW 6, 59, 239 (Weidenfeld and Nicholson 1970); Jules Coleman, RISKS AND Wrongs 198, 212, 222-223, 320, 330 (Oxford University Press 1992, repr. 2003); George P. Fletcher, Fairness and Utility in Tort Theory, 85 HARV. L. ReV. 537,
} 
the picture painted by loss allocation theories has found some acceptance in legal practice as well or, at the very least, has been influential. ${ }^{51}$ Nevertheless, the picture of tort law we get from lossallocation theories does not fit the practice of tort law the way many of their proponents would want it to. The starting point of all loss-allocation theories is a truism: losses happen in the world. The person(s) who suffers a loss will presumably seek to shift that loss to another, or to many others, if the legal system allows it. Because most often we can determine whether the legal system allows for the loss to be shifted by looking at the rules of tort law, it is not too problematic to go a step further and try to describe tort law in terms of cost allocation. This is a point of view like many others, and looking at tort law through the "cost allocation" lens may provide interesting insights: into the wealth-distributive effects produced by the tort law system, into how tort law deals with risks of various kinds, or into the incentives created by the tort law system. However, it is a step too far to further claim that tort law is best understood as the law that determines when losses ought to be shifted. Just because tort law plays a role in the allocation of costs in society does not necessarily mean that tort law's aims, structure, inner logic, and scope can best be explained as a pattern, intended or not, of cost allocation.

No one supporting the "torts-as-civil-wrongs" thesis would deny that tort law has an allocative effect. Tort law leads to the creation of remedial obligations, the performance of which, most often, will lead to a transfer of wealth from one party to another. ${ }^{52}$ The "torts-as-civil-wrongs" thesis objects only to the stronger claim that tort law can best be understood in terms of cost allocation, i.e. that the true reasons at play in tort law have to do with how costs should be allocated, or that the aim of tort law is to allocate costs in a certain manner (be it efficiently, equally, or on the basis of some other distributive criteria). The arguments against this claim, and in favour of the "tortsas-civil-wrongs" thesis, have been very well-formulated already by John Goldberg and Benjamin Zipursky in a well-known and well-researched paper titled "Torts as Wrongs" ${ }^{53}$ In the present

\footnotetext{
at 539, 550-51 (1972). One could also interpret some passages of Oliver Wendel Holmes's The Common Law in the same sense. See HOLMES, supra note 10, at 94-95 [such an interpretation of Holmes can be found, for instance, in Goldberg \& Zipursky, Torts as Wrongs, supra note 49, at 922].

${ }^{51}$ See, e.g., Lord Denning's arguments, supporting the decision in Nettleship v Weston, [1971] 2 Q.B. 691, at 700:

"Thus we are, in this branch of the law, moving away from the concept: 'No liability without fault'. We are beginning to apply the test: 'On whom should the risk fall?' Morally the learner driver is not at fault; but legally she is liable to be because she is insured and the risk should fall on her."

${ }^{52} \mathrm{An}$ exception is when the remedy for a tort is a prohibitive injunction designed to maintain the status quo. In such cases, courts are trying to prevent a different allocation instead of transferring a cost from one party to another; also, in such cases there is (yet) no loss to allocate.

${ }^{53}$ Goldberg \& Zipursky, Torts as Wrongs, supra note 49.
} 
thesis, we have defined civil wrongs in a broader way than Goldberg and Zipursky do in their work, ${ }^{54}$ but we can endorse their critique of loss-allocation theories without any objection. They have convincingly shown that the most prominent theories centred on loss allocation fail to provide an adequate interpretive account of some of the most prominent substantive features of the tort law system - such as the existence of torts that are actionable without proof of loss, the different treatment of omissions as opposed to actions, the diversity of remedies that exist in the law of torts, as well as the fact that in tort law cases claimants do not file their claims as private enforcers of public wrongs, but are required to show that their own rights or interests have been violated. ${ }^{55}$ Also, many cost-allocation theories fail to account for the structure of tort law, ${ }^{56}$ and most even fail to explain what makes tort law a distinctive legal category. ${ }^{57}$

Despite all the problems mentioned above, instrumentalist cost-allocation theories nevertheless formulate simple, straightforward, and concrete answers to the question: why have a law of torts to start with? The instrumentalist argument regarding the aims of tort law is easy to grasp. The purpose of tort law is to achieve one or more socially desirable external goals: to deliver better compensation to those in need, to deter antisocial conduct, to reduce the societal costs of accidents, etc. By contrast, the aims posited by legal scholars supporting the "torts-as-civil-wrongs" thesis seem, at least at first sight, much more difficult to pin down and articulate in simple terms.

This brings us to our second thesis, i.e. that the practice of tort law is best understood as a teleological practice. Ernest Weinrib, perhaps the most well-known modern proponent of the "torts-as-civil-wrongs" paradigm, seems to suggest, at least according to some authors who commented on his work, ${ }^{58}$ that the practice of tort law does not have a purpose, and to look for a

\footnotetext{
${ }^{54}$ See supra Chapter V Part E.2. Goldberg and Zipursky understand the object of primary tort duties to be a person's conduct, and civil wrongs as acts of wrongdoing, and dismiss strict liability as a mere oddity to be found at the "margin of tort law". See Goldberg \& Zipursky, Torts as Wrongs, supra note 49, at 929, 939, 951.

${ }^{55}$ Goldberg \& Zipursky, Torts as Wrongs, supra note 49, at 954-71.

${ }^{56}$ Goldberg \& Zipursky, Torts as Wrongs, supra note 49, at 953; Benjamin C. Zipursky, Civil Recourse, Not Corrective Justice, 91 GEO. L.J. 695 (2003). See also WeINRIB, The IDEA OF PRIVATE LAW, supra note 19, at 36-41. ${ }^{57}$ See Goldberg \& Zipursky, Torts as Wrongs, supra note 49, at 919. For a very good argument that understanding torts as wrongs (breaches of primary duties) leads to a better understanding of what makes tort law distinctive from contract law and the law of unjustified enrichment see Birks, The Concept of a Civil Wrong, supra note 49. Theories of tort law that focus on losses often tend to blur the boundaries between tort and other parts of private law (such as the law of contract and unjustified enrichment), as well as the boundaries between private law and public law (especially the boundary between tort law and compensation from special state funds or social security). ${ }^{58}$ Under some interpretations, Weinrib is seen as rejecting all inquiries into the purposes of tort law, and this rejection is attributed to his adherence to a "formalist jurisprudence". See, e.g., Goldberg \& Zipursky, Torts as Wrongs, supra note 49, at 972; Robert L. Rabin, Law for Law's Sake, 105 YALE L.J. 2261, 2270-71 (1996).
} 
purpose is to miss the point of what tort theory should do. Surely, it would be entirely unsatisfactory to answer the question "what is the point of tort law?" by saying that tort law does not really have a point, or that the question itself should not be asked. Yet, some cryptic passages from Weinrib's “The Idea of Private Law” seem to support such a reading. Weinrib did indeed make an argument against "functionalism", which he defined as "[comprehending] law through its goals". ${ }^{59}$ He also stated that if it were necessary to express private law's intelligibility in terms of purpose, then "the purpose of private law is [only] to be private law". ${ }^{60}$ Finally, and perhaps most confusingly, he compared the intelligibility of private law with the intelligibility of love. ${ }^{61}$ It is not all that surprising that some authors have found these statements baffling, tautological, or simply too obscure to be in any way illuminating. ${ }^{62}$ However, it would be too uncharitable to summarize Weinrib's argument as an argument against the purposiveness of private law tout court. Weinrib is not necessarily saying that tort law cannot be understood as a purposive practice. His main point is that whatever reason there is for tort law to exist, even expressed in terms of an end, aim, or purpose, can be "grasped only from within". ${ }^{63}$ What Weinrib forcefully argued against are theoretical constructions that explain or justify the practice of tort law as an instrument for the attainment of an external end (such as the compensation of accident victims or the deterrence of antisocial behaviour). His own theory, in fact, posits that tort law has a certain kind of internal end-an "intrinsic ordering" principle. ${ }^{64}$ The intrinsic ordering principle that makes tort law coherent, Weinrib argued, is corrective justice. ${ }^{65}$

\footnotetext{
Weinrib himself spoke of formalism as a methodological approach. See WeINRIB, THE IDEA OF PRIVATE LAW, supra note 19, at 22-46. However, formalism for Weinrib is an approach that focuses on internal intelligibility, coherence, and the separation between the legal and the political. His reasons for rejecting loss-allocation theories aimed at compensation or deterrence have to do with the facts that such theories do not live up to the standard of coherence demanded by formalism, and not the mere fact that they articulate the practice in instrumental terms. See id. at 4546: "The adverse judgment that formalism passes on the goals of compensation and deterrence in tort law is not due to an antipathy toward these goals considered on their own [...]. That goal is shunned in the tort context for the company it keeps, not for what it is. If compensation were conjoined to doctrinal and institutional features that reflected the same justificatory impulse [...]the demands of formalism would be fully met."

${ }^{59}$ WeINRIB, The IDEA OF PRIVATE LAW, supra note 19 , at 3.

${ }^{60} I d$. at 5 .

${ }^{61} I d$. at 5-6.

${ }^{62}$ See Richard A. Posner, The Problems of Jurisprudence 447 (Harvard University Press 1990); Richard A. Epstein, The Utilitarian Foundations of Natural Law, 12 HARV. J. L. \& PUB. POL'Y 711, 713 (1989); Owen Fiss, Coda, 38 U. TORONTO L.J. 229, 239-40 (1988).

${ }^{63}$ WeINRIB, THE IDEA OF PRIVATE LAW, supra note 19, at 5.

${ }^{64}$ Ernest J. Weinrib, The Monsanto Lectures: Understanding Tort Law, 23 VAL. U. L. REV. 485, 495-96 (1989).

${ }^{65}$ WeINRIB, THE IDEA OF PRIVATE LAW, supra note 19, at 75-80.
} 
We must, however, slightly distance ourselves from Weinrib's framework in order to properly understand the distinction between internal and external ends. Weinrib seems to equate the distinction between internal and external ends of the law with the distinction between law as an end in itself and law as a means to an end. ${ }^{66}$ In essence, this equation implies that the law is good or valuable either for its own sake or as a means to an external end, and that everything that has intrinsic value ought to be treated only as valuable for its own sake. This rather common reductionist move ${ }^{67}$ perhaps explains why Weinrib ended up stating that "the purpose of private law is [only] to be private law" ${ }^{68}$ Since Weinrib's theoretical project is committed to an apolitical, "formalist" account of private law, ${ }^{69}$ he was able to avoid the idea of an "end" altogether in his own account-for him, corrective justice is not the aim of private law, it is its form ${ }^{70} \mathrm{We}$ need not follow Weinrib in this regard, as it is possible for the law (including private law, and therefore also tort law) to be valued for the constitutive, inherently political role it plays in a life worth living, ${ }^{71}$ in which case its ends would still be internal despite being valued for the sake of something other than the law itself.

An external end is the kind of end which the law only serves, in some way or another, and does not, in any way, help constitute. The justificatory worth and validity of an external end is wholly independent from the law and, ${ }^{72}$ as a consequence, the measure of goodness of an external end lies outside of the practice it justifies. For instance, the compensation of accident victims can be defended as a worthwhile goal without any reference to tort law practices (including any reference to tort law norms, standards, or doctrines), and should tort law prove unsuitable as a means to provide compensation to accident victims, then it could even be abolished and replaced with something better. ${ }^{73}$ By contrast, an internal end is an end which derives its validity from the law it justifies, and for which the law is (at least partly) constitutive. ${ }^{74}$ The measure of goodness of an internal end is to be found within the practice it justifies. Justice, posited as an end of tort law or

\footnotetext{
${ }^{66}$ See id. at 3 (suggesting that goals should be "irrelevant in principle"), 4 (talking about ascribing to private law "the purpose of being itself"), and 5 ("Love is its own end. My contention is that, in this respect, private law is just like love").

${ }^{67}$ See Christine M. Korsgaard, Two Distinctions in Goodness, 92(2) The PhilosophiCAL ReVIEw 169, 170 (1983).

${ }^{68}$ WeINRIB, THE IDEA OF PRIVATE LAW, supra note 19, at 5.

${ }^{69} \mathrm{Id}$. at $22-23,45$.

${ }^{70} \mathrm{Id}$. at $28,56,204$.

${ }^{71}$ See infra Parts C.1. and D.1 of this chapter.

72 WeINRIB, The IDEA OF PRIVATE LAW, supra note 19, at 4.

${ }^{73} \mathrm{Id}$.

${ }^{74}$ Gardner, What is Tort Law for? Part 1: The Place of Corrective Justice, supra note 1415, at 2.
} 
private law, is an internal end, especially when it is understood in the Aristotelian sense that encompasses corrective and distributive justice. With justice as an internal end, the practice of tort law is aimed at specifying (spelling out), in various individual circumstances, what justice requires from private parties in their specific interactions with other private parties. ${ }^{75}$ Instead of a meansends relationship between the practice and its end, we are dealing with something akin to the relationship between a part and the whole.

The ancestry of the distinction between external and internal ends can be traced back to and connected with Aristotle's distinction between internal goods ("good in their own right") and external goods ("merely useful goods"), ${ }^{76}$ and the term telos, as it is understood in the Aristotelian tradition, is broad enough to encompass both types of ends. Thus, when we say that tort law is a teleological, or purposive, practice, we mean to say that the practice of tort law has an internal end (that it aims at a good that is internal to the practice of tort law). We agree with Weinrib that the practice of tort law is the kind of practice that can only be truly "grasped from within," "77 but from within the practice of tort law we see, and we will argue for, a composite internal aim. Thus, in the following, after (B) an introduction to the Aristotelian tradition of moral inquiry and (C) Aristotle's two forms of justice (corrective and distributive justice), we argue in (D) in favour of a mixed (or pluralist) account of the practice of tort law, ${ }^{78}$ which holds that the practice of tort law aims to achieve both corrective and distributive justice. Finally, in a concluding section, we explore how the pluralist account of the practice of tort law defended in this chapter may provide us with resources to resolve one of the most important normative questions involving strict liabilityunder what circumstances should strict liability displace fault-based liability? (E).

\footnotetext{
${ }^{75}$ See Martin Stone, The Significance of Doing and Suffering, in PHILOSOPHY AND THE LAW OF TORTS 131, 164 (Gerald J. Postema ed., Cambridge University Press 2001) (talking about corrective justice in these terms).

${ }^{76}$ See NE 1096b11-17.

77 WeINRIB, THE IDEA OF PRIVATE LAW, supra note 19, at 5.

${ }^{78}$ And we are definitely not alone in seeing the practice of tort law this way. For other arguments in favour of a mixed account (where both corrective and distributive justice are recognized as aims of tort law) see GORDLEY, Foundations of Private LaW..., supra note 47, at 8, 12-14; William Lucy, Philosophy of Private LaW 376418 (Oxford University Press 2007); Peter CAne, Responsibility In LAW And Morality 190 (Hart Publishing 2002) \& Peter Cane, Distributive Justice and Tort Law, 2001 N.Z. L. Rev. 401 (2001); Marc Loth, Corrective and distributive justice in tort law: On the restoration of autonomy and a minimal level of protection of the victim, 22(6) MAASTRICHT JOURNAL OF EUROPEAN AND COMPARATIVE LAW 788 (2015).
} 
B. An Introduction to the Aristotelian Tradition of Moral Inquiry

1. Aristotelian ethics

The Aristotelian tradition of moral inquiry was the dominant tradition in western moral philosophy for almost two millennia, from antiquity to the beginning of the Enlightenment. ${ }^{79}$ From the Enlightenment onwards, however, the Aristotelian tradition dwindled, and Aristotelian moral philosophy was pushed to the outer edges of moral academic debate. Interest in Aristotelian moral philosophy was only properly reignited recently, in the late 1950s, with the publication of "Modern Moral Philosophy" by Elisabeth Anscombe, ${ }^{80}$ and since the 1950s, more and more philosophers, including Julia Annas, ${ }^{81}$ Rosalind Hursthouse, ${ }^{82}$ Philippa Foot, ${ }^{83}$ Martha Nussbaum, ${ }^{84}$ Christine Swanton, ${ }^{85}$ Alasdair MacIntyre, ${ }^{86}$ John McDowell, ${ }^{87}$ and Bernard Williams,${ }^{88}$ as well as a small number of legal theorists, ${ }^{89}$ have been studying Aristotle and making contributions to the Aristotelian tradition. This renewed interest in the writings of Aristotle elevated the academic status of Aristotelian ethics (also termed "virtue ethics" or "aretaic ethics"), which is now seen as

\footnotetext{
${ }^{79}$ See Gordley, Foundations of Private LaW..., supra note 47, at 9-10 (placing the decline in interest for Aristotelian and Thomistic philosophy sometime around the $17^{\text {th }}$ century).

${ }^{80}$ Gertrude Elizabeth Margaret Anscombe, Modern Moral Philosophy, 33 (no. 124) PHILosophy 1 (1958).

${ }^{81}$ See especially Julia AnNAS, InTELligent ViRTue (Oxford University Press 2011, repr. 2013); Julia ANNAS, The MORALITY OF HAPPINESS (Oxford University Press 1995).

${ }^{82}$ See especially Rosalind Hursthouse, On ViRTue Ethics (Oxford University Press 1999, repr. 2010).

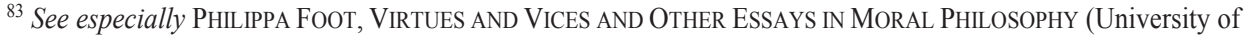
California Press/ Blackwell 1978); PhiLIPPA FoOt, NATURAL GoOdNESS (Clarendon Press 2001).

${ }^{84}$ See especially Martha C. Nussbaum, Aristotle on Human Nature and the Foundations of Ethics, in WoRLD, Mind, and EThics: Essays on the Ethical Philosophy of Bernard Williams 86-131 (J. E. J. Altham \& R. Harrison eds., Cambridge University Press 1995); Martha C. Nussbaum, Social Justice and Universalism: In Defense of an Aristotelian Account of Human Functioning, 90 ModERn PHILOLOGY S46-S73 (1993); Martha C. Nussbaum, Aristotelian Social Democracy, in LiBERALISM AND THE GOOD 203-52 (R. Douglas et al. eds., Routledge 1990). ${ }^{85}$ See especially Christine Swanton, Virtue Ethics: A Pluralistic View (Oxford University Press 2003). ${ }^{86}$ See especially ALASDAIR MACINTYRE, AFTER VIRTUE 174 (3 ${ }^{\text {rd }}$ ed., Bloomsbury 2007, repr. 2011); ALASDAIR Macintyre, Whose Justice? Which Rationality?, at 91 (University of Notre Dame Press 1988, repr. 2014). ${ }^{87}$ See especially JoHn MCDowell, Mind, VAlue \& Reality (Harvard University Press 1998).

${ }^{88}$ See especially BeRnard Williams, ETHiCS AND THe Limits of Philosophy (Fontana Press 1985, repr. Routledge Classics 2011).

${ }^{89}$ See especially Gordley, Foundations of Private Law..., supra note 47; Gregory S. AleXANDER \& EduARdo M. PeÑalver, An InTROduction to Property THEORY (Cambridge University Press 2012); Gregory S. AleXANDER, Property and Human Flourishing (Oxford University Press 2018). Other authors, such as Ernest Weinrib or Jules Coleman, have also been inspired by Aristotle, but are not Aristotelians, or even neo-Aristotelians, in the moral views they defended. Their moral accounts begin with Aristotle, but end up re-interpreting Aristotle within a broader Kantian (in Weinrib's case) moral theory or liberal (in Coleman's case) political theory.
} 
one of the three major approaches in normative theory, ${ }^{90}$ alongside deontology and consequentialism.

As an approach to moral questions, Aristotelian ethics stands apart from deontology and consequentialism in at least three important ways. First, Aristotelian ethics usually place more

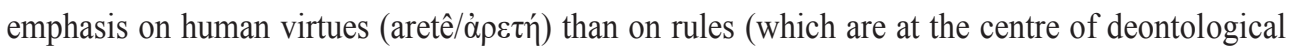
ethics) or the consequences of actions (which are at the centre of consequentialist ethics). ${ }^{91}$ This should not be read, however, in the sense that Aristotelian ethics ignore rules, or that modernity's principal ethical theories ignore virtue. It is more a matter of how rules and virtues relate to each other. In most modern ethical theory, the primary task of the moral philosopher is to get to the right rules and principles. The virtues are understood only as derivative notions in ethical theory, being defined as desires or dispositions to follow the right rules and principles. ${ }^{92}$ Thus, in most modern deontological and consequentialist moral theories, "the justification of the virtues depends upon some prior justification of rules and principles". ${ }^{93}$ What results, however, is an impoverished account of virtue, where virtue is seen as nothing more than a disposition to obey and respect the right moral rules and principles. In the Aristotelian tradition, to the contrary, the function and authority of rules is understood in terms of virtue, ${ }^{94}$ and not the other way around. Virtues and rules perform separate, but equally important, and connected, functions in the moral life. The acquisition of virtues is important because of the role virtuous actions play in the education and (moral) perfection of individual human behaviour. The rules and principles laid down by the state (polis) are important in the ethical life only inasmuch as they are enacted for and are expressive of

\footnotetext{
${ }^{90}$ Hursthouse, supra note 82, at 1-2. Rosalind Hursthouse \& Glen Pettigrove, Virtue Ethics, in THE STANFORD ENCYCLOPEDIA OF PHILOSOPHY (Edward N. Zalta ed., Winter 2018 Edition), available online at https://plato.stanford.edu/archives/win2018/entries/ethics-virtue/; Lawrence Solum, Legal Theory Lexicon: Welfare, Well-Being, and Happiness, LEGAL THEORY BLOG (May 31,2009) available online at https://lsolum.typepad.com/legaltheory/2009/05/welfare-wellbeing-and-happiness.html William J. Prior, Eudaimonism and Virtue, 35 THe JouRnal OF VALUE INQUIRY 325, 325 (2001). See, however, also Sujaina Hirji, What's Aristotelian about neo-Aristotelian Virtue Ethics?, 98 (3) PHILOSOPHY AND PHENOMENOLOGICAL ReSEARCH 671 (2018) (arguing that "we do not [...] find in Aristotle a distinct normative theory alongside deontology and consequentialism." Id. at 671); Loren E. Lomasky, The Impossibility of a Virtue Ethic, 22(3) ETHICAL THEORY AND MORAL PRACTICE 685 (2019) (rejecting virtue ethics as an alternative to deontology and consequentialism because it is too demanding, and proposing instead an ethic focused on the moderation of one's vices).

${ }^{91}$ Hursthouse \& Pettigrove, supra note 90.

92 See, e.g., John RaWLS, A THEORY OF Justice 192 (Belknap Press of Harvard University Press 1971): “The virtues are sentiments, that is, related families of dispositions and propensities regulated by a higher-order desire, in this case a desire to act from the corresponding moral principles."

${ }^{93}$ MACINTYRE, AFTER VIRTUE, supra note 86, at 138.

${ }^{94} I d$.
} 
the common good of all its citizens. From the perspective of any one individual human life, the acquisition and perfection of the virtues is a pre-condition for obtaining a correct understanding of what the common good is, and therefore for knowing which rules to obey and follow and which rules to fight against, dismiss, or ignore. Only after being educated in the virtues, will a practically reasoning agent truly understand that his own personal good is always aligned with the common good of the communities he inhabits. ${ }^{95}$ Through the performance of virtuous actions he will, in time, perfect his (perceptual) ability to discern right from wrong, learn how to govern and be governed, and align his desires in such a way as to perform virtuous actions for their own sake and in alignment with the common good. Therefore, finding the right justification for rules depends not only on a good understanding of virtue, but also on the acquisition of virtue through practical activity.

Second, authors working from within the Aristotelian tradition tend to emphasize more the role of stories in the understanding of, and education in, the ethical life. There is something more mathematical in the way utilitarianism or Kantian deontology are presented and understood that stands in stark contrast to the narrative (and often historical) understanding of Aristotelian philosophy. If the deontological tradition mostly relies on some kind of binomial logic (focused as it is on right and wrong, lawful and unlawful, "in line with duty" or "in breach of duty"), and the consequentialist tradition is mostly based on a logic of accumulation (as it is often focused on maximizing utility or pleasure and minimizing pain), the Aristotelian tradition relies more on the narrative arc (being focused on what it takes for a life to be well lived, from childhood to adulthood, and then into old age).

Third, the Aristotelian tradition of moral inquiry rejects the assumption, often made by modern deontological and consequentialist theories, that having correct beliefs about ethical questions is what matters for good practical reasoning. Aristotle's moral philosophy starts from the assumption that knowledge about practical matters is insufficient. ${ }^{96}$ For an agent to become good, or virtuous, the practice of doing the right thing is more important than arguing, reasoning, and forming beliefs.

\footnotetext{
${ }^{95}$ See Id. at 266: "For what education into the virtues teaches me is that my good as a man is one and the same as the good of those others with whom I am bound up in human community."

${ }^{96}$ D.S. Hutchinson, The Virtues of Aristotle 2 (Routledge \& Kegan Paul 1986).
} 
In other words, for ethics, the acquisition and development of virtues matters more than the acquisition and development of theories and principles of conduct. ${ }^{97}$ According to Aristotle:

[I]f arguments were sufficient by themselves to make people [good], ${ }^{98}$ the rewards they would command would justifiably have been many and large [...] and rightly

bestowed. In fact, however, arguments [...] seem unable to turn the many toward being fine and good [...]. [I] t is impossible, or not easy, to alter by argument what has long been absorbed as a result of one's habits. ${ }^{99}$

Aristotelians and neo-Aristotelians disagree about many aspects of detail and provide different interpretations of Aristotle's work, but they generally share a preoccupation with three key concepts and the relationship between them: "human flourishing" (eudaimonia), the virtues (aretê), and practical reasoning (phronēsis).

\section{Human flourishing}

Most authors who have contributed to the Aristotelian tradition believe that "there is a distinctively [good] human life to which all of one's capacities and abilities contribute", ${ }^{100}$ and that such a life, a life of "human flourishing" (eudaimonia), is the aim of all virtuous actions. ${ }^{101}$ To flourish and live a good life in the concrete social world in which we find ourselves, Aristotle posited, is the ultimate end of all human beings, the highest possible human good. ${ }^{102}$

Human flourishing, or eudaimonia, is "the highest possible human good", but not in the sense that it is a "good" 103 that trumps all other goods; instead, it is a good in which all other goods are subsumed, providing a unitary organizing principle for all other human goods. A flourishing life is made up of numerous different parts, all important in their own right, encapsulating many

\footnotetext{
${ }^{97} I d$. at 2-3.

${ }^{98}$ Terrence Irwin's translation uses the word "decent," but "good" is probably the better translation [see Richard McKeon's edition of THE BASIC WORKS OF ARISTOTLE, at 1108 (The Modern Library 2001), and HuTCHINSON, supra note 96 , at 2].

${ }^{99}$ NE 1179b5-17.

${ }^{100}$ GoRdLey, Foundations of PRivate LaW..., supra note 47, at 7 (The qualification "good" is our own addition to Gordley's formulation; the addition is necessary, because that which is "distinctively human" is not necessarily always good; arguably, certain kinds of evil are also distinctively human).

${ }^{101}$ As Michael Slote points out, however, not all modern virtue ethicists are "eudaimonists." Most notably, he lists, besides himself, James Martineau and Rosalind Hurthouse (in her later work) as virtue ethicists who have rejected eudaimonism. Michael Slote, EsSAYS ON the History of Ethics 34, n.23 (Oxford University Press 2010).

${ }^{102}$ NE 1095a18-22.

${ }^{103}$ The terms "good" and "goods" are used here in the broad sense of "that which is good", and not in the narrower sense of "merchandise" or "possessions".
} 
different, and sometimes incommensurable, goods or values. ${ }^{104}$ There are, therefore, many different ways of living a good, flourishing life, just as there are many different ways of living a life of wickedness. ${ }^{105}$ Nevertheless, the standard for judging whether a life is eudaimon is objective, in the sense that it is independent of an agent's or even a group of agents' subjective perspective or opinions. A person may subjectively be very happy and content with how life is turning out, yet not be eudaimon in the Aristotelian sense. ${ }^{106}$ Human flourishing or eudaimonia, therefore, is a unitary, but at the same time value-pluralist, and objective, aim of the ethical life. ${ }^{107}$ According to Aristotle, human beings require two categories of goods in order to flourish: virtues and external goods. ${ }^{108}$ Although the nature of virtues and external goods is very different, they constitute interrelated requirements of the flourishing life.

The virtues are needed for their own sake, or non-instrumentally, because virtuous actions are the component parts of the eudaimon life. Aristotle argues that the flourishing life must be understood in an active sense, as a life of doing that which is virtuous. The natural place of virtues is within human practices, ${ }^{109}$ and from virtuous engagement within a practice, the virtuous person gets something "good" that is inaccessible to those who do not engage in the same kind of practical activity or engage in that practical activity for the wrong reasons. Virtuous actions should be performed only for their own sake (i.e. they should be performed because they are virtuous). However, that does not exclude the possibility that the performance of virtuous actions will also have beneficial effects for the agent. ${ }^{110}$ The performance of virtuous actions leads to the perfection of virtue and it produces a special kind of enjoyment which comes from a "love of [a specific

\footnotetext{
104 AleXANDER, Property AND Human Flourishing, supra note 89, at 6, 9, 12.

105 See Gordley, Foundations of Private Law..., supra note 47, at 8; AlEXANDER, Property AND HuMAN FLOURISHING, supra note 89, at xii, xv.

106 See MACINTYRE, AFTER VIRTUE, supra note 86, at 175.

${ }^{107}$ See AleXANDER, Property AND HuMAn FlOURISHING, supra note 89, at xv-xvi, 5-6. See also, HuTCHINSON, supra note 96 , at 68 ;

${ }^{108}$ NE 1098b30-33, 1099a30-1099b6.

109 The terms "practice" and "human practice" are used throughout this chapter in the specific sense given to them by Alasdair MacIntyre, i.e. "any coherent and complex form of socially established cooperative human activity through which goods internal to that form of activity are realized in the course of trying to achieve those standards of excellence which are appropriate to, and partially definitive of, that form of activity, with the result that human powers to achieve excellence, and human conceptions of the ends and goods involved, are systematically extended." MACINTYRE, AFTER VIRTUE, supra note 86, at 218.

${ }^{110}$ Nor does it exclude negative effects (sacrifices). The virtue of courage, for instance, often requires personal sacrifices for a greater good.
} 
practice]", ${ }^{111}$ and which makes life "pleasant in itself". ${ }^{112}$ What is just, for instance, whether performed by the agent or by someone else, will please "the lover of justice"113 and, in general, "what accords with virtue will please the lover of virtue", ${ }^{114}$

The term "internal goods" is sometimes used to designate those goods one "gets" from engaging in virtuous activity within a practice. ${ }^{115}$ However, "internal goods" are primarily common goods which produce satisfaction in any one individual agent only if that agent's motivations are aligned with the common good of the practice. They are common in the sense that their achievement by a participant in the practice enriches the practice as a whole (and therefore the entire community of participants, not just one or a select group of participants). Internal goods thus have a noncompetitive quality, ${ }^{116}$ the result of which is that they are not subject to individual possession and should not become the object of any property rights.

Goods which are external to a practice are valued for the sake of something else than the practice itself. Typical examples include money, land, food, natural resources, fame, or power. What is characteristic of external goods is that they are the objects of competition. ${ }^{117}$ "They are such that the more someone has of them, the less there is for other people." ${ }^{118}$ External goods, therefore, are subject to individual possession and may form the object of property rights. ${ }^{119}$

External goods are also necessary for a flourishing life, but in two different ways: (i) as resources employed in the performance of virtuous actions, and (ii) as pre-conditions for the development of the virtues. ${ }^{120}$

\footnotetext{
${ }^{111}$ NE 1099a9.

${ }^{112}$ NE $1099 \mathrm{a} 6$.

${ }^{113}$ NE 1099a10-11.

${ }^{114}$ NE 1099a11.

${ }^{115}$ MACINTYRe, AfTER VIRTUE, supra note 86, at 219.

${ }^{116}$ A practice may be competitive (such as, for instance, the practice of playing professional chess), but its internal goods will remain non-competitive in the sense that the more they are achieved, the better everyone in the practice will be (e.g., the discovery of a new and superior opening sequence or strategy in chess may be an individual achievement, but it will enrich the entire community of persons who play and study chess).

${ }^{117}$ MACINTYRE, AFTER VIRTUE, supra note 86, 222.

${ }^{118} I d$.

${ }^{119} \mathrm{Id}$.

${ }^{120}$ NE 1099a30-1099b4.
} 
The role external goods play in the conception of the flourishing life should not be underestimated. ${ }^{121}$ Unlike many stoic philosophers, ${ }^{122}$ Aristotle did not believe that a life of virtue was possible for those who find themselves in abject poverty, alone, or going through extreme suffering. In the Nicomachean Ethics he wrote:

[Human flourishing] evidently also needs external goods . . since we cannot, or cannot easily, do [noble] actions if we lack the resources. For, first of all, in many actions we use friends, wealth, and political power just as we use instruments. Further, deprivation of certain [external goods] - for instance, good birth, good children, beauty - mars our blessedness. ${ }^{123}$

It is important at this point to emphasize that the category of external goods is extremely broad, including not only things that one has or possesses, but also relationships. In fact, relational goods occupy a place of pre-eminence in Aristotelian moral philosophy. Man is understood as a social creature $^{124}$ that can only live a life worth living in the company of others, on whom he relies and who rely on him in return. A person's character can be educated only through participation in various social practices, and without such an education, no one can properly develop the characteristic human virtues (aretê). ${ }^{125}$ Good social relationships, such as relationships of family,

${ }^{121}$ The role of external goods, especially in their relational form, is underestimated even by Aristotle. Aristotle's views on women and slaves, which are shocking by modern standards, but were perfectly in line with the practices of his own time, owe much to Aristotle's erroneous assumption that the behaviours he observed in women and slaves were due to natural abilities and characteristics, and not to the environment and social fabric in which women and slaves lived out their lives. See MACINTYRe, WhoSe Justice? Which RATionality?, supra note 86, at 105.

122 See, e.g., SeneCa the Elder, Declamations, volume I: Controversiae, Books 1-6, at 207-13, 215-19 [2.1.4-8, 2.1.10-13] (J. Henderson ed., M. Winterbottom trans., Harvard University Press 1974); LuCIUS ANNAEUS SENECA, 1 Ad LuCilium EPISTUlae MORALES. With an ENGLish translation By Richard M. GUMmere 113-15 [in Letter XVII] (Heinemann/C.P. Putnam's sons 1918, repr. 1925), available online at https://archive.org/details/adluciliumepistu01seneuoft/page/n7/mode/2up; the latter quoting also Epicurus ("The acquisition of riches has been for many men, not an end, but a change, of troubles.") $I d$. at 115; LUCIUS ANNAEUS SENECA, 2 Ad LuCILIUM EPISTULAE MORALES. With AN ENGLiSH TRANSLATION BY RichaRd M. GUMMERE 215-17 [in Letter LXXX] (William Heinemann Ltd./Harvard University Press 1920, repr. 1962), available online at https://archive.org/details/adluciliumepistu02seneuoft/page/n5/mode/2up;

${ }^{123} \mathrm{NE} 1099 \mathrm{a} 30-1099 \mathrm{~b} 4$.

${ }^{124}$ Aristotle, Politics [1253a2-5], in THe BASIC Works OF ARISTOTLE, at 1129 (Richard McKeon ed., The Modern Library 2001): "[M]an is by nature a political animal. And he who by nature and not by mere accident is without a state, is either a bad man or above humanity." See also NE 1097b11-12.

It is fascinating to see how the most interesting and promising new perspectives in the field of cognitive science are based precisely on this old, but somewhat forgotten paradigm. On this new wave of studies adopting an ecological approach to the study of the mind, i.e. where the mind is seen as embedded in its environment, see Gerd Gigerenzer, Smart Heuristics, in THINKING 39, 48-49 (John Brockman ed., Harper Perennial 2013).

${ }^{125}$ Aristotle makes this point in NE 1103a32-1103b25; See also MACINTYRE, AFTER VIRTUE, supra note 86, at 22021; ANNAS, INTELLIGENT VIRTUE, supra note 81, at 16-51. 
friendship, love, as well as good collegial relationships, relationships of neighbourhood, business relationships, work relationships, and political relationships and alliances, are essential external goods ${ }^{126}$ which have an equally important place next to non-relational external goods, such as food, water, shelter, good health, and patrimonial wealth.

There is a strong interdependency between virtue and external goods. Virtue is necessary for the healthy development and advancement of good social relationships, as well as for the correct management of worldly possessions. Without prudence, liberality, temperance, and magnificence, a person is likely to either squander their fortune or become a miser, and without friendliness, wittiness, and courage, a person will have a hard time building new good relationships and preserving existing ones. Conversely, external goods are necessary for the development and education of the virtues. The virtues can only be educated in the context of social practices, in which the existence and cultivation of social relationships is essential. Also, any one person who severely lacks non-relational external goods (for instance is starving, ill, or homeless) will find it much more difficult, if not impossible, to learn and cultivate the necessary human virtues because, on the one hand, too much of his energy will be devoted to alleviating his misery and, on the other hand, he will lack the resources to engage in and contribute to complex social practices in which he might otherwise excel.

\section{The virtues}

The virtues are "excellences of character", ${ }^{127}$ well-entrenched dispositional traits (hexeis) that cause an agent to act in a good way. ${ }^{128}$ They are, in other words, the qualities one needs in order

\footnotetext{
${ }^{126}$ Aristotle places a great degree of emphasis on "friendship", which he understands in a very extensive manner, including all relationships constituted for the pursuance of virtue and the common good (including family relationships, certain political relationships, as well as some work and business relationships) See NE 1155a5-15: "[Friendship] is most necessary for our life. For no one would choose to live without friends even if he had all the other goods. Indeed rich people and holder of powerful positions, even more than other people, seem to need friends. For how would one benefit from such prosperity if one had no opportunity for beneficence, which is most often displayed, and most highly praised, in relation to friends? And how would one guard and protect prosperity without friends, when it is all the more precarious the greater it is? But in poverty also, and in the other misfortunes, people think friends are the only refuge. Moreover, the young need friends to keep them from error. The old need friends to care for them and support the actions that fail because of weakness. And those in their prime need friends to do fine actions; for "when two go together $[\ldots]$ ", they are more capable of understanding and acting. "

${ }^{127}$ The expression is borrowed from J.O. Urmson, Aristotle on Excellence of Character, 71 (no. 834) NEW

BLACKFRIARS 33 (1990).

${ }^{128}$ HUTCHINSON, supra note 96, at 35-36.
} 
to live a flourishing life (eudaimonia), and the absence of which will frustrate a person from moving towards such a telos. ${ }^{129}$

It is characteristic of virtues that they are exhibited in, and built up from, those actions "in which they are instanced". ${ }^{130}$ The courageous person is the person who performs courageous acts, the just person is the person who acts in a just manner, and so on. The dispositions to act in a particular way that the virtues create are "well-entrenched in [their] possessor", ${ }^{131}$ in the sense that they say something about who a person is as a moral agent. He who possesses the virtues is "a morally good, excellent, or admirable person who acts and reacts well, rightly, as [he] should." 132 The virtues refer to something that a person is, not something that a person has. It is important for a correct understanding of the virtues to insist on the fact that they are not a means to an end, nor a preparatory exercise which is independent from the life of human flourishing. The virtues are "a necessary and central part"133 of a well-lived, flourishing, life, and virtuous actions are the component parts of such a life. It is often said that "a person has this or that virtue", or that "a person acquired (or should acquire) this or that virtue". However, in the Aristotelian tradition, these phrases do not imply that virtue is something that one can purchase or hoard like some valuable physical object, but that there is a developmental aspect to virtue. Virtue is "acquired" through education and through the habitual performance of virtuous actions.

Because the "possession" of virtues is a matter of becoming a certain type of person, the virtues also make those who acquire them reliable for others. However, they do so in a different way from mere habits (such as drinking coffee every morning, or driving the same route to work every day). ${ }^{134}$ Virtues of character imply, at the same time and in a harmonious manner, a disposition to act virtuously, a disposition to feel good when performing virtuous actions, a disposition to desire virtuous actions, and a disposition to approve of the virtuous actions of others (and disapprove of their unvirtuous actions). ${ }^{135}$ A person who possesses the virtue of honesty, for instance, is someone others can rely on to be honest in word and deed, in a natural, eager, and unhesitant way, and who will also disapprove of dishonesty when faced with it, will avoid consorting with those who are

\footnotetext{
${ }^{129}$ MACINTYRe, AFter VIRTUE, supra note 86, at 174.

${ }^{130}$ Anscombe, supra note 80, at 18.

${ }^{131}$ Hursthouse \& Pettigrove, supra note 90, at para. 1.1.

132 HuRsthouse, supra note 82, at 13.

${ }^{133}$ MACINTYRe, AFTER VIRTUE, supra note 86, at 174.

${ }^{134}$ Hursthouse \& Pettigrove, supra note 90, at para. 1.1.

${ }^{135}$ See HutChinson, supra note 96, at 93.
} 
dishonest, will admire the honesty of others, and will try very hard to bring up his children to be honest as well. ${ }^{136}$

Acting virtuously and doing the right thing is not easy, and the standards for virtue in the Aristotelian tradition are quite demanding. According to Aristotle, in a metaphorical sense, every virtue is a middle point positioned between two forms of excess (vices). ${ }^{137}$ For instance, courage is the middle point between rashness and timidity, temperance is the middle point between overindulgence and insensitivity, magnanimity is the middle point between thinking too little of yourself and having delusions of grandeur, liberality is the middle point between prodigality and meanness, and honesty is the middle point between being a liar and being tactless. ${ }^{138}$ The virtues are not merely traits of character, but excellences of character, because "each of the virtues involves getting things right", ${ }^{139}$ something that is only possible through the exercise of an ability known as "practical wisdom" (phronēsis).

\section{Practical wisdom}

Practical wisdom (phronesis) is the intellectual excellence required in order to engage in good practical reasoning. Practical reasoning is a specific type of reasoning which Aristotle distinguishes from theoretical reasoning (episteme) and productive reasoning (techne $).{ }^{140}$ Practical reasoning leads to actions, decisions, intentions, and the formulation of life plans, ${ }^{141}$ theoretical reasoning leads to the formulation of beliefs, explanations, and predictions, ${ }^{142}$ whereas productive reasoning leads to creative ideas in work and art. ${ }^{143}$ Practical reasoning is pursued as a means to

\footnotetext{
${ }^{136}$ HuRSTHOUSE, supra note 82, at 11.

${ }^{137}$ NE 1107a1-1107a09.

${ }^{138}$ See NE 1107b1-1108b7; MACINTYRE, AFTER VIRTUE, supra note 86, at 180.

${ }^{139}$ HurSTHOUSE, supra note 82, at 12. See also NE 1170a9-1170a11: "The excellent person, insofar as he is excellent, enjoys actions in accord with virtue, and objects to actions caused by vice, just as the musician enjoys fine melodies and is pained by bad ones."

${ }^{140}$ Compare NE 1140al et seq. (discussing productive reasoning), NE $1140 \mathrm{~b} 30$ et seq. (discussing theoretical reasoning), and 1140a25 et seq. (discussing practical reasoning). See also NE 1141a10 et seq. (where Aristotle discusses the differences between theoretical reasoning and practical reasoning).

In modern moral theory, practical reasoning is often contrasted only with theoretical reasoning. See, e.g., R. Jay Wallace, Practical Reason, in THE STANFORD ENCYCLOPEDIA OF PHILOSOPHY (Edward N. Zalta ed., 2014), available online at https://plato.stanford.edu/archives/sum2014/entries/practical-reason/

${ }^{141}$ See Gilbert Harman, Practical Aspects of Theoretical Reason, at 1, available online at https://pdfs.semanticscholar.org/539d/74b05c43ed7e80393a73a6c43e4fc7a84bbd.pdf. ${ }^{142} I d$.

${ }^{143}$ DAVID Ross, ARISTOTLE 195 (6 ${ }^{\text {th }}$ ed., Routledge 1995).
} 
conduct, theoretical reasoning is pursued for its own sake, and productive reasoning is pursued as a means to producing something useful or beautiful. ${ }^{144}$

The intellectual excellence of practical reasoning and the excellences of character can only be developed together, as a harmonious whole. According to Aristotle, the truly virtuous man must have both practical reasoning and virtues (excellences of character), and no man can acquire practical wisdom without first acquiring virtues. ${ }^{145}$ This is because vices morph how we perceive reality and cause us to be deceived about what goods are truly worth pursuing. ${ }^{146}$ Virtues, by contrast, allow us to be well oriented and to perceive events in the right way, thus laying the groundwork for good practical reasoning.

The quintessential practical question is "What am I to do now, under the present circumstances?"147 A distinctive feature of Aristotelian ethics is the fact that this question is seen as a part of a larger question, which has the function of integrating the present moment's choice into the narrative of an entire human life. That larger question is: "What sort of person am I to become?"148 Aristotle would have us pick our role models very carefully, individually and as a society, because the answer to the broader question provides the best practical guidance for answering its narrower instantiation. When the answer to "Who I am to become?" is "a good, virtuous, person," then "What am I to do now?" translates into "What would a virtuous man do now, under the present circumstances?"

An important part of what good practical reasoning has to offer is the ability to understand that "human beings are by nature such as to find their fulfilment [only] in relationship with others". ${ }^{149}$ The right way of interacting with others is a matter that is both ethical and political and, in fact, in Aristotle's philosophy, ethics is understood as a branch of politics. A virtuous and free man must

\footnotetext{
${ }^{144} I d$.

${ }^{145}$ HUTCHINSON, supra note 96, at 2.

${ }^{146}$ Id.; NE 1113a22-33; 1140b17-20; 1144a23-b1.

${ }^{147}$ Aristotle takes it as a given that this is a question only we human beings ask (as opposed to non-human animals, who do not have the capacity for practical rationality). See Aristotle, Politics [1253a8-18], in THE BASIC WORKS OF ARISTOTLE, at 1129 (Richard Mckeon ed., The Modern Library 2001).

${ }^{148}$ See MACINTYRE, AFTER VIRTUE, supra note 86, at 138.

${ }^{149}$ Gerard J. HugheS, ARistotle On Ethics 179 (Routledge 2001).
} 
acquire "the knowledge and the ability both to rule and be ruled", ${ }^{150}$ in other words, a good man must also be a good citizen. ${ }^{151}$

Virtues such as justice, liberality, or friendliness are concerned exclusively with interpersonal matters, i.e. with the right way of interacting with other persons. Unsurprisingly, justice

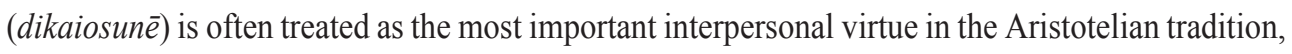
and Aristotle himself gave it a place of pre-eminence in his ethical theory. ${ }^{152}$ It is a matter of common sense that good relationships are difficult, if not impossible, to maintain when we act unjustly towards others, but flourish when our actions towards them are just. A citizen that is uneducated in the virtue of justice cannot properly understand what he owes others, or what he can legitimately ask from others.

Lato sensu, "justice" (dikaiosunē) was understood by Aristotle to mean "the practice of perfect virtue", ${ }^{153}$ i.e. adherence to, and respect for, the law of the state (polis), or "the exercise of all the virtues by each citizen in his relationships with other citizens". ${ }^{154}$ In a narrower sense, dikaiosune designates a specific virtue. Justice stricto sensu, or justice-as- $a$-virtue, requires that our dealings with others be fair. Thus, the just person is the person who is disposed, as a matter of character, to care for others and treat others fairly. Using the metaphor of the middle ground once more, it could be said that justice is placed between the vices of "doing injustice", where the agent does not have enough regard for the interests of others, and "suffering injustice", where the agent does not have enough regard for his own interests. ${ }^{155}$ However, what this metaphorical use may hide from view is the connection between the virtue of justice, on the one side, and the constitution and development of communities, institutions, and the laws that govern them, on the other. Justice, in its narrow sense, is a "concept by means of which the law in action, and not merely the moral

\footnotetext{
${ }^{150}$ MACINTYRe, Whose Justice? Which RATIONALity?, supra note 86 , at 103.

${ }^{151}$ MacInTYRe, After Virtue, supra note 86, at 158, 164; MACINTYRe, Whose Justice? Which RATIONALity?, supra note 86 , at 103.

152 Joe Sachs, Aristotle: Ethics, in INTERNET ENCYCLOPEDIA OF PHILOSOPHY, available online at https://www.iep.utm.edu/aris-eth/

${ }_{153}$ Anton-Hermann Chroust \& David L. Osborn, Aristotle's Conception of Justice, 17 Notre Dame L. REV. 129, 134 (1942); NE 1129b30.

${ }^{154}$ MACINTYRe, Whose Justice? Which RATIONALITY?, supra note 86, at 103.

${ }^{155}$ See MacInTYRe, After VIRTUE, supra note 86, at 180.
} 
conduct of man, can also be evaluated". ${ }^{156}$ As Aristotle pointed out, what is done in violation of justice is always unlawful, whereas unlawful acts are not always unjust. ${ }^{157}$

Justice stricto sensu is of two kinds: distributive justice and corrective ${ }^{158}$ justice.

When we said above that "the practice of tort law is aimed at specifying (spelling out), in various individual circumstances, what justice requires from private parties in their specific interactions with other private parties", ${ }^{159}$ by "justice" we meant "the virtue of justice" in its two forms. The argument that follows therefore depends very much on how corrective and distributive justice are defined and understood.

C. Distributive and Corrective Justice

The distinction between distributive and corrective justice is based on the types of acts and activities in which the virtue of justice manifests itself. (1) Distributive justice is exhibited in acts and activities concerned with the fair distribution of goods, whereas (2) corrective justice is exhibited in acts of righting (or correcting) wrongs. ${ }^{160}$

1. Distributive justice

Distributive justice is the part of the virtue of justice which has as its object the distribution of external goods. In this sense, it is possible to speak of a "practice of distributive justice" as a component part of the practice of politics, i.e. the part of politics that deals with how external goods ought to be distributed. Politics, in the Aristotelian tradition, is itself conceived as a practice with goods internal to itself. ${ }^{161}$ The acquisition of the virtue of distributive justice by participants in the practice, as well as the development of better methods, rules and principles of distribution, are some of its essential internal goods.

Practical reasoning about distributive justice goes deeply into the very fabric of the economic, political, and social frameworks of a community. ${ }^{162}$ Distributive justice is therefore not only a

\footnotetext{
${ }^{156}$ Chroust \& Osborn, supra note 153 , at 130.

${ }^{157}$ NE 1130b12-1130b13.

${ }^{158}$ Also known as commutative justice, or rectificatory justice.

${ }^{159}$ Supra Part B.3 of the present chapter.

${ }^{160}$ HuGHES, supra note 149, at 181 n.10.

${ }^{161}$ MACINTYRE, AFTER VIRTUE, supra note 86, at 264.

162 Julian Lamont \& Christi Favor, Distributive justice, in THE STANFORD ENCYCLOPEDIA OF PHILOSOPHY (Edward N. Zalta ed., Winter 2017 Edition), available online at https://plato.stanford.edu/archives/win2017/entries/justicedistributive/.
} 
virtue of individuals, but also a virtue of societies and institutions. ${ }^{163}$ Questions such as "who can marry whom, and in what kind of circumstances?", "who is allowed access to a particular profession, and under what conditions?", "who can hold political office, and how can access to political office be restricted?", "who is allowed to vote?," and "who is entitled to social security benefits?" are all questions of distributive justice. Even questions such as "who can be legally recognized as a person?" or "who can be a citizen of this or that state?" require an account of distributive justice.

External goods, as defined above, ${ }^{164}$ form the object of distributive justice. ${ }^{165}$ Money, land, natural resources, and honours are among the obvious things that belong to the category of external goods, but personhood, citizenship, filiation, access to public goods, as well as most social and political rights, also fit our definition of external goods and can be subject to distribution. Internal goods are excluded because they cannot be attributed, possessed, or owned, and therefore cannot be distributed.

The object of distributive justice may also consist of burdens, including taxes, penalties, and responsibilities. Some external goods correlate with burdens, and others come with accessory or associated burdens. A fair distribution of external goods can therefore not ignore the distribution of related burdens.

For our purposes, it is important to emphasize that legally protected interests and rights, as well as the legal duties and obligations that correlate with them, are external goods and constitute appropriate objects of distributive justice. "Whose and which interests are protected by the law?", "to what extent?", as well as "whose and which duties are enforced by the law?" and "to what extent?" are therefore appropriate questions within the practice of distributive justice.

\footnotetext{
${ }^{163}$ See RAWLS, supra note 92, at 3 (describing justice as "the first virtue of social institutions"). See also PLATO, REPUBLIC at 43 [368e-369a] ( $2^{\text {nd }}$ ed., G.M.A. Grube trans., revised by C.D.C. Reeve Hackett Pub. Co. 1992). (distinguishing between justice as a virtue of societies and justice as an individual virtue).

${ }^{164}$ Supra Part B.2 of this chapter.

${ }^{165}$ Aristotle indicated that anything that can be shared between members of a community can constitute the object of distributive justice, and provided the examples of money and honours. See NE 1130b31-33. Closer to our own times, the natural law scholar John Finnis identified "resources, opportunities, profits and advantages, roles and offices, responsibilities, taxes and burdens" as appropriate objects of distributive justice. JOHN FINNIS, NATURAL LAW AND NATURAL RIGHTS 166 (1980). Aristotle's and Finnis's formulations are open-ended and relatively broad, thus fitting very well with the idea that external goods and associated burdens are the objects of distributive justice. Other authors, however, adopt narrower conceptions of the object(s) of distributive justice. Robert Nozick, for instance, referred to distributive justice in "holdings", a term that seemingly excludes relational goods, as well as public goods. ROBERT NOZick, ANARChY, STATE AND UtOPIA 150 (Basil Blackwell 1974).
} 
Distributive justice requires (but should not be identified with) a method, a rule, or a principle of distribution according to which each person will receive his or her fair share of those goods that are susceptible to distribution. ${ }^{166}$

Aristotle wrote very little about distributive justice in the Nicomachean Ethics, but his short account contains all the necessary building blocks for a coherent theory. According to Aristotle, external goods ought to be distributed in proportion to merit. ${ }^{167}$ How merit is estimated, however, depends on the type of political organization within which the distribution is made. In a democracy, free citizenship is the standard, and all free men ought to receive an equal share of external goods, in an oligarchy the standard is either wealth or noble birth, and external goods are distributed in proportion to wealth or to degrees of nobility, whereas in an aristocracy the standard is virtue (understood as moral excellence), and the more virtuous can claim a higher proportion of external goods than the less virtuous. ${ }^{168}$ Of the three forms of political organization, Aristotle favoured aristocracy, because in any community true transcendent virtue is likely to be found in either one or a very small number of individuals. ${ }^{169}$ He envisioned either a monarchy led by one excellent individual (a "god among men") ${ }^{170}$ or a government in which only those men who possess a high degree of virtue simultaneously rule. ${ }^{171}$ Nevertheless, Aristotle understood that both options are unattainable ideals, and therefore proposed a system of limited democracy, mixed with "a strong dash of oligarchy"172 for the Greek city-states of his time.

In a world such as ours, in which the distribution of most external goods is derived from a multilevel system of legal sources ${ }^{173}$ which are intertwined with norms and standards set by private parties and organizations, and norms generated by formal and informal communities and institutions, ${ }^{174}$ we cannot simply follow the recommendations Aristotle outlined for the ancient

\footnotetext{
${ }^{166}$ See Macintyre, Whose Justice? Which Rationality?, supra note 86, at 104.

${ }^{167} \mathrm{NE} 1130 \mathrm{~b} 26$.

${ }^{168} \mathrm{NE} 1130 \mathrm{~b} 27-29$.

169 See Ross, supra note 143, at 265.

${ }^{170}$ Aristotle, Politics [1284a3-11], in The BASIC Works of ARISTOTLE, at 1195 (Richard Mckeon ed., The Modern Library 2001).

${ }^{171} I d$. at 1189 [1332a32-38].

172 Ross, supra note 143 , at 265.

${ }^{173}$ See Ramses A. Wessel \& Jan Wouters, The Phenomenon of Multilevel Regulation: Interactions between Global, EU and National Regulatory Spheres, InTERnATIONAL ORGANIZATIONS LAW REVIEW 257 (2007).

${ }^{174}$ Id.; see also Oliver Treib et al., Modes of Governance: A Note Towards Conceptual Clarification, 14(1) JOURNAL of European Public Policy 1 (2007); Grainne De Burca, Developing Democracy Beyond the State, Columbia Journal of Transnational Law 46, 101, 107 (2009); JAn M. Smits, Private Law 2.0: On the Role of Private ACtors in A Post-NATIONAL Society 8-12 (Eleven International Publishing 2011).
} 
Greek city-states. We can, however, think of ways to develop and implement his principles of distributive justice, to the extent they are coherent, rationally defensible, and normatively attractive. Thus, a modern Aristotelian theory of distributive justice would: first, have us design norms which aim towards the common good of those communities in which the norms originate and/or are applicable; second, require from our political communities to aim, first and foremost, at a distribution in which a sufficient quantity of external goods ${ }^{175}$ is supplied to all citizens so that the conditions for the existence and development of the virtues are satisfied; and third, require from our political communities to then distribute the remaining goods in proportion to virtue. The first principle and the third can be found expressly formulated by Aristotle. The second is a necessary corrective to Aristotle's theory of distributive justice. Aristotle understood that there was a link between the possession of external goods and the life of human flourishing, ${ }^{176}$ but he underestimated, in our view, the extent to which the lack of certain external goods can hinder the education and development of the virtues (and this corrective allows us to reject from within Aristotle's own framework arguments such as those justifying the exclusion of women, ${ }^{177}$ "natural slaves," and "barbarians"178 from the political and economic life of the polis).

The type of account of distributive justice we suggested above may sound distant, or perhaps even strange, to most proponents of modern liberalism, but while there are indeed some reasons to initially feel uneasy about Aristotle's account of distributive justice, the result of working through this uneasiness may leave fewer scars on the Aristotelian project than on some of the most influential modern liberal theories of justice. Particularly, there are three interconnected modern liberal ideas which are deeply ingrained in the dominant culture of our times, but which, upon closer scrutiny, do not seem to be superior to the pre-modern Aristotelian ideas they have replaced. In reflecting on these ideas, modern Aristotelian accounts of virtue and ethics provide perhaps the

\footnotetext{
${ }^{175}$ The way the principle is phrased above requires some added nuance, which was omitted only for the sake of brevity. It is not just the quantity of external goods that matters in this initial distribution, but also that the right kinds of external goods are first distributed. External goods are of many kinds, and some external goods are incommensurate with others (for instance, rights such as the right to a fair trial or the right to marry are of a different nature and cannot properly be weighed against property rights). In this first distribution, all those rights and obligations that ensure human dignity, the recognition of citizenship, lack of discrimination, are to be distributed alongside material goods that would ensure good physical and mental development and a decent education for all citizens.

${ }^{176} \mathrm{NE} 1099 \mathrm{a30}-1099 \mathrm{~b} 4$.

${ }^{177}$ See Aristotle, Politics [1259a37-1259b10], in THe BASIC WorKS OF ARISTOTLE, at 1143 (Richard Mckeon ed., The Modern Library 2001).

${ }^{178} \mathrm{Id}$. at 1128 [1252a32-1252b8], 1145 [1260a33-1260b7].
} 
best standpoint for a sustained and coherent critique of the moral and political presuppositions ingrained in the most recent liberal theories of justice. ${ }^{179}$

What are these three interconnected ideas? First, we have come to think and speak of distributive justice not as a virtue or as a practice with internal goods, but as a (factual or normative) state of affairs. A few examples from some of the most influential theories of distributive justice showcase this shift in modern discourse quite clearly. Rawls's two principles of justice, for instance, posit an ideal normative state of affairs (an ideal system of rules) in which rights and liberties are distributed equally, but in which social and economic inequalities are justified as long as they arise out of conditions of fair equality of opportunity (the "equality of opportunity principle") and they are to be to the greatest benefit of the least advantaged members of society (the "difference principle"). ${ }^{180}$ Similarly, Dworkin's theory of "resource egalitarianism" also proposes an ideal state of affairs - in which the allocation of resources mimics a desert-island auction in which people start off with equal resources, but are allowed to end up with an unequal share of economic benefits because of the choices they make. ${ }^{181}$ Going a bit further back in time, and further to the left, Marx's distributive principle of "to each according to his need" is also based on an ideal image of human nature, of the state, and of the world even, in which all distinctions of class and all relations of dominance have been eliminated. ${ }^{182}$ And the examples can be piled on ${ }^{183}$ becauseand here we move on to our second point - from the Enlightenment onwards, the idea of a human telos lost its central place in moral philosophy. Without it, any image of "man-as-he-should-be" has also (almost) disappeared from modern moral and political theory. ${ }^{184}$ The ideal element in

\footnotetext{
${ }^{179}$ Especially worth mentioning are the ideas formulated by Alasdair MacIntyre and Julia Annas, who have been, more than any other philosopher or scholar consulted for this chapter, very influential on how the author of this book has come to understand the contrast between modern liberal theories and Aristotelian virtue ethics.

${ }^{180}$ RAWLS, supra note 92 , at 60-61, 302-03.

${ }^{181}$ RONALD DWORKIN, Justice FOR HEDGeHogs 351-64 (The Belknap Press of Harvard University Press 2011); Ronald DWorkin, SOVEREIGn VirTue. The Theory AND Practice OF EQuality 65-109 (Harvard University Press 2000); Ronald Dworkin, What is Equality? Part 2: Equality of Resources, 10(4) PHILOSOPHY \& PUBLIC AFFAIRS 283 (1981).

${ }^{182}$ Karl Marx, Critique of the Gotha Program, in KARL MARX. SeleCted Writings 564-70 (David McLellan ed., Oxford University Press).

${ }^{183}$ In tort law theory, the best example can be found in the work of Jules Coleman. See CoLEMAN, RisKS AND WRONGS, supra note 50, at 310: "[...] the annulment view appears to hold that justice requires that a certain state of the world be brought about, not that anyone in particular has a special reason in justice for bringing it about. And this is precisely the way we think about distributive justice." (emphasis added); See also, Jules Coleman, The Mixed Conception of Corrective Justice, 77 IowA L. REV. 427, 432 (1991-1992).

${ }^{184}$ One significant exception in modernity is Friedrich Nietzsche, whose moral theory is indeed based on an ideal picture of "man-as-he-should-be" (the Übermensch). See FriedRICH NiETZSChe, ThUS SpOKE ZARATHustRa (R. J. Hollingdale trans., Penguin Books 2003).
} 
modern moral theories has been, for the most part, transmuted somewhere else: in the typical deontological theory it is the ideal system of principles or rules, whereas in the typical consequentialist theory it is an ideal (factual) state of the world. This key observation was made by Alasdair MacIntyre, who has also argued that the rejection of Aristotle's account of the human telos by the most influential moral theories of the Enlightenment and post-Enlightenment has led not to progress, but to incoherence in both moral and political philosophy. ${ }^{185}$ According to MacIntyre, in the Aristotelian tradition, there is an essential contrast between "man-as-he-happensto-be" and "man-as-he-could-be-if-he-realized-his-telos", and moral precepts have the purpose of enabling man to pass from the former state to the latter. ${ }^{186}$ It is in this sense that moral precepts are teleologically justified: they aim at correcting, improving, and educating human nature. ${ }^{187}$ By rejecting the notion of a human telos, and therefore removing "man-as-he-could-be-if-he-realizedhis-telos" from their accounts, modern moral theorists have condemned themselves to formulating moral schemes based only on the remaining elements: human nature as it actually is ("man-as-hehappens-to-be") and a set of moral precepts. ${ }^{188}$ Consequently, "what is the connection between these two remaining elements?" and "what purpose do moral precepts serve, if any?" emerged in post-Enlightenment philosophy as fundamentally unresolvable questions. Third, some of the most influential modern theories of justice either reject or cannot make sense of the notions of merit (of an individual human being) and the common good (of a political community). Making distributions based on desert only makes sense within a political project in which all the members of a community are working together, towards the achievement of a common purpose. In more precise terms, the Aristotelian notion of desert "is at home only in the context of a community whose primary bond is a shared understanding both of the good for man and of the good of that community, and where individuals identify their primary interests with reference to [both] these goods." 189 This type of political project is, however, more and more foreign to us, and the manner in which influential authors, such as John Rawls and Bruce Ackerman, have articulated the premises of their theories of distributive justice is illustrative. ${ }^{190}$ Both Rawls and Ackerman

\footnotetext{
${ }^{185}$ MACINTYRE, AFTER VIRTUE, supra note 86, at 61-73.

${ }^{186} I d$. at 65.

${ }^{187} \mathrm{Id}$.

${ }^{188} \mathrm{Id}$.

${ }^{189} \mathrm{Id}$. at 290 .

${ }^{190}$ We should also just mention here, even if just in passing, that the premises discussed bellow appear, in more nuanced forms, also in the theories of justice developed by Robert Nozick and Ronald Dworkin. The choice to
} 
understand the notions of merit and the common good as fundamentally unrelated to each other and irrelevant to (distributive) justice.

Rawls rejected merit-based conceptions of justice expressly. He believed that inequalities in society "cannot possibly be justified by an appeal to the notions of merit or desert" 191 because both native endowments and superior character depend on factors beyond the control of the person who possesses them. ${ }^{192}$ However, every time Rawls spoke of "superior character" or "virtue" he referred to something like, or closely analogous to, native endowments. ${ }^{193}$ The meaning Rawls assigned to terms such as "virtue" or "character" takes into consideration only how people are by nature and/or by circumstance. He never even considered a conception of virtue (or character) which would be derived from an account of "human-nature-as-it-could-be-if-man-realized-histelos," instead of human nature as it is. Yet, such a conception of virtue would be less vulnerable to Rawls's argument because an excellence of character that is acquired through action can be ascribed to an agent the same way his actions are (including his choices). In the Aristotelian tradition, virtue is something that is learned and developed through right action, not a mere native propensity; and, as mentioned earlier, the "possession" or "acquisition" of virtue is a dynamic process of constant improvement - a matter of becoming a certain type of person. ${ }^{194}$ Moreover, Rawls's account of justice cannot even possibly accommodate a coherent notion of merit because it purports to be neutral between various conceptions of the good. Consequently, his theory of justice lacks, and in fact does not even purport to provide, an account of the common good. The entire project is aimed at articulating principles of justice that would be agreed on by any rational person placed behind a "veil of ignorance". ${ }^{195}$ However, the conditions behind Rawls's veil of ignorance are such that each and every party to the original agreement would not know where they would be born, to what parents, what social class they would belong to, or how intelligent they would be; ${ }^{196}$ and most importantly, each contracting party would not know their own conception

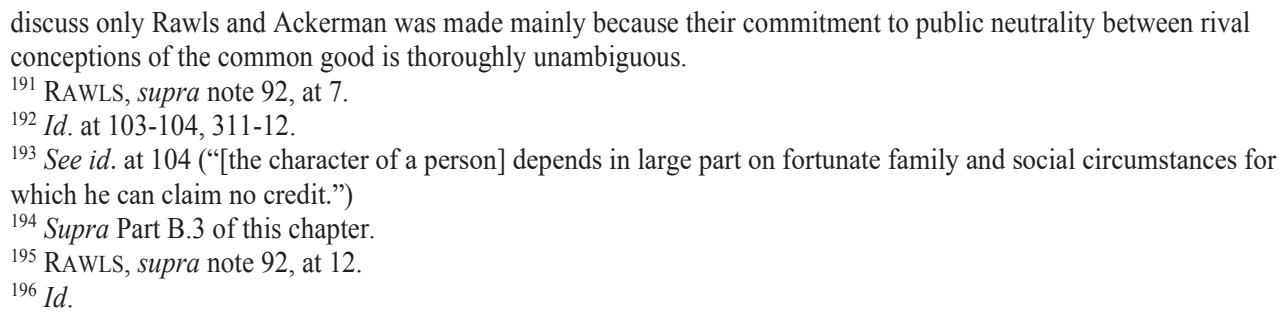


of the good. ${ }^{197}$ In fact, all the contracting parties (collectively) behind the veil of ignorance would not have any conception of their own good or of the common good. ${ }^{198}$ Interestingly enough, despite being despoiled of any conception of the good and of most of the bonds that contribute to personal identity, Rawls's contracting parties are still presumed to know and be able to articulate what their interests would be in actual human communities. Rawls's assumption that any person would prefer "more rather than less primary goods"199 but still accept the difference principle as he formulated $\mathrm{it}^{200}$ should arouse only suspicion. Without the components of personal identity, what such hypothetical interests would be in the real world becomes a matter of pure imagination, not of deductive reasoning. Many more arrangements could be imagined behind a "veil of ignorance" as alternatives to Rawls's two principles of justice, ${ }^{201}$ and between such alternative arrangements there seems to be no rational criterion of choice.

Bruce Ackerman's "Social Justice in the Liberal State"202 provides a different, more unusual but nonetheless interesting, account of political liberalism and of distributive justice which further reinforces the assumption that the common good has no place in a modern liberal theory of justice. Ackerman's method of deriving principles of distributive justice, which he referred to as "neutral dialogue" 203 or "constrained conversation", 204 is derived from three basic principles: (a) the principle of rationality — according to which all power relations must be rationally justified, ${ }^{205}$ (b) the principle of consistency - according to which any reason advanced by a "power wielder" on a particular occasion must "not be inconsistent with the reasons he advances to justify his other claims to power"; ${ }^{206}$ and (c) the principle of neutrality - which holds that:

No reason is a good reason if it requires the power holder to assert:

\footnotetext{
${ }^{197} I d$. at $12,18,93$.

${ }^{198} I d$. at 12 .

${ }^{199}$ RAWLS, supra note 92, at 93.

${ }^{200}$ Id. at $302-03$.

${ }^{201}$ For instance, a rational person who is less risk-averse may reasonably accept a distribution in which the worst off in society do not benefit from redistributions, but where the chance of ending up in the lower social class is very low, whereas the chance of ending up in a higher social class is higher and the benefits enjoyed by the better off are much higher.

${ }^{202}$ BruCE ACKerman, Social Justice In the Liberal State (Yale University Press 1980).

${ }^{203} \mathrm{Id}$. at 12 .

${ }^{204} \mathrm{Id}$. at 14 .

${ }^{205} I d$. at 4-5.

${ }^{206} \mathrm{Id}$. at 7.
} 
(a) that his conception of the good is better than that asserted by any of his fellow citizens, or

(b) that, regardless of his conception of the good, he is intrinsically superior to one or more of his fellow citizens. ${ }^{207}$

It is this last principle, the principle of "neutrality", and specifically the first set of reasons it rejects, that has the effect of ousting any conception of the common good from Ackerman's theory of distributive justice. If the participants to a "neutral dialogue" cannot even put forward a conception of the good, they most definitely cannot agree on a good that would be common in their political community. The principle of neutrality makes it impossible to even have a productive dialogue about which goods are worth pursuing, individually or collectively. The ability to assert and argue that a particular conception of the good is better than another advanced by a fellow citizen is a precondition of any political project based on the common good. Without it, and without some rational criteria to resolve disagreements which arise from rival accounts of the good, political projects aimed at the common good are bound to fail. The liberal solution, which to a certain extent runs through Rawls's theory and is explicitly articulated by Ackerman, is to not even bother with the common good, and work instead towards a political project in which, in an atomized manner, individuals can each maximally and frictionlessly pursue their own good as they understand it.

Aristotelian distributive justice provides an alternative framework to the "public neutrality" thesis that runs through Rawls's and Ackerman's theories, and that does require serious thinking about the common good and an argumentative space for formulating and debating rival conceptions of the good for man and the common good of communities. ${ }^{208}$

2. Corrective justice

Corrective justice is also a part of the virtue of justice, but has as its object the righting of wrongs, rather than the distribution of external goods. Associated to the virtue of corrective justice,

\footnotetext{
${ }^{207} I d$. at 11 .

${ }^{208}$ As a side point, it is only at the level of argument that conceptions of justice, and of ethics in general, which rely on "public neutrality" and "individual interests" (seen separately from the common interest) became dominant. In their actual practice, modern liberal states never truly adhered to the neutrality thesis. As Robert and Edward Skidelsky pointed out: "the French state is not neutral in its treatment of hijab wearers, nor is any liberal state neutral with regard to heroin." ROBERT SKIDELSKY \& EDWARD SKIDELSKY, HOW MUCH IS ENOUGH: MONEY AND THE GOOD LIFE 87 (Penguin Books 2013).
} 
there are characteristic actions, activities, attitudes, and beliefs that constitute a "practice of corrective justice". 209

There are a few abstract commonalities between corrective and distributive justice. Both forms of justice involve a norm (or a set of norms) of fairness or equality, according to which each person is given his or her due. ${ }^{210}$ Also, they are both relational notions: corrective and distributive justice constitute "virtue in relation to another". ${ }^{211}$ However, corrective justice and distributive justice rely on different kinds of norms of equality and relate individuals in distinctive ways. They are, in an essential sense, very different forms of justice, and play distinctive roles in practical reasoning. ${ }^{212}$

First, the type of equality embedded in all corrective justice norms is "arithmetic equality", whereas the type of equality embedded in distributive justice norms is "proportional equality". 213 Corrective justice restores equality in situations that resemble the following mathematical pattern: say a line $(\mathrm{AB})$ is cut into unequal parts ( $\mathrm{AC}$ being the larger part and $\mathrm{CB}$ the smaller), and say that $\mathrm{D}$ is the halfway point between $\mathrm{A}$ and $\mathrm{B}$, equality is restored if $\mathrm{DC}$, which is the amount by which $\mathrm{AC}$ exceeds the half, is taken away from the $\mathrm{AC}$ segment and added to the $\mathrm{CB}$ segment. ${ }^{214}$ Corrective justice regards the interaction between two parties as an interaction between equals, and aims to restore equality when it is disturbed. Distributive justice follows a different kind of mathematical pattern which requires at least four terms: say $\mathrm{A}$ is the number we assign to a person's merit, and that person is given an entitlement over an external good valued at $X$, and a second person, whose level of merit is evaluated at B, is given an entitlement over an external good valued at $\mathrm{Y}$, distributive equality is achieved if A divided by $\mathrm{X}$ equals B divided by $\mathrm{Y} .{ }^{215}$

\footnotetext{
${ }^{209}$ Jules Coleman noted that the key to understanding the bounds of the "practice of corrective justice" is the more informal, or non-legal, set of actions and attitudes in which one person says to another :"There is a mess that you are responsible for, and because you are, you are going to have to do something about it." COLEMAN, RISKS AND WRONGS, supra note 50, at 479.

As long as "mess" is interpreted as an "inter-personal wrong", we are in agreement with Coleman, but Coleman seems to have interpreted "mess" to mean "wrongful losses" (in which case Coleman's definition of the relevant "mess" is too narrow). See id., at 329 ("corrective justice imposes a duty to repair wrongful losses on those agents responsible for them.”) (emphasis added).

${ }^{210}$ Stone, supra note 75 , at 152.

${ }^{211}$ NE $1129 \mathrm{~b} 27$.

${ }^{212}$ COLEMAN, RiSKS AND WrongS, supra note 50, at 309-10.

${ }^{213}$ NE 1132al-3.

${ }^{214} \mathrm{NE} 1132 \mathrm{a} 25-29$.

215 NE 1131a30-1131b9.
} 
The parties to a distributive justice relationship need not enter the relationship as equals, and unequal distributions may be obtained if there are differences of merit between them.

Second, corrective justice and distributive justice create different kinds of relationships between individuals and, because of this, they provide different kinds of reasons for acting. In distributive justice, all the individuals who make up a community are related to each other, but in a mediated way, through some criterion of merit. ${ }^{216}$ Thus, any right distribution of external goods requires the consideration of simultaneous claims made by all the members of the community. A distribution that ignores the legitimate claims of even one member of the community would be ab initio unjust, because it would imply that the omitted person has no merit, no worth, or no personhood in the community. Also, because the just nature of the community as a whole is at stake when an unequal distribution exists, each member of the community has a reason to act in accordance with the principles of distributive justice. ${ }^{217}$ Corrective justice, by contrast, is based on an immediate relation between two parties and, in principle, generates reasons for acting only between the person who wronged another and the person who is wronged. ${ }^{218}$ No other person in the community will have any reason to act on the basis of corrective justice. If, for instance, person A wrongs person B by destroying a beautiful object which belongs to B, B cannot ask, on the basis of corrective justice, the entire community to compensate him, nor can someone other than B call A to account. This is because only A and B have reasons based on corrective justice to react to the destruction of B's property. However, if one member of our community is starving, for whatever reason, and the rest of us have sufficient food, each one of us has a reason in distributive justice to contribute toward alleviating his hunger. Also, the person who is starving in a community of plenty has a claim against all the members of the community to be treated better.

It was stated above that "in principle, corrective justice generates reasons for acting only between the person who wronged another and the person who is wronged." The nuance was necessary because often corrective justice also requires the intervention of a third party. When the parties are unable to correct an injustice born from their voluntary or involuntary transaction themselves, because they disagree with regard to what happened between them or with regard to what one owes the other, a neutral third party (the judge) is often tasked with declaring what justice requires

\footnotetext{
${ }^{216}$ Stone, supra note 75 , at 152 .

${ }^{217}$ COLEMAN, RiSKS AND WRONGS, supra note 50, at 312.

${ }^{218} I d$. at 313, 319; Stone, supra note 75, at 152.
} 
of the two parties and with restoring the pre-existing equality between the parties. The judge (dikastes $^{219}$ ) must also possess the virtue of justice. His actions will exhibit virtue when he treats the parties as equals and restores unjust situations to equality, ${ }^{220}$ and exhibit vice when he does not treat the parties as equals ${ }^{221}$ or when he fails to provide a remedy that would correct the interpersonal wrong that triggered the dispute (the injustice).

It is possible to cumulate reasons for acting based on corrective justice with reasons for acting based on distributive justice and derive both sets of reasons from the same, or similar, sets of facts. For instance, if due to a serious accident for which A is responsible, B loses most of his property and the ability to work, B can, of course, ask for compensation from A on the basis of corrective justice. However, if, for whatever reason, A cannot compensate B (or can only compensate B to very a limited extent, or up until A compensates B), B will also have valid claims based in distributive justice - for instance, for social security benefits, medical assistance, etc. ${ }^{222}$ This does not mean that the two reasons for acting do not remain distinct. In our example, A has a reason to act and compensate $\mathrm{B}$ in corrective justice because through his actions he wronged $\mathrm{B}$. At the same time, he also has a different set of reasons to act in distributive justice. Such reasons to act have nothing to do with the fact that he wronged B, but are grounded in the fact that at least one member of the community has fallen below the minimum of external goods (the "safety net") to which he is entitled as a member of that community. For instance, A's reasons for paying his fair share in taxes (which, in turn, will be used in a national compensation scheme or for financing the social security system) are derived from an account which specifies how much each member of the community ought to contribute toward common (or public) projects. B's entitlements to payments from a compensation scheme or from social security are, in turn, also best explained in terms of

\footnotetext{
${ }^{219}$ The ancient Greek term for judge comes from the word dicha, which means "split in two". WEINRIB, THE IDEA OF PRIVATE LAW, supra note 19, at 65.

${ }^{220}$ NE 1132a6-7.

${ }^{221}$ Stone, supra note 75 , at 156.

${ }^{222}$ For a similar example, see COLEMAN, RiSKS AND WRONGS, supra note 50, at 313: "It may turn out that if I take all your possessions, you will fall below the social safety net. And everyone has a responsibility to see to it that people are situated above the safety net. I now have two connected responsibilities: one to return what I have taken; the other to see to it that you rise above the safety net. I now have two connected responsibilities: one to return what I have taken; the other to see to it that you rise above the safety net. I can discharge both by returning your possessions to you. Suppose I do not. Then you are below the safety net. In that case the duties of others under distributive justice apply. Each person has a duty to see to it that you rise above the safety net."
} 
the right distributions in the community: B has fallen below the safety net, and therefore is entitled to a higher share of external goods than he currently enjoys.

In addition to the reasons at play in corrective justice, as Jules Coleman rightly pointed out, any "proper conception of corrective justice will specify a mode of rectification as well as a reason for doing so."223

Starting with the latter issue, the reason for any corrective-justice-based mode of rectification is the occurrence of an interpersonal wrong, or, put differently, corrective action (rectification) is required because a wrong occurred. ${ }^{224}$ The mode of rectification, however, is more difficult to articulate in a simple sentence or formula. The formula we have inherited from Aristotle's account of corrective justice is still a good starting point, but some further explanation is necessary. According to Aristotle, an unjust "transaction" (the interpersonal wrong) always leads to a situation in which the wrongdoer, or the person responsible for the wrong, realizes a "gain," whereas the victim suffers a quantitatively equivalent "loss". 225 Corrective justice restores the parties to a state of equality by requiring the party who has gained (the party responsible for the wrong) to return the quantity in excess to the party who has suffered the loss (the victim). ${ }^{226}$

This account of the mode of rectification in corrective justice appears problematic, but only if the meaning of "gain" and "loss" is derived from plain language, or if the two terms are taken to refer only to "property", "possessions", or, at best, "holdings". 227 Under such interpretations of Aristotle, the scope of corrective justice becomes too narrow. In essence, any such conceptions of redress would work very well in disputes triggered by the unlawful taking of property: if A unlawfully takes an object that belongs to $\mathrm{B}$, returning the object does indeed restore the initial

\footnotetext{
${ }^{223}$ COLEMAN, RISKS AND WrONGS, supra note 50, at 311 (emphasis added).

${ }^{224}$ See WeInRIB, The IDEA OF PRIVATE LAW, supra note 19, at 135; Ernest J. Weinrib, Corrective Justice in a Nutshell, 52 (4) U. ToRonTO. L. J. 349, 350 (2002); Stone, supra note 75, at 159; In this respect, "civil recourse theory" follows a similar line of reasoning. See Goldberg \& Zipursky, Torts as Wrongs, supra note 49, at 973: “ “ "[W]hen a tort is committed, the victim of the mistreatment not only has suffered a setback in the eyes of the law but is also recognized as having a legitimate grievance against the wrongdoer. The defendant has violated her legal rights and that violation entitles her to a remedy as against the wrongdoer" (emphasis added).

${ }^{225} \mathrm{NE} 1132 \mathrm{a} 5-1132 \mathrm{~b} 20$; Stone, supra note 75, at 155.

${ }^{226} \mathrm{NE} 1132 \mathrm{a} 10-12$.

${ }^{227}$ The term "holdings" appears, for instance, very often in Weinrib's work, under the assumption that it captures very well the "quantity" Aristotle refers to in the Nicomachean Ethics. See, e.g., WEINRIB, THE IDEA OF PRIVATE LAW, supra note 19, at 60 ("Aristotle identifies equality as the mean of justice in holdings"), 63 ("the parties do not have the same quantity of holdings"). However, Weinrib attributes the term only to Aristotle, as in his own theory of corrective justice "the equality of corrective justice is the abstract equality of free and purposive beings under the Kantian concept of right" (Id. at 58), not an equality of "holdings".
} 
equality of holdings between the parties. However, in cases of destruction of property, physical injury, or death, the term "gain", at the very least, must be understood in a somewhat metaphorical sense, because otherwise there is no real equivalence to speak of between gain and loss. If $\mathrm{A}$ destroys B's property or infringes B's bodily integrity, we can, sure enough, say that B suffered a loss, but it is harder to say, in plain language at least, that A realized a "gain." A does not seem to own, possess, or hold more of anything compared to what he owned, possessed, or held prior to destroying B's property or before injuring B. ${ }^{228}$

The standard solution to this problem is to assign a different, broader, meaning to the terms "gain" and "loss". Thomas Aquinas, for instance, in a well-known passage from his Commentary on the Nicomachean Ethics, identifies the "quantity" at stake in corrective justice with an expression of the will:

[T] his division of action and passion brings about inequality because the assailant and the murderer have more of what is esteemed good, inasmuch as they have done their own will and so seem, as it were, to have gained. But the man who is wounded or murdered has more of evil insofar as he is deprived against his will of wellbeing or life, and so he seems as it were to have suffered a loss. ${ }^{229}$ (emphasis added)

The modern solution, proposed by authors such as Ernest Weinrib and Martin Stone, is to define the "quantity" gained by one party and lost by the other in normative terms. At stake, according to their interpretation of Aristotle, are the pre-existing entitlements that the parties had before the wrong occurred. According to Weinrib:

[E]quality is merely Aristotle's way of referring to the entitlement of each of the interacting parties to have what is rightfully theirs. A defendant who breaches that equality realizes a gain solely in the sense of having more than he or she ought to have as a matter of corrective justice, and similarly, mutatis mutandis, with the plaintiff's loss. Just as equality refers to the norm to which the interaction between

\footnotetext{
${ }^{228}$ For a similar argument, with similar examples, see LUCY, supra note 78, at 295-96.

${ }^{229}$ ThOMAS Aquinas, 1 COMmentary ON THE NicOMACHEAN ETHICS 411 [V. L.IV:C 952] (C. I. Litzinger trans., Henry Regnery Co. 1964).
} 
the parties ought to conform, so gain and loss refer to a correlatively structured violation of that norm. ${ }^{230}$ (emphasis added)

In a similar vein, Martin Stone wrote:

Fortunately, Aristotle himself indicates a different way of understanding the sort of equivalence in question here, one which makes property-taking a special-and not the paradigm-case of a transactional departure from equality: Following a wrongful transaction a victim has "too little" and the injurer "too much" simply in the sense that the injurer has that which, as a matter of justice, belongs to the victim: in a case of personal injury, the loss inflicted is his (the injurer's) to bear. On this understanding, we must of course give up the thought that Aristotle is even purporting to supply an independent test for identifying legal wrongs; the existence of the relevant losses and gains does not appear apart from the whole system of legal entitlements which specify the relevant notion of wrongdoing. ${ }^{231}$ (emphasis added)

It is doubtful that Aristotle had entitlements in mind, and even less likely that he had legal entitlements in mind. However, the solution proposed by Weinrib and Stone adds something of value to the original Aristotelian account, and we fully endorse the solution they propose. In fact, we would go even further. The virtue of corrective justice manifests itself in all actions aimed at restoring the initial entitlements of two parties linked by the occurrence of a wrong, even if the relevant wrong is not a legal wrong and even if the entitlements at stake are not legal entitlements. Thus, the practice of corrective justice is broader, encompassing not only legal wrongs, but also wrongs which are non-legal, i.e. which fall outside the ambit of any legal system. ${ }^{232}$ If I negligently bump into someone in a busy metro, and I don't cause a sufficiently serious injury, it is very unlikely that my action can be characterized as a legal wrong, ${ }^{233}$ but the situation may nevertheless be such that some corrective action, for instance in the form of an apology, is required. In such

\footnotetext{
${ }^{230}$ Weinrib, Corrective Justice in a Nutshell, supra note 224, at 354-55.

${ }^{231}$ Stone, supra note 75 , at 155.

${ }^{232}$ See also Gardner, What is Tort Law for? Part 1: The Place of Corrective Justice, supra note 1415, at 50: "[T]here is also corrective justice beyond tort law, and indeed beyond law. It exists in raw morality too, in the raw morality of trips to the beach, students in trouble, and disappointed children."

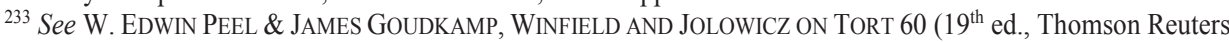
2014); CEES VAN DAM, EUROPEAN TORT LAW 112 (2 $2^{\text {nd }}$ ed., Oxford University Press 2013); Collins v Wilcock, [1984] WLR 1172, 1177.
} 
cases, the apology is an informal mode of rectification for a non-legal interpersonal wrong. Granted, non-legal manifestations of corrective justice are not the focus of Weinrib's or Stone's accounts, or of the present thesis for that matter, but their study is apt to further refine our understanding of corrective justice and to remind us of the essentially human component of corrective justice (which is also present, but often overlooked, in more formalized specifications of corrective justice such as we find in tort law). When we said that all corrective justice remedies aim at equality, what we meant was that they aim to mend the relationship between the two parties linked by the wrong, by restoring it to some form of normative balance. Talk of "equivalence" between "quantities" and "entitlements" in modern corrective justice accounts of tort law is meant to underline the fact that a person becomes the victim of a wrong when one of his or her primary rights or entitlements (to life, body, liberty, privacy, property, etc.) is violated (the "loss"), and that a person is responsible for a wrong when he or she violates the duty that correlates to that primary right (the "gain"). Failing to respond to the initial injustice (the wrong) by not correcting or remedying it is also an injustice, because then the relationship between the parties to the first injustice remains broken.

The paradigm form of corrective injustice, i.e. the failure to correct an interpersonal wrong, can be committed only by the parties to the wrong or by the third party tasked by them to declare what justice requires them to do (the judge). A judge is acting without virtue when he fails to order or instruct the party responsible for the wrong to correct it. The person responsible for the wrong is acting without virtue when he fails to take responsibility for the wrong, or when he admits the wrong but does not offer to correct it. Lastly, the victim may also act unvirtuously, for instance, by refusing reasonable offers for compensation and reconciliation made by the wrongdoer in good faith. However, we must be nuanced in this regard. The victim of a wrong may refuse certain corrective measures not out of ill-will and resentment, but out of forgiveness, in which case he or she transcends the wrong and the relationship between the parties is restored through mercy, not justice.

The practice of tort law specifies and instantiates, in an institutional setting, what corrective justice requires from the parties to a civil wrong. The typical mode of rectification in the practice of tort law is the payment of monetary compensation. However, with all of the above in mind, tort law scholars and practitioners should be aware that there is room for diversity and even for experimentation with more varied modes of rectification, so that the parties' pre-existing 
entitlements be fully recognized and their relationships be better restored to balance (or, in cases of irreversible harm, to at least a semblance of balance). Thus, tort law need not be, and in fact it is already not, tied only to the remedy of monetary compensation; ${ }^{234}$ in some circumstances, injunctions, declarations, or apologies provide sufficient, and perhaps even better, redress for civil wrongs.

D. Corrective Justice, Distributive Justice, and the Aims of Tort Law

1. The plural aim of tort law

A different question entirely from the reasons at play in corrective and distributive justice is the logical connection between the two forms of justice. Does corrective justice require, and does it depend on, a pre-existing account of distributive justice, or can corrective justice operate independently from distributive justice? The question can also be rephrased in the more provocative, but practical, phrasing used by Jules Coleman: "Can one appeal to considerations of corrective justice in ways that might sustain distributive injustices?"235

This is the key question that frames much of the contemporary academic debate regarding the internal aims of tort law. Based on how this question is answered, two main types of internal accounts of tort law can be found in contemporary academic scholarship: corrective justice accounts, and pluralist (or "mixed") accounts. ${ }^{236}$ Corrective justice theorists generally believe that it is possible to appeal to considerations of corrective justice in the practice of tort law independently from any considerations of distributive justice, and that the practice of tort law instantiates only principles of corrective justice. ${ }^{237}$ Pluralist accounts, in contrast, hold that the

\footnotetext{
${ }^{234}$ This is an assumption that can be found in Coleman's account of corrective justice. See COLEMAN, RISKS AND WRONGS, supra note 50, at 329: "[the duty corrective justice] imposes is to repair the loss. There may be other agent-relative reasons for acting that arise as a consequence of wrongfully injuring another, for example, the duty to apologize or to forbear from future harming, but these do not arise from corrective justice."

${ }^{235}$ COLEMAN, RiSKS AND WRONGS, supra note 50, at 310.

${ }^{236}$ Accounts of tort law that refer to distributive justice (or injustice) are rare. See Aditi Bagchi, Distributive Injustice and Private Law, 60 Hastings LAW Journal 105, at 105 n.1 (2008). Accounts that refer only to distributive justice are even rarer, and almost never purport to provide an internal justification of the practice. See, e.g., Guido Calabresi, Some Thoughts on Risk Distribution and the Law of Torts, 70 YALE L. J. 499 (1961); Patrick S. Atiyah, Personal Injury in the Twenty-First Century: Thinking the Unthinkable, in WrongS AND REMEDIES IN THE TwENTY-FIRST CENTURY 1 (Peter Birks ed., Clarendon Press 1996); Gregory Keating, The Idea of Fairness in the Law of Enterprise Liability, 95 MiCH. L. REV. 1266 (1997).

${ }^{237}$ See COLEMAN, RISKS AND Wrongs, supra note 50; WEINRIB, THE IDEA OF PRIVATE LAW, supra note 19; Weinrib, Corrective Justice in a Nutshell, supra note 224.
} 
reasons at play in corrective justice and those at play in distributive justice coexist in the practice of tort law and the two forms of justice jointly constitute tort law's normative foundation. ${ }^{238}$

At first glance, and for quite some time, corrective justice accounts seemed to provide a very attractive internal, non-instrumental moral foundation for the practice of tort law. ${ }^{239}$ This is because corrective justice makes sense of the structure of tort law and provides a very attractive account of the characteristic reason for the imposition of legal obligations and the enforcement of their correlative remedial rights within the practice of tort law. The bilateral structure of the adjudicative process in tort law, the bilateral structure of the remedies available, and the bilateral structure of the legally relevant interaction between the parties (i.e. the civil wrong) can all be explained in terms of the bilateral structure of corrective justice. ${ }^{240}$ Also, corrective justice makes sense of the relationship between wrongs and remedies by identifying the characteristic reason supporting the legal obligations and correlative remedial rights of the parties: the obligation to correct exists because the two parties are linked by the occurrence of a civil wrong, ${ }^{241}$ one party having suffered the wrong and the other being responsible for it.

Yet, despite the advantages mentioned above, corrective justice accounts have had to respond to charges of "emptiness" and "opacity" because they have been unable to provide a catalogue of legal wrongs or, at the very least, a rule or principle that makes it possible to identify civil wrongs when they occur. ${ }^{242}$ Without such a catalogue, rule, or principle, a very significant portion of the practice of tort law is left unexplained and without normative guidance. Questions such as: "did this defendant owe this claimant a duty to start with?" (the violation of which would constitute a

\footnotetext{
${ }^{238}$ See infra note 255 , and the accompanying text.

${ }^{239}$ Historically, corrective justice theories positioned themselves in opposition to consequentialist, and especially lawand-economics-inspired, accounts of tort law. The starting point of modern corrective justice theory is often identified with George Fletcher's "Fairness and Utility in Tort Theory", published in 1972 in the Harvard Law Review [George Fletcher, Fairness and Utility in Tort Theory, 85 HARV. L. REV. 537 (1972)]. His account of tort law, like Coleman's later, and then Weinrib's, begins with a sustained critique of the Law and Economics theories of tort law from the 1960s and 1970s, which relied on a very particular version of consequentialist functionalism. For a historical overview and an introduction to the most influential moral accounts of tort law that followed on the footsteps of Fletcher's theory, see David G. Owen, Foreword: Why Philosophy Matters to Tort Law, in PhILOSOPHICAL Foundations of TORT LAW 1 (David G. Owen ed., Oxford University Press 1995); John Oberdiek, Introduction: Philosophical Foundations of the Law of Torts, in PHILOSOPHICAL FoundATIONS OF THE LAW OF TORTS 1 (John Oberdiek ed., Oxford University Press 2014).

${ }^{240}$ WeINRIB, The IDEA OF PRIVATE LAW, supra note 19, at 65-66.

${ }^{241}$ Id., at 135; Weinrib, Corrective Justice in a Nutshell, supra note 224, at 350; Stone, supra note 75, at 159.

${ }^{242}$ See Richard W. Wright, Substantive corrective justice, 77 IowA L. REV. 625, 630 (1992); LuCY, supra note 78, at 305-08; Marc A. Loth, Corrective and distributive justice in tort law: On the restoration of autonomy and a minimal level of protection of the victim, 22 (6) MAASTRICHT JOURNAL OF EUROPEAN AND COMPARATIVE LAW 788, 794, 806-07 (2015).
} 
civil wrong) or "should liability in this or that case be fault-based or strict?" cannot be answered without specifying what we owe each other and what we are entitled to at a primary level (above, we referred to this level as the level of first order entitlements and duties ${ }^{243}$ ). If indeed "losses" and "gains" in corrective justice theories ought to be understood in a normative sense, then the "whole system of legal entitlements which specify the relevant notion of wrongdoing" 244 must also be justified.

The normative and explanatory power of corrective justice reaches its limit when it comes to how civil wrongs are defined (or ought to be defined) in tort law practice. Corrective justice, by itself, not only does not, but cannot, provide a catalogue of civil wrongs, nor specify a set of rules or principles that would allow private parties to determine which events can be characterized as civil wrongs. This is because the definition of civil wrongs is a matter of distributive justice. If we are to look at tort law from the perspective of all private parties before any wrong occurs between them, tort law duties appear as burdens and their correlative rights as external goods. ${ }^{245}$ Thus, from this ex ante perspective, when courts make tort law rules which indicate what the duties we owe others are (as well as what our rights against others are) their judgments play a constitutive role in a pattern of distribution. ${ }^{246}$ Therefore, we can conclude that in addition to correcting wrongs, tort law is also in the business of distributing primary duties and entitlements to natural and legal persons.

How primary entitlements and duties are defined is "a problem of distributive justice that [comes] into being only because the law of torts exists." 247 The types of entitlements and duties that tort law creates and protects are specific to tort law. Should tort law be replaced, for instance, with a compensation scheme based on national solidarity or a New Zeeland type accident compensation scheme, ${ }^{248}$ this would not entail a redistribution of the same external goods. Instead, such a radical

\footnotetext{
${ }^{243}$ Supra Chapter V Part E.3.

${ }^{244}$ Stone, supra note 75 , at 155.

${ }^{245}$ Peter Cane uses the term "resources" instead of "external goods," but made the same overall point in his Distributive Justice and Tort Law. See Cane, Distributive Justice and Tort Law, supra note 78, at 404.

${ }^{246}$ Id. 404-05.

${ }^{247}$ John Gardner, What is Tort Law for? Part 2. The Place of Distributive Justice, in PHILOSOPHICAL FoundATIONS OF THE LAW OF TORTS 335, 336 (John Oberdiek ed., Oxford University Press 2014).

${ }^{248}$ For more information on New Zeeland's compensation scheme see GEOFFREY W. R. PALMER, COMPENSATION FOR INCAPACITY: A STUDY OF LAW AND SOCIAL CHANGE IN NEW ZEALAND AND AUSTRALIA (Oxford University Press 1979); TERENCE G. ISON, ACCIDENT COMPENSATION: A COMMENTARY On THE NEW ZEALAND SCHEME (Croom Helm 1980); Lewis N. Klar, New Zealand's Accident Compensation Scheme: A Tort Lawyer's Perspective,
} 
reform would first abolish the primary entitlements and duties that are specific to tort law, together with its remedial apparatus, and then create an entirely different set of legal entitlements and duties. Often, such compensation schemes operate in parallel to tort law or as subsidiary mechanisms of compensation for victims who are unable to identify their tortfeasors or are unable to recover compensation from them, ${ }^{249}$ thus further reinforcing the idea that what is distributed by such schemes is of a different nature than what is distributed by the tort system.

It is important at this point to highlight that what is being distributed ex ante in tort law are "normative quantities" - entitlements and their correlative duties — and these are the same quantities that corrective justice aims to equalize ex post (after the wrong occurs). ${ }^{250}$ The primary entitlements and duties that tort law defines (and, by defining, also distributes in society) are such that their violation constitutes a civil wrong, i.e. a wrong which triggers a corrective mechanism dictated by law. The formulation of primary duties and entitlements in tort law already envisions the bilateral and correlative structure of their violation. Also, because these primary duties and entitlements are legal, their distribution also implies the distribution of the right for the victim "to conscript the court (and its officers) in his or her quest for corrective justice against the wrongdoer." 251 Thus, from the perspective of potential victims of torts, it can also be said that tort law distributes access to the legal mechanisms of corrective justice. ${ }^{252}$ From the perspective of potential tortfeasors, tort law can be said to distribute access to an institutional form of responsibility. John Goldberg and Benjamin Zipursky's account of tort law is perfectly on point insofar as it insists that tort law provides "civil recourse" to the victims of wrongs ${ }^{253}$ and a

33 U. Toronto L.J. 80 (1983); Geoffrey W. R. Palmer, New Zealand's Accident Compensation Scheme: 20 Years on, 44 U. TOROnto L.J. 223 (1994); IAN CAMPBell, COMPENSATION FOR PERSONAL InJURY In NEW ZEALAND: ITS RISE AND Fall (Auckland University Press 1995), and Stephen Todd, Privatization of Accident Compensation: Policy and Politics in New Zealand, 39 WASHBURN L.J. 404 (2000); Ken Oliphant, Landmarks of No-Fault in the Common law, in ShifTs in Compensation Between Private and Public Systems 43, $68-75$ (Springer 2007).

${ }^{249}$ A very good example is the French compensation system for victims of violent crimes. See Loi n ${ }^{\circ} 77-5$ du 3 janvier 1977 garantissant l'indemnisation de certaines victimes de dommages corporels résultant d'une infraction, JORF du 4 janvier 1977, p. 77.

${ }^{250}$ See supra Part C.2 of this chapter. This is very much in line with the traditional Thomistic idea that corrective justice is dependent on a pre-existing account of distributive justice. See AQUINAS, 1 COMMENTARY ON THE NiCOMACHEAN ETHICS, supra note 229, at 400, 419-20 [V. L.IV:C 928 \& 969].

${ }^{251}$ Gardner, What is Tort Law for? Part 2. The Place of Distributive Justice..., supra note 247, at 340.

${ }^{252} I d$. at 340,344 .

${ }^{253}$ John C. P. Goldberg \& Benjamin C. Zipursky, Civil Recourse Revisited, 39 Fla. ST. U. L. ReV 341 (2011); John C.P. Goldberg \& Benjamin C. Zipursky, Accidents of the Great Society, 64 MD. L. REV. 364, 402-03 (2005); Benjamin C. Zipursky, Civil Recourse, Not Corrective Justice, supra note 56; Benjamin C. Zipursky, Rights, Wrongs, and Recourse in the Law of Torts, 51 VAND. L. REV. 1 (1998). 
"concrete, institutionalized, and practical form of moral responsibility for having [wronged] someone"254 to tortfeasors. However, what Goldberg and Zipursky seem to either overlook or leave unacknowledged is the fact that by providing civil recourse and responsibility, tort law plays a constitutive role in the distribution of a set of rights and duties in society.

To sum up, from an internal perspective, tort law is partly constitutive of both corrective and distributive justice. In other words, tort law has a plural aim.

2. Flavours of pluralism

In recent years, an ever-growing number of authors have argued in favour of, or even advanced their own, pluralist (or mixed) accounts of tort law. ${ }^{255}$ These pluralist accounts of tort law differ among each other almost as much as they differ from the monist, corrective justice based theories they offer to replace, but can still be divided, somewhat roughly, into two major categories: authors such as Peter Cane $^{256}$ and Izhak Englard ${ }^{257}$ promote what we could call a "strong" or "unordered" version of moral pluralism, whereas others, including James Gordley, 258

\footnotetext{
${ }^{254}$ John C.P. Goldberg \& Benjamin C. Zipursky, Tort Law and Responsibility, in PHILOSOPHICAL Foundations OF THE LAW OF TORTS 17, 36 (John Oberdiek ed., Oxford University Press 2014).

${ }^{255}$ See IzHaK Englard, The Philosophy OF ToRT LaW (Dartmouth Pub. Co. 1993); Izhak Englard, The Idea of Complementarity as a Philosophical Basis for Pluralism in Tort Law, in PHILOSOPHICAL Foundations OF TORT LAW 183-95 (David G. Owen ed., Oxford University Press 1995, repr. 2001); Gary T. Schwartz, Mixed Theories of Tort Law: Affirming Both Deterrence and Corrective Justice, 75 TEX. L. REV. 1801, 1804 (1997); PETER CANE, The Anatomy of Tort Law (Hart Publishing 1997); Peter Cane, Distributive Justice and Tort Law, 2001 N.Z. L. Rev. 401 (2001); Bruce Chapman, Law, Incommensurability, and Conceptually Sequenced Argument, 146 U. PA. L. Rev 1487 (1998); Bruce Chapman, Pluralism in Tort and Accident Law: Towards a Reasonable Accommodation, in Philosophy AND THE LAW OF TORTS 276 (Gerald J. Postema ed., Cambridge University Press 2001); Mark Geistfeld, Economics, Moral Philosophy, and the Positive Analysis of Tort Law, in PHILOSOPHY AND THE LAW OF TORTS 250 (Gerald J. Postema ed., Cambridge University Press 2001); GORDLEY, FoundATIONS OF PRIVATE LAW..., supra note 47, at 12, 159-284; LuCY, supra note 78, at 376-418; Gardner, What is Tort Law for? Part 1: The Place of Corrective Justice, supra note 1415; Gardner, What is Tort Law for? Part 2. The Place of Distributive Justice..., supra note 247; Hanoch Sheinman, Tort Law and Distributive Justice, in PHILOSOPHICAL Foundations OF THE LAW OF TORTS 354 (John Oberdiek ed., Oxford University Press 2014); Benjamin Shmueli, Legal Pluralism in Tort Law Theory: Balancing Instrumental Theories and Corrective Justice Theories and Corrective Justice, $48 \mathrm{U}$. Mich. J. L. Reform 745 (2015); Marc Loth, Corrective and Distributive Justice in Tort Law: On the Restoration of Autonomy and a Minimal Level of Protection of the Victim, 22(6) MAASTRICHT JOURNAL OF EUROPEAN AND COMPARATIVE LAW 788 (2015).

${ }^{256}$ Cane, The ANatomy of Tort LaW..., supra note 255, at 224-25; Cane, Distributive Justice and Tort Law..., supra note 255 .

${ }^{257}$ Englard, The Philosophy OF TORT LAW..., supra note 255; Englard, The Idea of Complementarity as a Philosophical Basis for Pluralism in Tort Law..., supra note 255.

${ }^{258}$ GoRdLey, Foundations OF PRIVATE LAW..., supra note 47, at 12, 159-284.
} 
John Gardner, ${ }^{259}$ Bruce Chapman, ${ }^{260}$ and Marc Loth $^{261}$ have articulated theories that rely on a "weaker", or "ordered", account of moral pluralism in tort law. ${ }^{262}$

Unordered pluralist accounts differ from ordered pluralist accounts in how the relationship between corrective and distributive justice is understood. In unordered pluralist theories, corrective and distributive justice are understood to be wholly independent aims of tort law practice, which have a simultaneous pull on the behaviour or decisions of its participants, and are often in tension (sometimes even directly in conflict with each other). According to Peter Cane: "[in tort law], as in the lives of individuals, conflicts of goals tend to be resolved by giving priority to one goal over another (or others) in the circumstances of individual cases according to value judgments which may themselves, in different circumstances, conflict with other social goals." ${ }^{263}$ Similarly, Izhak Englard's pluralism assumes "the inherently contradictory nature of the various aims and functions of the law of torts." ${ }^{264}$ For both authors, plurality and indeterminacy in all human life, including tort law and other social institutions, is both inevitable and desirable. ${ }^{265}$ Also, both Cane and Englard consider the methodological insistence on coherence in tort law theory ${ }^{266}$ to be misguided. Cane considers it incompatible with human nature and human morality lato sensu because it is "typical of human beings that they pursue in their lives a large number of different goals, at least some of which conflict among themselves" 267 and "adherence to a single goal is often taken as a sign of pathological obsessiveness and may even be considered a moral fault." ${ }^{268}$ Englard takes a different approach, and seems to suggest that the practice of tort law, seen from an internal perspective (he particularly references doctrinal writing and judicial reasoning ${ }^{269}$ ), simply does not

\footnotetext{
${ }^{259}$ Gardner, What is Tort Law for? Part 2. The Place of Distributive Justice..., supra note 247.

${ }^{260}$ Chapman, Law, Incommensurability, and Conceptually Sequenced Argument..., supra note 255; Chapman, Pluralism in Tort and Accident Law: Towards a Reasonable Accommodation ..., supra note 255.

${ }^{261}$ Loth, Corrective and Distributive Justice in Tort Law..., supra note 255.

${ }^{262}$ Hanoch Sheinman's theory escapes our categorization. His conclusion is that tort law's justice is "fully distributive as well as fully corrective", in the sense that corrective justice is merely "a distinct category of distributive justice". Sheinman, supra note 255, at 354-55.

${ }^{263}$ CANE, THE ANATOMY OF TORT LAW..., supra note 255, at 225.

${ }^{264}$ Englard, The Idea of Complementarity as a Philosophical Basis for Pluralism in Tort Law..., supra note 255, at 183.

${ }^{265}$ CANe, The ANATOMY OF TORT LAW..., supra note 255, at 225; Englard, The Idea of Complementarity as a Philosophical Basis for Pluralism in Tort Law..., supra note 255, at 183.

${ }^{266}$ A strong requirement of coherence is characteristic, for instance, to Weinrib's account of tort law. See WEINRIB, THE IDEA OF PRIVATE LAW, supra note 19, at 12-14, 87.

${ }^{267}$ CANE, THE ANATOMY OF TORT LAW..., supra note 255, at 224.

${ }^{268} \mathrm{Id}$. at 225 .

${ }^{269}$ Englard, The Idea of Complementarity as a Philosophical Basis for Pluralism in Tort Law..., supra note 255, at 185.
} 
seem to be that keen on avoiding contradiction, smoothing out inconsistencies, or self-adjusting its principles, rules, and standards in a harmonious manner (the way Weinrib, ${ }^{270}$ for instance, suggests it does). ${ }^{271}$

In ordered pluralist theories, the plurality of aims in tort law remains sensitive to the requirement of coherence. Thus, the aims of tort law are ordered in a logically coherent scheme that explains how and why each part of tort law practice contributes to either corrective or distributive justice. James Gordley's account of tort law draws much of its substance from the Aristotelian and Thomistic notion of commutative (or corrective ${ }^{272}$ ) justice, ${ }^{273}$ but, of course, he acknowledges that in the tradition he draws upon the concept of commutative justice "cannot be divorced from distributive justice". ${ }^{274}$ In his version of Aristotelian private law theory, both distributive and commutative justice are concerned with the allocation of "resources": 275 distributive justice aims to ensure, at the social level, that each person has a fair share of resources, whereas commutative justice aims to ensure, in individual transactions between two parties, "that no one increases his share by depriving another of his resources." 276 Bruce Chapman's account borrows a framework from social choice theory for analysing multi-criterial decision-making, ${ }^{277}$ and suggests that the plural values found in tort law should be ordered according to a "conceptually sequenced argument". ${ }^{278}$ A conceptually sequenced argument exists when, for instance, the claimant is allowed in a first stage of decision-making to bring one argument for liability that is based on Value A (such as corrective justice), but in a second stage the defendant is allowed to bring a

\footnotetext{
${ }^{270}$ WeINRIB, The IDEA OF Private LaW, supra note 19, at 14.

${ }^{271}$ Englard, The Idea of Complementarity as a Philosophical Basis for Pluralism in Tort Law..., supra note 255, 185-186.

${ }^{272}$ Gordley prefers the term "commutative justice" over corrective justice in his account, but the meaning of commutative justice in his theory is similar, if not identical, to the meaning of corrective justice in the present thesis. ${ }^{273}$ GORDLEY, Foundations of PRIVATE LAW..., supra note 47, at 182-216.

${ }^{274} I d$. at 12 .

${ }^{275}$ Gordley never defines the term, but insofar as he is referring to the usual, dictionary, sense of "resources" (the Oxford English Dictionary definition is "stocks or reserves of money, materials, people, or some other asset, which can be drawn on when necessary"), his account is too narrow. See OXFORD ENGLISH DictionARY ONLINE, vo resource (n.) (Oxford University Press, last accessed on 2 April 2020).

In the present account, we advanced the claim that all external goods may become the subject matter of distributive justice. However, the external goods with which tort law is concerned are normative by nature; tort law distributes entitlements and duties (and, as matter of corrective justice, creates rights and obligations in response to breaches of its primary entitlements and their correlative duties).

${ }^{276}$ GORDLEY, Foundations OF PrIVATE LAW..., supra note 47, at 13.

${ }^{277}$ Chapman, Pluralism in Tort and Accident Law: Towards a Reasonable Accommodation..., supra note 255, at 281-87.

${ }^{278}$ Id. at 280 .
} 
counter-argument that is based on Value B (such as a concern for welfare or distributive justice). ${ }^{279}$ Chapman's account tries to show that sequencing arguments in this manner explains tort law's key doctrines better than Weinrib's monist account without departing from Weinrib's methodological requirements (particularly the requirement of coherence). ${ }^{280}$ John Gardner builds on Peter Cane's account of corrective and distributive justice in tort law, ${ }^{281}$ but goes beyond it by explaining how the two forms of justice are ordered within the practice. For Gardner, a complete explanation and justification of tort law must begin with corrective justice, ${ }^{282}$ but must also acknowledge that corrective justice cannot fully justify tort law. ${ }^{283}$ Corrective justice in his account "enjoys some kind of explanatory priority" 284 because it "provides the structure [...] within which distributive justice operates". ${ }^{285}$ However, Gardner argues that tort law also instantiates norms of distributive justice, and it does so in two ways: first, by allocating primary entitlements and duties in society; ${ }^{286}$ and second, by distributing losses between the parties to a dispute through doctrines like mitigation, remoteness of damage, or contributory negligence. ${ }^{287}$ Last but not least, Marc Loth has argued that "corrective and distributive justice do their work in coordination" 288 in tort law. He also accords corrective justice priority over distributive justice, ${ }^{289}$ but in his theory distributive justice also plays a very important role. Like Gardner, Loth envisions instantiations of distributive justice in two distinct stages of tort law adjudication: first, distributive justice "plays its subsidiary role in the substantiation of restoration and in the determination of the remedy that is most appropriate or in the assessment of the amount of damages to be compensated", and second, distributive justice plays a role in the justification and limitation of liability (alongside corrective

\footnotetext{
${ }^{279}$ See id. at 309-10 (discussing the problem of "excuses" against liability), 312 (discussing the requirement of "reasonable care" in the tort of negligence), 312-16 (discussing the common law approach to "collateral benefits") ${ }^{280} I d$. at $316-17$.

${ }^{281}$ Gardner, What is Tort Law for? Part 2. The Place of Distributive Justice..., supra note 247, at 338

${ }^{282}$ Gardner, What is Tort Law for? Part 1: The Place of Corrective Justice, supra note 1415, at 6.

${ }^{283}$ Gardner, What is Tort Law for? Part 2. The Place of Distributive Justice..., supra note 247, at 337.

${ }^{284} \mathrm{Id}$. at 338 .

${ }^{285}$ Id. at 338, 349, quoting Cane, Distributive Justice and Tort Law..., supra note 255, at 413.

${ }^{286}$ Gardner, What is Tort Law for? Part 2. The Place of Distributive Justice..., supra note 247, at 338-46. This portion of Gardner's argument is beyond reproach, and we owe much of our own understanding of the role of distributive justice in tort law to Gardner's contribution.

${ }^{287}$ This part of Gardner's theory we must, however, reject on the same grounds that we invoked against loss-based theories of tort law in general. See supra Part A.1 of this chapter. All three doctrines mentioned above (mitigation, remoteness of damage and contributory negligence) are better explained on the basis of corrective justice.

${ }^{288}$ Loth, Corrective and Distributive Justice in Tort Law..., supra note 255, at 799.

${ }^{289} \mathrm{Id}$. at 800 .
} 
justice). ${ }^{290}$ Building on Amartya Sen's and Martha Nussbaum's "capabilities approach", ${ }^{291}$ Loth formulates a risk-benefit principle according to which tort law "distributes good and bad opportunities" 292 in a way that should at the very least secure a minimum level of protection to people's capabilities. ${ }^{293}$ However, he also adds that considerations of distributive justice "behave like a cuckold in the nest of private law; once they are in, they tend to dominate the deliberation on liability". ${ }^{294}$ With this statement, Loth seems to move closer to an unordered (or perhaps an only-partly-ordered) account of tort law's aims. If, on the one hand, corrective justice considerations have priority over distributive justice and considerations of distributive justice occupy a well-defined domain, but, on the other hand, considerations of distributive justice may sometimes nevertheless take over the entire justification of liability, ${ }^{295}$ then the order between corrective and distributive justice becomes quite blurry.

Our own account can be described as one of ordered pluralism, in which the aims of distributive and corrective justice are ordered in a serial (or lexicographical) manner: ${ }^{296}$ in a first stage, the definition of primary entitlements and duties specifies the requirements of distributive justice; then, in a second stage, after a primary entitlement is violated and its correlative duty breached, tort law specifies the requirements of corrective justice. We should also add at this point that in the Aristotelian tradition there is also a third and final stage, in which the notion of equity comes into play, overriding justice in those exceptional circumstances in which strict adherence to the established principles of justice and their instantiations in the law would lead to inequitable outcomes. $^{297}$

Determining first order duties and entitlements is a matter that requires thinking about what each member of a community may legitimately hold as an entitlement against other members of that

\footnotetext{
${ }^{290} I d$.

291 See Amartya Sen, The Idea OF Justice (Penguin Books 2010); Amartya Sen, Equality of What?, in TANNER Lectures on Human Values 353 (Sterling M. McMurrin ed., University of Utah Press 1980); Martha C. Nussbaum, Frontiers of Justice: Disability, Nationality, Species Membership (The Belknap Press of Harvard University Press 2006).

${ }^{292}$ Loth, Corrective and Distributive Justice in Tort Law..., supra note 255, at 800.

${ }^{293}$ Id. at $804-08$.

${ }^{294} \mathrm{Id}$. at 800 .

${ }^{295}$ The manner in which he justifies the decision of the Hoge Raad in the baby Kelly case is a very good example of how he envisions considerations of distributive justice dominating the deliberation on liability. See id. at 803, 80708 .

296 The terms "serial" and "lexicographical" are borrowed from John Rawls. See RAWLS, supra note 92, at 42-43.

${ }^{297}$ See NE 1137a32-1138a4.
} 
community, and conversely, what each member of the community owes others. Such an inquiry, which logically precedes the event that triggers corrective justice (the wrong), follows the rationality of distributive justice, not corrective justice. However, from the occurrence of a civil wrong to the determination of the most appropriate remedy, the practice of tort law reflects the structure and rationality of corrective justice. In this second step, tort law specifies, in an institutional and legal context, a moral norm of corrective justice. ${ }^{298}$ The wrong in tort law is understood as a bilateral and correlative relationship between a party that bears responsibility for the wrong and another who is a victim of that same wrong. The typical procedure in tort law also involves two parties: the party who considers himself a victim having the power to initiate proceedings against the party he considers responsible for the wrong. ${ }^{299}$ Finally, the remedy is also bilateral and correlative, consisting of the pronouncement and, if necessary, the enforcement of an obligation which the losing defendant must perform for the benefit of the winning claimant [such as the payment of a sum of money as compensation, the repair or return of an object, abstaining from certain kinds of behaviour, or (more rarely) performing a positive duty].

Thus, in the ordered account we propose, distributive justice and corrective justice stand in a relationship of codependency in tort law, but this relationship of codependency does not take away their distinctiveness. Because primary duties and entitlements are distributed in a large social group, they will always be formulated with a certain degree of generality, which is missing both in the remedial rights and obligations that specify corrective justice and in the wrong that triggered them. Prior to the occurrence of a wrong, private parties engage in various activities, take on various roles, and plan their lives while holding various entitlements against others as well as certain duties toward others, the violation of which they know (or should know) constitutes a legal wrong. The law, and tort law in particular, plays a constitutive role in distributing these entitlements and duties, and in informing private parties of what they are and when they apply, so that they may build flourishing relationships. The right to be free of manufacturing defects in products for instance is distributed to all consumers alike, and the corresponding duty to all producers. The legal system guides manufacturers toward the right kind of relationship with consumers, where products are free of injury-inducing defects. However, from the moment a

\footnotetext{
${ }^{298}$ Gardner, What is Tort Law for? Part 1: The Place of Corrective Justice, supra note 1415, at 25.

${ }^{299}$ As mentioned above, in legal proceedings, typically to the two parties we must add a neutral and impartial judge, who is tasked with specifying the parties' respective rights and obligations. Supra Part C.2. of this chapter.
} 
particular producer breaches its duty toward a particular consumer, these two parties (and only they) become inter-linked by the occurrence of a civil wrong. From that moment on, the mechanisms and rationality of corrective justice take over. Ex post, or after the wrong, the parties appear before a judge as "doer" 300 and "sufferer" of the same wrong, ${ }^{301}$ and should be restored, as far as it is possible and practicable, to the normative equality they enjoyed before the wrong occurred.

\section{E. Conclusion}

The critique of modern moral theories of tort law which we started this chapter with was by no means driven by dismissive intentions. Not only this chapter, but this entire study, should be read as a contribution to the ongoing contemporary debate regarding the moral underpinnings of tort law. The broader project of the "moral theorists" 302 has not here been put into question, but instead has been mostly synthetized, but also adapted, and in part rebuilt from a neo-Aristotelian perspective. It is perhaps a cliché to quote Newton, but the shoulders of many giants have carried us throughout this study. ${ }^{303}$

That being said, it was necessary to also criticize many of those authors who have taught us so much, insofar as they have turned a blind eye to the role of strict liability in tort law. As Gregory Keating also noted, contemporary moral theorists of tort law have "sought either to fit the round peg of strict liability into the square hole of negligence liability"304 or, even worse, to write off strict liability as an insignificant fringe phenomenon within the practice. ${ }^{305}$ Adding to, and going beyond, Keating's critique, ${ }^{306}$ we posited that the problematic treatment of strict liability norms by some of the most influential modern moral theorists of tort law stemmed from: (1) ill-conceived

\footnotetext{
300 "Doer" here should be read "responsible for" the wrong or "in breach of a primary duty".

${ }^{301}$ See WeINRIB, The IDEA OF PRIVATE LAW, supra note 19, at xi, 142-43; Stone, supra note 75, at 138, 159, 161, 163; Martin Stone, On the Idea of Private Law, 9 CANADIAN Journal OF LAW AND JuRISPRUdEnCE 235, 248 (1996).

${ }^{302}$ This is a term borrowed from and used in the same sense indicated by Gregory Keating in "Strict Liability Wrongs. Keating, supra note 1, at 293.

${ }^{303}$ The reference is, of course, to Newton's famous phrase: "If I have seen further, it is by standing on the shoulders of giants." Isaac Newton, Letter from Sir Isaac Newton to Robert Hooke (1675), available online at https://digitallibrary.hsp.org/index.php/Detail/objects/9792\#.

${ }^{304}$ Keating, supra note 1, at 293-94 (referring to Jules Coleman).

${ }^{305}$ Id. at 294 (referring to John Goldberg and Benjamin Zipursky).

${ }^{306}$ According to Keating, the main issue is that moral theories of tort law have been unable or unwilling to characterize strict liability torts as interpersonal wrongs. Id. at 294-95.
} 
definitions of strict tort liability, or 2) disregard of the role of distributive justice as a constitutive aim of tort law, alongside corrective justice.

We have argued that in modern tort law scholarship there are at least three relatively widespread definitions of strict liability that ought to be rejected because they do not accurately capture what is truly common to most strict liability regimes, do not reflect the understanding that practitioners have of strict liability, and/or do not paint an image of strict liability rules that is normatively defensible. They are: (1) definitions based on the idea that strict liability is synonymous with liability based on causation alone, (2) definitions that describe all tortious liability as prima facie strict, and (3) definitions that start from the premise that all liability not based on personal and subjective fault should fall in the category of strict liability. Instead, we defended the traditional doctrinal definition of strict liability, according to which strict liability refers to those civil wrongs in which the legal element of fault is absent. This is the conception that prevails amongst textbook and treatise writers, as well as most legal practitioners, ${ }^{307}$ and this is the conception of strict liability that has truly challenged and displaced fault-based liability from the hegemonic place it secured for itself during the $19^{\text {th }}$ century. It is not a perfect definition of strict liability because many forms of liability fall somewhere in between fault and strict liability so defined, but it does capture an "ideal type" around which stricter forms of liability gravitate. ${ }^{308}$

With regard to the second critique, our thesis has been that the practice of tort law has two constitutive aims, being built to achieve both distributive and corrective justice. Tort law, it was argued, reflects an ordered pluralism, distributive and corrective justice being ordered in a serial (or lexicographical) manner: in a first stage, by defining primary entitlements and duties, tort law specifies the requirements of distributive justice; then, in a second stage, after a primary entitlement is violated and its correlative duty breached, tort law specifies the requirements of corrective justice. The occurrence of a "civil wrong", as defined in Chapter V, ${ }^{309}$ marks the conceptual boundary between the two stages. Before two persons are brought together in a tortfeasor-victim relationship, i.e. before the tortfeasor violates a primary duty (and therefore also before the victim's correlative entitlement is infringed), the influence of tort law on the lives of our two legal subjects is limited to the distribution of the duty and entitlement in question. They

\footnotetext{
${ }^{307}$ See supra Chapters II and III.

${ }^{308}$ See supra Chapter IV Part D.1.

${ }^{309}$ See supra Chapter V Part E.2.
} 
can, at this stage, only make normative demands as citizens in their political community and ask that the scope of the primary duty and its correlative entitlement be expanded or restricted. From the moment the civil wrong occurs, however, the victim can make a new normative demand, this time (only) from the tortfeasor himself. The mechanisms of corrective justice kick in at this stage, generating, in principle, ${ }^{310}$ reasons for acting only between the tortfeasor and the victim. The tortfeasor now has a legal obligation to remedy the wrong, and the victim has a correlative right to receive redress and, if necessary, to engage the assistance of the state in order to enforce said right (tort law providing, among other things, an avenue for "civil recourse"311).

In Chapter VI, we have shown that the key differences between fault and strict liability lie in the normative narrative shaping our perceptions of the interpersonal problems remedied by the legal system. The choice between fault and strict liability ultimately can be reduced to a choice between two different ways of defining civil wrongs, i.e. two different ways of formulating primary duties and their correlative entitlements. We have also seen that these defences follow a pattern, and therefore can be generalized. First, civil wrongs in which the element of fault is absent are based on non-universal primary duties and entitlements, binding members of a group to all other persons, or members of a group to members of the same or a different group, as opposed to fault-based liability, which typically relies on primary duties and entitlements that bind all persons to all others. Second, in the case of strict liability torts, the ascription of liability is not based on a direct causal link between the behaviour of the tortfeasor and the damage suffered by the victim, but on the identification of two (or more) connected relationships, usually of a different nature. ${ }^{312}$

When combined, the substantive differences between fault and strict liability regimes revealed that the normative choice between fault-based liability and strict liability is never a straightforward choice between rival solutions to a commonly agreed upon problem, but a more fundamental choice about what the problem is to start with. ${ }^{313}$ Primary duties and entitlements generate a sort of "normative lens" which warps our perception of civil wrongs. Through this lens, we construct our stories about what is a wrongful involuntary transaction and what is merely an unfortunate life

\footnotetext{
${ }^{310}$ As already mentioned, when the parties are unable to correct an injustice born from their voluntary or involuntary transaction themselves, because they disagree with regard to what happened between them or with regard to what one owes the other, a neutral third party (the judge) is often tasked with declaring what justice requires of the two parties and with restoring the pre-existing equality between the parties. See supra Part C.2 of this chapter.

311 Supra, note 253.

${ }^{312}$ See supra Chapter VI Part D.

${ }^{313} \mathrm{Id}$.
} 
event for which no one is legally responsible. For instance, the same road traffic accident can be perceived as a tort if it is the consequence of wrongdoing (i.e. bad or faulty driving), or as a wrong in itself. Similarly, when a water boiler explodes and injures someone, we have the choice between looking into the acts or omissions of its producer or looking into the defectiveness of the boiler itself without inquiring about human agency at all.

The argument made in this chapter regarding the aims of tort law helps us understand this choice from the perspective of tort law's constitutive aims. To be specific, the choice between the two main ways of shaping primary duties and their correlative entitlements in tort law (i.e. the choice between fault-based and strict liability) is a matter of distributive justice. The distribution of primary duties and entitlements is not a matter that regards only the parties to a dispute; it is a matter that requires the consideration of simultaneous claims made by all the members of a political community. When these kinds of normative quantities are distributed, the just nature of the community as a whole is at stake, and when an unequal distribution is found, each member of the community with a voice in the practice of tort law has a reason to act in accordance with the principles of distributive justice. Questions such as how strict the responsibility of drivers ought to be (and how broad the correlative entitlements of other road traffic participants ought to be), or how strict the responsibility of producers ought to be (and how far the correlative protection of consumers extends) involve such distributive choices. Because such choices have been made before and must still be made in tort law practice, tort law's practitioners (lawyers, judges, legislatures, and academics) should not shy away from constructing and defending arguments about the right distribution of responsibilities in today's society. Nor should regular citizens, who can speak up against distributive injustice through the democratic means at their disposal (such as forming associations, speaking and writing about injustice, organizing protests, voting, etc). 


\section{CHAPTER VIII}

\section{A FINAL SUMMARY AND CONCLUSIONS}

Human beings are storytelling animals. ${ }^{1}$ We create and tell stories for many reasons: to put our children to sleep, to captivate the attention of an audience, to connect with other human beings, to justify our actions, to persuade people to vote the way we want them to, to entertain, to gain profit, or to explain how the world works, how it evolved, and what our role in "the grand scheme of things" is. Researchers also tell stories, but of a special variety. Their stories, whether we find them fascinating or dull, look for truth and aim to enhance human understanding. Some have argued that researchers should stay clear of storytelling. ${ }^{2}$ Others have been urging researchers of all disciplines to embrace the narrative form more, ${ }^{3}$ and there is some evidence that researchers who ignore the power of stories do so against their own self-interest (one recent publication has shown, for instance, that climate change researchers who present their research findings in narrative form are cited more frequently ${ }^{4}$ ).

Stories can also be part of the object of research, and this is often the case in normative fields of study, because all practical reasoning is dependent on the narrative form. As Alasdair MacIntyre

\footnotetext{
${ }^{1}$ See Alasdair Macintyre, After ViRTUe 250 ( $3^{\text {rd }}$ ed., Bloomsbury 2007, repr. 2011): "[M]an is in his actions and practice ... essentially a story-telling animal"; YUVAL NOAH HARARI, 21 LESSONS FOR THE 21ST CENTURY 273 (Spiegel \& Grau 2018): "Homo sapiens is a storytelling animal, that thinks in stories rather than in numbers or graphs, and believes that the universe itself works like a story, replete with heroes and villains, conflicts and resolutions, climaxes and happy endings."; YuVAL NOAH Harari, Homo Deus. A Brief History OF TOMORROW 155 (Harvill Secker 2015): "Sapiens . . . lives in a triple-layered reality. In addition to trees, rivers, fears and desires, the Sapiens world also contains stories about money, gods, nations and corporations. As history unfolded, the impact of gods, nations and corporations grew at the expense of rivers, fears and desires"; Steven Pinker, Toward a Consilient Study of Literature, 31 PHILOSOPHY AND LiteratuRE 162, 162 (2007): "“A]1l over the world, and probably for as long as they have existed, people invent characters and recount their fictitious exploits. This apparent frivolity is no small matter in human affairs"; JoNATHAN GOTTSCHALL, THE STORYTELLING ANIMAL: HOW STORIES MAKE Us HUMAN 177 (Mariner Books 2013): "Story is the glue of human social life — defining groups and holding them together. We live in Neverland because we can't not live in Neverland. Neverland is our nature. We are the storytelling animal."

${ }^{2}$ Yarden Katz, Against storytelling of scientific results, 10 NATURE METHODS 1045 (2013), available online at https://www.nature.com/articles/nmeth.2699.

${ }^{3}$ Martin Krzywinski \& Alberto Cairo, Storytelling, 10 NATURE Methods 687 (2013), available online at https://doi.org/10.1038/nmeth.2571; See also BRUNO LATOUR, SCIENCE IN ACTION: HOW TO FOLLOW SCIENTISTS AND ENGINEERS THROUGH SOCIETY (Harvard University Press 1987) (whose argument does not take the "ought" form, positing instead that the narrative form is inherent to science, because systems of belief, oral and written traditions, as well as practices and habits, are constitutive aspects of scientific activity).

${ }^{4}$ Ann Hillier, Ryan P. Kelly \& Terrie Klinger, Narrative Style Influences Citation Frequency in Climate Change Science, PLoS ONE 11(12): e0167983, available online at https://doi.org/10.1371/journal.pone.0167983.
} 
rightly pointed out: "I can only answer the question 'what am I to do?' if I can answer the prior question 'of what story or stories do I find myself a part?" In normative discourse, underlying assumptions often take the form of open or hidden narratives, stories about the world, or parts of it. Social reality provides the context in which we form intentions, make decisions, and perform actions, and the fabric of social reality is an interweaving of true and fictitious narratives. Social constructs such as money, property, governments, human rights, marriages, or torts only exist because of shared fictions (in the case of money, for instance, the shared fiction that something that exists in the natural world and has no real intrinsic value, like a piece of paper with certain colourful patterns on it, will count as a something of value in order to facilitate economic exchange). ${ }^{5}$ All social institutions exist and flourish because of a shared story, a narrative about their history, the need we have for them, their usefulness, efficiency, and/or the constitutive role they play in our way of life. Tort law's institutions are no different.

This study built a story about strict liability from four different perspectives. A slightly different sub-story emerged from each perspective, creating for the reader something akin to a "Rashomon effect" . ${ }^{6}$ However, unlike the multi-perspective storyline of Akira Kurosawa's Rashomon, ${ }^{7}$ all four sub-stories that make up the present account of strict liability are compatible with each other and come together to form a coherent overall picture of what strict liability is about in the law of torts.

The first vantage point chosen was that of a French jurist looking at the evolution of strict liability from 1804 to the present day. From this perspective, a doctrinal-historical account of strict liability in the French legal system was reconstructed in Chapter II. Our starting point, in 1804, coincided with the enactment of the French Civil Code, a time when strict liability regimes almost disappeared. Articles 1382 to 1386 [now numbered 1240 to 1244] of the French Civil Code of

\footnotetext{
${ }^{5}$ On the ontology of social reality and the role of shared fictions, see JOHN R. SEARLE, THE CONSTRUCTION OF Social Reality (The Free Press 1995); John R. SEArle, Making the Social World. The Structure of Human Civilization (Oxford University Press 2010).

${ }^{6}$ The term "Rashomon effect" is used to designate an epistemological framework required for understanding matters that are complex and ambiguous. It is characterized by the simultaneous coexistence of different, often incompatible, perspectives on the same event, issue, or object. See Robert Anderson, The Rashomon Effect in Communication, 41(2) CANADIAN JOURNAL OF COMMUNICATION 249 (2016).

${ }^{7}$ Rashomon is a Japanese film released in 1950, in which the death of a samurai is recounted through contradictory and inconsistent testimonies (of the samurai's ghost, delivered through a medium, of the samurai's wife, of a bandit suspected of murdering the samurai, and of a woodcutter who claims to have been an eye witness to the murder).
} 
1804 were initially designed to create a default system of liability based on fault alone, ${ }^{8}$ the cornerstone of which were articles 1382-1383 [now 1240-1241] which refer to liability resulting from intentional and negligent behaviour. The following three articles, 1383-1386 [now 12421244], were regarded by the French legislature at that time merely as special instances of faultbased liability. ${ }^{9}$

Strict liability regimes were not part of the system of liability envisaged by the drafters of the French Civil Code. Nevertheless, they emerged and expanded in French tort law practice over the course of the next two centuries, and they did so from two sources: first, from the progressive activity of French courts, which creatively reinterpreted articles 1383-1386 [now 1242-1244] ${ }^{10}$ of the French Civil Code, and (also creatively) developed a general principle of law applicable to nuisance cases (troubles de voisinage) ${ }^{11}$ and second, from legislative enactments within and outside of the Civil Code. Within the Civil Code, the only major change to the chapter on delicts and quasi-delicts was the introduction of articles 1386-1 to 1386-18 [now 1245 to 1245-17] dealing with liability for defective products. ${ }^{12}$ Outside of the Civil Code, special legislation introduced strict liability in specific areas such as: road traffic accidents, ${ }^{13}$ medical accidents, ${ }^{14}$ mining accidents, ${ }^{15}$ environmental damage, ${ }^{16}$ nuisance caused by "dangerous, inconvenient or unsanitary"

\footnotetext{
${ }^{8}$ Bertrand-de-Greuille, Communication officielle au Tribunat, and Tarrible, Discours devant le corps legislatif, in P. A. Fenet, 13 Recueil Complet des travauX PRÉParatoires du Code Civil 474, 475, 488 (Otto Zeller 1968).

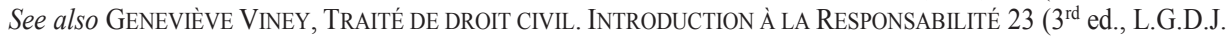
2008). (instituteurs), remains fault-based. Also, according to paragraph (2) of article 1242, a person who holds, under any title, a movable or immovable in which a fire started, can only be held liable if his fault or the fault of another for whom he is responsible (vicariously) is proven. All other hypotheses envisioned by articles 1242-1244 are governed by strict liability.

${ }^{11}$ Cass. Civ. 2e, 19 November 1986, Bull. civ. II, nº 172: "nul ne doit causer à autrui un trouble de voisinage" ["no person can cause to another a nuisance (trouble de voisinage)"]; D. 1988.16, note A. Robert.

${ }^{12}$ Loi no 98-389 du 19 mai 1998 relative à la responsabilité du fait des produits défectueux, JORF nº117 du 21 mai 1998, p. 7744.

${ }^{13}$ Loi no $85-677$ du 5 juillet 1985 tendant à l'amélioration de la situation des victimes d'accidents de la circulation et à l'accélération des procédures d'indemnisation, JORF du 6 juillet 1985, p. 7584.

${ }^{14}$ Loi n ${ }^{\circ} 2002-303$ du 4 mars 2002 relative aux droits des malades et à la qualité du système de santé, JORF du 5 mars 2002, p. 4118; Loi n 2002-1577 du 30 décembre 2002 relative à la responsabilité civile médicale, JORF du 31 décembre 2002, p. 22100.

${ }^{15}$ Loi du 9 Avril 1898 sur les responsabilités des accidents dont les ouvriers sont victimes dans leur travail, BULLETIN DE L'INSPECTION DU TRAVAIL, $\mathrm{n}^{\circ} 2$, 1898, also available online at http://travailemploi.gouv.fr/IMG/pdf/Loi du 9 avril 1898.pdf.

${ }^{16}$ Loi n ${ }^{\circ} 2008-757$ du $1 \mathrm{er}$ août 2008 relative à la responsabilité environnementale et à diverses dispositions d'adaptation au droit communautaire dans le domaine de l'environnement, JORF nº179 du 2 août 2008, p. 12361.
} 
establishments, ${ }^{17}$ accidents caused by industrial establishments (public or private) that work for the national army (la défense nationale), ${ }^{18}$ damage caused by aircraft, ${ }^{19}$ damage caused by cable cars, ${ }^{20}$ damage caused by mandatory vaccination, ${ }^{21}$ damage caused by nuclear materials, ${ }^{22}$ damage caused by oil pollution, ${ }^{23}$ and the vicarious liability of travel agents ${ }^{24}$ and organizers of cruises by sea. $^{25}$

The second vantage point chosen was that of an English jurist looking at the evolution of strict liability from the Norman conquest to the present day. It was necessary to go back further in time in Chapter III because the origin and evolution of strict liability in English law is more controversial than the origin of the existing forms of strict liability in France. According to what is still perhaps the most influential account of the history of tort law in England, liability rules evolved from broad rudimentary rules of absolute liability ${ }^{26}$ toward the narrower fault-based liability rules that have become the hallmarks of modernity. ${ }^{27}$ According to a second interpretation

\footnotetext{
${ }^{17}$ Environmental Code, articles L.511-1 to L.517-2.

${ }^{18}$ Loi du 3 mai 1921, accidents corporels ou matériels du fait des établissements travaillant pour la défense nationale : droit à réparation, JORF du 5 mai 1921, p. 5474.

${ }^{19}$ Loi du 31 mai 1924 relative à la navigation aérienne, JORF du 3 juin 1924, p. 5046. This law was incorporated in 1967 in the Code of Civil Aviation.

${ }^{20}$ Loi du 8 juillet 1941, servitudes de survol au profit des téléphériques, JORF du 27 août 1941, p. 3614.

${ }^{21}$ Art. L. 3111-9 of the Public Health Code (Code de la santé publique).

${ }^{22}$ Loi n ${ }^{\circ} 65-956$ du 12 novembre 1965 responsabilité des accidents d'origine nucléaire, JORF du 13 novembre 1965, p. 9996 ; Loi n 68-1045 du 29 novembre 1968 responsabilité des accidents d'origine nucléaire, JORF du 30 novembre 1968, p. 11229; Loi n 68-943 du 30 octobre 1968 relative à la responsabilité civile dans le domaine de l'énergie nucléaire, JORF du 31 octobre 1968, p. 10195 ; Loi n 65-956 du 12 novembre 1965 sur la responsabilité civile des exploitants de navires nucléaires, JORF du 13 novembre 1965, p. 9996 ;

${ }^{23}$ Loi n ${ }^{\circ} 77-530$ du 26 mai 1977 relative à la responsabilité civile et à l'obligation d'assurance des propriétaires de navires pour les dommages résultant de la pollution par les hydrocarbures, JORF du 27 mai 1977 p. 2993.

${ }^{24}$ Loi no 92-645 du 13 juillet 1992 fixant les conditions d'exercice des activités relatives à l'organisation et à la vente de voyages ou de séjours, JORF n¹62 du 14 juillet 1992, p. 9457.

${ }^{25}$ Loi n ${ }^{\circ} 66-420$ du 18 juin 1966 sur les contrats d'affrètement et de transport maritime, JORF du 24 juin 1966 p. 5206.

${ }^{26}$ It should be noted that whether or not the nature of liability in the early action for trespass was absolute is also a debatable matter. Compare, for instance, John Henry Wigmore, Responsibility for Tortious Acts: Its History in 3 Select ESSAys In ANGLO-AmeriCAN LEgal History 480 (Little, Brown and Co. 1909) (this essay first appeared in the Harvard Law Review, 1894, vol. VII, at 315, 383, 442), with OLIVER WeNDELL HolmeS, THE COMMON LAW 53 (Little, Brown, and Company 1881, repr. Holmes Press 2012), and Percy H. Winfield, The Myth of Absolute Liability, 42 L. Q. REV. 37 (1926).

27 TheOdore F.T. Plucknett, A CONCISE History OF the COMmOn LAW 463-64 ( $5^{\text {th }}$ ed., Little, Brown \& Co. 1956, repr. Liberty Fund 2010); M.A. Millner, NeGligenCE In Modern LAW 203 (Butterworth \& Co. 1967); James Barr Ames, Law and Morals, 22 HARV. L. ReV. 97, 99 (1908); Morris S. Arnold, Accident, Mistake, and Rules of Liability in the Fourteenth-Century Law of Torts, 128 U. PA. L. REV. 361, 364, 368-74 (1979); John H. Wigmore, Responsibility for Tortious Acts: Its History III, 7 HARV. L. REV. 441, 442 (1894).
} 
of historical sources, the English common law was always based on standards of negligence. ${ }^{28}$ And lastly, according to a third interpretation, ${ }^{29}$ the likely evolution of the common law of torts was from no or very little civil liability to an ever expanding law of torts. ${ }^{30}$ This latter account seemed more plausible, given everything else we know about the history of English law and of English institutions, and the account given in Chapter III follows this third narrative line.

After a very succinct introduction to medieval English tort law, the evolution of tort law in the $19^{\text {th }}$ and $20^{\text {th }}$ centuries became, once more, our focal point. England was "the world's first industrialized nation", ${ }^{31}$ having entered the $19^{\text {th }}$ century with the industrial revolution in full swing. The societal transformations brought by the industrial revolution progressed at a more accelerated pace and were more dramatic in England than in France, ${ }^{32}$ and yet the response of the law to the industrial revolution could not have been more different. In England, from the $19^{\text {th }}$ century onwards the tort of negligence grew in scope and practical importance, overshadowing all other torts. ${ }^{33}$ To this day, the tort of negligence remains the broadest and most important tort in English law, and is perhaps the closest thing to a default, fall-back, rule for liability ${ }^{34}$ (if such an analogy can legitimately be made). Strict liability regimes have been, and still are, special and narrowly construed, occupying less "territory" than they do in France. There is, for instance, no general rule of strict liability for things or any general principle of strict liability for the acts of others in England. That being said,

\footnotetext{
${ }^{28}$ C.H.S. FifoOt, History AND SOURCES OF THE COMMON LAW 187-95 (Greenwood Press 1970; originally Stevens $\&$ Sons Ltd. 1949); S.F.C. MiLSOM, Historical Foundations OF THE COMMON LAW 295-300 ( $2^{\text {nd }}$ ed., Butterworths 1981); See also Stephen C. Gilles, Inevitable Accident in Classical English Tort Law, 43 EMORY L. J. 575 (1994) (arguing, however, that the centrality of the inevitable accident defence in the early common law and the fact that the defence referred not only to the defendant having taken customary reasonable care, but also to have taken all possible practical care, taking into consideration his abilities and skill, thus indicating that the early cases may have been grounded on subjective negligence).

${ }^{29}$ See Robert L. Rabin, The Historical Development of the Fault Principle: A Reinterpretation, 15 GA. L. Rev. 925 (1980-1981); Percy H. Winfield, The History of Negligence in Torts, 42 L. Q. REV. 184, 185 (1926); Percy H. Winfield \& Arthur L. Goodhart, Trespass and Negligence, 49 L. Q. REV. 359 (1933).

${ }^{30}$ See supra note 37.

${ }^{31}$ Michael Lobban, Part four: Tort in The OXFord History of THE Laws of England. Volume XII (1820-1914). PRIVATE LAW 879 (William Cornish et al. eds., Oxford University Press 2010).

${ }^{32}$ Marcel Gillet, Au XIXe siècle : industrialisation linéaire ou industrialisation par bonds ?, 23 REVUE ÉCONOMIQUE 723, 724 (1972).

${ }^{33}$ This development, we have shown, was not without its ups and downs. Negligence standards began their development early in the $19^{\text {th }}$ century, but their evolution was not linear. The early $18^{\text {th }}$ century saw a rapid expansion of the law of negligence, which was, however, reigned in from the 1850s onwards. Then, in 1932, a new expansion and the beginning of the modern law of negligence in England was marked by Lord Atkin's speech in Donoghue v Stevenson. The law of negligence saw its broadest form in the 1960s and 1970s, but was narrowed down again after the Caparo decision in 1990. See supra Chapter III Part A.4.

${ }^{34}$ RODOLFO SACCO, LA COMPARAISON JURIDIQUE AU SERVICE DE LA CONNAISSANCE DU DROIT 83 (Economica, 1991).
} 
looking back at the number of strict liability torts we identified in Chapter III, at their cumulated ambit, and at their growing significance in English tort practice, we can safely say that strict liability torts cannot be quickly dismissed as forms of liability that belong to the "margin of tort law", 35 or as "a precarious patching over of a vulnerable spot that marks the outer boundaries of the domain of law in which it is situated" ${ }^{36}$

Strict liability torts may not have (yet) displaced the tort of negligence from its central place in the practice of English tort law, but they do occupy a significant amount of territory in that practice and provide a genuine alternative to the tort of negligence in their respective domains. There are, according to our findings, more strict liability torts in English law than many tort law scholars assume. ${ }^{37}$ Next to the well-known strict liability rule of Rylands $v$ Fletcher ${ }^{38}$ (which has indeed been interpreted narrowly by subsequent English case law ${ }^{39}$ ), the overall picture of strict liability wrongs in England includes: the torts of private and public nuisance, the liability for defective products under Part I of the Consumer Protection Act $1987,{ }^{40}$ the vicarious liability of employers for the acts of their employees, the tort of breach of non-delegable duty, the liability for animals belonging to a dangerous species under the Animals Act 1971, ${ }^{41}$ the tort of breach of statutory duty, the tort of trespass to land, the tort of conversion, the tort of defamation, the equitable wrongs of breach of fiduciary duty and breach of confidence, as well as statutory liability under the Harbours, Docks and Piers Clauses Act $1847,{ }^{42}$ the Carriage by Air Act 1961, ${ }^{43}$ the Nuclear Installations Act 1965, ${ }^{44}$ the Gas Act $1965,{ }^{45}$ the Civil Aviation Act 1982, ${ }^{46}$ the Environmental

\footnotetext{
${ }^{35}$ John C. P. Goldberg \& Benjamin C. Zipursky, Torts as Wrongs, 88 TEX. L. REV. 917, 952 (2010).

${ }^{36} I d$.

${ }^{37}$ See, e.g., W. EdWIn PEEL \& JAMES GOUdKAMP, WinfiELD AND JOLOWICZ ON TORT 27-28 (19 $9^{\text {th }}$ ed., Thomson

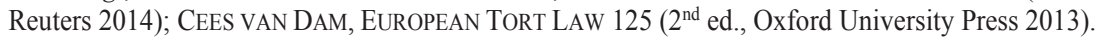

${ }^{38}$ Rylands v Fletcher, (1868) LR 3 HL 330 (House of Lords).

${ }^{39}$ Cambridge Water Co Ltd v Eastern Counties Leather Plc, [1994] 2 W.L.R. 53, [1994] 2 A.C. 264; Transco Plc v Stockport MBC, [2003] U.K.L.H. 61; [2004] 2 A.C. 1, at 9.

${ }^{40}$ Consumer Protection Act 1987, c.43.

${ }^{41}$ Animals Act 1971, c. 22.

${ }^{42}$ Section 74, Harbours, Docks and Piers Clauses Act 1847, c. 27 (Regnal. 10 and 11 Vict.).

${ }^{43}$ Carriage by Air Act 1961, c. 27 (Regnal. 9 and 10 Eliz 2), giving effect to the Convention concerning international carriage by air known as "the Warsaw Convention as amended at The Hague, 1955."

${ }^{44}$ Nuclear Installations Act 1965, c. 57, which implements the provisions of the 1960 Paris Convention of Third Party Liability in the field of Nuclear Energy and the 1963 Brussels Convention Supplementary to the Paris Convention.

${ }^{45}$ Gas Act 1965, c. 36, section 14.

${ }^{46}$ Civil Aviation Act 1982, c. 16, section 76(2).
} 
Protection Act 1990, ${ }^{47}$ the Water Industry Act 1991, ${ }^{48}$ the Merchant Shipping Act 1995, ${ }^{49}$ and the Environmental Damage (Prevention and Remediation) Regulations 2009. ${ }^{50}$

The aim of Chapters II and III was mainly to identify and describe the domains of strict liability in France and England. For this reason, both chapters can be read, at the same time, as historical narratives regarding the origin and evolution of strict liability in France and England and as a collection or catalogue of strict liability regimes. Finding all, or as many as possible, strict liability rules in two separate jurisdictions was a rather daunting task because no other comparatist has, to this author's knowledge, engaged in such an exercise before. This is understandable though, because this is an encyclopaedic process that borders on fastidiousness. ${ }^{51}$ Nevertheless, for the purposes of this study, this cataloguing process was a necessary preliminary step that allowed us to pin down the object(s) of our study.

The identification of strict liability regimes in Chapters II and III was based on the traditional doctrinal definitions of strict liability, which emphasize the absence of fault as a requirement for liability. Strict liability is usually defined as "liability without fault", 52 "liability regardless of

\footnotetext{
${ }^{47}$ Environmental Protection Act 1990, c. 43, sections 33(1), 63(2), 73(6).

${ }^{48}$ Water Industry Act 1991, section 209.

${ }^{49}$ Merchant Shipping Act 1995, c. 21 (see especially sections 153 \& 154).

${ }^{50}$ Environmental Damage (Prevention and Remediation) Regulations 2009, SI 2009/153, implementing Directive 2004/35/CE of the European Parliament and of the Council of 21 April 2004 on environmental liability with regard to the prevention and remedying of environmental damage.

${ }^{51}$ In France, the process was somewhat easier, because much of the work of mapping strict liability regimes in France was done already by a small number of French doctrinal scholars. In England, however, our list was reconstructed from fragments of legal doctrine and case law, as we have not found any doctrinal attempt to clearly delineate which common law and statutory torts are strict and which are fault-based.

${ }^{52}$ VAN DAM, supra note 37, at 297; Jules L. Coleman, The Morality of Strict Tort Liability, 18 WM. \& MARY L. REV. 259, 271 (1976-1977). For a long time, in fact, "liability without fault" and "strict liability" have been used interchangeably by legal scholars. See, e.g., Ezra Ripley Thayer, Liability without fault, 29 HARV. L. REV. 810 (1916); John B. Waite, Liability without fault, 18 MiCH. L. REV. 316 (1920); Kenzo Takayanagi, Liability without Fault in the Modern Civil and Common Law, 16 ILL.L.R. 163 (1921-1922); Kenzo Takayanagi, Liability without Fault in the Modern Civil and Common Law - II, 16 ILL.L.R. 268 (1921-1922); Kenzo Takayanagi, Liability without Fault in the Modern Civil and Common Law - III, 17 ILL.L.R. 187 (1922-1923); Kenzo Takayanagi, Liability without Fault in the Modern Civil and Common Law - IV , 17 ILL. L. R. 416 (1922-1923); Rufus C. Harris, Liability Without Fault, 6 TUL. L. REV. 337 (1931-1932); Fowler V. Harper, Liability Without Fault and Proximate Cause, 30 Mich. L. Rev. 1001 (1931-1932); William H. McBratney, New Trends Toward Liability Without Fault, 26 RocKY MnTN. L. ReV. 140 (1953-1954) ; Rev. Francis E. Lucey, Liability Without Fault and the Natural Law, 24 TenN. L. REV. (1955-1957); Cornelius J. Peck, Negligence and Liability without Fault in Tort Law, 46 WASH. L. REV. 225 (1970-1971); Richard Shields, Liability Without Fault. Rylands v. Fletcher Revitalised, 2 TrinITY C.L. REV. 124 (1999).
} 
fault", 53 "liability irrespective of fault", 54 or "liability that does not depend on proof of negligence or intent to do harm", 55 formulations that make it clear that fault may be present in strict liability cases, but is not a requirement.

Such fault-centred conceptualizations of strict liability offer a correct definition of strict liability, but they tell us only what strict liability is not (it is not fault-based liability) and bind our understanding of strict liability to a paradigm of tort law dominated by fault. Like a few other authors before us, we have found this problematic. ${ }^{56}$ When fault-liability is taken as the starting point, the foundations of strict liability become obscure and the category itself risks being reduced to a miscellanea of "weird" rules. ${ }^{57}$ We therefore looked for ways to go beyond the fault-centricity of traditional definitions of strict liability, and formulate a positive account of strict liability, i.e. an account which would provide insight into what strict liability is, not just what it is not. To this end, we decided to focus on the normative elements that replace fault or perform a similar normative function. And indeed, we have found that one or more elements replace fault in every single strict liability regime we have identified. ${ }^{58}$ Causation-based strict liability simply does not exist in modern legal practice. ${ }^{59}$

This is where the third and fourth perspectives came into play. These last two points of outlook can be said to have been "from above", in the sense that they were external to the French and English legal systems, while nevertheless remaining within the practice of tort law (i.e. that which is common to the English practice of tort law and the French practice of responsabilité civile délictuelle).

The coordinates for the third perspective were given by the values of security and freedom. Thus, in Chapter IV, we looked for ways to rank-order and taxonomize the various liability rules identified in prior chapters on a spectrum (or a continuum) which begins with the interest of victims

\footnotetext{
${ }^{53}$ Christian Witting, StReet On TORTS 15 (14 $4^{\text {th }}$ ed., Oxford University Press 2015); Cane, supra note 6, at 39. See also Gregory C. Keating, Is There Really No Liability Without Fault: A Critique of Goldberg \& Zipursky, 85 FORDHAM L. REV. RES GESTAE 24, 26 (2016-2017) ("liability without regard to fault").

54 PEEL \& GOUDKAMP, supra note 5 , at 53.

${ }^{55}$ BLACK'S LaW DiCTIONARY 1055, vo liability (10 ${ }^{\text {th }}$ ed., Bryan A. Garner ed., Thomson Reuters 2014).

56 See Peter Cane, Atiyah's Accidents, Compensation And the Law 91 ( $8^{\text {th }}$ ed., Cambridge University Press 2013): "The phrase 'liability without fault' merely eliminates fault as a necessary condition of liability; it does not put anything else in its place."

${ }^{57}$ See supra Chapter IV Part A.

${ }^{58}$ See supra Chapter IV Part D.

${ }^{59}$ See supra Chapter VII Part A.1.
} 
(or claimants) in security and ends with the interest of tortfeasors (or defendants) in freedom. ${ }^{60}$ For this purpose, we first broke down strict liability rules into their constitutive elements (prima facie and defences), and rank-ordered them based on how they combine the elements and defences. What we found is that liability rules, while diverse in terms of how they balance freedom and security through their elements and defences, tend to cluster around two combinations of elements and defences which can be taken as paradigmatic. Fault-based liability's typical form requires proof of a breach of duty under an objective standard (encoded in the element of faute in France, and the elements of duty of care and breach of duty in England), causation and damage, and allows for the defences of contributory negligence and external cause (force majeure / act of God). Strict liability's typical form requires the plaintiff to establish one or more strict element(s), causation, and damage, and the defendant can generally reduce or deny his liability by invoking the same two alternative defences: contributory negligence or external cause (force majeure / act of God).

There are some strict liability rules that do not fit the typical form and depart from it by adding or by subtracting one or more elements. Thus, in some cases, liability is made stricter by removing the element of causation (see vicarious liability rules in both France and England, or road traffic liability in France). In other situations, stricter forms of liability are obtained by removing one or more defences (the defence of contributory negligence, external cause, or both). Also, there is at least one strict liability rule which does not require proof of either causation or damage (see the tort of trespass, in England).

Towards the other end of the spectrum, between typical rules of strict liability and typical rules of fault liability, there are a small number of liability rules which are less strict than the typical form of strict liability, but which also sit uncomfortably in the category of fault-based liability. We have described these rules as "de facto strict liability rules" $"$ because the plaintiff"s prima facie case is not dependent on a showing of fault. The plaintiff benefits from a rebuttable presumption of fault, which means that the defendant is granted an additional defence to what is typical for strict liability rules, being allowed to show that he was not at fault in causing damage to the plaintiff. As defendants usually find it very difficult to rebut the presumption of fault operating in the plaintiff's favour, these fault-based rules operate in practice almost identically to strict liability rules.

\footnotetext{
${ }^{60}$ Within such a spectrum, all liability rules are understood as attempts by the law to balance the interests of the parties.

${ }^{61}$ Supra Chapter IV Part C.
} 
Finally, we have also seen that the line between fault-based liability and strict liability is further blurred by the existence of fault-based rules where the standard of care is heightened (as is the case with certain categories of professionals when damage is caused in the exercise of their profession), and by mechanisms which allow a judge to infer the defendant's fault from the circumstances of the accident the defendant was involved in and which led to the plaintiff's damage (see the doctrine of res ipsa loquitur). These rules prove that there are also variations in the fault-based area of the spectrum, and that some fault-based rules are based on stricter duties of care than others.

Despite such heterogeneity, all the forms of liability described above gravitate towards the typical form of strict liability, and when fault is absent from the list of elements of a civil wrong, one or several strict elements fill the normative vacuum left by the absence of fault. The existence such strict element or elements in all strict liability rules begged the question: are there any commonalities or patterns of normativity to be found in the various elements that replace fault? In order to address this question, we looked at our previously identified strict liability regimes through the fourth lens, that of the comparatist.

Chapter V is, in its entirety, a description of our point of outlook - the tertium comparationis. We looked for a point of outlook that could transcend the internal perspective of the French and the English legal systems, while remaining internal to the area of practice that encompasses English tort liability, English equitable wrongs, and the French responsabilité civile délictuelle (referred to throughout this study in short as "the practice of tort law"). To this end, we advanced the thesis that the social practices we associate with tort law, equitable wrongs, and la responsabilite civile délictuelle share a common telos: the just definition and correction of civil wrongs. The aim of defining civil wrongs (i.e. determining what constitutes, according to the law, a civil wrong and what does not) is embodied and specified in the formulation of primary duties and entitlements. Only events which can be characterized as breaches of primary duties (and infringements of the correlative primary entitlements) will count as civil wrongs. Therefore, a just definition of civil wrongs corresponds to a just determination of the content of primary duties and entitlements in the case of each individualized civil wrong. The content of remedial rights and duties is more connected to the second aim, that of the just correction of civil wrongs (i.e. the determination of legal responses to already defined civil wrongs). The justice of legal responses to civil wrongs corresponds to a just determination of the content of remedial rights and duties for each individualized civil wrong. 
In Chapter VI we made explicit comparisons between English law and French law, focusing on those circumstances in which at least one of the two legal systems resorted to strict liability. The comparative exercise focused on the primary normative level because the remedial responses in all the situations we looked at (i.e. when both legal systems opted for strict liability, and when one system opted for strict liability while the other for a fault-based functional equivalent) were very similar. The English and the French legal systems always respond to civil wrongs by creating personal obligations (or claims), and these remedial obligations almost invariably consist of monetary compensation.

Starting with the similarities at the primary level, we have found that the French and English legal systems define primary duties and their correlative entitlements similarly in the areas of product liability, liability for nuclear accidents, vicarious liability of employers for the acts of their employees, nuisance, and trespass to land. However, the details of these definitions diverge in some subtle points of detail. In the area of product liability, there are differences with regard to what counts as damage, how causation may be proven, and the relationship between product liability and other liability regimes. In the area of liability for nuclear accidents, there are differences with regard to the recoverability of pure economic loss. In the area of vicarious liability of employers for the acts of their employees, there is an important divergence with regard to the definitions of the underlying civil wrongs committed by employees, and with regard to the liability exposure of the employees when their employers are held vicariously liable. In the area of private nuisance, there are subtle differences regarding the definition of the term "neighbour" and the treatment of uncertain risks. Lastly, with regard to acts of interference with the possession of land, there are conceptual and procedural differences between the English tort of trespass to land and the French référé possessoire.

Moving on to the differences between how the French and the English legal systems define civil wrongs, when French law and English law differ in their definitions of civil wrongs, it is most often because a certain domain is governed by a strict liability rule in France, whereas in England a fault-based rule governs the field (or a mix between strict liability and fault-based liability). This is the case: (1) when a thing is involved in the causation of damage, (2) in most cases of liability for the civil wrongs committed by another (i.e. the liability of parents for their minor children, the liability of artisans for the acts of their apprentices, and the liability of persons who permanently 
organize, direct and control the life of another), (3) in cases of road traffic accidents, and, in part, (4) in cases of damage caused by animals.

There are, quite exceptionally, also liability problems to which English law responds with strict liability, whereas French law resorts only to fault-based liability (or a combination between strict liability and fault-based liability). These include civil wrongs dealing with: (1) the protection of entitlements over movable property, and (2) defamation.

Nevertheless, even when primary duties are defined very differently, as in the examples mentioned above, we have found a number of subtle points of convergence. Thus, we have seen that: the law of vicarious liability in England has been expanding and now partly overlaps with the French general principle of liability for others; although in France liability is strict and in England the tort of negligence dominates the area of liability for road traffic accidents, drivers are nevertheless held to a higher standard of care in England; petitory actions, which are not even conceived as remedies for wrongs in France, seem to protect possessory interests in a similar manner to the torts of conversion and trespass to goods; and in France, the applicability of fault-based liability (articles 1240-1241 of the Civil Code) in defamation cases has been restricted jurisprudentially to such an extent that fault-based liability has become almost inconsequential, making French law just about as strict as English law in this field.

From the comparisons made in Chapter VI, two recurring characteristics of strict liability norms emerged: first, we have found that strict liability norms are non-universal, in the sense that primary duties and entitlements take other forms than the all against all form that is characteristic to faultbased norms; and second, the link between potential tortfeasors and victims is mediated in strict liability cases, the ascription of liability typically requiring the identification of at least two connected relationships, whereas in fault-based liability the ascription of liability is direct (the relationship between victim and tortfeasor being unmediated). Both characteristics emerged as patterns which stood out especially when strict liability was contrasted with paradigmatic forms of fault liability.

In order to explain the non-universal nature of strict liability norms, we started with fault liability's propensity to universality. The primary duty of the tort of negligence - the duty of care - is a duty with universal undertones, and so is the general principle encoded in article 1240 of the French Civil Code. Although the duty of care element in the tort of negligence is relational and is often 
established on a case-by-case basis, there is no a priori limitation as to who can be a claimant and who can be a respondent in a negligence case. ${ }^{62}$ Abstracted from policy considerations, the duty of care in negligence has the potential to bind all persons to all others. The general principle of article 1240 of the French Civil Code is even enunciated as binding every person ("[t]out fait quelconque de l'homme") to all others ("qui cause à autrui"). This all to all universality is linked to fault's individualism and atomization, fault liability's primary duties (and correlative entitlements) being conferred upon individuals qua individuals. In contrast, strict liability duties and correlative entitlements are non-universal in precisely the sense that they are narrower and more targeted with regard to the subjects they address. Strict liability duties are still general duties, but they address, on either the passive or the active side, or on both sides at the same time, only a group or class of persons. The characteristic subject of a strict liability rule is not the individual qua individual, but the individual qua member of a group or class.

The duties that make up the primary level of strict liability wrongs can be further divided into three categories: (1) duties owed by members of a group or class to all others; (2) duties owed by all persons to members of a group or a class of persons; and (3) duties owed by members of a group or class to members of another group or class. Liability for the act of things (in France), liability for animals (in France), liability for nuclear accidents (in both France and England), and all forms of vicarious liability (in both France and England) belong to the first set of duties (i.e. owed by members of a group or class to all others). Only a gardien of a thing, a gardien of an animal, a nuclear operator, an employer, a parent, or a person who exercises a sufficient degree of control and direction over another person's life can be held strictly liable under these liability regimes, whereas the potential victim can be any person whatsoever. The English tort of trespass to land and its French equivalents (the wrongs which form the basis for a référé possessoire), as well as the torts of conversion and trespass to goods fall into the second category (duties owed by all to members of a class or group). These civil wrongs can be committed by any person but protect only that group or class of persons who possess land, buildings or goods, or have a right to possess goods. Lastly, the characteristic duties of product liability (in both France and England), liability for road traffic accidents under the loi Badinter (in France), as well as nuisance and trouble de voisinage belong to the third category (i.e. duties owed by members of a group or class to members

${ }^{62}$ Supra p. 239-40. 
of another group or class). With regard to product liability, the primary duty rests on producers, suppliers, or importers, whereas the primary entitlement is held by any natural person who may suffer personal injury or damage to property (usually consumers). The loi Badinter contains three sets of primary duties: (1) duties owed by drivers to other drivers; (2) duties owed by drivers to privileged victims (pedestrians, cyclists and passengers); and (3) duties owed by drivers to superprivileged victims (pedestrians, cyclists or passengers who are under the age of 16, older than 70 , or more than $80 \%$ disabled). The English tort of nuisance and the French trouble de voisinage are also based on duties owed by members of a group or class to members of a group or class, but in a different way. These civil wrongs do not create primary duties connecting persons from different groups, as in the cases of product liability and road traffic accidents. Instead, the potential claimants and defendants in nuisance cases belong to the same self-referential relational group: they must be neighbours.

There are exceptions to the universality of primary duties and entitlements even within the domain of fault-based liability, but the exceptions tend only to reinforce the correlation between strict liability and the non-universality of primary duties, rather than falsify it. Thus, even within the typically universalist fault-based paradigm, there are circumstances in which a group or class of persons is singled out, especially on the active side, and slightly different primary duties are ascribed to that group or class. However, in such situations, the primary duties owed by the group or class are almost invariably stricter than the general duty of care. For instance, the liability of drivers under the tort of negligence is based on a primary duty which is more demanding than the general duty of care, drivers being held to the standard of a "careful and experienced driver" and not the standard of a "reasonable driver" ${ }^{63}$ Also, another group which is often singled out is that of professionals, who owe stricter duties of care because their advanced qualifications in a specific field are taken into account when the victim's damage was caused while they were exercising their specialized functions. ${ }^{64}$ To sum up this idea, we can say that in the right kind of circumstances, the fact that the tortfeasor was a driver, a lawyer, a notary, a doctor, or an accountant matters for the

\footnotetext{
${ }^{63}$ See supra Chapter III Part A.4 and Chapter VI Part C.3.

${ }^{64}$ See PEEL \& GoudKAMP, supra note 37, at 147, 149; GENEVIÈVE VinEY ET AL., TRAITÉ DE DROIT CIVIL. LES CONDITIONS DE LA RESPONSABILITÉ 488-89 [n 471] (4 ${ }^{\text {th }}$ ed., L.G.D.J. 2013); VAN DAM, supra note 37, at 267-69; Panayotis J. Zepos \& Phoebus Christodoulou, Professional Liability, in 11 InTERNATIONAL ENCYCLOPEDIA OF COMPARATive Law, TorTs, Chapter 6, at 5, para. 9-10 (André Tunc ed., J.C.B. Mohr (Paul Siebeck) \& Martinus Nijhoff Publishers 1983).
} 
definition of primary duties and entitlements, but it matters in precisely the sense that the standards these groups of individuals are held to are higher than the ordinary standard of care.

Moving on to the mediated structure of strict liability norms, the contrast with fault-based liability norms provides once more a good point of departure. Fault-based liability links tortfeasors and victims in a straightforward ("direct" or "un-mediated") manner. The only relevant relationship when determining liability under fault-based norms is the causal relationship between the behaviour of the wrongdoer and the damage suffered by the victim. Strict liability norms, however, typically link tortfeasors and victims by way of two connected relationships held together by a nexus point. The elements of liability combine to form a narrative of two relationships: one relationship between the tortfeasor and the nexus point and a second relationship between the nexus point and the victim. It is therefore through the mediation of a nexus point that potential tortfeasors can be said to owe a duty to potential victims. For instance, we have shown that the primary duty and the correlative entitlement that bind the custodian of a thing to the victim in cases of liability for the act of things [article 1242 (1) of the French Civil Code] are based on the correct identification of two connected relationships: the relationship between the victim and the thing and the relationship between the thing and its custodian. Therefore, the nexus point in the ascription of liability is the idea of an "act of a thing". The same mediated structure supports virtually all forms of vicarious liability, ${ }^{65}$ the liability of custodians and keepers for the acts of their animals, product liability, liability for nuclear accidents, and liability for road traffic accidents under the loi Badinter. Moreover, even though it is perhaps less obvious, the torts of trespass to land, trespass to goods, conversion, and defamation also have a mediated normative structure. ${ }^{66}$

The mediated structure of their primary duties and entitlements is what allows strict liability regimes to bypass judgments regarding the quality of the defendant's behaviour. The locus of the wrong or, in other words, the problem that the liability rule is trying to address, is not in the behaviour of the tortfeasor, but in the nexus point, which is always somewhat removed and independent from the tortfeasor's decision-making process. There is a sort of imputability distance implied in all strict liability wrongs. In the context of some strict liability wrongs, such as vicarious

\footnotetext{
${ }^{65}$ With one notable exception - the liability of parents for the acts of their minor children in France [art. 1242 (4) of the French Civil Code], where the nexus point is the act of the child (analysed similarly to the "act of a thing"). See supra Chapter VI Part C.2 for an extensive discussion and critique of this rule.

${ }^{66}$ See supra Chapter VI Parts C.5 and C.6.
} 
liability or liability for the acts of things, the tortfeasor is not liable because of something he did, but because of who he is, i.e. how he relates to the real or primary culprit (who may be a thing or another person). In the context of other torts, such as trespass to land, trespass to goods or conversion, the tortfeasor is liable indeed for something he did, but for something he did to someone's land or goods, and not to the victim of the tort directly. The distance is created in the latter examples on the passive side of the primary duty, the victim being entitled to a remedy not because something was done to him or her, but because of his or her relationship to the property which was being interfered with.

These two structural characteristics of strict liability norms (their non-universality and mediated structure) ought to be taken seriously because of what they imply for the existing debates regarding the adoption, expansion, and even justification of strict liability regimes. There is more at stake when legal systems choose strict liability regimes over fault-based liability regimes than a slight preference for security over freedom and a corresponding "victim-friendly" narrative (which is often contrasted to the "business-friendliness" of fault-based liability). Strict liability's imputability distance, combined with its non-universal nature, point towards a deeper and subtler ideological rift. These characteristics suggest that, in any given area of tort law, what the proponents of fault-based liability and the proponents of strict liability disagree about is not how the law should respond to the same problem (by favouring potential victims over risk-takers or the other way around) or how legal responses can be made more efficient, but about what the problem is to start with.

Because the normative differences between fault and strict liability operate on the primary level of duties and entitlements, the move from fault to strict liability requires a powerful shift in the way events are perceived by legal actors. The key differences between fault and strict liability are differences in the normative narrative shaping our perceptions of the interpersonal problems that ought to be remedied by the legal system. In the interpretation we have offered, the choice between fault and strict liability implies a choice between two different ways of defining civil wrongs, i.e. two different ways of formulating primary duties and their correlative entitlements.

The final argument of this study allowed us to conclude that this choice (the choice between fault and strict liability) is in essence a matter of distributive justice. In Chapter VII the argument was made that, from a neo-Aristotelian perspective, the practice of tort law reflects an ordered 
pluralism, with two constitutive aims ordered in a serial (or lexicographical) manner: in a first stage, by defining primary entitlements and duties, tort law specifies the requirements of distributive justice; then, in a second stage, from the moment a primary entitlement is violated and its correlative duty breached, tort law specifies the requirements of corrective justice. The occurrence of a "civil wrong" (as defined in Chapter $\mathrm{V}^{67}$ ) marks the conceptual boundary between the two stages. Before two persons are brought together in a tortfeasor-victim relationship, i.e. before the tortfeasor violates a primary duty (and therefore also before the victim's correlative entitlement is infringed), the influence of tort law on the lives of legal subjects is limited to how primary duties and entitlements are ascribed and defined. The two fundamental questions that can be asked at this stage are: "who owes primary tort duties to others and which others hold correlative entitlements to those duties?", and "what is the content and scope of such duties and entitlements?" These are questions of just distribution. Taken together, the two questions can be rephrased as: "what is the just distribution of primary tort duties and their correlative entitlements (in this or that legal system)?" Thus, at this stage, every citizen can make normative demands based in distributive justice, but only to the effect of modifying the reach of primary duties and their correlative entitlements. From the moment the civil wrong occurs, however, the mechanisms of corrective justice kick in, generating moral and legal reasons for acting only between the tortfeasor and the victim. The victim of the wrong, and only the victim, is allowed to make a (new) normative demand, which is addressed not to the community or society at large, but only to the tortfeasor. The tortfeasor, and only the tortfeasor, has a legal obligation to remedy the wrong suffered by the victim, and the victim has a correlative right to receive redress. That being said, in the modern practice of tort law corrective justice is specified through legally enforceable obligations. For this reason, if necessary, the victim is also entitled to engage the assistance of the community (usually the state) in order to enforce said right. ${ }^{68}$

There is one key normative question about strict liability that this study has left (partly) unoperationalized, namely "when (in what kind of circumstances) is strict liability a more just solution than fault-based liability?" Our answer to this question is generic and perhaps a bit vague: that strict liability ought to be adopted only in those circumstances in which it is just to distribute

\footnotetext{
${ }^{67}$ See supra Chapter V Part E.2.

${ }^{68}$ In the words of Goldberg and Zipursky, modern tort law provides an avenue for "civil recourse". See the references made supra, in note 253 of Chapter VII.
} 
and legally enforce non-universal duties (i.e. duties owed by members of a group to members of another group, or by members of a group to all other individuals, or by all individuals to members of a group) with a mediated structure (i.e. where potential tortfeasors and potential victims are linked by way of two connected relationships held together by a nexus point). Furthermore, we have also suggested that a distribution of external goods (including legal duties) is just if: (1) it promotes the common good, and (2) it first allocates external goods that are necessary for a life of virtue equally to all citizens, and then distributes the remainder in proportion to merit (where merit is also understood in terms of virtue). ${ }^{69}$ For legal theorists who believe that normative theories should provide determinate solutions for every practical problem within their scope ${ }^{70}$ this type of answer is entirely unsatisfactory because it does not directly inform the legislature or judges about just (or the most just) liability solutions in concrete situations, such as road traffic accidents, environmental pollution, and so on. If we are held to such a standard, then we have, at least in part, failed to answer this last normative question adequately. But perhaps such an exacting standard is inappropriate for the subject-matter tackled by this study. Aristotle insisted that "every account of the actions we must do has to be stated in outline, not exactly." In matters of practical reason, a theory is perhaps superior not when it offers answers on a plate, but when it provides guidance while at the same time leaving sufficient room for experimentation, for difference, and for evolution.

Although the evolution of strict liability has not been linear, and there are still important differences between legal systems with regard to the scope of strict liability, the arrow of history points towards a future with more strict liability, not less. In this author's opinion, legal systems that are evolving in the same direction as the French and the English systems are going in the right direction. Our current and future liability problems seem hard, if not impossible, to address only by recognizing duties of care and setting standards of individual behaviour. Many of the problems that have arisen and will continue to arise from climate change, from the privatization of our digital space, or from the development of self-driving cars and artificial intelligence can only be addressed by collective action and community thinking. Strict liability, with its duties derived from group

\footnotetext{
${ }^{69}$ See supra Chapter VII Part C.1.

${ }^{70} \mathrm{See}$, for instance, Peter M. Gerhart, Tort LAW AND Social Morality xii-xiii (Cambridge University Press 2010) (who considers "excessive generality" and "lack of specificity" the cardinal sins of contemporary tort theory); Jody S. Kraus, Transparency and Determinacy in Common Law Adjudication: A Philosophical Defense of Explanatory Law and Economic Analysis, 93 VA. L. REV. 287, 304-311 (2007) (whose critique focuses on deontic moral theories of tort law and their "indeterminacy").
} 
membership and its imputability distance, especially when coupled with insurance mechanisms, with their cost-sharing distributive effects, is better suited for the complex modern interactions characteristic to such problems. Strict liability will not solve these new problems humanity is faced with, but the redistribution that comes with enacting new strict liability rules will morph our perception, reframing them as problems we face not apart, as uncoordinated individuals, but in common, as members of groups, collectives and communities. 


\section{TABLE OF CASES}

\section{France}

CA Aix-en-Provence, 8 June 2004, D. 2004.2678, note Mathilde Boutonnet; D.2005.186, obs. Denis Mazeaud; Michel Cannarsa et al., France (report), in EurOPEAN TORT LAW 2004, at 297 (Helmut Koziol \& Barbara C. Steininger eds., Springer 2005)

CA Aix-en-Provence, 8 June 2004, D. 2004.2678, note Mathilde Boutonnet; D.2005.186, obs. Denis Mazeaud

CA Paris, 10 February 1999, D. 2000.226, note Nathalie Mallet-Poujol

CA Paris, 9 June 2000, Resp. civ. et assur. 2001, comm. $\mathrm{n}^{0} 76$

CA Poitiers, 30 November 1955, JCP 1956.II.9125, note M. de Juglart

CA Versailles, 26 June 1989, D.1989.247 (IR)

CA Versailles, 4 February 2009, D. 2009.499; D. 2009.819, note Mathilde Boutonnet; Olivier Moréteau, France (report), in EUROPEAN TORT LAW 2009, at 199 (Helmut Koziol \& Barbara C. Steininger eds., De Gruyter 2010)

Cass. Ass. Plén., 12 July 2000, nº 98-10160, Bull. ass. plén., nº 8; D.2000.463, obs. Patrice Jourdain; RTD civ. 2000.842, obs. Patrice Jourdain; RTD civ. 2000.845, obs. Patrice Jourdain

Cass. Ass. Plén., 13 December 2002, nº 00-13787, Bull. ass. plén., n 4; D.2003.231, note Patrice Jourdain; JCP 2003.II.10010, note Hervio-Lelong; JCP 2003.I.154, obs. Geneviève Viney

Cass. Ass. Plén., 17 January 2003, nº 00-13787; D.2003.591, note Patrice Jourdain

Cass. Ass. Plén., 17 November 2000, pourvoi no 99-13.701, Bull. civ. 2000, JCP G 2000, II, 10438, concl. Sainte-Rose, rapp. P. Sargos, note F. Chabas ; D. 2001, 332, note D. Mazeaud; D. 2001, 336, note P. Jourdain

Cass. Ass. Plén., 25 February 2000, n 97-20.152, Bull. ass. plén., nº 2; D.2000.673, note Brun; JCP 2000.II.10295, concl. Kessous, note Billiau; Gaz. Pal. 2000.2.1462, note Rinaldi

Cass. Ass. Plén., 28 June 1996, D.1996.497, concl. Jean-François Weber, note Jean-Marie Coulon; RTD civ. 1997.216, obs. Jacques Normand; RTD civ. 1997.463, obs. Frédéric Zenati

Cass. Ass. Plén., 29 March 1991, no 89-15.231, Bull. ass. plén., no 1; D.1991.324, note Larroumet; Somm. 324, obs. Aubert; JCP 1991.II.21673, concl. Dontenwille, note Ghestin; Gaz. Pal. 1992.2.513, obs. Chabas; RTD civ. 1991.312, note J. Hauser; RTD civ. 1991.541, note Patrice Jourdain

Cass. Ass. Plén., 9 May 1984, Bull. ass. plén., no 4; D.1984.525, concl. J. Cabannes, note François Chabas ; JCP 1984.II.20255, obs. N. Dejean de la Bâtie (2 ${ }^{\text {nd }}$ case); JCP 1984.II.20291, Rapport Fedou; RTD civ. 508 (1984), obs. J. Huet (arrêt Fullenwarth)

Cass. Ch. Mixte, 28 March 1997, D.1997.294, comm Hubert Groutel

Cass. Ch. Réun, 13 February 1930, DP 1930.1.57, note Georges Ripert, rapport Le Marc'hadour, conclusions P. Matter ; S.1930.1.121, note Paul Esmein

Cass. Ch. Réun., 23 July 1862, D.1862.1.257

Cass. Ch. Réunies, 2 December 1941, DC 1942.25, note Ripert; S.1941.1.217, note H. Mazeaud; JCP 1942.II.1766 note Mihura (arrêt Franck) 
Cass. Civ 2e, 14 January 1999, nº 97-11.527, Bull. civ. II, nº 13; D. 1999. IR 50

Cass. Civ. 1re, 10 July 2013, nº 12-21.314, Bull. civ. I, n 157 ; D.2013. 2311; D.2013. 2306, avis conforme C. Mellottée; D.2013. 2312, note Ph. Brun; D.2013. 2315, note J.-S. Borghetti; D.2014. 47, obs. Ph. Brun \& O. Gout.

Cass. Civ. 1re, 15 December 2011, D. 2012, 297, note Nicolas Maziau; D. 2012, 323, note I. Gallmeister

Cass. Civ. 1re, 15 May 2007, Bull. civ. n 05-17947; JCP 2007.I.185, nº 8, obs. Ph. Stoffel-Munck; D.2007.1593, obs. I. Gallmeister; RTD civ. 2007.580, obs. Patrice Jourdain

Cass. Civ. 1re, 16 January 1982, JCP 1982.IV.107; Cass. Civ. 2e, 4 March 1987, Bull. civ. II, nº 63, p. 35

Cass. Civ. 1re, 18 July 1972, Bull. civ. 1 nº 189

Cass. Civ. 1re, 20 March 1989, D.1989.581, note Philippe Malaurie

Cass. Civ. 1re, 22 May 2008, nº 06-10.967, Bull. civ. I, no 149; D.2008 AJ 1544, obs. I. Gallmeister; D.2008 2894, obs. Ph. Brun \& P. Jourdain; RTD civ. 2008. 492, obs. P. Jourdain

Cass. Civ. 1re, 25 February 2010, nº 09-12.641

Cass. Civ. 1re, 25 June 2009, nº 08-12.781, Bull. civ. I, no 141; D.2009 AJ 1895

Cass. Civ. 1re, 26 March 1996, no 94-11.791 94-14.158, Bull. civ. 1996

Cass. Civ. 1re, 26 September 2012, no 11-17.738, Bull. civ. I, no 187; D.2012. 2853, obs. I. Gallmeister, note J.-S. Borghetti ; D. 2012. 2376, entretien C. Radé; D.2013. 40, obs. Ph. Brun \& O. Gout; D.2013. 2802, obs. Ph. Delebecque, J.-D. Bretzner \& I. Darret-Courgeon; RTD civ. 2013. 131, obs. P. Jourdain

Cass. Civ. 1re, 30 October 1995, Bull. civ. I, nº 383, RTD civ. 1996.136, obs. Patrice Jourdain

Cass. Civ. 1re, 8 April 2008, $n^{\circ}$ 07-11.251, Bull. civ. I, nº 104, D.2008.2402, obs. S. Lavric, note Laurent Neyret; RTD civ. 2008.489, obs. Patrice Jourdain

Cass. Civ. 1re, 9 July 2009, nº 08-11.073, Bull. civ. I, nº 176; D.2009 AJ 1968, obs. I. Gallmeister; D.2010 Pan. 49 n ${ }^{0}$ 2, obs. Ph. Brun ; RTD civ. 2009. 723, obs. P. Jourdain

Cass. Civ. 1re, 9 March 1983, Bull. civ. I no 92; JCP 1984.II.20295

Cass. Civ. 2e, 10 June 2004, Bull. civ. II, no 291; D.2004.2477; D.2005.185, obs. Philippe Delebecque, Patrice Jourdain \& Denis Mazeaud; RTD civ. 2004.738, obs. Jourdain

Cass. Civ. 2e, 10 May 2001, no 99-11287, Bull. civ. II, n 76; D. 2001.2851, rapp. Guerder, note Tournafond; D.2002.1315, obs. D. Mazeaud ; JCP 2001.II.10614, note J. Mouly ; RTD civ. 2001.601, obs. Patrice Jourdain (arrêt Levert)

Cass. Civ. 2e, 11 April 2002, Bull. civ. II, nº 72, p. 60

Cass. Civ. 2e, 12 December 2002, Bull. civ. II. n 289; RTD civ. 2003. 305, obs. Patrice Jourdain, JCP 2003.I.154, n 49 , obs. Geneviève Viney

Cass. Civ. 2e, 12 June 1996, D. 1996 IR 175

Cass. Civ. 2e, 13 January 1997, JCP 1997.II.22883

Cass. Civ. 2e, 13 June 1968, Bull. civ. II, no 176, p. 124

Cass. Civ. 2e, 14 October 1970, JCP 1971.II.16912, note N. Dejean de la Bâtie

Cass. Civ. 2e, 16 June 2005, nº 03-18.625, Bull. civ. II, $\mathrm{n}^{\circ} 156$

Cass. Civ. 2e, 16 March 1994, JCP 1994.IV.1326 
Cass. Civ. 2e, 17 June 1990, RTD civ. 1990, 507, obs. Patrice Jourdain

Cass. Civ. 2e, 17 March 2005, Bull. civ. II, n 73; D.2005.2357, obs. Mallet-Bricout \& Reboul-Maupin

Cass. Civ. 2e, 18 November 1987, Bull. civ. II, $\mathrm{n}^{\circ} 235$, p. 130

Cass. Civ. 2e, 19 February 1997, Bull. civ. II, n 56; D.1997.265, note Patrice Jourdain; JCP.1997.II.22848, concl. R. Kessous, note Geneviève Viney; Gaz. Pal., 3 October 1997, note François Chabas (arrêt Bertrand)

Cass. Civ. 2e, 19 November 1986, Bull. civ. II, nº 172; D. 1988.16, note A. Robert

Cass. Civ. 2e, 2 April 1997, n 95-19.986, Bull. civ. II, nº 110; Gaz. Pal. 1997 Pan. 283

Cass. Civ. 2e, 2 July 1997, D.1997.183

Cass. Civ. 2e, 2 November 1960, D. 1961.770; Bull. civ. II, p. 427; JCP 1962.II.12499, note Paul Esmein; RTD civ. 1962, p. 103, obs. A. Tunc

Cass. Civ. 2e, 21 July 1982, D. 1982. 449, concl. Charbonnier, note Larroumet ; JCP 1982. II. 19861, note Chabas; Defrénois 1982. 1689, obs. Aubert; RTD civ. 1982. 607, note G. Durry

Cass. Civ. 2e, 21 May 1997, D.1998.150, note B. Fages

Cass. Civ. 2e, 22 May 1995, D.1996.453

Cass. Civ. 2e, 22 May 1995, JCP 1995.II.22550, comm. Mouly, JCP 1995.I.3893, obs. Geneviève Viney, RTD civ. 1995. 899, obs. Patrice Jourdain

Cass. Civ. 2e, 23 March 1994, D. 1994.299, comm. Hubert Groutel; RTD civ. 1994. 627, obs. Patrice Jourdain

Cass. Civ. 2e, 24 February 2005, Bull. civ. II, n 50; JCP 2005.I.149, obs. Geneviève Viney; JCP 2005.II.10100, note Trébulle

Cass. Civ. 2e, 25 January 1995, Bull. civ. II, no. 27; RTD. civ. 1995. 382, obs. Patrice Jourdain

Cass. Civ. 2e, 28 May 2009, nº 08-13310, Bull. civ., II, n 128; JCP 2009.92, note J. Mouly; D.2009.1606, obs. I. Gallmeister; D.2009.2667, note N. Pierre; D.2010.55 obs. Philippe Brun; RTD civ. 2009.541, obs. Patrice Jourdain

Cass. Civ. 2e, 29 April 1976, JCP 1978.II.18793, note N. Dejean de la Bâtie

Cass. Civ. 2e, 29 June 1995, Bull. civ. II, nº 222, D.1996.59, obs. A. Robert

Cass. Civ. 2e, 3 March 1988, Bull. civ. II, nº 58

Cass. Civ. 2e, 3 October 1990, RTD civ. 1991. 354, obs. Patrice Jourdain

Cass. Civ. 2e, 4 June 1980, JCP 1981.II.19599, note Feddal

Cass. Civ. 2e, 4 March 1987, Bull. civ. II, no 63, p. 35

Cass. Civ. 2e, 6 May 1997, D.1997.503. comm. Hubert Groutel

Cass. Civ. 2e, 7 July 1976, JCP 1976.IV.296

Cass. Civ. 2e, 7 October 2004, $n^{0}$ 02-18.995, Bull. civ. II, $\mathrm{n}^{0}$ 445; D.2004.2692; Cass. Civ. $2^{\mathrm{e}}$, 16 June 2005, $\mathrm{n}^{\mathrm{o}}$ 03-18.625, Bull. civ. II, $\mathrm{n}^{\circ}$ 156; D.2005.1805, obs. J. Daleau; Cass. Civ. $1^{\text {re }}, 7$ July 2006, $\mathrm{n}^{\circ} 05-16.614$, Bull. civ. I, $\mathrm{n}^{\circ} 3566$

Cass. Civ. 2e, 8 April 2004, nº 03-11.653, Bull. civ. II, n 194; RTD Civ. 2004.217, obs. Patrice Jourdain; D.2004.2601, note Serinet; JCP 2004.II.10131, note Imbert (arrêt Olympique de Marseille) 
Cass. Civ. 2e, 8 June 1994, Bull. civ. II, no. 147; D. 1994 IR 181

Cass. Civ. 2e, 8 November 1993, Bull. civ. II, nº 316, JCP 1994.IV.84

Cass. Civ. 2e, 9 November 1971, D.1972.75 (Jurisp.); RTD civ. 1972. 400, obs. G. Durry

Cass. Civ. 3e, 11 May 2000, Bull. civ. III, no 106, D.2001.2231, obs. Patrice Jourdain

Cass. Civ. 3e, 12 February 1992, Bull. civ. III, nº 44

Cass. Civ. 3e, 21 May 2008, D.2008.1550, obs. Bigot de la Tuanne; D.2008.2458, obs. Mallet-Bricout \& Reboul-Maupin ; D.2008.2894, obs. Philippe Brun \& Patrice Jourdain; RTD civ. 2008.496, obs. Patrice Jourdain

Cass. Civ. 3e, 24 February 1999, nº 96-18.742, D.1999.79 (I.R.)

Cass. Civ. 3e, 9 February 2011, Bull. civ. III, nº 21

Cass. Civ., 12 October 1955, D.1956.301, note R. Rodière

Cass. Civ., 13 February 1957, Bull. civ. 1957.II.59

Cass. Civ., 14 November 1958, JCP 1959.II.10394, note R. Rodière

Cass. Civ., 16 December 1920, DP 1920.1.169, note R. Savatier

Cass. Civ., 16 June 1896, D.1898.1.433, concl. Sarrut, note Saleilles; S.1897.1.17, note A. Esmein

Cass. Civ., 19 February 1941, D.C.1941.85, note J. Flour

Cass. Civ., 1re, 3 June 2010, D. 2010. 1522, note P. Sargos

Cass. Civ., 25 November 1813, JP, tome 15, p. 671

Cass. Civ., 27 November 1844, DP 1845.1.13

Cass. Civ., 30 December 1936, DP 1937.1.5, rap. L. Josserand, note R. Savatier; S. 1937.1.137, note H. Mazeaud

Cass. Civ., 31 July 1905, S.1909.1.143; Cass. Req., 29 April 1913, D.1913.1.427, rapport Jaffard

Cass. Civ., 4 November 1945, JCP 1946.II.3110, note J.R.

Cass. Civ., 8 June 1961, Bull. civ. II, p. 433

Cass. Com., 12 October 1993, Bull. civ. IV, nº 338, p. 245; D. 1994.124, note Geneviève Viney; RTD civ. 1994.111

Cass. Com., 24 June 2008, Bull. civ. ${ }^{0}$ 07-11744; JCP G 2008.I.186, n 7, obs. Ph. Stoffel-Munck; D.2008.1895, Obs. I. Gallmeister; D.2008.2318, note J.S. Borgetti; RTD civ. 2008.685, obs. Patrice Jourdain

Cass. Com., 26 May 2010, Bull. civ. nº 08-18545. RTD civ. 2010.790, obs. Patrice Jourdain

Cass. Crim., 11 June 1970, Gaz. Pal. 1970 1970, p. 2, 146

Cass. Crim., 14 March 1973, Bull. Crim., nº 131, p. 313

Cass. Crim., 18 June 1980, D.1981.322 (IR), obs. Christian Larroumet

Cass. Crim., 20 June 1924, D.1925.1.94

Cass. Crim., 22 March 1988, no. 87-82802, Bull. Crim. no 142, available online at http://www.juricaf.org/arret/FRANCE-COURDECASSATION-19880322-8782802

Cass. Crim., 5 October 1977, D.1978.246 (IR) 
Cass. Crim., 9 March 1972, D.1972.342

Cass. Req., 21 October 1942, DA 1943.21

Cass. Req., 23 December 1879, S.1880.463

Cass. Req., 3 August 1915, DP 1917.1.79

Cass. Req., 30 March 1897, S. 1987.1.71

Cass. Req., 6 August 1907, S.1908.1.128

Cass., 27 October 1885, DP 1886.1.207; S.1886.1.33

CE, 19 July 2010, no. 328687, JurisData 2010-012229

Cons. const., 11 June 2010, n 2010-2 QPC, JORF, p.10847; D. 2010., 1976, obs. I. Gallmeister, note Daniel Vigneau, D. 2010, 1980, note Valérie Bernaud et Laurence Gay; D. 2011, 2565, obs. Anne Laude; RTD civ. 2010, 517, obs. Pascal Puig

TC, May 14, 2012, 6 decisions, JurisData 2012-010164, 2012-010165, 2012-010166, 2012-010169, 2012010170, 2012-010172; D. 2012 Jur. 1930, notes G.J. Martin \& J.-C. Msellati; Olivier Moréteau \& Alexandru-Daniel On, France (report) in EUROPEAN TORT LAW 2013, at 229, 241-42 (Ken Oliphant \& Barbara C. Steininger eds., De Gruyter 2013)

TGI Grasse, 17 June 2003, JurisData 2003-221748

TGI Nanterre, 18 September 2008, D. 2008.2916, note Mathilde Boutonnet

\section{United Kingdom}

A v National Blood Authority, [2001] 3 All ER 289

Aldred's case, (1610), 9 Co. 57b

Allen v Flood, [1898] A.C. 1

Anns v Merton LBC, [1978] A.C. 728

Armes v Nottinghamshire County Council, [2017] UKSC 60, [2018] A.C. 355

Atkinson v Newcastle Waterworks Co, (1877) 2 Ex. D. 441

Attorney-General v Corke, [1933] Ch. 89

Baker v Herbert, [1911] 2 KB 633

Baker v Quantum Clothing Group Ltd, [2011] UKSC 17; [2011] 1 W.L.R. 1003

Balfour v Barty-King, [1957] 1 Q.B. 496

Bamford v Turnley, (1862) 3 B. \& S. 62

Basely v Clarkson, (1681) 3 Lev 37

Batcheller v Tunbridge Wells Gas Co, (1901) 84 L.T. 765

Beckwith v Shordike, (1767) 4 Burr 2092

Bell v. Midland Ry. Co., 142 Eng. Rep. 462 (C.P. 1861)

Biffa Waste Services Ltd v Maschinenfabrik Ernst Hese GmbH, [2008] EWCA Civ 1238; [2009] Q.B. 725

Blue Sky One Ltd v Mahan Air, [2009] EWHC 3314 (Comm) 
Blyth v Birmingham Waterworks Co., (1856) 11 Ex. 781

Boardman v Phipps, [1967] 2 A.C. 46

Box v Jubb, (1879) 4 Ex.D 76

Boyer v Warbey, [1953] 1 Q.B. 234

Bradford (Mayor of) v Pickles, [1895] A.C. 587

Breslin v McKenna, [2009] NIQB 50

Bristol and West Building Society v Mothew, [1998] Ch. 1

British Waterways Board v Seven Trent Water, [2002] Ch. 25 (C.A.)

Cambridge Water Co Ltd v Eastern Counties Leather Plc, [1994] 2 W.L.R. 53, [1994] 2 A.C. 264

Caparo Industries Plc v Dickman, [1990] UKHL 2, [1990] 2 A.C. 605

Catholic Child Welfare Society v Various Claimants and the Institute of the Brothers of the Christian Schools, [2012] UKSC 56; [2013] 2 A.C. 1

Central Newbury Car Auctions Ltd v. Unity Finance Ltd, [1957] 1 Q.B. 371

Chauhan v Paul, [1998] C.L.Y. 3990, C.A.

Christie v Davey, [1893] 1 Ch. 316

Clark v Brims, [1947] K.B. 497

Clarke v Molyneux, (1877) 3 Q.B.D. 237

Coco v. AN Clark (Engineers) Ltd. [1968] F.S.R. 415

Collins v Wilcock, [1984] WLR 1172

Connor v Surrey CC, [2010] 3 W.L.R. 1302; [2010] EWCA Civ 286; [2011] Q.B. 429

Consolidated Co v Curtis \& Sons, [1892] 1 Q.B. 495

Conway v George Wimpey \& Co Ltd, [1951] 2 K.B. 266

Coote v Stone, [1971] 1 W.L.R. 279

Corby Group Litigation v Corby BC, [2008] EWCA Civ 463; [2009] 2 W.L.R. 609

Coulthard v Disco Mix Club Ltd, [2000] 1 W.L.R. 707

Cox v Ministry of Justice, [2014] EWCA Civ 132

Cox v Ministry of Justice, [2016] UKSC 10, [2016] A.C. 660

Crawshay v Collins, (1808) 15 Vesey Junior 218; 33 ER 736

Curtis v Betts, [1990] 1 W.L.R. 459

D\&F Estates Ltd. v Church Commissioners, [1989] A.C. 177

Dee v Telegraph Media Group Ltd, [2010] E.M.L.R. 20; [2010] 4 WLUK. 472

Dobson v Thames Water, [2009] 3 All E.R. 319; [2009] H.R.L.R. 19; [2009] EWCA Civ 28

Donaldson v McNiven, [1952] 1 All E.R. 1213 (C.A.)

Donoghue v Stevenson, [1932] UKHL 100, [1932] A.C. 562

Dorset Yacht v Home Office, [1970] A.C. 1004 
Douglas v Hello! Ltd (No. 5), [2003] EWHC 786 (Ch)

Dransfield v. British Insulated Cables Ltd., [1937] 4 All ER 382

Eastern and South African Telegraph Co Ltd v Cape Town Tramways Companies Ltd, [1902] A.C. 381

Ellis v Home Office, [1953] 2 Q.B. 135

Emmens v Pottle, (1885) 16 QBD 354

Exel Logistics Ltd. v Curran, [2004] EWCA Civ 1249

Ex p. Island Records, [1978] Ch. 122

Express and Echo Publications Ltd v Tanton [1999], I.R.L.R. 367

Fagan v Metropolitan Police Commissioner, [1969] 1 QB 439, [1968] 3 All ER 442, [1968] 3 WLR 1120

Fairchild v Glenhaven Funeral Services Ltd \& Others, [2002] 3 All ER 305

Fardon v. Harcourt-Rivington, (1932) 146 L. T. 391

Farrer v Nelson, (1885) 15 QBD 258

Fay v Prentice, (1845) 1 C.B. 828

Filliter v Phippard, (1847) 11 Q.B. 347

Fine Art Society v Union Bank of London, (1886) LR 17 QBD 705

Firth v Bowling Iron Co, (1878) 3 C.P.D. 254

Fletcher v Rylands, (1865) 3 H \& C 774, 159 ER 737 (Court of Exchequer)

Fletcher v Rylands, (1866) LR 1 Ex. 265 (Court of Exchequer Chamber)

Fowler v Lanning, [1959] 1 Q.B. 426

Froom v Butcher, [1976] Q.B. 286, 291 (CA)

Galashiels Gas Co v Millar, [1949] A.C. 275

Garden Cottage Foods v Milk Marketing Board, [1983] 3 W.L.R. 143; [1984] A.C. 130

Gee v Pritchard, (1818) 2 Swan 402

Gilbert v Stone, (1647) Style 72

Goldman v Hargrave, [1967] 1 A.C. 645

Greenock Corp v Caledonian Ry, [1917] A.C. 556

Groves v Lord Wimborne, [1898] 2 Q.B. 402

Hamby v Northage, (1579) Cary 76

Henderson v Henry E Jenkins \& Sons [1970], A.C. 282

Henderson v Merrett Syndicates Ltd., [1994] W.L.R. 761, [1995] 2 A.C. 145

Hillier v Air Ministry, [1962] C.L.Y. 2084

Hilton v Barker Booth Eastwood, [2005] U.K.H.L. 8; [2005] 1 W.L.R. 567

Hoare \& Co v McAlpine, [1923] 1 Ch. 167

Hollins v Fowler, (1874-75) LR 7 HL 757

Hollywood Silver Fox Farm Ltd v Emmett, [1936] 2 K.B. 468 
Home Office v Dorset Yacht Co Ltd, [1970] UKHL 2, [1970] A.C. 1004

Honeywill and Stein Ltd v Larkin Bros Ltd, [1934] 1 K.B. 191

Horrocks v Lowe, [1975] A.C. 135

Hunter v Canary Wharf Ltd, [1997] A.C. 655

Job Edwards Ltd. V Birmingham Navigations, [1924] 1 K.B. 341

John Summers \& Sons Ltd v Frost, [1955] 2 W.L.R. 825; [1955] A.C. 740

Jolliffe v Willmett \& Co, [1971] 1 All ER 478

Jones v Festiniog Ry, (1866) L.R. 1 Ex. 265

Keech v Sandford, (1726) Sel. Cas. t. King 61; 25 E.R. 223 (the Rumford Market case)

Kennaway v Thompson [1981] Q.B. 88

Lachaux v Independent Print Ltd, [2015] EWHC 2242 (Q.B.)

Lavender v Betts, [1942] 2 All ER 72

League Against Cruel Sports v Scott, [1986] Q.B. 240

Leakey v National Trust, [1980] Q.B. 485

Lee v Cheung [1990], 2 A.C. 374

Leeman v Montague, [1936] 2 All ER 1677

Letang v Cooper, [1964] 3 W.L.R. 573; [1965] 1 Q.B. 232

Lickbarrow v. Mason, 2 T.R. 63 (1787)

Liquid Veneer Company v Scott, (1912) 29 R.P.C. 639

Lister v Romford Ice and Cold Storage Co, [1957] A.C. 555; [1957] 1 All ER 125

Lochgelley Iron \& Coal Co v M’Mullan, [1934] A.C. 1

London Passenger Transport Board v Upson, [1949] A.C. 155

Lord Ashburton v Pape, [1913] 2 Ch 469

Mansfield v Weetabix Ltd, [1998] 1 W.L.R. 1263

Marfani \& Co Ltd v Midland Bank Ltd, [1968] 1 W.L.R. 956

Mason v Levy Auto Parts of England Ltd, [1967] 2 Q.B. 530

McKay and Another v Essex Area Health Authority [1982] 2 All ER 771 (CA)

Mercantile Credit Co Ltd v Hamblin, [1965] 2 Q.B. 242

Merlin and Another v British Nuclear Fuels Plc., [1990] 2 Q.B. 557, [1990] 3 W.L.R. 383

Miles v Forest Rock Co, (1918) 34 T.L.R. 500

Milne v Express Newspapers, [2004] E.M.L.R. 24

Mirvahedy v Henley, [2003] UKHL 16; [2003] 2 A.C. 491

Mohamud v WM Morrison Supermarkets plc, [2016] UKSC 11, [2016] A.C. 677

Monk v Warbey, [1935] 1 K.B. 75

Moore v Poyner, [1975] R.T.R. 127 
Moorgate Mercantile Co Ltd v Twitchings, [1977] A.C. 890

Morris v Ford Motor Co. Ltd., [1973] Q.B. 792

Morrison Sports Ltd v Scottish Power, [2010] UKSC 37; [2010] 1 W.L.R. 1934

Musgrove v Pandelis, [1919] 2 K.B. 43

Napier and Ettrick (Lord) v Hunter, [1993] A.C. 713

National Broach \& Machine Co. v Churchill Gear Machines Ltd., [1965] R.P.C. 61

National Coal Board v JE Evans \& Co (Cardiff) LD, [1951] 2 K.B. 861

National Telephone Co v Baker, [1893] 2 Ch. 186

Nettleship v Weston, [1971] 2 Q.B. 691

NG Chun Pui v Lee Chuen Tat, [1988] R.T.R. 298 (Privy Council)

Ng v Lee, [1988] R.T.R. 296

Nichols v Marsland, (1875) LR 10 Exch 255; (1876) 2 Ex.D. 1

Perry v Kendricks Transport Ltd, [1956] 1 W.L.R. 85

Philips v Britannia Hygienic Laundry Co, [1923] 2 K.B. 832

Pollard v Photographic Co, (1888) 40 Ch. D. 345

Powell v Fall, (1880) 5 Q.B.D. 597

Prenn v Simmonds, [1971] 1 W.L.R. 1381

Prince Albert v Strange, (1849) 41 E.R. 1171

R v Goldstein, [2006] 1 A.C. 456

R v Rimmington; R v Goldstein, [2006] 1 A.C. 456

R v Shorrock, [1994] Q.B. 279

R v Deputy Governor of Brixton Prison Ex p. Hague, [1992] 1 A.C. 58

Rashid v Sharif, [2014] EWCA Civ 377

Read v Croydon Corporation, [1938] 4 All ER 631

Read v J Lyons \& Co Ltd, [1947] A.C. 156; [1946] 2 All ER 471

Reedie v London and North Western Ry, (1849) 4 Exch. 244

Regal (Hastings) Ltd v Gulliver [1967] 2 AC 134

Reinham Chemical Works Ltd v Belvedere Fish Guano Co Ltd, [1921] 2 A.C. 465

Re Thomson, [1930] 1 Ch. 203

Richardson v LRC Products Ltd, [2000] Lloyd's Rep Med 280

Rickards v Lothian, [1913] A.C. 263

River Wear Commissioners v Adamson, (1877) App. Cas. 743

Roberts v CC Kent, [2008] EWCA Civ 1588; [2009] Po. L.R. 8

Robinson v Chief Constable of West Yorkshire Police, [2014] EWCA Civ 15

Roe v Minister of Health, [1954] 2 Q.B. 66 
Rookes v Barnard, [1964] A.C. 1122

Rylands v Fletcher, (1868) LR 3 HL 330 (House of Lords)

Sadleigh-Denfield v O'Callaghan, [1940] A.C. 880

Saltman Engineering Co v Campbell Engineering Co, (1948) 65 R.P.C. 203

Sargent (Garages) Ltd v. Motor Auctions (West Bromwich) Ltd, [1977] R.T.R. 121 (CA)

Scott v Shepherd, [1773] 96 Eng. Rep. 525

Seager v Copydex Ltd, [1967] 1 W.L.R. 923

Searle v Wallbank, [1947] A.C. 341

Sedleigh-Denfield v O'Callaghan, [1940] A.C. 880

Sempra Metals Ltd (formerly Metallgesellschaft Ltd) v Inland Revenue Commissioners, [2008] 1 A.C. 561

Sim v Stretch, [1936] 2 All ER 1237

Simpson v Weber, (1925) 133 LT 46

Skuse v Granada Television Ltd, [1996] E.M.L.R. 278

Smith v Leurs, (1945) 70 CLR 256

Smith v Stone, (1647) Style 65

Sobrinho v Impresa Publishing SA, [2016] EWHC 66 (QB)

Southport Corp v Esso Petroleum Co Ltd, [1954] 2 Q.B. 182

Spencer v London and Birmingham Rly Co, (1836) 8 Sim 193

Stannard v Gore, [2012] E.W.C.A. Civ. 1248; [2014] Q.B. 1

Tanks and Vessels Industries Ltd v Devon Cider Company Ltd, [2009] EWHC 1360 (Ch)

Terrapin Ltd. V Builders Supply Co (Hayes) Ltd., [1967] R.P.C. 375

The Mercantile Bank of India, Ltd. vs The Central Bank Of India, [1938] A.C. 287 (P.C.)

The Mostyn, [1928] A.C. 57

The Wagon Mound (No 2), [1967] 1 A.C. 617

Tinsley v Milligan, [1994] 1 A.C. 340

Transco Plc v Stockport MBC, [2003] U.K.L.H. 61; [2004] 2 A.C. 1

Turnbull v Warrener, [2012] EWCA Civ 412; [2012] P.I.Q.R. P16

United Scientific Holdings Ltd. v Burnley BC, [1978] A.C. 904

Waugh v James K. Allan Ltd [1964] 2 Lloyd's Rep 1

Welsh v Stokes, [2007] EWCA Civ 796; [2008] 1 W.L.R. 1224

West v Bristol Tramways Co, [1908] 2 K.B. 14

Westripp v Baldock, [1938] 2 All ER 779 (affd [1939] 1 All ER 279)

Wheeler v JJ Saunders Ltd, [1996] Ch. 19

Whiteley Limited v Hilt, [1918] 2 K.B. 809

Wilson and Clyde Coal Co v English, [1938] A.C. 57 
Woodland v Essex CC, [2013] UKSC 66; [2014] A.C. 537

Worsley v Hollins, [1991] RTR 252 (CA)

\section{Other national courts}

Australian Blue Metal Ltd v Hughes, [1963] A.C. 74 (Australia)

BGH 18 January 1983, ENTSCHEIDUNGEN DES BUNDESGERICHTSHOF IN ZIVILSACHEN 86, 240 (Germany) Greenman v. Yuba Power Products Inc., 59 Cal. 2d 57, 377 P.2d 897, 27 Cal. Rptr. 697 (1963) (United States)

HR 18 March 2005, ECLI:NL:HR:2005:5213, NJ 2006/606 (baby Kelly) (the Netherlands)

Walton Stores (Interstate) Ltd v Maher, (1988) ALR 513 (Australia)

\section{Court of Justice of the European Union}

CJEU, 21 December 2011, C-495/10, Centre hospitalier universitaire de Besançon v. Thomas Dutrueux, Caisse primaire d'assurance maladie du Jura; D.2012.926, note J.S. Borghetti; D.2012.1558, note P. Véron \& F. Vialla; RTD civ. 2012.329, obs. Patrice Jourdain; ECLI:EU:C:2011:869

CJEU, 21 June 2017, C-621/15, N.W., L.W., C.W.v Sanofi Pasteur MSD SNC, Caisse primaire d'assurance maladie des Hauts-de-Seine, Carpimko, ECLI:EU:C:2017:484

CJEU, 4 June 2009, C-285/08, Moteurs Leroy Somer v. Dalkia France, Ace Europe; D.2009.1731, note J.S. Borghetti; D.2010.49, obs. Philippe Brun \& O. Gout; RTD civ. 2009.738, obs. Patrice Jourdain; JCP G 2009.I.248, n 5, obs. Ph. Stoffel-Munck; JCP G 2009.II.26, obs. F. Picod; JCP G 2009.II.82, note Patrice Jourdain

ECJ, 10 January 2006, C-402/03, Bilka Lavprisvarehus A/S v. Jette Mikkelsen, Michael Due Nielsen, in JCP G 2006.II.10082, note L. Grynbaum; JCP G 2006.I.166, nº 12, note Philippe Stoffel-Munck

ECJ, 13 January 1993, C-293/91, Commission v. France, ECR I-0001; D.1993.566, note Jean-Louis Clergerie

ECJ, 14 March 2006, C-177/04, Commission v. France, RTD Civ. 2006.265, obs. Pauline Rémy-Corlay; RTD civ. 2006.335, obs. Patrice Jourdain; JCP G 2006.I.166, no 13, obs. Philippe Stoffel-Munck

ECJ, 25 April 2002, C-154/00 Commission v Greece [2002] ECR I-3879, ECLI:EU:C:2002:254

ECJ, 25 April 2002, C-183/00, Maria Victoria González Sánchez v Medicina Asturiana SA, ECLI:EU:C:2002:255

ECJ, 25 April 2002, C-183/00, María Victoria Gonzalez Sanchez v. Medicina Asturiana; D.2002.1670, note C. Rondey, D.2002.2462, note C. Larroumet; D.2002.2937, obs. J.-P. Pizzio; D.2003.463, obs. D. Mazeaud; RTD Civ. 2002.523, obs. Patrice Jourdain

ECJ, 25 April 2002, C-52/00, Commission v France; D. 2002.1670, obs. C. Rondey; D.2002.2462. note C. Larroumet; D. 2002.2935, obs. J-P. Pizzio; RTD civ. 2002.523, obs. Patrice Jourdain; RTD Civ. 2002.868, obs. J. Raynard; [2002] ECR I-3827, ECLI:EU:C:2002:252.

ECJ, 29 May 1997, C-300/95, European Commission v UK, EUROPEAN COURT REPORTS, p. I-02649 (1997); [1997] All ER (EC) 481 


\section{European Court of Human Rights}

ECHR, 21 February 1990, Powell and Rayner v. United Kingdom, no 9310/81; [1990] 12 EHRR 355, [1990] ECHR 2

ECHR, 6 October 2005, Draon v France, no 1513/03

ECHR, 6 October 2005, Maurice v France, no 11810/03; (2005) 42 EHRR 885

ECHR, 9 December 1994, Lopez Ostra v. Spain, nº 16798/90; RTD civ. 1996.507, obs. Marguénaud 


\section{BIBLIOGRAPHY}

\section{$\underline{\text { Books }}$}

ACKERMAN, Bruce, Social Justice in the Liberal State (Yale University Press 1980)

ADDISOn, Charles G., Wrongs and their Remedies: Being a Treatise on the Law of Torts (V. and R. Stevens and Sons 1860)

AleXANDER, Gregory S. \& PeÑAlver, Eduardo M., An Introduction to Property Theory (Cambridge University Press 2012)

ALEXANDER, Gregory S., Property and Human Flourishing (Oxford University Press 2018)

ANNAS, Julia, Intelligent Virtue (Oxford University Press 2011, repr. 2013)

ANNAS, Julia, The Morality of Happiness (Oxford University Press 1995)

AQUINAS, Thomas, Commentary on the Nicomachean Ethics, vol. 1 (C. I. Litzinger trans., Henry Regnery Co. 1964)

ARChBOLD, John Frederick, Criminal Pleading, Evidence and Practice $\left(59^{\text {th }}\right.$ ed., P.J. Richardson ed., Sweet \& Maxwell 2002)

ARISTOTLE, Nicomachean Ethics ( $2^{\text {nd }}$ ed., Terence Irwin trans., Hackett Publ. Co. 1999)

Aristotle, Nicomachean Ethics, in The Basic Works of Aristotle 935 (Richard McKeon ed., The Modern Library 2001)

Aristotle, Politics, in The Basic Works of Aristotle 1127 (Richard Mckeon ed., The Modern Library 2001)

ATIAS, Christian, Droit civil. Les biens (12 ${ }^{\text {th }}$ ed., LexisNexis 2014)

ATIYAH, Patrick S., Accidents, Compensation and the Law (Weidenfeld and Nicholson 1970)

ATIYAH, Patrick S., The Damages Lottery (Hart Publishing 1997)

ATIYAH, Patrick S., Vicarious Liability in the Law of Torts (Butterworths 1967)

ATYAH, Patrick S., The Rise and Fall of the Freedom of Contract (Oxford University Press 1979)

Aubry, Charles \& RAU, Charles-Frédéric, Cours de droit civil français, vol. 3 (3 ${ }^{\text {rd }}$ ed., Cosse 1856), available at https://gallica.bnf.fr/ark:/12148/bpt6k57900391

AusTiN, John, Lectures on Jurisprudence ( $2^{\text {nd }}$ ed., Burt Franklin 1970)

BAKER, J.H., An Introduction to English Legal History (3 ${ }^{\text {rd }}$ ed., Butterworths 1990)

vON BAR, Christian, The Common European Law of Torts, vol. 1 (Oxford University Press 1998)

BEEver, Allan, A Theory of Tort Liability (Hart Publishing 2016)

BERGEL, Jean-Louis, et al., Traité de droit civil. Les biens ( $2^{\text {nd }}$ ed., L.G.D.J. 2010)

BIRKS, Peter, An Introduction to the Law of Restitution (Clarendon Press 1985, repr. 1996)

Blackstone, William, Commentaries on the Laws of England (4 vols., 15 ${ }^{\text {th }}$ ed., A. Strahan 1809 , republished by Forgotten Books 2012)

BLOCH, Cyril, La cessation de l'illicite. Recherche sur une fonction méconnue de la responsabilité civile extracontractuelle (Dalloz 2008)

BogDAN, Michael, Comparative Law (Kluwer/Norstedts Juridik/Tano 1994) 
BRACTON, Henry, De Legibus Et Consuetudinibus Angliæ (George Woodbine ed., Samuel E. Thorne trans.) available online in bilingual format at http://bracton.law.harvard.edu/

BROWNE, Dennis, Ashburner's Principles of Equity (2 $2^{\text {nd }}$ ed., Butterworths 1933)

BRUDNER, Alan, The Unity of the Common Law (University of California Press 1995)

BRUN, Philippe, Responsabilité civile extracontractuelle ( $2^{\text {nd }}$ ed., LexisNexis - Litec 2009)

Burrows, Andrew, The Law of Restitution ( $3^{\text {rd }}$ ed., Oxford University Press 2002)

BuRROws, Andrew, Understanding the Law of Obligations: Essays on Contract, Tort, and Restitution (Hart Publishing 1998)

CABALLERO, Francis, Essai sur la notion juridique de nuisance (L.G.D.J. 1981)

VAn CAenegem, R.C., The Birth of the English Common Law ( $2^{\text {nd }}$ ed., Cambridge University Press 1988)

CAIRnS, Walter J. \& MACKEON, Robert, Introduction to French Law (Cavendish Publishing 1995)

CALABreSI, Guido, The Costs of Accidents: A Legal and Economic Analysis (2 ${ }^{\text {nd }}$ ed., Yale University Press 1970)

CAMPBELL, Ian, Compensation for Personal Injury in New Zealand: Its Rise and Fall (Auckland University Press 1995)

CANE, Peter, Atiyah's Accidents, Compensation and the Law (8 ${ }^{\text {th }}$ ed., Cambridge University Press 2013)

CANE, Peter, Responsibility in Law and Morality (Hart Publishing 2002)

CANE, Peter, The Anatomy of Tort Law (Hart Publishing 1997)

CARBOnNIER, Jean, Droit civil. Les biens, vol. 3 (19 ${ }^{\text {th }}$ ed., P.U.F. 2000)

CARBonnier, Jean, Droit Civil. Les Obligations, vol. 4 (22 $2^{\text {nd }}$ ed., PUF 2000)

CARVAL, Suzanne, La responsabilité civile dans sa function de peine privée (L.G.D.J. 1995)

CHABAS, François, Le droit des accidents de la circulation après la réforme du 5 juillet 1985 ( $2^{\text {nd }}$ ed., Gazette du Palais \& Litec 1988)

CHITTY, on Contracts. Volume 1. General Principles (31 ${ }^{\text {st }}$ ed., Hugh G. Beale gen. ed., Sweet \& Maxwell / Thomson Reuters 2012)

Coleman, Jules L., Risks and Wrongs (Oxford University Press 1992, repr. 2003)

Collart-Dutilleul, François \& Delebecque, Philippe, Contrats civils et commerciaux ( $7^{\text {th }}$ ed., Dalloz 2004)

COOKE, John, Law of Tort (9 $9^{\text {th }}$ ed., Pearson Education Ltd. 2009)

CORNU, Gérard, Vocabulaire juridique (10 ${ }^{\text {th }}$ ed., PUF 2014)

Dadomo, Cristian \& Farran, Susan, The French Legal System ( $2^{\text {nd }}$ ed., Sweet \& Maxwell 1996)

VAN DAM, Cees, European Tort Law ( $2^{\text {nd }}$ ed., Oxford University Press 2013)

DANIELS, Norman, Justice and Justification: Reflective Equilibrium in Theory and Practice (Cambridge University Press 1996)

DAVID, René, Les grands systèmes de droit contemporain (Dalloz 1966)

DEAKIN, Simon, et al., Markesinis and Deakin's Tort Law ( $5^{\text {th }}$ ed., Oxford University Press 2003) 
Demogue, René, Des Obligations en général, vol. 1 (A. Rousseau 1923), available online at https://gallica.bnf.fr/ark:/12148/bpt6k65173531

DENNING, (Lord) Alfred Thompson, Landmarks in the Law (Butterworths 1984)

DESCAMPS, Olivier, Les origines de la responsabilité pour faute personnelle dans le Code civil de 1804 (L.G.D.J. 2005)

DescheEmaeker, Eric, The Division of Wrongs: A Historical Comparative Study (Oxford University Press 2009)

DoBBS, Dan B., et al., Hornbook on Torts ( $2^{\text {nd }}$ ed., West 2016)

DoBBS, Dan B., The Law of Torts ( $3^{\text {rd }}$ repr., West 2004)

DOMAT, Jean, Les lois civiles dans leur ordre naturel; Le droit public et Legum delectus, vol. 1 (Aîné Nyon 1777)

DOMAT, Jean, Les lois civiles dans leur ordre naturel; Le droit public et Legum delectus, vol. 1 (Savoye 1756), available online at http://gallica.bnf.fr/ark:/12148/bpt6k117556w.r=Domat\%2C+Jean.langEN;

DOMAT, Jean, The civil law in its natural order, vol. 1 (Cuther S. Cushing trans., Little, Brown \& Co. 1853)

Duranton, Alexandre, Cours de droit français suivant le Code civil, vol. 10 (Alex-Gobelet 1830), available online at https://gallica.bnf.fr/ark:/12148/bpt6k9763850r

DwORKIN, Ronald, Justice for Hedgehogs (The Belknap Press of Harvard University Press 2011)

DWORKIN, Ronald, Sovereign Virtue. The Theory and Practice of Equality (Harvard University Press 2000)

EDELman, James, Gain-Based Damages Contract, Tort, Equity and Intellectual Property (Hart Publishing 2002)

ELLIOT, Catherine, et al., French Legal System (2 $2^{\text {nd }}$ ed., Pearson Education Limited 2006)

ENGLARD, Izhak, The Philosophy of Tort Law (Dartmouth Pub. Co. 1993)

EPSTEIN, Richard A., A Theory of Strict Liability-Toward a Reformulation of Tort Law (Cato Institute, San Francisco 1980)

Evans, Edward Payson, The Criminal Prosecution and Capital Punishment of Animals (E. P. Dutton and Company 1906)

FABRE-MaGnan, Muriel, Droit des obligations. Contrat et engagement unilatéral, vol. 1 (4 ${ }^{\text {th }}$ ed., P.U.F. 2016)

FABRE-MAGNAN, Muriel, Droit des obligations. Responsabilité civile et quasi-contrats, vol. 2 ( $3^{\text {rd }}$ ed., PUF 2007)

FENET, P. A., Recueil Complet des travaux préparatoires du Code Civil, vol. 13 (Otto Zeller 1968)

FEynMan, Richard P., What do you care what other People Think? Further Adventures of a Curious Character (Penguin Books 2007)

FifoOT, C.H.S., History and Sources of the Common Law (Greenwood Press 1970; originally Stevens \& Sons Ltd. 1949)

FINNIS, John, Natural Law and Natural Rights (1980)

FLEMING, John G., An Introduction to the Law of Torts (Clarendon Press 1985)

FLEMING, John G., The law of torts $\left(6^{\text {th }}\right.$ ed., The Law Book Company Ltd 1983)

FLoQUET, Amable, Essai historique sur l'Échiquier de Normandie (Rouen - Édouard Frère 1840) 


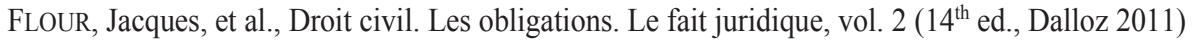

FooT, Philippa, Natural Goodness (Clarendon Press 2001)

Foot, Philippa, Virtues and Vices and Other Essays in Moral Philosophy (University of California Press/ Blackwell 1978)

FriedMANN, Wolfgang Gaston, Legal Theory ( $2^{\text {nd }}$ ed., Stevens \& Sons/Martinus Nijhoff 1949)

GERHART, Peter M., Tort Law and Social Morality (Cambridge University Press 2010)

VAN GERVEN, Walter, et al., Cases, Materials and Text on National, Supranational and International Tort Law (Hart Publishing 2000)

GHESTIN, Jacques, et al., Traité de droit civil. Introduction générale $\left(5^{\text {th }}\right.$ ed., L.G.D.J. 2018)

GILIKER, Paula, Vicarious Liability in Tort: A Comparative Perspective (Cambridge University Press 2010)

GLEnN, H. Patrick, Legal Traditions of the World (4 ${ }^{\text {th }}$ ed., Oxford University Press 2010)

GoldBerG, John C.P. \& ZIPURSKY, Benjamin C., Recognizing Wrongs (The Belknap Press of Harvard University Press 2020)

GoldBerG, John C.P. \& ZIPURSKY, Benjamin C., The Oxford Introductions to US Law. Torts (Oxford University Press 2010)

GomAA, Nooman M. K., Théorie des sources de l'obligation (L.G.D.J. 1968)

GordLeY, James, Foundations of Private Law. Property, Tort, Contract, Unjust Enrichment (Oxford University Press 2006)

GotTSCHALL, Jonathan, The Storytelling Animal: How Stories Make Us Human (Mariner Books 2013)

GoUdKAMP, James \& NolAN, Donal, Contributory Negligence: Principles and Practice (Oxford University Press 2018)

GRARE, Clothilde, Recherches sur la cohérence de la responsabilité délictuelle. L'influence des fondements de la responsabilité sur la réparation (Dalloz 2006).

GREEN, Sarah \& RANDALL, John, The Tort of Conversion (Hart Publishing 2009)

GROTII, Hugonis, De iure belli ac pacis libri tres: in quibus jus naturae, gentium, item juris publici praecipua explicantur (Guilielmum Blaeu 1632), available online at https://archive.org/details/hugonisgrotiidei00grot

GURRY, Francis, Breach of Confidence (Oxford University Press 1984)

HALPERIN, Jean- Louis, L'impossible code civil (PUF 1992)

HALPERIN, Jean-Louis, Histoire du droit des biens (Economica 2008)

HARARI, Yuval Noah, 21 Lessons for the 21st Century (Spiegel \& Grau 2018)

HARARI, Yuval Noah, Homo Deus. A Brief History of Tomorrow (Harvill Secker 2015)

HARPWOOD, Vivienne, Principles of Tort Law (4 ${ }^{\text {th }}$ ed., Cavendish Publishing Ltd. 2000, repr. 2002)

HART, H. L. A. \& HonORÉ, Tony, Causation in the Law ( $2^{\text {nd }}$ ed., Oxford University Press 1985, repr. 2002)

Heuston, R.F.V.\& ChAmBERS, R.S., Salmond and Heuston on the Law of Torts (Sweet \& Maxwell 1981) HoBBES, Thomas, Leviathan (Oxford University Press, repr. 1929)

Hogue, Arthur R., Origins of the Common Law (Indiana University Press 1966, repr. Liberty Fund 1986)

Holmes, Oliver Wendell, The Common Law (Little, Brown, and Company 1881, repr. Holmes Press 2012) 
HONORÉ, Tony, Responsibility and Fault (Hart Publishing 1999)

HuDSON, Alastair, Equity and Trusts ( $8^{\text {th }}$ ed., Routledge 2015)

HuGHES, Gerard J., Aristotle on Ethics (Routledge 2001)

Hume, David, A Treatise on Human Nature (CreateSpace Independent Publishing Platform 2012)

Hursthouse, Rosalind, On Virtue Ethics (Oxford University Press 1999, repr. 2010)

Hutchinson, D.S., The Virtues of Aristotle (Routledge \& Kegan Paul 1986)

IBBETSON, David, A Historical Introduction to the Law of Obligations (Oxford University Press 2001)

IsON, Terence G., Accident Compensation: A Commentary on the New Zealand Scheme (Croom Helm 1980)

JeSTAZ, Philippe \& JAMIN, Christophe, La doctrine (Dalloz 2014)

JESTAZ, Philippe, Les sources du droit (Dalloz 2005)

Joluiffe, J. E. A., The Constitutional History of Medieval England from the English Settlement to 1485 (Adam and Charles Black 1937)

JOSSERAND, Louis, De la responsabilité du fait des choses inanimées (Arthur Rousseau 1897)

KACZMAREK, Laurent, La responsabilité pour fait normal. Étude critique sur son originalité en matière extracontractuelle (Publibook 2012)

KANT, Immanuel, Groundwork of the Metaphysics of Morals (Mary Gregor \& Jens Timmermann eds. and trans., Cambridge University Press 2012)

KeEton, W. Page, et al., Prosser and Keeton on Torts ( $5^{\text {th }}$ ed., West 1984)

KeEtON. Robert E., et al., Cases and Materials on Tort and Accident Law (West Group 1998)

KÖTZ, Hein, Trust und Treuhand: eine rechtsvergleichende Darstellung des anglo-amerikanischen Trust und funktionsverwandter Institute des deutschen Rechts (Vandenhoeck \& Ruprecht 1963)

KozIOL, Helmut, Basic Questions of Tort Law from a Germanic Perspective (Jan Sramek Verlag 2012)

KyMLiCKA, Will, Contemporary Political Philosophy ( $2^{\text {nd }}$ ed., Oxford University Press 2002)

LATOUR, Bruno, Science in Action: How to Follow Scientists and Engineers through Society (Harvard University Press 1987)

LAWSON, F.H. \& MARKESINIS, Basil S., Tortious Liability for Unintentional Harm in the Common Law and the Civil Law, vol. 1 (Cambridge University Press 1982)

LE TOURnEAU, Philippe, et al., Droit de la responsabilité et des contrats. Régimes d'indemnisation $\left(10^{\text {th }}\right.$ ed., Dalloz 2014)

LuCY, William, Philosophy of Private Law (Oxford University Press 2007)

MACGILVRAY, Eric, Reconstructing Public Reason (Harvard University Press 2004)

MACINTYRE, Alasdair, After Virtue ( $3^{\text {rd }}$ ed., Bloomsbury 2007, repr. 2011)

MACINTYRE, Alasdair, Whose Justice? Which Rationality (University of Notre Dame Press 1988, repr. 2014)

MAINE, Henry Sumner, Dissertations on Early Law and Custom (Henry Holt and Company 1886)

MaITLAND, Frederic William, Equity, also The Forms of Action at Common Law (Cambridge University Press, reprinted 1929/ originally published in 1909) 
MALAURIE, Philippe \& AYNÈS, Laurent, Les biens ( $5^{\text {th }}$ ed., Defrénois 2013)

MaLAURIE, Philippe, et al., Droit des Obligations ( $8^{\text {th }}$ ed., L.G.D.J. 2016)

MALINVAUD, Philippe, Introduction à l'étude du droit (12 ${ }^{\text {th }}$ ed., LexisNexis/Litec 2008)

MARKESInIS, Basil S. \& UnBerATH, Hannes, The German Law of Torts: A Comparative Treatise (Hart Publishing 2002)

MARKESINIS, Basil S., Always on the Same Path: Essays on Foreign Law and Comparative Methodology. Volume II (Hart Publishing 2001)

MARKESINIS, Basil S., et al., Compensation for Personal Injury in English, German and Italian Law: A Comparative Outline (Cambridge University Press 2005)

MARKESINIS, Basil S., et al., The Tortious Liability of Statutory Bodies. A Comparative and Economic Analysis of Five Cases (Hart Publishing 1999)

MARTIN, Jill E., Hanbury \& Martin - Modern Equity (18 ${ }^{\text {th }}$ ed., Sweet \& Maxwell/Thomson Reuters 2009)

MAZEAUD, Henri, et al., Leçons de droit civil. Obligations. Théorie générale, vol. 2 ( $8^{\text {th }}$ ed., Montchrestien 1991)

MAZEAUD, Henri, et al., Traité théorique et pratique de la responsabilité civile délictuelle et contractuelle, vol. 1 ( $6^{\text {th }}$ ed., Montchrestien 1965)

MCDowELL, John, Mind, Value \& Reality (Harvard University Press 1998)

MEAGHER, Roderick Pitt, et al., Equity, Doctrines and Remedies ( $2^{\text {nd }}$ ed., Butterworths 1984)

MeurKens, Renée Charlotte, Punitive Damages. The Civil Remedy in American Law, Lessons and Caveats for Continental Europe (Kluwer 2014)

MicheLl, Paul, The Making of the Modern Law of Defamation (Hart Publishing 2005)

MiLL, John Stuart, Utilitarianism. And the 1868 Speech on Capital Punishment ( $2^{\text {nd }}$ ed., George Sher ed., Hackett Publishing Company, Inc. 2001)

MiLLNER, M.A., Negligence in Modern Law (Butterworth \& Co. 1967)

MILSOM, S.F.C., Historical Foundations of the Common Law (2 ${ }^{\text {nd }}$ ed., Butterworths 1981)

MitcheLl, Paul, A History of Tort Law 1900-1950 (Cambridge University Press 2015)

Moore, Michael S., Causation and Responsibility: An Essay in Law, Morals, and Metaphysics (Oxford University Press 2009)

MorÉTEAU, Olivier, L'estoppel et la Protection de la Confiance Légitime: Eléments d'un Renouveau du Droit de la Responsabilité (Droit Anglais et Droit Français) (Thèse pour le doctorat d'état en droit, Universite Jean Moulin - Lyon III 1990) available online at https://digitalcommons.law.lsu.edu/faculty scholarship/12/

MORÉTEAU, Olivier, Le juriste français entre ethnocentrisme et mondialisation (Dalloz 2014)

MOWBRAY, John, et al., Lewin on Trusts ( $17^{\text {th }}$ ed., Sweet \& Maxwell 2000)

NiETZSCHE, Friedrich, Thus Spoke Zarathustra (R. J. Hollingdale trans., Penguin Books 2003)

NORTH, Peter, Civil Liability for Animals (Oxford University Press 2012)

NozICK, Robert, Anarchy, State and Utopia (Basil Blackwell/Basic Books 1974)

Nussbaum, Martha C., Frontiers of Justice: Disability, Nationality, Species Membership (The Belknap Press of Harvard University Press 2006) 
ÖRÜCÜ, Esin, The Enigma of Comparative Law. Variations on a Theme for the Twenty-First Century (Springer-Science/Business Media 2004)

PALMER, Geoffrey W. R., Compensation for Incapacity: A Study of Law and Social Change in New Zealand and Australia (Oxford University Press 1979)

PeArCE, Robert A., \& Stevens, John, The Law of Trusts and Equitable Obligations $\left(4^{\text {th }}\right.$ ed., Oxford University Press 2006)

PeEL, W. Edwin, Treitel on The Law of Contract (13 ${ }^{\text {th }}$ ed., Thomson Reuters 2011)

PeEL, W. Edwin \& GoudKAMP, James, Winfield and Jolowicz on Tort (19 $9^{\text {th }}$ ed., Thomson Reuters 2014)

PERELL, Paul M., The Fusion of Law and Equity (Butterworths 1990)

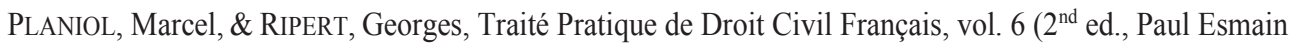
ed., L.G.D.J. 1952)

PLANIOL, Marcel, Traité élémentaire de droit civil, vol. 2 ( $9^{\text {th }}$ ed., L.G.D.J. 1923)

Plato, Republic (2 ${ }^{\text {nd }}$ ed., G.M.A. Grube trans., revised by C.D.C. Reeve Hackett Pub. Co. 1992)

PluCKNETT, Theodore F.T., A Concise History of the Common Law ( $5^{\text {th }}$ ed., Little, Brown \& Co. 1956, repr. Liberty Fund 2010)

Pollock, Frederick \& MAITLAND, Frederick William, The History of English Law before the Time of Edward I, vol. 1 (Cambridge University Press 1895)

PoLLOCK, Frederick, The Law of Torts: A Treatise on the Principles of Obligation arising from Civil Wrongs in the Common Law ( $3^{\text {rd }}$ ed., Stevens and Sons Ltd. 1892)

POSNER, Richard A., Economic Analysis of Law (Wolters Kluwer 2014)

PosNER, Richard A., The Problems of Jurisprudence (Harvard University Press 1990)

PothiER, Robert J., A Treatise on Obligations, Considered in a Moral and Legal View, vol. 1 (N. C. Newbern trans., Martin and Ogden 1802)

POTHIER, Robert J., Traité des obligations, selon les regles tant du for de la conscience que du for extérieur, vol. 1 (les frères Debure \& la veuve Rouzeau-Montaut 1774)

POTHIER, Robert J., Traités sur différentes matieres de droit civil, appliquées à l'usage du barreau ; et de jurisprudence françoise, vol. 1 (Jean Debure \& la veuve Rouzeau-Montaut 1773), available online at https://bibliotheque-numerique-patrimoniale.u-psud.fr/collection/item/4760-redirection

PROSSER, William L., Law of Torts ( $4^{\text {th }}$ ed., West 1971)

RAWLS, John, A Theory of Justice (Belknap Press of Harvard University Press 1971)

Reboul-Maupin, Nadège, Droit des biens ( $6^{\text {th }}$ ed., Dalloz 2016)

RICOEUR, Paul, Le juste (Esprit 1995)

Rogers, W. V. Horton, The Law of Tort (Sweet \& Maxwell 1989)

Ross, David, Aristotle (6 $6^{\text {th }}$ ed., Routledge 1995)

SACCO, Rodolfo, La comparaison juridique au service de la connaissance du droit (Economica, 1991)

SALEILLES, Raymond, Les accidents de travail et la responsabilité civile. Essai d'une théorie objective de la responsabilité délictuelle (Arthur Rousseau ed., Librairie nouvelle de droit et de jurisprudence 1897)

SALMOND, John W., The Law of Torts: A Treatise on the English Law of Liability for Civil Injuries ( $2^{\text {nd }}$ ed., 1910). 
SAMUEL, Geoffrey, An Introduction to Comparative Law Theory and Method (Hart Publishing 2014)

SAVATIER, René, Les métamorphoses économiques et sociales du droit civil d'aujourd'hui ( $2^{\text {nd }}$ ed., Dalloz 1959)

SEARLE, John R., Making the Social World. The Structure of Human Civilization (Oxford University Press 2010)

SEARLE, John R., The Construction of Social Reality (The Free Press 1995)

SELDEN, John, Table Talk: being the discourses of John Selden (E. Smith 1689; Israel Gollancz ed., repub. J.M. Dent and Co. 1898), available online at https://archive.org/details/tabletalkbeingd00milwgoog/

SEN, Amartya, The Idea of Justice (Penguin Books 2010)

SENECA THE ElDER, Declamations, volume I: Controversiae, Books 1-6 (J. Henderson ed., M. Winterbottom trans., Harvard University Press 1974)

SENECA, Lucius Annaeus, Ad Lucilium epistulae morales. With an English translation by Richard M. Gummere, vol. 1 (Heinemann/C.P. Putnam's sons 1918, repr. 1925), available online at https://archive.org/details/adluciliumepistu01seneuoft/page/n7/mode/2up

SENECA, Lucius Annaeus, Ad Lucilium epistulae morales. With an English translation by Richard M. Gummere, vol. 2 (William Heinemann Ltd./Harvard University Press 1920, repr. 1962), available online at https://archive.org/details/adluciliumepistu02seneuoft/page/n5/mode/2up;

SIEMS, Mathias, Comparative Law (Cambridge University Press 2014)

Simpson, A. W. Brian, A History of the Common Law of Contract: The Rise of the Action of Assumpsit (Oxford University Press 1975, repr. 2005)

SiNTEZ, Cyril, La sanction préventive en droit de la responsabilité civile : Contribution à la théorie de l'interprétation et de la mise en effet des normes (Dalloz 2011)

SKIDELSKY, Robert \& SKIDELSKY, Edward, How Much is Enough: Money and the Good Life (Penguin Books 2013)

SLOTE, Michael, Essays on the History of Ethics (Oxford University Press 2010)

SMITS, Jan M., Private Law 2.0: On the Role of Private Actors in a Post-National Society (Eleven International Publishing 2011)

STARCK, Boris, Essai d'une théorie générale de la responsabilité civile considérée en sa double fonction de garantie et de peine privée (L. Rodstein 1947)

StEelE, Jenny, Tort Law: Text, Cases and Materials (4 ${ }^{\text {th }}$ ed., Oxford University Press 2017)

Stenton, Doris Mary, English Justice Between the Norman Conquest and the Great Charter, 1066-1215 (The American Philosophical Society 1964)

StEvens, Robert, Torts and Rights (Oxford University Press 2007)

STORY, Joseph \& LYON, W.H., Commentaries on Equity as Administered in England and America, vol. 2 (14th ed., Little Brown \& Co. 1918).

STREET, Thomas Atkins, The Theory and Principles of Tort Law (Edward Thompson Co. 1906, repr. Beard Books 1999)

SwANTON, Christine, Virtue Ethics: A Pluralistic View (Oxford University Press 2003)

TAMBA, Adrian, Intentional Torts. O Cercetare a Common Law-ului American - Common Law, Equity, Torts Law (Hamangiu 2015) 
TERRÉ, François \& SimLER, Philippe, Droit civil. Les biens (10 ${ }^{\text {th }}$ ed., Dalloz 2018)

Terré, François, et al., Droit Civil. Les Obligations (12 ${ }^{\text {th }}$ ed., Dalloz 2018)

TOULLIER, Charles-Bonaventure-Marie, Le droit civil français suivant l'ordre du Code, vol. 11 (4 ${ }^{\text {th }}$ ed., Warée oncle et Warée fils aîné 1824), available online at https://gallica.bnf.fr/ark:/12148/bpt6k119157k

TuNC, André, et al., Pour une loi sur les accidents de la circulation (Economica 1981)

TUNC, André, La sécurité routière. Esquisse d'une loi sur les accidents de la circulation (Dalloz 1966)

URMSON, James O., Aristotle's Ethics (Blackwell 1988)

VINEY, Geneviève \& JouRDAIN, Patrice, Traité de droit civil. Les effets de la responsabilité $\left(2^{\text {nd }}\right.$ ed., L.G.D.J. 2001)

VINEY, Geneviève, et al., Traité de droit civil. Les conditions de la responsabilité (4 ${ }^{\text {th }}$ ed., L.G.D.J. 2013)

VINEY, Geneviève, et al., Traité de droit civil. Les effets de la responsabilité (4 ${ }^{\text {th }}$ ed., L.G.D.J. 2017)

VINEY, Geneviève, L'indemnisation des victimes d'accidents de la circulation (L.G.D.J. 1992).

VINEY, Geneviève, Traité de droit civil. Introduction à la responsabilité ( $3^{\text {rd }}$ ed., L.G.D.J. 2008)

VIRGO, Graham, The Principles of Equity \& Trusts (2 $2^{\text {nd }}$ ed., Oxford University Press 2016)

WEINRIB, Ernest J., Corrective Justice (Oxford University Press 2012)

WeINRIB, Ernest J., The Idea of Private Law (Oxford University Press 1995, repr. 2012)

White, G. Edward, Tort Law in America. An Intellectual History (Oxford Univ. Press 2003)

WILBURG, Walter, The development of a flexible system in the area of private law : inaugural address as rector magnificus of the Karl-Franzens University in Graz on November 22, 1950 (Herbert Hausmaninger trans., Manzsche Verlags- und Universitätsbuchhandlung 2000)

WiLLiAms, Bernard, Ethics and the Limits of Philosophy (Fontana Press 1985, repr. Routledge Classics 2011)

WILLIAMS, Glanville L., Liability for Animals (Cambridge University Press 1939)

WILSON, Arthur, The Supreme Court of Judicature Acts, 1873 and 1875 (Stevens and Sons 1875), available online at https://archive.org/details/supremecourtofju00wils

WinfIELD, Percy H., The Province of the Law of Tort (Tagore Law Lectures delivered in 1930) (Cambridge University Press 1931)

WitTING, Christian, Street on Torts (14 ${ }^{\text {th }}$ ed., Oxford University Press 2015)

Youngs, Raymond, English, French \& German Comparative Law ( $2^{\text {nd }}$ ed., Routledge Cavendish 2007)

ZwEIGERT, Konrad \& KöTZ, Hein, An Introduction to Comparative Law. The Institutions of Private Law, vol. 2 (Tony Weir trans., North-Holland Publishing Co. 1977)

ZwEIGERT, Konrad \& KÖTZ, Hein, An Introduction to Comparative Law, vol. 1 (North-Holland Publ. Co. 1977)

ZWEIGERT, Konrad \& KÖTZ, Hein, Introduction to Comparative Law ( $3^{\text {rd }}$ ed., Tony Weir trans., Oxford University Press repr. 2011) 
European Group on Tort Law, Principles of European Tort LaW. TeXt and COMmentary (Springer 2005)

European Tort LaW. BASIC TEXTS (2nd ed., Ernst Karner et al. eds., Jan Sramek Verlag 2018)

Formation OF CONTRACTS. A STUDY OF THE COMMON CORE OF LEGAL SYSTEMS (Rudolf B. Schlesinger gen. ed., Oceana Publications/Stevens \& Sons 1968, 2 vols.)

Justinian's Institutes. Translated With an Introduction by Peter Birks \& Grant McLeod, With the Latin TeXT OF PAUl KRUEGer (Peter Birks \& Grant McLeod trans., Duckworth 1987)

Loi BADINTER : LE BILAN DE 20 ANS D'APPLICATION (Philippe Brun \& Patrice Jourdain eds., L.G.D.J. 2007)

POUR UNE RÉFORME DU DROIT DE LA RESPONSABILITÉ CIVILE (François Terré ed., Dalloz, 2011)

Proposition de L'ASSOCIATION HENRI CAPITANT POUR UNE RÉFoRME DU DROIT DES BIENS (Hugues Périnet-Marquet dir., Litec 2009)

The Boundaries of Strict Liability in EuRopean ToRT LaW (Franz Werro \& Vernon Valentine Palmer eds., Bruylant/Staempfli/Carolina Academic Press 2004)

The Institutes of Gaius. Translated with an Introduction by W.M. Gordon and O.F. Robinson, with the Latin teXt of Seckel and Kuebler (W.M. Gordon \& O.F. Robinson trans., Cornell University Press 1988)

UnifiCATION OF TORT LAW: CAUSATION (J. Spier ed., Kluwer Law International 2000)

UnificATION OF TORT LAW: STRICT LiABILITY (B.A. Koch \& H. Koziol eds., Kluwer Law International 2002)

\section{Chapters}

AleXAnder, Larry \& FerZAn, Kimberly Kessler, Confused Culpability, Contrived Causation, and the Collapse of Tort Theory, in Philosophical Foundations of the Law of Torts 406 (John Oberdiek ed., Oxford University Press 2014)

ATIYAH, Patrick S., Personal Injury in the Twenty-First Century: Thinking the Unthinkable, in Wrongs and Remedies in the Twenty-First Century 1 (Peter Birks ed., Clarendon Press 1996)

Bagshaw, Roderick, The Development of Traffic Liability in England and Wales, in The Development of Traffic Liability 12 (Wolfgang Ernst ed., Cambridge University Press 2010).

BAŃKOwSKi, Zenon, MACCORMick, D. Neil, SuMmers, Robert \& WroblewsKi, Jerzy, On Method and Methodology, in Interpreting Statutes: A Comparative Study 9 (Dartmouth 1991)

BIRKS, Peter, Definition and Division: A Meditation on Institutes 3.13 in The Classification of Obligations 1 (Peter Birks ed., Clarendon Press 1997)

BIRKS, Peter, Introduction, in English Private Law, vol. 1 (Peter Birks ed., Oxford University Press 2000)

BIRKS, Peter, The Concept of a Civil Wrong, in Philosophical Foundations of Tort Law 31 (David G. Owen ed., Oxford University Press 1995)

BorghetTI, Jean-Sébastien, The Development of Product Liability in France, in The Development of Product Liability 87 (Simon Whittacker ed., Cambridge University Press 2010)

BRUNNER, Heinrich, The Sources of English Law in Select Essays in Anglo-American Legal History, vol. 2, at 7 (The Lawbook Exchange 1992; originally Little, Brown and Co. 1908) 
Burrows, Andrew, Judicial Remedies, in Principles of the English Law of Obligations 323 (Andrew Burrows ed., Oxford University Press 2015)

CANe, Peter, Fault and Strict Liability for Harm, in The Search for Principle: Essays in Honour of Lord Goff of Chieveley 171 (William Swadling \& Gareth Jones eds., Oxford University Press 1999)

CANNARSA, Michel, et al., France (report), in European Tort Law 2004, at 297 (Helmut Koziol \& Barbara C. Steininger eds., Springer 2005)

CAterinA, Raffaele, The Evolution of Possessory Actions in France and Italy, in The Consequences of Possession 95 (Eric Descheemaeker ed., Edinburgh University Press 2014)

Chapman, Bruce, Pluralism in Tort and Accident Law: Towards a Reasonable Accommodation, in Philosophy and the Law of Torts 276 (Gerald J. Postema ed., Cambridge University Press 2001)

CLAEYS, Eric R., On the "Property" and the "Tort" in Trespass, in Philosophical Foundations of the Law of Torts 122 (John Oberdiek ed., Oxford University Press 2014)

Coleman, Jules, Tort Law and Tort Theory. Preliminary Reflections on Method, in Philosophy and The Law of Torts 183 (Gerald J. Postema ed., Cambridge University Press 2001)

Cousy, Herman \& Droshout, Dimitri, Belgium, in Unification of Tort Law: Strict Liability 43 (B.A. Koch \& H. Koziol eds., Kluwer Law International 2002)

DAVIES, Derek, Restitution and Equitable Wrongs: an Australian Analogue, in Consensus ad Idem, Essays on Contract in Honour of Guenter Treitel 158 (F.D. Rose ed., Sweet \& Maxwell 1996)

DAVIES, John, Tort, in English Private Law, vol. 2, at 519, (Peter Birks ed., Oxford University Press 2000)

Dugdale, A. M., Principles of Liability in Tort, in Clerk \& Lindsell on Torts $1\left(19^{\text {th }}\right.$ ed., Anthony M. Dugdale et al. eds., Sweet \& Maxwell 2006)

ENGLARD, Izhak, The Idea of Complementarity as a Philosophical Basis for Pluralism in Tort Law, in Philosophical Foundations of Tort Law 183 (David G. Owen ed., Oxford University Press 1995, repr. 2001)

FAIRGRIEVE, Duncan, L'exception française? The French law of product liability, in Product Liability in Comparative Perspective 88 (Duncan Fairgrieve ed., Cambridge University Press 2005)

FEDTKE, Jörg \& Magnus, Ulrich, Germany, in Unification of Tort Law: Strict Liability 147 (B.A. Koch \& H. Koziol eds., Kluwer Law International 2002)

FINN, Paul D., The Fiduciary Principle, in Equity, Fiduciaries, and Trust 1 (T.G. Youdan ed., Carswell 1989)

Galand-CARVal, Suzanne, France in Unification of Tort Law: Strict Liability 127 (B.A. Koch \& H. Koziol eds., Kluwer Law International 2002)

LE GALL, Jean-Pierre, Chapter 3. Liability for Persons under Supervision, in International Encyclopedia of Comparative Law, Torts, vol. 11 (André Tunc ed., J.C.B. Mohr (Paul Siebeck) \& Martinus Nijhoff Publishers 1983)

GARDNER, John, Obligations and Outcomes in the Law of Torts, in Relating to Responsibility. Essays for Tony Honoré on his Eightieth Birthday 111 (Peter Cane \& John Gardner eds., Hart Publishing 2001)

Gardner, John, What is Tort Law for? Part 2. The Place of Distributive Justice, in Philosophical Foundations of the Law of Torts 335 (John Oberdiek ed., Oxford University Press 2014)

GeISTFELD, Mark, Economics, Moral Philosophy, and the Positive Analysis of Tort Law, in Philosophy and the Law of Torts 250 (Gerald J. Postema ed., Cambridge University Press 2001) 
GETZLER, Joshua, Patterns of Fusion, in The Classification of Obligations 157 (Peter Birks ed., Clarendon Press 1997)

GigerenZer, Gerd, Smart Heuristics, in Thinking 39 (John Brockman ed., Harper Perennial 2013)

GILIKER, Paula, Relationships Between Neighbours: England and Wales 1850-2000, in The Development of Liability Between Neighbours 29 (James Gordley ed., Cambridge University Press 2010)

GoldBerg, John C.P. \& ZIPURSKY, Benjamin C., Tort Law and Responsibility, in Philosophical Foundations of the Law of Torts 17 (John Oberdiek ed., Oxford University Press 2014)

GordLeY, James, The Functional Method in Methods of Comparative Law 107 (Pier Giuseppe Monateri ed., Edward Elgar 2012)

GoudKAMP, James, Rethinking Contributory Negligence, in Challenging Orthodoxy in Tort Law 309 (Erika Chamberlain et al. eds., Hart Publishing 2013)

GRAZIADEI, Michele, The Functionalist Heritage, in Comparative Legal Studies: Traditions and Transitions 31 (Pierre Legrand \& Roderick Munday eds., Cambridge University Press 2003)

HayauX DU TiLly, Emmanuel, et al., France, in European Civil Practice, vol. 2, at 139 ( $2^{\text {nd }}$ ed., Alexander Layton et al. eds., Thomson/Sweet \& Maxwell 2004)

Honoré, A. M., Chapter 7. Causation and Remoteness of Damage, in International Encyclopedia of Comparative Law, Torts, vol. 11 (André Tunc ed., J.C.B. Mohr (Paul Siebeck) \& Martinus Nijhoff Publishers 1983)

HuRD, Heidi M., Finding No Fault with Negligence, in Philosophical Foundations of the Law of Torts 387 (John Oberdiek ed., Oxford University Press 2014)

Infantino, Marta \& Zervogianni, Eleni, The Place and Space of Causation, in Causation in European Tort Law 3 (Marta Infantino \& Eleni Zervogianni eds., Cambridge University Press 2017)

JouRDAIN, Patrice, Retour sur l 'imputabilité, in Les droits et le Droit, Mélanges dédiés à B. Bouloc 511 (Dalloz 2007)

KeAting, Gregory C., A Social Contract Conception of the Tort Law of Accidents, in Philosophy and The Law of Torts 22 (Gerald J. Postema ed., Cambridge University Press 2001)

KEATING, Gregory C., Strict Liability Wrongs, in Philosophical Foundations of the Law of Torts 292 (John Oberdiek ed., Oxford University Press 2014)

Koch, Bernhard A. \& KozIOL, Helmut, Comparative Conclusions, in Unification of Tort Law: Strict Liability 395 (B.A. Koch \& H. Koziol eds., Kluwer Law International 2002)

Kozıol, Helmut, Comparative Conclusions, in Basic Questions of Tort Law from a Comparative Perspective 685 (Jan Sramek Verlag 2015)

LAWS, (Sir) John, The rule of reason - an international heritage, in Judicial review in international perspective: Liber Amicorum in Honour of Lord Slynn of Hadley 247 (Mads Andenas \& Duncan Fairgrieve eds., Kluwer Law International 2000)

LoBBAn, Michael, Part four: Tort in The Oxford History of the Laws of England. Volume XII (18201914). Private law 879 (William Cornish et al. eds., Oxford University Press 2010).

MACCORMicK, D. Neil, Four Quadrants of Jurisprudence, in Prescriptive Formality and Normative Rationality in Modern Legal Systems. Festschrift for Robert S. Summers 53 (Werner Krawietz et al. eds., Dunker \& Humbolt 2004) 
Magnus, Ulrich \& MARTín-CASALS, Miquel, Comparative Conclusions, in Unification of Tort Law: Contributory Negligence 259 (Ulrich Magnus \& Miquel Martín-Casals eds., Kluwer Law International 2004)

Metzger, Franz, The Last Phase in Medieval Chancery, in Law-Making and Law-Makers in British History 79 (Alan Harding ed., Royal Historical Society 1980)

Michaels, Ralf, The Functional Method of Comparative Law, in The Oxford Handbook of Comparative Law 339 (Mathias Reimann \& Reinhard Zimmermann eds., Oxford University Press 2006)

MorÉTEAU, Olivier \& ON, Alexandru-Daniel, France (report) in European Tort Law 2013, at 229 (Ken Oliphant \& Barbara C. Steininger eds., De Gruyter 2013)

MoréTEAU, Olivier, Basic Questions of Tort Law from a French Perspective, in Basic Questions of Tort Law from a Comparative Perspective 3 (Jan Sramek Verlag 2015)

MoRÉTEAU, Olivier, France (report), in European Tort Law 2009, at 199 (Helmut Koziol \& Barbara C. Steininger eds., De Gruyter 2010)

MorÉTEAU, Olivier, Premiers pas dans la comparaison des droits in Jurilinguistique: entre langues et droits 419 (Jean-Claude Gémar \& Nicholas Kasirer eds., Thémis 2005)

MorÉTEAU, Olivier, Revisiting the Grey Zone between Contract and Tort: The Role of Estoppel and Reliance in Mapping out the Law of Obligations, in European Tort Law 2004, at 60 (H. Koziol \& B. Steininger eds., Springer 2005)

Nolan, Donal \& DAVIES, John, Torts and Equitable Wrongs, in English Private Law 927 ( ${ }^{\text {rd }}$ ed., Andrew Burrows ed., Oxford University Press 2013)

Nussbaum, Martha C., Aristotelian Social Democracy, in Liberalism and the Good 203 (R. Douglas et al. eds., Routledge 1990)

Nussbaum, Martha C., Aristotle on Human Nature and the Foundations of Ethics, in World, Mind, and Ethics: Essays on the Ethical Philosophy of Bernard Williams 86 (J. E. J. Altham \& R. Harrison eds., Cambridge University Press 1995)

OBERDIEK, John, Introduction: Philosophical Foundations of the Law of Torts, in Philosophical Foundations of the Law of Torts 1 (John Oberdiek ed., Oxford University Press 2014)

OLIPHANT, Ken, Basic Questions of Tort Law from the Perspective of England and the Commonwealth, in Basic Questions of Tort Law from a Comparative Perspective 355 (Jan Sramek Verlag 2015)

OLIPHANT, Ken, Injunctions and Other Remedies in The Law of Tort 297 (Andrew Grubb ed., Butterworths 2002)

OliPHANT, Ken, Landmarks of No-Fault in the Common Law, in Shifts in Compensation between Private and Public Systems 43 (Springer 2007)

Owen, David G., Foreword: Why Philosophy Matters to Tort Law, in Philosophical Foundations of Tort Law 1 (David G. Owen ed., Oxford University Press 1995)

PERRY, Stephen R., Responsibility for Outcomes, Risk, and the Law of Torts, in Philosophy and The Law of Torts 72 (Gerald J. Postema ed., Cambridge University Press 2001)

Postema, Gerald J., Introduction. Search for an Explanatory Theory of Torts, in Philosophy and The Law of Torts 1 (Gerald J. Postema ed., Cambridge University Press 2001)

Rogers, W. V. Horton, England in Unification of Tort Law: Strict Liability 101 (B.A. Koch \& H. Koziol eds., Kluwer Law International 2002) 
Rogers, W. V. Horton, Fault under English Law, in Unification of Tort Law: Fault 65 (Pierre Widmer ed., Kluwer Law International 2005)

SCHÄFER, Hans-Bernd \& SCHÖNENBERGER, Andreas, Strict Liability versus Negligence: An Economic Analysis, in The Boundaries of Strict Liability in European Tort Law 37 (Franz Werro \& Vernon Valentine Palmer eds., Staempfli Publishers, Carolina Academic Press \& Bruylant 2004)

SCHWARTZ, Garry T., Rylands v Fletcher, Negligence and Strict Liability, in The Law of Obligations, Essays in Celebration of John Fleming 209 (Peter Cane \& Jane Stapleton eds., Oxford University Press 1998)

SEN, Amartya, Equality of What?, in Tanner Lectures on Human Values 353 (Sterling M. McMurrin ed., University of Utah Press 1980)

SHEINMAN, Hanoch, Tort Law and Distributive Justice, in Philosophical Foundations of the Law of Torts 354 (John Oberdiek ed., Oxford University Press 2014)

Simons, Kenneth W., Contributory Negligence: Conceptual and Normative Issues, in Philosophical Foundations of Tort Law 462 (David G. Owen ed., Oxford University Press 1995, repr. 2001)

SiMPSON, Edwin, Conflicts, in Breach of Trust 75 (Peter Birks \& Arianna Pretto eds., Hart Publishing 2002)

SMITS, Jan M., European Private Law: A Plea for a Spontaneous Legal Order, in European Integration and Law 55 (Deirdre M. Curtin, Jan M. Smits et al. eds., Intersentia 2006)

SMITS, Jan M., Redefining Normative Legal Science: Towards an Argumentative Discipline in Methods of Human Rights Research 45 (F. Coomans, F. Grünfeld, M. Kamminga, eds., Intersentia 2009)

SMITS, Jan, What is Legal Doctrine? On the Aims and Methods of Legal-Dogmatic Research, in Rethinking Legal Scholarship: A Transatlantic Dialogue 207 (Cambridge University Press 2017)

SPENCER, George, The History of the Court of Chancery in Select Essays in Anglo-American Legal History, vol. 2 (Little, Brown and Co. 1908, repr. The Lawbook Exchange 1992)

SPIER, Jaap \& HAAZEN, Olav A, Comparative Conclusions on Causation, in Unification of Tort Law: Causation 127 (J. Spier ed., Kluwer Law International 2000)

StAPLETon, Jane, A New 'Seascape'for Obligations: Reclassification on the Basis of Measure of Damages, in The Classification of Obligations 193 (Peter Birks ed., Clarendon Press 1997)

STONE, Ferdinand F., Chapter 5. Liability for Damage Caused by Things, in International Encyclopedia of Comparative Law, Torts, vol. 11 (André Tunc ed., J.C.B. Mohr (Paul Siebeck) \& Martinus Nijhoff Publishers 1983)

STONE, Martin, The Significance of Doing and Suffering, in Philosophy and The Law of Torts 131 (Gerald J. Postema ed., Cambridge University Press 2001)

TETTENBORN, Andrew, Wrongful Interference with Goods, in Clerk \& Lindsell on Torts 1003 (19 ${ }^{\text {th }}$ ed., Anthony M. Dugdale et al. eds., Sweet \& Maxwell 2006)

TUNC, André, Chapter 1. Introduction in International Encyclopedia of Comparative Law, Torts, vol. 11 (André Tunc ed., J.C.B. Mohr (Paul Siebeck) \& Martinus Nijhoff Publishers 1983)

Tunc, André, Chapter 14. Traffic Accident Compensation Law and Proposals, in International Encyclopedia of Comparative Law, Torts, vol. 11 (André Tunc ed., J.C.B. Mohr (Paul Siebeck) \& Martinus Nijhoff Publishers 1983)

VINEY, Geneviève \& GUÉGAN-LÉCUYER, Anne, The development of traffic liability in France, in The Development of Traffic Liability 50 (Wolfgang Ernst ed., Cambridge University Press 2010) 
Werro, Franz \& BÜYÜKSAGIS, Erdem, The Bounds Between Negligence and Strict Liability, in Comparative Tort Law: Global Perspectives 201 (Mauro Bussani \& Anthony J. Sebok eds., Edward Elgar Publishing 2015)

WERRO, Franz, et al., Strict Liability in European Tort Law : An Introduction, in The Boundaries of Strict Liability in European Tort Law 3 (Franz Werro \& Vernon Valentine Palmer eds., Staempfli Publishers, Carolina Academic Press \& Bruylant 2004)

Werro, Franz, Liability for Harm Caused by Things, in Towards a European Civil Code 921 (4 ${ }^{\text {th }}$ ed., Arthur Hartkamp et al. eds., Wolters Kluwer/Ars Aequi Libri 2011)

WIDMER, Pierre, Comparative Report on Fault as a Basis of Liability and Criterion of Imputation (Attribution), in Unification of Tort Law: Fault 331 (Pierre Widmer ed., Kluwer Law International 2005)

WIDMER, Pierre, Détermination et réduction de la réparation en droit suisse, in The Limits of Liability. Keeping the Floodgates Shut 137 (J. Spier ed., Kluwer Law International 1996)

Wigmore, John Henry, Responsibility for Tortious Acts: Its History in Select Essays in Anglo-American Legal History, vol. 3, at 480 (Little, Brown and Co. 1909)

Wilcox, Vanessa, Punitive Damages in England, in Punitive Damages: Common Law and Civil Law Perspectives 7 (Helmut Koziol \& Vanessa Wilcox eds., Springer 2009)

DE WiTTE, Bruno, et al., Chapter 5. Legal Instruments, Decision-Making and EU Finances, in The Law of the European Union and the European Communities 273 (P.J.G. Kapteyn et al. eds., Kluwer Law International 2008)

Wright, Richard W., The Standards of Care in Negligence Law, in Philosophical Foundations of Tort Law 249 (David G. Owen ed., Oxford University Press 1995, repr. 2001)

Zepos, Panayotis J. \& Christodoulou, Phoebus, Chapter 6. Professional Liability, in International Encyclopedia of Comparative Law, Torts, vol. 11 (André Tunc ed., J.C.B. Mohr (Paul Siebeck) \& Martinus Nijhoff Publishers 1983)

ZWEIGERT, Konrad, Méthodologie du droit comparé, in Mélanges offerts à Jacques Maury, vol. 1 (Dalloz 1960)

$\underline{\text { Articles }}$

Adams, George Burton, The Origin of the English Courts of Common Law, 30 YALE L.J. 798

Alexander, Gregory, Ownership and Obligations: The Human Flourishing Theory of Property, 43 HoNG KONG LAW JOURNAL 451 (2013), available online at http://scholarship.law.cornell.edu/cgi/viewcontent.cgi?article=2200\&context=facpub

Ames, James Barr, Law and Morals, 22 HARV. L. REV. 97 (1908)

Anderson, Robert, The Rashomon Effect in Communication, 41(2) CANADIAN JOURNAL OF COMMUNICATION 249 (2016)

Anscombe, Gertrude Elizabeth Margaret, Modern Moral Philosophy, 33 (no. 124) PHILOsoPHY 1 (1958)

Arnold, Morris S., Accident, Mistake, and Rules of Liability in the Fourteenth-Century Law of Torts, 128 U. PA. L. REV. 361 (1979)

Arthur Ripstein, Tort Law in a Liberal State, 1 J. TORT L. [ii] (2007)

Atiyah, Patrick S., Contracts, Promises and the Law of Obligations, 94 L. Q. REV. 193 (1978) 
Aubert, Jean-Luc, Indemnisation d'une existence handicapée qui, selon le choix de la mère, n'aurait pas dî être, D.2001.489

Aubert, Jean-Luc, L'arrêt Desmares : une provocation ... a quelles réformes ?, D.1983.1 (Chron.)

Aynès, Laurent, Préjudice de l'enfant, né handicapé : la plainte de Job devant la Cour de cassation, D. 2001.492

Bach, Louis, Reflexions sur le problème du fondement de la responsabilité civile en droit français, RTD civ. 1977.17

Bagchi, Aditi, Distributive Injustice and Private Law, 60 Hastings LaW Journal 105 (2008)

Baker, P. V., The Future of Equity, 93 L. Q. REV. 529 (1977)

Balkin, Jack, Understanding Legal Understanding: The Legal Subject and the Problem of Legal Coherence, 103 YALE L. J. 105 (1993);

Bayliss, Daniel, Breach of Confidence as a Breach of Fiduciary Obligations: A Theory, 9 AUCKLAND U. L. REV. 702 (2002)

Birks, Peter, Equity in the Modern Law: An Exercise in Taxonomy, 26 U.W. AustL. L. REV. 1 (1996)

Birks, Peter, Lionel Cohen Lecture: The Content of Fiduciary Obligation, 34 IsR. L. REV. 3 (2000)

Birks, Peter, Restitution and Wrongs, 35 CLP 53 (1982)

Birks, Peter, Six Questions in Search of a subject-Unjust Enrichment in a Crisis of Identity, [1985] JURID. REVIEW 227

Birks, Peter, Unjust Enrichment—A Reply to Mr. Hedley, 5 LEG. StUD. 67 (1985)

Bon, Pierre, La responsabilité du fait des personnes dont on a la garde : sur un rapprochement des jurisprudences administrative et judiciaire, RFDA 1991.991

Bonner, George A., The History of the Court of King's Bench, 11 BELL YARD: J.L. SOC'Y SCH. L. 3 (1933)

Bright, Susan \& McFarlane, Ben, Proprietary Estoppel and Property Rights, 64 CAMBRIDGE L. J. 449 (2005)

Buckley, R. A., Liability in Tort for Breach of Statutory Duty, 100 L.Q.R. 204, 223 (1984)

De Burca, Grainne, Developing Democracy Beyond the State, Columbia Journal of Transnational LAW 46 (2009)

Burrows, Andrew, Contract, Tort and Restitution-A Satisfactory Division or Not?, 99 L. Q. REV. 217 (1983)

Burrows, Andrew, We Do This at Common Law but That in Equity, 22 OXF. J. LEG. STUD. 1 (2002)

Bussani, Mauro \& Infantino, Marta Tort Law and Legal Cultures, 63 AM. J. CoMP. L. 77 (2015)

Bussani, Mauro \& Mattei, Ugo, The Common Core Approach to European Private Law, 3 Colum. J. EuR. L. 339 (1997)

Büyüksagis, Erdem \& van Boom, Willem H., Strict Liability in Contemporary European Codification: Torn Between Objects, Activities, and Their Risks, 44 GEORGETOWN JOURNAL OF INTERNATIONAL LAW 609 (2013)

Calabresi, Guido \& Hirschoff, Jon T., Toward a Test for Strict Liability in Torts, 81 YALE L.J. 1055 (1972)

Calabresi, Guido, Optimal Deterrence and Accidents: To Fleming James, Jr., 84 YALE L.J. 656 (19741975) 
Calabresi, Guido, Some Thoughts on Risk Distribution and the Law of Torts, 70 YALE L. J. 499 (1961)

Calais-Auloi, Jean, Menace européenne sur la jurisprudence française concernant l'obligation de sécurité du vendeur professionnel (CJCE, 25 avril 2002), D.2002.2458 (Chron.)

Cane, Peter, Distributive Justice and Tort Law, 2001 N.Z. L. Rev. 401 (2001)

Capitant, Henry, La responsabilité du fait des choses inanimées d'après l'arrêt des Chambres réunies du 13 février 1930, DH.1930.29 (Chron.)

Chabas, François, La situation faite au conducteur fautif de véhicule terrestre à moteur, Gaz. Pal. (3 February 1994)

Chapman, Bruce, Law, Incommensurability, and Conceptually Sequenced Argument, 146 U. PA. L. REV 1487 (1998)

Chroust, Anton-Hermann \& Osborn, David L., Aristotle's Conception of Justice, 17 NOTRE DAME L. REV. 129 (1942)

Coleman, Jules L., The Morality of Strict Tort Liability, 18 WM. \& MARY L. REV. 259 (1976-1977)

Coleman, Jules L., The Mixed Conception of Corrective Justice, 77 IowA L. REV. 427 (1991-1992)

Conaglen, Matthew, The Nature and Function of Fiduciary Loyalty, 121 LEG. Q. REV. 452 (2005)

Costich, Julia Field, The Perruche case and the issue of compensation for the consequences of medical error, 78 HEALTH POL'Y 8, 11 (2006)

van Dam, Cees, Who is Afraid of Diversity? Cultural Diversity, European Co-operation, and European Tort Law, 20 KING'S LAW JouRnAL 281 (2009), also available online at http://www.ceesvandam.info/default.asp?fileid $=460$

Descheemaeker, Eric, La dualité des torts en droit français. Délits, quasi-délits et la notion de faute, RTD civ. 435 (2010)

Descheemaeker, Eric, Protecting Reputation: Defamation and Negligence, 29 OXF. J. LEG. STUD. 603 (2009)

Dobbs, Dan B., Ending Punishment in "Punitive" Damages: Deterrence-Measured Remedies, 40 ALA. L. REV. 831 (1998)

Dorfman, Avihay, Reasonable Care: Equality as Objectivity, 41 LAW \& PHIL. 369 (2012)

Douglas, Simon, The Nature of Conversion, 68(1) CAMBRIDGE L. J. 198 (2009)

Dreyer, Emmanuel, Droit de la presse et droits de la personnalité, D.2011.780

Dworkin, Ronald, What is Equality? Part 2: Equality of Resources, 10(4) PHILOSOPHY \& PUBLIC AfFAIRS 283 (1981)

Englard, Izhak, Can Strict Liability be Generalized?, 2 OXF. J. LEG. STUD. 245 (1982)

Epstein, Richard A., A Theory of Strict Liability, 2 J. LEGAL STUD. 151 (1973)

Epstein, Richard A., Defenses and Subsequent Pleas in a System of Strict Liability, 3 J. LEGAL StUD. 165 (1974)

Epstein, Richard A., Intentional Harms, 4 J. LEGAL STUD. 391 (1975)

Epstein, Richard A., Medical Malpractice: The Case for Contract, 1 AM. BAR Found. RES. J. 87 (1976)

Epstein, Richard A., The Utilitarian Foundations of Natural Law, 12 HARV. J. L. \& PUB. POL'Y 711 (1989) 
Epstein, Richard A., Toward a General Theory of Tort Law: Strict Liability in Context, 3 J. TORT L. [Article no. 6] (2010)

Feldman, J-Ph., Le trouble voisinage du principe de precaution, D.2009.1369 (Chron.)

Ferrari, Franco, Comparative Remarks on Liability for One's Own Acts, 15 LOY. L.A. INT. \& COMP. L.J. $813(1993)$

Feuillet, Brigitte, The Perruche Case and French Medical Liability, 4 DreXel LAW REV. 139 (2011)

Fiss, Owen, Coda, 38 U. ToRONTO L.J. 229 (1988)

Fletcher, George P., Fairness and Utility in Tort Theory, 85 HARV. L. REV. 537 (1972)

Frankenberg, Günter, Critical Comparisons: Re-thinking Comparative Law, 26 HARV. INT'L. L. J. 411 (1985)

Gardner, John, The Purity and Priority of Private Law, 46 U. TORONTO L.J. 459 (1996)

Gardner, John, What is Tort Law for? Part 1: The Place of Corrective Justice, 30 LAW AND PHILOSOPHY $1(2011)$

Getzler, Joshua, Richard Epstein, Strict Liability and the History of Torts, 3 J. TORT L. [Article no. 3] (2010)

Giesen, Ivo, The Use and Influence of Comparative Law in Wrongful Life Cases, 8:2 UTRECHT LAW REVIEW 35 (2012)

Gilles, Stephen C., Inevitable Accident in Classical English Tort Law, 43 EMORY L. J. 575 (1994)

Gillet, Marcel, Au XIXe siècle : industrialisation linéaire ou industrialisation par bonds?, 23 REVUE ÉCONOMIQUE 723 (1972).

Gobert, Michelle, La Cour de cassation méritait-elle le pilori?, PETITES AFFICHES, at 4 (8 December 2000)

Goldberg, John C. P. \& Zipursky, Benjamin C., Civil Recourse Revisited, 39 Fla. ST. U. L. REv 341 (2011)

Goldberg, John C. P. \& Zipursky, Benjamin C., Torts as Wrongs, 88 TEX. L. REV. 917 (2010)

Goldberg, John C.P. \& Zipursky, Benjamin C., Accidents of the Great Society, 64 MD. L. REV. 364 (2005)

Goldberg, John C.P., \& Zipursky, Benjamin C., The Strict Liability in Fault and the Fault in Strict Liability, 85 FORDHAM L. REV. 743 (2016)

Golding, M. P., Kelsen and the concept of 'Legal System', 47 ARCHIV FÜR RECHTS- UND SOZIALPHILOSOPHIE 355 (1961)

Gordley, James, Myths of the French Civil Code, 42 AM. J. CoMP. L. 459 (1994)

Groutel, Hubert, La faute du conducteur victime dix ans après, D.1995.335 (Chron.)

Hage, Jaap, Anything Goes: An Apology for Parallel Distributed Legal Science, 36 INFORMAL LoGIC 271 (2016)

Hansmann, Henry \& Mattei, Ugo, The Functions of Trust Law: A Comparative Legal and Economic Analysis, 73 N.Y.U. LAW REV. 434 (1998)

Harper, Fowler V., Liability Without Fault and Proximate Cause, 30 Mich. L. REV. 1001 (1931-1932)

Harris, Rufus C., Liability Without Fault, 6 TUL. L. REV. 337 (1931-1932)

Hedley, Steve, Contract, Tort and Restitution: or, On Cutting the Legal System Down to Size, 8 LEG. STUD. $137(1988)$ 
Hillier, Ann, Kelly, Ryan P. \& Klinger, Terrie, Narrative Style Influences Citation Frequency in Climate Change Science, PLoS ONE 11(12): e0167983, available online at https://doi.org/10.1371/journal.pone.0167983

Hirji, Sujaina, What's Aristotelian about neo-Aristotelian Virtue Ethics?, 98 (3) PHILOSOPHY AND PHENOMENOLOGICAL RESEARCH 671 (2018)

Howarth, David, Many Duties of Care-Or A Duty of Care? Notes from the Underground, 26 OXF. J. OF LEG. STUD. 449 (2006)

Jaluzot, Béatrice, Méthodologie du droit comparé. Bilan et perspective, 57 R.I.D.C. 29 (2005)

Jansen, Nils, Duties and Rights in Negligence: A Comparative and Historical Perspective on the European Law of Extracontractual Liability, 24 OXF. J. LEG. STUD. 443 (2004)

Jones, Gareth, Restitution of Benefits Obtained in Breach of Another's Confidence, 86 LEG. Q. REV. 463 (1970)

Jonquet, Nicolas, et al, Les victimes de produits de santé épargnées par la CJCE, D.2003.1299 (Chron.)

Jørgensen, Stig, Liability and Fault, 49 TUL. L. REV. 329 (1974-1975)

Katz, Yarden, Against storytelling of scientific results, 10 NATURE METHODS 1045 (2013), available online at https://www.nature.com/articles/nmeth.2699

Kayser, Pierre, Un arrêt de l'Assemblée plénière de la Cour de cassation sans fondement juridique?, D.2001.1889

Keating, Gregory C., Is There Really No Liability Without Fault: A Critique of Goldberg \& Zipursky, 85 FORDHAM L. REV. RES GESTAE 24 (2016-2017)

Keating, Gregory C., The Idea of Fairness in the Law of Enterprise Liability, 95 MicH. L. REV. 1266 (1997)

Klar, Lewis N., New Zealand's Accident Compensation Scheme: A Tort Lawyer's Perspective, 33 U. TORONTO L.J. 80 (1983)

Korsgaard, Christine M., Two Distinctions in Goodness, 92(2) The Philosophical Review 169 (1983)

Koziol, Helmut, Punitive Damages-A European Perspective, 68 LA. L. REV. 741 (2008)

Kraus, Jody S., Transparency and Determinacy in Common Law Adjudication: A Philosophical Defense of Explanatory Law and Economic Analysis, 93 VA. L. REV. 287 (2007)

Krzywinski, Martin \& Cairo, Alberto, Storytelling, 10 NATURE METHODS 687 (2013), available online at https://doi.org/10.1038/nmeth.2571

Lambert-Faivre, Yvonne, Aspects juridiques, moraux et économiques de l'indemnisation des victimes fautives, D.1982.207 (Chron.)

Lambert-Faivre, Yvonne, La réparation de l'accident médical, obligation de sécurité : oui ; aléa thérapeutique : non, D.2001.570

Lécuyer, Hervé, Une responsabilité déresponsabilisante, 3 DROIT DE LA FAMILLE (1997), Repères 3

Leduc, Fabrice, La sanction de la faute du conducteur victime en question, RCA 2011, Étude 12, $\mathrm{n}^{0} 10$ (October 2011)

Lee, Maria, Civil Liability of the Nuclear Industry, 12 Journal of ENVIRONMENTAL LAW 317 (2000)

Levmore, Saul, Rethinking Comparative Law: Variety and Uniformity in Ancient and Modern Tort Law, 61 TUL. L. REV. 235 (1986-1987) 
Lewis, Richard, Insurers Agreements Not to Enforce their Strict Legal Rights, 48 MODERN LAW REVIEW $275(1985)$

Lewis, Richard, Insurers and Personal Injury Litigation: Acknowledging "the Elephant in the Living Room”, [2005] JOURNAL OF PERSONAL INJURY LAW 1

Lomasky, Loren E., The Impossibility of a Virtue Ethic, 22(3) ETHICAL THEORY AND MORAL PRACTICE 685 (2019)

Loth, Marc A., Corrective and distributive justice in tort law: On the restoration of autonomy and a minimal level of protection of the victim, 22 (6) MAASTRICHT JOURNAL OF EUROPEAN AND COMPARATIVE LAW 788 (2015)

Lucey, (Rev.) Francis E., Liability Without Fault and the Natural Law, 24 TENN. L. REV. (1955-1957)

MacCormick, D. Neil, Reconstruction after Deconstruction: A Response to CLS, 10 OXF. J. LEG. STUD. 539 (1990)

Markesinis, Basil S., Cause and Consideration: A Study in Parallel, 37 CAmBridge L.J. 53 (1978)

Markesinis, Basil S., Comparative Law-A Subject in Search of an Audience, 53 MODERN LAW REVIEW 1 (1990)

Markesinis, Basil, Réflexions d'un comparatiste anglais sur et à partir de l'arrêt Perruche, RTD civ. 77 (2001)

Mawdsley, R.D., Intentional Tortious Acts of Children and Parental Responsibility: The U.S. Common Law and Statutory Approaches to this Issue, 42 DE JURE 14 (2009)

Mazeaud, Henri, La "faute objective" et la responsabilité sans faute, D.1985 Chron. 13

McBratney, William H., New Trends Toward Liability Without Fault, 26 RocKY MNTN. L. REV. 140 (19531954)

von Mehren, Arthur T., Civil Law Analogues to Consideration: An Exercise in Comparative Analysis, 72 HARV. L. REV. 1009 (1959)

Mémeteau, Gérard, L'action de vie dommageable, JCP 2000.II.279

Michaud, Claude, Review of ROBERT-JOSEPH POTHIER D'HIER ET D'AUJOURD'HUI (Joël Moneger et al. eds., Economica 2001), 34 DIX-HUITIÈME SIÈCLE 666 (2002), available online at https://www.persee.fr/doc/dhs_0070-6760_2002_num_34_1_2517_t1_0666_0000_3

Mondoloni, Dominique, Legal Divisions: French versus English Libel Laws, 43(2) INDEX ON

CENSORSHIP 84, at 86 (2014), available online at

https://journals.sagepub.com/doi/pdf/10.1177/0306422014537174

Moreil, Sophie, Antennes relais: que reste-t-il au juge judiciaire?, D. 2012 Chron. 2978

Mourgeon, L., Pour la suppression de la responsabilité civile en cas d'accident et son remplacement par l'assurance de dommage, JCP 1981.I.3050

Mullis, Alastair \& Scott, Andrew, Tilting at Windmills: the Defamation Act 2013, 77 MoDERN LAW REV. 87 (2014)

Nussbaum, Martha C., Social Justice and Universalism: In Defense of an Aristotelian Account of Human Functioning, 90 MODERN PHILOLOGY S46-S73 (1993)

Palmer, Geoffrey W. R., New Zealand's Accident Compensation Scheme: 20 Years on, 44 U. TORONTO L.J. 223 (1994)

Palmer, Vernon Valentine, Trois principes de la responsabilité sans faute, 39(4) R.I.D.C. 825 (1987) 
Peck, Cornelius J., Negligence and Liability without Fault in Tort Law, 46 WASH. L. REV. 225 (1970-1971) Perry, Stephen R., The Impossibility of General Strict Liability, 1 CAN. J. L. \& JURISPRUDENCE 147 (1988) Pickering, A. L., Estoppel by Conduct, 55(3) L. Q. REV. 407 (1939)

Pierre, Philippe, La place de la responsabilité objective. Notion et rôle de la faute en droit français, REVUE JURIDIQUE DE L'OUEST 403 (2010)

Pinker, Steven, Toward a Consilient Study of Literature, 31 PHILOSOPHY AND Literature 162 (2007)

Polden, Patrick, Mingling the Waters. Personalities, Politics and the Making of the Supreme Court of Judicature, 61 CAMBRIDGE L. J. 575 (2002)

Posner, Richard A., A Theory of Negligence, 1 JouRnal OF LEGAL StUdiES 29 (1972)

Posner, Richard A., Strict Liability: A Comment, 2 JouRnAl of LEGAL StUdies 205 (1973)

Posner, Richard A., The Economic Approach to Law, 53 TEX. L. REV. 757 (1975)

Posner, Richard A., Utilitarianism, Economics and Legal Theory, 8 J. LEGAL STUD. 103 (1979)

Pound, Roscoe, Philosophy of Law and Comparative Law, 100 U. PA. L. REV. 1 (1951)

Priel, Dan, Tort law for Cynics, 75(5) THE Modern LAw REVIEW 703 (2014)

Pringsheim, Fritz, The Inner Relationship Between English and Roman Law, 5 CAMBrIDGE LAW JOURNAL 347 (1935).

Prior, William J., Eudaimonism and Virtue, 35 THE JOURNAL OF VALUE INQUIRY 325 (2001)

Prosser, William L., Book Review [FOWLER, VINCENT HARPER, A TREATISE ON THE LAW OF TORTS (The Bobbs-Merrill Company 1933)], 19 MINN. L. REV. 257 (1935)

Prosser, William L., Nature of Conversion, 42 CORNELL L.Q. 168 (1956-57)

Rabin, Robert L., Law for Law's Sake, 105 YALE L.J. 2261 (1996)

Rabin, Robert L., The Historical Development of the Fault Principle: A Reinterpretation, 15 GA. L. REV. 925 (1980-1981)

Radé, Ch., Réflexions sur les fondements de la responsabilité civile. 1 L'impasse, D. 1999. Chron. 313

Radé, Ch., Réflexions sur les fondements de la responsabilité civile. 2 Les voies de la réforme: la promotion du droit à la sûreté, D. 1999. Chron. 323

Radé, Christophe, Le renouveau de la responsabilité du fait d'autrui, D.1997.279 (Chron.)

Rawls, John, Outline of a Procedure for Ethics, 60 PHILOSOPHICAL REVIEW 177 (1951)

Reimann, Mathias, The Progress and Failure of Comparative Law in the Second Half of the Twentieth Century, 50 Aм. J. CoMP. L. 671 (2002)

Reitz, John C., How to Do Comparative Law, 46 AM. J. ComP. L. 617 (1998)

Rives-Lange, M. T., Contribution a l'étude de la responsabilité des maîtres et commetants, JCP 1970.1.2309

Robertson, Andrew, On the Function of the Law of Negligence, 33 OXF. J. OF LEG. STUD. 31 (2012)

Robinette, Cristopher J., The Prosser Notebook: Classroom as Biography and Intellectual History, 2010 U. ILL. L. REV. 577 (2010)

Rochfeld, Judith, Les ambiguïtés des directives d'harmonisation totale : la nouvelle répartition des compétences communautaire et interne, D.2009.2047 (Chron.) 
Rubin, Michael H., Bailment and Deposit in Louisiana, 35 LA. L. REV. 825 (1975)

Saint-Jours, Yves, Handicap congénital - Erreur de diagnistie prenatal - Risque thérapeutique sousjacent, D.2001.1263

Schwartz, Gary T., Mixed Theories of Tort Law: Affirming Both Deterrence and Corrective Justice, 75 TEX. L. REV. 1801 (1997)

Shields, Richard, Liability Without Fault. Rylands v. Fletcher Revitalised, 2 TRINITY C.L. REV. 124 (1999)

Shmueli, Benjamin, Legal Pluralism in Tort Law Theory: Balancing Instrumental Theories and Corrective Justice Theories and Corrective Justice, 48 U. MicH. J. L. REFORM 745 (2015)

Siems, Mathias, Numerical Comparative Law - Do We Need Statistical Evidence in Law in Order to Reduce Complexity?, 13 CARDOZO J. InT'L \& COMP. L. 521 (2005)

Simons, Kenneth W., The Puzzling Doctrine of Contributory Negligence, 16 CARDOZO L. REV. 1693 (19941995)

Singer, Joseph William, Normative Methods for Lawyers, 56 UCLA L. REV. 899 (2008-2009)

Stanton, K.M., New Forms of the Tort of Breach of Statutory Duty, 120 L.Q.R. 324 (2004)

Stapleton, Jane, A Personal Evaluation of the EEC Directive on Products Liability, 1 TORTS LAW JOURNAL 90 (1993)

Stevens, Robert, The Final Appeal: The Reform of the House of Lords and Privy Council 1867-1876, 80 L. Q. REV. 343 (1964)

Stone, Martin, On the Idea of Private Law, 9 CANADIAN JoURNAL OF LAW AND JURISPRUDENCE 235 (1996)

Sugarman, Steven, Doing Away with Tort Law, 73 CAL. L. REV. 555 (1985)

Takayanagi, Kenzo, Liability without Fault in the Modern Civil and Common Law, 16 ILL. L. R. 163 (19211922)

Takayanagi, Kenzo, Liability without Fault in the Modern Civil and Common Law - II, 16 ILL. L. R. 268 $(1921-1922)$

Takayanagi, Kenzo, Liability without Fault in the Modern Civil and Common Law - III, 17 ILL. L. R. 187 $(1922-1923)$

Takayanagi, Kenzo, Liability without Fault in the Modern Civil and Common Law - IV, 17 ILL. L. R. 416 $(1922-1923)$

Terré, François, Le prix de la vie, JCP 2000, Act., at 2267

Tettenborn, Andrew, Punitive Damages - A View from England, 41 SAN DIEGO L. REV. 1551 (2004)

Thayer, Ezra Ripley, Liability without Fault, 29 HARV. L. REV. 810 (1916)

Thomson, Judith Jarvis, Remarks on Causation and Liability, 13 PHILOSOPHY \& PuBLIC AfFAIRs 101 (1984)

Todd, Stephen, Privatization of Accident Compensation: Policy and Politics in New Zealand, 39 WASHBURN L.J. 404 (2000)

Treib, Oliver, et al., Modes of Governance: A Note Towards Conceptual Clarification, 14(1) JouRnAL OF EUROPEAN PUBLIC POLICY 1 (2007)

Trindade, F. A., Intentional Torts: Some Thoughts on Assault and Battery, 2 OXF. J. LEG. STUD. 211 (1982) 
Tutin, Marianne, Vicarious Liability: An Ever Expanding Concept?, 45 Industrial LAW JouRnAL 556 (2016)

Urmson, J.O., Aristotle on Excellence of Character, 71 (no. 834) NEW BLACKFRIARS 33 (1990)

Viney, Geneviève, Brèves remarques à propos d'un arrêt qui affecte l'image de la justice dans l'opinion, JCP 2001.I.286

Viney, Geneviève, L'interprétation par le CJCE de la directive du 25 juillet 1985 sur la responsabilité du fait des produits défectueux, JCP 2002.I.177

Viney, Geneviève, La faute de la victime d'un accident corporel : le présent et l'avenir, JCP 1984.I.3155

Viney, Geneviève, Vers un élargissement de la catégorie des "personnes dont on doit répondre": la porte entrouverte sur une nouvelle interprétation de l'article 1384, alinéa ler, du code civil, D.1991.157 (Chron.)

Viney, Geneviève, L'indemnisation des victimes de dommages causés par le fait d'un chose après l'arrêt de la Cour de Cassation (2 ${ }^{e}$ ch. civ.) du 21 juillet 1982, D.1982.201 (Chron.)

Waite, John B., Liability Without Fault, 18 MicH. L. REV. 316 (1920)

Weinrib, Ernest J., Corrective Justice in a Nutshell, 52 (4) U. TORONTO. L. J. 349 (2002)

Weinrib, Ernest J., The Monsanto Lectures: Understanding Tort Law, 23 VAL. U. L. REV. 485 (1989)

Wells, Michael L., A Common Lawyer's Perspective on the European Perspective on Punitive Damages, 70 LA. L. REV. 557 (2010)

Wessel, Ramses A. \& Wouters, Jan, The Phenomenon of Multilevel Regulation: Interactions between Global, EU and National Regulatory Spheres, INTERNATIONAL ORGANIZATIONS LAW REVIEW 257 (2007)

Wigmore, John H., Responsibility for Tortious Acts: Its History III, 7 HARV. L. REV. 441 (1894)

Williams, Glanville L., The Effect of Penal Legislation in the Law of Tort, 23 M.L.R. 233 (1960)

Williams, Glanville, The Aims of the Law of Tort, 4 CURRENT LEGAL PROBS. 137 (1951)

Winfield, Percy H. \& Goodhart, Arthur L., Trespass and Negligence, 49 L. Q. REV. 359 (1933)

Winfield, Percy H., The History of Negligence in Torts, 42 L. Q. REV. 184 (1926)

Winfield, Percy H., The Myth of Absolute Liability, 42 L. Q. REV. 37 (1926)

Woodbine, George E., The Origins of the Action of Trespass, 33 YALE L.J. 799 (1924)

Wright, Richard W., Substantive Corrective Justice, 77 IowA L. REV. 625 (1992)

Zipursky, Benjamin C., Civil Recourse, Not Corrective Justice, 91 GEO. L.J. 695 (2003)

Zipursky, Benjamin C., Rights, Wrongs, and Recourse in the Law of Torts, 51 VAND. L. REV. 1 (1998)

Zipursky, Benjamin, The Restatement (Third) and the Place of Duty in Negligence Law, 54 VAND. L. REV. $657(2001)$

Zipursky, Benjamin C., Richard Epstein and the Cold War in Torts, 3 J. TORT L. [Article no. 5] (2010)

Zweigert, Konrad, Des solutions identiques par des voies différentes (Quelques observations en matière de droit comparé), 18 R.I.D.C. 5 (1966) 


\section{Reports and Travaux Préparatoires}

Bertrand-de-Greuille, Communication officielle au Tribunat, in FENET, P. A., Recueil Complet des travaux préparatoires du Code Civil, vol. 13, at 474 (Otto Zeller 1968)

Explanatory Memorandum to the Nuclear Installations (Liability for Damage) Order 2016, No 562, available online at https://www.legislation.gov.uk/uksi/2016/562/pdfs/uksiem_20160562_en.pdf

Feynman, Richard P., Appendix F: Personal Observations on the Reliability of the Shuttle, PCSSCA, vol. II, at F5, also available online at https://science.ksc.nasa.gov/shuttle/missions/51-1/docs/rogerscommission/Appendix-F.txt

Law Commission \& Scottish Law Commission, Liability for Defective Products (1977), available at http://www.scotlawcom.gov.uk/files/8812/7989/7339/rep45.pdf

Law Commission, Aggravated, Exemplary and Restitutionary Damages Report, LC247 (16 December 1997), available online at https://s3-eu-west-2.amazonaws.com/lawcom-prod-storage11jsxou24uy7q/uploads/2015/04/LC247.pdf

Law Commission, Breach of Confidence, Law Com. No. 110, (October 1981), available online at http://www.lawcom.gov.uk/app/uploads/2016/08/LC.-110-BREACH-OF-CONFIDENCE-REPORT-ONA-REFERENCE-UNDER-SECTION-31e-OF-THE-LAW-COMMISSIONS-ACT-1965.pdf

Law Commission, Working Paper No 58 - Breach of Confidence (October 1974), available online at https://s3-eu-west-2.amazonaws.com/lawcom-prod-storage-11jsxou24uy7q/uploads/2016/08/No.058-

Breach-of-Confidence.pdf.

Lord Chancellor's Department, Royal Commission on Civil Liability and Compensation for Personal Injury [Pearson commission], Cmnd. 7054 (1978), Vol. I

Ministère de la Justice - Direction des Affaires Civiles et du Sceau, Avant-projet de loi portant réforme de la responsabilité civile (29 April 2016), available online at http://www.textes.justice.gouv.fr/art pix/avpjlresponsabilite-civile.pdf

Ministère de la justice, Projet de réforme de la responsabilité civile (March 2017), available online at http://www.justice.gouv.fr/publication/Projet_de_reforme_de_la_responsabilite_civile_13032017.pdf

Ministry of Justice, The Victims of Overseas Terrorism Compensation Scheme 2012, available at https://www.gov.uk/government/uploads/system/uploads/attachment data/file/243508/9780108512124.p df

Rapport à Monsieur Pascal Clément Garde des Sceaux, Ministre de la Justice, Avant-projet de réforme du droit des obligations (Articles 1101 à 1136 du Code civil) et du droit de la prescription (Articles 2234 à $2281 \mathrm{du}$ Code civil) at 157 (22 September 2005), available online at http://www.justice.gouv.fr/art pix/RAPPORTCATALASEPTEMBRE2005.pdf

Royal Commission on Civil Liability and Compensation for Personal Injury (1978) (Command 7054-I)

Tarrible, Discours devant le corps legislatif, in FENET, P. A., Recueil Complet des travaux préparatoires du Code Civil, vol. 13, at 488 (Otto Zeller 1968)

The Law Commission, Civil Liability for Dangerous Things and Activities, (1970) Law Com. No. 32

Treilhard, Présentation au corps législatif, et exposé des motifs, in FENET, P. A., Recueil Complet des travaux préparatoires du Code Civil, vol. 13, at 464 (Otto Zeller 1968) 


\section{Miscellaneous}

AMERICAN LAW INSTITUTE, RESTATEMENT (SECOND) OF TORTS, VOL. 2 (1965)

AMERICAN LAW INSTITUTE, RESTATEMENT (SECOND) OF TORTS, VOL. 3 (1977)

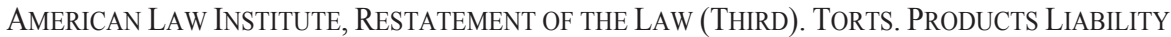

BLACK's LaW Dictionary (10 ${ }^{\text {th }}$ ed., Bryan A. Garner ed., Thomson Reuters 2014)

Central Intelligence Agency, The World Factbook, Country Comparison: GDP per capita, at https://www.cia.gov/library/publications/the-world-factbook/rankorder/2004rank.html

Code civil des français : éd. originale et seule officielle, available online at

http://gallica.bnf.fr/ark:/12148/bpt6k1061517/f339.image

Daniels, Norman, Reflective Equilibrium, in THE STANFORD ENCYCLOPEDIA OF PHILOSOPHY (Edward N. Zalta ed., 2016) available online at https://plato.stanford.edu/archives/win2016/entries/reflectiveequilibrium/

de Bechillonet, Denys, et al., L'arrêt Perruche, le droit et la part d'arbitraire, LE MoNDE, 21 December 2000

Department for Transport, Transport Statistics Great Britain 2015, at 16, available online at https://www.gov.uk/government/uploads/system/uploads/attachment_data/file/489894/tsgb-2015.pdf

Draft Common Frame of Reference (DCFR), available online at http://ec.europa.eu/justice/contract/files/european-private-law en.pdf and http://ec.europa.eu/justice/policies/civil/docs/dcfr_outline_edition_en.pdf (outline edition).

Gaillot-Mercier, Valérie, Troubles de voisinage, in ENCYCLOPÉDIE DALLOZ. RÉPERTOIRE DE DROIT CIVIL (updated 2015)

Harman, Gilbert, Practical Aspects of Theoretical Reason, at 1, available online at https://pdfs.semanticscholar.org/539d/74b05c43ed7e80393a73a6c43e4fc7a84bbd.pdf

Hursthouse, Rosalind \& Pettigrove, Glen, Virtue Ethics, in THE STANFORD ENCYCLOPEDIA OF PHILOSOPHY (Edward N. Zalta ed., Winter 2018 edition), available online at https://plato.stanford.edu/archives/win2018/entries/ethics-virtue/

Isaac Newton, Letter from Sir Isaac Newton to Robert Hooke (1675), available online at https://igitallibrary.hsp.org/index.php/Detail/objects/9792\#

Josserand, Louis, note DH.1930.25-29

Julien, Jérôme, Responsabilité du fait des animaux, in ENCYCLOPÉDIE DALLOZ. RÉPERTOIRE DE DROIT CIVIL (updated 2014)

Julliard, Jacques, Ne ricanons pas!, Le NouVEL OBSERVATEUR, 23 November 2000

Labrusse-Riou, Catherine, et al., La vie humaine comme prejudice?, LE MONDE, 24 November 2000

Lamont, Julian \& Favor, Christi, Distributive justice, in THE STANFORD ENCYCLOPEDIA OF PHILOSOPHY (Edward N. Zalta ed., Winter 2017 edition), available online at https://plato.stanford.edu/archives/win2017/entries/justice-distributive/

Légifrance translations, at http://www.legifrance.gouv.fr/Traductions/en-English/Legifrance-translations

Légifrance, À propos de l'ordre juridique français, at http://www.legifrance.gouv.fr/Aide/A-propos-de-lordre-juridique-francais 
Légifrance, Informations sur le texte du Loi du 9 Avril 1898 sur les responsabilités des accidents dont les ouvriers sont victimes dans leur travail, at http://www.legifrance.gouv.fr/affichTexte.do?cidTexte=JORFTEXT000000692875\&categorieLien=cid

Légifrance, Recherche simple dans les codes en vigueur, at http://www.legifrance.gouv.fr/initRechCodeArticle.do

Marlise Simons, French Uproar Over Right to Death for Unborn, The New York Times, available online at http:/www.nytimes.com/2001/10/19/world/french-uproar-over-right-to-death-for-unborn.html? r=0

Marx, Karl, Critique of the Gotha Program, in Karl MarX. SElected Writings 564 (David McLellan ed., Oxford University Press)

Ministère de la justice, Projet de réforme de la responsabilité civile (March 2017), available online at http://www.justice.gouv.fr/publication/Projet_de_reforme de_la responsabilite_civile_13032017.pdf

Ministère de la justice, Traduction de l'ordonnance du 10 février 2016 en langue anglaise (Ordonnance for the reform of the law of contract, the general regime of obligations, and proof of obligations), at www.textes.justice.gouv.fr/dossiers-thematiques-10083/loi-du-170215-sur-la-simplificationdu-droit12766/traduction-de-lordonnance-du-10-fevrier-2016-en-langue-anglaise-28998.html

Moréteau, Olivier, Les professeurs de droits ne seraient-ils que les gardiens du temple?, available online at http://jurexpat.blog.lemonde.fr/2014/09/12/les-professeurs-de-droits-ne-seraient-ils-que-les-gardiensdu-temple/

Murphy, Peter, Coherentism in Epistemology, in THE INTERNET ENCYCLOPEDIA OF PHILOSOPHY, available online at http://www.iep.utm.edu/coherent/\#SH1b

Nau, Jean-Yves, Le préjudice de vivre, LE MONDE, 26 November 2000

On, Alexandru-Daniel, Prevention and the Pillars of a Dynamic Theory of Civil Liability. A Comparative Study on Preventive Remedies (Master's thesis, Louisiana State University, Spring 2013)

OXFORD ENGLish Dictionary OnLINE, vo equity (n.), I. (Oxford University Press, July 2018). http://www.oed.com/view/Entry/63838?redirectedFrom=equity (last accessed on 29 October 2018)

OXFord English Dictionary ONLine, vo fusion (n.), 3.a. (Oxford University Press, July 2018), http://www.oed.com/view/Entry/75786?redirectedFrom=fusion\& (last accessed on 29 October 2018)

OXFORD ENGLISH DiCTIONARY ONLINE, vo resource (n.) (Oxford University Press, last accessed on 2 April 2020)

Reform Bill on Civil Liability (March 2017), Presented on the 13 March, 2017by Jean-Jacques Urvoas, garde des sceaux, Minister of Justice, Translated into English by Simon Whittaker, in consultation with Jean-Sébastien Borghetti, available online at http://www.textes.justice.gouv.fr/art_pix/reform_bill_on_civil_liability_march_2017.pdf

Sachs, Joe, Aristotle: Ethics, in INTERNET ENCYCLOPEDIA OF PHILOSOPHY, available online at https://www.iep.utm.edu/aris-eth/

Shields, Christopher, Aristotle, in The Stanford Encyclopedia of Philosophy (Edward N. Zalta ed., 2016), available online at https://plato.stanford.edu/archives/win2016/entries/aristotle/

Solum, Lawrence, Legal Theory Lexicon: Welfare, Well-Being, and Happiness, Legal THEORY Blog (May 31,2009) available online at https://solum.typepad.com/legaltheory/2009/05/welfare-wellbeing-andhappiness.html

The Maastricht Collection. Volume IV: Comparative Private LaW $\left(6^{\text {th }}\right.$ ed., Sascha Hardt $\&$ Nicole Kornet eds., Europa Law Publishing 2019) 
The Study Group on a European Civil Code and the Research Group on EC Private Law (Acquis Group), Principles, Definitions and Model Rules of European Private Law

UK Law Commission website: https://www.lawcom.gov.uk/

Wallace, R. Jay, Practical Reason, in THE STANFORD ENCYCLOPEDIA OF PHILOSOPHY (Edward N. Zalta ed., 2014), available online at https:/plato.stanford.edu/archives/sum2014/entries/practical-reason/

WEBSTER's THIRD NEW INTERNATIONAL DiCTIONARY UNABRIDGED, vol. 1 (Encyclopaedia Britannica 1986) 


\section{SUMMARY}

Strict liability is ubiquitous, but problematic. Almost all, if not all legal systems, have strict liability rules in place, but the diversity that exists with regard to the distribution of strict liability rules relative to fault-based rules, the scope of strict liability rules, and how strict liability is perceived by various legal actors can be downright perplexing. Above all else, strict liability norms pose a theoretical challenge to comparative law scholars and legal theorists who have struggled to explain and justify them.

The present research contributes to the existing comparative law and legal-theoretical debates around strict liability by combining comparative research with a normative inquiry into the goals of tort law as a practice. To this end, the present research employs three different methods of inquiry: the first method is doctrinal, consisting of a description of strict liability regimes from a perspective internal to the French and English legal systems; the second is comparative, looking at the commonalities of strict liability regimes in France and England, and their normative differences; and the third method is prescriptive (normative), providing an account of justice that is already presupposed by most of the existing strict liability norms and may in turn justify their existence alongside fault-based tort law norms.

Two recurring characteristics of strict liability norms emerge from the present study: first, strict liability norms are non-universal, in the sense that primary duties and entitlements take other forms than the all against all form that is characteristic to fault-based norms; and second, the link between potential tortfeasors and victims is mediated in strict liability cases, the ascription of liability typically requiring the identification of at least two connected relationships, whereas in fault-based liability the ascription of liability is direct (the relationship between victim and tortfeasor being unmediated). Consequently, the characteristic subject of a strict liability rule is not the individual qua individual, but the individual qua member of a group or class, and the duties that make up the primary level of strict liability wrongs can be further divided into three categories: (a) duties owed by members of a group or class to all others; (b) duties owed by all persons to members of a group or a class of persons; and (c) duties owed by members of a group or class to members of another group or class. Also, as opposed to fault-based liability, which links tortfeasors and victims in a straightforward ("direct" or "un-mediated") manner, strict liability norms typically link tortfeasors and victims by way of two connected relationships held together by a nexus point. The elements of liability combine to form a narrative of two relationships: one relationship between the tortfeasor and the nexus point and a second relationship between the nexus point and the victim. The mediated structure of their primary duties and entitlements is what allows strict liability regimes to bypass judgments regarding the quality of the defendant's behaviour. The locus of the wrong or, in other words, the problem that the liability rule is trying to address, is not in the behaviour of the tortfeasor, but in the 
nexus point, which is always somewhat removed and independent from the tortfeasor's decision-making process. There is, therefore, a sort of "imputability distance" implied in all strict liability wrongs.

The two structural characteristics of strict liability norms (their non-universality and mediated structure) ought to be taken seriously because of what they imply for the existing debates regarding the adoption, expansion, and even justification of strict liability regimes. There is more at stake when legal systems choose strict liability regimes over fault-based liability than a slight preference for security over freedom and a corresponding "victim-friendly" narrative (which is often contrasted to the "business-friendliness" of fault-based liability). Strict liability's imputability distance, combined with its non-universal nature, point towards a deeper and subtler ideological rift. These characteristics suggest that, in any given area of tort law, what the proponents of fault-based liability and the proponents of strict liability disagree about is not how the law should respond to the same problem (by favouring potential victims over risk-takers or the other way around) or how legal responses can be made more efficient, but about what the problem is to start with.

The key differences between fault and strict liability are differences in the normative narrative shaping our perceptions of the interpersonal problems that ought to be remedied by the legal system. In the interpretation we have offered, the choice between fault and strict liability implies a choice between two different ways of defining civil wrongs, i.e. two different ways of formulating primary duties and their correlative entitlements, a choice that is, in essence, a matter of distributive justice. 


\section{RÉSUMÉ}

La responsabilité objective est omniprésente, mais elle pose des problèmes pratiques et théoriques considérables. Presque tous, sinon tous les systèmes juridiques contiennent des règles de responsabilité objective. Néanmoins, il y a une diversité déroutante dans les systèmes de droit européen en ce qui concerne la division des règles soit en règles de responsabilité objective, soit en règles fondées sur la faute, la portée des règles de responsabilité objective et finalement la manière dont la responsabilité objective est perçue par les divers acteurs juridiques. Les normes de responsabilité objective posent surtout des complications théoriques pour les spécialistes du droit comparé et les théoriciens du droit, qui débâtent depuis longtemps leurs fondements.

Cette thèse est le résultat de la combinaison de trois méthodes de recherche : la méthode doctrinale, la méthode comparative et la méthode normative. Ainsi, après une description doctrinale des régimes de responsabilité objective dans les systèmes juridiques français et anglais, l'auteur examine les points communs et les différences entre les régimes de responsabilité objective qui existent en France et en Angleterre et leurs équivalents fonctionnels, et fournit ensuite une justification pour les normes de responsabilité objective identifiées selon une théorie mixte de la justice (selon laquelle la justice commutative et la justice distributive constituent ensemble le telos du droit privé).

Toutes les normes de responsabilité objective analysées dans cette étude présentent deux caractéristiques récurrentes: premièrement, les normes de la responsabilité objective ne sont pas universelles, dans le sens que la construction universelle "tous contre tous" qui est caractéristique aux normes fondées sur la faute n'existe pas dans les rapports juridiques de la responsabilité objective; et deuxièmement, le lien entre les auteurs potentiels du délit et les victimes potentielles est indirect, l'attribution de responsabilité exigeant généralement l'identification d'au moins deux relations liées, tandis que dans la responsabilité fondée sur la faute, l'attribution de responsabilité est directe. En conséquence, le sujet caractéristique d'une règle de responsabilité objective n'est pas l'individu en tant qu'individu, mais l'individu en tant que membre d'un groupe ou d'une classe ; et les devoirs primaires de responsabilité objective peuvent être subdivisés en trois catégories: a ) les devoirs dus par les membres d'un groupe ou d'une classe à tous ; b) les devoirs dus par toute personne aux membres d'un groupe ou d'une catégorie de personnes; et enfin c) les devoirs dus par les membres d'un groupe ou d'une classe aux membres d'un autre groupe ou d'une autre classe. En outre, contrairement à la responsabilité fondée sur la faute, qui lie les auteurs du délit et les victimes directement, les normes de responsabilité objective lient les auteurs du délit et les victimes en deux étapes, et l'ensemble des éléments du délit forment deux rapports normatifs connectés par un point de connexion : un rapport entre l'auteur du délit et le point de connexion et un autre rapport entre le point de connexion et la victime. 
Grâce à cette structure indirecte des devoirs et droits primaires, les régimes de responsabilité objective ne se préoccupent pas avec la qualité du comportement de l'auteur. Le problème que la règle de responsabilité essaie de résoudre ne réside pas dans le comportement de l'auteur du délit, mais dans le point de connexion, qui est toujours éloigné et indépendant du processus décisionnel de l'auteur du délit. Une sorte de "distance d'imputabilité" est donc sous-entendue dans tous les régimes de responsabilité objective.

Les deux caractéristiques structurelles des normes de responsabilité objective (leur non-universalité et leur structure normative indirecte) doivent être prises au sérieux en raison de ce qu'elles impliquent pour les débats concernant l'adoption, l'élargissement et la justification des régimes de responsabilité objective. Dans ces débats, le choix entre la responsabilité objective et la responsabilité pour faute prouvée ne doit pas être interprété comme une simple décision entre les valeurs de la sécurité et de la liberté, et entre ce qui est "favorable aux victimes" et ce qui est "favorable aux affaires". La distance d'imputabilité de la responsabilité objective, combinée avec sa nature non universelle, indique une rupture idéologique plus profonde et plus subtile. Ces caractéristiques indiquent que les partisans de la responsabilité fondée sur la faute et les partisans de la responsabilité objective sont en désaccord en ce qui concerne l'interprétation du problème juridique en tant que tel. Les différences entre la responsabilité pour faute prouvée et la responsabilité objective impliquent des différences entre les discours normatifs qui façonnent nos perceptions des problèmes interpersonnels auxquels le système juridique répond. Dans l'interprétation que l'auteur propose, le choix entre la responsabilité fondée sur la faute et la responsabilité objective implique un choix entre deux manières différentes de définir les délits et quasi-délits (c'est-à-dire deux manières différentes de formuler les devoirs primaires et leurs droits corrélatifs), un choix qui est essentiellement une question de justice distributive. 


\section{ACKNOWLEDGEMENTS}

I have accumulated many debts of gratitude while researching and writing this $\mathrm{PhD}$ thesis, and $\mathrm{I}$ can only hope that I have not forgotten any of my colleagues and friends who have helped, encouraged, and challenged me during this time. If I have forgotten to mention anyone, the omission is sincerely due to my poor memory, not lack of appreciation.

Among those who have shown me more kindness than I deserve, it seems only natural to first single out my two supervisors, Jan Smits and Olivier Moréteau. I feel blessed to have met them both at just the right time in my life, and to have had the chance to work under their wings in Maastricht and Baton Rouge. Jan guided and supported me throughout every stage of this long process, from research proposal to submission, and met with me countless times to discuss every idea and every paragraph I have put on paper. He had to endure late submissions and hear many apologies, but throughout this long and arduous process his managerial touch was always light and his tone ever encouraging. I cannot thank him enough for his patience, honest feedback, and for allowing me to take this project all the way to the end without any compromise. Olivier welcomed me into his life almost ten years ago when I started my LL.M at the LSU Paul M. Hebert Law Center and has since become like a father to me. It is hard to put into words just how much I treasure every memory I have with him from Louisiana, where, like a peripatetic pupil of antiquity, I followed him around at the LSU Law Center, the LSU Law Library, and on many adventures in New Orleans, Avery Island, and the beautiful Louisiana bayou. Olivier was the first person to whom I pitched this $\mathrm{PhD}$ research project. Without his enthusiastic initial response and his continuous support and encouragement I probably would never have had the confidence to begin, let alone persevere in my research. He commented extensively on each chapter, and his astute and pithy comments helped to greatly improve the quality of the present study.

The members of my assessment committee (Gijs van Dijck, Cees van Dam, Ivo Giesen, and James Gordley) also provided me with very insightful comments. They were gracious and complimentary even when they disagreed with my arguments or my conclusions and I am grateful (and flattered) that they accepted to read my thesis as carefully and attentively as they did. Equally, I am overjoyed that they have accepted to play an active part in my defence ceremony as the Opposition. I am very much looking forward to the probing questions they will ask during the ceremony, and I hope my answers will prove as stimulating as I have found their written feedback.

My thoughts on many of the topics discussed in this thesis surfaced, evolved, and then crystallized because I was able to speak about my research very often. I am grateful that I was invited to present my work at 
seminars, workshops, and conferences where colleagues actively engaged with me in many fiery debates and provided excellent feedback on my research. In this regard, I would particularly like to thank: Agustin Parise, who invited me to give three MEPLI Talks (in 2017, 2018, and 2020); Reinhard Zimmerman, who spent two hours after his Maastricht Private Law Lecture in 2017 speaking to a small number of PhD candidates, including me, and giving us feedback on our research; Antonia Waltermann who invited me to give an MLP2 talk in 2018; Philipp Hacker, who invited me to speak in Berlin, at Humboldt University, in 2016; Matthias Martin, who invited me to a Francois Geny talk in Nancy, in 2015; Pia Letto-Vanamo, who steered me in the right direction early on in my research, by giving me extensive feedback on an early paper I submitted for a workshop held at the European University Institute in 2015; and the organizers of and participants in the Jus Commune Research School seminars, where I received feedback from many fellow $\mathrm{PhD}$ researchers and specialists in the field of private law, feedback that was extremely helpful and much appreciated.

I would also like to warmly thank my two paranymphs, Cătălina Goanță and Mark Kawakami. Cătălina was the very first friend I made in Maastricht, and over the years our friendship only became deeper and more meaningful. Cătălina looked out for me like an older sister would look after her little brother: she helped me find a place to live when I moved to Maastricht, introduced me to my new colleagues, to her friends and family, prepared the most lavish and elaborate meals every time I visited her home, and always offered good advice and a kind word when I needed it most. When Cătălina wears her academic cloak she is an inspiration, and when she doesn't she is the most fun and adventurous friend a person could have. It is rare to find a friend who does everything with so much professionalism during working hours, but at the same time makes time for, and often organizes, movie nights, Eurovision and Sinterklaas parties, and karaoke nights with friends. It is a privilege and a joy to be her friend. Mark was, and is, my office mate, my teammate at football and Supreme Commander, and generally the person I had the most fun with in the last six years. Most importantly, he is a true and loyal friend, who readily admits that he is "flawed", but has nevertheless been an example to follow in all matters of life and career. Because he puts so much heart into all his relationships, he is one of the few examples I know of a person who is leading a truly flourishing life (in the Aristotelian sense, of course). The love he shows every day for his family, friends, colleagues, and students is overwhelming, and I am honoured he considers me a friend. There is no one else I would rather have next to me when facing a challenge (especially when that challenge takes the form of a bistecca alla Fiorentina and a few bottles of wine after an intense academic workshop). I cannot thank him enough for all the beautiful memories, stimulating conversations, and for his excellent humour.

I am especially thankful to my close friends and colleagues for their moral and (often also) substantive support. In particular, for all the encouragement, kind words, gentle nudges to finish my $\mathrm{PhD}$, great 
conversations, and for teaching me about the evilness of pineapple pizza, I would like to thank my housemate and beloved friend Matteo Bonelli. I have found equally supportive friends in Frank Nellen, William Bull, Jiangqiu Ge, Anna Beckers, Kate O’Reilly, Madalena Narciso, Mathias Müller, Megan Lana, Marilou Hubers, Paul Roos, Thera Dieleman, Șerban Văcărelu, Constantijn van Aartsen, Luca Bücken, Natasa Athanasiadou, Constanța Roșca, Cristopher Mondschein, Mihai Safta, Alexandru Adrian, Mădălina Gorgan, Daniel Cozma, Gabriel Cozma, Mihai Muntean, Ramona Muntean, Alexandra Pătrăuță, Sergiu Pușcaș, Bianca Pușcaş, and Dan Bizubac.

A special thanks goes out to my dear friends Willem Loof and Marieke Hopman, with whom I have had many conversations about my $\mathrm{PhD}$ research, and who also agreed to start a book club with me in which we discussed, among other books, Alasdair MacIntyre's "After Virtue". The exchange of ideas we had in our small book club helped me better understand and internalize MacIntyre's arguments, and our many other conversations greatly improved my thinking on a variety of legal issues. I am immensely grateful also for my friendship with Adrian Tamba, who shared his $\mathrm{PhD}$ thesis on intentional torts with me, sent me copies of select pages from books from his personal collection, and discussed with me at length the nature of trespass and battery, and with Matthias Martin, who helped me retrieve a few sources on French law that I could not access from Maastricht.

It was, without a doubt, a great pleasure to work on this book at the Faculty of Law of Maastricht University, where I have found a stimulating academic atmosphere and a group of colleagues, mentors and professors who were willing to discuss or argue with me about many of the ideas I have put forward in this book. In this regard, I would like to mention and thank: Bram Akkermans and Nicole Kornet, for being the most supportive and inspiring mentors; Gustavo Arosemena Solorzano, Jaap Hage, Antonia Waltermann, and David Roef, for teaching me about and arguing with me on matters of legal philosophy; Gerrit van Maanen, for his sage advice and for gifting me many of his tort law books upon his retirement; Caroline Cauffman, for her kind support and for lending me a few books from her personal library; and Lotte Meurkens, who also lent me two excellent books and was always happy to help me and share her knowledge and expertise. This book benefited enormously from Stephen Machon's careful proofreading and language editing. With the perfect balance between relentless nit-picking and a gentle touch on the text, Stephen substantially improved the readability of this study. I am deeply grateful for his excellent work.

I am thankful also to a small and select group of students who agreed either to help me in a few of the more time-consuming research tasks or to read and discuss with me a variety of papers on the moral foundations of strict liability: Anca Bliort, Natasha Huls, Leyla May Karataș, and Ștefan Cârjan. 
Last, but not least, I would like to thank my family: my parents, Mircea and Ghiorghiţa On, for their unlimited love and constant encouragement; my sister and my brother-in-law, Ana-Maria Negruț and Dan Negrut, as well as my two nephews - Casian and Fabian - for all the joy they bring into my life; and my first reader, first editor of the PhD manuscript, my harshest critic, and the love of my life, Jasmine Styles, for giving me a glimpse of paradise and a reason to live well. 


\section{Curriculum Vitae}

Alexandru Daniel On was a PhD researcher at Maastricht University (Faculty of Law), and a member of the Maastricht European Private Law Institute (MEPLI) between 2014 and 2020 when this study was written. His research and publications are focused on the law of torts, the law of obligations, and legal translation.

He holds an LL.B. degree from the Babeş-Bolyai University in Cluj-Napoca (2010), an LL.M. in Private Law from Babeş-Bolyai University (2011) and an LL.M. in Comparative Law from Louisiana State University (2013). He was the recipient of the first A. N. Yiannopoulos Endowed Scholarship (for the academic year 2011-2012) and was a research associate at the Center of Civil Law Studies (CCLS) between 2012 and 2014. He is also a special advisory editor for the Journal of Civil Law Studies. 


\section{VALORISATION ADDENDUM}

\section{Scientific and Societal Relevance}

Strict liability regimes are ubiquitous, but problematic. They exist in almost all, if not all, contemporary legal systems, but there is a great deal of diversity between legal systems with regard to the distribution of strict liability rules relative to fault-based rules, the scope of strict liability rules, and how they are perceived by various legal actors. This research was born from the belief that this divergence of practices and justifications opens the space for a debate about the concept of strict liability, the function of strict liability rules within the law of torts, and the factual instances that ought to be regulated by strict liability rules. This is a debate which has already engaged scholars specialized in legal philosophy, comparative law, and law and economics, as well as national doctrinal scholars.

The main findings of this study on strict liability contribute to the scientific debate in the fields of comparative law and the philosophy of tort law. In both fields of study, strict liability has been difficult to account for, but for different reasons. In the field of comparative law, strict liability proved difficult to account for in European harmonization projects because of the diversity of strict liability rules and the variation in their scope were considered insurmountable challenges to the formulation of model rules or proposals for harmonization. Authors contributing to the philosophy of tort law struggled with a different problem - the justification of strict liability. Many philosophical accounts of tort law are based on assumptions about the practice of tort law and the broader practice of responsibility that are incompatible with strict liability torts (for instance, that the practice of tort law is concerned only with wrongdoing, or only with efficient deterrence, or only with the compensation of worthy victims). This research is based on an argument about the goals of tort law that makes room for strict liability torts. In this regard, we have argued that the practice of tort law is concerned with giving each person their due (distributive justice) and with righting interpersonal wrongs (corrective justice), and that the choice of strict liability over fault-based liability is a matter of distributive justice. Such a choice implies a different distribution of primary entitlements and duties (i.e. the creation of a different type of interpersonal wrong), but does not take away the need for corrective justice when such primary entitlements and their correlative duties are violated.

By combining comparative research with a normative inquiry into the goals of tort law as a practice, we have found two recurring characteristics of strict liability norms: first, strict liability norms are nonuniversal, in the sense that primary duties and entitlements take other forms than the all against all form that is characteristic to fault-based norms; and second, the link between potential tortfeasors and victims is mediated in strict liability cases, the ascription of liability typically requiring the identification of at least two connected relationships, whereas in fault-based liability the ascription of liability is direct (the 
relationship between victim and tortfeasor being unmediated). Consequently, the characteristic subject of a strict liability rule is not the individual qua individual, but the individual qua member of a group or class, and the duties that make up the primary level of strict liability wrongs can be further divided into three categories: (a) duties owed by members of a group or class to all others; (b) duties owed by all persons to members of a group or a class of persons; and (c) duties owed by members of a group or class to members of another group or class. Also, as opposed to fault-based liability, which links tortfeasors and victims in a straightforward (“direct" or "un-mediated") manner, strict liability norms typically link tortfeasors and victims by way of two connected relationships held together by a nexus point. The elements of liability combine to form a narrative of two relationships: one relationship between the tortfeasor and the nexus point and a second relationship between the nexus point and the victim. The mediated structure of their primary duties and entitlements is what allows strict liability regimes to bypass judgments regarding the quality of the defendant's behaviour. The locus of the wrong or, in other words, the problem that the liability rule is trying to address, is not in the behaviour of the tortfeasor, but in the nexus point, which is always somewhat removed and independent from the tortfeasor's decision-making process. There is, therefore, a sort of "imputability distance" implied in all strict liability wrongs.

The societal impact of this research is more difficult to anticipate. The normative arguments presented have a high degree of abstraction and their operationalization would require the elaboration of further arguments (to be made in more concrete circumstances). The present research gives lawyers the tools for building arguments, judges the tools for shaping the jurisprudential evolution of the law (should they be inclined to at least a modicum of judicial activism), and legislatures the tools for shaping policy, but it does not provide any ready-made solutions. Nevertheless, in our conclusion, we have suggested that the arrow of history points towards a future with more strict liability, not less:

In this author's opinion, legal systems that are evolving in the same direction as the French and the English systems are going in the right direction. Our current and future liability problems seem hard, if not impossible, to address only by recognizing duties of care and setting standards of individual behaviour. Many of the problems that have arisen and will continue to arise from climate change, from the privatization of our digital space, or from the development of self-driving cars and artificial intelligence can only be addressed by collective action and community thinking. Strict liability, with its duties derived from group membership and its imputability distance, especially when coupled with insurance mechanisms, with their costs-sharing distributive effects, is better suited for the complex modern interactions characteristic to such problems. Strict liability will not solve these new problems humanity is faced with, but the re-distribution that comes with enacting new 
strict liability rules will morph our perception, reframing them as problems we face not apart, as uncoordinated individuals, but in common, as members of groups, collectives and communities.

\section{Audience}

This study is addressed mainly to academics, and more specifically legal academics. Many comparative tort law scholars and scholars working in the nascent field of philosophy of tort law will even find that many of the arguments presented above interact with their own work and with competing arguments that some of them have already made.

Additionally, the present work may be of interest to practising lawyers, judges and other policy-makers because it contributes to the understanding of strict liability and provides (some) normative guidance with regard to the adoption of new strict liability rules.

Lastly, the present study may be of interest to philosophers. There is interesting work being conducted by contemporary philosophers on the nature of responsibility, of rights, of duty, and especially on the existence and nature of group duties. Authors working on such problems may benefit from a better understanding of strict liability and could integrate insights from this thesis into their broader, more ambitious, arguments and theories.

\section{Innovation}

As mentioned above, the justifications of strict liability regimes and the relationship between strict liability and justice have been problematic topics for both comparatists and normative legal theorists. By presenting a novel pluralistic account of strict liability, this thesis contributes to the international academic discourse on tort law, while also offering lawyers, judges and legislatures a toolbox to make better informed decisions on whether, and in what circumstances, new strict liability regimes ought to be created.

The account of strict liability from this research relies on pre-existing work and interacts with arguments already made by other scholars. Nevertheless, it does bring significant innovations to the doctrinal, comparative and normative discourse on strict liability.

The doctrinal exposition of strict liability regimes was built not only from primary sources, but also from the doctrinal accounts of French and English scholars who have already worked on identifying strict liability regimes and describing their requirements (or elements). That said, the author of this thesis had to make choices between differing opinions and interpretations, and the accounts presented in Chapters II and III differ in construction, presentation, and detail from any preexisting accounts. The most important innovation in this stage of the research lies in the identification and cataloguing of strict liability regimes 
in France and England. In England in particular, this exercise had not, to this author's knowledge, yet been attempted in as systematic a manner. In fact, many English legal scholars assume that strict liability exists in such small pockets that it does not merit detailed exposition. Through our research, we show that despite some strict liability rules in England having narrowed in scope over the course of time, both the number of strict liability rules and their overall scope has increased. In France, similar doctrinal accounts of strict liability can be found, but only in the French language. Our exposition relies heavily on French doctrinal work, but has the added value of providing a doctrinal account of strict liability that is up to date and presented in the English language.

In the comparative parts of this research, a more traditional formal-conceptual classification of strict liability rules was supplemented with a problem-oriented version of comparative law functionalism, with the aim of identifying normative similarities and differences between strict liability rules and fault-based liability rules. The findings of this comparative exercise are original and bring new insight into the reasons for the obvious divergence between the French legal system and the English legal system with regard to the adoption of strict liability rules. Our main findings were that: first, strict liability norms are non-universal, in the sense that primary duties and entitlements take other forms than the all against all form that is characteristic to fault-based norms; second, the link between potential tortfeasors and victims is mediated, the ascription of liability typically requiring the identification of at least two connected relationships. Thus the choice to maintain a fault-based rule over strict liability is a choice to preserve, at least prima facie, a universal and individualistic solution that focuses on regulating interpersonal behaviour; in other words, it is a choice to see the interpersonal "wrong" as an individual's failure to behave in the right way. By contrast, in choosing strict liability over fault-based liability a legal system looks for a non-universal but also nonindividualistic solution that focuses on something other than the defendant's behaviour (the standard of safety of a product, or the relationship with another); most often, this means that the interpersonal "wrong" is seen as a collective or group failure.

Additionally, there are innovations also in some of the details of the comparisons made. We found, for instance, that even when France and England define strict liability wrongs in a similar manner, some of the details of these definitions still diverge in important ways. France and England define primary duties and their correlative entitlements very similarly in the areas of product liability, liability for nuclear accidents, vicarious liability of employers for the acts of their employees, nuisance, and trespass to land. Yet: in the area of product liability, there are differences with regard to what counts as damage, how causation may be proved, and the relationship between product liability and other liability regimes; in the area of liability for nuclear accidents there are differences with regard to the recoverability of pure economic loss; in the area of vicarious liability of employers for the acts of their employees there is an important divergence with 
regard to the definitions of the underlying civil wrongs committed by employees, and with regard to the liability exposure of employers when their employers are held vicariously liable; in the area of private nuisance there are subtle differences regarding the definition of the term "neighbour" and the treatment of uncertain risks; and lastly, with regard to acts of interference with the possession of land, there are conceptual and procedural differences between the English tort of trespass to land and the French référé possessoire. Conversely, in some areas where the definitions of civil wrongs fundamentally differ-one jurisdiction opting for strict liability and the other for (mainly) fault-based liability—we nevertheless found a number of subtle points of convergence. We have seen, for instance, that: the law of vicarious liability in England has been expanding and now partly overlaps with the French general principle of liability for others; although in France liability is strict and in England the tort of negligence dominates the area of liability for road traffic accidents, drivers are nevertheless held to a higher standard of care in England; petitory actions, which are not even conceived as remedies for wrongs in France, seem to protect possessory interests in a similar manner to the torts of conversion and trespass to goods; and, in France, the applicability of fault-based liability (articles 1240-1241 of the French Civil Code) in defamation cases has been restricted jurisprudentially to such an extent that fault-based liability has become almost inconsequential, making French law just about as strict as English law in this field.

Lastly, the present study brings a novel argument to the debate on the aims of tort law. By arguing that the practice of tort law has two constitutive aims, being built to achieve both distributive and corrective justice, we added a new voice and new arguments in favour of a pluralist account of tort law (and against those who argue for corrective justice alone, or distributive justice alone, as the aim of tort law). Our argument is that tort law reflects an ordered pluralism, distributive and corrective justice being ordered in a serial (or lexicographical) manner: in a first stage, by defining primary entitlements and duties, tort law specifies the requirements of distributive justice; then, in a second stage, after a primary entitlement is violated and its correlative duty breached, tort law specifies the requirements of corrective justice; and the occurrence of a "civil wrong" marks the conceptual boundary between the two stages.

\section{Implementation}

The findings of this study will be disseminated by submitting this manuscript for commercial publication, through presentations at conferences and symposia, and by further developing some aspects which were not central to this thesis in future academic articles. In the immediate term the author of this study intends to contribute also to the new edition of the Elgar Encyclopedia of Comparative Law with a chapter on strict liability that will refer back to the research conducted during the $\mathrm{PhD}$ programme, but will also, of course, go beyond it. 
